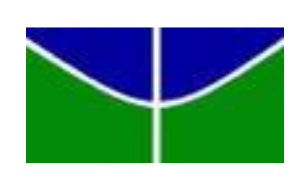

Universidade de Brasília - UnB

Faculdade de Economia, Administração, Contabilidade e Gestão de Políticas Públicas -FACE Programa de Pós-Graduação em Administração - PPGA

\title{
A IMPLEMENTAÇÃO DO COMPONENTE ESPECIALIZADO \\ DA POLÍTICA NACIONAL DE ASSISTÊNCIA FARMACÊUTICA \\ E A JUDICIALIZAÇÃO DA SAÚDE NO BRASIL
}

Samara Haddad Simões Machado

Brasília 
SAMARA HADDAD SIMÕES MACHADO

\section{A IMPLEMENTAÇÃO DO COMPONENTE ESPECIALIZADO DA POLÍTICA NACIONAL DE ASSISTÊNCIA FARMACÊUTICA E A JUDICIALIZAÇÃO DA SAÚDE NO BRASIL}

Tese de Doutorado apresentada ao Programa de PósGraduação em Administração da Universidade de Brasília - Faculdade de Economia, Administração, Contabilidade e Gestão de Políticas Públicas como requisito parcial para obtenção do título de Doutor em Administração.

Orientadora: Profa. Dra. Janann Joslin Medeiros.

Brasília 
Universidade de Brasília - UnB

Faculdade de Economia, Administração, Contabilidade e Gestão de Políticas Públicas -FACE

Programa de Pós-Graduação em Administração - PPGA

SAMARA HADDAD SIMÕES MACHADO

\section{A IMPLEMENTAÇÃO DO COMPONENTE ESPECIALIZADO \\ DA POLÍTICA NACIONAL DE ASSISTÊNCIA FARMACÊUTICA \\ E A JUDICIALIZAÇÃO DA SAÚDE NO BRASIL}

Tese de Doutorado apresentada ao Programa de Pós-Graduação em Administração da Universidade de Brasília - Faculdade de Economia, Administração, Contabilidade e Gestão de Políticas Públicas como requisito parcial para obtenção do título de Doutor em Administração.

Orientadora: Profa. Dra. Janann Joslin Medeiros.

Banca Examinadora:

Profa. Dra. Janann Joslin Medeiros - Orientadora

PPGA/FACE/UnB

Profa. Dra. Suylan de Almeida Midlej e Silva - Membro Interno

PPGA/FACE/UnB

Prof. Dr. Ricardo Corrêa Gomes - Membro Interno

PPGCont/FACE/UnB

Profa. Dra. Cláudia Souza Passador - Membro Externo

FEA-RP/USP

Prof. Dr. Maria Carolina Martinez Andion - Membro Externo

ESAG/UDESC

Prof. Dr. Tomás de Aquino Guimarães - Suplente

PPGA/FACE/UnB

Brasília, 02 de dezembro de 2016. 
À minha mãe, Nabiha, cujo exemplo e amor tanto influenciaram a presente pesquisa. 


\section{AGRADECIMENTOS}

A todos que contribuíram para a concretização da presente pesquisa, em especial, à minha mãe (in memoriam), que muito me apoiou em prol da conclusão deste trabalho, além de ser um exemplo de vida como mãe, mulher, professora e pesquisadora.

Ao meu pai, José Edson, que sempre demonstrou amor, incentivo e preocupação em mais esta etapa de minha vida.

À minha professora orientadora, Janann Joslin Medeiros, que muito me apoiou com a sua tão conhecida candura, demonstrando carinho e respeito incomensuráveis pelo próximo, apoiando-me no momento mais difícil de minha vida, não desacreditando em nenhum instante na presente pesquisa, guiando-me, ensinando-me os caminhos da ciência. Aqui expresso o meu mais profundo sentimento de gratidão!

Ao meu esposo, Mauricio, que demonstrou seu grande amor e companheirismo me dando suporte e incentivo no dia-a-dia, com afeição e paciência.

Ao meu filho, André, que sempre foi um anjo, enchendo-me de força e estímulo na elaboração de um estudo tão importante para mim.

Ao meu irmão, Daniel, pelo companheirismo, otimismo, cumplicidade e pela força dada durante esta jornada.

Ao meu outro irmão, Samuel, e à minha cunhada, Ivana, pelo constante apoio e carinho!

À minha amiga querida e companheira de todas as pesquisas, Vanessa Cabral, que por mais alguns anos me apoiou na busca pelo conhecimento e aperfeiçoamento. Obrigada!

Aos professores da Banca Examinadora: professora Doutora Cláudia Souza Passador, professora Doutora Maria Carolina Martinez Andion, professora Doutora Suylan de Almeida Midlej e Silva, professor Doutor Ricardo Corrêa Gomes, e professor Doutor Tomás de Aquino Guimarães, pelo aceite em participar desta etapa tão importante para minha formação como pesquisadora e pelas importantes contribuições e orientações prestadas na presente pesquisa.

Aos meus queridos amigos: Bruna Fraga, Juliana Penso, Juliana Pinheiro, Marcela Conti e Sérgio Nogueira, pela força nos mais diferentes momentos - aspecto tão importante em uma jornada tão intensa como esta.

À alegria e leveza da amiga Mônica Martins, que com seu sorriso de sempre foi tão importante para apoiar a realização da presente pesquisa em um momento tão importante de cuidados com meu filho André. 
Aos entrevistados, que disponibilizaram seu tempo e boa vontade para contribuir com esta singela pesquisa, tão importante para meu crescimento profissional e pessoal, cujas páginas possam contribuir com a realidade aqui explorada.

Aos meus eternos professores do Programa de Pós-Graduação em Administração da Universidade de Brasília (PPGA/UnB), pela bondade e ensinamentos de sempre.

À Sonária e a todos os funcionários do PPGA/UnB, que tanto nos ajudaram, das mais diversas formas, durante nossa vivência enquanto estudantes do curso em questão.

A todos os colegas do PPGA/UnB, que compartilharam em algum momento a presente jornada de estudos e formação ao longo dos últimos anos.

A todos, muito obrigada! 
"O verdadeiro espelho de nossos discursos é o curso de nossas vidas."

Michel de Montaigne

"O pássaro não canta porque está feliz, mas sim está feliz porque canta."

William James 


\section{RESUMO}

A presente pesquisa tem por objetivo propor um modelo prático de implementação de Políticas Públicas de medicamentos junto à judicialização da saúde. A judicialização, ou controle jurisdicional de Políticas Públicas, é uma competência legítima do Poder Judiciário de exigir a prestação dos direitos positivos constitucionais por parte do Poder Público, quando da falta ou omissão pela Política Pública responsável. Assim, faz-se importante discutir as questões inerentes ao direito à saúde, no que tange ao acesso aos medicamentos pelo Componente Especializado da Assistência Farmacêutica/Política Nacional de Assistência Farmacêutica, bem como pela via judicial, no Distrito Federal. Além do marco teórico sobre a implementação e o controle jurisdicional, a abordagem sobre as teorias que tratam da coordenação interorganizacional e as funções administrativa também se fez presente, a fim de embasar a análise dos aspectos de gestão relacionados aos seguintes fenômenos: implementação do Componente em questão e operacionalização do controle jurisdicional. Para atingir o objetivo da pesquisa, os fenômenos supramencionados foram analisados individualmente e quanto às suas interfaces e pontos de influência. A pesquisa se caracteriza como qualitativa, interpretativista, com finalidades exploratória e descritiva, e com estratégia de estudo por múltiplos casos. As fontes de evidências são qualitativas, fazendo uso de documentos oficiais, reportagens jornalísticas, artigos científicos e entrevistas. As entrevistas se deram com representantes do sistema de saúde e do sistema judiciário. Os documentos foram organizados, classificados e transferidos para o software Nvivo ${ }^{\circledR}$ - instrumento que apoiou o processo de codificação para a aplicação da análise de conteúdo. A princípio, os resultados permitiram uma descrição detalhada de cada um dos casos, seguida de uma análise integrativa. Neste sentido, foi possível notar que os dois fenômenos possuem o mesmo problema em comum: garantir o acesso da população aos medicamentos. Como resultado evidente, a Política tratada dispõe de previsão normativa consistente e um aparato administrativo bem estruturado, incluindo recursos financeiros custeados pelos entes federativos, estrutura descentralizada para a gestão, atividades e fluxos bem descritos e padronizados nacionalmente. As competências são bem definidas para a União e o Distrito Federal, garantindo responsabilidade nos processos. Para a judicialização, além dos órgãos essenciais à justiça e dos órgãos do Poder Judiciário, já bem estabelecidos, foi passível de identificação uma estrutura para a execução das demandas judiciais no Poder Executivo, que é recente e não dispõe de recursos humanos e financeiros suficientes ou formalização das atividades e dos fluxos. Foram evidenciados aspectos passíveis de melhoria no que diz respeito ao processo de judicialização, que envolve a atuação paralela dos Poderes Judiciário e Executivo. À esta relação se nomeou Sistema Interorganizacional Executivo-Judiciário, após identificar a lacuna de estudos na área. Pela ausência de estudos prévios, foram adaptadas as teorias de funções administrativas e coordenação para a sugestão de ações práticas que promovam maior efetividade e eficiência para o fluxo operacional da judicialização de medicamentos. Além deste fluxo operacional, o estudo também contribui com a proposição de um modelo teórico de categorias para o estudo da relação ExecutivoJudiciário em pesquisas futuras.

Palavras-chave: Implementação. Coordenação intergovernamental. Política Nacional de Assistência Farmacêutica. Judicialização da saúde. Acesso aos medicamentos. 


\begin{abstract}
This research had as its objective the proposal of a practical model for implementation of policy with respect to access to medication in conjunction with judicialization. Judicialization, or the jurisdictional control of public policies, is a legitimate competence of Brazilian judiciary to compel the provision of a positive constitutional right by the government when there is failure or omission on the part of the public policy in question. This study looks at the right do health with respect to the access to medications provided through the Specialized Component of the National Policy for Pharmaceutical Assistance (CEAF/PNAF) and via the judicial process in the Federal District. The theoretical framework, in addition to discussion of policy implementation and jurisdictional control, included related to interorganizational coordination and to the functions of public administration. These were chosen to support analysis of aspects related to the management of the phenomena of interest, implementation of the CEAF/PNAF and the operationalization of jurisdictional control, respectively. To fulfill research objectives, these two phenomena were analyzed first as individual cases and then with respect to their points of interface and influence. The research undertaken was qualitative and interpretative in nature, exploratory and descriptive in purpose, and used a multiple case study strategy. The sources of evidence employed were qualitative in nature and of four different types: official documents, journalistic accounts, scientific articles, and interviews. The interviews were conducted with representatives of the health system and the judiciary system. The documents were organized, classified and transferred to Nvivo ${ }^{\circledR}$ software, which was used to support the process of codification for the content analysis carried out. As results, detailed descriptions of each of the two cases studied were produced, followed by integrative analysis of the two. It was observed that the two phenomena share a common problem: assuring access of the population to medications. Principal findings revealed that $\mathrm{CEAF} / \mathrm{PNAF}$ is supported by consistent rules, a well-structured administrative apparatus, including financial resources from the respective federal entities, a decentralized management structure, and well-described and nationally standardized flows of activities and resources. The respective competences of the Federal and Federal District governments are well defined, assuring accountability in the processes. In addition to the independent organs considered essential to the judicial process, and the organs of the judiciary branch itself, all of them wellestablished, it was found that a structure exists in the executive branch for the execution of demands arising from the judicialization process. This structure is recent and has no human or financial resources of its own nor any formalized activities and flows. Aspects of the judicialization process admitting of improvement were identified. This process was seen to involve parallel activities by the executive and judiciary branches of government. The relationship of the two branches with respect to the judicialization of medications, after identification of a gap in studies in the area, was called the Interorganizational ExecutiveJudiciary System. In view of the lack of previous studies of this relationship, concepts were adapted from theories about administrative functions and interorganizational coordination for suggestion of practical actions to promote greater effectiveness and efficiency in the operational flow of the process of judicialization of medications. Another contribution of this study is the proposal of a theoretical model for future studies of the executive-judiciary relationship.
\end{abstract}

Keywords: Implementation. Intergovernmental coordination. National Policy for Pharmaceutical Assistance. Judicialization of health. Access to medications. 


\section{LISTA DE FIGURAS}

Figura 3.1 - Modelo conceitual para o Caso 01 - Assistência Farmacêutica Componente Especializado da Assistência Farmacêutica/Política Nacional de Assistência Farmacêutica.

Figura 3.2 - Modelo conceitual para o Caso 02 - Judicialização da saúde

Figura 3.3 - Categorias de análise preliminares para o estudo.

Figura 3.4 - Categorias de análise definitivas para o estudo

Figura 3.5 - Diagrama de organização da pesquisa

Figura 4.1- Principais elementos envolvidos na definição da natureza do problema do Caso 01

Figura 4.2 - Diagrama com principais elementos identificados do contexto social, econômico e político da Assistência Farmacêutica e implementação do Componente Especializado da Assistência Farmacêutica/Política Nacional de Assistência Farmacêutica.

Figura 4.3 - Estrutura organizacional da implementação do Componente Especializado da Assistência Farmacêutica/Política Nacional de Assistência Farmacêutica no Distrito Federal.

Figura 4.4 - Organograma do Ministério da Saúde com ênfase nas áreas envolvidas na gestão e implementação do Componente Especializado da Assistência Farmacêutica/Política Nacional de Assistência Farmacêutica......

Figura 4.5 - Organograma da Secretaria de Estado de Saúde do Distrito Federal, com enfoque nas áreas envolvidas na implementação do Componente Especializado da Assistência Farmacêutica/Política Nacional de Assistência Farmacêutica.

Figura 4.6 - Responsabilidades dos entes implementadores pelos medicamentos do Grupo 1A do Componente Especializado da Assistência Farmacêutica/Política Nacional de Assistência Farmacêutica.

Figura 4.7 - Responsabilidades dos entes implementadores pelos medicamentos do Grupo 1B do Componente Especializado da Assistência Farmacêutica/Política Nacional de Assistência Farmacêutica.

Figura 4.8 - Responsabilidades da Secretaria de Estado de Saúde do Distrito Federal - ente implementador pelos medicamentos do Grupo 2 do Componente Especializado da Assistência Farmacêutica/Política Nacional de Assistência Farmacêutica

Figura 4.9 - Fluxograma das atividades para a execução do Componente Especializado da Assistência Farmacêutica/Política Nacional de Assistência Farmacêutica no Distrito Federal. 
Figura 4.10 - Atividades para a execução do Componente Especializado da Assistência Farmacêutica/Política Nacional de Assistência Farmacêutica no Distrito Federal - parte I, nível distrital.

Figura 4.11 - Atividades para a execução do Componente Especializado da Assistência Farmacêutica/Política Nacional de Assistência Farmacêutica no Distrito Federal - parte II, nível federal.

Figura 5.1 Diagrama proposto quanto aos principais elementos envolvidos na identificação da natureza do problema do Caso 02 .

Figura 5.2 Diagrama com principais elementos identificados do contexto social, econômico e político da judicialização da saúde.

Figura 5.3 Gráfico da quantidade de ações judiciais em saúde por ano, na SESDF.

Figura 5.4 Estrutura organizacional do controle jurisdicional exercido no DF e na União.

Figura 5.5

Organograma do Ministério Público da União.

Figura 5.6 Relações estabelecidas diante da judicialização de medicamentos nível federal e distrital.

Figura 5.7 Fluxo da operacionalização de acesso a medicamentos por via judicial - Casos do Tipo 01.

Figura 5.8 Fluxo da operacionalização de acesso a medicamentos por via judicial - Casos do Tipo 02.

Figura 5.9 Fluxo da operacionalização de acesso a medicamentos por via judicial - Casos do Tipo 03.

Figura 5.10 Figura 5.10 - Fluxo da operacionalização de acesso a medicamentos por via judicial - Casos do Tipo 04 .

Figura 5.11 Figura 5.11 - Fluxo da operacionalização de acesso a medicamentos por via judicial - Casos do Subtipo A.....

Figura 5.12 Fluxo da operacionalização de acesso a medicamentos por via judicial - Casos do Subtipo B.

Figura 6.1 Distribuição visual dos códigos por categorias para o caso 01 Assistência Farmacêutica-CEAF/PNAF.

Figura 6.2 Distribuição visual dos códigos por categorias para o caso 02 Judicialização da saúde.

Figura 6.3 Linha histórica sobre o CEAF/PNAF e a judicialização da saúde no Brasil, nos níveis Federal e Distrital.

Figura 6.4 Modelo da implementação do CEAF/PNAF. 380

Figura 6.5 Modelo da operacionalização da judicialização de medicamentos. 381

Figura 6.6 Modelo operacional proposto para a judicialização de medicamentos no Brasil, nos níveis Federal e Distrital. 
Figura 6.7 Modelo para o estudo de sistemas interorganizacionais executivo- 388 judiciário... 


\section{LISTA DE QUADROS}

Quadro 3.1 - Definições, meios para observação e fontes de evidência das variáveis de pesquisa.

Quadro 4.1 Síntese das previsões normativas para atos discricionários pelo gestor na implementação do Componente Especializado da Assistência Farmacêutica/Política Nacional de Assistência Farmacêutica.

Quadro 4.2 Etapas diretivas do Ministério da Saúde para acesso aos medicamentos do Componente Especializado da Assistência Farmacêutica/Política Nacional de Assistência Farmacêutica.

Quadro 4.3 Etapas implementadas pela Secretaria de Estado de Saúde do Distrito Federal para acesso aos medicamentos do Componente Especializado da Assistência Farmacêutica/Política Nacional de Assistência Farmacêutica

Quadro 4.4 Prática dos atos discricionários na implementação do Componente Especializado da Assistência Farmacêutica/Política Nacional de Assistência Farmacêutica no Distrito Federal.

Quadro 4.5 Fortalezas da Assistência Farmacêutica e do Componente Especializado da Assistência Farmacêutica/Política Nacional de Assistência Farmacêutica reconhecidos pela área da saúde.

Quadro 4.6 Fragilidades da Assistência Farmacêutica e do Componente Especializado da Assistência Farmacêutica/Política Nacional de Assistência Farmacêutica reconhecidos pela área da saúde.

Quadro 4.7 Síntese dos resultados das categorias do Caso 01 - Assistência Farmacêutica - Componente Especializado da Assistência Farmacêutica/Política Nacional de Assistência Farmacêutica.

Quadro 5.1 Síntese do uso da discricionariedade jurídica na saúde

Quadro 5.2 Síntese de aspectos relacionados às ações judiciais por medicamentos...

Quadro 5.3 Síntese do uso da discricionariedade jurídica na saúde.

Quadro 5.4 Fortalezas e fragilidades do contexto da judicialização da saúde.

Quadro 5.5 Fortalezas e fragilidades do contexto da judicialização da saúde e respectivas dimensões. 
Quadro 5.6 Síntese dos resultados das categorias do caso 02 - Judicialização da saúde.

Quadro 6.1 Aspectos que justificam a organização da relação executivo-legislativo nas demandas de saúde $-1^{\text {a }}$ versão parcial.

Quadro 6.2 Aspectos do planejamento do CEAF/PNAF e da judicialização importantes para o processo de judicialização de medicamentos $-1^{\mathrm{a}}$ versão parcial.

Quadro 6.3 Aspectos que justificam a organização da relação executivo-legislativo nas demandas de saúde $-2^{\text {a }}$ versão parcial.

Quadro 6.4 Aspectos do planejamento do CEAF/PNAF e da judicialização importantes para o processo de judicialização de medicamentos $-2^{\mathrm{a}}$ versão parcial.

Quadro 6.5 Aspectos que justificam a organização da relação executivo-legislativo nas demandas de saúde $-3^{\text {a }}$ versão parcial..

Quadro 6.6 - Aspectos do planejamento do CEAF/PNAF e da judicialização importantes para o processo de judicialização de medicamentos $-3^{\mathrm{a}}$ versão parcial.

Quadro 6.7- Aspectos que justificam a organização da relação executivo-legislativo nas demandas de saúde $-4^{\mathrm{a}}$ versão parcial.

Quadro 6.8 - Aspectos do planejamento do CEAF/PNAF e da judicialização importantes para o processo de judicialização de medicamentos $-4^{\mathrm{a}}$ versão parcial.

Quadro 6.9 - Aspectos que justificam a organização da relação executivo-legislativo nas demandas de saúde - versão final.

Quadro 6.10 Aspectos do planejamento do CEAF/PNAF e da judicialização importantes para o processo de judicialização de medicamentos versão final. 


\section{LISTA DE TABELAS}

Tabela 4.1 - Recursos financeiros e participação relativa no financiamento do Componente Especializado da Assistência Farmacêutica, em 2011, estratificados por esfera de gestão.

Tabela 4.2 Recursos financeiros e participação relativa no financiamento do Componente Especializado da Assistência Farmacêutica, em 2011, estratificados por esfera de gestão.

Tabela 4.3 Repasse de recursos financeiros da União para o Distrito Federal, por trimestre

Tabela 5.1 Custos de três medicamentos de alto custo, por ações judiciais ao MS, entre 2006 e 2010.

Tabela 5.2 Valores, em reais, gastos pelo Ministério da Saúde para o atendimento de decisões judiciais, de 2005 a 2012.

Tabela 5.3 Valores, em reais, gastos pelo Ministério da Saúde para o atendimento de decisões judiciais, de 2012 a 2014.

Tabela 6.1 Distribuição do número de códigos por categorias para o caso 01 Assistência Farmacêutica-CEAF/PNAF.

Tabela 6.2 Distribuição do número de códigos por categorias para o caso 02 Judicialização da saúde 


\section{LISTA DE ABREVIATURAS E SIGLAS}

AA

ABRAMGE

ABS

AEPAC

$\mathrm{AF}$

AFR

$\mathrm{AMBr}$

AN

AN

ANS

ANVISA

APAC

CAMEDIS

CATES

CBAF

CCFT

CEAF

CEAF/PNAF

CEIS

CESAF

$\mathrm{CF}$

CGCEAF

CIB

CID

CIR

CIT

CMDE
- Aparato Administrativo

- Associação Brasileira de Medicina de Grupo

- Atenção Básica de Saúde

- Autorização Especial de Procedimento Ambulatorial

- Assistência Farmacêutica

- Atividades, Fluxos e Rotinas

- Associação Médica de Brasília

- Aparato Normativo

- Aparato Normativo

- Conselho Regional de Medicina

- Agência Nacional de Vigilância Sanitária

- Autorização de Procedimentos de Alta Complexidade/Custo

- Câmara de Mediação em Saúde

- Centro de Atenção Especializada

- Componente Básico da Assistência Farmacêutica

- Comissão Central de Farmácia e Terapêutica

- Componente Especializado da Assistência Farmacêutica Componente Especializado da Assistência

Farmacêutica/Política Nacional de Assistência Farmacêutica

- Complexo Econômico-Industrial da Saúde

- Componente Estratégico da Assistência Farmacêutica

- Constituição Federal

Coordenação-geral do Componente Especializado da Assistência Farmacêutica

- Comissões Intergestores Bipartite Classificação Estatística Internacional de Problemas e Doenças Relacionadas à Saúde

- Comissões Intergestores Regionais

- Comissão Intergestores Tripartite

- Componente de Medicamentos de Dispensação Excepcional 


\begin{tabular}{|c|c|c|}
\hline $\mathrm{CNJ}$ & - & Conselho Nacional de Justiça \\
\hline CNS & - & Comissão Nacional de Saúde \\
\hline CNS & - & Cartão Nacional de Saúde \\
\hline CONASEMS & - & Conselho Nacional de Secretarias Municipais de Saúde \\
\hline CONASS & - & Conselho Nacional de Secretários de Saúde \\
\hline CONITEC & - & Comissão Nacional de Incorporação de Tecnologias \\
\hline CONJUR & - & Consultoria Jurídica \\
\hline $\mathrm{CPF}$ & - & Cadastro de Pessoa Física \\
\hline CPMF & - & Contribuição Provisória sobre Movimentação Financeira \\
\hline CRM & - & Conselho Regional de Medicina \\
\hline CSDF & - & Conferência de Saúde do Distrito Federal \\
\hline CSEP & - & Contexto Social, Econômico e Político \\
\hline DAF & - & Departamento de Assistência Farmacêutica \\
\hline DAF & - & Departamento de Assistência Farmacêutica \\
\hline $\mathrm{DF}$ & - & Distrito Federal \\
\hline DGIS & - & $\begin{array}{l}\text { Departamento de Gestão e Incorporação de Tecnologias em } \\
\text { Saúde }\end{array}$ \\
\hline DIASF & - & Diretoria de Assistência Farmacêutica \\
\hline DIREG & - & DiretorIa de Regulação \\
\hline DL & - & Dispensa de Licitação \\
\hline $\mathrm{DN}$ & - & Discricionariedade 'Normativa' \\
\hline DO & - & Discricionariedade 'Operacional' \\
\hline DPDF & - & Defensoria Pública do Distrito Federal \\
\hline DPU & - & Defensoria Pública da União \\
\hline DST & - & Doença Sexualmente Transmissível \\
\hline $\mathrm{EC}$ & - & Emenda Constitucional \\
\hline $\mathrm{EO}$ & - & Estrutura Organizacional \\
\hline EUA & - & Estados Unidos da América \\
\hline FENASAÚDE & - & Federação Nacional da Saúde \\
\hline FEPECS & . & Fundação de Ensino e Pesquisa em Ciências da Saúde \\
\hline FHB & - & Fundação Hemocentro de Brasília \\
\hline
\end{tabular}




\begin{tabular}{|c|c|c|}
\hline FIOCRUZ & - & Fundação Osvaldo Cruz \\
\hline FTN & - & Formulário Terapêutico Nacional \\
\hline FUC & - & Fundação Universitária de Cardiologia \\
\hline GCEAF & - & $\begin{array}{l}\text { Gerência do Componente Especializado da Assistência } \\
\text { Farmacêutica }\end{array}$ \\
\hline GEAI & - & Gerência da Assistência Intensiva \\
\hline GM & - & Gabinete do Ministro \\
\hline $\mathrm{HCB}$ & - & Hospital da Criança de Brasília José Alencar \\
\hline HIV/AIDS & - & $\begin{array}{l}\text { Human Immunodeficiency Virus/Acquired Immunodeficiency } \\
\text { Syndrome }\end{array}$ \\
\hline IC & - & Instituto de Cardiologia \\
\hline ICIPE & - & Instituto do Câncer Infantil e Pediatria Especializada \\
\hline IESS & - & Instituto de Estudos de Saúde Suplementar \\
\hline INAMPS & - & Instituto Nacional de Assistência Médica da Previdência Social \\
\hline $\mathrm{LC}$ & - & Lei Complementar \\
\hline LME & - & $\begin{array}{l}\text { Laudo de Solicitação, Avaliação e Autorização de } \\
\text { Medicamento do Componente Especializado da Assistência } \\
\text { Farmacêutica }\end{array}$ \\
\hline LOA & - & Lei Orçamentária Annual \\
\hline LOS & - & Lei Orgânica da Saúde \\
\hline MAPS & - & Ministério da Previdência e da Assistência Social \\
\hline MDCE & - & Medicamentos de Dispensação em Caráter Excepcional \\
\hline MPU & - & Ministério Público da União \\
\hline MS & - & Ministério da Saúde \\
\hline NATs & - & Núcleos de Apoio Técnico \\
\hline $\mathrm{NE}$ & - & Normas Embasadoras \\
\hline NJUD & - & Núcleo Jurídico \\
\hline NP & - & Natureza do Problema \\
\hline NUGEST & - & Núcleo de Gestão \\
\hline $\mathrm{OAB}$ & - & Ordem dos Advigados do Brasil \\
\hline PAM & - & Pedido de Aquisição de Medicamento \\
\hline PCDT & - & Protocolos Clínicos e Diretrizes Terapêuticas \\
\hline
\end{tabular}


PGDF

PJDFT

PNAF

PNM

POSDCORB

PROSUS

REME

RENAME

RENASES

RF

RG

$\mathrm{RH}$

SAS

SCTIE

SES

SESAI

SGEP

SGTES

SIA

SMS

STA

STF

SUAG

SUS

SVS

TCU

UF

USP

UTI

VIII CNS
- Procuradoria Geral do Distrito Federal

- Tribunal de Justiça do Distrito Federal e Territórios

- Política Nacional de Assitência Farmacêutica

- Política Nacional de Medicamentos Acrônimo de Planejar, Organizar, Apoio de Pessial, Direcionamento ou Guia, Coordenação, Registro, Orçamento.

- Promotoria de Justiça de Defesa da Saúde

- Relação de Medicamentos Essenciais

- Relação Nacional de Medicamentos Essenciais

- Relação Nacional de Serviços e Ações de Saúde

- Recursos Financeiros

- Registro Geral

- Recursos Humanos

- Secretaria de Atenção à Saúde

- Secretaria de Ciência, Tecnologia e Insumos Estratégicos

- Secretaria de Estado de Saúde

- Secretaria Especial de Saúde Indígena;

- Secretaria de Gestão Estratégica e Participativa

- Secretaria de Gestão do Trabalho e da Educação na Saúde

- Sistema de Informação Ambulatorial

- Secretaria Municipal de Saúde

- Suspensão de Tutela Antecipada

- Supremo Tribunal Federal

- Secretaria de Administração Geral

- Sistema Único de Saúde

- Secretaria de Vigilância em Saúde

- Tribunal de Contas da União

- Unidade da Federação

- Universidade de São Paulo

- Unidade de Terapia Intensiva

- VIII Conferência Nacional de Saúde 


\section{SUMÁRIO}

1 INTRODUÇÃO ........................................................................................................... 19

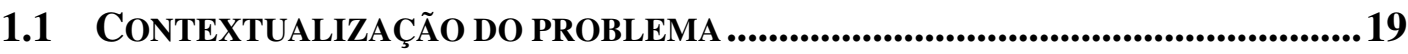

1.2 DEFINIÇÃO DO PROBLEMA DE PESQUISA .....................................................24

1.3 OBJETIVOS DE PESQUISA GERAL E ESPECÍFICOS ..........................................26

1.4 DELIMITAÇÃO DA PESQUISA

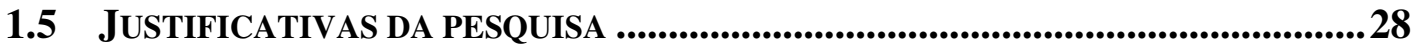

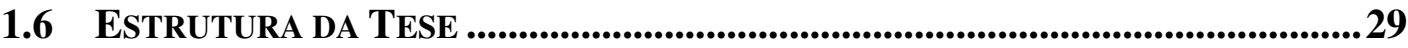

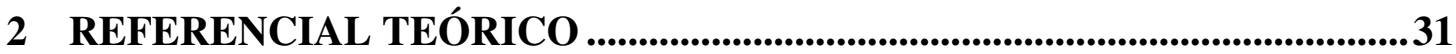

2.1 A implementação de Políticas Públicas e a discricionariedade ADMINISTRATIVA

2.2 COORdenaÇão INTEROganizacional Na IMPlementaÇão de Políticas PúBLICAS 37

2.3 FunÇões da Administração Pública 40

2.4 Controle JURiSdicional da Administração PúbliCA ...........................43

3 METODOLOGIA..........................................................................................................48

3.1 CaRACTERIZAÇÃo GERAL dA PESQUISA .............................................................48

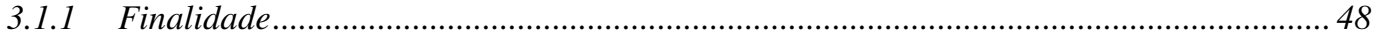

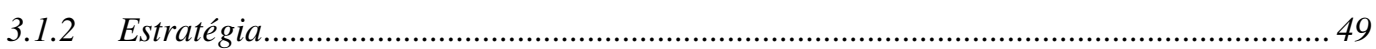

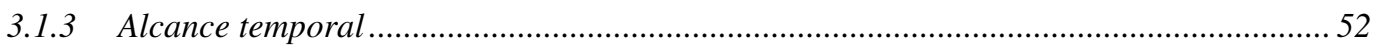

3.1.4 Caráter e fontes das evidências ..................................................................................... 52

3.2 MODELOS CONCEITUAIS E CATEGORIAS DE ANÁLISE .........................................53

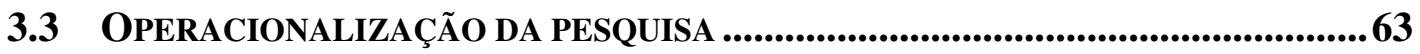

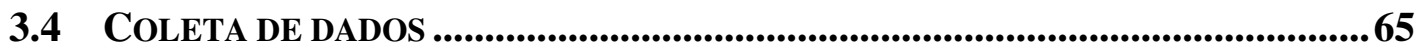

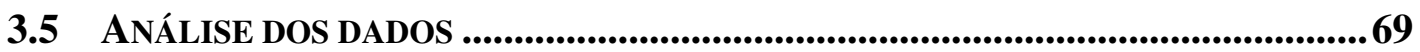

3.6 LIMITAÇÕES METODOLÓGICAS …..................................................................................70

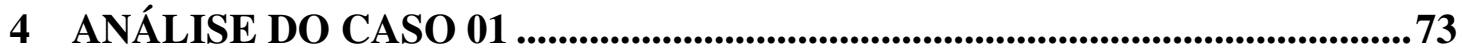


4.1 NATUREZA Do PRoblema.....................................................................................73

4.2 CONTEXTo Social, ECONÔMICO E POLítico ....................................................86

4.2.1 Momento 01 - período 1982-2009 - Criação do Componente de Medicamentos de Dispensação Excepcional.

4.2.2 Momento 02 - período 2009-2013 - Revisão do Componente de Medicamentos de Dispensação Excepcional e criação do Componente Especializado da Assistência Farmacêutica. 93

4.2.3 Momento 03 - período 2013-2016 - Conjuntura atual do Componente Especializado da Assistência Farmacêutica.

4.3 APARATO NORMATIVO ........................................................................................99

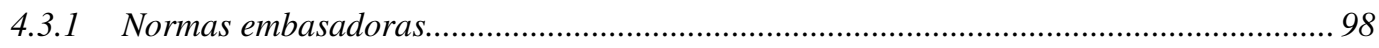

4.3.2 Discricionariedade normativa .................................................................................. 104

4.4 APARATO ADMINISTRATIVO...........................................................................110

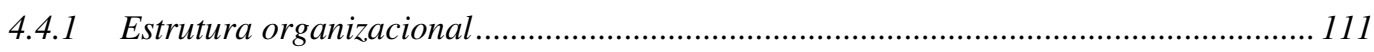

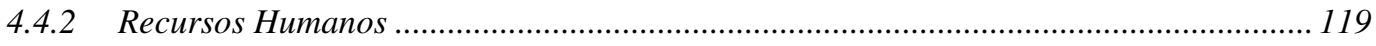

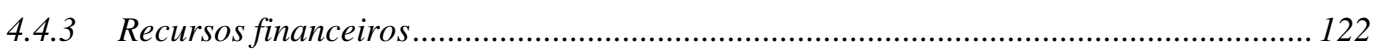

4.4.4 Atividades, fluxos e rotinas ................................................................................ 131

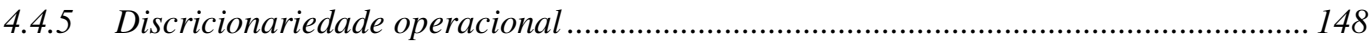

4.5 Aspectos CONFlituosos ENTRE A EXECUÇÃo Do CEAF/PNAF E A

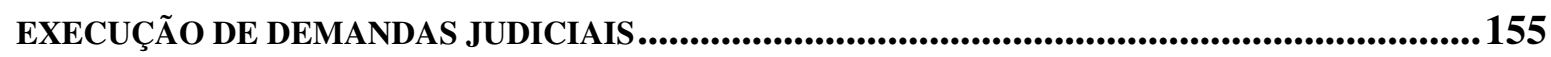

4.6 Síntese dos Resultados das Categorias do Caso 01 - AssistênCia

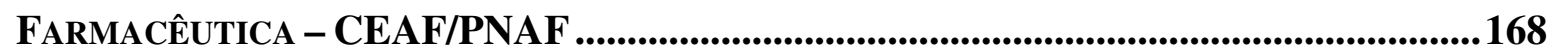

5 ANÁLISE DO CASO 02 ….................................................................................. 172

5.1 NATUREZA do PROBlema..................................................................................172

5.2 CONTEXTO SOCIAL, ECONÔMICO E POLÍTICO.............................................183

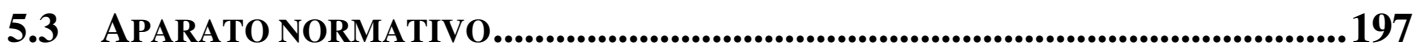

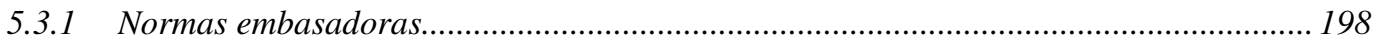

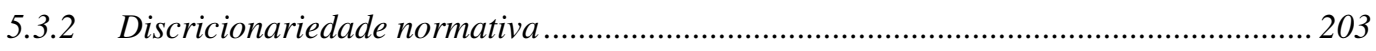

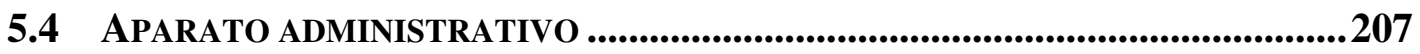

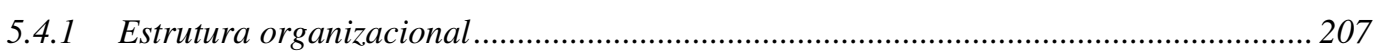

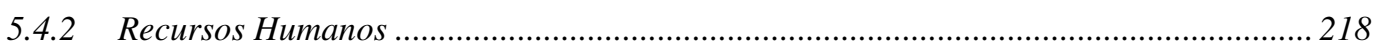

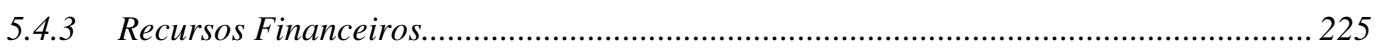

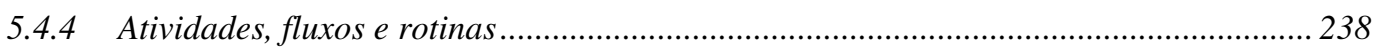

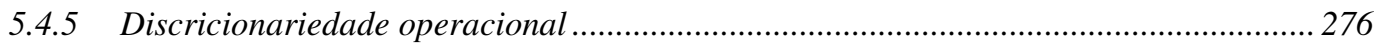


5.5 Aspectos conflituosos ENTRE A EXECuÇão do CEAF/PNAF E A EXECUÇÃO DE DEMANDAS JUDICIAIS

5.6 Síntese dos RESUltados dAS CATEgorias do CASO 02 - JUdiCIALIZAÇÃo DA SAÚDE 310

6 ANÁLISE INTEGRATIVA DOS CASOS ....................................................314

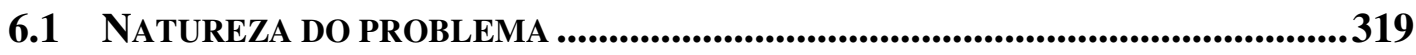

6.2 CONTEXTO SOCIAL, ECONÔMICO E POLÍTICO_................................................338

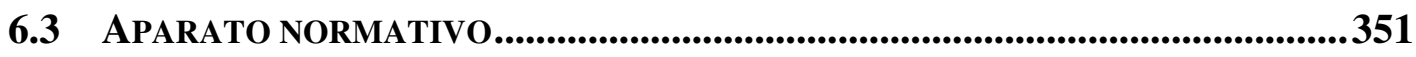

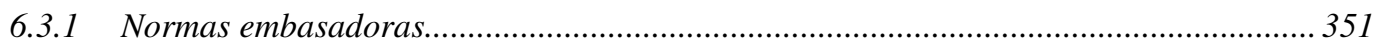

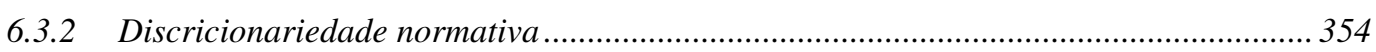

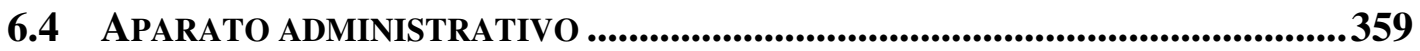

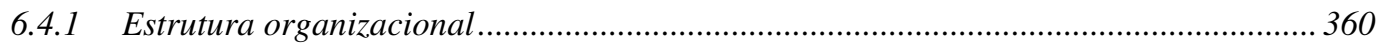

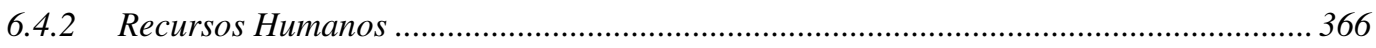

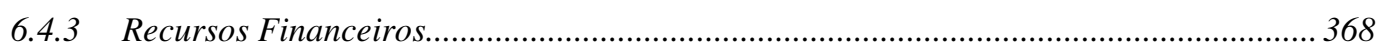

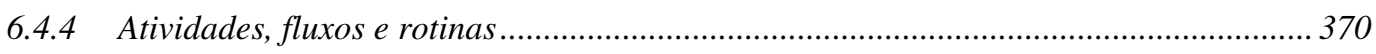

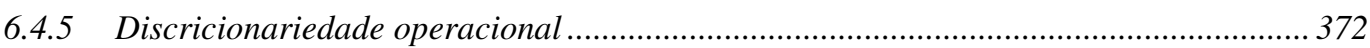

6.5 Aspectos conflituosos ENTRE A EXECuÇão do CEAF/PNAF E A

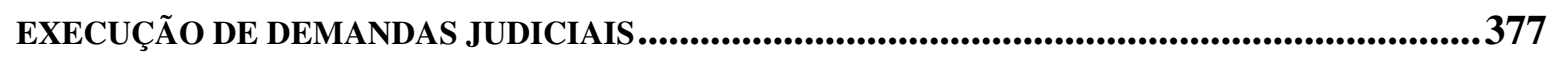

6.6 Propostas de modelos Quanto às ATIVIdades EnTre o Poder EXECUTIVO E O PODER JUdICIÁRIO ......................................................................................380

7 CONCLUSÕES E RECOMENDAÇÕES .......................................................389

REFERÊNCIAS ..................................................................................................399

AP $\hat{\boldsymbol{E}} \boldsymbol{N D I C E} \boldsymbol{A}$ - ORGANIZAÇÃO DAS ENTREVISTAS .........................................438

$\boldsymbol{A P} \hat{\boldsymbol{E} N D I C E} \boldsymbol{B}$ - ROTEIRO PARA ENTREVISTAS DOS ATORES DO SISTEMA

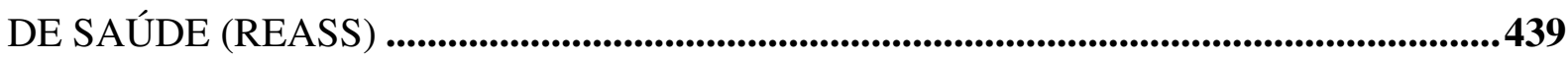

APÂNDICE $\boldsymbol{C}$ - ROTEIRO PARA ENTREVISTAS DOS ATORES DO JUDICIÁRIO (REAJ) 441

APÂEDICE D - ORGANIZAÇÃO DA PESQUISA DOCUMENTAL -

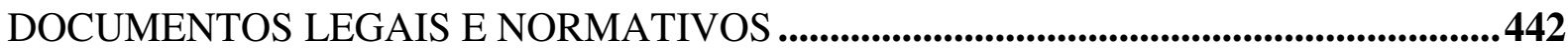

$\boldsymbol{A P} \hat{\boldsymbol{E} N D I C E} \boldsymbol{E}$ - ORGANIZAÇÃO DA PESQUISA DOCUMENTAL - ATAS .....451 $\boldsymbol{A P} \hat{\boldsymbol{E}} \boldsymbol{N D I C E} \boldsymbol{F}$ - ORGANIZAÇÃO DA PESQUISA DOCUMENTAL - LIVROS E MANUAIS 
APÂEDICE $\boldsymbol{G}$ - ORGANIZAÇÃO DA PESQUISA DOCUMENTAL JURISPRUDÊNCIAS E OUTROS REGISTROS JUDICIAIS

$\boldsymbol{A P} \hat{\boldsymbol{E} N D I C E} \boldsymbol{H}$ - ORGANIZAÇÃO DA PESQUISA DOCUMENTAL - SITES INSTITUCIONAIS 456

APÂEDICE I - ORGANIZAÇÃO DA PESQUISA DOCUMENTAL - NOTÍCIAS DO SISTEMA DE SAÚDE 458

$\boldsymbol{A P} \hat{\boldsymbol{E} N D I C E} \boldsymbol{J}$ - ORGANIZAÇÃO DA PESQUISA DOCUMENTAL - NOTÍCIAS DO SISTEMA JUDICIÁRIO. 460

$\boldsymbol{A P} \hat{\boldsymbol{E} N D I C E} \boldsymbol{K}$ - ORGANIZAÇÃO DA PESQUISA DOCUMENTAL - ARTIGOS CIENTÍFICOS

APÊNDICE L - RELAÇÃO DE NORMAS QUE AMPARAM A ASSISTÊNCIA FARMACÊUTICA BRASILEIRA E O CEAF/PNAF - PUBLICAÇÕES ENTRE OS ANOS 1970 E 1999. .464

APÊNDICE M - RELAÇÃO DE NORMAS QUE AMPARAM A ASSISTÊNCIA FARMACÊUTICA BRASILEIRA E O CEAF/PNAF - PUBLICAÇÕES ENTRE OS ANOS 2000 E 2005

APÊNDICE N - RELAÇÃO DE NORMAS QUE AMPARAM A ASSISTÊNCIA FARMACÊUTICA BRASILEIRA E O CEAF/PNAF - PUBLICAÇÕES ENTRE OS ANOS 2006 E 2010 . 466

APÊNDICE O - RELAÇÃO DE NORMAS QUE AMPARAM A ASSISTÊNCIA FARMACÊUTICA BRASILEIRA E O CEAF/PNAF - PUBLICAÇÕES NO ANO DE 2011

APÊNDICE P - RELAÇÃO DE NORMAS QUE AMPARAM A ASSISTÊNCIA FARMACÊUTICA BRASILEIRA E O CEAF/PNAF - PUBLICAÇÕES NO ANO DE 2012 468

APÊNDICE Q - RELAÇÃO DE NORMAS QUE AMPARAM A ASSISTÊNCIA FARMACÊUTICA BRASILEIRA E O CEAF/PNAF - PUBLICAÇÕES NO ANO DE 2013

APÊNDICE R - RELAÇÃO DE NORMAS QUE AMPARAM A ASSISTÊNCIA FARMACÊUTICA BRASILEIRA E O CEAF/PNAF - PUBLICAÇÕES NO ANO DE 2014

APÊNDICE S - RELAÇÃO DE NORMAS QUE AMPARAM A ASSISTÊNCIA FARMACÊUTICA BRASILEIRA E O CEAF/PNAF - PUBLICAÇÕES ENTRE OS ANOS 2015 E 2016. 
APÊNDICE T - ESTRUTURA ORGANIZACIONAL RESPONSÁVEL PELA IMPLEMENTAÇÃO DO CEAF/PNAF NO DF

APÊNDICE U - RECURSOS HUMANOS ENVOLVIDOS COM A IMPLEMENTAÇÃO DO CEAF/PNAF NO DF 473

APÊNDICE V - ÓRGÃOS E RESPECTIVAS COMPETÊNCIAS FINANCEIRAS RELACIONADAS À IMPLEMENTAÇÃO DO CEAF/PNAF NO DF 475

APÊNDICE W - ESTRUTURA ORGANIZACIONAL E RESPECTIVAS ATIVIDADES NA IMPLEMENTAÇÃO DO CEAF/PNAF NO DF 476

APÊNDICE X - RELAÇÃO DE NORMAS QUE AMPARAM A JUDICIALIZAÇÃO DA SAÚDE NO BRASIL - PUBLICAÇÕES ENTRE OS ANOS 1980 A 2005 478

APÊNDICE Y - RELAÇÃO DE NORMAS QUE AMPARAM A JUDICIALIZAÇÃO DA SAÚDE NO BRASIL - PUBLICAÇÕES ENTRE OS ANOS 2007 A 2009 479

APÊNDICE $\mathbf{Z}$ - RELAÇÃO DE NORMAS QUE AMPARAM A JUDICIALIZAÇÃO DA SAÚDE NO BRASIL - PUBLICAÇÕES ENTRE OS ANOS 2010 E 2011 480

APÊNDICE AA - RELAÇÃO DE NORMAS QUE AMPARAM A JUDICIALIZAÇÃO DA SAÚDE NO BRASIL - PUBLICAÇÕES ENTRE OS ANOS 2012 A 2016 481

APÊNDICE AB - SÍNTESE DO CONCEITO DE DISCRICIONARIEDADE JURÍDICA E SEUS ASPECTOS PRINCIPAIS 482

APÊNDICE AC - ESTRUTURA ORGANIZACIONAL RESPONSÁVEL PELO CONTROLE JURISDICIONAL DA PNAF NO DF E NA UNIÃO 483

APÊNDICE AD - RECURSOS HUMANOS ENVOLVIDOS COM O CONTROLE JURISDICIONAL DA PNAF NO DF E NA UNIÃO 484

APÊNDICE AE - ÓRGÃOS E RESPECTIVAS COMPETÊNCIAS FINANCEIRAS RELACIONADAS À JUDICIALIZAÇÃO DE MEDICAMENTOS 486

APÊNDICE AF - RELAÇÃO DAS DATAS DAS REUNIÕES DO COMITÊ EXECUTIVO DE SAÚDE DO DISTRITO FEDERAL

APÊNDICE AG - ESTRUTURA ORGANIZACIONAL E RESPECTIVAS ATIVIDADES NO CONTROLE JURISDICIONAL DA PNAF NO DF E NA UNIÃO.....489

APÊNDICE AH - RELAÇÃO DE NORMAS DA SAÚDE QUE AMPARAM A JUDICIALIZAÇÃO 
APÊNDICE AI - RELAÇÃO DE NORMAS IMPORTANTES PARA CONTRIBUIR COM A JUDICIALIZAÇÃO DA SAÚDE.........................................................492 


\section{PRÓlOGO}

Aproveito este possível espaço de discurso para apresentar um pouco dos motivos que me levaram à confecção das linhas que se seguem, tal qual elas aqui finalmente se apresentam.

Talvez não seja praxis a redação de um prólogo em arquivos acadêmicos de algumas áreas do conhecimento, porém, a abordagem qualitativa da pesquisa talvez reforce o ensejo de expor este histórico, uma vez que este pode ser um importante meio de reflexão sobre os pressupostos inerentes ao estudo de um objeto parcialmente conhecido pelo pesquisador. Assim, desde o início da presente pesquisa houve uma preocupação em compreender como o objeto se apresentava para mim e como a própria ciência dos métodos percebe o papel do pesquisador e seus pontos mais sensíveis em uma pesquisa qualitativa.

Este breve texto introdutório trata, portanto, de algumas questões de trajetória profissional e pessoal e, neste sentido, tem-se a opção da redação aqui existente em primeira pessoa do singular.

Desde a conclusão de minha graduação como farmacêutica, dei início à minha vida profissional como professora universitária em cursos de farmácia e em tantos outros da área da saúde. Como professora, tenho atuado em cenários de prática profissional, tais como: Hospitais Universitários (HUs), Hospitais Regionais (HRs) da Secretaria de Estado de Saúde do Distrito Federal (SES/DF) e Unidades Básicas de Saúde (UBSs) do Distrito Federal.

Tal experiência muito me evidenciou a realidade da Assistência Farmacêutica em serviços de maior e menor complexidade. Desde a gestão até o contato com o paciente/usuário do medicamento, tenho percebido as diversas dificuldades em garantir um atendimento completo às necessidades do cidadão. E, a cada dia, com maior intensidade, tenho o conhecimento de mais casos de judicialização de serviços e tecnologias de saúde.

Em paralelo ao meu labor, complementei minha formação me especializando na gestão de serviços e sistemas de saúde, e em meu curso de Mestrado abordei o processo de formulação da primeira política de medicamentos do Brasil.

Após estes estudos iniciais, a finalização do Mestrado me trouxe um desejo por desenvolver um atividade que pudesse gerar um impacto positivo no âmbito da saúde, ainda que pequeno. Ou seja, almejava trabalhar com uma agenda de pesquisa que pudesse refletir beneficamente para a prática profissional farmacêutica e, consequentemente, para o seu objetivo maior: garantir o cuidado à saúde e a melhora da qualidade de vida do paciente. 
E assim, já no primeiro ano do curso de Doutorado, a questão da judicialização era forte como ideia central de minha pesquisa de conclusão da presente etapa acadêmica, bem como uma força natural de compreender este cenário e estudar os atores envolvidos no referido processo.

Como profissional de saúde, a percepção sobre o crescente destaque que a judicialização vinha ganhando no dia-a-dia dos estabelecimentos de saúde, nas notícias da imprensa e nas discussões acadêmicas representava, para mim, um alerta sobre como tal prática vinha sendo organizada e como influía sobre o sistema de saúde. A preocupação latente desencadeou, então, a ideia original do estudo aqui exposto.

Durante o meu primeiro ano de Doutorado, o tema aqui abordado foi construído de forma bem preliminar, junto à minha professora orientadora. E nos anos seguintes, o assunto se apresentou a mim em diferentes situações, em meio às histórias e casos pessoais de sujeitos que passavam por minha vida.

Apesar das experiências descritas não garantirem um conhecimento exato do fenômeno definido como objeto de estudo da presente Tese, a reflexão sobre os pressupostos que eu tinha (ideias prévias e senso comum) era importante e de grande valia para gerar uma consciência mais clara de tudo o que o pesquisador traz para a pesquisa. Assim, sempre foi importante pensar e repensar os pressupostos que eu poderia trazer e torná-los evidentes nas diversas fases do estudo.

De fato, a partir do trabalho que se apresenta, creio ter sido possível adotar uma postura mais neutra durante a coleta, análise e redação dos resultados. E, de forma surpreendente, a análise se mostrou um campo bastante neutro, uma vez que os dados se mostraram novos e "falavam por si só".

Pensar no impacto que os serviços farmacêuticos têm sobre a qualidade de vida da população e sobre a garantia à saúde faz com que o tema aqui em destaque seja desafiador e instigante. Mas sendo o desejo de melhorar a pasta da Saúde no Distrito Federal e, potencialmente, contribuir com melhorias em outras regiões do Brasil, a força motriz para a confecção das linhas que se seguem, o cuidado sobre o desenvolvimento do método se tornou ainda mais prioritário.

Após as contribuições da Banca Examinadora para a presente pesquisa e o contato inicial com o objeto de pesquisa, alguns ajustes foram realizados até que o delineamento tenha se definido tal qual se apresentará nas próximas páginas. 
Como colocado por Montaigne (2000, p. 162) e acolhido por mim, transpondo para uma situação de desenvolvimento de um trabalho de pesquisa: "Ninguém faz o plano exato de sua vida, e só deliberamos momento a momento". Assim, o fenômeno que parecia ser conhecido por mim foi se desvelando de forma incrível durante a pesquisa.

Estando surpreendida pelos resultados, espero que a reflexão sobre o acesso aos medicamentos no Brasil e o contexto da judicialização contribua com a agenda de pesquisa supramencionada e reflita em melhoria prática para o nosso sistema nacional de saúde. 


\section{INTRODUÇÃO}

O Sistema Único de Saúde (SUS) deve disponibilizar ações e serviços que garantam o direito à saúde a todos os cidadãos brasileiros. Tal direito social compõe o direito fundamental da dignidade humana, garantido constitucionalmente. É, então, dever do Estado garantir a saúde por meio da prestação de serviços. Porém, em muitos casos, não há cobertura dos serviços necessários a todos os cidadãos. E é nestas situações em que o direito não é prestado de forma universal e integral e o serviço não é disponibilizado pelo SUS que o Poder Judiciário é acionado (SILVA et al., 2013; FERREIRA, 20110).

Neste sentido, o Poder Judiciário acaba demandando o atendimento às ações judiciais, em prol da concretização do direito à saúde. Porém, nem sempre as decisões deste Poder observam as Políticas de saúde relacionadas ou respeitam as normas orçamentárias. (MAZZA; MENDES, 2014). E também é reconhecido que o sistema judiciário não possui competência técnica para avaliar se o tratamento pleiteado é o adequado ao requerente da ação (SILVA et al., 2013).

Diante deste cenário, a presente Tese tem por norte compreender o processo de implementação do Componente Especializado da Assistência Farmacêutica/Política Nacional de Assistência Farmacêutica (CEAF/PNAF) frente à realidade da judicialização de acesso a medicamentos. Como parâmetro, as linhas a seguir destacam a contextualização e definição do problema de pesquisa, os objetivos e a delimitação da pesquisa, a justificativa e a relevância do estudo e modo como este se encontra estruturado.

\subsection{Contextualização do problema}

A Reforma Sanitária Brasileira foi resultado de um amplo movimento social acerca dos conceitos e das concepções de saúde, acarretando na incorporação de um novo modelo de saúde ao Estado. O envolvimento de diversos segmentos sociais àquele movimento refletiu o foco principal de uma mudança, que teve por base a ampliação dos direitos de cidadania, as mudanças nos paradigmas de atenção à saúde, os conceitos de igualdade e universalidade e o papel do Estado sobre a saúde coletiva (GERSCHMAN; SANTOS, 2006). Neste sentido, houve uma transição entre o sanitarismo campanhista, o modelo médico-assistencialista

privatista e o modelo neoliberal, a partir dos anos 1980. À época substituiu-se o Instituto Nacional de Assistência Médica da Previdência Social (INAMPS) e o Ministério da Previdência e da Assistência Social (MAPS) pelo SUS (PEREIRA, 1996). 
O modelo anterior ao SUS evidenciou muitas desigualdades sociais e a exclusão de parte da população, por ter sido financiado pela Previdência Social, por ter dividido as responsabilidades entre as instituições públicas e privadas e por ter remetido o usufruto do sistema à contribuição previdenciária. A VIII Conferência Nacional de Saúde (VIII CNS) foi responsável por um importante marco de discussões, em paralelo ao processo nacional de descentralização administrativa da saúde - característica do federalismo brasileiro (MENDES, 1999; BOBBIO, MATTEUCCI; PASQUINO, 1993; OLIVEIRA, 1987). O sistema de saúde vigente conseguiu, consequentemente, ampliar o acesso a uma grande parcela da população, mediante àquele movimento que teve origem na sociedade civil, e não pelo governo (PAIM et al., 2011).

No novo contexto, a Reforma Sanitária culminou em um modelo de saúde que é direito de todo cidadão e dever do Estado, conforme expresso no art. 196 da Constituição Federal (CF) de 1988, in verbis:

\footnotetext{
Art. 196. A saúde é direito de todos e dever do Estado, garantido mediante políticas sociais e econômicas que visem à redução do risco de doença e de outros agravos e ao acesso universal e igualitário às ações e serviços para sua promoção, proteção e recuperação.
}

Na década de 1990, apresentam-se como atos importantes a Lei Orgânica da Saúde Lei n. 8.080, de 19 de setembro de 1990 -, que regula as ações e os serviços de saúde, e a Lei n. 8.689, de 27 de julho de 1993, que extinguiu o INAMPS e transferiu as competências ao SUS.

Aquele novo e complexo sistema que surgia passava a seguir o princípio da descentralização, com gestão federal, estadual e municipal, de forma articulada e com papéis bem designados, garantindo, porém, a autonomia local para a priorização de problemas municipais (DRAIBE, 1992). Além deste princípio, outros previstos pela Lei Orgânica da Saúde são: a regionalização, a hierarquização, a resolubilidade e a participação complementar do setor privado (SILVA et al., 2013). Em tal processo de gestão também é possível observar a democratização do processo decisório e a participação social no planejamento, no monitoramento e na avaliação do SUS (BRASIL, 2009a).

A Lei n. 8.080/1990, além de dispor sobre a organização do SUS, também prevê que o sistema deve funcionar seguindo os princípios da universalidade, integralidade e equidade, para o atendimento em saúde. Estes regem as ações e os serviços em saúde, sobretudo, aqueles prestados no bojo da assistência farmacêutica (SILVA et al., 2013). 
Transversa a referida discussão está a compreensão primária de que a Carta Magna estabelece os valores, os princípios e as regras para o reconhecimento e a efetivação dos direitos ali previstos, de forma explícita ou implícita (CAMBI, 2007). Em seu art $1^{\circ}$, a CF de 1988 define o Estado democrático de direito e fundamenta o arcabouço dos direitos sociais na dignidade da pessoa humana e na garantia dos direitos fundamentais, a saber: a liberdade, a igualdade e o mínimo existencial. A liberdade se refere à autonomia existencial e é garantida pela não intervenção do Estado. A igualdade é o direito de ser tratado igualmente em relação aos outros cidadãos, e exige ações, por parte do Estado, para esta garantia. E o mínimo existêncial refere-se às condições básicas de saúde, educação, alimentação, trabalho, moradia, transporte, lazer, segurança, previdência social, proteção à maternidade e à infância e assistência aos desamparados (SILVA et al., 2013).

A partir da Carta Magna que está no cerne do ordenamento jurídico brasileiro, despontam os processos, como formas de garantir os direitos em questão (CAMBI, 2007). As demandas judiciais individuais podem ser o resultado do não atendimento do direito à saúde dentro das exigências legais previstas. Por exemplo, os princípios do atendimento universal (atendimento de todos) e da integralidade (atendimento do cidadão para todas as necessidades deste), muitas vezes, não são atendidos (SILVA et al., 2013).

Porém, tal entendimento passou por mudanças em sua aceitação, uma vez que até meados do século XX, o Poder Judiciário somente considerava a previsão de direitos redigidos em Lei como a fonte exclusiva das normas. Ou seja, as constituições não possuíam força normativa. Logo, o processo legislativo poderia omitir questões essenciais de proteção ao cidadão, ainda que houvesse previsão constitucional, e o Poder Judiciário não aceitaria como reclamo esse tipo de matéria. Com a fase neoconstitucional, mudanças importantes trouxeram o reconhecimento da força normativa da CF de 1988 e desenvolveram a interpretação e a jurisdição constitucional (FARIA, 2012).

Diante da mudança de paradigmas jurídicos, o Estado-Juiz ${ }^{1}$ passou à obrigação de cumprir os direitos fundamentais contidos na Carta Magna. Independente da redação de Lei, a jurisdição constitucional ganhou força para a proteção dos direitos transindividuais (SANTOS et al., 2012).

\footnotetext{
${ }^{1}$ Apesar da atribuição de prezar pelo cumprimento da Constituição Federal (CF) de 1988 pelo Estado, a opção pela denominação "Estado-Juiz", e não somente "Estado", se deu para diferenciar o poder em destaque nesse contexto. Partindo do conjunto de poderes do Estado, aquele que preza pela efetivação dos direitos sociais será o poder ou função jurisdicional, complementar às funções legislativa e administrativa. Destaca-se o uso do termo "Estado-Juiz" na literatura da área (FONTANA, 2009).
} 
$\mathrm{Na}$ presente pesquisa, o maior foco de discussão e análise aponta para o papel do Judiciário na garantia dos direitos - que possuem natureza indeterminada, por serem de interesse comum a toda a sociedade, sendo de todos e de ninguém específico, simultaneamente. Tal ação remete a uma abordagem jurisdicional que visa garantir os direitos coletivos, ao passo que também garante os direitos individuais. Ou seja, este novo paradigma de interpretação da própria Carta Magna gera a demanda de garantir a tutela adequada aos referidos direitos, ao mesmo tempo em que enfrenta desafios para manter a cientificidade do sistema processual em meio à dificuldade de resguardar o direito transindividual que conflita com outros interesses transindividuais (SANTOS et al., 2012).

A contribuir com os objetivos da CF de 1988 no que tange a questão da saúde, foram desenvolvidas políticas específicas farmacêuticas, como, por exemplo, a PNAF e a Política Nacional de Medicamentos (PNM). Estas orientam ações voltadas à garantia do acesso da população a medicamentos de qualidade e seguros, bem como ao uso racional dos mesmos, embasando mudanças importantes para a Assistência Farmacêutica (AF) brasileira (BRASIL, 2006a).

A PNM foi aprovada pela Portaria GM/MS n. 3.916, de 30 de outubro de 1998, e implementou um novo paradigma de AF básica. À época, havia a necessidade de regulamentação específica na área de medicamentos na pasta da saúde. Então, o processo de implementação da Política se deu no início de 1999, com o objetivo de assegurar à população o acesso aos medicamentos dispostos como essenciais, promovendo seu uso racional e garantir sua segurança, eficácia e qualidade. O objetivo final, neste sentido, se dá na melhoria da qualidade de vida da população. Os produtos devem estar disponíveis para atender a maioria dos problemas de saúde da população, segundo critérios epidemiológicos, quando a mesma necessite, nas formas farmacêuticas apropriadas (BRASIL, 1998).

A PNAF, oficializada pela Resolução CNS n. 338, de 06 de maio de 2004, originou algumas ações de Políticas setoriais e programas. Algumas destas foram: o incentivo ao desenvolvimento tecnológico de fármacos e medicamentos e redução da dependência externa quanto à produção de fármacos; a regulação e monitorização do mercado de medicamentos; a ampliação e qualificação do acesso ao medicamento; e, a racionalização e ampliação do financiamento da AF (BRASIL, 2004; BRASIL, 2006a). Neste sentido, tal Política direciona a formulação de outras Políticas setoriais, destacando as Políticas de ciência e tecnologia, de desenvolvimento industrial e as de medicamentos (BRASIL, 2004). 
Ainda sobre a PNAF, é preciso destacar que esta direciona a criação dos Programas dos Componentes Básico, Estratégico e Especializado da AF. Tais componentes são parte integrante do bloco de financiamento da referida Assistência, no que tange aos grupos de medicamentos disponibilizados pelo SUS e organizados em diferentes listas. O elenco dos medicamentos segue a prevalência de doenças e de programas governamentais específicos de tratamento e repasse de recursos para as esferas estadual e municipal (BRASIL, 2004; BRASIL, 2009b).

Seguindo as diretrizes estabelecidas pela PNM, os princípios e eixos estratégicos definidos pela PNAF, além dos princípios constitucionais, devem promover a organização do SUS no que compete ao aprimoramento dos instrumentos e das estratégias para a ampliação do acesso da população aos serviços de saúde e aos medicamentos. Foram definidos, a partir da Portaria GM/MS n. 204, de 29 de janeiro de 2007, os Componentes Básico, Estratégico, e Especializado da AF. Tais programas organizam o fornecimento de medicamentos pelo SUS, regulamentando as responsabilidades das esferas federal, estadual e municipal no processo de compra e disponibilização dos mesmos (BRASIL, 2009b).

O Componente Especializado foi regulamentado pela Portaria GM/MS n. 2.981, de 26 de novembro de 2009, e somente em $1^{\circ}$ de março de 2010, o termo anterior "Componente de Medicamentos de Dispensação Excepcional” foi substituído por "Componente Especializado da Assistência Farmacêutica”. Com a descentralização da AF no Brasil, os Estados agregaram a responsabilidade pela avaliação das prescrições dos medicamentos de alto custo, além da dispensação dos mesmos pelo Programa de Medicamentos Excepcionais. Junto à responsabilidade de cada ente federativo, foi definido um cofinanciamento para cada procedimento padronizado. Com a alteração do Programa e reorientação do mesmo para o Componente Especializado, tem-se uma maior garantia na integralidade do tratamento medicamentoso, por meio da definição prévia dos diagnósticos atendidos pelo programa e do elenco de tratamentos fornecidos para cada caso (BRASIL, 2010a).

Entre os componentes supramencionados, o Especializado (também denominado como de dispensação excepcional ou de alto custo) é um alvo importante de ações judiciais para o acesso aos medicamentos em todo o Brasil (PANDOLFO, DELDUQUE, AMARAL; 2012; BRANDAO et al., 2011; MACEDO, LOPES, BARBERATO-FILHO, 2011; MACHADO, 2011). Entre os estudos que abordam a referida temática, Macedo et cols. (2011) apresentam alguns dados que demonstram o perfil das ações judiciais impetradas à Secretaria de Estado da Saúde de São Paulo (SES/SP) entre os anos de 2005 e 2009. Ali foi possível observar que entre os medicamentos requeridos, $14,3 \%$ fazem parte da lista de medicamentos do 
Componente Básico, 19,5\% estão na lista do Programa do Componente Especializado (antigo Componente de Medicamentos Excepcionais) e 66,2\% não faziam parte de nenhuma lista. A partir daí, tem-se a percepção da existência de ações judiciais referentes a medicamentos que não estão previstos nas relações oficiais de medicamentos do SUS e ações relacionadas a medicamentos já previstos pelos programas governamentais.

Tal cenário não é incomum ou inesperado, uma vez que a partir da ampliação do exercício da jurisdição constitucional no Brasil, com o cumprimento da CF de 1988 e dos direitos sociais, várias questões sociais tiveram destaque e encaminhamentos ao sistema judiciário. Não foi diferente com a área da saúde em geral, já que os cidadãos se tornaram mais consciente de seus direitos, frente à redemocratização trazida pela Carta Magna (FONTANA, 2009). Assim, o debate sobre o direito à saúde tem sido deslocado para a área jurídica, pois, na falha ou omissão do Poder Público, o Poder Judiciário deve conferir eficácia a este direito (FERREIRA, 2011).

\subsection{Definição do problema de pesquisa}

O acesso aos medicamentos no Brasil reflete um cenário complexo, resultante da interação entre as diversas organizações e os atores dos poderes público e privado, das estruturas das Políticas e do sistema de saúde, das estratégias de implementação destas Políticas e da articulação entre a CF de 1988 e as normativas infraconstitucionais.

As Políticas são os meios para a concretização dos direitos fundamentais, e a sua implementação faz parte do processo de garantia de fornecimento de produtos e serviços aos usuários (FONTANA, 2009)

Atualmente, o Brasil possui normas específicas relacionadas à $\mathrm{AF}$ e ao acesso aos medicamentos em todo seu território. A PNAF orienta o fornecimento de medicamentos pelo SUS, gratuitamente, conforme evidências sobre seus efeitos e segurança para os tratamentos das doenças prevalentes. Tem-se, então, a previsão constitucional e de normativas infraconstitucionais de que o Estado deve garantir o fornecimento de medicamentos como meio importante para a garantia da saúde (MAZZA; MENDES, 2014; SILVA et al., 2013; FERREIRA, 2011; CAMBI, 2007).

Em contraponto a isto, há evidências de falhas na execução das Políticas de saúde e, em alguns casos, de AF. Nesta seara, o Poder Judiciário tem competência constitucional de garantir a concretização do direito à saúde. Logo, o sistema judiciário pode ser acionado para 
tais demandas e, mais do que isto, evidenciou-se um aumento no número de demandas judiciais nessa área os últimos anos (MAZZA, MENDES; 2014).

Sobre a questão, Barroso (2007) atenta que a judicialização se concretizou a partir do momento em que a Carta Magna ganhou força normativa - ação reforçada pelo aumento no ímpeto por defesa estimulado por movimentos sociais, além da ascensão do sistema judiciário.

Especificamente na área da saúde, o aumento das demandas judiciais pode estar relacionado à maior consciência dos usuários sobre a alternativa em questão, ou ainda, em relação aos medicamentos não incluídos nas listas padronizadas para a dispensação no SUS (VIEIRA; ZUCCHI, 2007). Por sua vez, o aumento da consciência sobre a via judicial de acesso aos medicamentos pode estar relacionado a uma maior divulgação da judicialização da saúde e/ou a um maior conhecimento sobre os direitos em saúde (INTERFARMA, 2016).

Neste ínterim, tem-se a existência de duas vias de fornecimento de medicamentos pelo Poder Público: a via regular, por meio das ações de AF do SUS, e a via judicial. Assim, são evidentes os problemas em potencial com a provisão de um mesmo produto por vias diferentes. Nos casos de intervenção do Poder Judiciário, será garantida a concessão de direitos a alguns cidadãos, em detrimento da coletividade. Logo, os demais cidadãos dependerão das Políticas universalistas para terem seus direitos atendidos. Em paralelo, a execução das demandas judiciais pode ainda deslocar recursos financeiros das Políticas de saúde.

Diante do cenário apontado, faz-se importante observar que os órgãos do Poder Executivo precisam lidar com as atividades paralelas do Poder Judiciário sobre os mesmos objetos de seu trabalho - aqui, o acesso aos medicamentos. Depara-se, então, com o problema relacionado a tais atuações, que ocorrem, simultaneamente, de modo prático. Logo, um dos grandes e atuais problemas da Administração Pública é compreender como se dá a implementação de Políticas de saúde e de medicamentos frente à introdução relativamente recente e crescente da judicialização e, a partir daí, propor soluções administrativas para os possíveis problemas a serem evidenciados. 


\subsection{Objetivos de pesquisa geral e específicos}

A partir do estudo do tema "Políticas Públicas", da observação do campo da saúde pública e da contextualização que identificou o cenário da judicialização de medicamentos, as linhas que se seguem tem por objetivo compreender o processo de implementação do CEAF/PNAF enquanto estratégia de acesso aos medicamentos pelo SUS e a judicialização da saúde. Para tal tem-se os seguintes objetivos específicos:

1) Descrever a implementação do CEAF/PNAF;

2) Descrever a operacionalização da judicialização de medicamentos no Distrito Federal;

3) Compreender a interface entre uma Política de saúde e a judicialização da saúde;

4) Identificar as influências da judicialização da saúde sobre a AF no Distrito Federal; e

5) Identificar os elementos positivos e as falhas no modelo existente de acesso aos medicamentos no Brasil por meio da dinâmica do SUS e do controle jurisdicional.

6) Propor um modelo operacional para a judicialização de medicamento.

\subsection{Delimitação da pesquisa}

A informação de que os medicamentos do CEAF/PNAF são alvos significativos de ações judiciais para a garantia de acesso à saúde os coloca como um grupo de medicamentos que deve ser estudado para a compreensão da situação da saúde pública e da judicialização da saúde no Brasil.

Além disso, a escolha de estudo da PNAF é importante, uma vez que a referida Política é um marco na área de AF, sendo a segunda Política de medicamentos do Brasil. Trata-se da Política que melhor definiu as frentes de ação para a Assistência em questão.

Portanto, pelo aumento significativo no número de ações judiciais para o acesso aos medicamentos do CEAF/PNAF ser uma questão de destaque na sociedade atual, trata-se de uma realidade importante no cenário governamental de implementação de Políticas e provisão de serviços.

Diante da contextualização do problema de pesquisa aqui evidenciado, observou-se na literatura uma lacuna quanto ao estudo da operacionalização da judicialização da saúde, no sentido de que não se tem uma investigação e/ou descrição sobre os processos administrativos que envolvem a atuação do sistema judiciário. 
E ainda, a discussão sobre as demandas judiciais na saúde não trata da investigação do processo de implementação da Política e suas interfaces com a atividade de judicialização.

Assim, a primeira delimitação do estudo diz respeito à investigação sobre a rede de implementação do CEAF/PNAF, especificamente, para a compreensão inicial da via de acesso aos medicamentos pela Política em questão. Como fenômeno paralelo, a pesquisa também se propôs a investigar a operacionalização da judicialização de medicamentos - a segunda via de acesso aos medicamentos.

De fato, tem-se um expressivo crescimento de ações judiciais por acesso aos medicamentos, acarretando em problemas relacionados ao orçamento de Municípios, Estados e até da União, tendo em vista que reduz o financiamento desses produtos pelas vias regulares de acesso pelo SUS (MACEDO; LOPES; BARBERATO-FILHO, 2011; VIEIRA; ZUCCHI, 2007).

A partir de tal constatação, a presente pesquisa teve por trajetória o estudo das influências do processo de judicialização sobre a Política de medicamentos elencada e a análise destes fenômenos em termos de gestão. Assim, deseja-se compreender melhor a coexistência da oferta de medicamentos pela via regular e pela via judicial de acesso aos medicamentos.

Não pretendem aqui ser objetos do estudo a diferença de acesso por cada componente de medicamentos da PNAF (Componentes Básico, Estratégico e Especializado), as possíveis causas da falha da Política de medicamentos ou o questionamento sobre a legitimidade da busca pela via judicial por parte do cidadão.

Para o entendimento dos fenômenos propostos, alguns pontos dificultadores se apresentam, a saber:

- O estado incipiente e fragmentado do conhecimento sobre o assunto, caracterizado pela falta de diálogo entre as diferentes áreas de conhecimento (saúde, direito e administração);

- A complexidade do problema de interesse que envolve várias áreas de conhecimento distintas; e

- A necessidade de acesso a diferentes fontes de informações necessárias para a compreensão de dois processos distintos (implementação de uma Política e judicialização de um direito).

Logo, pelos fenômenos centrais da pesquisa serem profundos e ainda inexplorados, a compreensão do problema é tarefa complexa. Aliado a isto, o CEAF/PNAF é estruturado 
seguindo os princípios da descentralização do sistema de saúde, o que significa que os diferentes entes federativos (União, Estados, Municípios e Distrito Federal) dividem responsabilidades sobre a gestão do componente.

Sobre o Distrito Federal, enquanto Unidade da Federação (UF), este reúne competências de Estado e de Município na organização do SUS e da AF. Além disso, a proximidade física entre os órgãos do Distrito Federal e da União acabam por gerar um padrão único de relação dos três níveis de governo, o que não é possível em outras localidades.

Em função das características supramencionadas, define-se como foco da pesquisa o estudo do Poder Público (Executivo e Judiciário) no Distrito Federal, pois, além dos dois Poderes descritos, é possível o estudo destes em dois níveis distintos, a saber: 1) o Federal; e, 2) o Distrito Federal.

A pesquisa delimita-se a estudar a implementação do CEAF/PNAF pelo Distrito Federal e pela União, além de estudar a operacionalização da judicialização da saúde na referida UF e na União.

\subsection{Justificativas da pesquisa}

O foco proposto para a pesquisa envolve um tema atual e que possui um grande impacto para a saúde pública, tanto em termos de gestão quanto orçamentários (MAZZA; MENDES, 2014). Logo, seu estudo se justifica pela importância teórica e prática que a análise da judicialização traz para a Administração Pública e para o controle judiciário.

No campo da Administração Pública, as linhas que se seguem tem relevância por estender os conhecimentos sobre a implementação de Políticas Públicas. Além disso, o objetivo de mapear os espaços, os atores e os processos envolvidos na implementação do CEAF/PNAF e na operacionalização do acesso aos medicamentos pela judicialização, contribui para a elucidação de contextos não antes descritos.

De acordo com a descrição dos Casos e com os produtos aqui gerados, é possível que tal análise possa também ser útil para discussões futuras acerca da implementação de outras Políticas Públicas, seja de saúde ou de outras áreas. Logo, as ações aqui manifestam poderão ser replicadas para outros casos.

A questão aqui em destaque é plural por envolver diferentes áreas profissionais e de estudo, como, por exemplo, a saúde, o Direito e a Administração. E ainda, a presente pesquisa justifica-se também pela realização de interlocução entre as distintas áreas de conhecimento 
com interesse no acesso aos medicamentos pelo Poder Público, a fim de ampliar o entendimento entre os diferentes profissionais envolvidos com a implementação dessa Política.

É compreensível que, atualmente, as discussões até o momento são ainda fragmentadas, e o presente estudo justifica-se também pela falta, até agora, de descrição do modus operandi da AF na vigência das ações judiciais observadas tanto no Distrito Federal, quanto nos demais Estados e Municípios. Logo, o estudo terá valia para possíveis discussões envolvendo outras regiões nacionais.

O trabalho aqui empreendido é relevante por buscar a identificação de possíveis problemas e a proposição de sugestões de aprimoramento das atividades envolvidas no processo de judicialização de Políticas de saúde, o que pode refletir na melhoria da qualidade da atenção à saúde, na ampliação do acesso aos medicamentos e na otimização dos gastos com a saúde.

Diante do alto custo dos medicamentos e da premissa de acesso universal e integral aos referidos produtos pelos cidadãos brasileiros, a presente pesquisa tem o potencial de contribuir com uma ampla descrição da temática e discussão sobre os desafios atuais para uma efetiva promoção da AF junto à judicialização e consequente efetiva assistência à saúde para a população.

\subsection{Estrutura da Tese}

A presente Tese está estruturada em sete capítulos, incluindo este capítulo introdutório.

O segundo capítulo trata da fundamentação teórica da pesquisa, que aborda quatro temas de importância para a análise dos casos estudados. O primeiro tema versa sobre o processo de implementação de Políticas Públicas e a discricionariedade administrativa. O segundo tema refere-se aos aspectos teóricos e às classificações de Alexandre (1998) sobre a coordenação governamental. A terceira subseção aborda as funções da Administração Pública propostas por Gulick e Urwick (2005). E o quarto assunto envolve uma revisão sobre o controle jurisdicional da Administração Pública.

No terceiro capítulo têm-se os métodos executados para a confecção da presente pesquisa. Para a classificação e explicação dos métodos adotados são desenvolvidas as subseções sobre a estratégia e a caracterização da pesquisa. Depois, são explicados e apresentados os modelos conceituais e as categorias de análise que embasam a codificação e a 
análise dos dados. E ainda, são descritos os procedimentos de coleta e análise dos dados, encerrando-se com a discussão sobre as limitações metodológicas aqui identificadas.

O capítulo quatro é o primeiro de três capítulos que tratam dos resultados. Este expõe o caso de implementação do CEAF/PNAF, apresentando os resultados da análise de cada uma das cinco categorias de análise, especificamente para o Caso 01, com base na identificação dos fluxos de implementação do CEAF/PNAF.

Já o capítulo 5 trata do Caso 02 do controle jurisdicional das Políticas de saúde, com ênfase na judicialização de medicamentos. Com estrutura idêntica a do capítulo quatro, este trata da análise das mesmas cinco categorias descritas em subseções. Aqui se tem ainda uma tipificação dos principais casos judiciais relacionados aos medicamentos e aos fluxos operacionais executados para cada tipo distinto.

Os dados apresentados nos capítulos 4 e 5 foram analisados sob a perspectiva de uma pesquisa exploratória e descritiva. Logo, as informações foram sistematizadas para que os dois cenários fossem compreendidos e detalhados. A partir daí, fez-se no capítulo 6 uma discussão integrada dos dois casos e a apresentação da construção de um modelo prático para a judicialização de medicamentos no Distrito Federal, que reúna os elementos identificados no presente estudo. Esta parte do estudo se deu à luz das teorias de implementação, de coordenação governamental, das funções administrativas e do controle jurisdicional de Políticas Públicas. Aqui ainda se tem uma linha histórica da implementação do CEAF/PNAF e a judicialização da saúde no Brasil, além de apresentar um modelo final de implementação de uma Política de saúde diante do fenômeno da judicialização.

O sétimo e último capítulo trata das conclusões finais sobre os resultados da pesquisa empreendida, apresenta suas contribuições teóricas e metodológicas e recomenda alguns novos estudos a partir da observação dos resultados aqui produzidos.

O trabalho se encerra com a relação de referências utilizadas na pesquisa, além de Apêndices. 


\section{REFERENCIAL TEÓRICO}

Nas linhas a seguir tem-se a fundamentação teórica que embasou e orientou a presente pesquisa. O primeiro tema abordado - a implementação de Políticas Públicas e programas públicos - foi fundamental para elucidar o problema de interesse. A partir do cenário previamente contextualizado sobre a saúde pública brasileira e o problema do acesso aos medicamentos, elegeu-se como foco o processo de implementação do Componente Especializado da Assistência Farmacêutica/Política Nacional de Assistência Farmacêutica (CEAF/PNAF), investigando o processo de demanda a medicamentos por via judicial. As categorias de análise utilizadas para orientar a coleta e análise dos dados tiveram por base a literatura que trata de implementação de Políticas Públicas. Acrescentou-se aqui a discussão sobre a discricionariedade administrativa, identificada na revisão de literatura como sendo um aspecto importante para a análise da implementação.

Aliado aos conceitos e às perspectivas da implementação, a própria análise dos dados apontou para a pertinência do estudo das discussões sobre as funções da Administração Pública e a coordenação interorganizacional, uma vez que os casos explorados na pesquisa em questão envolvem dois Poderes Públicos, onde nestes tem-se as organizações que participam nos processos de implementação da política e/ou de operacionalização da judicialização.

Por fim, são apresentados nesta parte do estudo os aspectos relacionados ao controle jurisdicional das Políticas Públicas, a fim de sustentar a análise quanto à atuação do Poder Judiciário frente às responsabilidades do Poder Executivo.

\subsection{A implementação de Políticas Públicas e a discricionariedade administrativa}

Antes de abordar o processo de implementação de uma Política Pública, faz-se importante resgatar, em primeiro lugar, a conceituação das Políticas Públicas, por apresentar elementos a serem considerados na análise do processo em questão.

Algumas definições trazem consigo características importantes, como a de Lynn (1980), que conceitua as Políticas enquanto ações governamentais criadas e viabilizadas para produzir resultados específicos. Posteriormente, tal definição é complementada com a ideia do governo poder decidir ou não em seguir por diferentes linhas de atuação ou de priorização de problemas, incluindo-se aí questões relacionadas aos interesses particulares, à racionalidade 
limitada e a outros fatores influenciadores sobre as decisões. Define-se, então, Política Pública enquanto uma escolha do governo sobre o que realizar ou não (DYE, 1984).

É possível acrescentar à conceituação de Lynn (1980) o entendimento de eficácia, eficiência e efetividade das Políticas Públicas, pois se espera que as ações empreendidas pelo governo atinjam os objetivos para os quais elas foram criadas, sendo executadas da melhor forma possível. Neste sentido, segundo Castro (2006), a eficácia se refere ao alcance dos resultados, enquanto a eficiência verifica a relação entre os recursos utilizados no processo, em termos dos custos e benefícios, e a efetividade afere os impactos das ações, onde o que importa são os benefícios que as ações geram para a população alvo.

O conceito de Dye (1984) considera que as Políticas envolvem um processo de escolha de ação por parte do governo. Em outro perfil de análise e discussão, tal elemento tem relação com a liberdade de escolha e a atuação do gestor dentro de suas funções públicas. Neste contexto, a liberdade diz respeito ao conceito de discricionariedade administrativa, que delimita a liberdade do gestor aos limites legais e dos princípios. A discricionariedade será a margem de atuação do administrador, onde ele deve eleger um comportamento que traga a solução mais adequada ao problema concreto, dentro dos parâmetros legais e segundo o princípio da razoabilidade (MARQUES, MARQUES; 2016).

Tem-se ainda a definição de Peters (1986), que interpreta a Política Pública como uma ação do governo que impacta na vida dos cidadãos. Já Mead (1995) entende que uma Política Pública seria a atuação do governo frente à identificação de problemas públicos - alvos dos estudos de cientistas políticos que poderiam auxiliar na melhora da atuação estatal por meio de mudanças nas instituições decisórias.

Em geral, é possível perceber que os autores supramencionados resgatam a ideia da complexidade do processo político governamental e a existência de fatores influenciadores à Política. Os cenários que envolvem as políticas são, de fato, complexos, a ponto de não permitir total previsão das preferências, dos interesses e das ideias dos atores envolvidos. Tudo isso é sintetizado por Lasswell (1936), cuja ideia é a de identificar na vida da Política Pública quais atores estão envolvidos e recebendo "o quê", "quando" e "como" no processo em questão.

No entanto, as Políticas Públicas não serão resultados somente das decisões do governo ou das decisões de grupos de interesse externos. Sobre a questão, Evans, Rueschmeyer e Skocpol (1985) pontuam que é a relação entre o governo e os grupos externos e internos de influência que define e molda as Políticas, caracterizando uma participação plural. E esta característica geral pode ser evidenciada na etapa específica de implementação, 
dependendo do problema priorizado, dos grupos de interesse envolvidos na temática e do contexto nacional.

Além dos conceitos apresentados, outros vários modelos trazem diferentes perspectivas para o estudo de uma Política, como, por exemplo, o ciclo da política pública (FREY, 2000), que apresenta os estágios de priorização de problemas, de definição de agenda, de formulação de alternativas, de tomada de decisão, de implementação e de avaliação das Políticas.

A etapa de implementação pode ser compreendida como aquilo que é desenvolvido entre o governo estabelecer uma intenção de ação e os impactos desta ação (O'TOOLE, 2000). Ou, ainda, como sendo as ações derivadas dos objetivos definidos para a Política. E se estes objetivos não são alcançados, pode haver um problema de gestão desta Política (MINOGUE, 1983). Em um terceiro olhar sobre o referido processo, Souza (2002) aponta que a implementação se refere à transformação de uma política em ação. Silva e Melo (2000) complementam Souza ao destacarem que durante a implementação existe um processo dinâmico entre as decisões e o que é implementado, um influenciando e modificando o outro, continuamente.

Apesar da classificação relacionada ao ciclo de vida de uma Política Pública apresentar as etapas supramencionadas (FREY, 2000), tais fases não são lineares ou com início e fim bem definidos. Na verdade, na prática, é possível compreendê-las enquanto processos dinâmicos, que se entrelaçam, se sobrepõem e se adaptam à cada caso.

O campo de análise de Políticas Públicas, inicialmente, compreendia a formulação como a etapa determinante para os resultados destas. Ou seja, a etapa de implementação estaria separada conceitualmente e empiricamente da formulação e os implementadores somente preencheriam o que foi planejado pelos formuladores. Porém, com base em muitos estudos de caso, sabe-se que os resultados não somente são moldados pelas condições da implementação, mas podem ser determinados por elas (PALUMBO; CALISTA, 1990).

Silva e Melo (2000) reforçam que a formulação não pode ser determinante único sobre os resultados finais, uma vez que contradiz a realidade onde não há informação perfeita passada até o implementador, clareza absoluta dos objetivos da política, recursos ilimitados para a implementação e regras e gestão perfeitas que atinjam os implementadores.

Ao encontro do que foi citado por Silva e Melo (2000), se não houvesse problemas com a implementação, as Políticas Públicas seriam todas eficazes, eficientes e efetivas quanto aos seus objetivos. Assim, tem-se contingências que afetam a execução das Políticas e moldam os sucessos e as falhas na implementação. 
A partir daí, não somente o desenho da Política pode apresentar ambiguidades e influenciar na implementação, mas também outras variáveis, quais sejam: a burocracia ou as organizações que implementam a Política, os outros atores que recebem essa incumbência do governo, os problemas gerenciais ou organizacionais, entre outros (LIPSKY, 1980).

Segundo Lipsky (1980), a burocracia se refere aos implementadores da linha de frente dos produtos e serviços, também chamados burocratas de rua (street-level bureaucracy). Estes seriam, na prática do sistema de saúde, os servidores (profissionais de saúde e técnicos administrativos atuantes nos serviços de saúde, por exemplo) que tem contato direto com o cidadão e podem ter a possibilidade de tomar decisões frente aos serviços que podem alterar o previsto na Política inicial.

Outros autores têm abordado a temática da implementação com conceitos relacionados aos decisores (principais) e aos executores (agentes). Aqui a burocracia é um agente executor e possui importância para a implementação da Política, conforme seus objetivos originais (KIEWIET; RODERICK; MCCUBBINS, 1991).

Nos estudos de implementação de Políticas Públicas, são identificáveis duas abordagens principais, a saber: 1) top-down; e, 2) bottom-up (MATLAND, 1995). A primeira pressupõe que somente representantes específicos da sociedade podem legitimar alterações, adaptações e a própria definição das Políticas. Assim, tem-se os formuladores (decisores políticos) e os implementadores (burocratas), sendo a implementação um processo linear e hierárquico. Já a abordagem bottom-up considera as condições, as ações e os comportamentos dos implementadores da linha de frente, frequentemente chamados "burocratas de rua", bem como dos usuários. Para estes últimos, a execução dos serviços pode interferir mais nos resultados que o próprio delineamento da Política (SILVA; MELO, 2000; PALUMBO; CALISTA, 1990).

No entanto, a dicotomia top-down versus bottom-up já é questionada por autores como Elmore (1979), Sabatier (1986) e Matland (1995), quanto à possibilidade de ser mais bem trabalhada e substituída por outros modelos que incorporem todos os elementos e reconheçam o processo de implementação com todas as suas variáveis e complexidade.

Elmore (1979) aprimora a perspectiva top-down e bottom up ao definir as abordagens forward mapping (que concentra a autoridade e controle sobre os formuladores, que definirão os passos específicos para o cumprimento das metas e intenções da Política) e backward mapping (que considera que o controle do processo está na etapa final da política, com os 
implementadores, mas que ainda pode haver um controle superior por meio de incentivos, barganhas e outras técnicas de persuasão).

A perspectiva bottom-up apresenta na atuação dos burocratas de rua o aspecto discricionário de agirem conforme possuem liberdade para tal e, potencialmente, tais ações podem interferir nos resultados das Políticas. Logo, em consonância ao referido entendimento e acompanhando os avanços propostos por Elmore (1979), Sabatier (1986) e Matland (1995), a presente pesquisa parte do pressuposto de que tanto os decisores quanto os implementadores contribuem com os resultados de uma Política durante a sua implementação.

Avançando ainda mais nesta perspectiva, nas linhas que se seguem, o mais adequado foi considerar um somatório das perspectivas, uma vez que, tendo sido identificado o Ministério da Saúde (MS) enquanto órgão formulador e implementador das Políticas de medicamentos, no que tange à problematização, percebe-se que na prática ocorre maior complexidade nestas relações do que o previsto na abordagem top-down.

Diante do exposto até aqui, é possível verificar que a literatura apresenta algumas variáveis influenciadoras no processo de implementação e que podem ser objeto de estudo para a análise das Políticas Públicas. Alguns exemplos seriam a ambiguidade no desenho da Política, os limites técnicos das organizações com a incumbência de implementar alguma Política, a influência dos burocratas que tomam decisões no momento de sua implementação, no sentido de alterar os desfechos esperados, entre outros (MAY, WINTER, 2007; LIPSKY, 1980). Ou seja, o monitoramento da Política durante a sua implementação poderia levar à identificação de tais questões, além da elaboração de ações corretoras de problemas, uma vez que a implementação de uma política é dinâmica por sofrer influência de tantas variáveis. Sobre a qustão, Pressman e Wildavsky (1984) assim sintetizam os fatores influenciadores: 1) ambiguidade no desenho da política; 2) existência de vários implementadores; e, 3) discricionariedade dos implementadores. Na presente pesquisa são de interesse os fatores (2) e (3).

A implementação envolve não somente a intenção por trás da Política, mas também a ação. Logo, a participação e relevância do papel do implementador pode impactar em maior ou menor grau a execução da Política (HILL; HUPE, 2005). Muitos autores apontam que a participação de múltiplos atores com ideias e perspectivas diferentes pode alterar a implementação de uma Política (PRESSMAN; WILDAVSKY, 1984). Entre esses múltiplos atores, além das coalizões que formam o governo, há os grupos de interesse e os movimentos sociais, considerando a existência de grupos formais e informais (PETERS, 1998). O 
formulador da Política, o decisor e o implementador podem, então, ser um mesmo ator ou um grupo de atores, e pode haver diferença de poder ou de papel entre eles.

Sobre os vários elementos supramencionados pelos diferentes autores e existentes na execução de uma Política Pública, Lima e D’Ascenzi (2013) estudaram os modelos analíticos de implementação daquelas que consideram estes elementos. Aqueles autores destacam dois modelos de análise, a saber: 1) a etapa de formulação e as normas derivadas dela; e, 2) o contexto onde a Política é implementada.

O primeiro modelo se assemelha ao modelo top-down (MATLAND, 1995), quando considera os formuladores como determinantes principais dos resultados das políticas; e o segundo modelo se caracteriza como o bottom-up (MATLAND, 1995), pois agrega força ao momento e aos atores envolvidos com a implementação em si.

O primeiro modelo considera a formulação como uma etapa de cunho político e que define as metas que devem ser alcançadas pela implementação - uma etapa administrativa e que visa cumprir o que foi especificado na formulação. Ou seja, a formulação tem característica decisória, e a implementação é de cunho técnico, de operacionalização. Neste sentido, a análise volta-se às normas, pois estas determinam o que será realizado na implementação. E espera-se que os formuladores possam desenhar a Política de maneira clara, para que os implementadores tenham menor margem para a discricionariedade (LIMA; D’ASCENZI, 2013).

Diante do exposto, Lima e D’Ascenzi (2013) reúnem quatro tipos de variáveis que influenciam o sucesso da implementação, a saber:

1) A natureza do problema alvo da Política (que inclui o tamanho da população-alvo e a existência de uma intervenção disponível e acessível);

2) As normas (grau em que o plano e seus objetivos claros definem a implementação);

3) O contexto social, econômico e político que pode influenciar a execução da política; e

4) A organização do aparato administrativo (inclui a estrutura organizacional e a disponibilidade e qualidade dos recursos humanos).

Como esta primeira proposta não considera que os processos políticos, tecnológicos e organizacionais podem alterar o curso da implementação e que os formuladores não detêm controles sobre estes aspectos, tem-se um segundo modelo proposto. Este, apresentado por Lima e D’Ascenzi (2013), ressalta que a discricionariedade dos implementadores é inevitável e pode ser benéfica ao processo. Então, a análise foca nos implementadores como os atores 
que conhecem as peculiaridades locais e no potencial de mudança da Política durante a sua execução. Ou seja, o processo pode não ser hierárquico, necessariamente, se houver definições posteriores à formulação feitas pelos implementadores, e pode não ser linear pelo potencial da implementação alterar a formulação (SILVA, MELO, 2000; MATLAND, 1995; PRESSMAN; WILDAVSKY, 1984).

$\mathrm{Na}$ presente pesquisa foram unidos os modelos, procurando equilibrar os elementos superestimados nos padrões de análise anteriores e considerando tanto o papel da estrutura normativa quanto da discricionariedade dos implementadores para a trajetória da Política e os resultados alcançados. São discriminados, portanto, como fundamentos para a análise da implementação os aspectos que se seguem: 1) a natureza do problema (tamanho da população-alvo e ação); 2) a estrutura normativa; 3) o contexto social, econômico e político; 4) a organização do aparato administrativo (estrutura organizacional e recursos humanos); e, 5) a discricionariedade.

E ainda foram levadas em consideração as contribuições de Easton (1965) para o estudo das Políticas Públicas, com a introdução inicial da importância do ambiente e dos próprios resultados das Políticas enquanto influência sobre a formulação. A partir daí, é possível inferir que a política é dinâmica e a sua implementação requer ou gera, muitas vezes, uma readequação frente à formulação inicial.

As considerações de Elmore (1989) e Silva e Melo (2000) sobre a limitação de recursos na implementação de Políticas e o dissenso dos implementadores (com discricionariedade) sobre a Política formulada também são correntes importantes que devem ser investigadas. Do mesmo modo, a existência de vários implementadores, como observado por Pressman e Wildavsky (1984), também é importante para a compreensão do problema em estudo, demandando uma ampliação da revisão teórica para a coordenação entre organizações na gestão governamental.

\subsection{Coordenação interorganizacional na implementação de Políticas Públicas}

Lotta e Vaz (2012) atentam para uma intenção de mudança nos arranjos institucionais brasileiros no sentido de passar do modelo de gestão hierarquizado, funcional e setorial (ainda muito presente) para um modelo sistêmico, transversal, intersetorial, participativo e voltado para a efetividade. Sobre a questão, Galvão, Lotta e Bauer (2012) esclarecem que estes novos arranjos institucionais não tem por base somente a melhora da coordenação do tipo federativa, mas sim, por novos tipos de relações que atendam aos problemas intersetoriais. 
Existem diversos tipos de arranjos possíveis para melhorar a articulação entre as organizações e potencializar os resultados das Políticas. Entre os quais, estão os arranjos intraorganizacionais, os interorganizacionais, os arranjos federativos e os arranjos entre as organizações públicas e a sociedade ou mercado. Para a análise da implementação, sob o ponto de vista dos arranjos institucionais, as investigações podem identificar os atores envolvidos no processo, como e se eles foram envolvidos antes da execução da Política, quais são as regras de incentivos, quais são as normas de repasse e quais são os papéis de cada envolvido (LOTTA; VAZ, 2012).

Silva e Melo (2000) ressaltam que não existe coordenação perfeita e que o processo de formulação não consegue controlar ou prever todos os aspectos envolvidos na implementação. Logo, existem problemas de coordenação intergovernamental, o que caracteriza a influência dos implementadores nos resultados das Políticas (contrariando a abordagem top-down). Neste sentido, é importante que a Política tenha espaço para as decisões também durante o processo de implementação, pois será nesta etapa que as dificuldades operacionais rotineiras se evidenciarão e deverão ser tratadas.

Ao encontro disto, a coordenação interorganizacional remete a um processo coletivo, onde mais de uma organização se envolve para a tomada de decisão em prol de um objetivo comum. Ou seja, para as Políticas que possuem muitos atores interessados e envolvidos nos processos, tem-se a proposta de trabalho em redes, com o desenvolvimento de relações interorganizacionais e, principalmente, mediante a criação de mecanismos de coordenação entre tais organismos (BARBOSA; MEDEIROS, 2005).

Sobre as relações interorganizacionais, Grandori e Soda (1995) elencam alguns mecanismos possíveis para a articulação entre organizações, em uma rede interorganizacional, a saber: 1) mecanismos de formação de rede (network mechanisms); 2) mecanismos de comunicação, decisão e negociação; 3) mecanismos de coordenação social e controle; 4) mecanismos de integração dos papéis e responsabilidades; 5) estruturas de coordenação de pessoal; 6) usufruto de métodos de coordenação horizontais e de relações hierárquicas e de autoridade, a depender da situação; 7) sistema de planejamento e controle; 8) sistemas de incentivo; 9) sistemas de seleção; 10) sistemas de informação; e, 11) infraestrutura e apoio público.

Alexander (1998) trata da temática da coordenação interorganizacional ao afirmar que existem vários níveis para as estruturas de coordenação. Neste sentido, aquele autor comenta que os termos relacionados à coordenação foram diferentes ao longo dos anos. Primeiramente, houve menção ao termo "mecanismos de coordenação". Posteriormente, surgiram os termos 
"formas ou formatos de coordenação", "esquemas ou sistemas de coordenação" e "estruturas de coordenação" - este último, assumido por Alexander (1998) em seus trabalhos, é definido como a forma pela qual os mecanismos de coordenação relacionam os centros de decisão de uma organização ou de várias organizações em um sistema interorganizacional.

Sobre as estruturas de coordenação, Alexander (1998) definiu três níveis de estruturas, pois havia a lacuna teórica, à época, sobre as possíveis formas que a coordenação poderia tomar. O primeiro nível, que diz respeito ao contexto da relação, é chamado de metaestrutura, que envolve todo o sistema interorganizacional e caracteriza o maior nível dos elementos sociais e organizacionais. A estrutura define as características básicas de interação, sendo três os tipos de coordenação identificados no nível meta, a saber: 1) relações de mercado (caracterizadas pelo ajuste espontâneo das relações entre partes autónomas via preços, ou seja, com o objetivo de garantir a troca de recursos e atividades entre as organizações envolvidas, estas terão suas relações ajustadas na melhor forma para as devidas trocas e para os interesses comuns pelo mecanismo de preço); 2) relações solidárias (tampouco apresentam hierarquia em suas relações - as trocas neste tipo de relação são mediadas por compartilhamento de valores e afiliações comuns); e, 3) relações hierárquicas (são aquelas nas quais as organizações tem por base de suas ações e interações o uso da autoridade).

Um segundo nível de coordenação é denominado por aquele autor como mesoestrutura e diz respeito às diferentes formas que podem ser assumidas por um arranjo interorganizacional. Distinguindo as formas, é a relativa importância atribuída aos elementos de mercado, solidariedade e hierarquia. Em um extremo seriam as associações onde não se tem relações de hierarquia, tampouco relações de mercado. As tribos, os clãs e as comunas coletivas são exemplos deste tipo de arranjo. No outro extremo tem-se as associações onde não há relações solidárias nem relaçóes de mercado, como, por exemplo, as organizações condutoras - para o sistema interorganizacional, haverá uma organização que será a responsável pela coordenação das demais organizações da rede (ALEXANDER, 1998; BARBOSA; MEDEIROS, 2005). Entre os extremos de rede solidária e rede hierárquica existem pontos intermediários representados por uma variedade de arranjos que possuem uma mistura dos três elementos supramencionados, com maior peso para um ou outro destes. $\mathrm{Ou}$ seja, podem apresentar características de mercado, aliadas às características hierárquicas e solidárias. São exemplos deste tipo de redes interorganizacionais: as alianças, as joint ventures, as associações, as federações e os consórcios. 
Por fim, Alexander (1998) identifica as microestruturas de coordenação, que podem ser caracterizadas por relações informais ou mais institucionalizadas. Como exemplos de mecanismos informais têm-se os contatos interpessoais em reuniões, o compartilhamento de informação por meio de ligações telefônicas ou correspondência entre as partes e a realização de reuniões pontuais entre representantes de organizaçoes interessadas em determinada questão. As comissões, as coordenações ou os comitês são exemplos de relações formais.

Por fim, espera-se que, a partir da perspectiva da coordenação interorganizacional, a melhora no desempenho das Políticas Públicas e nas práticas de gestão pública no Brasil (LOTTA; VAZ, 2012).

\subsection{Funções da Administração Pública}

Suresh (2016) explica que, em 1937, Gulick e Urwick apresentaram um trabalho voltado à definição de Administração Pública, bem como uma proposta em prol da melhora desta. Aqui se deu a apresentação do acrônimo POSDCORB, que possui letras que sustentam, cada uma, um princípio. A letra $\mathrm{P}$ relaciona-se a planejar algo, a letra $\mathrm{O}$ é de organizar; a letra $\mathrm{S}$ é de apoio de pessoal; a letra D significa direcionamento ou guia; a letra $\mathrm{C}$ indica coordenação; a letra R significa registro; e, por fim, a letra B sugere o termo "orçamento".

Aquele autor comenta que a fórmula supramencionada fez muito sucesso na Administração Pública dos Estados Unidos da América (EUA) e do Reino Unido, porém, possui um limitante. Ele explica que se surgirem novas questões ou demandas nas organizações, uma vez que sua gestão não logrará seguir somente uma linha pré-definida ou uma mesma fórmula "eternamente". Ou seja, o acrônimo propõe uma fórmula limitada, que não responde a todas as questões, o que limitaria a sua aplicação prática.

Talbott (1987) aponta que os componentes mais conhecidos para as atividades de gestão já criadas foram os elementos articulados por Gulick e Urwick. Aquele autor destaca que existem elementos relacionados às atividades de gestão (management), para níveis de execução das atividades meio e atividades fim, e aspectos relacionados às atividades de administração (administration), para níveis de decisão nas empresas.

No caso do POSDCORB, sua proposição se deu como componentes para a gestão e, desde sua criação, vários outros componentes ou termos foram adicionados por outros autores, incluindo-se as funções de avaliação, comunicação, controle, inovação e representação (TALBOTT, 1987). 
A título de ilustração e diferenciação, como exemplos de elementos já propostos para a administração (administration), têm-se os seguintes aspectos: estrutura, estratégia, recursos humanos, estilo gerencial, sistemas e procedimentos, conceitos e valores compartilhados e forças e habilidades corporativas (TALBOTT, 1987).

Timney (1995), que se aprofunda em teorias orçamentárias, destaca a importância da função orçamento do acrônimo para a área pública. Aquele autor reforça que o acrônimo foi um avanço, pois incorporava ideias como, por exemplo, de eficiência e de tomada de decisão racional.

Pindur, Rogers e Kim (1995), por sua vez, reforçam que o POSDCORB se refere às sete atividades muito bem conhecidas para a gestão e que sua criação surgiu a partir de um trabalho de Gulick e Urwick desenvolvido com base nos ensinamentos de Henri Fayol.

A proposta de Pindur et cols. (1995) é de que as sete funções do acrônimo sejam universais para a gestão das organizações. Logo, Gulick e Urwick pretendiam analisar as práticas administrativas e criar regras gerais para as mesmas, pois pensava que as características das organizações advêm dos administradores para a formulação de ideias para uma gestão efetiva, e que as organizações eram hierárquicas. O POSDCORB também tem por base o entendimento de que cada gestor consegue supervisionar um número limitado de indivíduos, de que os funcionários devem trabalhar em unidades de comando para conhecerem exatamente suas funções e de que as organizações não devem combinar atividades muito diferentes nas mesmas unidades. Tais pressupostos foram importantes contribuições de Gulick para o fenômeno da departamentalização (PINDUR, ROGERS, KIM; 1995).

Cabe destacar que o modelo de Gulick e Urwick traz as funções administrativas que contribuem para as estruturas de gestão e para o entendimento da função do executivo (PINDUR, ROGERS, KIM; 1995).

Abordando o trabalho dos autores Gulick e Urwick (2005), o POSDCORB se refere a todo o trabalho de responsabilidade do chefe do Poder Executivo como exemplo representativo de quem exercerá tais funções. O termo reúne elementos funcionais do trabalho no Poder Executivo. E, conforme apontado por aqueles autores, as funções se relacionam às ações de gestão e administração, uma vez que os termos "management" e "administration" perderam suas características específicas. 
Retomando as funções administrativas, o POSDCORB se refere às seguintes atividades ou elementos:

1) Planejamento - trata-se do trabalho de organizar e programar as tarefas que precisam ser feitas e os meios para tal, para que sejam atingidos os objetivos da organização;

2) Organização - é o estabelecimento de uma estrutura de autoridade formal, com as subdivisões de atividades, que é definida e coordenada em busca do objetivo da organização;

3) Apoio de pessoal/assessoramento - são as atividades de recrutamento e treinamento de recursos humanos, além do trabalho envolvendo o estabelecimento de um bom ambiente de trabalho e clima organizacional;

4) Direção - é a função de tomar decisões e incorporá-las em regras e instruções gerais ou específicas, utilizando-as para agir como um líder da organização;

5) Coordenação - é a função de estabelecer e manter as inter-relações das várias partes do trabalho;

6) Registro (informação) - trata-se de manter a comunicação e o repasse das informações sobre o andamento das atividades entre os envolvidos nos processos, o que inclui manter os subordinados e o próprio gestor ciente das situações, por meio das informações provenientes de registros, de pesquisas e de inspeções internas; e

7) Orçamento - a última função refere-se às atividades relacionadas ao orçamento, tanto na forma do planejamento fiscal, da contabilidade e do controle fiscal (GULICK; URWICK, 2005).

Entende-se que, a partir desta relação de funções, os gestores lograrão encontrar um padrão dentro do qual se encaixará a maior parte das atividades e dos deveres que se apresentam no trabalho no sistema executivo. Gulick e Urwick (2005) atentam que é necessária a adoção de todas as funções, a partir do momento em que se aceita a incorporação do POSDCORB, e que o adequado seria a organização e a separação destas funções como subdivisões do executivo.

As funções administrativas apresentadas embasam a presente pesquisa do ponto de vista da análise das atividades detectadas para cada um dos Casos que serão apresentados. E, aliadas aos fundamentos teóricos abordados (o processo de implementação e a atividade de coordenação), visam a análise do fenômeno estudado da perspectiva dos elementos da Administração Pública. 


\subsection{Controle jurisdicional da Administração Pública}

A previsão constitucional do direito à saúde acabou por gerar duas consequências naturais, a saber: 1) a obrigatoriedade da oferta dos serviços em saúde aos cidadãos brasileiros, a partir da formulação e implementação de políticas governamentais; e, 2) a busca pela via judicial para a garantia de seus direitos, quando entendido como necessário, por parte do cidadão (MACEDO; LOPES; BARBERATO-FILHO, 2011).

A Constituição Federal (CF) de 1988 estabeleceu o Estado Democrático Brasileiro cujo ordenamento jurídico tem por base o princípio fundamental da dignidade da pessoa humana. A este se unem os valores supremos da Carta Magna, quais sejam: igualdade, justiça, liberdade, segurança, bem estar e desenvolvimento e direitos fundamentais à vida e à integridade física. Estes últimos estão diretamente relacionados ao direito à saúde e todo o conjunto de direitos que caracteriza o Estado como um Estado Social de Direito, que objetiva a justiça social e o alcance dos direitos subjetivos, como, por exemplo, o direito à saúde (SANTOS, 2012).

O Estado deve prover condições para que os cidadãos vivam dignamente e usufruam de ações que garantam a sua saúde. Logo, a CF de 1988 demanda que o Estado preste serviços para a garantia de alguns direitos, denominados direitos positivos. Ou seja, a Carta Magna determina que o governo deve garantir os direitos existenciais mínimos e, ao mesmo tempo, determina que o Estado tem o dever de intervir na proteção dos direitos fundamentais (SANTOS, 2012). Neste sentido, o Poder Judiciário é provido da função constitucional de controlar a garantia dos direitos fundamentais na sociedade (BARROS, 2016; SANTOS, 2012).

O neoconstitucionalismo traz a concepção de que a CF de 1988 possui força normativa e deve ser atendida, independentemente da existência de dispositivos infraconstitucionais. Assim, os direitos supramencionados devem, necessariamente, ser efetivados pelo Poder Público por meio das Políticas Públicas. Ou seja, não há discricionariedade administrativa no sentido de definir a concretização ou não destes direitos de acordo com a conveniência do Poder Executivo (BARROS, 2016).

A aplicação de ações que garantam a provisão dos direitos constitucionais é, então, de responsabilidade dos Poderes Executivo e Legislativo, quanto à execução e a previsão orçamentária destas ações (LEITE, 2012). E conforme a Carta Magna tem-se ainda o Poder Judiciário, já que a organização do Estado Brasileiro se dá por três Poderes. A este terceiro Poder é incumbida a função de impor ao Poder Público a positivação de um direito, ou seja, a 
concretização de um direito que está falho. Normalmente, a atuação do sistema jurídico é acionada diante da omissão ou ineficácia das Políticas Públicas - algo considerado como uma violação do direito fundamental (BARROS, 2016; GOMES, 2012; LEITE, 2012).

São exemplos de direitos sociais: a saúde, a educação, a moradia, a segurança, a previdência social, o trabalho, o lazer, a proteção à maternidade e à infância e a assistência aos desamparados (BARROS, 2016). Sendo a saúde um dos direitos sociais, as ações propostas pelo governo devem estar alinhadas não somente com as leis infraconstitucionais, mas também com os princípios constitucionais. Logo, o que pode vir a ser analisado e julgado, em casos de falhas, será a legalidade e a constitucionalidade dos atos administrativos (CALADO, 2016).

A literatura jurídica explica que, ainda que não haja uma solução que harmonize a necessidade de prestação dos direitos sociais com os investimentos necessários para realizálos, os limites orçamentários não são uma justificativa para a omissão da Política Pública. Neste sentido, é possível que os recursos disponíveis não sejam suficientes para a execução das Políticas Públicas, acarretando a necessidade do gestor em fazer escolhas e priorizar algumas ações em detrimento de outras. Tal fato não justifica a omissão ou falha da prestação do direito, uma vez que é preciso considerar as escolhas realizadas pelo gestor e a utilização adequada do orçamento disponível (BARROS, 2016). Sobre a questão, Spink (2003) reforça o entendimento de orçamento limitado e necessidade de maior eficiência para os governos ao implementar Políticas Públicas diversas.

Souza (2001) aborda a importância da democracia, da participação dos cidadãos nas Políticas Públicas, do empoderamento e do orçamento participativo, que objetiva, entre outros aspectos, uma distribuição mais equânime dos recursos escassos. Logo, a perspectiva de estudar o orçamento participativo traz como vantagem ao processo de implementação de uma Política Pública e à análise da judicialização a possibilidade de beneficiar grande parte da população e garantir maior poder decisório para esta.

Para o direito à saúde, é dever do Estado o fornecimento de ações e serviços que garantam atendimento integral e com acesso universal e igualitário aos cidadãos. Nesta pasta, o acesso aos medicamentos é entendido não somente como direito à saúde, mas estende-se como direito à vida. E por este ser um direito subjetivo e assegurado à generalidade dos indivíduos, os direitos fundamentais possuem supremacia, conforme o entendimento do Supremo Tribunal Federal (STF). Logo, o fornecimento de medicamentos relaciona-se à garantia do direito à saúde, à vida e à dignidade da pessoa, sendo lícito até mesmo a 
judicialização de medicamentos não registrados pela Agência Nacional de Vigilância Sanitária (ANVISA) (LEITE, 2012).

Há algumas características do Sistema Único de Saúde (SUS) também dispostas na CF de 1988. O princípio da unicidade do sistema é o primeiro quesito, que determina que o sistema seja operado pelos três entes federativos. Logo, todos são responsáveis pela prestação do direito à saúde. Outros princípios são: a universalidade (que garante o acesso de todos os cidadãos aos serviços de saúde) e a integralidade (que confere o acesso aos serviços de todas as complexidades que sejam necessárias para a sua condição de saúde) (GOMES, 2012).

Santos (2012) afirma que os países em desenvolvimento, como, por exemplo, o Brasil, não conseguem garantir a dignidade aos seus cidadãos, o que amplia de forma crescente a busca por soluções judiciais para garantir efetividade aos direitos constitucionais.

Os processos judiciais que reivindicam o acesso aos medicamentos se mantêm desde a década de 1990, iniciados com as primeiras ações relacionadas aos medicamentos antirretrovirais para Human Immunodeficiency Virus/Acquired Immunodeficiency Syndrome (HIV/AIDS), e até hoje crescem em quantidade e custos. São características importantes observadas em todos os Estados brasileiros: o atendimento a essas ações com base quase unicamente na prescrição medicamentosa; ações relacionadas aos medicamentos que já estão ou não incorporados na Assistência Farmacêutica (AF) do SUS; ações relacionadas aos medicamentos sem registro sanitário no País ou sem a indicação clínica reconhecida pelo órgão regulatório; e, por fim, ações normalmente relacionadas a uma solicitação individual (PEPE et al., 2010).

Para ilustrar os investimentos nesse setor, os gastos do MS com medicamentos, no ano de 2003, chegaram a quase $\mathrm{R} \$ 2$ bilhões, correspondendo a 5,8\% do orçamento daquela pasta. Já em 2010, o valor atingiu R \$ 6,5 bilhões, correspondendo a 12,5\%; aliado à extinção da Contribuição Provisória sobre Movimentação Financeira (CPMF) e à discussão pela aprovação da Emenda Constitucional (EC) n. 29, de 13 de setembro de 2000, que regulamenta o financiamento da saúde brasileira (BRASIL, 2010).

Para melhor discriminar, no ano de 2007, o gasto do MS com medicamentos foi de $10,7 \%$ do seu orçamento e, mesmo assim, foram gastos adicionalmente mais de R\$ 500 milhões para o atendimento das ações judiciais (MACEDO; LOPES; BARBERATO-FILHO, 2011).

Por um lado, os processos judiciais acarretam aos gestores a incumbência de realocar recursos previstos para as ações coletivas, para casos individuais ou de poucos. Tais situações vão de encontro ao próprio princípio da equidade em saúde e, potencialmente, da 
universalidade, em função do contingenciamento de recursos (ANDRADE et al., 2008). E ainda, as ações se concretizam, muitas vezes, por meio do deferimento de recursos referentes aos medicamentos já previstos para dispensação pela via regular de acesso, podendo-se questionar a avaliação técnica dos casos. Ou seja, existem casos onde os objetos das ações são medicamentos já constantes na lista nacional de medicamentos para disponibilização pelo SUS, e outros casos em que são solicitados medicamentos não constantes nas listas e, portanto, de eficácia e segurança questionáveis para a indicação clínica apresentada pelo proponente da ação.

Sobre a questão, Vieira e Zucchi (2007) apresentam um estudo onde $38 \%$ dos medicamentos solicitados por ações judiciais contra a Secretaria Municipal de Saúde (SMS) da cidade de São Paulo não constavam em listas de medicamentos do governo. Destes, ainda assim, $73 \%$ poderiam ser substituídos por medicamentos existentes em listas do SUS. Inclusive, a substituição poderia trazer maior segurança ao tratamento, já que $75 \%$ dos gastos foram destinados aos medicamentos que ainda requerem mais estudos para comprovação de sua eficácia clínica.

Partindo-se de um conceito de governança que envolve as regras administrativas, os regimes legais e judiciais e as práticas que prescrevem ou constringem ações governamentais, é possível perceber que as políticas normalmente estão sujeitas aos fatores intervenientes, direcionadores, priorizadores (HILL; HUPE, 2005). Neste sentido, em relação aos fatores que podem influenciar uma Política Pública, a questão da judicialização da saúde vem sendo debatida em diferentes áreas de conhecimento.

Muitos autores na área do Direito, como, por exemplo, Ferreira (2011), percebem a judicialização da saúde como uma intervenção do Poder Judiciário sobre as atribuições dos demais Poderes quanto à condução de Políticas Públicas. Porém, estes também compreendem o papel do Direito na redução da desigualdade social, frente aos fatores dificultadores (a coexistência das esferas coletiva e individual e a problemática da alocação de recursos, por exemplo). A literatura da área propõe, então, refletir se a judicialização da saúde pode contribuir para a melhoria do sistema com uma orientação para a equidade.

Na área da saúde, a judicialização é colocada por Ferraz (2010) sob a preocupação da escassez de recursos para o atendimento das necessidades da população para a proteção da saúde. Aqui aquele autor defende que a alocação desses recursos deve seguir a lógica de justiça distributiva, protegendo a justiça social. Compreende-se, portanto, que os mandatos judiciais garantem a eficácia do direito à proteção da saúde, porém, de indivíduos específicos, e não da coletividade. Ou seja, para este entendimento, a Política Pública estaria sofrendo uma 
intervenção judiciaria, um direcionamento quanto à alocação de recursos, e uma priorização de alguns indivíduos frente à totalidade.

Ferraz (2010) ainda destaca uma comparação de alocação de uma mesma quantidade de recursos para dois fins. No ano de 2008, o MS teve um gasto de cerca de R 400 milhões para atender parte do calendário de vacinação de seis milhões de crianças menores de 02 anos de idade. Em paralelo, o Estado de São Paulo dispendeu o mesmo valor no cumprimento de ações judiciais que beneficiaram aproximadamente, e somente, 35 mil indivíduos.

Compreende-se, então, que o sistema judiciário tem atuado cada vez mais em prol da efetividade constitucional e como protetor dos direitos existenciais mínimos. Tal atuação se dá pelo controle do Poder Público responsável, determinando o cumprimento de demandas judiciais que caracterizam a prestação de algum direito social (BARROS, 2016). No caso do direito à saúde, percebe-se que o SUS não é autossuficiente no atendimento das demandas da população, o que faz com que os cidadãos também busquem as decisões compulsórias emitidas pelo sistema judiciário para o cumprimento deste direito (LEITE, 2012). 


\section{METODOLOGIA}

A presente pesquisa tem por objetivo propor um modelo prático de implementação de Políticas Públicas de medicamentos junto à judicialização da saúde.

Para demonstrar como se procurou alcançar o objetivo geral, bem como os objetivos específicos mencionados no capítulo Introdução, as linhas que se seguem assim destacam a estrutura da presente Tese: 1) caracterização geral da pesquisa, onde se define a finalidade, a estratégia, o alcance temporal, o caráter das evidências e as fontes das evidências; 2) a apresentação das categorias de análise utilizadas na pesquisa, bem como dos modelos conceituais - utilizados para orientar a coleta e análise de dados; 3) as etapas da operacionalização da pesquisa e o tratamento dos métodos de coleta e análise de dados; e, 4) apontamento de algumas limitações metodológicas.

\subsection{Caracterização geral da pesquisa}

No entendimento de que o objeto da presente pesquisa reflete uma realidade complexa, pela própria natureza humana das relações sociais, a jornada aqui empreendida demandou a interpretação do significado dos processos revelados na análise dos dados. Portanto, o paradigma de análise aqui adotado para a construção do conhecimento é de cunho interpretativista (DENZIN, 2006).

E com a interpretação do fenômeno e a obtenção de experiência específica a partir do método desenvolvido, as proposições e o conhecimento construídos seguem o raciocínio indutivo. Logo, as interpretações derivam um conhecimento potencialmente aplicável a objetos semelhantes (SILVERMAN, 2009).

Além da perspectiva epistemológica, é importante definir para o estudo suas características quanto à finalidade, a estratégia, o alcance temporal, o caráter das evidências e as fontes das evidências.

\subsubsection{Finalidade}

Em termos de finalidade, a pesquisa pode ser exploratória, descritiva ou explanatória (GIL, 2009; CRESSWELL, 2007). O primeiro tipo - exploratório - é utilizado quando os objetos do estudo são pouco conhecidos, cuja investigação pode trazer informações para outras pesquisas. A segunda finalidade é a descritiva, que descreve o fenômeno em seu 
contexto. E a terceira é a explanatória, que objetiva explicar relações causais, com base em uma teoria (GIL, 2009; CRESWELL, 2007).

O presente estudo caracteriza-se como exploratório e descritivo. É exploratório por se tratar de uma abordagem nova, no que tange a ampla descrição proposta para o cenário do acesso de medicamentos no Distrito Federal. O estudo exploratório possibilita melhores esclarecimentos sobre os processos sociais e suas variáveis (CRESSWELL, 2007). Já a abordagem descritiva prevê a identificação das características do processo de implementação de uma Política Pública e as influências de atores sobre tal processo, ou seja, a descrição da realidade em estudo (GIL, 2009). Logo, além da finalidade exploratória, a pesquisa agrega também a descritiva, concomitantemente.

\subsubsection{Estratégia}

Pelo foco principal do presente estudo voltar-se para a implementação de uma Política de saúde e da judicialização do objeto de tal Política (isto é, o acesso a medicamentos), a estratégia utilizada na pesquisa em questão é a investigação, em profundidade, destes dois processos, além da realização de uma análise integrativa entre os resultados obtidos.

$\mathrm{O}$ modelo de pesquisa em questão foi adequado para o alcance dos objetivos geral e específicos do presente estudo. Pois, sendo o objetivo geral da pesquisa compreender o processo de implementação do CEAF/PNAF enquanto estratégia de acesso aos medicamentos pelo SUS e a judicialização da saúde, os objetivos específicos delimitam as etapas para o alcance do objetivo geral. Neste sentido, faz-se importante, primeiramente, compreender como se dá a implementação da Política em si (primeiro objetivo específico). Em paralelo, é igualmente necessário compreender o fenômeno da judicialização e como se opera o processo (segundo objetivo específico). Como fenômenos que se relacionam, faz-se importante também entender os pontos de interface entre as atuações dois sistemas (Executivo e Judiciário) quanto à Política em questão (terceiro objetivo específico).

A análise dos fenômenos, a identificação das características necessárias e a identificação das influências da judicialização sobre o processo de implementação (quarto objetivo específico) complementam o entendimento das relações entre os dois sistemas, uma vez que a identificação das influências acrescenta uma compreensão melhor da relação entre a implementação da Política e o seu controle pelo Judiciário. 
Por fim, a identificação dos pontos positivos e das falhas do fluxo atual (quinto objetivo específico) torna possível a proposição de um novo modelo operacional da judicialização de medicamentos.

Destarte, fez-se uma investigação qualitativa na forma de um estudo de múltiplos casos (YIN, 2001), uma vez que a estratégia adotada oferece um potencial de descrições e explanações profundas e bem fundamentadas para casos de ocorrência natural na sociedade. Ou seja, o método qualitativo aproxima o pesquisador dos participantes e ao contexto da pesquisa, e os dados qualitativos obtidos possibilitam a compreensão de realidades complexas como aquela aqui investigada - o objeto de pesquisa envolve fenômenos sociais do mundo objetivo e subjetivo (MILES; HUBERMAN; SALDAÑA, 2014).

Yin (2001) diferencia as estratégias de pesquisa (experimentos, pesquisas históricas, levantamentos, estudos de caso e análise de informações em arquivos) quanto à finalidade em três tipos, a saber: 1) o tipo de questão de pesquisa; 2) o nível de controle que o pesquisador tem sobre o evento estudado; e, 3) o foco em acontecimentos históricos ou mais contemporâneos. O estudo de caso é indicado em situações que apresentam questões de pesquisa do tipo "como" e "por que", onde o pesquisador tem pouco controle sobre o evento e cujo foco se dá em acontecimentos contemporâneos.

Os estudos de caso, enquanto estratégias para a compreensão de eventos particulares, podem envolver casos únicos ou múltiplos casos e até vários níveis de análise (EISENHARDT, 1989). Neste sentido, os casos aqui evidenciados envolvem diferentes níveis de análise sob a perspectiva dos níveis federativos. Ou seja, cada um dos casos é investigado nos níveis federal e distrital, e dependendo da categoria (se mais conceitual ou mais operacional), tem-se a identificação e discussão dos resultados para cada um destes níveis.

Benbasat, Goldstein e Mead (1987) apontam que o estudo de caso é apropriado para fenômenos que são observados em seu ambiente natural, para os quais não se realiza manipulação ou controle de variáveis e, de preferência, com a observação de múltiplas fontes de evidências.

Para fenômenos ainda não explorados, cujas características ainda não estão bem definidas, o estudo de caso é relevante (MACNEALY, 1997). Tal estratégia qualitativa de pesquisa, segundo Macnealy (1997), é capaz de prover informações do contexto onde o evento está inserido, bem como evidenciar informações do próprio evento (caso) em estudo. Além disso, o estudo de caso pode fornecer informações ricas em detalhes sobre problemas que ainda não foram bem definidos ou explorados. 
Cresswell (2007) sugere que é o contexto que determina o número de casos a serem investigados. Assim, para o fenômeno de interesse da presente pesquisa, dois casos foram selecionados. Estes, em suma, são as duas formas ou vias de acesso atualmente existentes aos medicamentos fornecidos pelo poder público: a via regular de acesso aos medicamentos do Componente Especializado da Assistência Farmacêutica/Política Nacional de Assistência Farmacêutica (CEAF/PNAF) e a via judicial de acesso aos medicamentos.

É preciso destacar que os dois casos aqui apontados não são exatamente equiparáveis. Cada uma das vias possui características peculiares, sobretudo, porque são originadas de dois Poderes diferentes do governo, a saber: 1) Executivo; e, 2) Judiciário. A pesquisa empreendida nos mesmos foi necessária para o entendimento global do fenômeno.

A título de melhor definição dos cenários e compreensão dos resultados dos casos em questão, a 'via regular de acesso' é aquela proveniente da implementação do CEAF/PNAF, por intermédio do sistema de saúde (ramo executivo), e a 'via judicial de acesso' é proveniente da judicialização da saúde, por intermédio do sistema de justiça (ramo judiciário).

A implementação do CEAF/PNAF foi, então, estudada e apresentada nos resultados do Caso 01, e a judicialização de medicamentos foi apresentada no Caso 02. Cada qual foi estudado em dois âmbitos, a saber: o federal e o distrital.

Em estudos de caso é recomendada a aplicação de múltiplas fontes de informação, para o melhor entendimento do objeto. Sobre a questão, Miles, Huberman e Saldaña (2014) apontam que a utilização de casos múltiplos acrescenta confiabilidade aos achados, por ampliar as fontes de informações.

$\mathrm{Na}$ seleção dos casos que devem ser pesquisados é recomendada a aplicação do princípio da lógica da replicação. Além de empregar os mesmos instrumentos e procedimentos em todos os casos estudados, existem dois tipos possíveis de aplicação do princípio, a saber: 1) a lógica da replicação literal; e, 2) a lógica da replicação teórica. $\mathrm{Na}$ replicação literal, a seleção tem por norte os casos que levam a resultados semelhantes ao final do estudo (pelas características dos casos selecionados), e na replicação lógica tem-se aqueles que apresentam condições teóricas diferentes na expectativa de resultados contrastantes, mas por razões previsíveis (DUBÉ; PARÉ, 2003; YIN, 2001). Assim, na presente pesquisa foram aplicados os mesmos procedimentos planejados para poder revelar as diferenças e compreendê-las, sendo esta constituída de múltiplos casos, de natureza qualitativa, exploratória e descritiva. 


\subsubsection{Alcance temporal}

Quanto ao alcance temporal, a pesquisa se dá modo transversal, porém, com perspectiva longitudinal (VIEIRA, 2004). A princípoios, entende-se a importância da análise do fenômeno e de suas transformações ao longo do tempo.

O presente estudo retrata o fenômeno da judicialização de medicamentos abordando dois objetos, a saber: 1) a implementação do CEAF/PNAF; e, 2) a judicialização de medicamentos. Para cada qual se fez um resgate histórico quanto à saúde pública e à judicialização da saúde, desde as mudanças previdenciárias entre os anos 1930 e 1945 até o ano de 2016 para a saúde pública; e para a judicialização, desde a Constituição Federal (CF) de 1988, que deu início a este processo, até 2016.

Além dos resgates históricos e com o auxílio destes, tem-se a observação e descrição do funcionamento atual dos sistemas de acesso aos medicamentos pela Política, e de acesso pela judicialização, respectivamente.

\subsubsection{Caráter e fontes das evidências}

Os dados qualitativos são fontes de informações com potencial para desvelar uma realidade ampla e inexplorada, pois podem retratar um objeto sem dissociá-lo do contexto no qual está inserido, o que garante maior confiabilidade às informações (MILES; HUBERMAN; SALDAÑA, 2014). E isto é particularmente pertinente na presente pesquisa, uma vez que o estudo do fenômeno da judicialização da saúde, sob o aspecto de análise proposto, ainda não tinha sido realizado. Neste sentido, a investigação teve cunho qualitativo, e as finalidades supramencionadas, exploratória e descritiva.

Ao encontro das informações anteriores, segundo Creswell (2007), a abordagem qualitativa permite ao investigador a exploração de casos únicos ou múltiplos casos. Assim, a escolha do caráter dos dados se alinha à estratégia da pesquisa.

Para lidar com a interpretação de realidades sociais e apresentar características peculiares, adotou-se, então, a lógica qualitativa de pesquisa. Neste sentido, o estudo fez uso de uma combinação entre entrevistas em profundidade (fontes primárias) e documentos do tipo institucionais e artigos científicos (fontes secundárias) (SILVERMAN, 2009; BAUER; GASKELL, 2008; BRYMAN, 1988). 
Segundo Yin (2001), o estudo de caso é uma pesquisa que tem por base várias fontes de evidências, com a organização formal dos dados do estudo e com uma relação lógica entre os objetivos da pesquisa, as evidências identificadas e as conclusões do trabalho. Aquele autor reforça a importância de triangulação dos dados de fontes distintas, confrontando evidências de uma variedade de perspectivas que focam em um mesmo fenômeno. Tais evidências podem ser provenientes de documentos, entrevistas, observação direta, observação participante, entre outros.

Com o objetivo de atender ao rigor metodológico proposto por Yin (2001) e Yanow (2006), a presente pesquisa reuniu quatro fontes de evidências distintas para o esclarecimento do fenômeno, trabalhando-as em triangulação na procura de um relato rico, compreensivo e robusto.

Antes de apresentar como os dados supramencionados na presente pesquisa foram coletados e trabalhados, expõe-se, primeiramente, os aspectos conceituais teóricos que orientaram as ações de coleta e análise.

\subsection{Modelos conceituais e categorias de análise}

Para a operacionalização do presente estudo foram elaborados, inicialmente, dois modelos conceituais, elecando-se as categorias utilizadas para a coleta e análise dos dados dos casos analisados.

Os dois modelos conceituais iniciais elaborados a partir da problematização e da fundamentação teórica propiciaram a seleção adequada das fontes de evidências, bem como a escolha das formas de coleta e análise dos dados apropriadas.

A problematização realizada evidenciou a existência de duas vias para o acesso aos medicamentos fornecidos pelo poder público. Neste sentido, foram propostos dois modelos conceituais preliminares para a pesquisa. $\mathrm{O}$ primeiro modelo é o acesso via a implementação da Política (CEAF/PNAF) por implementadores da União e do Distrito Federal, cuja existência se deu na revisão documental preliminar. Porém, como informações ainda não elucidadas, questionou-se como seriam as relações entre os vários órgãos do Poder Executivo envolvidos quanto à função de garantir o acesso aos medicamentos do CEAF/PNAF aos usuários do sistema de saúde.

O modelo conceitual proposto para o Caso 01 foi esquematizado na Figura 3.1, a seguir. 


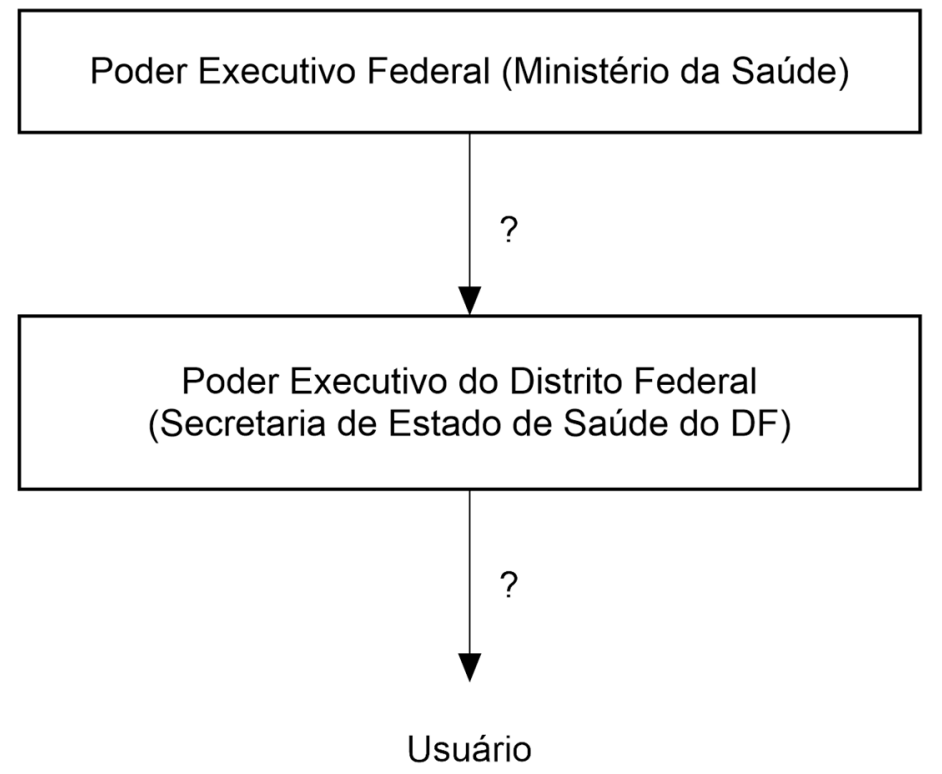

Figura 3.1 - Modelo conceitual para o Caso 01 - Assistência Farmacêutica - Componente Especializado da Assistência Farmacêutica/Política Nacional de Assistência Farmacêutica.

Fonte: Da autora.

O segundo modelo conceitual (vide Figura 3.2, a seguir) foi proposto para o Caso 02, que teve por base informações identificadas durante a problematização do objeto da pesquisa. Este ainda se refere ao modo como se dá a judicialização da saúde, quanto às relações estabelecidas entre os órgãos do sistema de saúde, os órgãos do sistema judiciário e o usuário (no caso, o usuário do sistema de saúde ou o cidadão brasileiro usuário do sistema judiciário) no Distrito Federal e na União. 


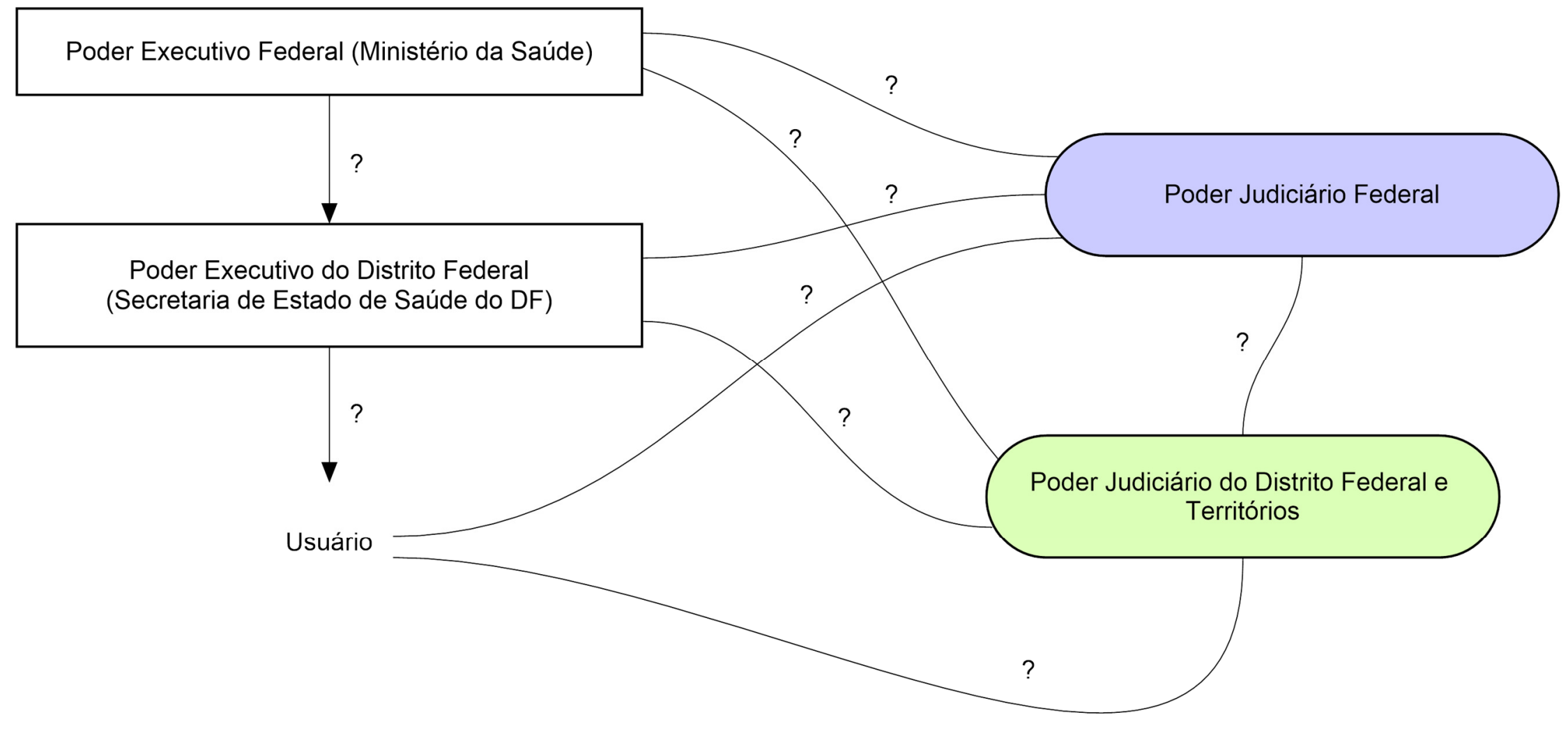

Figura 3.2 - Modelo conceitual para o Caso 02 - Judicialização da saúde. Fonte: Da autora. 
Os modelos supramencionados já refletiam parcialmente a realidade do fenômeno de interesse, uma vez que identificam os órgãos envolvidos, tanto a nível federal quanto a nível distrital. E, a fim de levantar os dados necessários para o cumprimento dos objetivos específicos e preencher as lacunas dos modelos gerais de relações para os Casos 01 e 02, fezse necessária a definição dos elementos a serem investigados em cada um dos Casos, ou seja, das categorias de análise.

A construção das categorias de análise teve por base a literatura de implementação de Políticas e programas públicos, possibilitando o elenco das variáveis relacionadas à execução de ações públicas. Neste sentido, a definição das categorias atende à investigação de atividades do Poder Público e, ao mesmo tempo, respeita a necessidade de levar em consideração o funcionamento do sistema executivo e do sistema judiciário em prol de um mesmo direito constitucional, e a exigência metodológica de que as mesmas categorias de análise sejam aplicadas em um estudo de múltiplos casos (YIN, 2001), Em suma, percebeu-se a adequação das categorias apontadas com respeito à análise de ações governamentais na literatura de implementação de Política Pública para a caracterização de ações estatais gerais. Logo, seriam apropriadas para averiguar tanto a implementação de uma Política quanto a operacionalização da judicialização de uma Política.

Para a definição das categorias, o trabalho realizado por Lima e D’Ascenzi (2013) foi particularmente relevante, uma vez que reuniu os elementos trazidos por autores clássicos das duas principais abordagens da literatura de implementação de Políticas Públicas, quais sejam:

1) A natureza do problema alvo da Política (que inclui o tamanho da população-alvo e a existência de uma intervenção disponível e acessível);

2) As normas (grau em que o plano e seus objetivos claros definem a implementação);

3) O contexto social, econômico e político que pode influenciar a execução da Política;

4) A organização do aparato administrativo (inclui a estrutura organizacional e a disponibilidade e qualidade dos recursos humanos); e

5) A discricionariedade.

A partir do conjunto de variáveis em questão, que é resultado da combinação dos modelos analíticos apresentados por Lima e D’Ascenzi (2013), fez-se uma relação preliminar de categorias para o presente estudo, apresentado na Figura 3.3, a seguir. 


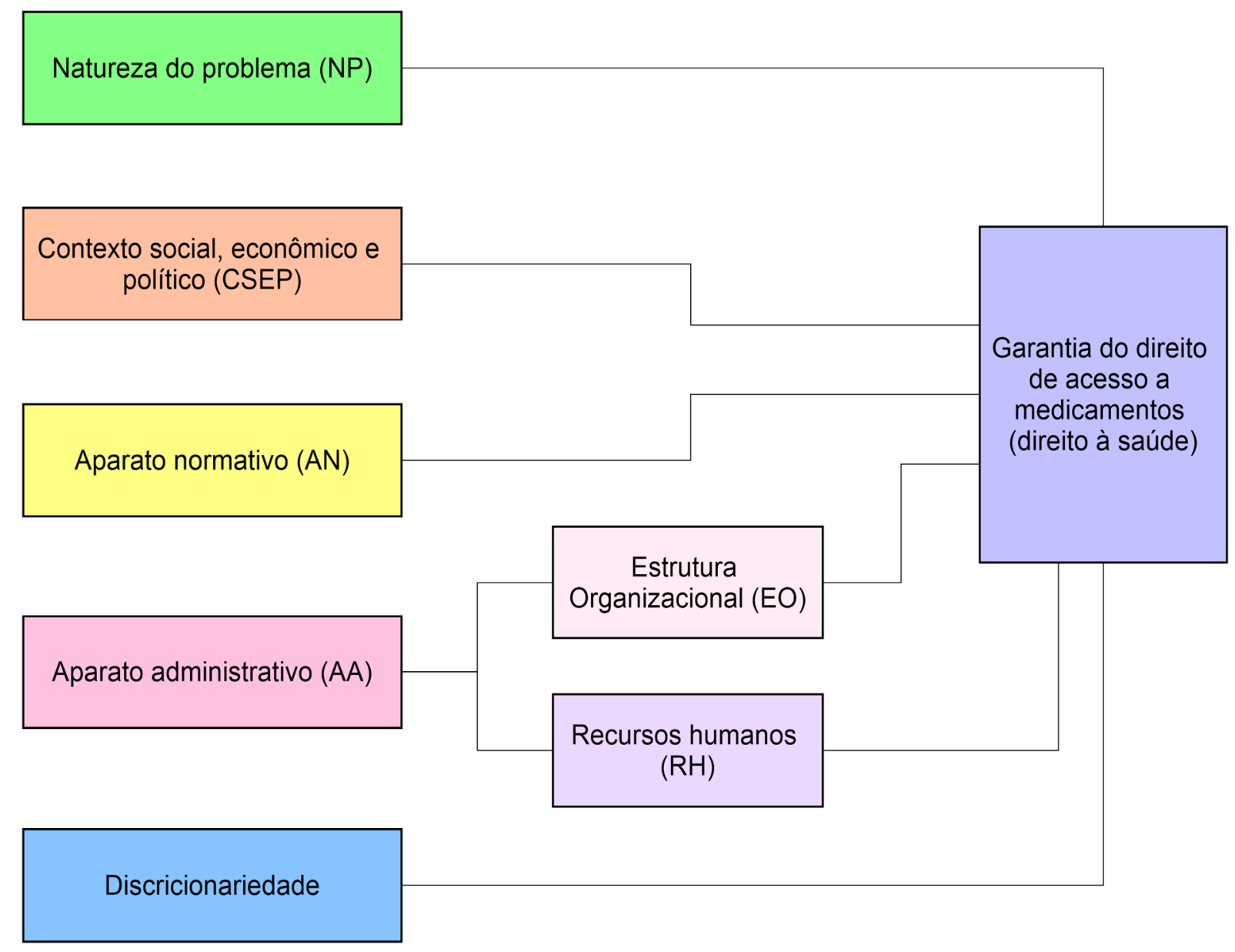

Figura 3.3 - Categorias de análise preliminares para o estudo.

Fonte: Da autora.

Após o início do processo de coleta e análise preliminar de dados, a relação de categorias foi ajustada, conforme o objeto da análise.

Um dos ajustes realizados foi o desmembramento da categoria discricionariedade em duas subcategorias, motivado pela evidência dos dados que apontam para matizes importantes no conceito em questão. Primeiramente, quanto ao conceito em si, é preciso considerar que a discricionariedade diz respeito à liberdade de atuação do profissional frente às limitações legais para sua atuação. Neste sentido, a pesquisa preliminar para a compreensão dos objetos de estudo identificou que tal elemento pode ser tratado de duas formas distintas, a saber: 1) tem-se a limitação normativa para a atuação dos profissionais (existe, de fato, a liberdade que as normas garantem à atuação do profissional); e, 2) o uso em si da discricionariedade e como os profissionais, de fato, agem em suas funções; ou seja, como estes fazem uso de suas liberdades de atuação. Entendeu-se, portanto, a existência de uma margem para diferentes 
ações e que, dependendo do caso estudado, o profissional pode fazer uso de formas diferentes ou mesmo não fazer uso desta liberdade.

Diante do exposto, a categoria inicial denominada discricionariedade foi redefinida como discricionariedade 'normativa' e discricionariedade 'operacional', qualificando a liberdade prevista das normas e o uso desta, respectivamente. E as novas subcategorias foram incluídas, respectivamente, nas categorias Aparato Normativo (AN) e Aparato Administrativo (AA), de acordo com a afinidade de conteúdo com cada uma delas - a primeira se refere à normatização, e a segunda, ao modus operandi. Para o $\mathrm{AN}$, em função da inclusão da subcategoria discricionariedade 'normativa', foi imprescindível a criação de outra subcategoria para o conteúdo inicialmente designado à categoria. Assim, criou-se a subcategoria das normas embasadoras; ou seja, a categoria original AN ficou constituída por duas subcategorias, a saber: 1) normas embasadoras; e, 2) discricionaridade 'normativa'.

Como esclarecimento, faz-se o uso das aspas simples para os subtipos de discricionariedade por serem termos introduzidos e sugeridos a partir desta pesquisa, sem antecedente teórico e conceitual, com o intuito, então, de destacar uma particularidade para os termos em questão.

Outra alteração que se deu no modelo inicial das categorias de análise foi a inclusão de duas subcategorias à categoria $\mathrm{AA}$, além da supramencionada discricionariedade 'operacional'. Foram incluídas nesta categoria os Recursos Financeiros (RF) e as Atividades, Fluxos e Rotinas (AFR), a partir de uma necessidade advinda da análise preliminar das fontes de evidências, ainda na construção dos elementos para a análise dos dados.

Por fim, e também como resultado da análise preliminar realizada, uma nova categoria foi proposta ao estudo: aspectos conflituosos entre a execução do Componente Especializado da Assistência Farmacêutica/Política Nacional de Assistência Farmacêutica e de demandas judiciais. Esta é constituída por dados existentes nos respectivos casos que refletem a interface entre a Política e a judicialização, no sentido de serem questões que merecem ser consideradas pelos dois processos e, muitas vezes, não o são. A versão final das categorias de análise que inclui as novas categorias é apresentada na Figura 3.4, a seguir.

A flexibilidade na proposição das categorias e para outros elementos da construção metodológica é defendida por Eisenhardt (1989), que pontua que as adequações contribuem para o maior enriquecimento do trabalho, já que permitem o melhor aproveitamento dos dados da pesquisa. Logo, aquela autora prevê e defende que os estudos de caso podem requerer ajustes durante o processo de transição entre a coleta e a análise dos dados. É neste momento que se refere a análise preliminar supramencionada. 


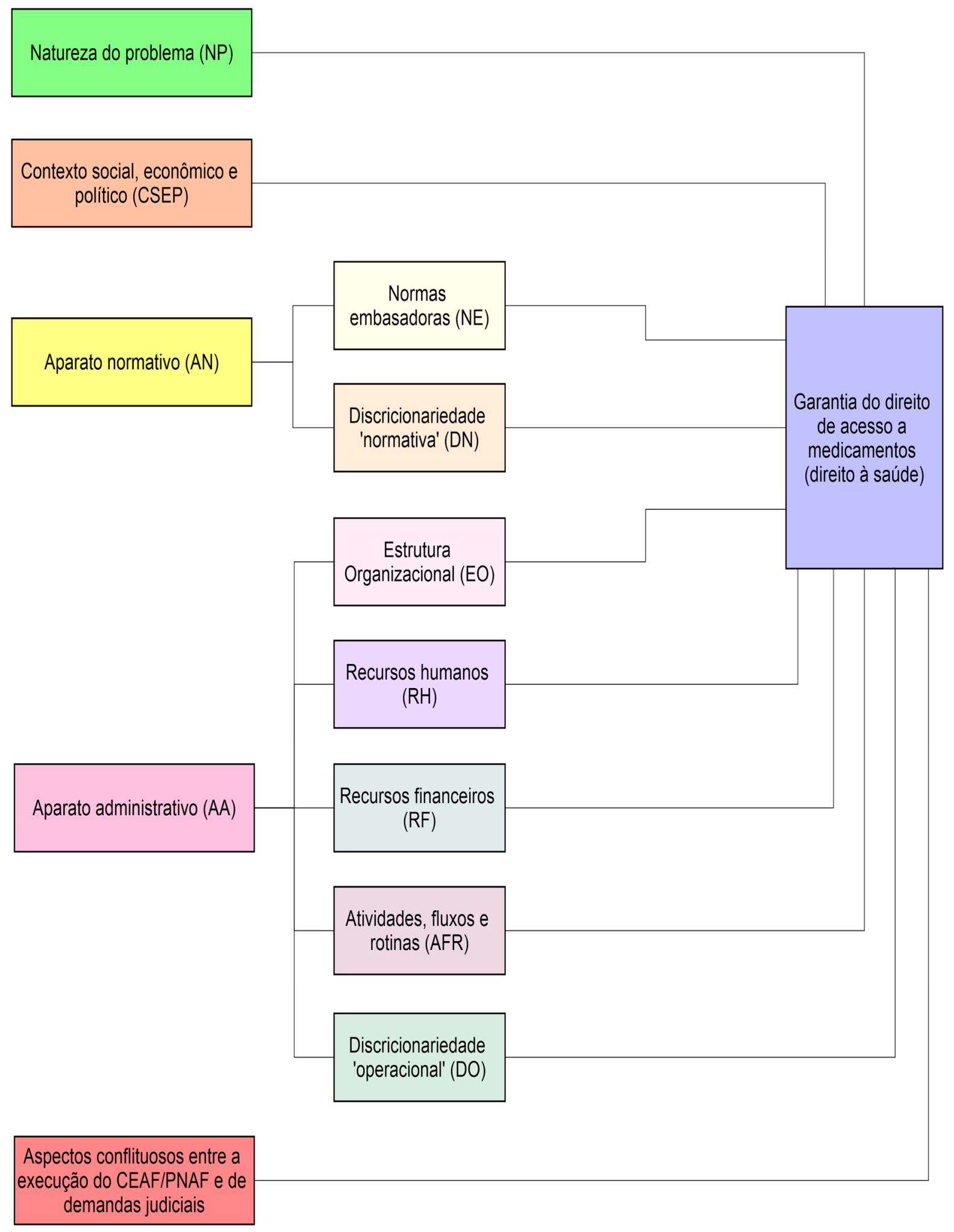

Figura 3.4 - Categorias de análise definitivas para o estudo.

Fonte: Da autora. 
Para a operacionalização da presente pesquisa, seguindo os preceitos do rigor metodológico, foram elaborados descritores do conteúdo de cada categoria de análise para orientar a codificação. Tal definição se deu para que a análise dos dados fosse realizada sistematicamente e de modo padronizado em todos os documentos analisados e para os dois casos.

A operacionalização das categorias e subcategorias é apresentada no Quadro 3.1, a seguir. 
Quadro 3.1 - Definições, meios para observação e fontes de evidência das variáveis de pesquisa (continua).

\begin{tabular}{|c|c|c|c|c|c|}
\hline $\begin{array}{l}\text { ALVO/FOCO da } \\
\text { pesquisa }\end{array}$ & $\begin{array}{l}\text { Categorias de } \\
\text { análise }\end{array}$ & Subcategorias & Meio para atingimento & Descritores/Finalidade & $\begin{array}{l}\text { Fontes de } \\
\text { evidência }\end{array}$ \\
\hline \multirow{7}{*}{$\begin{array}{l}\text { CASO } 01- \\
\text { Acesso a } \\
\text { medicamentos via } \\
\text { SUS. } \\
\text { CASO } 02 \text { - } \\
\text { Acesso a } \\
\text { medicamentos via } \\
\text { judicialização. }\end{array}$} & $\begin{array}{l}\text { (1) Natureza do } \\
\text { problema (NP) }\end{array}$ & - & $\begin{array}{l}\text { Observação de como a } \\
\text { problemática "acesso a } \\
\text { medicamentos" é compreendida } \\
\text { pelos envolvidos. }\end{array}$ & $\begin{array}{l}\text { Descrição do(s) problema(s) a ser(em) } \\
\text { resolvido(s) pela implementação do } \\
\text { CEAF/PNAF e pela judicialização, sua(s) } \\
\text { extensão(ões) e ação(ões) corretiva(s). }\end{array}$ & \multirow[t]{7}{*}{$\begin{array}{l}\text { Documentos } \\
\text { (oficiais e artigos } \\
\text { científicos) e } \\
\text { entrevistas }\end{array}$} \\
\hline & $\begin{array}{l}\text { (2) Contexto social, } \\
\text { econômico e político } \\
(\mathrm{CSEP})\end{array}$ & - & $\begin{array}{l}\text { Observação da história da } \\
\text { implementação do CEAF/PNAF } \\
\text { e da judicialização da saúde. }\end{array}$ & $\begin{array}{l}\text { A história da implementação da política e da } \\
\text { judicialização: expõe o contexto social, } \\
\text { econômico e político, sendo estes percebidos a } \\
\text { partir do apoio governamental por meio da } \\
\text { disponibilização de recursos ao programa. }\end{array}$ & \\
\hline & \multirow[t]{2}{*}{$\begin{array}{l}\text { (3) Aparato } \\
\text { Normativo (AN) }\end{array}$} & $\begin{array}{l}\text { 3.1 Normas } \\
\text { embasadoras }\end{array}$ & Identificação das normas & $\begin{array}{l}\text { Observação da clareza dos objetivos da } \\
\text { política e das demais normas e da previsão e } \\
\text { disponibilidade de recursos, financeiro } \\
\text { principalmente. }\end{array}$ & \\
\hline & & $\begin{array}{l}3.2 \\
\text { Discricionariedade } \\
\text { 'normativa' }\end{array}$ & $\begin{array}{l}\text { Identificação do distanciamento } \\
\text { entre normas e prática }\end{array}$ & $\begin{array}{l}\text { Observação do grau em que o plano estrutura } \\
\text { as ações. }\end{array}$ & \\
\hline & \multirow[t]{3}{*}{$\begin{array}{l}\text { (4) Aparato } \\
\text { administrativo (AA) }\end{array}$} & $\begin{array}{l}4.1 \text { Estrutura } \\
\text { organizacional }\end{array}$ & $\begin{array}{l}\text { Identificação da estrutura } \\
\text { organizacional para a } \\
\text { implementação das ações. }\end{array}$ & $\begin{array}{l}\text { Compreensão sobre estrutura organizacional } \\
\text { para a implementação do CEAF/PNAF e a } \\
\text { operacionalização da judicialização da saúde. }\end{array}$ & \\
\hline & & $\begin{array}{l}4.2 \text { Recursos } \\
\text { Humanos }\end{array}$ & $\begin{array}{l}\text { Identificação da previsão quanto } \\
\text { aos recursos humanos para a } \\
\text { implementação das ações. }\end{array}$ & $\begin{array}{l}\text { Compreensão sobre os recursos humanos } \\
\text { previstos para a implementação do } \\
\text { CEAF/PNAF e a operacionalização da } \\
\text { judicialização da saúde. }\end{array}$ & \\
\hline & & $\begin{array}{l}4.3 \text { Recursos } \\
\text { Financeiros }\end{array}$ & $\begin{array}{l}\text { Identificação da previsão quanto } \\
\text { aos recursos financeiros para a } \\
\text { implementação das ações. }\end{array}$ & $\begin{array}{l}\text { Compreensão sobre os recursos financeiros } \\
\text { previstos e alocados para a implementação do } \\
\text { CEAF/PNAF e a operacionalização da } \\
\text { judicialização da saúde. }\end{array}$ & \\
\hline
\end{tabular}


Quadro 3.1 - Definições, meios para observação e fontes de evidência das variáveis de pesquisa (conclusão).

\begin{tabular}{|c|c|c|c|c|c|}
\hline $\begin{array}{l}\text { ALVO/FOCO } \\
\text { da pesquisa }\end{array}$ & $\begin{array}{l}\text { Categorias de } \\
\text { análise }\end{array}$ & Subcategorias & Meio para atingimento & Descritores/Finalidade & $\begin{array}{l}\text { Fontes de } \\
\text { evidência }\end{array}$ \\
\hline \multirow{2}{*}{$\begin{array}{l}\text { CASO } 01 \text { - } \\
\text { Acesso a } \\
\text { medicamentos via } \\
\text { SUS. }\end{array}$} & & $\begin{array}{l}\text { 4.4 Atividades, } \\
\text { fluxos e rotinas }\end{array}$ & $\begin{array}{l}\text { Identificação das rotinas e } \\
\text { fluxos para a implementação } \\
\text { das ações. }\end{array}$ & $\begin{array}{l}\text { Compreensão sobre os fluxos e rotinas para a } \\
\text { implementação do CEAF/PNAF e a } \\
\text { operacionalização da judicialização da saúde. }\end{array}$ & \multirow{2}{*}{$\begin{array}{l}\text { Documentos } \\
\text { (oficiais e artigos } \\
\text { científicos) e } \\
\text { entrevistas }\end{array}$} \\
\hline & & $\begin{array}{l}4.5 \\
\text { Discricionariedade } \\
\text { 'operacional' }\end{array}$ & & $\begin{array}{l}\text { Adaptação da prática prevista, pelos } \\
\text { implementadores, para reduzir a distância } \\
\text { entre os objetivos e o realizado }\end{array}$ & \\
\hline
\end{tabular}

Fonte: Da autora. 
Após a apresentação dos modelos conceituais e das categorias do estudo em questão, a próxima subseção explica quais foram as etapas de operacionalização da pesquisa.

\subsection{Operacionalização da pesquisa}

A presente pesquisa foi operacionalizada em etapas, e a descrição destas faz parte do rigor metodológico aqui delimitado. Sobre a questão, Eisenhardt (1989) já ponderava que devem ser feitas anotações completas sobre os aspectos observados durante a coleta de dados da pesquisa. Neste sentido, entendeu-se aqui ser apropriado estender tal conceito para toda a execução do estudo e, assim, proceder com um relatório sobre as partes da pesquisa e dos possíveis percalços identificados. Esta ideia vai ao encontro dos conceitos de Yin (2001) e Dubé e Paré (2003), que elencavam o protocolo de atividades como parte importante da pesquisa, onde se identificam os procedimentos a serem realizados. Por fim, Benbasat, Goldstein e Mead (1987) reforçam que a descrição da coleta de dados é essencial para o julgamento da credibilidade dos resultados.

Com base nos autores supramencionados, apresenta-se aqui o registro e a descrição da presente pesquisa, não somente para a coleta dos dados, mas para os demais procedimentos e etapas realizadas.

O estudo teve início, então, com a revisão da literatura para a identificação de lacunas de pesquisa ao redor da questão de acesso aos medicamentos - interesse inicial da pesquisadora -, que originaram a escolha do problema voltado à compreensão da implementação do CEAF/PNAF e a judicialização da saúde. A partir da definição do problema, fez-se a revisão de literatura e estruturação da fundamentação teórica preliminar. A partir daí, seguiu-se com algumas atividades que se mostraram bastante dinâmicas no decorrer da pesquisa, que se retroalimentavam e moldavam umas às outras. Por exemplo, a fundamentação teórica deu base à construção das categorias, mas após a análise preliminar dos dados, foram estabelecidos os ajustes já descritos sobre as categorias e subcategorias.

Após a estruturação do escopo teórico, foram definidos os modelos conceituais e as categorias de pesquisa supramencionadas. Além destes elementos, foram definidos os aspectos de estratégia e métodos de coleta e análise dos dados adequados para atender os objetivos da presente pesquisa. Em paralelo, fez-se a seleção preliminar das fontes de evidências. Para todas as fontes de evidências (documentos oficiais, artigos e entrevistas), fezse uso da técnica do snow ball, que, a priori, é designada para a seleção de entrevistados, mas que foi adaptada no decorrer do estudo para todas as fontes. Ou seja, o andamento da própria 
pesquisa desvelou novas possíveis referências ou entrevistados que puderam ser incorporados às fontes de dados durante a execução da etapa de coleta de dados.

Após a seleção das fontes teve início a busca pelos documentos e artigos científicos, o contato com os entrevistados e o agendamento das entrevistas, e as entrevistas propriamente ditas, reunindo, então, os materiais com os dados da pesquisa, proveniente das três fontes supramencionadas.

Os documentos foram, então, organizados, as entrevistas foram transcritas e todos os documentos foram catalogados por meio de classificação desenvolvida para a presente pesquisa, incluídos no software Nvivo ${ }^{\circledR}$. Após a inclusão deu-se a codificação com base nas categorias de análise definitivas da pesquisa.

Realizou-se, primeiramente, a análise e codificação preliminar de alguns documentos para familiarização com o processo e o material. A leitura e codificação preliminar propiciou um reconhecimento inicial dos tipos de documentos coletados, originando o ajuste feito nas categorias. Seguiu-se, então, com a codificação de todos os documentos, com base nas categorias finais. O próprio processo de codificação incitou a busca por outros documentos ou pela realização de outras entrevistas (como, por exemplo, a entrevista com um profissional da área de Direito), para melhor esclarecer os aspectos identificados na presente pesquisa. Apesar de se tratar da etapa de codificação como se fosse algo único (ou linear), vivenciou-se uma construção dinâmica que envolvia retorno e realimentação de etapas anteriores, novas leituras da fundamentação teórica e coleta de dados adicionais.

Após a reunião de todos os documentos e codificação por meio do software Nvivo ${ }^{\circledR}$, procedeu-se à análise dos materiais e construção dos capítulos de exploração e descrição dos casos (Capítulos 4 e 5) e do capítulo de análise integrada dos casos, a partir do confronto com as teorias pré-identificadas (Capítulo 6).

A análise dos dados permitiu a elaboração da proposta de modelo operacional da implementação da Política junto à judicialização da saúde, bem como da proposta de modelo para a pesquisa do sistema interorganizacional aqui identificado.

Na Figura 3.5, a seguir, tem-se um resumo da organização e delineamento da presente pesquisa 


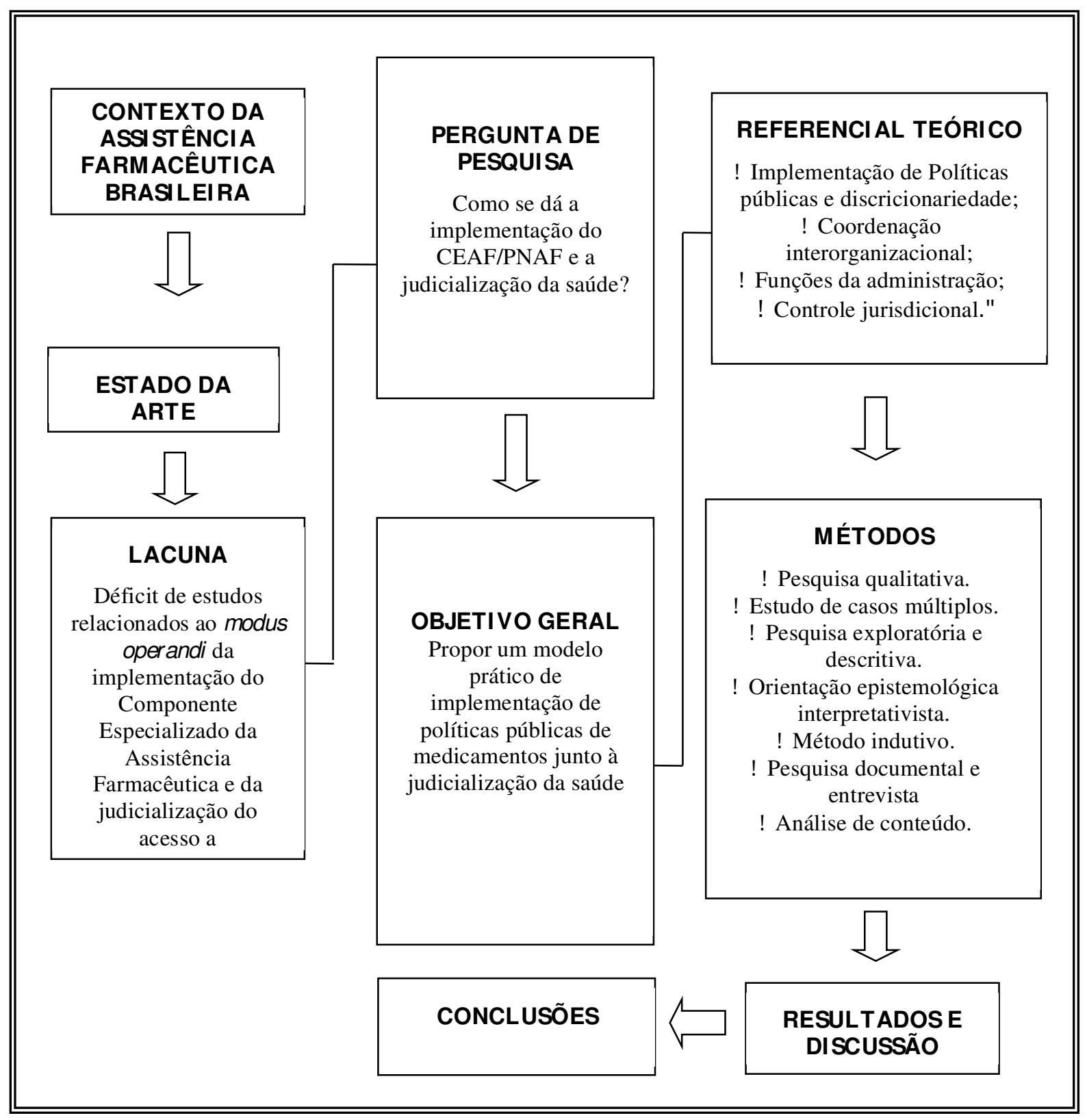

Figura 3.5 - Diagrama de organização da pesquisa.

Fonte: Da autora.

\subsection{Coleta de dados}

A coleta de dados partiu da busca por artigos científicos e documentos pertinentes relacionados aos temas "implementação do Componente Especializado da Assistência Farmacêutica/Política Nacional de Assistência Farmacêutica" e "judicialização da saúde", bem como pela aplicação de roteiros de entrevistas para atores também condizentes aos casos. 
Os instrumentos para a pesquisa foram aprimorados após a codificação e análise preliminar, em função do objeto não ser completamente compreendido a priori. A instrumentação totalmente pré-determinada é inapropriada para os estudos de exploração, em função das informações não possuírem uma natureza confirmatória (MILES; HUBERMAN; SALDAÑA, 2014). Neste sentido, fez-se uma construção metodológica aberta aos ajustes pertinentes durante a execução da pesquisa, respeitando o seguimento das bases teóricas e metodológicas estruturantes.

A codificação e a análise preliminar de alguns documentos foi, então, um mecanismo de validação da pertinência dos tipos de documentos coletados, contribuindo para a melhoria das categorias de análise. Além disso, fez-se uma entrevista piloto que auxiliou na construção do roteiro semi-estruturado final de guia das entrevistas.

A presente pesquisa utilizou quatro fontes de dados, a saber: 1) artigos científicos (dados secundários); 2) documentos oficiais (dados secundários); 3) documentos jornalísticos (dados secundários); e, 4) documentos derivados das transcrições das entrevistas (dados primários), em consonância à variabilidade de fontes recomendada por Eisenhardt (1989).

Em relação aos artigos científicos, a coleta dos dados envolveu uma pesquisa bibliográfica com os seguintes descritores (aplicados isoladamente ou em combinação em bases de dados nacionais): "acesso a medicamentos", "medicamentos de alto custo", "ações judiciais” e “judicialização da saúde”.

Quanto à pesquisa por documentos oficiais, a busca teve início pelos sites institucionais dos órgãos identificados como envolvidos no(s) Caso(s) 01 e/ou 02. A partir daí, foram consideradas as indicações por outros documentos que surgiam nas bases de dados eletrônicas ou apontadas pelos entrevistados partícipes da presente pesquisa. Os documentos foram selecionados de acordo com a pertinência e contribuição para com os casos investigados. Logo, a escolha é caracterizada como proposital, e não aleatória.

Para as reportagens, foram realizadas buscas pelos sites jornalísticos e sites institucionais dos mesmos órgãos supramencionados na busca dos documentos oficiais. Portanto, foram coletadas reportagens publicadas em sites da imprensa e em sites dos órgãos da saúde e do Judiciário. Muitas reportagens públicas em sites do governo são provenientes de sites de imprensa, mas o fato de estarem disponibilizadas no site institucional transmite o olhar do órgão que a veicula. E para a adequada interpretação sobre as fontes, todas as reportagens estão classificadas nos Apêndices da presente pesquisa com a especificação da organização de origem (por exemplo, se veiculadas pela Defensoria Pública da União - DPU ou pelo Ministério da Saúde - MS). 
Com o objetivo de esclarecer as questões apresentadas nas fontes documentais, nas reportagens e nos artigos científicos, e de garantir a multiplicidade das fontes de informações (MILES; HUBERMAN; SALDAÑA, 2014; BENBASAT; GOLDSTEIN; MEAD, 1987), a coleta de dados também envolveu a realização de entrevistas semiestruturadas (MACNEALY, 1997) que serviram para sanar dúvidas e confirmar ou acrescentar informações aos dados das demais fontes.

A partir das leituras iniciais sobre o tema e a pesquisa inicial dos documentos, foi estabelecida uma proposta preliminar de seleção de entrevistados. A lista preliminar foi incrementada por informações da análise preliminar dos documentos ou mesmo das próprias entrevistas realizadas e indicações por novos entrevistados.

Foram entrevistados atores do sistema de saúde, do sistema judiciário e de órgão essencial à justiça (na classificação das organizações envolvidas utilizada no estudo). No Apêndice A tem-se uma relação dos entrevistados de acordo com o cargo ou função exercida e com uma especificação sobre o tipo de informação que abordaram nas entrevistas (sobre a implementação da Política e/ou sobre a judicialização da saúde).

Os entrevistados foram registrados de acordo com seu cargo ou função, mantendo o anonimato. A eles foram apresentados os objetivos da pesquisa, fez-se um agradecimento inicial pela participação, foi solicitado o consentimento e a autorização da gravação, comunicado o sigilo das informações prestadas e informado os procedimentos sobre a divulgação dos dados.

Os instrumentos para a realização das entrevistas e os roteiros semiestruturados constam nos Apêndices B e C da presente pesquisa. Para a estruturação dos roteiros, fez-se uma entrevista piloto, onde se teve conhecimento sobre a Assistência Farmacêutica (AF) e sobre a interface com a judicialização da saúde, realizada com farmacêutico que exercia função de gestão de medicamentos, submetido à Diretoria de Assistência Farmacêutica da Secretaria de Estado de Saúde do Distrito Federal (DIASF/SES/DF). Esta entrevista piloto não compõe o escopo final de entrevistas, uma vez que aquele profissional não atua em setor específico da judicialização da saúde ou do CEAF/PNAF. Sua função se relaciona com a programação e compra dos medicamentos do CEAF/PNAF, bem como dos demais componentes da AF. Porém, a entrevista foi importante como ponto de partida para a compreensão do fenômeno e elaboração dos roteiros semiestruturados aqui utilizados.

Ainda em relação às entrevistas, é preciso registrar que esta etapa se deu até a saturação das informações sobre os dois casos. Ou seja, entendeu-se que foi atingido o limite de informações por este meio a partir da percepção da repetição das informações entre as 
respostas dos entrevistados - a não aparência de novos temas, de novas questões com respeito a uma categoria ou novos insights. Sobre a questão, Bowen (2008) observa que identificar o ponto de saturação em pesquisas qualitativas é um desafio para os pesquisadores, pois não existem guias que explicitem o que seja a saturação de dados ou saturação teórica. Aquele autor ainda elucida que a saturação se dá quando o conjunto de dados da pesquisa está completo, o que pode ser percebido pela replicação ou redundância dos dados, observada quando se persiste em acrescentar novos participantes à pesquisa.

Após a identificação e obtenção dos documentos, estes foram classificados e organizados em grupos, de acordo com o tipo de informação apresentada. A classificação final dos documentos (incluindo as entrevistas transcritas) se estrutura nos tipos descritos conforme se segue:

1) EN - transcrição das entrevistas;

2) LN - documentos legais e normativos (Apêndice D);

3) AT - atas (Apêndice E);

4) LM - livros e manuais (Apêndice F);

5) $\mathrm{J}$ - jurisprudências e outros registros judiciais (Apêndice $G$ );

6) SI - sites institucionais (Apêndice $\mathrm{H}$ );

7) NS - notícias do sistema de saúde - reportagens jornalísticas (Apêndice I);

8) NJ - notícias do sistema judiciário - reportagens jornalísticas (Apêndice J) ;e

9) $\mathrm{AR}$ - artigos científicos (Apêndice $\mathrm{K}$ ).

As listas originais de todos os documentos utilizados na presente pesquisa se encontram nos Apêndices indicados na classificação.

No total, foram elencados e utilizados na pesquisa 295 documentos. Incluindo as transcrições das entrevistas (14), foram analisados 309 documentos.

A mesma classificação se deu para a identificação dos documentos nos Capítulos 4 e 5, na análise dos Casos 01 e 02. Foram utilizadas as siglas para a identificação do tipo documental e a numeração, organizada nos Apêndices.

Após apresentar as fontes de evidência e os procedimentos de coleta dos dados, a seguir, tem-se a discussão da etapa de análise. 


\subsection{Análise dos dados}

O procedimento de análise envolveu a codificação dos dados de acordo com a categoria de análise, sendo aplicado igualmente às quatro fontes de dados, realizando-se a confrontação e triangulação dos resultados obtidos das diferentes fontes. Conforme Patton (1999), a triangulação de dados pode estar relacionada a diferentes fontes de dados, diferentes pesquisadores executores da pesquisa, diferentes teorias para os mesmos dados ou, por fim, diferentes métodos. O estudo em questão fez uso da triangulação dos dados das quatro fontes supramencionadas.

Quanto à técnica de análise, os dados obtidos da pesquisa documental, bem como os das entrevistas foram interpretados a partir da análise de conteúdo. O uso da análise de conteúdo prevê rigor metodológico para a inferência sobre os textos, a fim de aprimorar a objetividade da análise (ROCHA; DEUSDARÁ, 2005). Ou seja, é preciso determinar procedimentos sistematizados e objetivos para a codificação e descrição dos conteúdos, a fim de realizar a inferência sobre as mensagens colocadas pelo emissor (SILVA; GOBBI; SIMÃO, 2005). E, conforme apresentado até o momento, os procedimentos realizados foram todos registrados, bem como houve sistematização e repetição da aplicação dos métodos de coleta e análise em todos os documentos. A técnica de análise apresentada tem como referência principal a obra de Laurence Bardin, denominada L'analyse de contenu (ROCHA; DEUSDARÁ, 2005).

O procedimento prático da análise de conteúdo envolve a identificação dos pilares teóricos e a elaboração das categorias para a investigação. No presente estudo, as categorias foram definidas a partir da contribuição teórica de Lima e D’Ascenzi (2012), adaptada a partir da percepção sobre os casos obtida pela análise preliminar de alguns documentos.

Delimitadas as teorias de base e as categorias gerais, foram definidos os descritores de cada categoria, a fim de padronizar o procedimento de codificação.

Segundo Bauer e Gaskell (2000), o referencial de codificação deve se ajustar às considerações teóricas e aos documentos para a análise. E conforme Silva, Gobbi e Simão (2005), na presente pesquisa foram definidos preliminarmente as categorias, codificados alguns documentos e entrevistas e aperfeiçoadas as categorias. Após os ajustes pertinentes, fez-se a codificação final de todos os documentos e entrevistas, sendo analisados os resultados obtidos da codificação. 
Não houve padrão para o tamanho das unidades textuais analisadas. Logo, se a informação necessária para explicar o código estivesse em frases ou parágrafos, toda a unidade era codificada de forma variável. Seguiu-se, portanto, o critério de estabelecimento de uma ideia completa a cada trecho codificado.

O processo de codificação deu-se a partir da leitura e interpretação dos conteúdos de todos os grupos de textos com o uso do software Nvivo ${ }^{\circledR}$. E como os resultados da pesquisa podem ser apresentados pela quantificação e/ou interpretação dos códigos (BAUER; GASKELL, 2000), optou-se pela interpretação dos códigos e pela citação direta de trechos de documentos e de entrevistas, para melhor compreensão da descrição.

A partir da análise qualitativa do corpus do texto, foram desenvolvidas as descrições estruturadas em sequências de características explicativas do fenômeno (BAUER; GASKELL, 2000; SILVA; GOBBI; SIMÃO, 2005) nos Capítulos 4 e 5. Nestes mesmos capítulos tem-se os trechos de entrevistas e de documentos que, de acordo com Dubé e Paré (2003), é uma das formas de aproximar o leitor ao fenômeno estudado. No Capítulo 6 procedeu-se uma análise dos casos descritos anteriormente, à luz de teorias da Administração.

Encerrada a análise dos dados e de apresentação dos resultados obtidos nos Capítulos 4, 5 e 6 do presente estudo, fez-se o reconhecimento das limitações metodológicas da pesquisa, apontadas no item que se segue.

\subsection{Limitações metodológicas}

Uma limitação inicial prevista na presente pesquisa, por ter sido utilizado o método qualitativo por meio de estudo de caso, é a produção de resultados muito específicos para o cenário estudado, com dificuldade de reprodução para outras áreas e Políticas. Sobre a questão, Macnealy (1997) destaca que os estudos de caso normalmente têm resultados não generalizáveis, que se restringem a situações específicas.

Yin (2001) pontua que os resultados obtidos pelo referido método não seguirão a lógica de generalização a partir da amostragem de casos. Aquele autor defende que os estudos de caso podem contribuir para uma construção teórica aplicável a outros casos e contextos seria o caso da presente pesquisa, que apresentou informações importantes para diferentes pesquisas subsequentes. Por exemplo, as linhas que se seguem caracterizam e descrevem os dois casos supramencionados de forma inédita, e outros pesquisadores podem, a partir do conhecimento apresnetado, dar início a novas pesquisas com o mesmo objeto ou pesquisas que comparem os resultados com aqueles de outras pesquisas relacionadas a outros objetos. 
Macnealy (1997) observa que, muitas vezes, os estudos de caso são reconhecidos como formas menos criteriosas de pesquisa, sem rigor metodológico. Porém, dentro do escopo da pesquisa qualitativa, o presente estudo se deu mediante planejamento inicial da pesquisa e seguimento de etapas sistematizadas para a definição do delineamento metodológico, para a coleta de dados e análise de dados (YANOW, 2006).

A fim de evitar limitações frequentemente atribuídas aos estudos qualitativos quanto à realização de inferências na análise, mantendo a confiabilidade do método, algumas outras medidas foram tomadas quanto ao rigor metodológico. Os instrumentos para a realização das entrevistas e para a organização documental foram disponibilizados nos Apêndices, para que os leitores e outros pesquisadores tenham clara compreensão do processo que levou aos resultados obtidos. E ainda, além da sistematização clara do método, como estratégia para aumentar a confiabilidade dos resultados tem-se a triangulação (EISENHARDT, 1989).

No presente estudo a triangulação se deu com os dados primários e secundários obtidos pelas diferentes fontes de evidências. Aliás, fez-se uso das três técnicas denominadas por Schwartz-Shea (2006) de "primeira ordem", para garantir qualidade em pesquisa qualitativa: descrição rica e detalhada, reflexão e triangulação. A descrição rica e detalhada envolve o detalhamento narrativo do evento/contexto e pessoa/interação suficiente para apoiar a interpretação do pesquisador com dados que evidenciam/apoiam a interpretação. A reflexão implica em manutenção por parte do pesquisador da consciência sobre seu próprio papel em todas as fases do projeto de pesquisa. A exigência de reflexividade parte da premissa de que a objetividade na pesquisa qualitativa é difícil, e convém aos pesquisadores se entenderem como instrumentos no processo de produção científica (SCHWARTZ-SHEA, 2006). Neste sentido, aqui foi fundamental manter consciência do fato da pesquisadora ser formada em Farmácia e vigiar os possíveis efeitos que tal aspecto poderia acarretar nas interpretações dos dados.

O uso de entrevistas também trouxe a limitação da dificuldade de acesso a potenciais entrevistados. Algumas entrevistas não puderam ser realizadas e, como medida corretiva deste problema ainda durante o período de coleta, fez-se a busca de outros atores com atuação nas mesmas áreas. Assim, foram realizadas entrevistas que supriram a lacuna de informações deixada pela não realização daquelas originalmente projetadas.

Cabe também o registro de que uma das entrevistas realizadas (entrevistado 9EN) não pôde ser gravada, por não haver o aceite de gravação pelo entrevistado. Então, procedeu-se com a anotação manual das informações, durante a entrevista e, logo ao final do procedimento, uma gravação complementar por parte da pesquisadora com as informações 
obtidas pela conversa. A gravação se deu logo após o término da entrevista, para registrar as informações ainda recentes na memória e suprir possíveis falhas do registro do escrito ali executado, em função do volume de informações transmitidas. A entrevista com o entrevistado 13EN também teve característica peculiar. O procedimento de coleta dos dados ali obtidos se deu por meio eletrônico, por encaminhamento de questões da pesquisa e recebimento das respostas por endereço eletrônico. Por fim, a entrevista realizada com o entrevistado 14EN se deu por meio telefônico.

$\mathrm{Na}$ vigência das situações supramencionadas, os problemas foram contornados com estratégias ativas de busca por atores interessantes para a elucidação do caso, e de adaptações do formato das entrevistas (presencial, telefônica, eletrônica) para cada caso, sem que houvesse risco de prejuízo dos dados coletados. Outra questão foi a seleção dos entrevistados. Neste caso, a seleção se deu em vista da compreensão do tema por meio da escolha de entrevistados variados, que representassem as diversas facetas do objeto. Logo, o número de entrevistados foi o adequado para explorar de forma consistente o tema e gerar compreensão e esgotamento das questões (FRASER; GONDIM, 2004).

As possíveis limitações de tempo ou recursos (YIN, 2001) foram evitadas pela ausência de maiores contratempos na realização da pesquisa e pela grande disponibilidade de documentos sobre os casos estudados, além da facilidade de acesso às evidências.

Macnealy (1997) observa que os estudos de caso podem ter custos significativos para a sua realização, como no caso dos custos com as transcrições das gravações de entrevistas (MACNEALY, 1997). Porém, os custos da presente pesquisa se referiram exatamente ao serviço de transcrição das entrevistas e à execução das entrevistas, e não inviabilizaram a pesquisa. Tendo sido reconhecidas as principais limitações relacionadas ao delineamento proposto, foram realizados os ajustes supramencionados para a ampliação da confiabilidade dos resultados obtidos. 


\section{ANÁLISE DO CASO 01}

O primeiro caso em destaque na presente pesquisa é o da implementação da Política Nacional de Assistência Farmacêutica (PNAF), no que tange o objetivo da garantia do acesso aos medicamentos, por meio do Componente Especializado da Assistência Farmacêutica (CEAF).

A análise do caso segue a organização das cinco categorias finais propostas no capítulo aqui intitulado Metodologia. Logo, no primeiro caso tem-se a apresentação e discussão dos dados referentes à Natureza do Problema (NP), ao Contexto Social, Econômico e Político (CSEP), ao Aparato Normativo (AN) e suas subcategorias normas embasadoras e discricionariedade normativa, ao Aparato Administrativo (AA) e suas subcategorias estrutura organizacional, recursos humanos, recursos financeiros, atividades, fluxos e rotinas e discricionariedade operacional e, por fim, os aspectos conflituosos entre a Execução do CEAF/PNAF e a Execução de Demandas Judiciais (AC) identificados entre os poderes Executivo e Judiciário quando da implementação do Componente em questão.

\subsection{Natureza do Problema}

Na primeira categoria, no que tange à NP, a análise dos dados leva à definição da problemática alvo da execução do CEAF/PNAF, tal como sua extensão e como a política propõe lidar com as referidas questões.

A partir dos elementos identificados na presente pesquisa para esta categoria, fez-se um diagrama que reúne os pontos relevantes - a descrição do problema, conforme evidenciado na Figura 4.1, a seguir. 


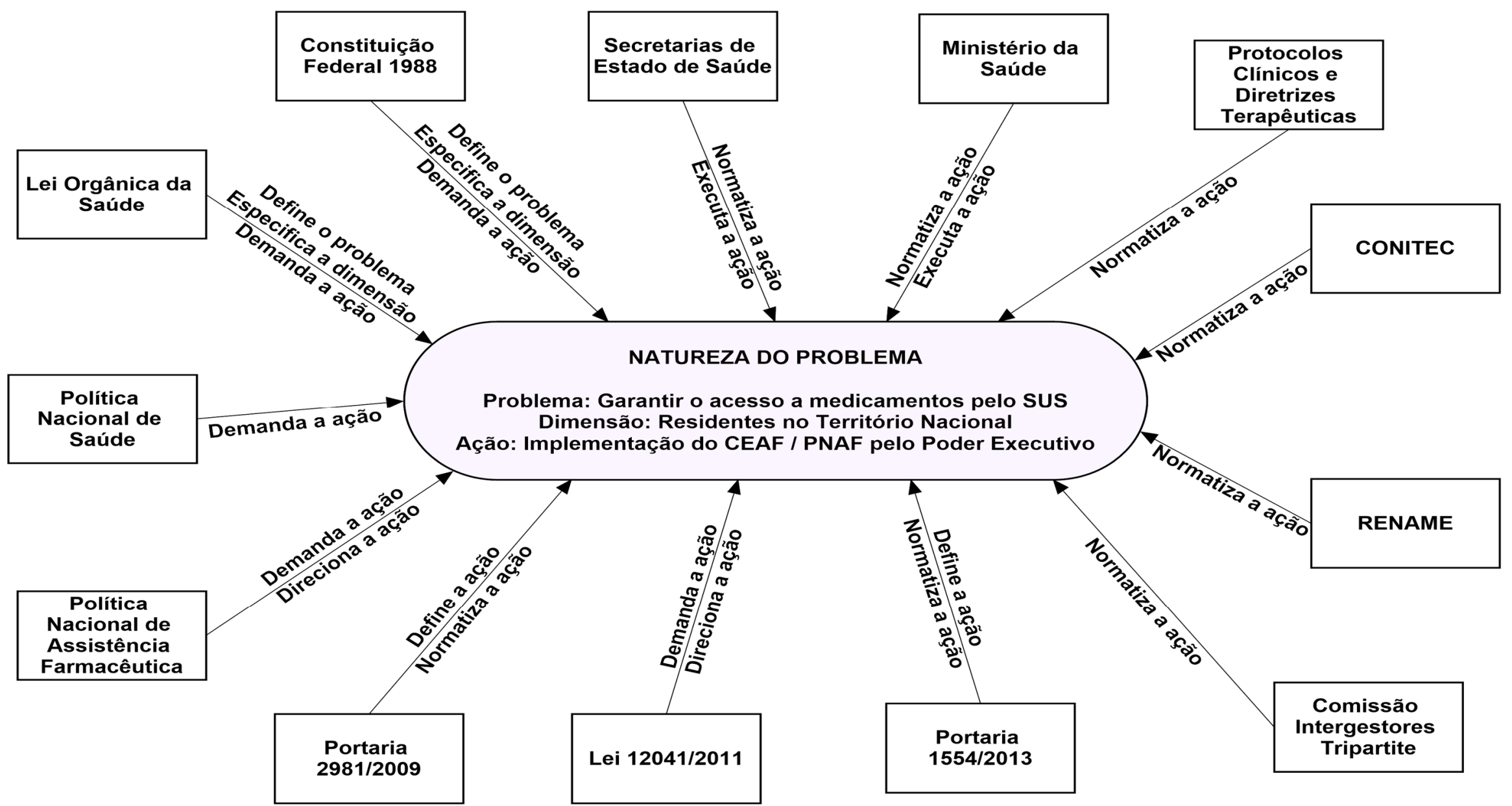

Onde: CEAF - Componente Especializado da Assistência Farmacêutica; CONITEC - Comissão Nacional de Incorporação de Tecnologias no Sistema Único de Saúde; PNAF - Política Nacional de Assistência Farmacêutica; RENAME - Relação Nacional de Medicamentos Essenciais.

Figura 4.1 - Principais elementos envolvidos na definição da natureza do problema do Caso 01.

Fonte: Da autora. 
A análise apresentada na Figura 4.1 atenta que o ponto inicial a ser considerado é objeto da Constituição Federal (CF) de 1988 (documento 1LN). Esta dispõe sobre as ações destinadas à garantia do direito à saúde, que pertencem ao conjunto denominado Seguridade Social - ações que deverão ser implementadas seguindo alguns objetivos (universalidade da cobertura e do atendimento, por exemplo) (art. 194, parágrafo único, CF de 1988).

Primeiramente cabe investigar a diferença para a aplicação do princípio citado nos três sistemas do conjunto de Seguridade Social, uma vez que são vertentes deste conjunto a Previdência Social, a Assistência Social e a Saúde. Logo, o princípio da universalidade adquire nuances distintos para cada uma das áreas supramencionadas (MARTINS, 2005). No que tange à Previdência Social, o direito compreende a incidência da universalidade de forma diferente para sistemas contributivos e não contributivos. No caso do Brasil, cujo sistema é contributivo, a cobertura do regime alcançará somente aqueles que contribuíram. Porém, para os itens Assistência Social e Saúde, a universalidade será plena. Ou seja, independente do pagamento de contribuição, todos que necessitarem poderão se beneficiar dos dois direitos, conforme os arts. 196 e 203 da CF de 1988 (VIANNA, 2010).

$\mathrm{O}$ art. 196 da Carta Magna em questão estabelece que a saúde seja direito de todos e um dever do Estado, e que deve ser garantida por meio de políticas sociais e econômicas. Tais políticas devem ter por norte a redução do risco de doenças e agravos à saúde, além de fornecer acesso universal e igualitário às ações e serviços de promoção, proteção e recuperação da saúde. De forma complementar, seu art. 198 acrescenta que o atendimento deve ser integral, priorizando as ações de prevenção, porém, dispondo de todos os tipos de atendimentos.

Seguindo as previsões da CF de 1988, foi sancionada a Lei n. 8.080, em 19 de setembro de 1990, conhecida como Lei Orgânica da Saúde, que dispõe sobre as condições para as ações de promoção, proteção e recuperação da saúde, bem como da organização e do funcionamento dos serviços de saúde em todo o território nacional. Segundo esta normativa (documento $2 \mathrm{LN}$ ), a saúde é um direito fundamental do ser humano, e o Estado deverá prover as condições necessárias para tal. Define-se, então, o Sistema Único de Saúde (SUS) como o conjunto das ações e serviços de saúde prestados por instituições públicas federais, estaduais e municipais (BRASIL, 1990a).

Consta como âmbito de atuação do SUS a assistência terapêutica integral, inclusive farmacêutica (art. $6^{\circ}$ da Lei n. 8.080/1990). E, em texto constitucional acrescido pela Lei n. 12.401, de 28 de abril de 2011 (documento 3LN), define-se a assistência terapêutica integral 
pela oferta de procedimentos terapêuticos e - de interesse direto para o objeto da presente pesquisa - a dispensação de medicamentos e produtos de interesse para a saúde, in verbis:

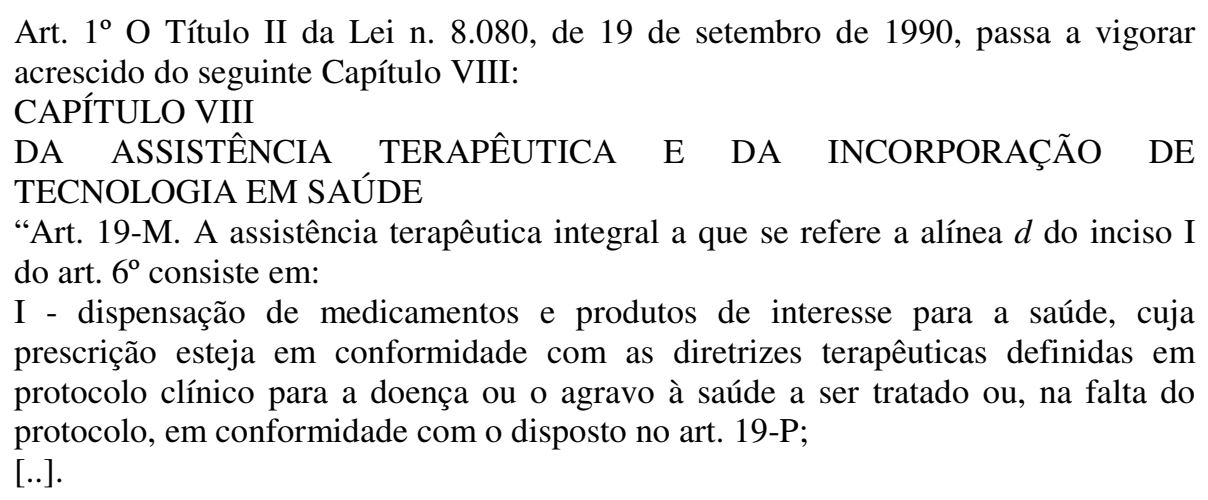

A Lei n. 8.080/1990 especifica que o SUS deve operar seguindo a lógica da universalidade (acesso para todos) em todos os níveis de assistência à saúde e a lógica da integralidade (assistência dispondo de todos os níveis de complexidade necessários) para a atenção à saúde individual e coletiva (documentos 2LN e 1AR) (BRASIL, 1990a; VIEIRA; ZUCCHI, 2007).

A CF de 1988, enquanto previsão normativa, demanda a formulação e implementação de políticas de saúde que garantam a disponibilização de medicamentos pelo SUS, de forma universal e integral. O Poder Executivo é o responsável pela viabilização destas políticas e ações. Para tanto, a Assistência Farmacêutica (AF) deve seguir os princípios e diretrizes do sistema de saúde em questão.

Entende-se que o Estado é responsável por formular e implementar as ações por meio de mecanismos que garantam o alinhamento entre os objetivos, a burocracia executora, os atores políticos e os atores técnicos-administrativos. Sobre a questão, tem-se aqui a denominação coordenação das ações, que pode ser realizada de forma intragovernamental ou intergovernamental (GOMES, 2010). Para a Saúde, a área de AF era um exemplo de campo de ação governamental a ser organizado por meio de coordenação executiva.

A PNAF (documento 4LN), aprovada em 2004 pelo Conselho Nacional de Saúde (CNS), é a política norteadora das políticas setoriais, entre as quais, as políticas de medicamentos. E a AF, enquanto conceito, envolve as ações para a disponibilização de medicamentos à população, conforme o art. $1^{\circ}$ da Resolução CNS n. 338, de 06 de maio de 2004, in verbis: 
Art. $1^{\circ}$ Aprovar a Política Nacional de Assistência Farmacêutica, estabelecida com base nos seguintes princípios:

$[\ldots]$;

III - a Assistência Farmacêutica trata de um conjunto de ações voltadas à promoção, proteção e recuperação da saúde, tanto individual como coletivo, tendo o medicamento como insumo essencial e visando o acesso e ao seu uso racional. Este conjunto envolve a pesquisa, o desenvolvimento e a produção de medicamentos e insumos, bem como a sua seleção, programação, aquisição, distribuição, dispensação, garantia da qualidade dos produtos e serviços, acompanhamento e avaliação de sua utilização, na perspectiva da obtenção de resultados concretos e da melhoria da qualidade de vida da população;

[...]. (grifo meu)

A Política em questão, inserida em um expediente nacional de ciência, tecnologia e inovação em saúde, tem como um de seus objetivos guiar as ações de garantia do acesso integral, equânime e universal aos medicamentos no SUS (documento 1LM). Neste sentido, tem-se os eixos estratégicos da PNAF, evidenciados no art. $2^{\circ}$ da Resolução CNS n. 338, de 06 de maio de 2004, in verbis:

\footnotetext{
Art. 2 A Política Nacional de Assistência Farmacêutica deve englobar os seguintes eixos estratégicos:

I - a garantia de acesso e equidade às ações de saúde, inclui, necessariamente, a Assistência Farmacêutica;

II - manutenção de serviços de assistência farmacêutica na rede pública de saúde, nos diferentes níveis de atenção, considerando a necessária articulação e a observância das prioridades regionais definidas nas instâncias gestoras do SUS;

[...];

VII - utilização da Relação Nacional de Medicamentos Essenciais (RENAME), atualizada periodicamente, como instrumento racionalizador das ações no âmbito da assistência farmacêutica;

XIII - promoção do uso racional de medicamentos, por intermédio de ações que disciplinem a prescrição, a dispensação e o consumo.
}

Cabe destacar a introdução de um novo princípio, além da universalidade e da integralidade, citado em diversos documentos da área: o princípio da equidade. Tal princípio doutrinário (do SUS) se faz presente na Lei Orgânica da Saúde, em seu art. $7^{\circ}$, inc. IV, como a igualdade de assistência à saúde (BRASIL, 1990a).

A equidade também pode ser relacionada aos direitos constitucionais de igualdade e justiça, uma vez que trata do atendimento dos desiguais de acordo com suas necessidades. Em outras palavras, fornecer mais cuidados para aqueles que precisam de mais cuidados e fornecer menos a quem precisa de menos. As políticas de saúde expressam tal princípio, pois são formuladas para a diversidade de casos e situações de risco existentes no Brasil (FIOCRUZ, 2016). 
Sobre o princípio da equidade, Duarte (2000) explica que se trata de um mecanismo de discriminação positiva; uma tentativa de compensar os efeitos causados pelas desigualdades sociais. Ou seja, diante da falta de oportunidades de alguns segmentos da população, as Políticas tentam reduzir os impactos negativos finais ao ampliar as oportunidades em um segundo momento.

No que tange especificamente à $\mathrm{AF}$, no Brasil, há de se considerar a Política Nacional de Saúde (PNS), que norteia as ações em saúde em geral. Em função de sua importância clínica, por exemplo, os medicamentos são considerados insumos estratégicos essenciais para o sucesso desta política maior (BRASIL, 2014a). Assim, a PNS se desdobra em inúmeras outras políticas (como, por exemplo, a PNAF), outros programas e outras ações, que tem por gerência o Ministério da Saúde (MS), em articulação com os demais Estados e Municípios. A Secretaria de Ciência, Tecnologia e Insumos Estratégicos do Ministério da Saude (SCTIE/MS), por meio de seu Departamento de Assistência Farmacêutica (DAF/MS), são os responsáveis pelas ações voltadas à gestão dos medicamentos (BRASIL, 2014a).

Como resposta à demanda do SUS e da PNAF no que tange o acesso e o uso racional de medicamentos, o MS definiu os Componentes da Assistência Farmacêutica, para organização e gestão destes insumos. O documento $5 \mathrm{LN}$ apresenta os três componentes da AF, a saber: 1) Componente Básico da Assistência Farmacêutica (CBAF); 2) Componente Estratégico da Assistência Farmacêutica (CESAF); e, 3) Componente Especializado da Assistência Farmacêutica (CEAF) (BRASIL, 2007).

O antigo Componente de Medicamentos de Dispensação Excepcional (CMDE) de 2006 (documento 6LN) (BRASIL, 2006d) foi revisto para atender a cobertura necessária para as diversidades do território nacional, observando os critérios clínicos-epidemiológicos. Logo, o DAF/MS o redefiniu criando o CEAF, segundo o documento 2LM (BRASIL, 2010a). A Portaria GM/MS n. 2.981, de 26 de novembro de 2009, altera a denominação CMDE e a substitui por CEAF (documento 7LN) (BRASIL, 2009b).

O CBAF define o elenco de medicamentos de referência para a Atenção Básica em Saúde. Assim, a seleção se dá com base nos critérios epidemiológicos e consequente tratamento dos problemas de saúde mais evidentes na população (BRASIL, 2010a).

O CESAF abrange programas de saúde específicos que envolvem os tratamentos com antirretrovirais do Programa Nacional de DST/AIDS (PN-DST/AIDS) - Portaria MS n. 236, de 02 de maio de 1985, imunobiológicos, sangue e hemoderivados, e para o controle de endemias, tais como: hanseníase, malária, tuberculose, doença de chagas, leishmaniose, entre outras (BRASIL, 2007). 
Por fim, o CEAF foi elaborado para suprir as demandas por medicamentos de alto custo (BRASIL, 2014a). Em sua maioria, estes são indicados para doenças de baixa prevalência. Porém, há situações de necessidade por medicamentos de maior custo para o tratamento de doenças prevalentes. Isto posto, foram definidos dois critérios para a organização desta oferta. O primeiro se refere à previsão de medicamentos de alto custo para casos de refratariedade, ou intolerância ao medicamento, ou ainda, agravamento do quadro clínico. O segundo critério se refere aos medicamentos para doenças que não possuem tratamento na Atenção Básica de Saúde, porém, são prevalentes e requerem atenção especializada (Alzheimer, por exemplo). Para tais situações tem-se a previsão de medicamentos de alto custo para alguns quadros clínicos, que evidenciem eficácia ${ }^{2}$ clínica e segurança comprovadas (BRASIL, 2010a).

Sobre a questao, o entrevistado $2 \mathrm{EN}$ assim afirma:

Geralmente, são medicamentos de mais alto impacto, mas na verdade, são medicamentos ambulatoriais que pertencem, geralmente, a segunda e terceira linhas de cuidados.

A execução dos componentes da AF visa garantir a integralidade do tratamento medicamentoso (MINISTÉRIO DA SAÚDE, 2016a), conforme princípio do SUS, e o direito à saúde, conforme previsão pela CF de 1988. Porém, para que haja viabilidade desta execução, deve haver normatização para a gestão e a oferta dos produtos e serviços associados (como, por exemplo, o ato da dispensação dos medicamentos, que envolve a entrega e a orientação sobre o uso).

No caso do CEAF, os tratamentos cobertos são ambulatoriais, e as indicações de uso dos medicamentos estão definidas nos Protocolos Clínicos e Diretrizes Terapêuticas (PCDT), publicados pelo MS (documentos 7LN e 8LN) (BRASIL, 2009b; 2013a). Além disso, a previsão somente se dá para doenças descritas no CID-10 (Classificação Estatística Internacional de Problemas e Doenças Relacionadas à Saúde - 10 a revisão) (BRASIL, 2013a).

\footnotetext{
2 Os termos "eficácia", "efetividade" e "eficiência", além de presentes na Administração, também são muito utilizados na área farmacêutica e, por isso, cabe defini-los tal qual são utilizados na área clínica. A eficácia se refere ao atributo do medicamento de cumprimento de sua finalidade. Logo, se um medicamento é dito analgésico, ele terá o efeito analgésico proposto. Porém, este dado é obtido em meio experimental; então, ele será efetivo quando cumprir este mesmo objetivo no ambiente real, com o medicamento já em comercialização. Por fim, será eficiente quando for efetivo e economicamente vantajoso (CONSELHO FEDERAL DE FARMÁCIA, 2008).
} 
O documento $2 \mathrm{SI}$, do MS, explica que os medicamentos do CEAF são apresentados nos PCDT, organizados por linhas de cuidado. Além dos medicamentos, têm-se outras tecnologias em saúde, uma vez que os protocolos são estruturados, apresentando a assistência à saúde completa para cada doença a ser tratada. Isto é, para o atendimento integral das doenças cobertas pelo CEAF, há uma interação entre a Relação Nacional de Medicamentos Essenciais (RENAME) e a Relação Nacional de Serviços e Ações de Saúde (RENASES) (MINISTÉRIO DA SAÚDE, 2016a).

Neste sentido, o documento 3LN assim define o PCDT, in verbis:

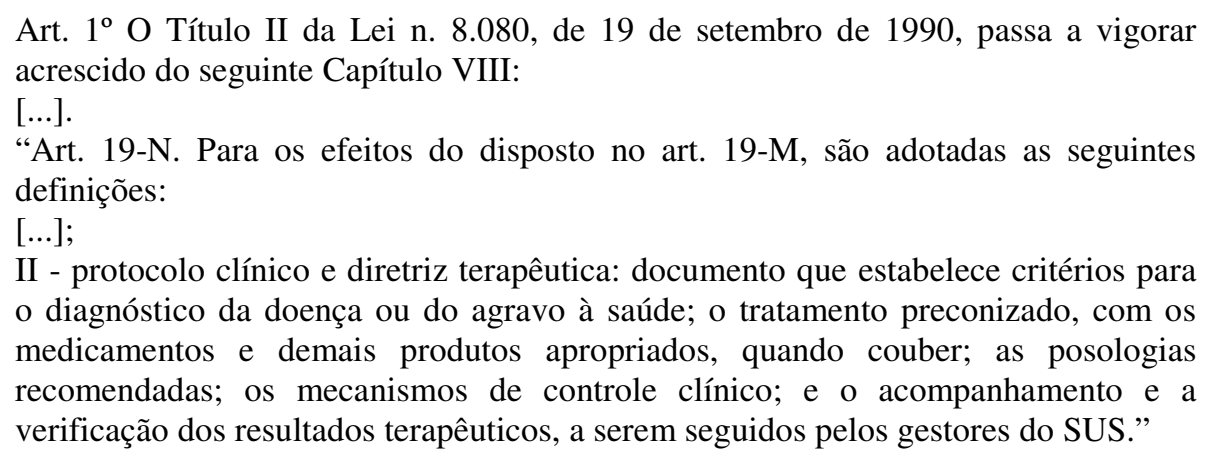

Sobre a questão, o entrevistado $2 \mathrm{EN}$ atenta:

Bem, o componente especializado, ele é uma estratégia de acesso a medicamentos em nível ambulatorial. Então, ele não trabalha com nenhuma situação de urgência, emergência. São sempre de situações de atendimento ambulatorial. E que todos os procedimentos, eles estão descritos em protocolos clínicos e diretrizes terapêuticas, publicados em forma de Portaria pelo Ministério da Saúde.

É essencial destacar que, na ausência de PCDT nacional e padronização de um medicamento importante para um Estado ou Município, tem-se a possibilidade da elaboração de protocolos estaduais e municipais, sob financiamento do respectivo ente federativo. Assim, tem-se o documento $3 \mathrm{LN}$, in verbis:

Art. $1^{\circ}$ O Título II da Lei n. 8.080, de 19 de setembro de 1990, passa a vigorar acrescido do seguinte Capítulo VIII:

$[\ldots]$.

“Art. 19-P. Na falta de protocolo clínico ou de diretriz terapêutica, a dispensação será realizada:

I - com base nas relações de medicamentos instituídas pelo gestor federal do SUS, observadas as competências estabelecidas nesta Lei, e a responsabilidade pelo fornecimento será pactuada na Comissão Intergestores Tripartite;

II - no âmbito de cada Estado e do Distrito Federal, de forma suplementar, com base nas relações de medicamentos instituídas pelos gestores estaduais do SUS, e a responsabilidade pelo fornecimento será pactuada na Comissão Intergestores Bipartite; 
III - no âmbito de cada Município, de forma suplementar, com base nas relações de medicamentos instituídas pelos gestores municipais do SUS, e a responsabilidade pelo fornecimento será pactuada no Conselho Municipal de Saúde.

Reforçando os dados anteriores e no sentido de qualificar o acesso aos medicamentos no âmbito do SUS, o DAF/MS tem coordenado as seguintes ações:

a) Revisão permanente da Relação Nacional de Medicamentos Essenciais e do Formulário Terapêutico Nacional;

b) Desenvolvimento e implantação do Sistema Nacional de Gestão da Assistência Farmacêutica (Hórus) como uma ferramenta para a qualificação da gestão da Assistência Farmacêutica no Brasil, no âmbito dos Componentes Básico, Estratégico e Especializado da Assistência Farmacêutica;

c) Capacitação de recursos humanos para a qualificação da gestão da Assistência Farmacêutica, compreendendo que essa ação pode contribuir para a ampliação do acesso racional dos medicamentos;

d) Coordenação da revisão permanente dos marcos regulatórios que definem as formas de acesso a medicamentos e insumos a saúde em nível ambulatorial e;

e) Participação direta no processo de revisão dos Protocolos Clínicos e Diretrizes Terapêuticas do Ministério da Saúde (BRASIL, 2010a, p. 23, grifo meu).

A estratégia de disponibilização dos medicamentos essenciais e seguros é, portanto, uma entre as diversas aplicadas para atender ao direito constitucional à saúde dos cidadãos (BRASIL, 2014a). E, como citado no documento ministerial, são estratégias importantes a revisão da RENAME, do Formulário Terapêutico Nacional (FTN) e dos PCDT do MS.

O documento 3LN designa a responsabilidade da atualização da RENAME para a Comissão competente, in verbis:

Art. $1^{\circ}$ O Título II da Lei n. 8.080, de 19 de setembro de 1990, passa a vigorar acrescido do seguinte Capítulo VIII:

[...].

“Art. 19-Q. A incorporação, a exclusão ou a alteração pelo SUS de novos medicamentos, produtos e procedimentos, bem como a constituição ou a alteração de protocolo clínico ou de diretriz terapêutica, são atribuições do Ministério da Saúde, assessorado pela Comissão Nacional de Incorporação de Tecnologias no SUS.

$[\ldots] . "$

E ainda, conforme o documento 9LN, a Comissão Nacional de Incorporação de Tecnologias no SUS (CONITEC) teve sua regulamentação atualizada em 2011, bem como os critérios para a seleção dos medicamentos do referido sistema de saúde (BRASIL, 2011c; MINISTÉRIO DA SAÚDE, 2016a).

Cabe destacar que o CEAF foi criado em paralelo a uma revisão do CBAF, e da própria RENAME, segundo os documentos 2SI e 2LM, o que tornou possível evitar 
repetições de medicamentos e tratamentos entre as listas, pois, a racionalidade do tratamento segue uma lógica clínica que tem início no cuidado existente na Atenção Básica de Saúde (BRASIL, 2010a).

Grande parte dos tratamentos feitos pelo CEAF é de doenças crônicas. Mas, as terapias, que são linhas de frente para grande parte das doenças, estão previstas no Componente Básico, em função do menor grau de complexidade inicial dos agravos (BRASIL, 2010a). Logo, a partir da piora do quadro clínico, em alguns casos, tem-se a necessidade da adoção de alternativas terapêuticas à primeira linha de tratamento. Ou seja, inicia-se o tratamento pelo $\mathrm{CBAF}$ e, se houver agravo ou não resposta ao tratamento, pode ser necessário um tratamento pelo CEAF.

Faz-se importante recordar que, de acordo com as listas de medicamentos previstas pela Portaria GM/MS n. 1.554, de 30 de julho de 2013, e os respectivos PCDT, há indicações de tratamento que já se iniciam com o elenco do próprio CEAF (BRASIL, 2010a; 2013a), o que é reforçado pelas palavras do entrevistado $2 \mathrm{EN}$, expressas a seguir:

\begin{abstract}
Essa primeira linha, ela está na atenção básica. Ela não está no componente especializado. Quando o paciente é refratário a essa linha de cuidado, aí sim, ele vai utilizar os fármacos modificadores do curso da doença e os biológicos. E aí essa segunda e terceira linha, está no componente especializado. Então, o componente especializado, ele politicamente, ele tem esse objetivo, atender segunda e terceira linhas de cuidado. Mas, claro que isso é variável de protocolo para protocolo. Por exemplo, o protocolo de esclerose múltipla, ele é totalmente inserido dentro do componente especializado, desde a primeira linha, entendeu? Assim, como outros protocolos, como hepatite de grau $\mathrm{C}$ crônica.
\end{abstract}

É essencial a articulação entre o Componente Especializado e o Componente Básico, para que se respeite a racionalidade clínica do tratamento, na forma de alternativas terapêuticas sequenciadas, conforme o agravo da doença ou a não resposta ao tratamento precedente.

Além da gestão de cada componente, considerando a articulação entre os três para a cobertura integral da assistência à saúde, o CEAF prevê a execução articulada entre os três entes federativos, para que possa ser adequadamente financiado e viabilizado. Tem-se, então, a previsão de pactuação entre a União, os Estados, o Distrito Federal e os Municípios (BRASIL, 2009b).

A competência do fornecimento dos medicamentos pela União, Estados, Distrito Federal e Municípios não está prevista na CF de 1988, mas sim, em atos administrativos federais, estaduais e municipais, segundo o documento 2AR (BARROSO, 2016). 
Além disso, o próprio CEAF está dividido em três grupos que possuem organizações e formas de financiamento diversas. Por definição da Portaria GM/MS n. 2.981, de 26 de novembro de 2009, tem-se:

Grupo 1 - Medicamentos sob responsabilidade da União

Grupo 2 - Medicamentos sob responsabilidade dos Estados e Distrito Federal

Grupo 3 - Medicamentos sob responsabilidade dos Municípios e Distrito Federal (BRASIL, 2009b).

A organização em três grupos prevê responsabilidades distintas entre os entes, além de gestão e financiamentos diferentes. E, em termos clínicos, com o objetivo de ampliar o acesso aos medicamentos e demonstrando a racionalidade clínica que embasa a construção dos elencos de medicamentos, os documentos 7LN e 8LN apresentam os critérios para definição das listas de medicamentos de cada um dos três grupos supracitados, in verbis:

Art. 11. O Grupo 1 foi constituído sob os seguintes critérios:

I - maior complexidade da doença a ser tratada ambulatorialmente;

II - refratariedade ou intolerância a primeira e/ou a segunda linha de tratamento;

III - medicamentos que representam elevado impacto financeiro para o Componente; $\mathrm{e}$

IV - medicamentos incluídos em ações de desenvolvimento produtivo no complexo industrial da saúde.

Art. 12. O Grupo 2 foi constituído sob os seguintes critérios:

I - menor complexidade da doença a ser tratada ambulatorialmente em relação aos elencados no Grupo 1; e

II - refratariedade ou intolerância a primeira linha de tratamento.

Art. 13. O Grupo 3 foi constituído sob os seguintes critérios:

I - fármacos ${ }^{3}$ constantes na Relação Nacional de Medicamentos Essenciais vigente e indicados pelos Protocolos Clínicos e Diretrizes Terapêuticas, publicados na versão final pelo Ministério da Saúde, como a primeira linha de cuidado para o tratamento das doenças contempladas neste Componente (BRASIL, 2009b; 2013a).

A execução do CEAF, Grupos 1 e 2, deve ser feita pelas Secretarias de Saúde dos Estados e do Distrito Federal. Já o Grupo 3 é de execução pelos Municípios e pelo Distrito Federal, e tem suas normas de execução integradas ao CBAF, em regulamentação específica.

\footnotetext{
${ }^{3} \mathrm{O}$ conceito de fármaco deve ser diferenciado de medicamento para melhor compreensão sobre os documentos da área farmacêutica. Assim, entende-se por fármaco a molécula biologicamente ativa, que possui estrutura química conhecida (PRISTA, 2003). Já o medicamento é o produto acabado, o produto farmacêutico, tecnicamente obtido ou elaborado, que possui finalidades curativa, paliativa, preventiva ou dignóstico (BRASIL, 1973). O medicamento incorpora em sua composição o fármaco e outras substâncias inertes denominadas excipientes.
} 
Ou melhor, o Grupo 3 se refere aos medicamentos do Componente Básico - linha de frente dos PCDT (BRASIL, 2013a). Neste sentido, a presente pesquisa envolve as atividades previstas pelos Grupos 1 e 2 do CEAF/PNAF, por não haver sobreposição com o outro componente de medicamentos: o CBAF.

A partir da informação anterior e de explicação pelo entrevistado $3 \mathrm{~N}$, compreende-se que, na prática, a execução do CEAF se dá no nível estadual:

[...] o Ministério, ele é responsável pelo planejamento e pelas diretrizes, certo? E ele é de execução estadual. Então, em todas as unidades da federação, quem é responsável pela execução do componente especializado, são as Secretarias Estaduais de Saúde. Então, ele não passa para o nível de município, certo? O DF, ele diferente no sentido de que nós compartilhamos as atribuições de estado e município. Então, sob a ótica do componente especializado, nós somos vistos como um estado. Mas, por outro lado, sob a ótica do componente básico, nós somos vistos como um município.

O entrevistado $1 \mathrm{EN}$ assim reforça a questão:

A execução do componente especializado é competência dos estados. Então, toda a
parte de agenciamento do medicamento até acesso ao medicamento pelo individuo, a
competência é dos estados. Ao Ministério da Saúde cabe fazer o controle, o
monitoramento e o acompanhamento em termos de gestão do componente
especializado, articulado justamente com os estados e municípios que são quem
executam o próprio componente.

Como o SUS tem organização regionalizada e hierarquizada (art. $3^{\circ}$ - documento 10 LN), a execução do CEAF pelos Estados, Municípios e pelo Distrito Federal segue a mesma lógica (BRASIL, 2011b).

A Secretaria de Estado de Saúde do Distrito Federal (SES/DF), no documento 3SI, apresenta o CEAF, suas Portarias de aprovação, regras de execução e financiamento e os três Grupos de medicamentos, de acordo com as características, responsabilidades e formas de organização (SECRETARIA DE ESTADO DE SAÚDE DO DISTRITO FEDERAL, 2016b). Portanto, considerando a previsão normativa e o caráter peculiar, o Distrito Federal é responsável pelos Grupos 2 e 3, além de executar a disponibilização do Grupo 1, após repasse feito pelo MS.

A implementação do CEAF/PNAF exige a participação de diferentes esferas estatais. Assim, conforme Evans, Rueschmeyer e Skocpol (1985), existem políticas que serão implementadas sob influência de diferentes atores dentro do próprio governo, deflagrando relações de influência intra e intergovernamentais. 
No caso da Saúde, trata-se de uma competência concorrente aos três entes, de repartição vertical, pois são diferenciadas as participações de cada um dos entes. E para a implementação do componente estudado são identificadas relações de coordenação intergovernamental previstas nas normativas, uma vez que são demandadas ações articuladas entre a União, os Estados, os Municípios e o Distrito Federal, desenhando políticas de acordo com as singularidades de cada região. Sobre a questão, Rua (2005, p. 1) assim destaca:

[...] entende-se por coordenação técnico-política um conjunto de mecanismos e procedimentos destinados a compor ou articular as decisões e ações do conjunto de entes governamentais - políticos e burocratas - de maneira a obter resultados concertados, intercomplementares e consistentes; ou seja: não-erráticos, nãosuperpostos e não-contraditórios, que expressem e façam sentido em um projeto de longo prazo.

É importante, portanto, o cumprimento das responsabilidades por cada um dos entes federativos, pois, como apresenta o documento 8LN:

\begin{abstract}
Art. 14. A não disponibilização de medicamentos no âmbito deste Componente não garante a integralidade do tratamento e provoca desequilíbrio financeiro, devendo os gestores do SUS, em pactuação nas instâncias gestoras, promover ações que restabeleçam o acesso aos medicamentos estabelecidos nas linhas de cuidado definidas nos Protocolos Clínicos e Diretrizes Terapêuticas publicados na versão final pelo Ministério da Saúde e o equilíbrio financeiro (BRASIL, 2013a).
\end{abstract}

Ao considerar que a própria construção do CEAF se deu por meio de pactuação entre os três entes federativos, via Comissão Intergestores Tripartite (CIT), em 28 de fevereiro de 2013 (BRASIL, 2013a), reforça-se a responsabilidade já citada da União, dos Estados, dos Municpipios e do Distrito Federal.

Além da garantia do acesso aos medicamentos por todos (princípio da universalidade) e dos medicamentos necessários a cada tipo de problema (princípio da integralidade), os documentos destacam a importância da promoção do uso racional destes componentes. Logo, mais do que somente a disponibilização dos produtos, as mesmas ações garantidoras devem prezar pela qualidade de tais processos. Ou seja, a definição do elenco de medicamentos se dá com base em critérios epidemiológicos, técnicos farmacêuticos, clínicos e farmacoeconômicos.

Tem-se, então, um desafio de alta complexidade, onde o Estado deve executar uma gestão articulada entre os três entes federativos, ou entre a União e o Distrito Federal, incorporando os preceitos do SUS, da PNAF e dos critérios técnicos farmacêuticos para a 
definição e atualização do elenco do CEAF, bem como sua eficiente disponibilização, aliada à promoção do uso racional destes insumos.

No presente Caso, infere-se a partir dos seguintes dados:

1) Que o problema é a execução de ações que atendam à garantia do acesso aos medicamentos pelo SUS, incluída no direito constitucional à saúde;

2) Que seu alcance implica no fornecimento, de acordo com a necessidade de cada um, para todos os residentes em território nacional; e

3) Que para lidar com este problema, é a implementação pelo Poder Executivo, do Componente de Medicamentos Especializados da Assistência Farmacêutica, como tecnologia de intervenção, submetido à PNAF.

\subsection{Contexto Social, Econômico e Político}

Durante a presente pesquisa ficou foi possível perceber que, para compreender o desenvolvimento do CEAF/PNAF, faz-se importante uma visão geral da Saúde pública e da AF, bem como para a definição do problema priorizado pela Política em questão.

Com base em tais informações contextuais, ficam mais nítidas as particularidades relacionadas à execução do componente. Alguns elementos relevantes já foram apresentados na definição da natureza do problema, e o objetivo desta segunda categoria é trazer melhor embasamento para a apreensão do processo de implementação e minúcias da área aqui analisada.

Elaborou-se, então, um diagrama (vide Figura 4.2, a seguir) que reúne os achados quanto aos momentos históricos importantes para a evolução da AF e, por consequência, do CEAF. 


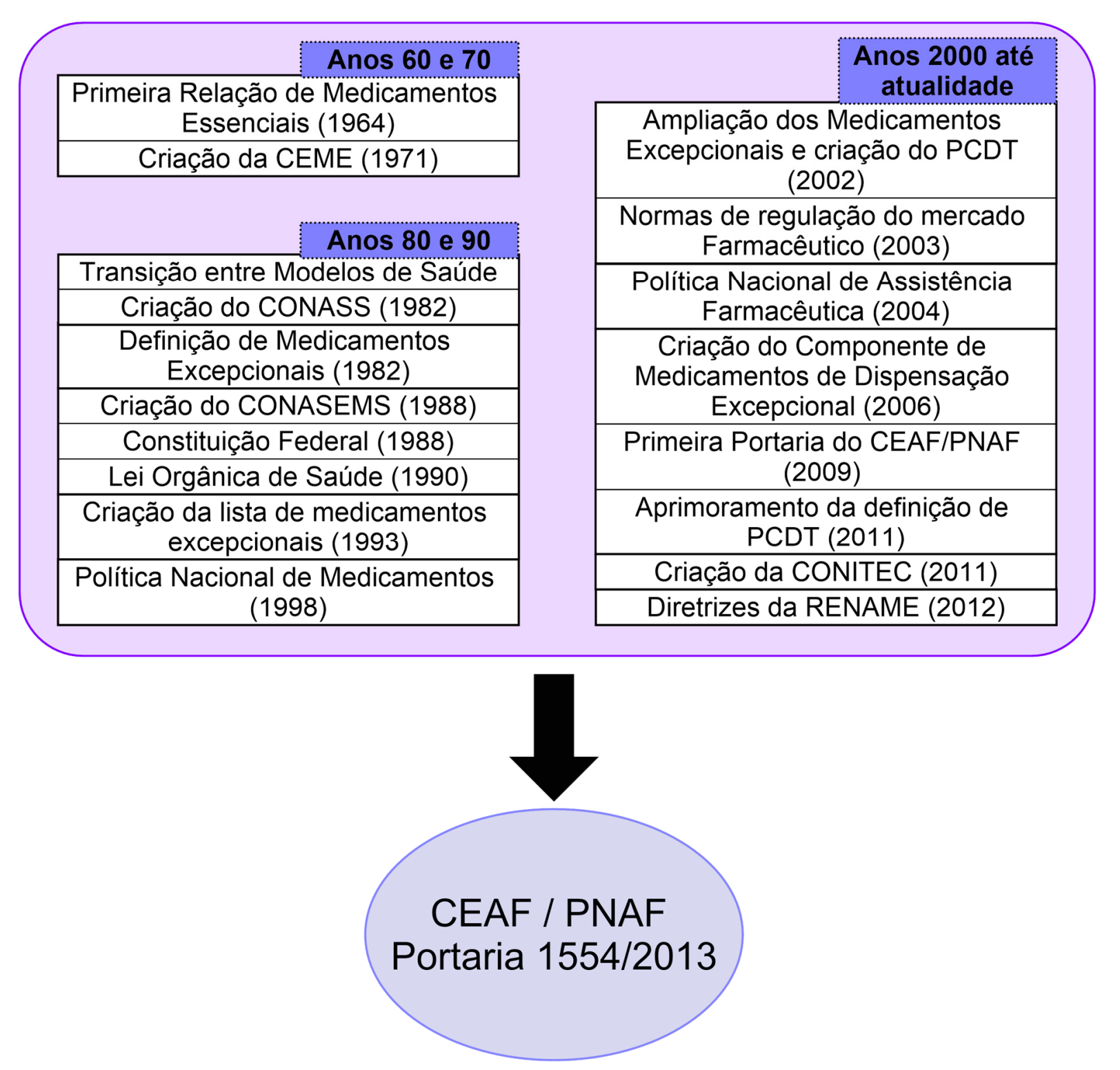

Figura 4.2 - Diagrama com principais elementos identificados do contexto social, econômico e político da Assistência Farmacêutica e implementação do Componente Especializado da Assistência Farmacêutica/Política Nacional de Assistência Farmacêutica.

Fonte: Da autora.

No período prévio à organização do SUS, a AF não tinha representatividade no âmbito da Saúde pública e se resumia ao setor industrial e à área comunitária, composta pelas farmácias e drogarias (documento 3AR) (KORNIS; BRAGA; ZAIRE, 2008).

Segundo dados dos documentos 2AR e 4AR, entre 1870 e 1930, o Estado promoveu ações em Saúde no modelo denominado campanhista, marcado pelo uso da força de polícia e pela ausência de estrutura para ações curativas. A partir dos anos 1930 teve início a construção do sistema nacional de saúde, que não possuía cobertura universal e atendia 
somente os cidadãos que contribuíam com os Institutos de Previdência (BARROSO, 2016; RODRIGUES, 2016).

Em 1953, o Ministério da Saúde e Educação foi desmembrado, originando o atual MS (BARROSO, 2016).

Ainda anterior à criação do sistema público de saúde, percebe-se algumas alterações da AF no SUS, apresentando uma evolução da prática no contexto da saúde pública brasileira (documento 5AR). Em 1964, o Decreto n. 53.612, de 26 de fevereiro de 1964, criou a relação de medicamentos essenciais, sendo um dos primeiros atos legais que qualificou a inserção da área na agenda pública de Saúde. A partir daí, já na década de 1970, foi emitido o Decreto n. 68.806, de 25 de junho de 1971, que dispôs sobre a criação da Central de Medicamentos (CEME) (PAULA et al., 2009).

A partir da década de 1980, teve início a transição do sistema de saúde entre o modelo campanhista, o médico-assistencialista e, por fim, o modelo neoliberal. O movimento sanitarista defendia a universalização do sistema de saúde (BARROSO, 2016). Já o documento 3LM acrescenta que as mudanças econômicas e políticas pelas quais o Brasil passava nos anos 1970 e 1980 foram importantes para reforçar a insatisfação com o modelo de atenção à saúde vigente. Para mais, tal processo transcorria ao lado da busca pela redemocratização. Logo, o referido movimento sanitário embasou a reforma sanitária brasileira (BRASIL, 2006c).

Em prol da atuação descentralizada e hierárquica no sistema, em 1982, os Secretários Estaduais de Saúde conseguiram se organizar e criar o Conselho Nacional de Secretários de Saúde (CONASS). E em 1988 foi criado o Conselho Nacional de Secretários Municipais de Saúde (CONASEMS), aliado a um movimento de municipalização da saúde (BRASIL, 2006c).

As grandes mudanças foram, então, alcançadas na Assembleia Constituinte, com a promulgação da CF de 1988, que culminaram na concretização do SUS em 1990 (BARROSO, 2016; PEREIRA, 1996).

O documento 4AR ainda acrescenta que a Carta Magna assegurou um sistema de saúde amparado pelo princípio da solidariedade, pelo qual este é financiado pelos entes federativos, com igualdade na participação dos custeios e distributividade na prestação dos serviços - características que garantem a proteção social sob dois aspectos: 1) o cidadão tem direito ao acesso aos serviços de saúde prestados pelo Estado (natureza positiva); e, 2) o Estado não pode praticar atos prejudiciais à saúde do cidadão (natureza negativa) (RODRIGUES, 2016). 
Acrescenta-se que o direito à saúde assegurado pela CF de 1988 é amplo e não somente envolve a prestação de serviços de saúde, mas sim, de ações que garantam qualidade de vida. De outro modo, o direito à saúde vincula-se ao direito à paz, à cultura, à educação, ao meio ambiente equilibrado, entre outros. Isto se deve ao exercício pleno da cidadania e à garantia de vida digna aos cidadãos brasileiros (documento 6AR) (CORREA; MASSAFRA, 2004).

Em paralelo ao início da vigência da Carta Magna de 1988, em setembro de 1990, foi publicada a Lei n. 8.080 - Lei Orgânica da Saúde -, que define a organização e o modelo operacional do SUS (BRASIL, 1990; BRASIL, 2006c; BARROSO, 2016).

Entre os anos 1980 e 1999 houve um crescimento intenso do mercado farmacêutico mundial. Em tal período, o mercado que movimentava US\$ 5 bilhões passou a movimentar US\$ 120 bilhões - fato ocorrido em um cenário marcado por poucas empresas multinacionais onde somente 10 empresas responderiam por metade (VIEIRA; ZUCCHI, 2007).

Enquanto em países de baixa renda, o consumo de medicamentos caiu entre os anos 1985 e 1999, de 3,9\% para 2,9\% do total, nos países de alta renda, o acesso não somente aumentava como concentrava a maior parte do consumo mundial. No ano 2000, só os Estados Unidos da América (EUA) consumiam 52\% dos medicamentos comercializados em todo o mundo. Em contrapartida, no Brasil houve uma estimativa de que $41 \%$ da população não tinha acesso a medicamentos (documento 1AR) (VIEIRA; ZUCCHI, 2007).

Em meio ao referido contexto, o MS formulou em 1998, a Política Nacional de Medicamentos - PNM (documento 11LN) - documento pioneiro no Brasil e norteador da AF no contexto do SUS. Entre as diretrizes gerais daquela Política estão: a reorientação da AF, a adoção da relação de medicamentos essenciais, a garantia da segurança, eficácia e qualidade dos medicamentos e a promoção do uso racional de medicamentos (BRASIL, 1998). Diante do cenário de falha de acesso a medicamentos por quase metade da população brasileira, era essencial a priorização deste problema e sua inserção na agenda, o que culminou na formulação da Política em questão.

Além das diretrizes, têm-se as prioridades colocadas como indispensáveis para o alcance do objetivo geral da PNM, a saber:

1) revisão permanente da RENAME;

2) cuidado com a AF no tocante à organização das responsabilidades das três esferas do governo;

3) promoção do uso racional de medicamentos; e

4) organização das atividades de vigilância sanitária de medicamentos (BRASIL, 1998). 
A PNM responde ao proposto pela Lei n. 8.080/1990 quanto à criação de uma política de medicamentos (BRASIL, 1990). Logo, ela atende aos princípios e diretrizes do SUS, propondo ações que consolidem o sistema e melhorem a qualidade de vida da população, auxiliando no desenvolvimento social do País (BRASIL, 1998).

Ainda sobre a PNM, o documento 7AR atenta que a Política é um marco pelas definições da organização da AF no novo sistema de saúde e pela introdução do termo medicamentos essenciais ${ }^{4}$. Esta ainda normatiza a descentralização da AF e as responsabilidades de cada ente governamental, como, por exemplo a seleção dos medicamentos essenciais a partir de cada esfera governamental e níveis de atenção à saúde (MAGARINOS-TORRES; PEPE; OSORIO-DE-CASTRO, 2013).

Em 2003 foi sancionada a Lei n. 10.742 - normativa que dispõe sobre as normas de regulação do setor farmacêutico, para que a AF tenha equilíbrio e competitividade no setor, a ponto de garantir a oferta de medicamentos com preços regulados. Para tanto, é criada a Câmara de Regulação do Mercado de Medicamentos (CMED) (documento 12LN) (BRASIL, 2003).

No ano seguinte, em 06 de maio de 2004, é publicada a Resolução n. 338, que aprova a PNAF, voltada à estruturação da AF sobre os princípios da universalidade, integralidade e equidade. Neste sentido, conforme o documento $4 \mathrm{LN}$, in verbis:

II - a Assistência Farmacêutica deve ser compreendida como política pública norteadora para a formulação de políticas setoriais, entre as quais destacam-se as políticas de medicamentos, de ciência e tecnologia, de desenvolvimento industrial e de formação de recursos humanos, dentre outras, garantindo a intersetorialidade inerente ao sistema de saúde do país (SUS) e cuja implantação envolve tanto o setor público como privado de atenção à saúde;

[...]. (BRASIL, 2004, p.1).

O desenvolvimento da AF brasileira é marcado por diversas estratégias para a saúde pública, que possuem o medicamento como insumo principal. Algumas destas são: o aumento do financiamento; o consequente aumento da cobertura dos tratamentos (novos medicamentos adicionados ao elenco padrão e novas doenças-alvo de tratamentos); a ampliação do acesso

\footnotetext{
${ }^{4}$ Entende-se por medicamentos essenciais aqueles necessários para suprir as demandas epidemiológicas da população e que, obrigatoriamente, tenham comprovadas a eficácia e segurança. Além disso, devem atender critérios como menor custo tratamento/dia, apresentação mais adequada ao manejo, entre outros (MAGARINOS-TORRES; PEPE; OSORIO-DE-CASTRO, 2013).
} 
aos medicamentos pelos cidadãos e ações voltadas à promoção do uso e à prescrição racionais de medicamentos (BRASIL, 2014a).

Para a coordenação e execução das ações derivadas da PNAF, o DAF/MS tem papel crucial (documento 2SI). Aquele Departamento é responsável, entre outras atividades, in verbis, por:

II - formular e implementar, e coordenar a gestão das Políticas Nacionais de Assistência Farmacêutica e de Medicamentos, incluindo sangue, hemoderivados, vacinas e imunobiológicos, na qualidade de partes integrantes da Política Nacional de Saúde, observados os princípios e as diretrizes do SUS;

V - normatizar, promover e coordenar a organização da assistência farmacêutica, nos diferentes níveis da atenção à saúde, obedecendo aos princípios e diretrizes do SUS; [...]. (MINISTÉRIO DA SAÚDE, 2016a , p.1).

E é neste cenário de trabalho com as Políticas de AF que o DAF/MS busca a ampliação de acesso e o aumento da cobertura dos tratamentos ao desenvolver o CEAF. Porém, antes do atual CEAF, houve um modelo anterior (o CMDE).

Na presente pesquisa, a análise dos dados em questão permitiu ordenar a história do CEAF/PNAF em três momentos, a saber: 1) Criação do CMDE; 2) Revisão do CMDE e criação do CEAF; e, 3) Conjuntura atual do CEAF.

\subsubsection{Momento 01 - período 1982-2009 - Criação do Componente de Medicamentos de Dispensação Excepcional}

Em 15 de dezembro de 1982, pela Portaria Interministerial MPAS/MS/MEC n. 3 (documento $13 \mathrm{LN}$ ), foi oficializado pela primeira vez o termo "medicamentos excepcionais". Aquela Portaria, que dispunha sobre a RENAME, também estabeleceu que, em caráter excepcional, poderiam ser adquiridos medicamentos não existentes na RENAME, mediante justificativa por escrito da prescrição excepcional, feita pelo médico responsável e homologada pela instituição prestadora do atendimento (BRASIL, 1982). Naquele momento somente existia a RENAME e não havia relação de medicamentos excepcionais. Ou melhor, todos os medicamentos não constantes na RENAME eram considerados "excepcionais".

Passados 11 anos, em 1993, foi criada a primeira lista de medicamentos excepcionais, que continha somente dois medicamentos (ciclosporina e eritropoietina humana) - indicados para o tratamento de pacientes transplantados e portadores de doenças renais crônicas. Tal lista foi disposta pela Portaria SAS/MS n. 142, de 06 de outubro de 1993 (documento 14 LN) (BRASIL, 1993b). Poucos anos depois, a Portaria SAS/MS n. 204, de 06 de novembro de 
1996 (documento 15LN) ampliou a lista para 32 fármacos, com 55 apresentações farmacêuticas diferentes (BRASIL, 1996).

Já em 2002 foi publicada a Portaria GM/MS n. 1.318, de 23 de julho (documento 16LN), que definiu os novos medicamentos excepcionais e estabeleceu o critério de que o diagnóstico, a indicação tratamento e outras questões clínicas deveriam seguir os Protocolos Clínicos e Diretrizes Terapêuticas publicados pelo MS (BRASIL, 2002). Neste momento surge também o termo "medicamentos de alto custo"; e o Manual Técnico dos Protocolos Clínicos e Diretrizes Terapêuticas faz uso do termo "Programa de Medicamentos Excepcionais".

Sobre a questão, o entrevistado 1EN explica que os PCDT são mais amplos do que somente a especificação de uma linha de tratamento medicamentoso:

\footnotetext{
É o protocolo da doença, não é o protocolo do medicamento. Lá no início, lá em 2000 , quando surge o primeiro protocolo clínico até 2004 , o protocolo é muito vinculado ao medicamento. Então, por isso que nós temos o protocolo da esquizofrenia refratária. Ele não falava dos medicamentos no início do tratamento, só quando o paciente não tinha mais a eficácia de nenhum tratamento da atenção básica. E nós mudamos esse modelo em 2008. É o protocolo da doença.

[...].

Essa transformação do conceito do protocolo está, inclusive, incluído na Lei 2.401 de 2011 e no Decreto n 7508, que é um protocolo clinico. Então, ele não é o protocolo apenas do medicamento, ele dá todas as orientações, diagnósticos, tratamento no âmbito do SUS. Ou seja, no SUS é essa forma que vai fazer desde o diagnóstico até o tratamento.
}

Na sequência dos fatos, a Portaria GM/MS n. 2.577, de 27 de outubro de 2006, aprovou o CMDE (documento 6LN) (BRASIL, 2006d). Segundo o documento 2LM, o entendimento sobre o referido Componente é de que seja:

Uma estratégia da Política de Assistência Farmacêutica que tem por objetivo disponibilizar medicamentos no âmbito do Sistema Único de Saúde para tratamento de agravos inseridos nos seguintes critérios: a) doença rara ou de baixa prevalência, com indicação de uso de medicamento de alto valor unitário ou que, em caso de uso crônico ou prolongado, seja um tratamento de custo elevado; e b) doença prevalente, com uso de medicamento de alto custo unitário ou que, em caso de uso crônico ou prolongado, seja um tratamento de custo elevado desde que: b.1) haja tratamento previsto para o agravo no nível da atenção básica, ao qual o paciente apresentou necessariamente intolerância, refratariedade ou evolução para quadro clínico de maior gravidade, ou b.2) o diagnóstico ou estabelecimento de conduta terapêutica para o agravo estejam inseridos na atenção especializada (BRASIL, 2010a, p. 39) 
Ora, o documento 2AR definiu como medicamentos excepcionais:

\begin{abstract}
Os medicamentos de "dispensação" em caráter excepcional são aqueles destinados ao tratamento de patologias específicas, que atingem número limitado de pacientes, e que apresentam alto custo, seja em razão do seu valor unitário, seja em virtude da utilização por período prolongado. Entre os usuários desses medicamentos estão os transplantados, os portadores de insuficiência renal crônica, de esclerose múltipla, de hepatite viral crônica B e C, de epilepsia, de esquizofrenia refratária e de doenças genéticas como fibrose cística e a doença de Gaucher (BARROSO, 2016, p.19).
\end{abstract}

E dias antes da publicação da Portaria de aprovação do componente, em 05 de outubro de 2006, a CIT, já havia pactuado em reunião a repartição do financiamento do CMDE entre a União e os Estados, uma vez que estes últimos estavam com orçamento negativo por custearem os medicamentos e os casos judiciais (BARROSO, 2016).

Posteriormente foi publicada a Portaria MS n. 1.321, de 05 de junho de 2007, que definiu os recursos que a União repassaria como cofinanciamento para os Estados e o Distrito Federal referentes à competência maio-junho de 2007, para a aquisição e distribuição de Medicamentos de Dispensação em Caráter Excepcional (BARROSO, 2016).

\title{
4.2.2 Momento 02 - período 2009-2013 - Revisão do Componente de Medicamentos de Dispensação Excepcional e criação do Componente Especializado da Assistência Farmacêutica
}

$\mathrm{O}$ antigo CMDE foi, pois, revisto para atender a cobertura necessária, conforme os critérios clínicos-epidemiológicos, e o DAF/MS atuou definindo o CEAF (documento 2LM) (BRASIL, 2010a).

Os estudos do DAF/MS que culminaram na criação do CEAF partiram da análise das demandas levantadas pelos diferentes atores com interesses na questão. Foram consideradas as demandas dos gestores estaduais e municipais, das entidades interessadas, do setor produtivo, da sociedade civil, da Comissão de Incorporação de Tecnologias do MS, do próprio DAF/MS e da própria judicialização (BRASIL, 2010a).

O CEAF foi, então, aprovado pela Portaria GM/MS n. 2.981/2009, que além de regular o Componente, também oficializa a substituição do termo anterior: "Componente de Medicamentos de Dispensação Excepcional” (documento 7LN) (BRASIL, 2009b).

Uma estratégia importante para uma boa execução do CEAF foi a melhor definição do termo "Protocolos Clínicos e Diretrizes Terapêuticas", bem como sobre aspectos da 
assistência terapêutica e dos cuidados com a incorporação de tecnologias em saúde no SUS. Isto foi realizado por meio da Lei n. 12.401/2011 (documento 3LN) (BRASIL, 2011a).

Ainda em 2011, acompanhando o ditame supramencionado e a gestão de novas tecnologias em saúde, o Decreto n. 7.646, de 21 de dezembro de 2011, definiu a criação da CONITEC no SUS, além de considerações sobre o processo administrativo para incorporação, exclusão e alteração de tecnologias em saúde pelo SUS (documento 9LN) (BRASIL, 2011c).

Anterior à CONITEC, o documento 7LN destaca a previsão de uma Comissão de Incorporação de Tecnologias do MS, in verbis:

Art. 18. A incorporação, exclusão ou substituição de medicamentos ou ampliação de cobertura para medicamentos já padronizados no âmbito deste Componente, ocorrerá mediante os critérios estabelecidos pela Comissão de Incorporação de Tecnologias do Ministério da Saúde (CITEC/MS), conforme ato normativo específico e pactuação na CIT (BRASIL, 2009b).

E em 2012 foram iniciados os trabalhos da CONITEC (MINISTÉRIO DA SAÚDE, 2015 ; 2016c). Sobre o procedimento de incorporação de tecnologias, o entrevistado 1EN assim se expressou:

Se ele (ente federativo) quiser incluir na lista do componente especializado, qualquer ente, qualquer pessoa, ele faz a solicitação a CONITEC. [...] Tem que ser formalizado e no componente especializado tem algumas regras a incorporação, não basta ter a recomendação da CONITEC. A CONITEC é um dos critérios, mas além da recomendação da CONITEC, a gente tem que ter atualização ou elaboração do protocolo clínico, pois não basta ter apenas o medicamento. O CEAF está padronizado com a linha de cuidado da doença em si, além de pactuação na CIT, sobre quem que vai pagar esse medicamento.

Em 2012, a Resolução CIT n. 1, de 17 de janeiro, apresenta as diretrizes nacionais da RENAME no âmbito do SUS. Entre outros aspectos, o referido ditame define a RENAME, in verbis:

Art. $2^{\circ}$ A RENAME compreende a seleção e a padronização de medicamentos indicados para atendimento de doenças ou de agravos no âmbito do SUS.

Parágrafo único. Para os fins do disposto nesta Resolução, medicamentos essenciais são aqueles definidos pelo SUS para garantir o acesso do usuário ao tratamento medicamentoso (BRASIL, 2012a).

O documento $17 \mathrm{LN}$ reestrutura a RENAME e passa a incluir os medicamentos do CEAF na mesma lista nacional, in verbis: 
Art. $4^{\circ}$ A RENAME é composta por:

I - Relação Nacional de Medicamentos do Componente Básico da Assistência Farmacêutica;

II - Relação Nacional de Medicamentos do Componente Estratégico da Assistência Farmacêutica;

III - Relação Nacional de Medicamentos do Componente Especializado da Assistência Farmacêutica;

IV - Relação Nacional de Insumos Farmacêuticos; e

V - Relação Nacional de Medicamentos de Uso Hospitalar (BRASIL, 2012a).

No mesmo ano, a Portaria GM/MS n. 533, de 28 de março de 2012, definiue o elenco de medicamentos e insumos da RENAME no âmbito do SUS (documento 18LN) (BRASIL, 2012b).

Ainda destacando o aprimoramento do CEAF ao longo dos anos, em 30 de julho de 2013 foi publicada a Portaria n. 1.554, que estabeleceu as regras de financiamento e execução deste Componente no âmbito do SUS (documento 8LN). Entre as regras de financiamento é preciso destacar as responsabilidades de cada um dos entes federativos no custeio do componente. Para tanto, os medicamentos foram organizados em três grupos, conforme a sistematização do financiamento e gestão (BRASIL, 2013a). Neste sentido, a referida Portaria foi alterada pela Portaria MS n. 1.996, de 11 de setembro de 2013 (documento 19 LN) (BRASIL, 2013b).

O documento 2SI ainda acrescenta a informação de que, com a Portaria GM/MS n. 1.554/2013, o elenco do Grupo 1 foi composto por 86 fármacos em 156 apresentações farmacêuticas, sendo que destes, 49 fármacos em 79 apresentações são adquiridos pelo MS. Já o Grupo 2 foi composto por 54 fármacos em 119 apresentações farmacêuticas. Considerando os medicamentos dos Grupos 1, 2 e 3 (grupo de medicamentos do CBAF que introduzem o tratamento dos PCDT), o CEAF é formado atualmente por 198 fármacos em 389 apresentações farmacêuticas (MINISTÉRIO DA SAÚDE, 2016a).

\subsubsection{Momento 03 - período 2013-2016 - Conjuntura atual do Componente Especializado da Assistência Farmacêutica}

O CEAF é considerado pelo MS uma estratégia inovadora em saúde, uma vez que amplia de forma significativa a cobertura de tratamentos, em prol da integralidade da assistência à saúde. Além do que, pela característica do alto custo destes medicamentos, tal investimento também passa a ser uma estratégica de estímulo ao Complexo EconômicoIndustrial da Saúde (CEIS) para o País (BRASIL, 2014a), o que estimula o desenvolvimento tecnológico nacional e a economicidade, já que o Brasil não pode depender da produção e 
conhecimento estrangeiros agregado às referidas tecnologias. Em função disto, o País deve se preocupar com a sustentabilidade do sistema de saúde, sendo este universal.

O MS observa justamente os resultados positivos com a normatização da gestão do CEAF. O documento 1LM destaca que vários PCDT foram publicados, o que denota maior cobertura de tratamentos e, por serem documentos que sistematizam não somente o tratamento, como todo o cuidado quanto à doença, houve grande parceria com a Secretaria de Atenção à Saúde (SAS) e a Secretaria de Vigilância em Saúde (SVS) do MS.

Outro ponto interessante foi o sucesso na incorporação de medicamentos com garantia da viabilidade orçamentária, por meio das análises farmacoeconômicas da CONITEC. Também foi percebida economia significativa no orçamento do SUS com as aquisições selecionadas de medicamentos (BRASIL, 2014a).

No âmbito do Distrito Federal, considerando as questões colocadas quanto à seleção de medicamentos enquanto tecnologias em saúde, no SUS foram noticiadas duas iniciativas relacionadas aos assuntos (documento $1 \mathrm{SI})$.

Em 2014, foi ministrada a palestra intitulada Impacto orçamentário das inclusões de medicamentos na REME/DF, organizada pela Diretoria de Assistência Farmacêutica da Secretaria de Estado de Saúde do Distrito Federal (DIASF/SES/DF), com o apoio da Gerência de Planejamento Orçamentário em Saúde da referida Secretaria de Estado, além do Núcleo de Monitoramento, Acompanhamento e Controle da DIASF/SES/DF. E em 2015 foi organizada a palestra de divulgação da Relação de Medicamentos Padronizados do Distrito Federal (REME-DF) (SECRETARIA DE ESTADO DE SAÚDE DO DISTRITO FEDERAL, 2016b).

Quanto aos gastos com medicamentos, é preciso destacar que em 2003, o MS gastou quase $\mathrm{R} \$ 2$ bilhões com a aquisição de medicamentos - valor que correspondia à 5,8\% do orçamento do órgão. Já em 2010, o gasto foi de aproximadamente $\mathrm{R}$ \$ 6,5 bilhões, equivalente a 12,5\% do orçamento daquele ano (MINISTÉRIO DA SAÚDE, 2016a).

O documento 8AR investigou os investimentos com medicamentos feitos pelos entes federativos no período 2005-2009. Neste, a União ampliou a designação de recursos para a aquisição de medicamentos em 63,5\%. Já os Estados e o Distrito Federal ampliaram os investimentos próprios em 112,4\%. Por último, os Munícipios tiveram aumento de 22,7\%. No total, em 2009, os gastos com medicamentos no País foram de R \$ 8,9 bilhões (VIEIRA; ZUCCHI, 2013).

O documento 1NS destaca que os gastos com as compras de medicamentos em 2010 foram de R\$ 6,9 bilhões, e aumentaram em 78\% em quatro anos, atingindo R\$ 12,4 bilhões em 2014 (MINISTÉRIO DA SAÚDE, 2015). Já em 2015, os gastos foram de R\$15,8 
bilhõess com a compra de medicamentos, representando um aumento de $129 \%$ frente ao que foi gasto em 2010 (MINISTÉRIO DA SAÚDE, 2016a; 2016c).

$\mathrm{Na}$ apresentação dos aspectos contextuais onde a Política de interesse foi desenvolvida e é executada, considerou-se o histórico da saúde pública no Brasil e, inserido neste, a AF ali existente. Neste sentido, faz-se importante observar as mudanças trazidas pelo avanço da democracia e das funções do Estado. Sobre a questão, o documento 9AR sintetiza que a democracia liberal causou uma transição entre um governo coercitivo à um governo regulador e interventor denominado Welfare State (Estado Social). Porém, a manutenção deste Estado se tornou dispendiosa, e fatores políticos e econômicos causaram uma crise que culmina em uma reforma neoliberal pautada pelos interesses de mercado, da livre iniciativa e da disciplina fiscal, argumentando pela necessidade de redução dos gastos públicos, o que significa, no plano administrativo, que a gestão das Políticas Públicas deve incorporar uma lógica de racionalidade econômica do setor privado em prol da sustentabilidade (CONSELHO NACIONAL DE SECRETÁRIOS DE SAÚDE, 2016a).

As Políticas e os programas de saúde, portanto, se envolvem em meio ao contexto atual outrora apresentado. E no que tange à seleção de medicamentos (documento 10LN e 2NS), é possível perceber que a racionalidade dos custos passa a ser abordada a partir da avaliação econômica comparativa dos benefícios de cada medicamento e dos custos em relação às tecnologias já incorporadas (BRASIL, 2011c; MINISTÉRIO DA SAÚDE, 2016c).

\subsection{Aparato Normativo}

Em resgate ao que foi apresentado anteriormente, grande parte da regulamentação da temática em estudo foi citada e descrita nas categorias NP e CSEP. Mas, os dados ainda revelaram outras normas que também amparam o CEAF/PNAF.

Na presente seção, que trata da categoria AN, tem-se a organização e apresentação de todas as normas evidenciadas na pesquisa. Para melhor compreensão, a apresentação dos resultados é dividida em duas partes. A primeira trata das normas embasadoras propriamente ditas, seguidas pela exposição das oportunidades para exercício de poder discricionário por parte dos implementadores da Política permitida nas normas. Tais oportunidades foram aqui denominadas discricionariedade normativa, para distinguí-las da discricionariedade operacional, que será tratada na discussão da categoria AA. 


\subsubsection{Normas embasadoras}

As normas identificadas nos artigos científicos e documentos utilizados na presente pesquisa, além da menção pelos entrevistados, embasam as Políticas de saúde, a AF e o CEAF/PNAF no Brasil e no Distrito Federal.

São muitos os ditames relacionados à área, principalmente por caracterizarem muitos anos de desenvolvimento da saúde pública brasileira. Ademais, é possível observar nos resultados evidenciados nas linhas que se seguem que a maior parte dos atos normativos foram publicados nos últimos anos, tendo em vista que o trabalho de sistematização das ações relacionadas à disponibilização de medicamentos é relativamente recente. Os documentos foram organizados em Quadros que constam como Apêndices aqui existentes, discutidos em sequência cronológica, para trazer maior clareza ao assunto em função do volume de informações.

O primeiro Quadro, apresentado no Apêndice L, destaca as normas publicadas no período 1970-1999. Um marco normativo para a área farmacêutica, datado de 1973, foi a Lei n. 5.991 (documento 20LN). Esta teve importância por regular o controle sanitário de medicamentos e insumos relacionados, além de apresentar conceitos da área até hoje utilizados. E para a problemática em questão, este assunto é essencial, pois remete às exigências mínimas para comercialização de medicamentos, o que inclui o registro destes produtos no País (de responsabilidade atual da Agência Nacional de Vigilância Sanitária ANVISA) (BRASIL, 1973). Ou seja, para a disponibilização do produto no Brasil, é necessário seu registro pela ANVISA, que prevê a comprovação de eficácia e segurança para a(s) finalidade(s) registrada(s).

Posteriormente, a Portaria MS n. 3/1982 (documento 13LN) inovou ao regulamentar a possibilidade de aquisição de medicamentos não previstos pelo SUS. À época não havia ainda a organização dos medicamentos em componentes, e a cobertura de tratamentos era menor; porém, sempre houve uma lista padrão de produtos para organização da gestão destes insumos. Tal brecha nas compras demandava justificativa clínica por parte do prescritor, mas era possível obter outros medicamentos quaisquer, desde que comprovada a necessidade para o quadro, bem como sua eficácia e segurança (BRASIL, 1982).

A Carta Magna trouxe o importante fundamento jurídico do direito à saúde, que demanda toda essa organização do governo para o provimento da assistência à saúde aos cidadãos brasileiros (BRASIL, 1988; 2010a). E a partir desta foi possível a existência da Lei Orgânica da Saúde, que prevê a organização descentralizada e hierárquica do sistema de 
saúde. Tal ditame é essencial para a compreensão da organização da AF e, pontualmente, de como se operacionaliza o CEAF/PNAF nos dias de hoje (BRASIL, 1990a; 2006c).

Na presente pesquisa, ao observar o caso do Distrito Federal, é preciso destacar a Lei Orgânica do Distrito Federal, promulgada em 08 de junho de 1993 (documento 21LN). Entre diversos artigos e parágrafos do referido ditame, vale destacar a designação de competência ao Distrito Federal sobre a prestação de serviços de assistência à saúde da população, seguindo as diretrizes da CF de 1988. A Lei em questão apresenta a responsabilidade distrital de implementar Políticas que garantam o acesso universal e igualitário aos serviços de saúde (BRASIL, 1993b).

$\mathrm{Na}$ sequência temporal, algumas Portarias Ministeriais (PMs) versam sobre os medicamentos ditos excepcionais. Para que fosse possível a aquisição destes medicamentos, algumas normativas da SAS/MS foram criadas para registrar os códigos dos novos medicamentos no Sistema de Informações Ambulatoriais do SUS (SIA/SUS). Como exemplo tem-se as Portarias MS n. 142/1993, n. 204/1996 e SAS n. 17, de 22 de janeiro de 1997 (documentos 14LN, 15LN e 22LN) (BRASIL, 1993c; 1996; 1997).

Em 1998, já com a estrutura do SUS definida pela Lei Orgânica da Saúde, foi elaborada a primeira PNM (RODRIGUES, 2016; SECRETARIA DE ESTADO DE SAÚDE DO DISTRITO FEDERAL, 2016a; BRASIL, 1998). Aquela Política foi importante para a AF uma vez que estabeleceu como objetivo garantir a eficácia, a segurança e a qualidade dos medicamentos, além do seu uso racional e o acesso àqueles essenciais (documento 10AR) (TEIXEIRA, 2011). Os critérios técnicos farmacêuticos são importantes, pois embasam a AF e definem os requisitos mínimos para o fornecimento de medicamentos pelo SUS. Isto é, para garantir um tratamento adequado e seguro aos pacientes, a seleção de medicamentos deve seguir os critérios específicos da área. $\mathrm{O}$ que significa que o não seguimento dos mesmos acarreta risco ao tratamento e à saúde dos indivíduos, desde a falha terapêutica até as reações adversas medicamentosas.

Retomando a crescente organização dos medicamentos excepcionais, a Portaria SAS/MS n. 409, de 05 de agosto de 1999 (documento 23LN), sistematiza a solicitação destes e institui a Autorização de Procedimentos de Alta Complexidade/Custo (APAC) para este processo de fornecimento dos medicamentos constantes no SIA/SUS (BRASIL, 1999), evidenciando uma preocupação com a criação de fluxos e registros, até mesmo porque as evidências são de incorporação e crescimento constante da lista destes medicamentos.

O Quadro que consta no Apêndice $\mathrm{M}$ é composto pelos atos normativos do período 2000-2005, apresentados a seguir. 
Em 2002, a Portaria GM/MS n. 1.318, de 23 de julho de 2002 (documento 16LN), criou o Programa de Medicamentos Excepcionais (BRASIL, 2002a). Tal normativa assegurou um grande salto para a ampliação da oferta de medicamentos no SUS. A partir daí, além da RENAME, cria-se uma lista de medicamentos também necessários, porém, de alto custo e que eram demandados por uma parcela menor da população. Neste sentido, é possível inferir que o fato de haver um programa que garanta uma previsão de compra e exija um planejamento prévio pelos gestores faz com que muitos indivíduos possam usufruir dos novos medicamentos ofertados.

Em 2002 e 2005 são publicadas novas Portarias (SAS/MS n. 921, de 22 de novembro de 2002, e SAS/MS n. 203, de 19 de abril de 2005) (documentos 24LN e 25LN) de inclusão de medicamentos excepcionais no SIA/SUS, indicando a ampliação da lista e oferta de novos produtos (BRASIL, 2002b; 2005)

A determinação das normas de regulação para o setor farmacêutico (por meio da Lei n. 10.742/2003) (documento 12LN) exige o registro dos medicamentos na ANVISA para comercialização no Brasil (BRASIL, 2003). Tal condição traz consigo o requisito de haver eficácia e segurança comprovadas para a(s) indicação(ões) de registro. Assim, as indicações clínicas estarão embasadas por comprovação científica, uma vez que o entendimento técnico farmacêutico é importante para compreender o que embasa a seleção de medicamentos para as listas de padronizados do SUS.

A Resolução que institui a PNAF (CNS n. 338/2004) (documento 4LN), além de orientar o desenvolvimento de ações que garantam o acesso aos medicamentos, também estimula a promoção do uso racional de medicamentos e a utilização da RENAME. No primeiro aspecto do ditame, quanto ao uso racional, tem-se explícita a intenção de disciplinar as prescrições, a dispensação e o consumo. Quanto ao segundo ponto, cita-se a utilização da RENAME como forma de racionalizar as ações no âmbito da AF. Daí se entende que a RENAME é formulada com base em critérios técnicos, existindo mérito para que o documento seja, de fato, seguido (BRASIL, 2004).

Dando continuidade, o Quadro apresentado no Apêndice $\mathrm{N}$ reúne as normas publicadas entre os anos 2006 e 2010, discutidas a seguir.

No período 2006-2010, alguns atos normativos dão sequência ao aprimoramento do Programa de Medicamentos Excepcionais. Neste contexto, a Portaria n. SAS/MS n. 768, de 26 de outubro de 2006 (documento 26LN), define um novo documento pelo qual o usuário solicitava um medicamento excepcional (BRASIL, 2006c). 
A Portaria n. 2.577, de 27 de outubro de 2006 (documento 6LN), trouxe grande avanço e ampliação do elenco de medicamentos do SUS ao criar o CMDE como parte integrante da PNAF. E acaba demandando o desenvolvimento de novas estratégias pelo MS para a execução do referido Componente (BRASIL, 2006d). No ano seguinte, a Portaria GM/MS n. 204, de 29 de janeiro de 2007 (documento 5LN), reorganiza o repasse de recursos federais para os demais entes federativos, para as ações e os serviços de saúde (BRASIL, 2007a).

As retificações da Portaria n. 2.577, 26 de fevereiro de 2007, e de 26 de abril de 2007, e as Portarias GM/MS n. 1.869, de 04 de setembro de 2008, e GM/MS n. 106, de 22 de janeiro de 2009 (documentos 27LN, 28LN, 29LN, 30LN, respectivamente), fazem alterações de cunho financeiro, dos códigos dos produtos no SIA/SUS e as quantidades máximas dos medicamentos para os tratamentos (BRASIL, 2007b; 2007c; 2008; 2009f).

Em 2009, como marco para o objeto da presente pesquisa, deu-se a publicação da Portaria GM/MS n. 2.981/2009, que define, enfim, o CEAF (SECRETARIA DE ESTADO DE SAÚDE DO DISTRITO FEDERAL, 2016b; BRASIL, 2009b).

Sobre esta e outras publicações do MS, o entrevistado 2EN assim comenta as normativas:

\footnotetext{
Então, é aquilo, o Ministério ele está regulamentando como que nós devemos agir por forma desses protocolos. E nós somos, enquanto estado, executor do componente especializado. De forma geral, o componente especializado, ele trabalha com medicamentos que tem alguns critérios específicos. Geralmente, são medicamentos de mais alto impacto, mas na verdade, são medicamento ambulatoriais que pertencem, geralmente, a segunda e terceira linhas de cuidados.
}

As normas do ano de 2010 abordaram algumas renovações da Portaria GM/MS n. 2.981/2009 em relação aos artigos da norma e das atualizações da lista de medicamentos. Neste sentido, têm-se os seguintes ditames: Portaria GM/MS n. 343, de 22 de fevereiro de 2010; retificação da Portaria n. 343/2010, 3 de março de 2010; Portaria GM/MS n. 743, de 8 de abril de 2010; Portaria GM/MS n. 3.128, de 14 de outubro de 2010; Portaria GM/MS n. 3.439, de 11 de novembro de 2010; e, Portaria SCTIE/MS n. 19, de 30 de dezembro de 2010 (documentos 31LN, 32LN, 33LN, 34LN, 35LN e 36LN, respectivamente) (BRASIL, 2010d; 2010e; 2010f; 2010g; 2010h; 2010i).

O ano 2011 foi marcado por algumas publicações normativas importantes, que estão apresentadas no Apêndice O. Em tal período, algumas Portarias realizaram revisões e ajustes de normativas prévias, a saber: Portaria SCTIE/MS n. 2, de 16 de março de 2011; Portaria 
SCTIE/MS n. 7, de 13 de junho de 2011; Portaria GM/MS n. 2.079, de $1^{\text {o }}$ de setembro de 2011; e, Portaria GM/MS n. 2.928, de 12 de dezembro de 2011 (documentos 37LN, 38LN, 39LN e 40LN, respectivamente) (BRASIL, 2011i; 2011j; 20111; 2011m).

A Lei n. 12.401/2011 foi também significativa para a AF no Brasil, uma vez que acrescentou à Lei Orgânica da Saúde a definição de "assistência terapêutica", além dos requisitos para a incorporação de tecnologias em saúde no SUS. E ainda de importância na presente pesquisa, tal ditame apresenta a definição de protocolos clínicos e a necessidade de seguimento destes para o acesso aos medicamentos pelo SUS (BRASIL, 2011a).

O Decreto n. 7.508, de 28 de junho de 2011, regulamenta a Lei Orgânica da Saúde de 1990 (BRASIL, 2011b). A Lei n. 12.466, de 24 de agosto de 2011 (documento 41LN) também acrescenta artigos à Lei Orgânica à Saúde, porém, definindo o papel dos espaços de pactuação no sistema de saúde, a saber: a CIT, o CONASS e o CONASEMS (BRASIL, 2011e).

Para o objeto em estudo, o Decreto n. 7.646/2011 (documento 9LN), tem extrema validade, uma vez que dispõe sobre a CONITEC. Além de formalizar a competência e composição da referida Comissão, também versa sobre a inclusão, exclusão ou alteração de tecnologias padronizadas no SUS (BRASIL, 2011c). Esta norma é de extrema importância por garantir a uma comissão técnica competente a atividade de realizar as revisões da RENAME, segundo critérios de análise farmacêutica e clínica.

Em suma, desde a criação do CEAF/PNAF, muitas normas foram formuladas. Neste sentido, tem-se também o Quadro apresentado no Apêndice P, que reúne as ormas de um único ano: 2012.

Em 2012 foi expedida uma Lei Complementar (LC) que definiu valores mínimos a serem aplicados pelos entes governamentais na área da saúde - LC n. 141, de 13 de janeiro (documento 16LN) (BRASIL, 2012c). Este marco regulatório tem sua importância por exigir um investimento mínimo para a saúde pública e, assim, tentar viabilizar uma oferta de serviços de melhor qualidade e cobertura adequada à população.

A Resolução CIT n. 1, de 17 de janeiro de 2012, e a Portaria GM/MS n. 533, de 28 de março de 2012, apresentam as diretrizes para a seleção de medicamentos a serem priorizados segundo dados epidemiológicos do País, bem como a própria lista de medicamentos atualizada (documentos 17LN e 18LN) (BRASIL, 2012a; 2012b).

Outras Portarias descreveram atualizações da lista de medicamentos do CEAF/PNAF, a saber: Portaria GM/MS n. 1.091, de 28 de maio de 2012; e, Portaria GM/MS n. 1.103, de 28 de maio de 2012 (documentos 42LN e 43LN) (BRASIL, 2012f; 2012g). 
O ano 2013 foi permeado por normas de atualização da lista de medicamentos do CEAF/PNAF. Estas e outras estão apresentadas em Quadro exposto no Apêndice Q. No referido período, muitas Portarias foram publicadas em prol da atualização de procedimentos ou para inclusão de medicamentos na lista do CEAF/PNAF, a saber: Portaria SAS/MS n. 257, de 12 de março de 2013; Portaria SAS/MS n. 284, de 20 de março de 2013; Portaria SAS/MS n. 745, de 05 de julho de 2013; Portaria n. 1.996, de 11 de setembro de 2013; Portaria GM/MS n. 2.978, de 04 de dezembro de 2013; Portaria GM/MS n. 2.979, de 04 de dezembro de 2013; Portaria GM/MS n. 2.981, de 4 de dezembro de 2013; Portaria SAS/MS n. 1.447, de 26 de dezembro de 2013; e, Portaria GM/MS n. 3.293, de 26 de dezembro de 2013 (documento de 44LN a 52LN, respectivamente) (BRASIL, 2013d; 2013e; 2013f; 2013b; 2013g; 2013h; 2013i; 2013j; 20131).

A fim de aprimorar o financiamento e as diretrizes para a execução do CEAF/PNAF, foi criada a Portaria GM/MS n. 1.544, de 30 de julho de 2013 (MINISTÉRIO DA SAÚDE, 2016a; SECRETARIA DE ESTADO DE SAÚDE DO DISTRITO FEDERAL, 2016b; BRASIL, 2013a). Esta norma é importante por reforçar a participação dos entes federativos nos respectivos grupos para os quais haverá aporte financeiro e/ou gestão da compra e armazenamento dos medicamentos.

A Portaria GM/MS n. 2.135, de 25 de setembro de 2013, é um documento interessante pois, ao apresentar as diretrizes para o processo de planejamento no SUS, tem-se a responsabilização dos entes e a abertura para o planejamento regionalizado (documento 53LN) (BRASIL, 2013c).

Em Quadro apresentado no Apêndice R foi possível reunir as Portarias publicadas no ano de 2014. Em tal período, tiveram destaque as seguintes normas que tratam da atualização da lista do CEAF/PNAF: Portaria SCTIE/MS n. 6, de 25 de fevereiro de 2014; Portaria GM/MS n. 799, de 05 de maio de 2014; Portaria SAS/MS n. 683, de 06 de agosto de 2014; Portaria n. 2.127, de 30 de setembro de 2014; Portaria n. 49, de 22 de dezembro de 2014; e, Portaria n. 2.865, de 29 de dezembro de 2014 (documentos 54LN a 59LN) (BRASIL, 2014b; 2014c; 2014d; 2014e; 2014f; 2014g).

E por último, em Quadro sobre a emissão de normas, situado no Apêndice S, têm-se as Portarias que datam do período 2015-2016. Assim como no ano anterior, em 2015 são observadas Portarias somente para atualização da lista de medicamentos ou procedimento do CEAF/PNAF, quais sejam: Portaria GM/MS n. 410, de 13 de abril de 2015; Portaria SAS/MS n. 361, de 23 de abril de 2015; Portaria SCTIE/MS n. 29, de 22 de junho de 2015; Portaria 
SAS/MS n. 583, de 8 de julho de 2015; e, Portaria GM/MS n. 1.330, de 08 de setembro de 2015 (documentos 60LN a 64LN) (BRASIL, 2015a; 2015b; 2015c; 2015d; 2015e).

E em referência ao ano de 2016, tem-se a última Portaria divulgada sobre o repasse de recursos da União para os Estados e Distrito Federal: Portaria n. 1.055, de 24 de maio 2016 (documento 65LN) (BRASIL 2016a). Esta se refere ao repasse para os meses de abril, maio e junho de 2016. Ou seja, as Portarias Ministeriais são emitidas por trimestre.

Diante do exposto, a presente categoria expôs os resultados referentes ao embasamento normativo que organiza e direciona a implementação do CEAF/PNAF. Tais normas abordam as questões de preocupação da área farmacêutica para um acesso racional aos medicamentos do SUS. Ou seja, diversos critérios e conceitos compõe esta relação de atos normativos, que são essenciais para o alcance de uma gestão adequada de produtos farmacêuticos.

\subsubsection{Discricionariedade normativa}

A subcategoria discricionariedade parte do conceito relacionado à liberdade de ação do administrador na Administração Pública, conforme interesses públicos e seguindo os limites estabelecidos por Lei.

\footnotetext{
Não se confundem discricionariedade e arbitrariedade. Ao agir arbitrariamente o agente está agredindo a ordem jurídica, pois terá se comportado fora do que lhe permite a lei. Seu ato, em consequiência, é ilícito e por isso mesmo corrigível judicialmente. Ao agir discricionariamente o agente estará, quando a lei lhe outorgar tal faculdade (que é simultaneamente um dever), cumprindo a determinação normativa de ajuizar sobre o melhor meio de dar satisfação ao interesse público por força da indeterminação quanto ao comportamento adequado à satisfação do interesse público no caso concreto (MELLO, 2005, p. 401).
}

A considerar o entendimento de Mello (2005), a presente pesquisa identificou aberturas normativas que garantem tal liberdade ao administrador. Portanto, a partir das normas apresentadas na seção anterior, apontam-se aqui os limites previstos na regulamentação para a liberdade do administrador, que foi um achado tanto dos dados secundários quanto primários.

Em geral, as diretrizes para planejamento do SUS determinam que os entes federados possuam responsabilidade individual sobre este aspecto da gestão. Porém, cabe ressaltar que o planejamento deve ser individualizado (respeitando as necessidades de saúde da população de cada região de saúde), mas deve respeitar a articulação e a integração entre os entes. Logo, a 
oportunidade de planejamento deve ser restrita às necessidades do sistema como um todo, que são, na prática, identificadas e pactuadas nas comissões compostas por gestores.

As deliberações se iniciam nas Comissões Intergestores Regionais (CIR), passam pelas Comissões Intergestores Bipartite (CIB) (Municípios e Estados), até a CIT (União, Estados e Municípios). Mas é preciso também respeitar as diretrizes definidas pelos Conselhos e Conferências de Saúde (mecanismo de participação social na gestão do SUS). Todo o viés de planejamento deve ser concretizado em Planos de Saúde, conforme predisposto na Portaria n. 2.135/2013 (documento 53LN) (BRASIL, 2013c).

No aspecto financeiro, foi identificado que a União, os Estados, os Municípios e o Distrito Federal têm obrigatoriedade de contribuírem com valores mínimos para custeio das ações em saúde (LC n. 141/2012) (documento 16LN) (BRASIL, 2012c). Neste sentido, os entes estarão seguindo a Lei n. 8.080/1990, além do Decreto n 7.508/2011, que a regulamenta quanto à organização e gestão descentralizada do sistema de saúde (BRASIL, 1988; 1990a; 2011b). Assim, tem-se a liberdade para tal investimento, desde que se sigam os valores mínimos estipulados.

Conforme apresentado na identificação do problema da Política (CEAF/PNAF), devese garantir a oferta dos medicamentos dos Grupos 1 e 2 para a população (BRASIL, 2009b), de acordo com a demanda de cada região. Logo, deve ser alinhada a exigência de custeio mínimo com as responsabilidades dos entes de uma oferta adequada. A liberdade de planejamento é, então, cerceada por ter que atender aos valores mínimos, ao mesmo tempo em que deve atender à execução adequada do fornecimento de medicamentos, segundo as características epidemiológicas de cada região.

Seguindo o texto constitucional de que a saúde é um direito de todos e dever do Estado, e seguindo o argumento apresentado anteriormente de que as regiões - e no caso da presente pesquisa - o Distrito Federal - devem ofertar os medicamentos dos Grupos 1 e 2 do CEAF/PNAF de acordo com as necessidades regionais, a Lei Orgânica do Distrito Federal (documento 21LN) reforça novamente um aspecto a ser pensado sobre a discricionariedade. Em seu capítulo II, que trata da saúde, tal ditame afirma no inc. XXIV de seu art. 207, que o sistema de saúde do Distrito Federal tem como responsabilidade, in verbis:

Art. 207. Compete ao Sistema Único de Saúde do Distrito Federal, além de outras atribuições estabelecidas em lei:

$[\ldots]$

XXIV - prestar assistência farmacêutica e garantir o acesso da população aos medicamentos necessários à recuperação de sua saúde;

$[\ldots]$. 
Aqui é possível notar que a discricionariedade é bem limitada no contexto da saúde pública, uma vez considerando que as necessidades da população devem ser sempre atendidas. É notório que a execução terá também as suas diretrizes. Mas, em termos de macro e micro planejamentos, tem-se uma rede de premissas a serem cumpridas, pois existem muitas normas, nos diversos níveis de complexidade, que demandam pela atenção universal e integral à saúde.

Tal fato também é confirmado no art. 215 da Lei Orgânica do Distrito Federal, in verbis:

Art. 215. O Sistema Único de Saúde do Distrito Federal contará, sem prejuízo das funções do Poder Legislativo, com três instâncias colegiadas e definidas na forma da lei:

I - a Conferência de Saúde;

II - o Conselho de Saúde;

III - os Conselhos Regionais de Saúde.

$[\ldots]$.

Mesmo havendo previsão de que as ações em saúde sejam pactuadas com participação social, os ditames constitucionais e infraconstitucionais devem sempre ser tomados por respeito. A partir daí, é possível entender que estes serão as margens para a atuação discricionária dos gestores, conforme a própria definição de discricionariedade.

O mesmo Decreto que regulamenta a Lei Orgânica da Saúde e versa sobre a organização geral do sistema de saúde (Decreto n. 7.508/2011) também pontua, especificamente, que os Estados, os Municípios e o Distrito Federal poderão realizar a padronização de medicamentos para suas regiões. Retomando, a RENAME lista os medicamentos padronizados para todo o País e é elaborada considerando as diversidades regionais para tal. Todavia, ainda assim, é possível criar listas específicas da região ou adotar a RENAME e uma lista complementar (documento 10LN) (BRASIL, 2011b).

Neste ínterim, a CIT pactua que as revisões da RENAME devem ser feitas pelo MS, por meio da CONITEC. Entretanto, os demais entes federativos poderão definir outros medicamentos de forma suplementar à RENAME. Mas aquela Comissão ressalta que é preciso respeitar os seguintes aspectos: os critérios epidemiológicos; a organização dos serviços; a complexidade do atendimento de cada caso; outros critérios pactuados na CIB e no Conselho Distrital de Saúde; a justificativa para a saúde pública que valide o elenco diferente; e, a análise e recomendação da CONITEC. A lista complementar estadual, distrital ou municipal somente pode conter medicamentos registrados na ANVISA (documento 14LN) 
(BRASIL, 2011b; 2012a). De fato, existem critérios pré-estabelecidos, relacionados às áreas de vigilância sanitária, epidemiologia, $\mathrm{AF}$ e até médica que consideram a análise e escolha dos melhores tratamentos para a inclusão no SUS. A própria ANVISA já possui critérios rigorosos para o registro de medicamentos no País. Portanto, a escolha de tecnologias em saúde não é um processo acrítico e, apesar da liberdade dos entes na definição de listas complementares de medicamentos, estas deverão seguir critérios técnicos para a sua aprovação e manutenção.

Existem vários documentos que dispõe sobre as mesmas práticas, direta ou indiretamente. Logo, a reflexão sobre estes evidencia que o limite à discricionariedade na atividade de seleção de medicamentos seria composto pela responsabilidade financeira dos entes, bem como pela responsabilidade de planejamento local em saúde. Quer dizer, a seleção pode ser realizada localmente, porém, respeitando os valores mínimos de investimento prédeterminados, a garantia de investimento para a oferta com cobertura universal e integral e o planejamento que atenda as diretrizes pactuadas nas Comissões Intergestores.

Em paralelo à etapa de padronização, para os medicamentos do CEAF/PNAF, a dispensação ${ }^{5}$ para os usuários se dá obrigatoriamente seguindo protocolos clínicos e diretrizes terapêuticas. Isto porque o MS estabeleceu como regra diferenciada de acesso aos medicamentos especializados o enquadramento do paciente nos quadros apresentados pelos PCDT (BRASIL, 2011b). Tais documentos orientam os tratamentos adequados para as diferentes fases da doença e para as alternativas terapêuticas em casos de intolerância, perda de eficácia ou reação adversa (BRASIL, 2011a).

O art. 19-P da Lei n. 12.401/2011 (documento 3LN) destaca, in verbis, como será feita a dispensação de medicamentos na ausência de protocolos e diretrizes:

Art. $1^{\circ}$ O Título II da Lei n. 8.080, de 19 de setembro de 1990, passa a vigorar acrescido do seguinte Capítulo VIII:

[...].

"Art. 19-P. Na falta de protocolo clínico ou de diretriz terapêutica, a dispensação será realizada:

I - com base nas relações de medicamentos instituídas pelo gestor federal do SUS, observadas as competências estabelecidas nesta Lei, e a responsabilidade pelo fornecimento será pactuada na Comissão Intergestores Tripartite;

\footnotetext{
${ }^{5} \mathrm{O}$ conceito de dispensação, por ser uma definição técnica farmacêutica, é mais completo do que o simples repasse do medicamento ao usuário. Na verdade, a ação envolve a entrega do produto mediante uma prescrição por profissional competente (se exigido para o medicamento), feita pelo profissional farmacêutico, mediante a orientação sobre os riscos e benefícios em potencial do tratamento, além de aspectos como, por exemplo, a posologia, o armazenamento, os cuidados com a administração, entre outros (BRASIL, 2010a).
} 
II - no âmbito de cada Estado e do Distrito Federal, de forma suplementar, com base nas relações de medicamentos instituídas pelos gestores estaduais do SUS, e a responsabilidade pelo fornecimento será pactuada na Comissão Intergestores Bipartite;

III - no âmbito de cada Município, de forma suplementar, com base nas relações de medicamentos instituídas pelos gestores municipais do SUS, e a responsabilidade pelo fornecimento será pactuada no Conselho Municipal de Saúde." (BRASIL, 2011a).

O Distrito Federal, bem como os Estados e os Municípios, tem autonomia para elaborar protocolos clínicos e diretrizes terapêuticas que direcionem os tratamentos dos medicamentos que não fazem parte da RENAME. Sobre a questão, os dados evidenciam limites talvez indiretos para esta prática. Os protocolos e diretrizes deverão se referir aos medicamentos registrados no Brasil e cuja seleção respeite os critérios supramencionados. Para além disso, os regulamentos não determinam nenhuma obrigatoriedade na redação destes protocolos.

Tem-se uma outra particularidade quanto ao CEAF: a liberdade dos entes de escolher entre alguns medicamentos de alguns PCDT para a seleção local. Ou seja, existem alguns PCDT que apresentam mais de uma alternativa terapêutica para uma mesma finalidade. Logo, o ente federativo pode escolher qual padronizar, desde que se garantam as linhas de cuidado. Sobre a questão, a Portaria n. 2981, de 26 de novembro de 2009 e sua atualização, predisposta na Portaria GM/MS n. 1.554/2013 (documentos 7LN e 8LN) e dois entrevistados (1EN e 2EN) assim destacam:

Art. 12. Cabe à esfera de gestão do SUS responsável a seleção dos medicamentos entre as formas de organização do Grupo 06, Subgrupo 04, da Tabela de Procedimentos, Medicamentos, Órteses, Próteses e Materiais Especiais do SUS que define os procedimentos dos Grupos 1 e 2, desde que garantidas as linhas de cuidado definidas nos Protocolos Clínicos e Diretrizes Terapêuticas publicados na versão final pelo Ministério da Saúde (BRASIL, 2013a).

Então, ficando na parte dos medicamentos do componente especializado, se ele (ente federativo) registra, se ele quer incorporar algum outro medicamento, deve dar entrada na CONITEC. Esse medicamento não faz parte do CEAF, entendeu? É um programa estadual. E daí o gerenciamento, forma de controle, é de competência do próprio estado. Mas, além disso, do elenco de medicamento que nós temos no componente especializado...agora não lembro qual que é o artigo da portaria. Mas, ele define que o ente federativo responsável pelo financiamento, ele pode selecionar os medicamentos dentro da mesma forma de organização.

[...] Garante que tem vários procedimentos. O que é um procedimento? Procedimento é ser medicamento, mas não apenas medicamento. Ele é vinculado ao CID, ao sexo, faixa etária, quantitativo máximo preconizado baseado nos protocolos clínicos. Isso é um procedimento. [...] O componente especializado ele está no grupo 6, medicamentos, subgrupo 0604, componente especializado assistência farmacêutica. Forma de organização, que é a classificação de cada medicamento pela ATC da OMS. E daí o procedimento que é medicamento passa por indicação. O estado...o ente federativo pelo financiamento, ele pode selecionar um dos medicamentos de cada forma de organização, desde que não haja prejuízo na 
linha de cuidado da doença, preconizado no protocolo clínico (Entrevistado 1EN, grifos meu).

Hoje, é o seguinte. Hoje, a gente tem a política de protocolos. Então, existem medicamentos que não são incluídos pelo Ministério ou indicações que não são incluídas pelo Ministério, que nós temos incluído mediante aprovação de um protocolo, que nós denominamos protocolo estadual. E todos os estados denominam assim, também, entendeu? (Entrevistado 2EN).

Quanto à operacionalização do CEAF/PNAF, a normativa do componente (BRASIL, 2013a) especifica que são responsabilidades do Distrito Federal as seguintes atividades, para cada grupo de medicamentos:

1) Grupo 1A - recebimento dos medicamentos pelo MS e programação, armazenamento, distribuição e dispensação destes para o tratamento das doenças previstas.

2) Grupo 1B - recebimento dos recursos pelo MS e aquisição, programação, armazenamento, distribuição e dispensação dos medicamentos para o tratamento das doenças previstas.

3) Grupo 2 - financiamento, aquisição, programação, armazenamento, distribuição e dispensação dos medicamentos para o tratamento das doenças previstas.

Para estas, somente a etapa de dispensação possui exigências detalhadas. O financiamento possui suas nuances quanto ao investimento mínimo a ser seguido. As demais etapas de gestão (aquisição, programação, armazenamento e distribuição) são de execução livre para os gestores locais.

Quanto à execução do CEAF/PNAF, a Portaria vigente do Componente (Portaria n. 1554/2013) especifica as regras e etapas a serem realizadas. Aqui é interessante observar que aquele Componente, em função do seu alto custo, possui um sistema de execução bem previsto e padronizado para a execução por qualquer Estado ou Município (BRASIL, 2013a).

Como etapas da execução têm-se as que se seguem: solicitação, avaliação, autorização, dispensação e renovação da continuidade do tratamento. Quanto às responsabilidades para cada um dos grupos e quanto à execução das etapas, a norma não explicita aspectos a serem individualizados pelos gestores. Somente no parágrafo único do art. 39 da Portaria n. 1554/2013 faz-se a citação de um documento chamado "Recibo de Medicamentos" (RME), a ser preenchido no ato da entrega, que poderá ser elaborado pelo executor e deverá conter informações mínimas dispostas em um anexo exemplo no ditame em questão. Os demais documentos para a solicitação pelo usuário têm modelos padrão a serem seguidos (BRASIL, 2013a).

Como síntese das normas que possuem abertura para o poder discricionário dos gestores locais, tem-se o Quadro 4.1, a seguir. 
Quadro 4.1 - Síntese das previsões normativas para atos discricionários pelo gestor na implementação do Componente Especializado da Assistência Farmacêutica/Política Nacional de Assistência Farmacêutica.

\begin{tabular}{|l|l|}
\hline NORMA & ASPECTO DISCRICIONÁRIO \\
\hline Portaria n. 2.135, de 25 de setembro de 2013 & $\begin{array}{l}\text { Responsabilidade dos entes quanto à criação de planos } \\
\text { de saúde locais. }\end{array}$ \\
\hline Lei n. 8.080, de 19 de setembro de 1990 & $\begin{array}{l}\text { Define que os entes tem responsabilidade de gerir o } \\
\text { sistema de saúde diante das peculiaridades locais, de } \\
\text { forma descentralizada quanto ao planejamento e da } \\
\text { execução. }\end{array}$ \\
\hline Lei n. 12.401, de 28 de abril de 2011 & $\begin{array}{l}\text { Possibilidade de confecção de Protocolos Clínicos e } \\
\text { Diretrizes Terapêuticas (PCDT) pelos Estados, } \\
\text { Municípios e pelo Distrito Federal, na ausência destes } \\
\text { documentos do nível federal. }\end{array}$ \\
\hline Decreto n. 7.508, de 28 de junho de 2011 & $\begin{array}{l}\text { Regulamenta a Lei n. 8.080/1990 e a responsabilidade } \\
\text { de gestão local do Sistema Unico de Saúde (SUS) } \\
\text { pelos entes federativos. }\end{array}$ \\
\hline Lei Complementar n. 141, de 13 de janeiro de 2012 & $\begin{array}{l}\text { Regulamenta o § 3o do art. 198 da Carta Magna de } \\
\text { 1988 e determina que os entes federativos devem } \\
\text { investir nas ações e nos serviços de saúde de forma } \\
\text { livre, porém, seguindo valores mínimos. }\end{array}$ \\
\hline Portaria n. 1.554, de 30 de julho de 2013 & $\begin{array}{l}\text { Autonomia de escolha entre medicamentos da Relação } \\
\text { Nacional de Medicamentos Essenciais (RENAME) e } \\
\text { dos PCDT quando for o caso de haver mais de uma } \\
\text { alternativa terapêutica para a mesma indicação clínica. } \\
\text { Não especificação de normas para a operacionalização } \\
\text { das etapas de aquisição, programação, armazenamento } \\
\text { e distribuição. }\end{array}$ \\
\hline
\end{tabular}

Fonte: Da autora.

\subsection{Aparato Administrativo}

A categoria Aparato Administrativo (AA), após a revisão do modelo de análise, foi dividida em cinco subcategorias, a saber: 1) estrutura organizacional; 2) recursos humanos; 3) recursos financeiros; 4) atividades, fluxos e rotinas; e, 5) discricionariedade operacional.

Tal ordenamento visa facilitar a compreensão do leitor do presente estudo ao fenômeno estudado. Assim, tem-se, em primeiro lugar, os órgãos envolvidos com o fenômeno da implementação - asopecto naturalmente seguido pelas informações sobre os recursos humanos destes. Em seguida, estão os achados quanto ao ordenamento financeiro para a implementação do CEAF/PNAF. Por fim, são exibidas as atividades, os fluxos operacionais e as rotinas práticas, cuja análise ainda reflete na forma de uso da discricionariedade exposta pelas normativas supramencionadas. 


\subsubsection{Estrutura organizacional}

Com os resultados identificados como estrutura organizacional para a implementação do CEAF/PNAF, fez-se um diagrama (vide Figura 4.3, a seguir) com os órgãos e departamentos envolvidos neste processo, para sua apresentação inicial.

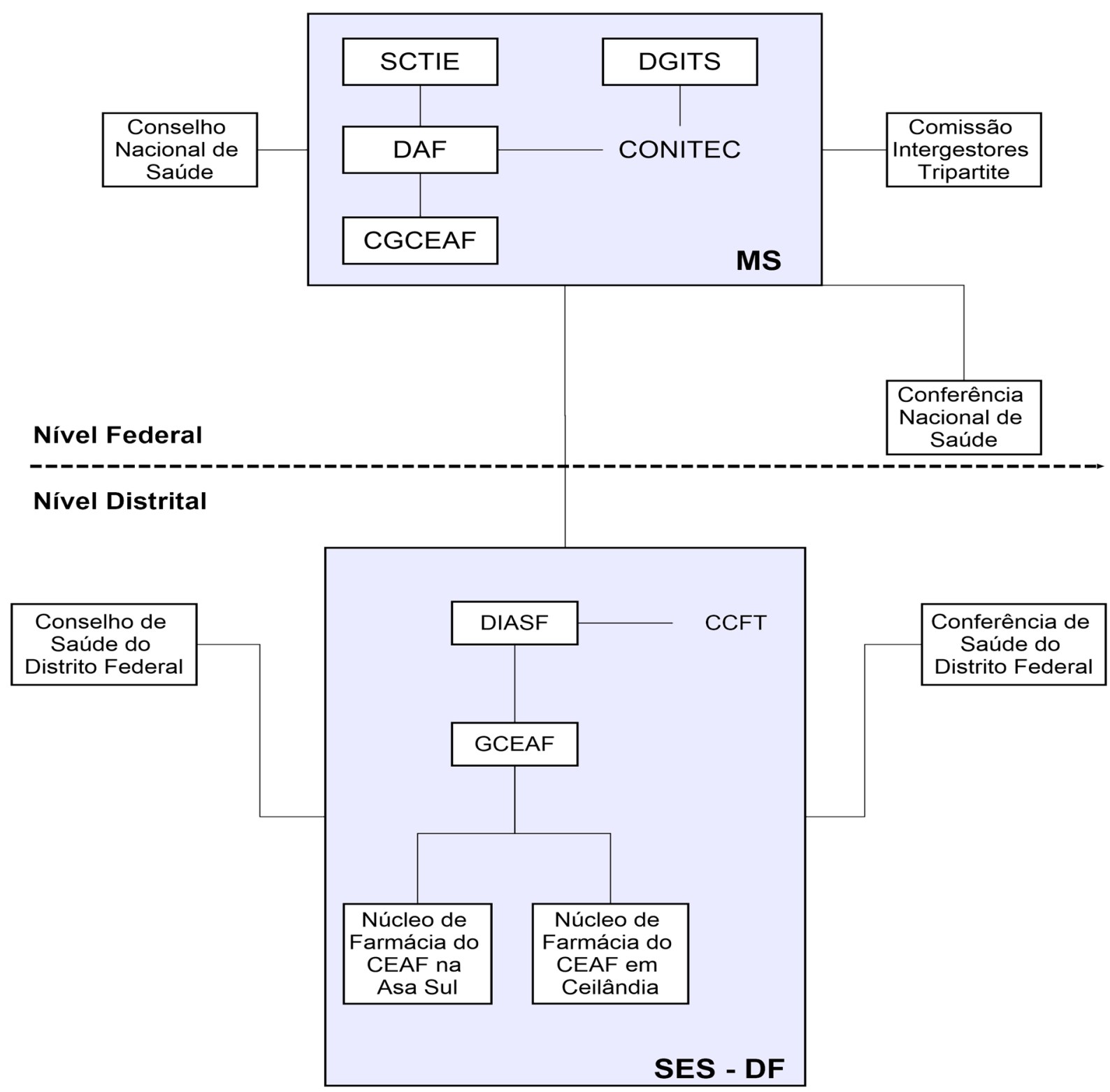

Onde: SCTIE - Secretaria de Ciência e Tecnologia e Insumos Estratégicos; DGIS - Departamento de Gestão e Incorporação de Tecnologias em Saúde; DAF - Departamento de Assistência Farmacêutica; CGCEAF Coordenação-geral do Componente Especializado da Assistência Farmacêutica; DIASF - Diretoria de Assistência Farmacêutica; CCFT - Comissão Central de Farmácia e Terapêutica; GCEAF - Gerência do Componente Especializado da Assistência Farmacêutica; CEAF - Componente Especializado da Assistência Farmacêutica.

Figura 4.3 - Estrutura organizacional da implementação do Componente Especializado da Assistência Farmacêutica/Política Nacional de Assistência Farmacêutica no Distrito Federal.

Fonte: Da autora. 
A observação do ambiente macro evidencia que o SUS é composto por uma rede regionalizada e hierarquizada. Para que esta disposição tenha funcionamento adequado, as diretrizes a serem seguidas envolvem o que predispõe o art. 198 da Carta Magna de 1988, in verbis:

\footnotetext{
Art. 198. As ações e serviços públicos de saúde integram uma rede regionalizada e hierarquizada e constituem um sistema único, organizado de acordo com as seguintes diretrizes:

I - descentralização, com direção única em cada esfera de governo;

II - atendimento integral, com prioridade para as atividades preventivas, sem prejuízo dos serviços assistenciais;

III - participação da comunidade.

$[\ldots]$.
}

O sistema de saúde é único, porém, formado por uma rede. Devido à grande extensão territorial, cada esfera governamental deverá ter uma única direção. Todas as normativas posteriores à CF de 1988 estão alinhadas nesta premissa, desde as atividades de gestão até as operacionais. Isto porque, segundo os documentos, as esferas federal, estadual e municipal possuem tanto competência de gestão (local) quanto de execução do CEAF/PNAF.

Os documentos $2 \mathrm{LN}$ e 10LN reforçam a descentralização político-administrativa, a descentralização dos serviços para os Municípios e a regionalização e hierarquização da rede de serviços (BRASIL, 1990a; 2011b). A PNM também organiza as responsabilidades pelos entes federal, estadual e municipal, respeitando a descentralização (BRASIL, 1998). E a política atual - PNAF - segue as mesmas premissas e ainda acrescenta que é um eixo estratégico a descentralização das ações, porém, tem-se a preocupação com a pactuação para superar a fragmentação em programas desarticulados (BRASIL, 2004).

A articulação entre os três entes se dá por meio das CIR, CIB e CIT. E nestas se pactua sobre a atualização dos elencos de medicamentos, a gestão e execução da AF, as estratégias de aumento de financiamento, a qualificação da AF e outras questões relacionadas ao acesso aos medicamentos (documentos 2LM e 53LN) (BRASIL, 2010a; 2013c).

Todas as esferas têm competências sobre o CEAF/PNAF. Logo, é preciso cooperação para que não haja sobreposição entre as atuações e a ineficiência do sistema, gerando equilíbrio e acréscimo de valor por meio de resultados integrados (documento 2AR) (BARROSO, 2016). Para o caso em questão, por se tratar da implementação do CEAF no Distrito Federal, serão consideradas somente as esferas federal e distrital. 
A presente pesquisa também detectou a influência das entidades do setor produtivo e da sociedade civil sobre a avaliação e gestão do Componente aqui analisado, uma vez que o DAF/MS considera as demandas de todos os setores ao monitorar e revisar o CEAF (BRASIL, 2010a). Neste caso, compreende-se que os canais para a ocorrência de tais participações se dão nos espaços previstos para o SUS de negociação e pactuação, que são as Conferências de Saúde (municipais, estaduais e nacional) e os Conselhos de Saúde (municipais, estaduais e nacional) (BRASIL, 1993c). No caso do Distrito Federal, a instância de deliberação do SUS é o Conselho de Saúde do Distrito Federal (CSDF) (documento 4SI) (SECRETARIA DE ESTADO DE SAÚDE DO DISTRITO FEDERAL, 2016c).

O trabalho de formulação e gestão do CEAF/PNAF, iniciado em 2008, é feito sob a coordenação do Departamento de Assistência Farmacêutica e Insumos Estratégicos da Secretaria de Ciência, Tecnologia e Insumos Estratégicos (DAF/SCTIE/MS) (documento 1LM) (BRASIL, 2014a).

A AF organiza-se no País por responsabilidade compartilhada entre os três entes federativos. Para o caso estudado, tem-se, então, o MS enquanto gestor federal, e a SES/DF como gestor distrital, que acumula as responsabilidades de Estado e Município (documento 8LN) (BRASIL, 2013a). As duas esferas são, então, competentes para a gestão e execução do CEAF/PNAF, segundo as responsabilidades sobre cada Grupo de medicamentos do componente (BRASIL, 2013a).

Sobre a questão dos Grupos, vale recordar que os Grupos 1 e 2 do CEAF/PNAF são organizados em Portaria como se segue:

1) Grupo 1 - medicamentos sob responsabilidade de financiamento pelo MS;

a) Grupo $1 \mathrm{~A}$ - medicamentos com aquisição centralizada pelo MS e fornecidos às Secretarias de Saúde dos Estados e do Distrito Federal;

b) Grupo 1B - medicamentos financiados pelo MS mediante transferência de recursos financeiros às Secretarias de Saúde dos Estados e do Distrito Federal.

2) Grupo 2 - medicamentos sob responsabilidade das Secretarias de Saúde dos Estados e do Distrito Federal (BRASIL, 2013a).

No Distrito Federal, a aplicação das responsabilidades tem como resultado:

1) Grupo 1 - a gestão é resultado da interação entre o MS e a SES/DF;

a) Grupo $1 \mathrm{~A}$ - aquisição centralizada pelo MS e medicamentos fornecidos à SES/DF;

b) Grupo $1 \mathrm{~B}$ - financiamento pelo MS mediante repasse de recursos à SES/DF;

2) Grupo 2 - a gestão é resultado do trabalho da SES/DF. 
As atividades para cada esfera, em cada grupo, serão destacadas na subcategoria atividades, fluxos e rotinas. Neste momento, o que se observa é que o MS desempenha aparente papel de implementador central deste programa (sob a perspectiva top-down), e o Distrito Federal faz papel de implementador "de ponta" (perspectiva bottom-up) (SILVA; MELO, 2000; PALUMBO; CALISTA, 1990; PRESSMAN, WILDAVSKY, 1984). De fato, os dois órgãos desempenham papéis na formulação e execução das ações. O Ministério em questão é um formulador de Políticas nacionais e participa da implementação, conforme responsabilidades quanto ao Grupo 1: CEAF/PNAF. A SES/DF tem competência de formular Políticas distritais e operacionaliza o componente em seus Grupos 1 e 2. Nota-se, portanto, que as competências não se sobrepõem na organização do CEAF/PNAF, uma vez que o objetivo é promover eficiência à Política, e não superposição e fragmentação da ação.

O documento 2SI informa que a estrutura do MS atual, aprovada em agosto de 2013, possui a SCTIE como setor sob o qual está subordinado o DAF (documentos 2SI e 6SI) (MINISTÉRIO DA SAÚDE, 2016a; 2016d).

E os dados ainda revelam que o MS tem a responsabilidade específica de avaliar a incorporação, exclusão ou alteração de tecnologias em saúde no SUS, além de elaborar e revisar os PCDT, por meio do assessoramento da CONITEC (CONITEC, 2016; MINISTÉRIO DA SAÚDE, 2016a). Por sua parte, a CONITEC é uma comissão assistida pelo Departamento de Gestão e Incorporação de Tecnologias em Saúde do Ministério da Saúde (DGITS/MS) (CONITEC, 2016).

Diante do exposto, elaborou-se um organograma dos órgãos envolvidos com a implementação do CEAF/PNAF no nível federal, conforme evidenciado na Figura 4.4, a seguir. 


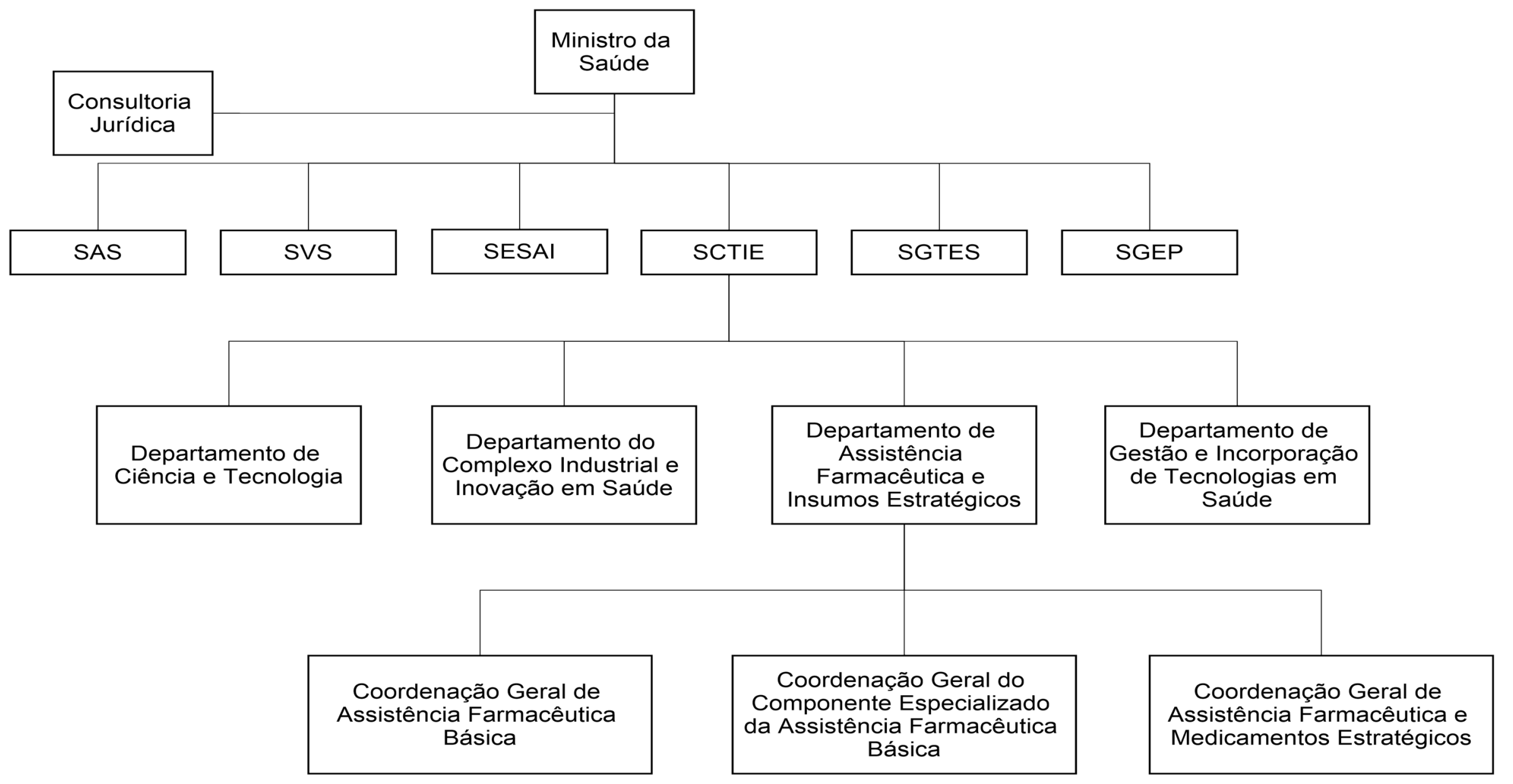

Onde: SAS - Secretaria de Atenção à Saúde; SVS - Secretaria de Vigilância em Saúde; SESAI - Secretaria Especial de Saúde Indígena; SCTIE - Secretaria de Ciência, Tecnologia e Insumos Estratégicos; SEGTES - Secretaria de Gestão do Trabalho e da Educação na Saúde; SGEP - Secretaria de Gestão Estratégica e Participativa.

Figura 4.4 - Organograma do Ministério da Saúde com ênfase nas áreas envolvidas na gestão e implementação do Componente Especializado da Assistência Farmacêutica/Política Nacional de Assistência Farmacêutica.

Fonte: Adaptado de Ministério da Saúde (2016d). 
Passando para o nível distrital, a gestão da saúde é feita pela SES/DF e pelas instâncias de pactuação, a Conferência de Saúde do Distrito Federal e o CSDF (BRASIL, 1993c). Neste sentido, conforme a Portaria GM/MS n. 1.554/2013 (documento 8LN), ratifica-se, in verbis, parte da informação supramencionada:

Art. 23. Para os medicamentos constantes dos Grupos 1 e 2, a execução é descentralizada e de responsabilidade das Secretarias de Saúde dos Estados e do Distrito Federal, sendo realizada de acordo com os critérios definidos nesta Portaria e na legislação vigente.

Conforme a estrutura atual da SES/DF, definida em novembro de 2015, as partes da Secretaria envolvidas com o CEAF/PNAF são, em ordem hierárquica, do departamento superior até a base, as que se seguem: 1) Subsecretaria de Atenção Integral à Saúde; 2) Coordenação de Atenção Especializada à Saúde; 3) DIASF; 4) Gerência do Componente Especializado da Assistência Farmacêutica (GCEAF); e, 5) Núcleo de Farmácia do Componente Especializado na Asa Sul e Núcleo de Farmácia do Componente Especializado em Ceilândia (SECRETARIA DE ESTADO DE SAÚDE DO DISTRITO FEDERAL, 2016a).

Sobre a estrutura atual da SES/DF, o entrevistado 2EN assim se expressou a respeito dos departamentos e das gerências que trabalham em prol do CEAF/PNAF:

\begin{abstract}
No caso da SESDF, que é a nossa experiência, como que funciona? O componente especializado, ele é executado por uma gerência, que é a Gerência do Componente Especializado da Assistência Farmacêutica, que é vinculada aqui a nós na Diretoria de Assistência Farmacêutica, certo? A gerência do componente especializado no Distrito Federal, ela é composta por dois núcleos que são as farmácias. Então, a gente tem o Núcleo [...] como que é o nome? Núcleo de Farmácia de Componente Especializado da Asa Sul e Núcleo de Farmácia do Componente Especializado da Ceilândia, certo? E a gente já tem a previsão de que todas as unidades que nós inaugurarmos vai ser feita por meio de um núcleo vinculado à gerência.
\end{abstract}

As atividades finalísticas, de contato com o paciente, deverão ser executadas por estabelecimentos de saúde vinculados ao SUS, conforme predisposto na Portaria GM/MS n. 1.554/2013 (documento 8LN), in verbis: “Art. 24 A solicitação, dispensação e renovação da continuidade do tratamento ocorrerão somente em estabelecimentos de saúde vinculados às unidades públicas designadas pelos gestores estaduais de saúde".

Ao encontro de tal informação, o entrevistado $2 \mathrm{EN}$ já havia informado sobre os núcleos da gerência do CEAF/PNAF, e a SES/DF informa oficialmente pelo documento 3SI estes mesmos locais onde as atividades serão realizadas: 
Acesso aos medicamentos

$\mathrm{O}$ atendimento inicial é realizado nos telefones: [...].

$\mathrm{O}$ atendente do Call-Center agendará data e horário para comparecimento em uma das unidades (Farmácia Ambulatorial Especializada da Asa Sul ou da Ceilândia).

Endereços das unidades do Componente Especializado: [...]. (SECRETARIA DE ESTADO DE SAÚDE DO DISTRITO FEDERAL, 2016b).

Em janeiro de 2012 foi divulgada a inauguração da segunda "Farmácia de Alto Custo" ou, ainda, "Farmácia Especializada". Até o momento, o Distrito Federal possuía somente uma unidade de farmácia pública para a dispensação dos medicamentos do CEAF, localizada no bairro Asa Sul, em Brasília, Distrito Federal. Logo, com a abertura da segunda unidade, houve uma melhor regulação do sistema e atendimento aos pacientes de todas as Regiões Administrativas (RAs) do Distrito Federal (AGÊNCIA BRASÍLIA, 2012a).

Sobre a questão, o secretario da pasta da Saúde à época, Rafael Barbosa, citou no documento 3NS: "O modelo descentralizado vai melhorar o atendimento de forma sensível, trazendo mais conforto aos pacientes" (AGÊNCIA BRASÍLIA, 2012a, p.1).

$\mathrm{O}$ relato daquele secretário se devia à previsão de transferência de aproximadamente oito mil usuários que estavam sendo atendidos na unidade da Farmácia Especializada da Asa Sul para a nova unidade da Ceilândia - usuários estes que eram provenientes de cidades distantes do Plano Piloto, tais como: Ceilândia, Taguatinga, Samambaia, Brazlândia, Recanto das Emas etc. A nova unidade se estrutura em dois prédios, sendo um para cadastramento de novos pacientes, e o segundo para atendimento dos pacientes e para a entrega dos medicamentos (AGÊNCIA BRASÍLIA, 2012a).

Foi identificada, por fim, a Comissão Central de Farmácia e Terapêutica (CCFT), que é subordinada à Subsecretaria de Atenção Integral à Saúde, bem como a DIASF, e realiza a revisão da relação de medicamentos do Distrito Federal (SECRETARIA DE ESTADO DE SAÚDE DO DISTRITO FEDERAL, 2016a).

No caso da SES/DF, o organograma interno relacionado ao CEAF/PNAF está disposto na Figura 4.5, a seguir. 


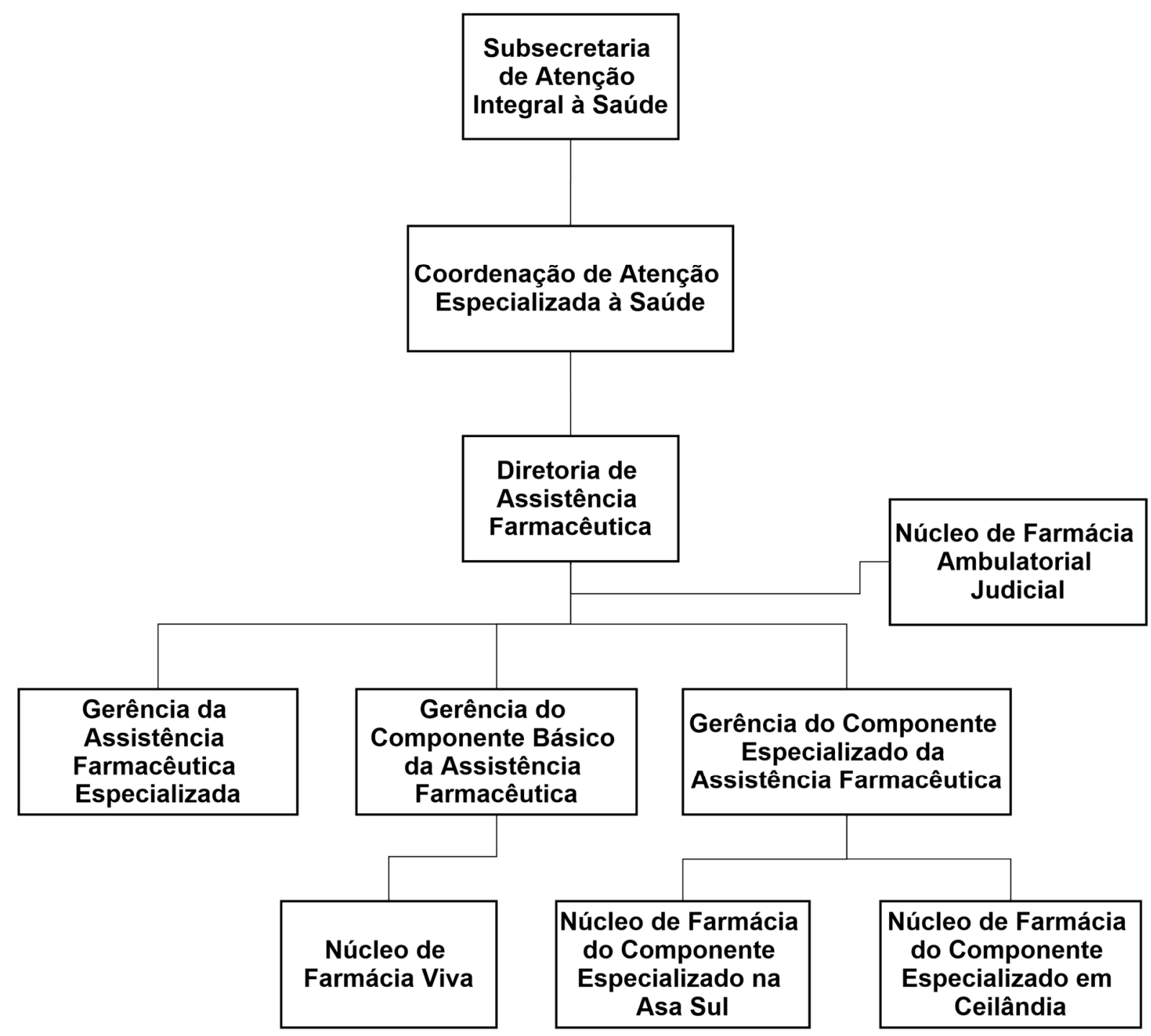

Figura 4.5 - Organograma da Secretaria de Estado de Saúde do Distrito Federal, com enfoque nas áreas envolvidas na implementação do Componente Especializado da Assistência Farmacêutica/Política Nacional de Assistência Farmacêutica.

Fonte: Secretaria de Estado de Saúde do Distrito Federal (2016b).

Com as últimas instâncias de implementação do CEAF/PNAF - as farmácias de atendimento ao usuário -, tem-se a apresentação final das estruturas organizacionais envolvidas com a implementação do Componente em questão.

Um Quadro resumo das entidades que participam na implementação do CEAF/PNAF e as fontes que permitiram sua identificação se faz presente no Apêndice T. 


\subsubsection{Recursos Humanos}

Relembrando os órgãos que participam na implementação do CEAF/PNAF, a nível federal tem-se: o CNS, a Conferência Nacional de Saúde, a CIT e o MS, com o DAF e a CONITEC. Já no nível distrital foram identificados os que se seguem: o CSDF, a Conferência de Saúde do Distrito Federal e a SES/DF, com a DIASF, a GCEAF e os Núcleos de Farmácias Especializadas.

O SUS tem como premissa a gestão com a participação da sociedade, que se dá via participação das Conferências de Saúde e dos Conselhos de Saúde na pactuação das ações. Tem-se, então, como estrutura institucional e decisória do SUS, os órgãos gestores (MS, nível federal, as secretarias estaduais e as secretarias municipais), as Comissões Intergestores (CIB e CIT) e os Colegiados Participativos, constituindo uma rede (Conselhos Nacional, Estaduais e Municipais) (documento 4LM) (BRASIL, 2002c).

Os Conselhos e Conferências são compostos por representantes do governo, dos prestadores de serviços de saúde, dos profissionais de saúde e dos usuários do SUS (BRASIL, 2016b). Na presente pesquisa, os órgãos com esta composição são: o CNS, a Conferência Nacional de Saúde, o CSDF e a Conferência de Saúde do Distrito Federal.

Os recursos humanos do CNS seguem esta mesma constituição geral (documento 5SI) com:

[...] 48 conselheiros titulares e seus respectivos primeiro e segundos suplentes, representantes de entidades e movimentos sociais de usuários do Sistema Único de Saúde (SUS), entidades de profissionais de saúde, incluída a comunidade científica, entidades de prestadores de serviço, entidades empresariais da área da saúde e governo federal (MINISTÉRIO DA SAÚDE, 2016b).

O CSDF também especifica em documento sua constituição, conforme se segue:

[...] representantes de entidades e movimentos representativos de usuários do DF, entidades representativas de trabalhadores da área da saúde do DF, governo e prestadores de serviços de saúde do DF, sendo o seu Presidente eleito entre os membros do Conselho (SECRETARIA DE ESTADO DE SAÚDE DO DISTRITO FEDERAL, 2016c).

Para a CIT, os dados evidenciam que esta comissão é formada por representantes do MS, do CONASS e do CONASEMS, paritariamente (BRASIL, 2009d). 
No caso do DAF/SCTIE/MS, a informação sobre os recursos humanos envolvidos com o CEAF/PNAF foi desvelada pelo entrevistado 1EN, assim expresso: "Na coordenação do componente especializado, na verdade, nós temos quatro equipes distintas. Temos 25 pessoas e o coordenador. Hoje, nós estamos sem, atualmente".

Assessorando o DAF/SCTIE/MS, tem-se a CONITEC, que assim delibera por Plenário constituído por (CONITEC, 2016):

I - do Ministério da Saúde:

a) Secretaria de Ciência, Tecnologia e Insumos Estratégicos do Ministério da Saúde, que o presidirá;

b) Secretaria-Executiva;

c) Secretaria Especial de Saúde Indígena;

d) Secretaria de Atenção à Saúde;

e) Secretaria de Vigilância em Saúde;

f) Secretaria de Gestão Estratégica e Participativa; e

g) Secretaria de Gestão do Trabalho e da Educação na Saúde;

II - da Agência Nacional de Saúde Suplementar - ANS;

III - da Agência Nacional de Vigilância Sanitária - ANVISA;

IV - do Conselho Nacional de Saúde - CNS;

V - do Conselho Nacional de Secretários de Saúde - CONASS;

VI - do Conselho Nacional de Secretarias Municipais de Saúde - CONASEMS; e

VII - do Conselho Federal de Medicina - CFM, especialista na área [...].

Em relação ao Distrito Federal, os entrevistados 2EN e 3EN explicaram que a DIASF é gerida por um Diretor e que cada Componente de medicamentos da AF possui um gerente. Assim, tem-se um gestor geral da DIASF, que supervisiona a GCEAF/DIASF/SES/DF, coordenada, por sua vez, por um gestor.

Em relação à CCFT/SES/DF, esta é assim constituída:

a) Presidente da CCFT - Diretor da DIASF;

b) Secretário executivo;

c) Secretário administrativo;

d) Médico do Núcleo de Controle de Infecção Hospitalar;

e) Médico clinico;

f) Médico pediatra;

g) Médico infectologista; e

h) Dois Farmacêuticos da SES/DF (SECRETARIA DE ESTADO DE SAÚDE DO DISTRITO FEDERAL, 2016a): 
Para a operacionalização do CEAF/PNAF nos Núcleos de Farmácias Especializadas da Asa Sul e da Ceilândia, os dados evidenciam uma proposta mínima para funcionamento e realização das atividades. Por exemplo, a Farmácia de Alto Custo da Asa Sul opera com 22 farmacêuticos e 27 assistentes administrativos (DATASUS, 2016). Já a Farmácia de Alto Custo da Ceilândia foi organizada para funcionar com 10 farmacêuticos e 32 assistentes administrativos. Neste sentido, cabe aos farmacêuticos a orientação técnica sobre o uso racional dos medicamentos adquiridos (AGÊNCIA BRASÍLIA, 2012a).

Além dos profissionais que executam a parte administrativa do processo, desde o cadastro do paciente até a entrega do medicamento, a Portaria GM/MS n. 1.554/2013 normatiza que um profissional de Ensino Superior especialista da área deve avaliar cada caso e emitir parecer sobre a adequação ou não ao PCDT. Quer dizer, o paciente deverá encaminhar toda a documentação solicitada e um médico especialista ou outro profissional competente deverá realizar uma análise para identificar concordância com os critérios de inclusão no protocolo (BRASIL, 2013a).

Sobre a questão, o entrevistado $2 \mathrm{EN}$ assim se expressou:

\footnotetext{
A gente envia isso (documentação do paciente) para a avaliação técnica. A regra é que a avaliação técnica seja feita pelo coordenador de especialidade. Então, o coordenador da especialidade médica... A Portaria diz que pode ser profissional de saúde.

$[\ldots]$.

É que a maioria dos estados não tem médico especialista disponível para fazer isso. Então, o Ministério não poderia exigir [...].

Você tem que conhecer muito bem o protocolo. Os protocolos, eles não são tão fáceis. Por exemplo, o protocolo de deficiência de crescimento, ele é muito difícil.
}

Conforme o exposto, quando necessário, a equipe farmacêutica realiza a análise e, em Estados que não possuem médicos para todas as especialidades, é comum a presença de equipes de farmacêuticos executando tal função. Porém, o entrevistado $2 \mathrm{EN}$ destaca que é preciso conhecer muito bem os PCDT, em função de sua complexidade. Uma vez que os referidos protocolos se referem a todo cuidado de atenção à saúde, que vai além do tratamento medicamentoso, o campo do conhecimento transcende a área técnica farmacêutica, perpassando conhecimentos clínicos médicos. E é nesta questão que os documentos se tornam complexos e exigem outros olhares para a análise, o que é extremamente importante, pois caracteriza um trabalho multidisciplinar e evidencia como é difícil já para profissionais de saúde lidarem com estes tratamentos. Então, o trabalho em questão exige sim recursos humanos especializados e com formação na área da saúde. 
O Quadro apresentado no Apêndice U resume os resultados quanto aos recursos humanos e as fontes primárias e secundárias de dados utilizadas na sua identificação.

\subsubsection{Recursos financeiros}

Em relação aos recursos financeiros relacionados ao CEAF/PNAF, a presente seção destaca o panorama dos medicamentos no Brasil nos últimos anos, e como se dá a organização financeira para manutenção do Componente.

A AF do SUS é parte importante das Políticas de saúde brasileiras, pois, o medicamento desempenha papel de destaque no cuidado à saúde. Segundo o documento 2LM, observa-se um aumento constante no emprego de recursos para as etapas de gestão destes produtos, incluindo recursos humanos, materiais e financeiros (BRASIL, 2010a).

$\mathrm{O}$ documento 1LM acrescenta que o CEAF/PNAF envolve uma quantidade significativa de medicamentos, considerando a totalidade dos padronizados e, principalmente, representam uma parte importante dos gastos com a AF no Brasil (BRASIL, 2014a). Isto reforça, então os cuidados que os dados da pesquisa evidenciam em relação à seleção adequada destes medicamentos, à exigência de cumprimento dos requisitos dos protocolos para que se tenha uma utilização com indicação terapêutica com comprovação científica, além de toda a organização quanto às responsabilidades de cada ente com todo o processo.

Tendo em vista que o volumoso orçamento reservado para este Componente, os dados indicam que toda a divisão de responsabilidades entre os entes foi pensada para manter a sustentabilidade do sistema e o equilíbrio financeiro.

O que melhor evidencia a preocupação com a otimização de recursos alocados para a compra e gestão de medicamentos é a análise dos dados sobre os gastos com estes produtos. Sobre tais informações, os achados da pesquisa mostram os gastos da União, via MS, no ano de:

- 2003 - aproximadamente R \$ 2 bilhões (5,8\% do orçamento total do órgão);

- 2010 - aproximadamente R $\$$ 6,5 bilhões (12,5\% do orçamento total do órgão);

- 2014 - aproximadamente $\mathrm{R} \$ 12,4$ bilhões; e

- 2015 - aproximadamente R\$ 15,8 bilhõess (documentos 2LM, 1NS, 2SI) (BRASIL, 2010a; MINISTÉRIO DA SAÚDE, 2015; 2016a; 2016c). 
O documento 2LM reforça que, apesar do montante anual, o volume de recursos continua sendo insuficiente (BRASIL, 2010a). E vale destacar a informação de que o valor utilizado no ano de 2015 foi superior ao dobro do valor do ano de 2010, e que o MS ampliou em $53 \%$ a oferta de medicamentos pelo SUS no mesmo periódo. A RENAME, que possuía 343 itens em 2010, passou a ter 844 itens em 2015 (MINISTÉRIO DA SAÚDE, 2016c).

Para o Distrito Federal, no ano de 2016, o documento 46 NJ detalhou as questões orçamentárias para a área da saúde. Neste sentido, os dados assim evidenciam:

a) Orçamento inicial: $\mathrm{R} \$ 6,2$ bilhões (recursos destinados ao Fundo de Saúde do Distrito Federal, à Fundação Hemocentro de Brasília (FHB) e à Fundação de Ensino e Pesquisa em Ciências da Saúde (FEPECS).

Destinos:

- $71 \%(\mathrm{R} \$ 4.431 .596 .809,00)$ : recursos humanos e encargos;

- $27 \%$ (R \$ 1.702.277.158,00): outras despesas correntes;

- $2 \%(\mathrm{R} \$ 142.784 .061,00)$ : investimentos; e

- 0,1\% (R\$ 650.000,00): inversões financeiras (MINISTÉRIO PÚBLICO DO DISTRITO FEDERAL E TERRITÓRIOS, 2016a).

b) Gastos até fevereiro de 2016: 8,02\% da dotação inicial destinada ao Fundo de Saúde do Distrito Federal.

Destinos:

- $\mathrm{R} \$$ 349.694.256,00: pagamento de servidores (deste valor, 95\% são recursos oriundos da União e $5 \%$ originaram-se de recursos distritais);

- $\quad \mathrm{R} \$ 868.708,76$ : manutenção de serviços para a frota de veículos da saúde;

- $\mathrm{R} \$$ 4.233.216,43: programa de descentralização progressiva de ações de saúde;

- R\$20.902.063,00: aquisição de medicamento;

- R\$ 6.944.378,99: construção das unidades básicas de saúde nas localidades de Samambaia e Ceilândia (Setor Sol Nascente);

- $\mathrm{R}$ \$ 5.432.512,47: atendimento de serviços assistenciais complementares em saúde, prestados pelo Instituto de Cardiologia - Fundação Universitária de Cardiologia (ICFUC); 
- $\mathrm{R}$ \$ 2.096.276,00: aquisição de máquinas e equipamentos para combate e controle do vírus da dengue, Zika e Chikungunya.

- $\mathrm{R}$ \$ 21.170.713,65: prestação de serviços de preparo, fornecimento e distribuição de refeições para pacientes por meio da empresa Sanoli indústria e alimentação hospitalar (deste valor, $\mathrm{R} \$ 9.550 .198,89$ são relativos ao período novembro-dezembro de 2014; o restante refere-se ao pagamento indenizatório sem cobertura contratual no mês janeiro de 2016); e

- $\mathrm{R} \$$ 6.631.710,56: cobertura de contrato de gestão firmado para o período de $1^{\circ}$ de março de 2014 a 28 de fevereiro de 2019, referente a ações de assistência à saúde no Hospital da Criança de Brasília José Alencar (HCB) para o Instituto do Câncer Infantil e Pediatria Especializada (ICIPE) (MINISTÉRIO PÚBLICO DO DISTRITO FEDERAL E TERRITÓRIOS, 2016a).

Os gastos com medicamentos, por se referirem somente ao ano de 2016, é com destaque o responsável pela maior parte dos recursos designados à saúde. Em aproximadamente dois meses houve uma gasto de mais de 20 milhões de reais somente com estes insumos. Neste sentido, vale destacar que é de responsabilidade do Distrito Federal a compra destes produtos, pois ainda se tem a contribuição decorrente do repasse da União.

Os dados do CEAF/PNAF retomam a organização do componente em grupos, uma vez que tal sistematização envolve não somente as atividades de gestão, mas, principalmente, a lógica do financiamento. A separação tem por base o princípio de solidariedade entre os entes no financiamento do componente.

A organização pautada pela cooperação federativa, em termos de recursos financeiros, é marcada pelos seguintes aspectos: monitoramento das responsabilidades com o financiamento por cada ente; otimização dos recursos, a partir das compras que são centralizadas; e, estímulo ao desenvolvimento tecnológico e a produção local, para os casos de compras centralizadas de medicamentos estratégicos para o SUS, em processos de transferência tecnológica (documento 1LM) (BRASIL, 2014a).

O documento $14 \mathrm{LN}$ ratifica que o financiamento é compartilhado pelos três entes, sendo que o Distrito Federal acumula direitos e obrigações reservadas aos Estados e Municípios (BRASIL, 2012a). E o documento 5LN relembra que a corresponsabilização já está normatizada pela CF de 1988 e pela Lei Orgânica da Saúde de 1990 (BRASIL, 2007). 
Em período anterior ao CEAF/PNAF, não havia a pactuação de valores mínimos no financiamento dos medicamentos excepcionais. Logo, não havia conhecimento ou mensuração dos valores pagos por cada medicamento pelos diferentes Estados e do montante investido por cada Unidade da Federação (UF) com estas aquisições. A ausência de controle ou previsão estimulou a forma de organização atual do componente (BRASIL, 2014a).

A Portaria GM/MS n. 2.981/2009 inovou a forma de financiamento, pois, o DAF/MS realizou previamente um estudo sobre a participação dos entes quanto ao emprego dos recursos financeiros e a estrutura existente. Neste sentido, foi possível repensar as responsabilidades quanto aos custos e às atividades de gestão. Para a organização do CEAF/PNAF em grupos, observou-se que, no ano de 2008, o MS foi responsável por 91,88\% dos gastos, e os Estados e o Distrito Federal por 8,12\%. Com base nestes valores, o proposto na Portaria em questão foi de reajuste dos percentuais para $87 \%$ da União, $12 \%$ para os Estados e $1 \%$ para os Municípios para o ano de 2009. Em estudos do DAF/MS, nos anos de 2011, 2012 e $1^{\circ}$ semestre de 2013, observou-se uma manutenção destes percentuais, de forma proporcional, com um equilíbrio entre os entes (BRASIL, 2014a).

É preciso destacar um dado divulgado do ano de 2011 acerca dos valores investidos pelos entes no programa. Na Tabela 4.1, a seguir, é possível notar o volume de recursos alocados somente para este Componente, uma vez que se tem outros dois componentes da AF no País. E ainda, o mesmo documento 1LM também informa os valores investidos pelo Distrito Federal, conforme evidenciado na Tabela 4.2, a seguir. 
Tabela 4.1 - Recursos financeiros e participação relativa no financiamento do Componente Especializado da Assistência Farmacêutica, em 2011, estratificados por esfera de gestão.

\begin{tabular}{|c|c|c|c|c|c|}
\hline ÓRGÃO & GRUPO 1A* & GRUPO 1B & GRUPO 2 & TOTAL & $\%$ \\
\hline MS & $\mathrm{R} \$ 2.217 .281 .102,05$ & $\mathrm{R} \$ 897.419 .887,01$ & - & $\mathrm{R} \$ 3.114 .700 .989,06$ & 88,38 \\
\hline SES & $-\mathrm{R} \$ 17.594 .643,70$ & $\mathrm{R} \$ 70.926 .376,30$ & $\mathrm{R} \$ 356.373 .017,99$ & $\mathrm{R} \$ 409.704 .750,59$ & 11,62 \\
\hline TOTAL & $\mathrm{R} \$ 2.199 .686 .458,35$ & $\mathrm{R} \$ 968.346 .263,31$ & $\mathrm{R} \$ 356.373 .017,99$ & $\mathrm{R} \$ 3.524 .405 .739,65$ & 100 \\
\hline
\end{tabular}

* Grupo 1A - Foram considerados os investimentos para financiamento da quantidade total distribuída dos medicamentos, os recursos empregados para financiamento antes da centralização de cada medicamento e os recursos empregados no ressarcimento dos estoques para os medicamentos centralizados no período.

Onde: MS - Ministério da Saúde; SES - Secretarias Estaduais de Saúde.

Fonte: Brasil (2014a).

Tabela 4.2 - Recursos financeiros e participação relativa no financiamento do Componente Especializado da Assistência Farmacêutica, em 2011, estratificados por esfera de gestão.

\begin{tabular}{|c|c|c|c|c|c|c|}
\hline \multirow{2}{*}{ ÓRGÃO } & \multicolumn{2}{|c|}{ GRUPO 1B } & \multirow{2}{*}{$\%$} & \multirow{2}{*}{ GRUPO 2} & \multirow{2}{*}{$\%$} & \multirow{2}{*}{ TOTAL } \\
\hline & Transferência MS & Investimento SES & & & & \\
\hline SES/DF & $\mathrm{R} \$ 14.570 .375,66$ & $\mathrm{R} \$ 787.463,42$ & & $\mathrm{R} \$ 7.125 .104,76$ & 2,00 & $\mathrm{R} \$ 22.482 .943,84$ \\
\hline SES & $\mathrm{R} \$ 70.926 .376,30$ & 100 & $\mathrm{R} \$ 356.373 .017,99$ & 100 & $\mathrm{R} \$ 409.704 .750,59$ & \\
\hline
\end{tabular}

Onde: MS - Ministério da Saúde; SES - Secretarias Estaduais de Saúde; SES/DF - Secretaria de Estado de Saúde do Distrito Federal.

Fonte: Adaptado de Brasil (2014a). 
Outra informação financeira disponível ao público são as Portarias de repasse de recursos da União para o Distrito Federal. Em cada Portaria tem-se a publicação do valor médio mensal de três meses próximos ao trimestre do repasse (com um mês de diferença), bem como o valor repassado para o trimestre em questão. Nos valores discriminados são especificados os ajustes realizados sobre o valor médio previsto e o que, de fato, foi transferido (documento 65LN) (BRASIL 2016a). Os dados em questão foram reunidos na Tabela 4.3, a seguir.

Tabela 4.3 - Repasse de recursos financeiros da União para o Distrito Federal, por trimestre (continua).

\begin{tabular}{|c|c|c|}
\hline Período & $\begin{array}{l}\text { Valor }(\mathbf{R} \$) \text { médio mensal } \\
\text { aprovado em: }\end{array}$ & Valor $(\mathrm{R} \$)$ de pagamento de: \\
\hline $\begin{array}{l}\text { Setembro, outubro e novembro de } \\
2012\end{array}$ & $\mathrm{R} \$ 1.304 .069,24$ & - \\
\hline Janeiro, fevereiro e março de 2013 & - & $\mathrm{R} \$ 1.304 .069,24$ \\
\hline $\begin{array}{l}\text { Dezembro/2012, } \\
\text { fevereiro de } 2013\end{array}$ & $\mathrm{R} \$ 1.249 .754,48$ & - \\
\hline Abril, maio e junho de 2013 & - & $\begin{array}{c}\mathrm{R} \$ 1.255 .402,31(+\mathrm{R} \$ 5.647,82 \\
\text { por ressarcimento de estoques) }\end{array}$ \\
\hline Março, abril e maio de 2013 & $\mathrm{R} \$ 1.337 .744,48$ & - \\
\hline Julho, agosto e setembro de 2013 & - & $\mathrm{R} \$ 1.337 .744,48$ \\
\hline Junho, julho e agosto de 2013 & $\mathrm{R} \$ 858.684,02$ & - \\
\hline Outubro, novembro e dezembro & - & $\mathrm{R} \$ 858.684,02$ \\
\hline $\begin{array}{l}\text { Setembro, outubro e novembro de } \\
2013\end{array}$ & $\mathrm{R} \$ 1.187 .538,46$ & - \\
\hline Janeiro, fevereiro e março de 2014 & - & $\begin{array}{c}\mathrm{R} \$ 1.599 .265,95 \text { (ajuste a maior de } \\
\mathrm{R} \$ 412.628,84 \text { e a menor de } \mathrm{R} \$ \\
901,35)\end{array}$ \\
\hline $\begin{array}{l}\text { Dezembro de 2013, janeiro e } \\
\text { fevereiro de } 2014\end{array}$ & $\mathrm{R} \$ 919.904,22$ & - \\
\hline Abril, maio e junho de 2014 & - & $\mathrm{R} \$ 919.904,22$ \\
\hline Março, abril e maio de 2014 & $\mathrm{R} \$ 1.298 .409,73$ & - \\
\hline Junho, agosto e setembro de 2014 & - & $\mathrm{R} \$ 1.298 .409,73$ \\
\hline Junho, julho e agosto de 2014 & $\mathrm{R} \$ 1.090 .024,77$ & - \\
\hline $\begin{array}{l}\text { Outubro, novembro e dezembro de } \\
2014\end{array}$ & - & $\mathrm{R} \$ 1.090 .024,77$ \\
\hline $\begin{array}{l}\text { Setembro, outubro e novembro de } \\
2014\end{array}$ & $\mathrm{R} \$ 1.226 .542,68$ & - \\
\hline Janeiro, fevereiro e março de 2015 & - & $\mathrm{R} \$ 1.226 .542,68$ \\
\hline $\begin{array}{l}\text { Dezembro/2014, janeiro e } \\
\text { fevereiro de } 2015\end{array}$ & $\mathrm{R} \$ 260.945,59$ & - \\
\hline
\end{tabular}


Tabela 4.3 - Repasse de recursos financeiros da União para o Distrito Federal, por trimestre (conclusão).

\begin{tabular}{|c|c|c|}
\hline Período & $\begin{array}{l}\text { Valor }(\mathbf{R} \$) \text { médio mensal } \\
\text { aprovado em: }\end{array}$ & Valor $(R \$)$ de pagamento de: \\
\hline Abril, maio e junho de 2015 & - & $\begin{array}{c}\mathrm{R} \$ 967.954,34 \text { (ajuste a maior de } \\
\mathrm{R} \$ 694.428,21 \text {; ressarcimento de } \\
\text { estoques de } \mathrm{R} \$ 13.735,09 \text { e ajuste a } \\
\text { menor de } \mathrm{R} \$ 1.154,56 \text { ) }\end{array}$ \\
\hline Março, abril e maio de 2015 & $\mathrm{R} \$ 1.102 .849,94$ & - \\
\hline Julho, agosto e setembro de 2015 & - & $\mathrm{R} \$ 1.102 .849,94$ \\
\hline Junho, julho e agosto de 2015 & $\mathrm{R} \$ 1.486 .225,60$ & - \\
\hline $\begin{array}{l}\text { Outubro, novembro e dezembro de } \\
2015\end{array}$ & - & $\begin{array}{c}\mathrm{R} \$ 896.793,20 \text { (ajuste a menor de } \\
\mathrm{R} \$ 589.432,40 \text { ) }\end{array}$ \\
\hline $\begin{array}{l}\text { Setembro, outubro e novembro de } \\
2015\end{array}$ & $\mathrm{R} \$ 1.068 .687,02$ & - \\
\hline Janeiro, fevereiro e março de 2016 & - & $\begin{array}{c}\mathrm{R} \$ 1.071 .234,91 \text { (ajuste a maior de } \\
\mathrm{R} \$ 2.547,89 \text { ) }\end{array}$ \\
\hline $\begin{array}{l}\text { Dezembro de 2015, janeiro e } \\
\text { fevereiro de } 2016\end{array}$ & $\mathrm{R} \$ 915.233,84$ & - \\
\hline Abril, maio e junho de 2016 & - & $\mathrm{R} \$ 915.233,84$ \\
\hline
\end{tabular}

Fonte: Da autora.

Para a divisão já conhecida dos Grupos do CEAF/PNAF, a seguir, tem-se a divisão quanto ao financiamento (documentos 8LN, 2SI e 3 SI) (BRASIL, 2013a; MINISTÉRIO DA SAÚDE, 2016a; SECRETARIA DE ESTADO DE SAÚDE DO DISTRITO FEDERAL, 2016b):

1) Grupo 1 - medicamentos financiados pelo MS;

a) Grupo $1 \mathrm{~A}$ - medicamentos com aquisição centralizada pelo MS;

b) Grupo 1B - medicamentos financiados pelo MS mediante transferência de recursos;

2) Grupo 2: medicamentos financiados pela SES/DF.

O poder de compra pelo MS aumenta a partir da centralização da aquisição dos medicamentos do Grupo 1A. Logo, a estratégia se mostra importante para tentar minimizar os impactos dos altos gastos com este Componente. Além disso, as regras de financiamento e a divisão em Grupos com responsabilidades pré-definidas normatizam a participação relativa de cada ente quanto aos custos envolvidos.

O financiamento do SUS já estava previsto pelos arts. 195 e 198, §1º da CF de 1988, e foi amplamente normatizado em atos posteriores. Segundo a Carta Magna, a saúde, enquanto 
parte da seguridade social, será financiada pela União, pelos Estados, pelos Municípios e pelo Distrito Federal. E ainda, deve haver recursos mínimos reservados, anualmente, para a saúde, por estes três entes (documento 1LN) (BRASIL, 1988).

A Lei Orgânica da Saúde acrescenta que os recursos financeiros, tecnológicos, materiais e humanos das três esferas governamentais devem ser agregados em prol da saúde pública e prestação de serviços de assistência à saúde (documento 2LN) (BRASIL, 1990a).

Neste sentido, a Portaria GM/MS n. 204/2007 (documento 5LN), em seus arts. $3^{\circ} \mathrm{e} 5^{\circ}$, especifica, in verbis:

\footnotetext{
Art. $3^{\circ}$ Os recursos federais destinados às ações e aos serviços de saúde passam a ser organizados e transferidos na forma de blocos de financiamento.

[...].

Art. $5^{\circ}$ Os recursos federais que compõem cada bloco de financiamento serão transferidos aos Estados, ao Distrito Federal e aos Municípios, fundo a fundo, em conta única e específica para cada bloco de financiamento, observados os atos normativos específicos.

$[\ldots]$.
}

O documento 53LN define que os Planos Estaduais de Saúde deverão estabelecer como os recursos serão aplicados e a previsão de repasse anual destes aos Municípios. O Plano Estadual de Saúde deve ser pactuado na CIB (para os casos de Estados e Municípios) e aprovados pelo Conselho Estadual de Saúde (BRASIL, 2013c). No caso do Distrito Federal, tem-se a a aprovação pelo CSDF.

É preciso também destacar que o art. $3^{\circ}$, inc. V, da LC n. 141/2012 (documento 16LN) padroniza que os recursos mínimos destinados às ações e aos serviços de saúde (art. 200 da CF de 1988, e art. $6^{\circ}$ da Lei n. 8.080/1990) envolvem, dentre outros, in verbis, o custeio de:

\footnotetext{
Art. $3^{\circ}$ Observadas as disposições do art. 200 da Constituição Federal, do art. $6^{\circ}$ da Lei n. 8.080, de 19 de setembro de 1990, e do art. $2^{\circ}$ desta Lei Complementar, para efeito da apuração da aplicação dos recursos mínimos aqui estabelecidos, serão consideradas despesas com ações e serviços públicos de saúde as referentes a: $[\ldots]$

V - produção, aquisição e distribuição de insumos específicos dos serviços de saúde do SUS, tais como: imunobiológicos, sangue e hemoderivados, medicamentos e equipamentos médico-odontológicos;

[...]. (grifo meu)
}

O mesmo ditame ratifica a Portaria GM/MS n. 204/2007 (documento 5LN) e orienta que os recursos para ações e serviços públicos de saúde devem ser movimentados por meio dos fundos de saúde. Ademais, normatiza os valores mínimos a serem aplicados, in verbis: 


\begin{abstract}
Art. $5^{\circ}$ A União aplicará, anualmente, em ações e serviços públicos de saúde, o montante correspondente ao valor empenhado no exercício financeiro anterior, apurado nos termos desta Lei Complementar, acrescido de, no mínimo, o percentual correspondente à variação nominal do Produto Interno Bruto (PIB) ocorrida no ano anterior ao da lei orçamentária anual.

$[\ldots]$.

Art. $6^{\circ}$ Os Estados e o Distrito Federal aplicarão, anualmente, em ações e serviços públicos de saúde, no mínimo, $12 \%$ (doze por cento) da arrecadação dos impostos a que se refere o art. 155 e dos recursos de que tratam o art. 157, a alínea "a" do inciso I e o inciso II do caput do art. 159, todos da Constituição Federal, deduzidas as parcelas que forem transferidas aos respectivos Municípios.

Art. $7^{\circ}$ Os Municípios e o Distrito Federal aplicarão anualmente em ações e serviços públicos de saúde, no mínimo, $15 \%$ (quinze por cento) da arrecadação dos impostos a que se refere o art. 156 e dos recursos de que tratam o art. 158 e a alínea "b" do inciso I do caput e o $\S 3^{\circ}$ do art. 159 , todos da Constituição Federal.

Art. $8^{\circ}$ O Distrito Federal aplicará, anualmente, em ações e serviços públicos de saúde, no mínimo, $12 \%$ (doze por cento) do produto da arrecadação direta dos impostos que não possam ser segregados em base estadual e em base municipal (BRASIL, 2012c).
\end{abstract}

Outros pontos importantes da LC n. 141/2012 são:

- O Fundo de Saúde será a unidade orçamentária e gestora dos recursos para as ações e serviços públicos de saúde. Os recursos somente serão movimentados de outra forma para os casos de recursos repassados à unidades do MS de uma outra maneira;

- O investimento em saúde da União para os Estados, os Municípios e o Distrito Federal será dividido respeitando as demandas de cada região, isto é, os problemas de saúde de cada população, a oferta de ações e serviços em saúde e outras questões (epidemiologia, demografia, aspectos socioeconômicos e espaciais). Aliado à isto, também será considerada a situação de cada região, no sentido dos investimentos poderem ser direcionados para reduzir as desigualdades de oferta de ações e serviços de saúde;

- Os valores referentes ao tópico anterior serão publicados pelo MS anualmente, após pactuação com a CIT; e

- O Tribunal de Contas deverá fiscalizar a adequada transferência e aplicação dos recursos mencionados nos itens anteriores.

Por fim, a qualquer tempo, quaisquer questões que tenham impacto sobre o financiamento (como, por exemplo, a seleção de medicamentos da RENAME) são pactuadas na CIT (BRASIL, 2009b; 2012a; BRASIL, 2013a). O objetivo da pactuação é a análise integral do problema e a manutenção da estabilidade financeira. 
O CEAF é, então, a estratégia da PNS que garante a disponibilização de medicamentos com grande impacto orçamentário dentro da AF brasileira (BRASIL, 2010a). Cabe pontuar que os recursos financeiros não se limitam somente àqueles previstos para a aquisição dos medicamentos em si, mas também a toda a estrutura necessária para tal planejamento. $\mathrm{O}$ documento 2LM relembra a questão quando vislumbra o "exponencial aumento de recursos financeiros postos à disposição da aquisição, distribuição e organização do acesso aos mesmos" (BRASIL, 2010a, p. 13).

Um Quadro que resume e relaciona as entidades envolvidas e suas respectivas responsabilidades para o financiamento do componente foi organizado, bem como as respectivas fontes de informação, situado no Apêndice V.

\subsubsection{Atividades, fluxos e rotinas}

Com base nas subseções anteriores, a apresentação e discussão dos resultados da presente subcategoria seguirá a ordem criada a partir da subcategoria estrutura organizacional. Em seguida, tem-se a sequência dos órgãos anteriormente discutidos para a apresentação das atividades, fluxos e rotinas identificadas.

Em relação aos órgãos de negociação, têm-se, primeiramente, as Comissões. Estas desempenham atividades de discussão e pactuação relacionadas ao CEAF/PNAF. Os pontos de debate são: a gestão e execução da $\mathrm{AF}$, os recursos investidos, a revisão das listas de medicamentos e outras questões relacionadas à área (documentos 2LM e 53LN) (BRASIL, 2010a; 2013c).

A exemplo, o MS tem como atividade pactuar com a CIT a transferência de medicamentos entre o CEAF/PNAF e outros Componentes da AF, ou entre os grupos deste mesmo Componente. Além disso, o MS e a CIT são responsáveis por acordar a ampliação da lista do CEAF/PNAF, o aumento da cobertura de tratamentos com os medicamentos já incorporados e de quem será a responsabilidade do financiamento. Mas devem decidir sobre os referidos tópicos sempre respeitando a oferta adequada no SUS e o equilíbrio financeiro do sistema (documento 8LN) (BRASIL, 2013a).

Os Conselhos e Conferências contribuem por meio de seus relatórios, pactuados com diferentes grupos de interesse, com diretrizes à saúde pública e recomendações às Políticas e programas existentes. A partir destes, o DAF/SCTIE/MS considera as recomendações no 
processo de avaliação e gestão do CEAF/PNAF (documentos 14LN e 53LN) (BRASIL, 1993c; 2013c).

No caso específico do CSDF, este tem como atividades a aprovação do orçamento da saúde do Distrito Federal e o acompanhamento de sua execução, além da aprovação do Plano se Saúde do Distrito Federal, a cada quatro anos, em concordância com o documento 4SI (SECRETARIA DE ESTADO DE SAÚDE DO DISTRITO FEDERAL, 2016c).

Investigando os órgãos de gestão do CEAF/PNAF, a nível federal foi identificado o DAF/SCTIE/MS. Enquanto implementador do CEAF, são competências deste órgão, conforme os documentos 7LN e 8LN (BRASIL, 2009b; 2013a), as atividades de:

1) Aquisição centralizada dos medicamentos do Grupo $1 \mathrm{~A}$ e encaminhamento destes à SES/DF; e

2) Repasse de recursos para o Grupo $1 \mathrm{~B}$ à SES/DF.

Além das competências como implementador, têm-se algumas outras atividades do Departamento, que se referem à gestão do componente de medicamentos:

$[\ldots]$;

II - formular e implementar, e coordenar a gestão das Políticas Nacionais de Assistência Farmacêutica e de Medicamentos, incluindo sangue, hemoderivados, vacinas e imunobiológicos, na qualidade de partes integrantes da Política Nacional de Saúde, observados os princípios e as diretrizes do SUS;

$[\ldots]$;

IV - coordenar a organização e o desenvolvimento de programas, projetos e ações, em áreas e temas de abrangência nacional;

V - normatizar, promover e coordenar a organização da assistência farmacêutica, nos diferentes níveis da atenção à saúde, obedecendo aos princípios e diretrizes do SUS;

VI - programar a aquisição e a distribuição de insumos estratégicos para a saúde, em particular para a assistência farmacêutica, em articulação com o Departamento de Logística em Saúde da Secretaria-Executiva;

[...];

IX - elaborar e acompanhar a execução de programas e projetos relacionados à produção, à aquisição, à distribuição, à dispensação e ao uso de medicamentos no âmbito do SUS; e

$X$ - coordenar a implementação de ações relacionadas à assistência farmacêutica e ao acesso aos medicamentos no âmbito dos Programas de Assistência Farmacêutica do Ministério da Saúde (documento 2SI) (MINISTÉRIO DA SAÚDE, 2016a) (grifo meu).

Todas as ações supramencionadas, se bem executadas, garantem o acesso da população aos medicamentos e, potencialmente, até a ampliação da oferta e do acesso. É importante notar que o próprio órgão compreende seu papel enquanto implementador na descrição da segunda competência, qual seja: "II - formular e implementar, e coordenar a 
gestão das Políticas Nacionais de Assistência Farmacêutica e de Medicamentos" (MINISTÉRIO DA SAÚDE, 2016a).

O entrevistado $1 \mathrm{EN}$, que atua a nível federal, assim endossa o documento oficial do MS:

\begin{abstract}
A execução do componente especializado é competência dos estados. Então, toda a parte de gerenciamento do medicamento até acesso ao medicamento pelo indivíduo, a competência é dos estados. Ao Ministério da Saúde cabe fazer o controle, o monitoramento e o acompanhamento em termos de gestão do componente especializado, articulado justamente com os estados e municípios que são quem executam o próprio componente. [...] Mas, nós temos a equipe de aquisição, que é responsável por fazer a aquisição dos medicamentos do grupo 1A. [...] uma equipe faz a programação, que é justamente a programação e distribuição dos medicamentos aos estados, os medicamentos do grupo 1A. Uma equipe responsável pelo sistema informatizado, que é o Orion especializado, que é um sistema que está hoje em 14 estados, inclusive, aqui no DF.
\end{abstract}

Segundo aquele entrevistado, têm-se na Coordenação-Geral do Componente Especializado da Assistência Farmacêutica (CGCEAF) quatro equipes. A equipe da qual o entrevistado faz parte é a de gestão. As outras equipes são: aquisição, programação e supervisão do sistema informatizado Hórus.

O sistema Hórus é o Sistema Nacional de Gestão da Assistência Farmacêutica. É um dos instrumentos de registro da AF. Além deste, os Estados e os Municípios podem ter sistemas específicos que passam a fazer parte do SIA/SUS e outros programas do MS, bem como possuir bases de dados próprias (BRASIL, 2015f).

O DAF/SCTIE/MS ainda desempenha a revisão da RENAME e dos PCDT, com auxílio da CONITEC (documento 1LM) (BRASIL, 2014a). Esta atividade é importante, pois, o modelo de componente do CEAF/PNAF é bem específico e exige acompanhamento constante quanto à vigência dos protocolos e avaliação das tecnologias padronizadas. $\mathrm{O}$ conjunto de atividades envolve, então, a inclusão, a exclusão e a alteração de medicamentos da RENAME, além da revisão dos PCDT (documento 15LN) (BRASIL, 2012b).

Em termos de rotina, para haver a inclusão de medicamentos nos Grupos 1, 2 ou 3 do CEAF/PNAF, faz-se importante a publicação prévia dos PCDT do MS, e todo o processo deve ser pactuado com a CIT. No caso de uma incorporação de medicamento ou ampliação do uso daqueles já existentes para outros tratamentos, o DAF/SCTIE/MS deverá calcular o impacto financeiro (BRASIL, 2013a).

Conforme o art. 12 do Decreto n. 7.646/2011 (documento 9LN), as atividades relacionadas à revisão da RENAME serão executadas pela Secretaria-Executiva da CONITEC, in verbis: 
Art. 12. À Secretaria-Executiva da CONITEC compete:

I - realizar análise prévia dos requerimentos administrativos apresentados à CONITEC, por meio de avaliação da conformidade formal da documentação e das amostras apresentadas nos termos do art. 15;

II - providenciar, a pedido do Plenário da CONITEC, a submissão das matérias a consulta pública; e

III - praticar todos os atos de gestão administrativa necessários ao desenvolvimento das atividades da CONITEC, inclusive a sistematização de informações para subsidiar as atividades dos membros do Plenário, nos termos de regimento interno.

Parágrafo único. Os integrantes da Secretaria-Executiva deverão firmar termo de confidencialidade e declarar eventual conflito de interesse relativamente aos assuntos tratados no âmbito da CONITEC.

Para as atividades relacionadas à RENAME, tanto os componentes desta comissão quanto outras instituições convidadas deverão declarar eventual conflito de interesse, por se tratar de ações de seleção de produtos para posterior aquisição pelo governo. Poderão ser convidados para discutir questões técnicas com a CONITEC outras instituições, autoridades, técnicos nacionais e internacionais e cientistas (BRASIL, 2011c).

Ainda de acordo com o art. 15 do Decreto n. 7.646/2011 (documento 9LN), a revisão da RENAME é feita mediante requerimento administrativo, e o documento de solicitação para esse processo administrativo deve ser protocolado na Secretaria-Executiva da CONITEC, in verbis, acompanhado de:

Art. 15. A incorporação, a exclusão e a alteração pelo SUS de tecnologias em saúde e a constituição ou alteração de protocolos clínicos e diretrizes terapêuticas serão precedidas de processo administrativo.

$\S 1^{\circ} \mathrm{O}$ requerimento de instauração do processo administrativo para a incorporação e a alteração pelo SUS de tecnologias em saúde e a constituição ou alteração de protocolos clínicos e diretrizes terapêuticas deverá ser protocolado pelo interessado na Secretaria-Executiva da CONITEC, devendo ser acompanhado de:

I - formulário integralmente preenchido, de acordo com o modelo estabelecido pela CONITEC;

II - $\mathrm{n}$ úmero e validade do registro da tecnologia em saúde na ANVISA;

III - evidência científica que demonstre que a tecnologia pautada é, no mínimo, tão eficaz e segura quanto aquelas disponíveis no SUS para determinada indicação;

IV - estudo de avaliação econômica comparando a tecnologia pautada com as tecnologias em saúde disponibilizadas no SUS;

$\mathrm{V}$ - amostras de produtos, se cabível para o atendimento do disposto no §2o do art. 19-Q, nos termos do regimento interno; e

VI - o preço fixado pela CMED, no caso de medicamentos.

Para cada processo é feito um relatório pela CONITEC, encaminhado ao Secretário da SCTIE/MS para a decisão final. Se necessário, o Secretário pode abrir uma audiência pública para auxiliar a tomada de decisão. Para os casos de revisão dos PCDT, o Secretário deve 
encaminhar o processo à Secretaria responsável pelo programa ou ação relacionado à solicitação.

Por fim, a decisão final é publicada no Diário Oficial da União (DOU). Se necessário, em processo simplificado e de exceção, o Ministro da Saúde poderá determinar a alteração de uma tecnologia em saúde (BRASIL, 2011c).

O MS tem como funções, portanto, o planejamento federal da AF e do CEAF/PNAF, o monitoramento e a avaliação do CEAF/PNAF no Brasil, o financiamento dos Grupos 1A e 1B do CEAF/PNAF, a aquisição centralizada dos medicamentos do Grupo 1A, a gestão dos grupos do CEAF/PNAF mediante pactuação na CIT, a revisão da RENAME e dos PCDT por meio da CONITEC, entre outras.

A nível distrital, a SES/DF é a responsável pelas atividades de elaboração e gestão das Políticas Públicas de saúde. As ações formuladas devem ter como objetivos a promoção, a prevenção, a proteção e a recuperação da saúde (SECRETARIA DE ESTADO DE SAÚDE DO DISTRITO FEDERAL, 2016a).

Assim como analisado para o MS, comparativamente, são atividades de responsabilidade da SES/DF:

1) Recebimento dos medicamentos do Grupo $1 \mathrm{~A}$ pelo MS, e programação, armazenamento, distribuição e dispensação destes aos usuários;

2) Aquisição dos medicamentos do Grupo $1 \mathrm{~B}$, com os recursos repassados pela União, e programação, armazenamento, distribuição e dispensação destes aos usuários; e

3) Financiamento, aquisição, programação, armazenamento, distribuição e dispensação dos medicamentos do Grupo 2 aos usuários (documentos 7LN e 8LN) (BRASIL, 2009b; 2013a)

Para as atividades descritas para a SES-DF e, anteriormente, para o MS, quanto à gestão dos medicamentos do CEAF, foram elaboradas três Figuras (vide Figuras 4.6, 4.7 e 4.8) para facilitar o entendimento destas relações (documentos 7LN e 8LN) (BRASIL, 2009b; 2013a). O delineamento destas relações atende ao objetivo da presente pesquisa: a compreensão da implementação do CEAF/PNAF nos âmbitos federal e distrital. 


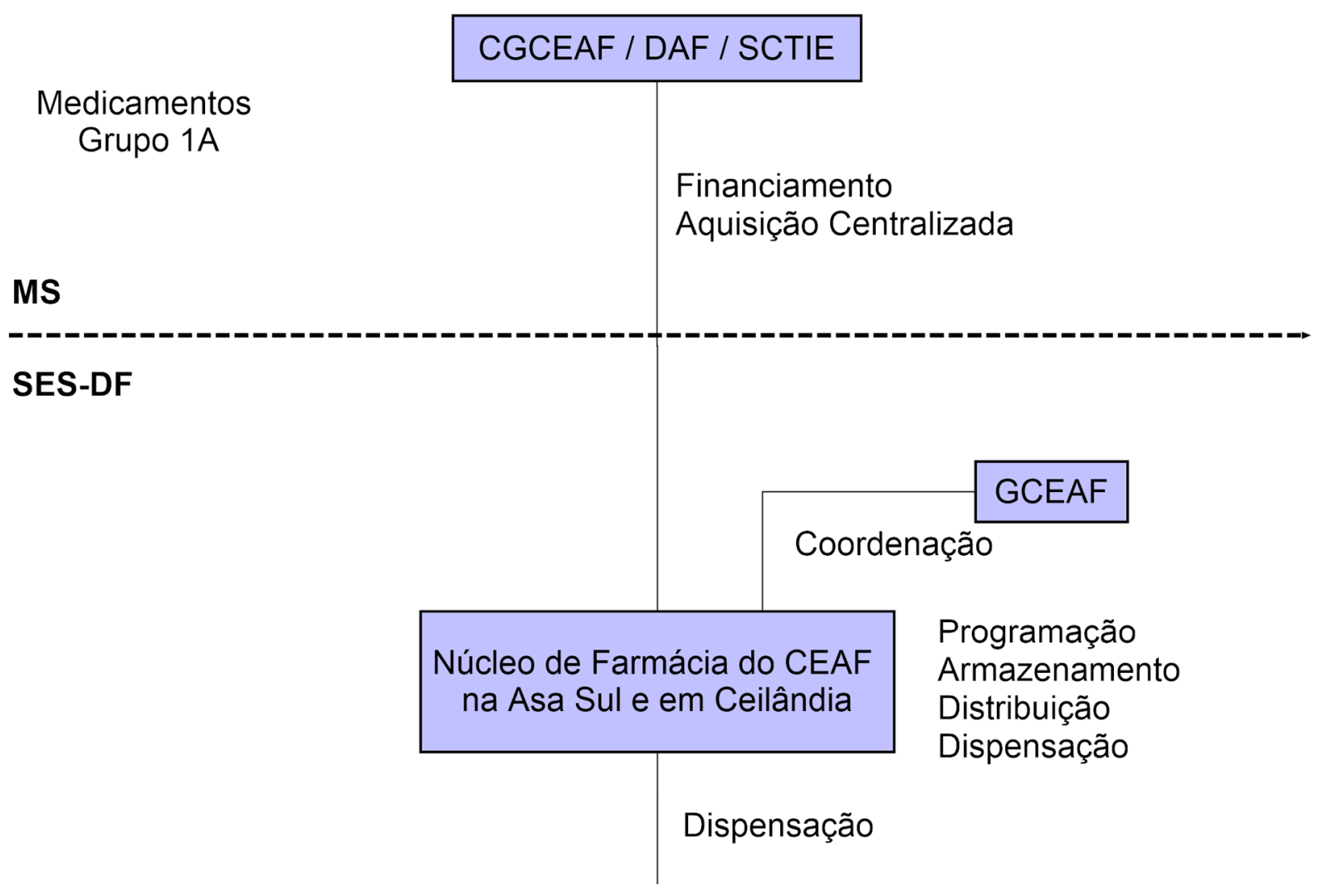

\section{Usuário}

Onde: CGCEAF - Coordenação geral do Componente Especializado da Assistência Farmacêutica; DAF Diretoria de Assistência Farmacêutica; SCTIE - Secretaria de Ciência, Tecnologia e Insumos Estratégicos; GCEAF - Gerência do Componente Especializado da Assistência Farmacêutica; CEAF - Componente Especializado da Assistência Farmacêutica.

Figura 4.6 - Responsabilidades dos entes implementadores pelos medicamentos do Grupo 1A do Componente Especializado da Assistência Farmacêutica/Política Nacional de Assistência Farmacêutica.

Fonte: Da autora. 


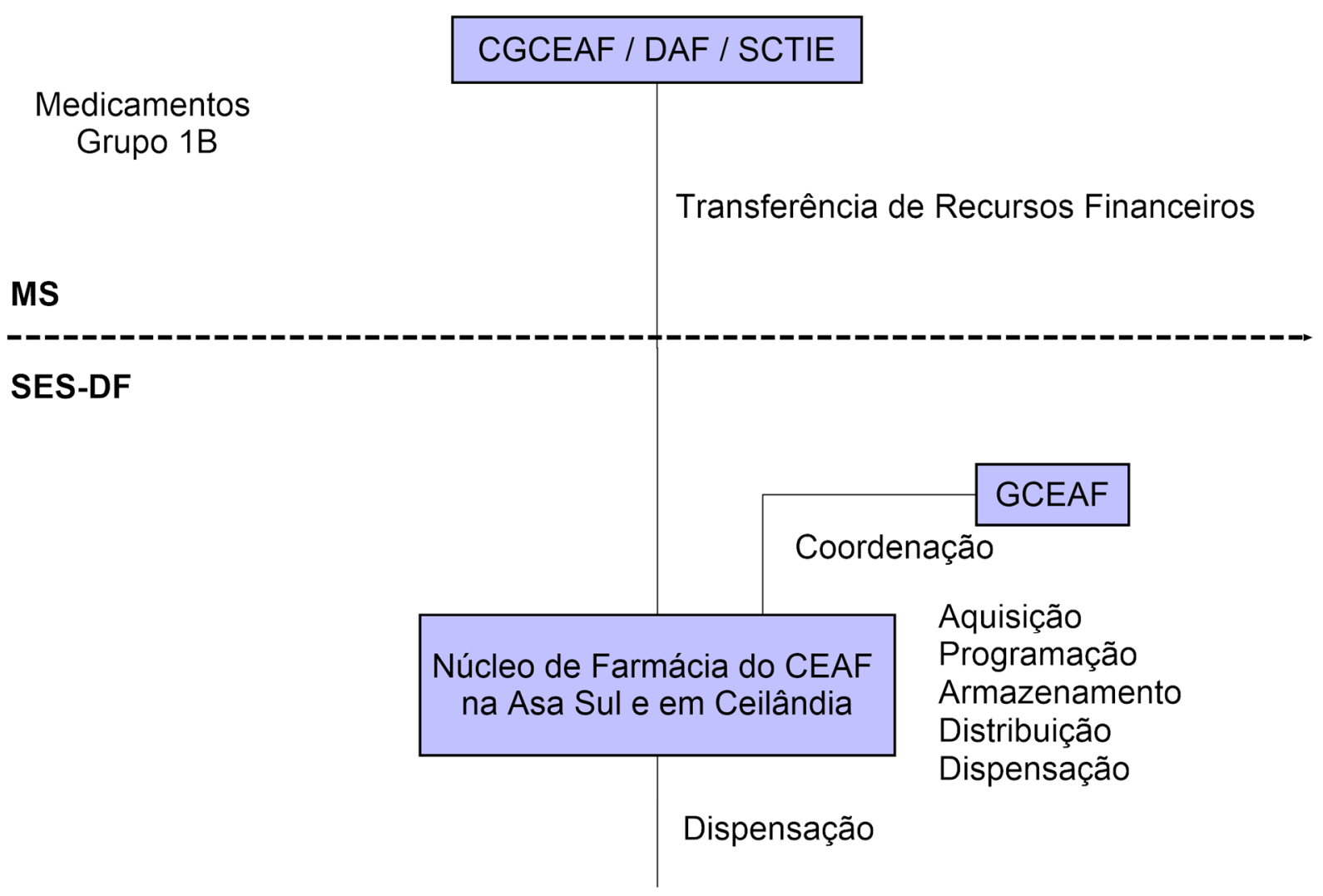

\section{Usuário}

Onde: CGCEAF - Coordenação geral do Componente Especializado da Assistência Farmacêutica; DAF Diretoria de Assistência Farmacêutica; SCTIE - Secretaria de Ciência, Tecnologia e Insumos Estratégicos; GCEAF - Gerência do Componente Especializado da Assistência Farmacêutica; CEAF - Componente Especializado da Assistência Farmacêutica.

Figura 4.7 - Responsabilidades dos entes implementadores pelos medicamentos do Grupo 1B do Componente Especializado da Assistência Farmacêutica/Política Nacional de Assistência Farmacêutica.

Fonte: Da autora. 


\section{CGCEAF / DAF / SCTIE}

\section{Medicamentos \\ Grupo 2}

\section{MS}

\section{SES-DF}

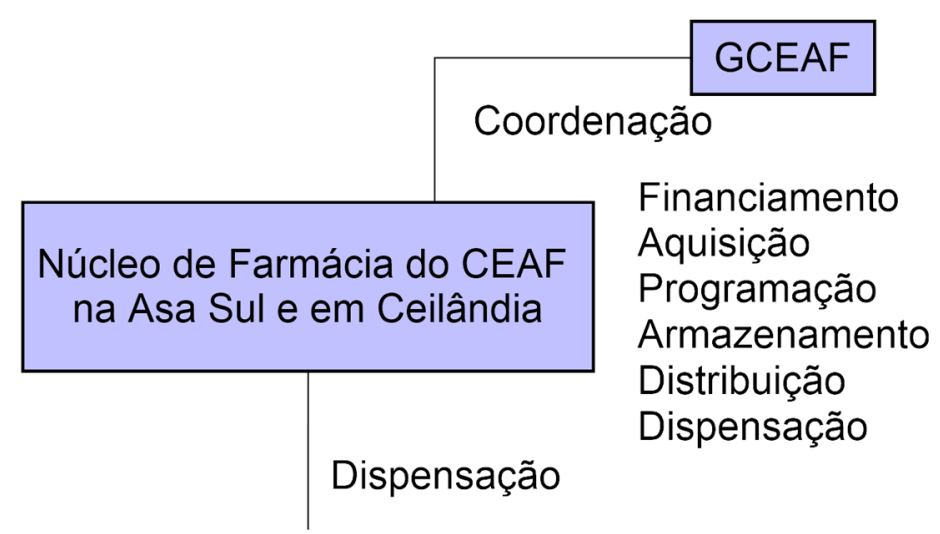

Usuário

Onde: CGCEAF - Coordenação geral do Componente Especializado da Assistência Farmacêutica; DAF Diretoria de Assistência Farmacêutica; SCTIE - Secretaria de Ciência, Tecnologia e Insumos Estratégicos; GCEAF - Gerência do Componente Especializado da Assistência Farmacêutica; CEAF - Componente Especializado da Assistência Farmacêutica.

Figura 4.8 - Responsabilidades da Secretaria de Estado de Saúde do Distrito Federal - ente implementador pelos medicamentos do Grupo 2 do Componente Especializado da Assistência Farmacêutica/Política Nacional de Assistência Farmacêutica.

Fonte: Da autora.

No organograma da SES/DF, tem-se a DIASF - uma unidade de direção que tem como atividade geral a normatização dos programas e ações da AF do Distrito Federal. São atividades específicas da DIASF:

1) Formular a Política de Assistência Farmacêutica do Distrito Federal, em acordo com a PNM e a PNAF;

2) Planejar a operacionalização dos componentes a nível distrital; 
3) Coordenar a seleção de medicamentos, a padronização da REME/DF e do Formulário Terapêutico da SES/DF;

4) Coordenar a gestão dos medicamentos da SES/DF (programação, aquisição, distribuição, avaliação e monitoramento);

5) Coordenar as atividades do CEAF/PNAF no Distrito Federal;

6) Coordenar as atividades que garantam o acesso aos medicamentos pela SES/DF (SECRETARIA DE ESTADO DE SAÚDE DO DISTRITO FEDERAL, 2016a).

$\mathrm{Na}$ análise das atividades oficiais descritas para a DIASF/SES/DF, não há explicitamente a elaboração de PCDT regionais, mas somente a elaboração de formulários terapêuticos do Distrito Federal. Porém, tem-se a possibilidade de expansão da lista do CEAF/PNAF - medicamentos que somente são dispensados ao usuário se houver o seguimento de PCDT da doença. E apesar de não se fazer claro nas atividades da referida Diretoria, tem-se a evidência de atividade de gestão do CEAF/PNAF, e neste, por sua vez, está prevista a elaboração de protocolos regionais.

Sobre a GCEAF/DIASF/SES-DF, assim se manifestou o entrevistado 2EN:

Bom, a gerência executa o componente especializado de acordo com as normas dos protocolos e de acordo com a Portaria que regulamenta o componente especializado, que é a Portaria n. 1554 de 2013, certo? Essa é a Portaria vigente, ela revogou... a de 2009.

A gerência do CEAF/PNAF na SES/DF é a responsável da DIASF pela gestão deste Componente. E conforme as visitas realizadas aos órgãos de gestão do Componente no Distrito Federal, a gerência foi transferida da DIASF/SES/DF para a Farmácia Especializada da Asa Sul, para manter maior proximidade com a execução do Componente.

A execução das ações se dá nos locais de atendimento ao público, nos serviços de base. No Distrito Federal, as "Farmácias de Alto Custo" (ou os Núcleos de Farmácias Especializadas na Asa Sul e na Ceilândia) tem como prática a operacionalização das etapas descritas na Portaria GM/MS n. 1.554/2013 (documento 8LN).

Para o acesso ao medicamento deste Componente, o paciente deve seguir o fluxo já previsto pelo MS e endossado pela SES/DF, que inclui as etapas aqui identificadas. O MS elabora as regras gerais para a realização do Componente, e os Estados devem cumpri-los.

Para a identificação de possíveis adaptações distritais, propõe-se apresentar as orientações ministeriais e, na sequência, o executado pelo Distrito Federal. 
No Quadro 4.2, a seguir, têm-se as etapas diretivas descritas nos documentos 2SI, 7LN e 8LN do Ministério da Saúde (BRASIL, 2009b; 2013a; MINISTÉRIO DA SAÚDE, 2016a).

Quadro 4.2 - Etapas diretivas do Ministério da Saúde para acesso aos medicamentos do Componente Especializado da Assistência Farmacêutica/Política Nacional de Assistência Farmacêutica.

\section{ETAPAS PARA ACESSO AOS MEDICAMENTOS DO CEAF/PNAF - MS}

Orientações gerais: “A solicitação de medicamentos corresponde ao pleito do paciente ou seu responsável na unidade designada pelo gestor estadual” (MINISTÉRIO DA SAÚDE, 2016a, p.1).

ETAPA 1: Cadastro do paciente e solicitação do medicamento pelo usuário. Devem-se levar os documentos:

a) Cópia do Cartão Nacional de Saúde (CNS);

b) Cópia de documento de identidade*;

c) Laudo para Solicitação, Avaliação e Autorização de Medicamentos do Componente Especializado da Assistência Farmacêutica (LME), adequadamente preenchido;

d) Prescrição Médica devidamente preenchida;

e) Documentos exigidos nos Protocolos Clínicos e Diretrizes Terapêuticas publicados na versão final pelo Ministério da Saúde, conforme a doença e o medicamento solicitado; e

f) Cópia do comprovante de residência.

OBS 1: A cópia de documento de identidade e a cópia do comprovante de residência não serão exigidos para as populações indígena e penitenciária.

ETAPA 2: Avaliação da solicitação por um profissional da área da saúde vinculado ao programa estadual.

ETAPA 3: Autorização pelo profissional avaliador.

ETAPA 4: Dispensação do(s) medicamento(s).

ETAPA 5: Renovação da continuidade do tratamento.

OBS 2: "Todos os medicamentos dos Grupos 1 e 2 devem ser dispensados somente de acordo com as recomendações dos Protocolos Clínicos e Diretrizes Terapêuticas e para as doenças (definidas pelo CID-10) contempladas no CEAF” (MINISTÉRIO DA SAÚDE, 2016a, p.1).

Fonte: Da autora.

As Portarias n. 2.981/2009 (e sua atualização) e n. 1.554/2013 regulamentam oficialmente estas atividades (BRASIL, 2009b; 2013a).

As etapas executadas pela SES/DF (documento 3SI) estão organizadas no Quadro 4.3, a seguir, a partir da análise do fluxograma oficial do órgão datado de 08 de janeiro de 2016 (SECRETARIA DE ESTADO DE SAÚDE DO DISTRITO FEDERAL, 2016b). 
Quadro 4.3 - Etapas implementadas pela Secretaria de Estado de Saúde do Distrito Federal para acesso aos medicamentos do Componente Especializado da Assistência Farmacêutica/Política Nacional de Assistência Farmacêutica.

\section{ETAPAS PARA ACESSO AOS MEDICAMENTOS DO CEAF/PNAF - SES/DF}

Orientações gerais: "O atendente do Call-Center agendará data e horário para comparecimento em uma das unidades (Farmácia Ambulatorial Especializada da Asa Sul ou da Ceilândia). O paciente ou responsável deve apresentar-se à Unidade de atendimento com pelo menos 15 minutos de antecedência em relação ao horário agendado para atendimento" (SECRETARIA DE ESTADO DE SAÚDE DO DISTRITO FEDERAL, 2016b, p.1)

\section{RECEPÇÃO}

ETAPA 1: Recepção do paciente ou responsável.

Nesta etapa verifica-se a lista de agendamento do núcleo.

\section{NÚCLEO DE CADASTRO}

ETAPA 2: Cadastro do paciente e solicitação do medicamento.

a) Documentos pessoais - Registro Geral (RG), Cadastro de Pessoa Física (CPF), Cartão Nacional de Saúde Cartão do SUS (CNS) e comprovante de endereço (original e cópia);

b) Documentos específicos - Laudo de Solicitação, Avaliação e Autorização de Medicamento do Componente Especializado da Assistência Farmacêutica (LME) adequadamente preenchido, receita médica, relatórios médicos, exames complementares e termo de esclarecimento (original e cópia).

OBS 1: O termo de esclarecimento está disponível nos Protocolos Clínicos e Diretrizes Terapêuticas (PCDT) no site do Ministério da Saúde (MS).

OBS 2: Caso a documentação não esteja completa, deve-se agendar com o call-center um retorno para apresentação das pendências e finalização da etapa de solicitação.

NÚCLEO DE AVALIAÇÃO - Médico

ETAPA 3: Avaliação técnica.

Verifica-se se o paciente possui todos os critérios de inclusão no protocolo e se não possui algum critério de exclusão.

NÚCLEO DE AUTORIZAÇÃO - Farmacêutico

ETAPA 4: Autorização.

Analisa-se o processo do paciente e convoca-se o mesmo para comparecimento na Farmácia. Na presença deste, confere-se toda a documentação e, se deferido o processo, emite-se a autorização e encaminha-se o paciente para a dispensação.

\section{NÚCLEO DE DISPENSAÇÃO}

ETAPA 5: Dispensação do(s) medicamento(s).

OBS 3: É necessário apresentar documento original de identificação com foto para a retirada do(s) medicamento(s). E, no caso de medicamentos termossensíveis, deve-se levar recipiente térmico e gelo.

\section{NÚCLEO DE RENOVAÇÃO}

ETAPA 6: Renovação.

OBS 4: A renovação deve ser realizada a cada três meses para a manutenção do cadastro e não é necessário agendamento.

Fonte: Da autora. 
Sobre a questão apresentada, o entrevistado 2EN assim reforça o entendimento das etapas da SES/DF:

a) Etapa 1:

O Ministério fala, "olha, você tem que ter a etapa de solicitação". Então, como que nós organizamos? A gente tem o serviço de agendamento. Por que nós temos uma carência muito grande de profissionais. [...]

b) Etapa 2:

Então, a solicitação, ela envolve a apresentação dos documentos do paciente e toda a relação de exames e formulários. Geralmente relatórios médicos e formulários que estão previstos nos protocolos, certo? Essa eu diria que é a etapa mais complexa do componente especializado. [...]

c) Etapa 3:

d) Etapa 4:

Bom, a avaliação [...] feita a documentação completa com todos os exames, formulários e documentos que são exigidos na portaria e no protocolo em questão, nós enviamos isso para a avaliação técnica. A regra é que a avaliação técnica seja feita pelo coordenador de especialidade. [...]

Aí feita a avaliação técnica, a gente liga para o paciente. Mas, agora nós mesmos, pois aqui a gente tem um serviço de call center contratado. Nessa etapa a gente liga para agendar para vir para fazer a autorização, certo? A autorização, ela é sempre feita por farmacêuticos. Na Portaria diz que é um profissional de nível superior. Porque? A autorização vai refletir na avaliação técnica, se a avaliação técnica for deferida, ele vai ser autorizado. Se foi indeferido, vai ser não autorizado.

\section{e) Etapa 5:}

Aí ele autorizado, vai para o setor de dispensação, onde vai ser feito, então, a dispensação do medicamento para o paciente. E aqui o farmacêutico da autorização já explicou tudo para ele. Por exemplo, [...] nós temos a política de fazer a dispensação para três meses de tratamento. O paciente que, geralmente, não altera a dose e que vai continuar. Agora, o médico que tem um paciente, por exemplo, de dor. A gente não entrega três meses, primeiro porque geralmente são medicamentos de controle especial. E segundo, ele altera muito a dose. Então, no meio do mês ele vai voltar a farmácia com uma nova dose. Então, tudo isso já está bem definido em procedimentos próprios de como o farmacêutico da autorização vai proceder. 
f) Etapa 6:

Bom, a dispensação está vinculada à $\mathrm{APAC}^{6}$. A APAC tem vigência de três meses. A cada três meses, o paciente tem que voltar para fazer a renovação da continuidade do tratamento. E aí no protocolo diz quais são os documentos que o paciente tem que apresentar na renovação. Geralmente, é o documento padrão do componente especializado que é a $\mathrm{LME}^{7}$, que é o laudo de solicitação dos medicamentos, e a receita. Mas, por exemplo, tem protocolos que exigem exames de monitoramento.

A partir da sistematização e comparação das etapas propostas pelo MS e executadas pela SES/DF, é possível perceber que as orientações são seguidas, e as medidas de cuidado à saúde são respeitadas. Por se tratar de tratamentos complexos, todas as precauções são necessárias para que as autorizações sejam emitidas para os casos em que não haja contraindicação para uso dos medicamentos, e para os quais os benefícios existam comprovadamente.

Neste sentido, na Figura 4.9, a seguir, tem-se um fluxograma simplificado que aponta as etapas de execução do CEAF/PNAF na SES/DF.

\footnotetext{
${ }^{6}$ Autorização de Procedimentos de Alta Complexidade/Custo (BRASIL, 2013a).

7 Laudo para Solicitação, Avaliação e Autorização de Medicamentos do Componente Especializado da Assistência Farmacêutica (BRASIL, 2013a).
} 


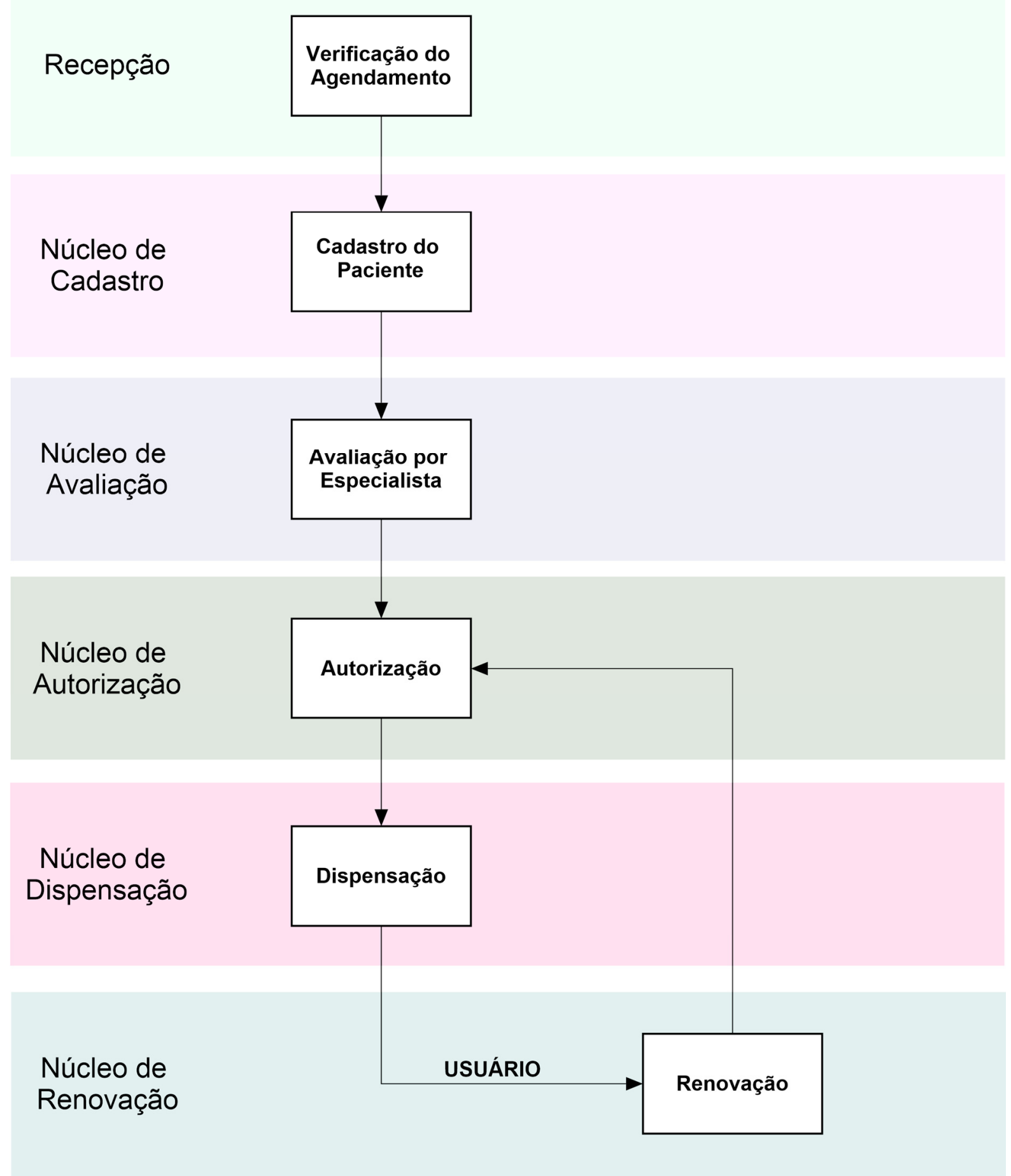

Figura 4.9 - Fluxograma das atividades para a execução do Componente Especializado da Assistência Farmacêutica/Política Nacional de Assistência Farmacêutica no Distrito Federal.

Fonte: Da autora.

A análise documental das atividades da SES/DF em relação ao CEAF/PNAF evidenciou que a CCFT é responsável pelas atividades de seleção dos medicamentos e de criação de critérios para a inclusão de novos medicamentos, para o uso e a avaliação do uso 
dos medicamentos (SECRETARIA DE ESTADO DE SAÚDE DO DISTRITO FEDERAL, 2016a).

A síntese dos fluxos e das rotinas sob a responsabilidade dos respectivos entes implementadores e as fontes que permitiram sua identificação é apresentada no Apêndice W.

Ainda como sistematização dos resultados analisados, as Figuras 4.10 e 4.11, a seguir, evidenciam as relações e os fluxos de atividades entre os órgãos, quanto à implementação do CEAF/PNAF no Distrito Federal. 


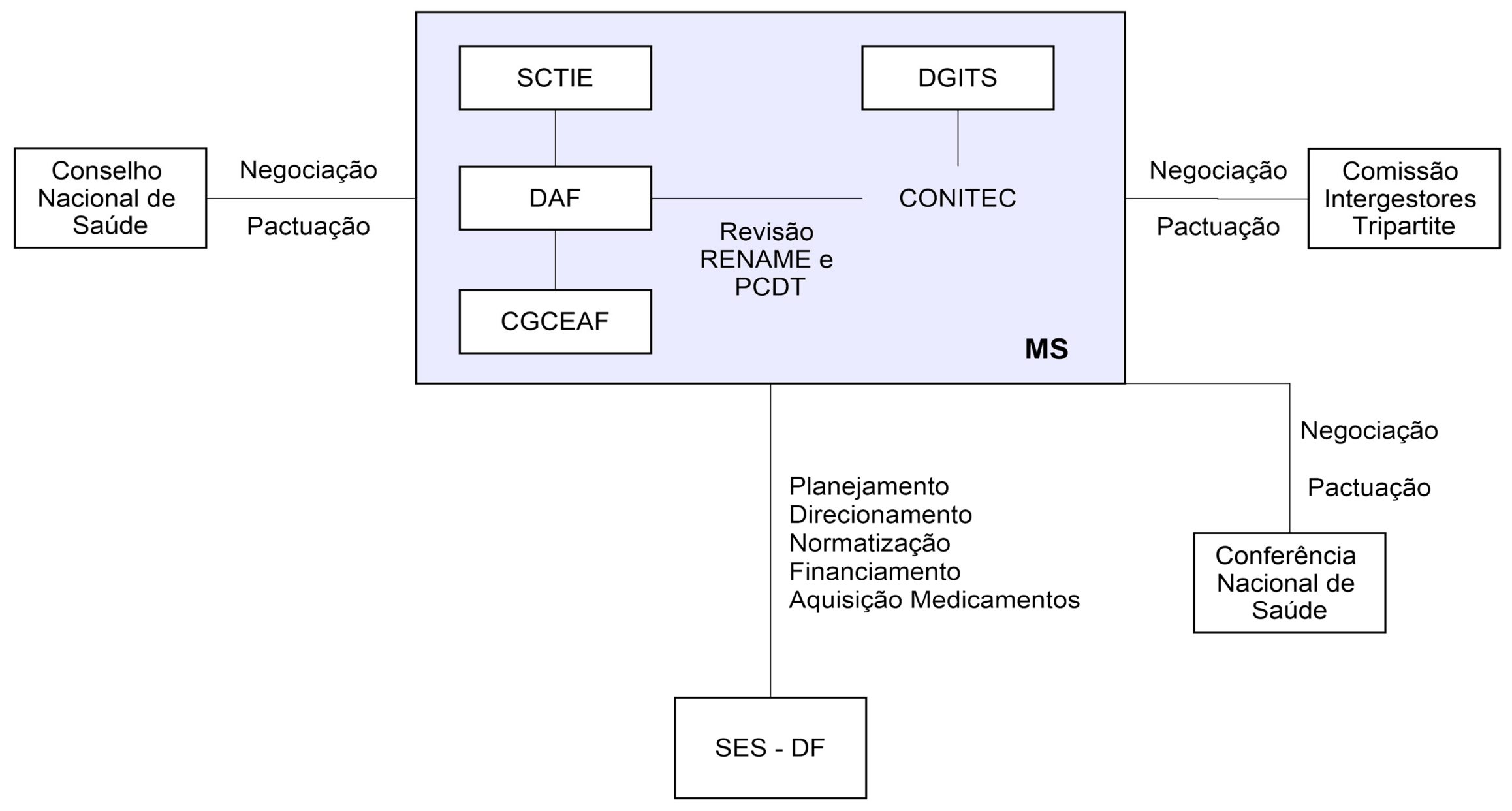

Onde: SCTIE - Secretaria de Ciência, Tecnologia e Insumos Estratégicos; DAF - Diretoria de Assistência Farmacêutica; CGCEAF - Coordenação geral do Componente Especializado da Assistência Farmacêutica; RENAME - Relação Nacional de Medicamentos Essenciais; PCDT - Protocolo

Figura 4.10 - Atividades para a execução do Componente Especializado da Assistência Farmacêutica/Política Nacional de Assistência Farmacêutica no Distrito Federal parte I, nível federal.

Fonte: Da autora. 


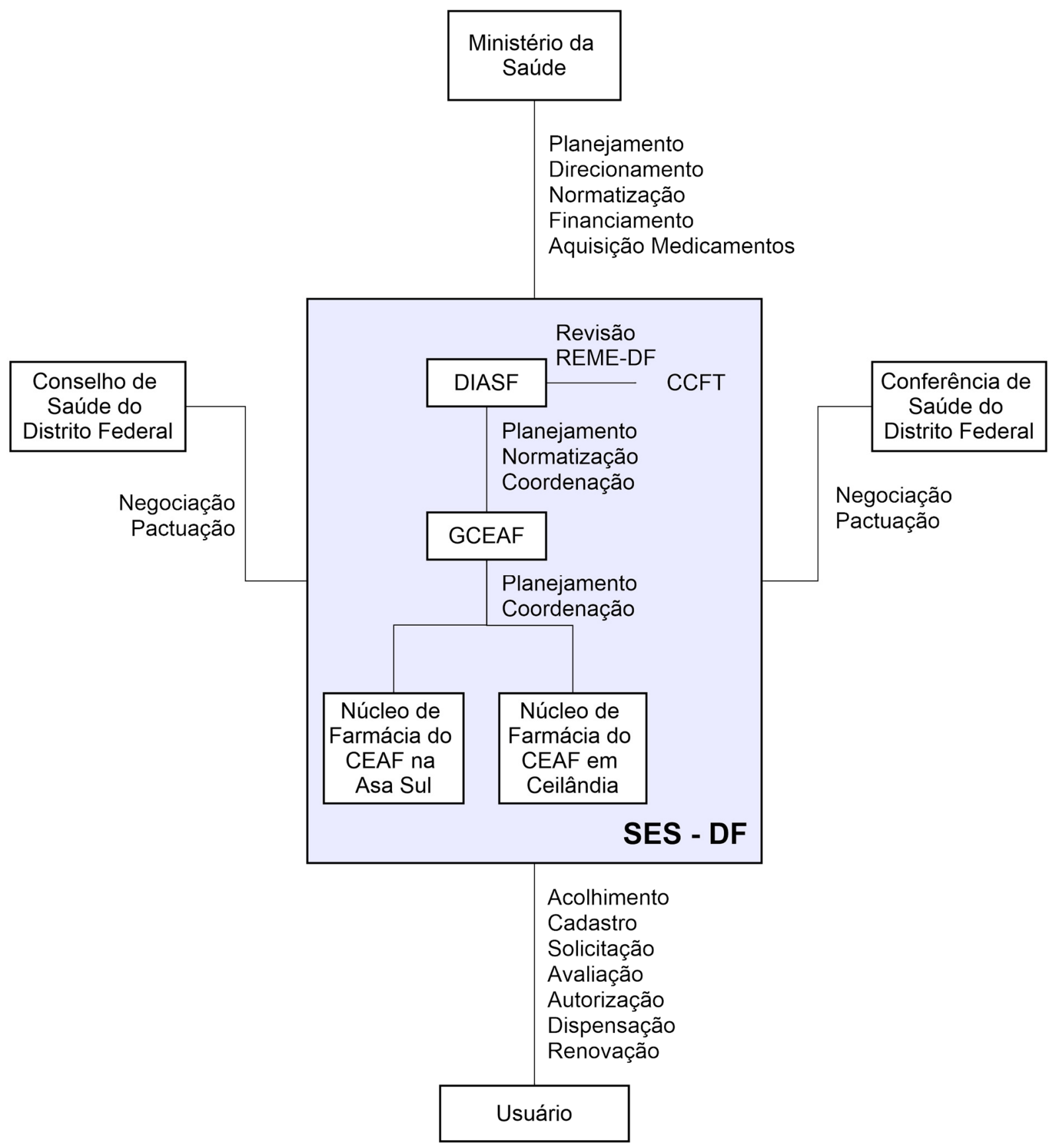

Onde: DIASF - Diretoria de Assistência Farmacêutica; REME-DF - Relação de Medicamentos Essenciais do Distrito Federal; CCFT - Comissão Central de Farmácia e Terapêutica; GCEAF - Gerência do Componente Especializado da Assistência Farmacêutica; CEAF - Componente Especializado da Assistência Farmacêutica; SES-DF - Secretaria Estadual de Saúde do Distrito Federal.

Figura 4.11 - Atividades para a execução do Componente Especializado da Assistência Farmacêutica/Política Nacional de Assistência Farmacêutica no Distrito Federal - parte II, nível distrital.

Fonte: Da autora. 


\subsubsection{Discricionariedade operacional}

Na presente subcategoria têm-se os resultados referentes às práticas discricionárias na execução do CEAF/PNAF.

1) Elaboração do Plano de Saúde do Distrito Federal

Ao passo que a elaboração do Plano de Saúde é uma possibilidade de planejamento adaptado à realidade local do gestor, o mesmo é demandado e acaba sendo obrigatório, uma vez que deve conter a previsão da alocação dos recursos anuais para a área da saúde.

Assim, os Estados e o Distrito Federal elaboram planos de saúde regionais. E no caso do Distrito Federal, o documento 4SI informa que o CSDF tem como atividade aprovar o Plano de Saúde do Distrito Federal a cada quatro anos (SECRETARIA DE ESTADO DE SAÚDE DO DISTRITO FEDERAL, 2016c).

2) Seleção entre os medicamentos da RENAME e dos PCDT na existência de múltiplas alternativas terapêuticas para a mesma indicação clínica.

Para o Componente especializado, por haver obrigatoriedade de seguimento dos PCDT para dispensação dos medicamentos, existe a possibilidade de manejo de medicamentos do componente. Para alguns protocolos tem-se mais de uma alternativa terapêutica equivalente (BRASIL, 2013a). Ou seja, o gestor pode optar pela aquisição entre as alternativas, o que se mostra interessante caso um medicamento seja de aquisição economicamente melhor que o outro. Por vezes, pode ser que um mesmo medicamento tenha mais de uma indicação clínica e, se previsto para outro componente ou no próprio CEAF/PNAF, é mais eficiente adquirir o mesmo medicamento, em quantidades maiores.

Sobre a questão, o entrevistado 2EN assim se manifestou:

\footnotetext{
Que eu não lembro o número. Mas, então, essa é a Portaria vigente. Nessa Portaria, está descrito todo o elenco de medicamentos. Mas, lembrando, esse elenco é o elenco do Ministério. Nós como estado, podemos ao executar o protocolo, ampliar ou diminuir, certo? Então, a gente que define o elenco próprio. Existe a possibilidade da nossa próxima portaria, a gente definir um elenco mínimo.
}

Como explicado pelo entrevistado $1 \mathrm{EN}$, na subcategoria discricionariedade normativa, alguns PCDT apresentam mais de uma alternativa terapêutica para a escolha. Logo, os 
Estados deverão escolher entre os medicamentos apresentados, pois, havendo equivalência entre os produtos, não há justificativa ou racionalidade de gestão para manter a aquisição de dois medicamentos padronizados.

3) Seleção de medicamentos fora da RENAME e elaboração de listas suplementares

As portarias garantem a adequação das listas de medicamentos padronizadas de acordo com as características epidemiológicas locais. Pela enorme extensão territorial do Brasil, não considerar a variabilidade regional seria produzir ações em saúde, por vezes, desnecessárias para algumas localidades.

Sobre a questão e atestando que a adequação da lista do CEAF/PNAF é feita no Distrito Federal, os entrevistados $2 \mathrm{EN}$ e o $3 \mathrm{EN}$ assim se manifestaram:

Bom, a gerência executa o componente especializado de acordo com as normas dos protocolos e de acordo com a Portaria que regulamenta o componente especializado, que é a Portaria n. 1554 de 2013, certo? [...] Mas, então, essa é a Portaria vigente. Nessa Portaria, está descrito todo o elenco de medicamentos. Mas, lembrando, esse elenco é o elenco do Ministério. Nós como estado, podemos ao executar o protocolo, ampliar ou diminuir, certo? Então, a gente que define o elenco próprio. Existe a possibilidade da nossa próxima portaria, a gente definir um elenco mínimo. [...] O exemplo clássico, micofenolato de mofetila para lúpus. O Ministério não coloca, não aprova, porque não tem nem indicação em bula. Mas, é uma indicação clássica que tem milhões de evidências na literatura, todo mundo usa. Então, a gente faz essa dispensação excepcional (Entrevistado 2EN).

Ela colocar o elenco mínimo, isso. Que o Ministério considera o elenco mínimo para poder atender os protocolos. Mas, por hora a gente [...] Pode reduzir. Mas, o que a realidade é o que os estados aumentam (Entrevistado 3EN).

Sobre a criação de outras listas, o entrevistado 4EN exemplifica:

Por exemplo, vai depender do diagnóstico, do CID. O Ministério contempla alguns (tratamentos). Por exemplo, artrite reumatoide, o Ministério contempla. Agora, por exemplo, se pegar psoríase, aí é fora do protocolo, e o que acontece? O estado está pagando, porque o GDF é uma "mãe" também. Você sabe que, por exemplo, em Goiás nenhuma cidade paga. Em outros estados, a maioria dos outros estados não tem. 
4) Elaboração de protocolos estaduais

Conforme a previsão normativa, os Estados podem elaborar protocolos próprios para direcionar os tratamentos não cobertos nacionalmente. Neste sentido, os entrevistados 1EN, 2EN e 4EN confirmam a prática na SES/DF, conforme os relatos que se seguem:

Então, ficando na parte dos medicamentos do componente especializado, se ele registra (estado), se ele quer incorporar algum outro medicamento, seja, na mesma condição que a gente, deve dar entrada no CEAF. Esse medicamento não faz parte do CEAF, entendeu? É um programa estadual. E daí o gerenciamento e forma de controle é de competência do próprio estado (Entrevistado 1EN).

Hoje, a gente tem a política de protocolos. Então, existem medicamentos que não são incluídos pelo Ministério ou indicações que não são incluídas pelo Ministério, que nós temos incluído mediante aprovação de um protocolo, que nós denominamos protocolo estadual. E todos os estados denominam assim, também, entendeu? (Entrevistado 2EN).

Mas a gente tem os protocolos federais e os protocolos de cada estado. [...] a gente tem das duas fontes, do Ministério da Saúde, que são para protocolos específicos. E do GDF. [...]

Isso que eu vou te falar, agora. Era paciente nosso, pegava pelo GDF. O GDF comprava, chegava, na farmácia central. O Ministério mandava os medicamentos do protocolo deles. Tem dois estoques aqui. Um estoque físico que é do Ministério, um estoque físico que é da Secretaria de Saúde (Entrevistado 4EN).

Sobre a mesma questão, se houver conflito entre os tipos de tratamento ou mesmo se não ficar claro para os pacientes a existência de múltiplos protocolos, pode haver falta de compreensão sobre a questão. Pois, se o MS financiar e adquirir um determinado medicamento que também é selecionado pelo Distrito Federal (ou por outros Estados) e, em determinado mês, o Estado não conseguir comprar, haverá o medicamento, porém, somente para os pacientes incluídos no protocolo do MS. Sobre a problemática em questão, os entrevistados 4EN e 5EN assim se mabnifestaram:

Mas, veja só, é aí que está o problema. Nos estados, é dispensado o mesmo medicamento com duas fontes no mesmo lugar. Esse é um dos problemas. Porque o paciente chega aí, o paciente que não entende muito, vamos supor. Não entende muito que o protocolo dele é um protocolo que o estado vai pagar o medicamento. No entanto, ele chega aí e tem outros na fila que pegam do Ministério da Saúde. Então, ele vai ver o outro pegando o medicamento do Ministério da Saúde e ele vai ficar sem o dele, porque o da Secretaria não tem. E é o mesmo medicamento. Aí que é problemático (Entrevistado 4EN).

O Adalimumabe (medicamento) a gente tem das duas fontes: do Ministério da Saúde, que são para protocolos específicos e do GDF. No momento, quando eles vieram, não tinha o do GDF. A paciente recebia pelo GDF. Já estava há muito tempo em falta, então entrou com uma ação judicial. [...] Isso que eu vou te falar agora. Era paciente nossa, pegava pelo GDF. O GDF comprava o Adalimumabe e chegava, via 
Farmácia Central. O Ministério mandava Adalimumabe para o protocolo deles. Tem dois estoques de Adalimumabe aqui. Um protocolo que é... Quer dizer, um estoque físico que é do protocolo do Ministério e um estoque físico de Adalimumabe que é da Secretaria de Saúde. A paciente pegava pela Secretaria de Saúde, porque ela não se encaixava no protocolo de lá. E esse daqui ficou em falta. E ela ligou aí: "Tem? Eu sou da Secretaria", "Não, não tem”, “Tem do Ministério?”, “Tem”, “Ah, então, peraî". Aí entrou com mandado de busca e apreensão (Entrevistado 5EN).

Ainda sobre a mesma questão, o entrevistado 7EN também relata a mesma experiência com protocolos paralelos dos dois entes federativos:

Então, por exemplo, Palivizumabe, a gente tem o protocolo do Ministério da Saúde, mas o DF tem um protocolo expandido. Então, dentro do hospital hoje, a gente tem, por exemplo, o Palivizumabe que é o do Ministério, o estoque que é do Ministério e o estoque que é da Secretaria. É o mesmo medicamento, muitas vezes é o mesmo lote. Mas, a gente tem que separar lá dentro, por conta da justificativa que a gente tem que dar para o Ministério, tem todo o controle para que haja o repasse. Só que como o DF tem protocolo expandido, a gente pode usar também em alguns outros casos que não tem comprovação de eficácia e não tem comprovação de segurança. Então, é questionado, mas o DF mantém expandido, e aí arca sozinho com o custo.

Algumas questões operacionais podem comprometer a boa execução da Política, onde o uso da discricionariedade pode gerar um conflito na execução. Porém, se avaliada a importância de uma nova incorporação, medidas administrativas devem ser tomadas para evitar problemas operacionais ou para realizar o melhor manejo possível em uma situação de desabastecimento.

\section{5) Criação de APAC especial}

As rotinas já previstas por Portaria, para o CEAF/PNAF, especificam que sejam seguidos os Protocolos Ministeriais, e as etapas de cadastro, avaliação, autorização, dispensação e renovação devem ser feitas mediante lançamento da APAC. Porém, quando se tem a possibilidade da criação de listas e protocolos estaduais, a liberação de uma APAC, em termos de gerenciamento, poderia levar à confusão dos procedimentos.

A partir da problemática em questão, fazendo uso da liberdade de gestão local, foi criada no Distrito Federal a Autorização Especial de Procedimento Ambulatorial (AEPAC). Sobre a questão, o entrevistado 4EN assim se manifestou:

[...] "ah, vamos criar uma unidade separada desse [...] para o estado atender aqueles pacientes que não estão incluídos nos protocolos". A gente chama de AEPAC. A APAC é do Ministério da Saúde. Aí gente, criou uma outra sigla que é Autorização Especial de Procedimento Ambulatorial. Que a gente chama da AEPAC. 
Sobre a mesma questão, o entrevistado 2EN também relatou:

\begin{abstract}
Então, foi esses casos que a gente...foi dado nome, eu nem sei te dizer se existe uma portaria, realmente. Não existe uma portaria falando sobre a AEPAC, sobre Autorizações Especiais. Então, eram esses casos que a coordenação (coordenação de especialistas da avaliação), ela entendia a necessidade do medicamento para aquela situação específica do paciente e havia liberação. Só que neste caso, é aquilo que eu te falei, é a Secretaria que assume a responsabilidade de financiar isso.
\end{abstract}

A criação do referido documento aparenta responder a uma necessidade operacional prática, de cunho administrativo. Em verdade, tal ação segue práticas mais importantes, que seriam o foco da preocupação quanto à gestão do CEAF/PNAF, que seriam as criações de listas e protocolos estaduais. Estas sim são operações que exigem cuidado, para que o acesso aos medicamentos sejam ampliados de modo efetivo e mantendo a sustentabilidade econômica do sistema.

Destarte, a AEPAC pode significar um instrumento conflituoso se ela substituir os protocolos, devendo, portanto, ser utilizada para unificar o procedimento e sistematizar as etapas de execução do Componente, mesmo para listas e protocolos estaduais, conforme relata o entrevistado $3 \mathrm{EN}$ :

E outra, fica muito difícil de você fazer a gestão. Como é que você vai ter uma execução totalmente regulamentada e outra que foge totalmente. Então, mesmos para as AEPAC, a gente faz a mesma. Tem que apresentar o laudo padronizado do Ministério da Saúde. Então, assim, a gente segue a mesma diretriz (Entrevistado $3 \mathrm{EN})$.

6) Dispensação sem seguimento aos PCDT

A presente pesquisa desvelou outra situação específica do Distrito Federal quanto à execução do CEAF/PNAF fora do preconizado na Portaria n. 1.554/2013. Desde o ano de 2008, alguns medicamentos são dispensados sem o seguimento das etapas previstas para o componente (cadastro, avaliação, autorização, dispensação, renovação). O serviço realizava as atividades conforme as normas, seguindo os PCDT vigentes à época. Porém, diante de um vertiginoso aumento no número de casos judiciais e, como uma tentativa à época de reduzir a judicialização, alguns pacientes passaram a receber o tratamento mesmo não estando incluídos nos requisitos dos protocolos. Assim, em 2008, os pacientes iniciaram tal recebimento - ação advinda até os dias atuais, mesmo fora dos protocolos. Sobre a questão, segundo o entrevistado 3EN, tem-se o planejamento de resolver essa não conformidade. Mas, depois do ocorrido, não houve mais casos desta natureza. 
O entrevistado 2EN assim explicou os casos em questão:

[...] por exemplo, vamos falar de antipsicóticos atípicos. Os antipsicóticos atípicos, eles são incluídos no componente especializado, apenas no protocolo de esquizofrenia e transtorno esquizoafetivo e agora o bipolar. Então, são esses três protocolos. O diagnóstico...o diagnóstico anteriormente, antes de ter o boom da judicialização, quando estava começando, fez-se uma medida administrativa.

\section{E o entrevistado $3 \mathrm{EN}$ continuou:}

[...] então, muitos casos foram autorizados pela coordenação médica. Então, para casos que não estavam prescritos dentro dos protocolos, a saúde mental era o que a gente abria bastante. Então, hoje a gente ainda tem alguns resquícios de quadros de depressão, de fobias, que a gente libera antipsicóticos. Só que essa via, como ela não é financiada pelo Ministério, é a Secretaria que banca. Então, é a Secretaria que compra com financiamento próprio, porque senão, seria desvio de recursos, se a gente utilizasse. Então, assim, isso para a saúde mental, eu sei que parou de fazer isso há muitos anos atrás. Talvez, principalmente, por conta de uma demanda muito grande e você não tinha um protocolo para isso. Então, assim, eu estou tentando finalizar isso agora, até nos próximos meses, de encaminhar para as coordenações que a gente tem hoje, todos esses casos que são fora dos PCDT. E que às vezes, fica uma situação muito excepcional, "ah, para aquele caso". E nessa, a gente já tem uns três mil pacientes. Diferente do Ministério da Saúde, que você tem protocolo, cumpre critério de inclusão, critério de exclusão. Então, a gente está trabalhando nesse sentido, de colocar, a coordenação vai falar, "não, esses casos aqui não tem protocolo do Ministério, mas nós entendemos a necessidade, entendeu, que o medicamento está descrito bem, assim, para essa situação clínica e vamos fazer um protocolo".

Dos casos listados de discricionariedade, talvez o que exija cuidado com o seu manejo seja o último, já que este foge de qualquer abertura normativa para a sua realização, uma vez que, ou o paciente deve receber o tratamento por se enquadrar nos protocolos ministeriais já existentes, ou deve ser inserido em novos protocolos elaborados pelos Estados.

$\mathrm{O}$ entrevistado $2 \mathrm{EN}$ finaliza seu relato ressaltando sua preocupação quanto ao tema em questão:

A gente segue, entendeu? Mas, assim, é um instrumento que o nosso objetivo é acabar. Mas, eu não posso, por exemplo, pegar um paciente que é atendido desde de 2008 e deixar de prestar assistência a ele. Então, esse caso não tem como (Entrevistado 2EN).

Conforme o Quadro 4.4, que trata das normas que possuem abertura para o poder discricionário dos gestores locais, fez-se uma análise da discricionariedade praticada na SES/DF. O preenchimento do Quadro em questão seguiu as experiências numeradas e apresentadas na presente subcategoria. 
Quadro 4.4 - Prática dos atos discricionários na implementação do Componente Especializado da Assistência Farmacêutica/Política Nacional de Assistência Farmacêutica no Distrito Federal.

\begin{tabular}{|c|c|c|}
\hline NORMA & ASPECTO DISCRICIONÁRIO & $\begin{array}{l}\text { USO DA } \\
\text { DISCRICIONARIEDADE }\end{array}$ \\
\hline $\begin{array}{l}\text { Portaria MS n } 2.135 \text {, de } 25 \text { de } \\
\text { setembro de } 2013\end{array}$ & $\begin{array}{l}\text { Responsabilidade dos entes quanto } \\
\text { à criação de planos de saúde locais. }\end{array}$ & $\begin{array}{l}\text { Elaboração de Plano de Saúde do } \\
\text { Distrito Federal. }\end{array}$ \\
\hline $\begin{array}{l}\text { Lei n. } 8.080 \text {, de } 19 \text { de setembro de } \\
1990\end{array}$ & $\begin{array}{l}\text { Define que os entes tem } \\
\text { responsabilidade de gerir o sistema } \\
\text { de saúde diante das peculiaridades } \\
\text { locais, de forma descentralizada } \\
\text { quanto ao planejamento e da } \\
\text { execução. }\end{array}$ & $\begin{array}{l}\text { Elaboração de Plano de Saúde do } \\
\text { Distrito Federal; seleção entre os } \\
\text { medicamentos da Relação } \\
\text { Nacional de Medicamentos } \\
\text { Essenciais (RENAME) e dos } \\
\text { Protocolos Clínicos e Diretrizes } \\
\text { Terapêuticas (PCDT); seleção de } \\
\text { medicamentos fora da RENAME e } \\
\text { elaboração de listas suplementares; } \\
\text { elaboração de protocolos estaduais; } \\
\text { criação de Autorização de } \\
\text { Procedimentos de Alta } \\
\text { Complexidade/Custo (APAC) } \\
\text { especial. }\end{array}$ \\
\hline $\begin{array}{l}\text { Lei n. } 12.401 \text {, de } 28 \text { de abril de } \\
2011\end{array}$ & $\begin{array}{l}\text { Possibilidade de confecção de } \\
\text { PCDT pelos Estados, pelos } \\
\text { Municípios e pelo Distrito Federal, } \\
\text { na ausência destes documentos a } \\
\text { nível federal. }\end{array}$ & $\begin{array}{l}\text { Elaboração de protocolos } \\
\text { estaduais. }\end{array}$ \\
\hline $\begin{array}{l}\text { Decreto n. } 7.508 \text {, de } 28 \text { de junho } \\
\text { de } 2011\end{array}$ & $\begin{array}{l}\text { Regulamenta a Lei n. } 8.080 \text {, de } 19 \\
\text { de setembro de } 1990 \text {, e a } \\
\text { responsabilidade de gestão local do } \\
\text { Sistema Único de Saúde (SUS) } \\
\text { pelos entes federativos. }\end{array}$ & $\begin{array}{l}\text { Elaboração de Plano de Saúde do } \\
\text { Distrito Federal; seleção entre os } \\
\text { medicamentos da RENAME e dos } \\
\text { PCDT; seleção de medicamentos } \\
\text { fora da RENAME e elaboração de } \\
\text { listas suplementares; elaboração de } \\
\text { protocolos estaduais; criação de } \\
\text { APAC especial. }\end{array}$ \\
\hline $\begin{array}{l}\text { Lei Complementar n. 141, de } 13 \text { de } \\
\text { janeiro de } 2012\end{array}$ & $\begin{array}{l}\text { Regulamenta o } \$ 3^{\circ} \text { do art. } 198 \text { da } \\
\text { Carta Magna de } 1988 \text { e determina } \\
\text { que os entes federativos devem } \\
\text { investir nas ações e serviços de } \\
\text { saúde de forma livre, porém, } \\
\text { seguindo valores mínimos. }\end{array}$ & $\begin{array}{l}\text { Os dados da pesquisa mostraram o } \\
\text { investimento dos valores mínimos } \\
\text { por parte do DF (MINISTÉRIO } \\
\text { PÚBLICO DO DISTRITO } \\
\text { FEDERAL E TERRITÓRIOS, } \\
\text { 2016a). }\end{array}$ \\
\hline \multirow[t]{2}{*}{$\begin{array}{l}\text { Portaria MS n. } 1.554 \text {, de } 30 \text { de } \\
\text { julho de } 2013\end{array}$} & $\begin{array}{l}\text { Autonomia de escolha entre os } \\
\text { medicamentos da RENAME e dos } \\
\text { PCDT quando for o caso de haver } \\
\text { mais de uma alternativa terapêutica } \\
\text { para a mesma indicação clínica. }\end{array}$ & $\begin{array}{l}\text { Seleção entre medicamentos da } \\
\text { RENAME e dos PDCT. }\end{array}$ \\
\hline & $\begin{array}{l}\text { Não especificação de normas para } \\
\text { a operacionalização das etapas de } \\
\text { aquisição, programação, } \\
\text { armazenamento, distribuição e } \\
\text { dispensação. }\end{array}$ & $\begin{array}{l}\text { Os dados da pesquisa evidenciaram } \\
\text { a inclusão da etapa de recepção do } \\
\text { paciente e de ligação para o } \\
\text { agendamento do comparecimento } \\
\text { do paciente (etapa de dispensação) } \\
\text { (SECRETARIA DE ESTADO DE } \\
\text { SAÚDE DO DISTRITO } \\
\text { FEDERAL, 2016b). }\end{array}$ \\
\hline
\end{tabular}

Fonte: Da autora. 


\subsection{Aspectos conflituosos entre a execução do CEAF/PNAF e a execução de demandas judiciais}

A partir da análise inicial dos documentos aqui destacados, tanto relacionados ao caso da $\mathrm{AF}$, quanto ao caso da judicialização, foi possível perceber pontos conflituosos nos discursos da saúde e do Direito relacionados à execução da PNAF (gestão e disponibilização de medicamentos).

Neste sentido, a fim de contemplar os conflitos de interesse entre o ramo executivo e o ramo judiciário do govern, uma nova categoria foi incluída na análise e aqui reportada.

As evidências permitem compreender que os sistemas de saúde e judiciário possuem o objetivo comum de dar cumprimento ao direito constitucional à saúde. Logo, a presente pesquisa considera a inexistência de um conflito de interesse quanto à finalidade das ações. Porém, a análise dos dados demonstrou conflitos nos discursos de uma área sobre o trabalho executado pela outra, possivelmente por desconhecimento ou pela difícil assimilação das características do trabalho técnico da outra área.

A operacionalização da presente categoria envolveu a análise daquilo que é dito pelas respectivas áreas (saúde e Direito) sobre tópicos importantes para a problemática da judicialização. Os discursos analisados tratam, às vezes, de questões relacionadas à gestão de medicamentos, mas que têm importância para a análise da judicialização, e outras vezes explicitamente sobre a judicialização.

Os trechos codificados foram organizados por temas, onde a análise identificou conflitos entre os critérios exigidos para a implementação da Política e os critérios admitidos nas decisões judiciais e, consequente, aplicados para execução da oferta de medicamentos pela via judicial:

1) Aspectos do sistema de saúde;

2) Aspectos da Assistência Farmacêutica e do CEAF/PNAF;

3) Aspectos técnicos farmacêuticos;

4) Aspectos da padronização de medicamentos;

5) Aspectos da padronização de protocolos;

6) Aspectos da atuação do farmacêutico; e

7) Aspectos da judicialização da saúde. 
1) Aspectos do sistema de saúde

O Decreto n. 7.508/2011 (documento 10LN), relacionado às normas de organização do SUS, explica que a colaboração entre os entes federativos para o desenvolvimento das ações e serviços em saúde é regulada por Contratos Organizativos da Ação Pública Saúde (BRASIL, 2011b), o que indica que o funcionamento da rede regionalizada e hierarquizada do SUS é normatizado e pactuado conforme as ações. O caso da oferta de medicamentos em que se vislumbram diferentes responsabilidades, previsão de recursos alocados por cada ente e meta de melhoria ao acesso aos medicamentos, é um exemplo de implementação integrada em saúde.

Ao pensar que existem aspectos de previsão para a execução de Políticas de saúde, entende-se que os serviços e as ações em saúde recebem um cuidado especial quando estruturados. Assim, tem-se um empenho na organização e gestão de tais ações, qualificando o sistema de saúde.

O Decreto em questão ainda destaca que o acesso à AF universal e igualitária pressupõe os seguintes aspectos: que o indivíduo seja atendido pelo SUS; que a prescrição medicamentosa tenha sido feita por profissional em exercício no SUS; que a prescrição esteja em conformidade com a RENAME e com os PCDT, ou com listas e protocolos estaduais, distrital ou municipais; e, que a dispensação seja realizada em local indicado pela gestão do SUS (BRASIL, 2011b).

Em uma análise integradora dos atos normativos em saúde, os pressupostos em questão indicam que o acesso ao direito constitucional à saúde é viabilizado por meio do SUS. Ao mesmo tempo em que o Estado garante o direito à saúde, ele deve fazê-lo por meio da oferta dos serviços. Logo, entende-se que o acesso às ações que garantam este direito se daria pelo usufruto do sistema de saúde.

Retomando os pressupostos do Decreto n. 7.508/2011 (documento 10LN), o indivíduo deve usufruir do SUS, o profissional prescritor que realiza a ponte entre o paciente e o acesso à AF deve ser do SUS, o acesso ao medicamento deve ser em local previsto pelo SUS e, com destaque, a prescrição deve estar adequada às relações de medicamentos e protocolos existentes. O direito à saúde e à assistência à saúde será atendido e, para tanto, o governo deve dispor dos serviços. Logo, o paciente deverá ter pleno acesso aos serviços.

Por fim, tem-se como questões importantes a possível ampliação do acesso do usuário à $\mathrm{AF}$, desde que haja justificativa apropriada, e a possibilidade do MS determinar regras específicas de cesso aos medicamentos especializados (BRASIL, 2011b). 
O MS é o órgão competente para avaliar as necessidades em saúde da população e revisar as ações em curso. Neste ínterim, é preciso destacar a importância que do MS e dos demais órgãos da área no pensar e repensar o sistema a partir de um olhar técnico da saúde. Logo, a avaliação e a proposição de ações em saúde são realizadas por órgãos competentes, com conhecimento de base, para que as ações sejam adequadas ao cuidado à saúde.

Sobre a organização em redes, o Decreto n. 7.508/2011, a Portaria GM/MS n. 204/2007 e a Lei n. 12.466/2011 (documentos 10LN, 5LN e 41LN) acrescentam que o funcionamento deve ser pactuado nas Comissões Intergestores. E estas avaliarão a cooperação federativa quanto às questões financeiras, operacionais e administrativas das ações, e se todas estas estão de acordo com os planos de saúde dos entes envolvidos, pactuados nos Conselhos de Saúde (BRASIL, 2007, 2011b, 2011e). Tal fato somente reforça o esforço e o trabalho conjunto que embasa e acompanha a oferta final dos serviços em saúde. E a Portaria GM/MS n. 204/2007 ratifica tal argumento, ressaltando a necessidade de fortalecer mecanismos gerenciais para o bom acompanhamento das ações de saúde no SUS (BRASIL, 2007).

É missão da SES/DF, enquanto parte do SUS, que o cidadão tenha acesso universal à atenção integral e humanizada à saúde. Para tanto, deve prezar pela confiança, excelência nos serviços e avaliação por meio de indicadores (documento 1SI) (SECRETARIA DE ESTADO DE SAÚDE DO DISTRITO FEDERAL, 2016a). Infere-se pelos documentos supramencionados a preocupação com um atendimento em saúde adequado, amplo e de referência na prestação dos serviços. A partir daí, tem-se muitas etapas até a oferta dos serviços, e a presente pesquisa deve ser sabedora de uma adequada análise ou intervenção sobre o SUS.

2) Aspectos da Assistência Farmacêutica e do CEAF/PNAF

Assim como para o SUS, a AF possui bases congruentes para a elaboração de suas ações. A PNAF norteia para a garantia de acesso e equidade das ações em AF no SUS, para a racionalização da oferta dos serviços de acordo com as necessidades regionais, para o uso racional dos medicamentos, por meio de iniciativas que disciplinem a prescrição, a dispensação e o uso (BRASIL, 2004). Neste sentido, a Resolução CNS/MS n. 338/2004 (documento 4LN) destaca os seguintes aspectos da AF: o acesso adequado e garantido aos medicamentos e o uso adequado destes produtos. Por se tratar de uma área de conhecimento, exige-se o saber técnico para o sucesso das ações sobre prescrição, dispensação e consumo racionais. 
Quanto ao CEAF/PNAF, seguindo as premissas do sistema, este Componente foi criado e pactuado na CIT. O objetivo da discussão que acarretou na reestruturação do Componente foi corrigir problemas de acesso, financiamento e cobertura de tratamento (BRASIL, 2014a). Logo, entende-se que o próprio sistema de saúde realiza monitoramento e avaliação das ações, sendo capaz de revisar e modificar ações em prol da ampliação do acesso aos medicamentos.

O documento 2SI informa que, para as doenças contempladas no Componente, tem-se a garantia de integralidade no tratamento (MINISTÉRIO DA SAÚDE, 2016a). Quer dizer, para os usuários que possuem determinados diagnósticos enquadrados no CID-10, o tratamento, em suas diversas linhas, está previsto para o SUS. Para estes CIDs, o sistema entende a cobertura integral, e que estes pacientes não precisarão recorrer à outras formas de tratamento.

Recentemente, no ano de 2014, uma avaliação do CEAF/PNAF considerou a nova versão do Componente uma importante inovação para a saúde, uma vez que repensou desde a relação de medicamentos até o financiamento e a operacionalização deste (BRASIL, 2014a). A responsabilização dos entes sobre o Componente criou mecanismos para ampliar o acesso, melhorar a sustentabilidade orçamentária, melhorar as relações federativas e estimular outras áreas, como, por exemplo, o desenvolvimento tecnológico nacional (para a área farmacêutica).

A partir dos documentos supramencionados, infere-se que é importante extrair o trabalho que está por trás das ações finais, pois reflete a importância que os envolvidos da área da saúde possuem para o bom funcionamento do sistema e para a execução de ações que envolvam a saúde pública.

3) Aspectos técnicos farmacêuticos

O conhecimento técnico da saúde e da farmácia embasam as ações da $\mathrm{AF}$ e do CEAF/PNAF. Entre as ações especializadas que fortalecem o sistema estão:

I. a criação de estratégias para promover o uso racional dos medicamentos;

II. a revisão permanente da relação de tecnologias incorporadas pelo sistema;

III. a revisão permanente e criação de novos PCDT;

IV. o desenvolvimento e melhora do HÓRUS; e

V. a otimização de recursos com a compra centralizada de medicamentos pela União (BRASIL, 2014a). 
Os conteúdos dos itens são técnicos e específicos. E se negligenciados podem reduzir a eficiência do sistema ou reduzir a segurança sobre os procedimentos em saúde.

O primeiro item - sobre a promoção do uso racional dos medicamentos - prevê estratégias importantes, pois somente o contato/acesso com os medicamentos não basta para a eficácia e segurança do tratamento. Por vezes, dependendo da complexidade do caso e do perfil do paciente, o uso correto do medicamento somente se dá se houver acompanhamento por profissional apto; ou ainda, a própria prescrição deve ser analisada para a garantia de sua adequação, entre possíveis associações de muitos medicamentos.

Seguindo o raciocínio predisposto, os itens dois e três envolvem a noção de critérios clínicos para a seleção de medicamentos e elaboração dos protocolos de tratamento, o que detém tamanha complexidade que deve ser realizado por equipe multiprofissional, incluindo prescritores especialistas.

O desenvolvimento do sistema HÓRUS reflete a complexidade de organização da AF e a demanda sobre a criação de um sistema que se encaixe nas necessidades do dia a dia. Com o HÓRUS, o gestor farmacêutico tem melhor controle sobre os medicamentos disponíveis e em falta, o que possibilita maior organização na gestão dos materiais e melhor controle sobre a disponibilização dos produtos. Tal fato se mostra de importância para garantir o acesso aos medicamentos do SUS, e conhecer o funcionamento também tem seu valor para o entendimento e a intervenção sobre a AF no sistema de saúde público.

Por fim, para realizar interposição no acesso aos medicamentos no Brasil, é preciso conhecer alguns aspectos de cunho financeiro, como, por exemplo, a redução de gastos lograda pela compra centralizada do MS. Logo, ações paralelas que não preveem tal modalidade de compra podem acarretar maiores gastos para o sistema, o que é importante principalmente pelo montante gasto com a aquisição de medicamentos.

4) Aspectos da padronização de medicamentos

A seleção de medicamentos é estratégia importante para o funcionamento do sistema e necessário conhecimento multidisciplinar para que o trabalho tenha qualidade.

Neste sentido, o Decreto n. 7.646/2011 (documento 9LN) situa que a elaboração de relações padronizadas de medicamentos é uma ação em prol do bom serviço clínico, mas também da racionalidade administrativa (BRASIL, 2011c).

Com a elaboração de uma lista, são incluídos apenas os medicamentos necessários para aquela população e que tenham comprovadas a sua eficácia, segurança, melhor relação 
custo-benefício, menor custo-tratamento, melhor apresentação para o uso necessário e outros aspectos que se mostrem importantes (documento 7AR) (MAGARINOS-TORRES; PEPE; OSORIO-DE-CASTRO, 2013). Tais aspectos demonstram que a definição da lista não é aleatória e, pelo contrário, sua elaboração exige conhecimento na área. Logo, não há arbitrariedade na definição dos medicamentos padronizados, bem como não padronizados, em relação a todas as alternativas terapêuticas disponíveis. Faz-se importante destacar a existência de critérios para todo o processo, com justificativas clínicas, tecnológicas e administrativas.

E o processo é tão delicado e específico que as normas admitem e até orientam para a elaboração de listas estaduais, distrital e municipais, pois reconhecem a importância de considerar as variabilidades regionais para melhorar a eficiência.

Retomando e reforçando algumas diretrizes, a CONITEC elabora a lista nacional respeitando os parâmetros de eficácia, eficiência e efetividade relacionados à área farmacêutica, a identificação das tecnologias mais relevantes para a população, além de seguir o objetivo de garantir a universalidade e a integralidade no SUS a partir do uso do melhor conhecimento técnico-científico disponível (documento 9LN) (BRASIL, 2011c). Neste sentido, tem-se a ratificação da preocupação do uso do conhecimento como pilar do sistema.

O uso do conhecimento técnico-científico é considerado uma nova área do conhecimento denominada "saúde baseada em evidências" ou "medicina baseada em evidências". Segue-se um princípio de racionalidade individual e sistêmica, além do respeito às referências científicas que embasam a aplicação dos produtos farmacêuticos (BRASIL, 2014a).

5) Aspectos da padronização de protocolos

Ao encontro da promoção do uso racional de medicamentos está a ação de padronização de protocolos, bem como a padronização das listas de medicamentos. Após a padronização da lista, respeitando uma seleção racional e objetiva, o passo seguinte é a formulação dos protocolos que discorrem sobre a forma de uso. Até porque, para muitos medicamentos, tem-se mais de uma indicação clínica para o uso, e os protocolos definem as indicações que são consideradas as melhores, da perspectiva de eficácia e segurança.

A Lei n. 12.401/2011 aprofunda a questão dos protocolos e destaca que o uso dos medicamentos do CEAF/PNAF, no SUS, se dá mediante critérios. Logo, o consumo tende a não ser feito simplesmente para que haja tratamento, sem racionalidade. Os casos necessitam 
de indicação justificável para que o medicamento seja empregado. Cita-se o paciente estar na fase evolutiva da doença para a qual há comprovação de benefício com o uso, ou ter utilizado outro produto que não fez mais efeito, ou ter tido intolerância ou efeito adverso a outros tratamentos anteriores (BRASIL, 2011a).

O processo de indicação de medicamentos ao usuário do SUS segue a comprovação de eficácia, efetividade, segurança, boa avaliação econômica e registro e autorização de uso no país (BRASIL, 2011a).

A Portaria SAS/MS n. 142/1993 e a Lei n. 12.401/2011 (documentos 14LN e 3LN) são coerentes em colocar as mesmas orientações quanto ao tratamento do componente especializado. Porém, uma situação é de conhecimento da saúde e vem demandando medidas apropriadas para correção, quanto ao seguimento dos PCDT. Sobre a questão, o entrevistado 2EN assim se manifestou:

\begin{abstract}
Mas, geralmente os médicos não conhecem o protocolo. Então, ele nem sabe que para a gente ter acesso ao medicamento, a gente vai precisar ter acesso aos exames. Então, o paciente chega lá com a receita. Então, até a gente explicar para o paciente que ele precisa trazer tudo. Aí ele vai voltar no médico, o médico vai organizar os exames, trazer para gente. Então, isso gera um desconforto. A gente tem atuado no sentido de fazer com que esse processo seja o menos demorado possível, dando ampla publicidade ao que a gente precisa. Tanto no nosso site, quanto no site no Ministério. E a gente também faz treinamento com os médicos frequentemente.

$\mathrm{E}$ isso é um problema, porque o médico que a gente tem acesso para fazer treinamento é o médico da SES, no máximo do HUB. E a demanda maior é do serviço privado.
\end{abstract}

Aquele entrevistado continua a explanação sobre as estratégias e público alvo para a divulgação dos PCDT:

Os especialistas (são o público alvo), porque? Eles estão geralmente em hospitais.
Melhor, eles estão em hospitais, então, você tem um acesso a uma informação
melhor, a divulgação da informação. Então, muitas vezes os farmacêuticos dos
hospitais, ainda mais agora com esses núcleos (núcleos de farmácia clínica). Então,
assim, o farmacêutico entra em contato com conosco, já pede as informações, a
gente encaminha os formulários. Agora, da rede, realmente, a gente tem bem mais
dificuldade. [...]
Os especialistas, que é quem fazem a avaliação técnica da próxima etapa, trabalham
dentro da farmácia. Então, a gente tem contato com eles e eles, geralmente, são a
nossa fonte de divulgação para os colegas, entendeu?

O entrevistado 2EN apresenta, então, uma problemática sobre o conhecimento do prescritor sobre o PCDT e a dificuldade no encaminhamento da documentação completa e adequadamente preenchida para a realização do cadastro do paciente. Como medida de correção, tem-se uma tentativa de melhor publicação dos documentos, buscando ativamente 
estes prescritores nos hospitais e passivamente por meio de divulgação em sítio eletrônico (MS e SES/DF). Ainda assim, é difícil acessar todos os profissionais, e outra estratégia é realizar a divulgação e orientação por meio de outros profissionais que estão no serviço. São aliados do processo os farmacêuticos da SES/DF que estão nos hospitais e Unidades Básicas de Saúde (UBSs) e os prescritores que participam da etapa de avaliação das solicitações no fluxo de acesso ao CEAF/PNAF.

Diante das dificuldades, faz-se importante destacar que a prescrição coerente aos PCDT tem embasamento técnico de que as indicações previstas são as melhores dentro dos critérios objetivos já apresentados. Logo, o seguimento dos protocolos auxilia a prática da prescrição e sustenta a prática clínica. Seguindo este entendimento, os PCDT são aliados à clínica e reforçam a tentativa de melhora do atendimento pelo SUS.

6) Aspectos da atuação do farmacêutico

Ao lado dos cuidados já descritos com a operacionalização da AF no SUS, um aspecto muitas vezes negligenciado é participação do profissional farmacêutico nos serviços.

Por deter o conhecimento na área e ser o profissional competente para viabilizar as ações já descritas, é importante considerar que a presença do profissional em saúde é parte significativa do processo e contribui para o sucesso as ações.

Sobre a questão, o entrevistado 2EN assim relata ao tratar das etapas para acesso aos medicamentos do CEAF: "Todo o paciente, ele passa pelo farmacêutico. Ele nunca é atendido sem passar pelo farmacêutico".

E o entrevistado 3EN também comenta:

\begin{abstract}
Então, assim, é importante uma supervisão farmacêutica. Porque diversas vezes há um exame que talvez a pessoa não saiba identificar, ou um relatório. Só que na prática, eu acho que não há necessidade de você colocar um farmacêutico ali, nessa porta de entrada. Mas, ele vai passar, em algum momento, ele vai passar pelo farmacêutico, isso é fato.
\end{abstract}

Além da presença do farmacêutico nas fases de atendimento ao paciente, também é importante a participação do profissional na formulação das ações. No caso citado pelos entrevistados $2 \mathrm{EN}$ e $3 \mathrm{EN}$, o farmacêutico faz uso de seu conhecimento técnico clínico para 
priorizar os casos que terão atendimento imediato, sem seguir o fluxo tradicional até a dispensação do medicamento.

\footnotetext{
E aqui, também, a gente alguns protocolos que não precisa agendamento. Que são esses que a gente faz atendimento integral na hora, que é dor crônica, fenilcetonúria, fibrose cística, transplantes, hepatite C (Entrevistado 2EN).

E eventualmente, casos que a gente considere que precise dar uma prioridade. Às vezes, o paciente está internado, numa situação que algum médico entra em contato conosco. Então, a gente prioriza (Entrevistado 3EN).
}

O farmacêutico, de fato, é importante para a definição de critérios para operacionalizar a Política de acesso aos medicamentos, uma vez que racionaliza a disponibilização de medicamentos, além de orientar os usuários com relação ao tratamento em si.

7) Aspectos da judicialização da saúde

Um dos aspectos que motivaram a criação do componente especializado aos moldes atuais foi o número crescente de ações judiciais individuais para o fornecimento de medicamentos (documento 2LM) (BRASIL, 2010a). Ou seja, a presente pesquisa evidencia que o fenômeno da judicialização demanda ajustes na AF do SUS. Logo de início é simples inferir que, se há a judicialização, possivelmente há problemas com a via regular de acesso aos medicamentos e demais tecnologias em saúde.

Os dados suoramenciobados destacam que a revisão do componente e a criação do CEAF/PNAF reduziram as ações judiciais individuais por inserir novas doenças cobertas por tratamentos e novos medicamentos para estas e outras doenças já inseridas (BRASIL, 2010a).

Em 27 de abril de 2016, o CONASS reuniu os gestores estaduais de saúde e representantes do Fórum Nacional do Poder Judiciário para Monitoramento e Resolução das Demandas de Assistência à Saúde do Conselho Nacional de Justiça (CNJ). O encontro foi motivado pelo aumento constante das ações judiciais e do consequente impacto sobre o SUS (CONSELHO NACIONAL DE SECRETÁRIOS DE SAÚDE, 2016c). Diante do exposrto, apesar dos ajustes já realizados sobre o CEAF/PNAF e sobre a AF, e a queda percebida anteriormente sobre as ações judiciais, o cenário da judicialização voltou a mudar.

Ainda no Fórum em questão, os secretários estaduais de saúde apresentaram aos representantes do sistema judiciário alguns dos conflitos que o sistema de saúde enfrenta quanto à execução das ações judiciais, a saber: 
I. a falta de orçamento para cumprir as decisões judicias de garantia de tratamentos e outras ações em saúde;

II. o bloqueio de contas pessoais dos gestores; e

III. as ordens de prisão contra os gestores da saúde (CONSELHO NACIONAL DE SECRETÁRIOS DE SAÚDE, 2016c).

Em contrapartida, o sistema de saúde busca promover ações, como a revisão das listas e protocolos, para reduzir a judicialização e talvez isto deva ser trabalhado em conjunto com o sistema judiciário, para que as ações sejam mais efetiva, com a perspectiva combinada dos diferentes profissionais. Sobre a questão, o secretário de saúde do Distrito Federal, Rafael Barbosa, em exercício em 2012, comentou sobre a judicialização e as estratégias elaboradas para lidar com o problema (documento $1 \mathrm{NJ})$ :

Nossos esforços nesses últimos dois anos já foram percebidos pela população. Os números de judicialização caíram em relação à gestão passada porque temos buscado estratégias para melhorar o atendimento, como os mutirões da Saúde (DEFENSORIA PÚBLICA DO DISTRITO FEDERAL, 2013a).

Como resultado do encontro promovido pelo CONASS, alguns depoimentos são importantes para a reflexão quanto aos conflitos entre sistema de saúde e sistema judiciário. Na ocasião, o presidente do CONASS e secretário de estado da saúde do Rio Grande do Sul, João Gabbardo dos Reis, assim se manifestou:

\footnotetext{
Vamos aproveitar muito essa oportunidade de aprofundar esse diálogo com os membros do Judiciário, pois ele é fundamental. Com certeza, a questão da judicialização é um dos maiores problemas que enfrentamos em todas as secretarias e nossos temas prioritários sempre são liderados por essa questão das demandas judiciais (CONSELHO NACIONAL DE SECRETÁRIOS DE SAÚDE, 2016c).
}

O secretário estadual de Saúde de São Paulo, David Uip, expôs que o Estado de São Paulo formou uma parceria com a Universidade de São Paulo (USP), e que a instituição tratará da elaboração de pareceres sobre a eficácia dos medicamentos judicializados:

Firmaremos outros convênios com universidades no interior do estado para termos retaguarda daquilo que, à princípio, não temos evidências científicas necessárias. É fundamental termos um fórum técnico de discussão para buscar alternativas que solucionem essas questões (CONSELHO NACIONAL DE SECRETÁRIOS DE SAÚDE, 2016c). 
O documento 4NS apresenta diversas outras opiniões de gestores da saúde sobre a judicialização, conforme trechos transcritos expostos a seguir (CONSELHO NACIONAL DE SECRETÁRIOS DE SAÚDE, 2016c).

\begin{abstract}
Nós tínhamos apenas uma ouvidoria e juntamos a ela esse núcleo técnico que vai atuar como porta de entrada para a solução das demandas de saúde, na busca de evitar a geração de processos judiciais (Secretária de Estado da Saúde do Amapá, Renilda Costa).
\end{abstract}

Estamos tendo dificuldade com os juízes e desembargadores, com a utilização do instrumento do Mandando de Segurança como uma decisão judicial. [...] Nós queremos ampliar esse diálogo, queremos cumprir as decisões judiciais, mas é complicado. Nós queremos ter a oportunidade de colocar a nossa defesa, de mostrar os transtornos que isso traz para o paciente, para o Sistema Único de Saúde, para o orçamento da Secretaria e para o coletivo como um todo. Peço que o CNJ transmita esse conhecimento para todos os estados para que esses equívocos não prejudiquem o SUS (secretário de Estado da Saúde do Goiás e vice-presidente do CONASS, Leonardo Vilela).

Devemos ter uma proposição concreta e criarmos um grupo de secretários que em interlocução com esse grupo do $\mathrm{CNJ}$, formule mudanças legais que permitam que os juízes não tenham mais que decidir com base nessa legislação posta, gastando um recurso enorme para administrar uma consequência quando, na verdade, temos que resolver a causa. [...]

Os municípios, os prestadores filantrópicos e privados que prestam serviço ao SUS e as representações das entidades de classe têm de ser ouvidos. É fundamental ter melhor entendimento entre aquilo que está disposto em dispositivos legais, com a efetiva prática do exercício das atividades e ações que dispomos para atender a população (secretário de Estado da Saúde do Espírito Santo, Ricardo Oliveira),

Não existe mágica para resolver esse problema. É só definitivamente a questão do diálogo, das diversas experiências exitosas que podem ser estendidas para o país e adequadas às realidades das regiões. Esse é o caminho a meu ver (secretário de Estado da Saúde de Minas Gerais, Fausto Pereira dos Santos).

No Distrito Federal nós temos percebido isso em relação não só contra os secretários, mas também contra os diretores de hospital, os superintendentes, os gerentes etc. Todos estão recebendo notificações pessoais em relação às suas ações, isso independentemente de haver demonstração de dolo ou de má fé o que gera um grau de instabilidade tão grande que o gestor tem medo de tomar ações legítimas de gestão que são boas para a população, com receio de ter responsabilização pessoal. Essa tendência é extremamente cruel, porque não só é injusta com a pessoa do gestor, como engessa a gestão (secretário estadual de Saúde do Distrito Federal, Humberto Fonseca).

Além dos problemas colocados pela saúde que envolvem a judicialização, também é importante citar as estratégias sugeridas ou estabelecidas para a redução dos conflitos entre os sistemas. Neste sentido, como síntese dos resultados da pesquisa quanto às potenciais medidas corretivas tem-se o que se segue:

a) Realização do próprio evento para aproximação com o sistema judiciário;

b) Implantação de Núcleos Técnicos da saúde no sistema judiciário; 
c) Tentativa de diálogo para melhor lidar com as ações judiciais;

d) Sugestão de estabelecimento da atuação dos secretários de saúde junto ao Comitê do CNJ para a discussão da judicialização da saúde;

e) Ampliação da parceria das secretarias estaduais em saúde com outras instituições, como universidades, para melhorar o embasamento técnico das decisões;

f) Embasamento das decisões judiciais por pareceres técnicos; e

g) Redução da burocracia para garantir agilidade aos processos.

Apesar das limitações pré-existentes em todas as Políticas e ações, o CEAF/PNAF tem boas avaliações quanto ao seu impacto e demonstra ser um grande avanço para a AF (BRASIL, 2010a).

Ao passo que há formas de operacionalizar o componente que traz racionalidade e economia, o contrário poderá dificultar a busca do gestor pelo menor preço, diminuir o incentivo sobre a indústria brasileira para a produção dos medicamentos de alto custo, dificultar a relação dos gestores com os prescritores, entre outros aspectos (BRASIL, 2010a). Neste sentido, tem-se a importância de conhecer a base para o funcionamento do componente e pensar na melhoria do sistema a partir de uma estrutura já pensada e que detém intenção e critérios para um bom funcionamento da AF.

Como síntese dos pontos apresentados pela área da saúde que estão relacionados com questões conflituosas na análise da judicialização, tem-se os Quadros 4.5 e 4.6, a seguir. 
Quadro 4.5 - Fortalezas da Assistência Farmacêutica e do Componente Especializado da Assistência Farmacêutica/Política Nacional de Assistência Farmacêutica reconhecidos pela área da saúde.

\begin{tabular}{|c|c|}
\hline $\begin{array}{l}\text { Fortalezas da Assistência Farmacêutica e } \\
\text { Componente Especializado da Assistência } \\
\text { Farmacêutica/Política Nacional de Assistência } \\
\text { Farmacêutica reconhecidos pela saúde }\end{array}$ & Dimensões do contexto \\
\hline $\begin{array}{l}\text { Previsão normativa de organização para as ações em } \\
\text { redes de entes federativos. }\end{array}$ & 1) Aspectos do sistema de saúde. \\
\hline $\begin{array}{l}\text { Preocupação em fortalecer mecanismos gerenciais } \\
\text { para o bom acompanhamento das ações em saúde no } \\
\text { Sistema Único de Saúde (SUS). }\end{array}$ & 1) Aspectos do sistema de saúde. \\
\hline $\begin{array}{l}\text { Avaliação e revisão do Componente Especializado, } \\
\text { com aumento da cobertura e integralidade de } \\
\text { tratamento para os casos previstos nos Protocolos } \\
\text { Clínicos e Diretrizes Terapêuticas (PCDT). }\end{array}$ & $\begin{array}{l}\text { 2) Aspectos da Assistência Farmacêutica e do } \\
\text { Componente Especializado da Assistência } \\
\text { Farmacêutica/Política Nacional de Assistência } \\
\text { Farmacêutica. }\end{array}$ \\
\hline $\begin{array}{l}\text { Estratégias para promover o uso racional dos } \\
\text { medicamentos }\end{array}$ & $\begin{array}{l}\text { 3) Aspectos técnicos farmacêuticos. } \\
\text { 7) Aspectos da atuação do farmacêutico. }\end{array}$ \\
\hline $\begin{array}{l}\text { Revisão permanente da relação de tecnologias } \\
\text { incorporadas pelo sistema }\end{array}$ & 3) Aspectos técnicos farmacêuticos. \\
\hline Revisão permanente e criação de novos PCDT; & 3) Aspectos técnicos farmacêuticos. \\
\hline $\begin{array}{l}\text { Desenvolvimento e melhora do Sistema Nacional de } \\
\text { Gestão da Assistência Farmacêutica - HÓRUS }\end{array}$ & 3) Aspectos técnicos farmacêuticos. \\
\hline $\begin{array}{l}\text { Otimização de recursos com a compra centralizada de } \\
\text { medicamentos pela União }\end{array}$ & 3) Aspectos técnicos farmacêuticos. \\
\hline Ampliação das linhas de cuidado. & 4) Aspectos da padronização de medicamentos. \\
\hline $\begin{array}{l}\text { Estratégias de trabalho conjunto com o sistema } \\
\text { judiciário (implantação de núcleos técnicos da saúde } \\
\text { no judiciário; realização de eventos conjuntos; } \\
\text { propostas de trabalho integrado entre Secretarias } \\
\text { Estaduais de Saúde e Conselhos de Justiça). }\end{array}$ & 8) Aspectos da judicialização da saúde. \\
\hline
\end{tabular}

Fonte: Da autora. 
Quadro 4.6 - Fragilidades da Assistência Farmacêutica e do Componente Especializado da Assistência Farmacêutica/Política Nacional de Assistência Farmacêutica reconhecidos pela área da saúde.

\begin{tabular}{|c|c|}
\hline $\begin{array}{l}\text { Fragilidades da Assistência Farmacêutica e } \\
\text { Componente Especializado da Assistência } \\
\text { Farmacêutica/Política Nacional de Assistência } \\
\text { Farmacêutica reconhecidos pela saúde }\end{array}$ & Dimensões do contexto \\
\hline $\begin{array}{l}\text { Complexidade na oferta de ações e serviços por uma } \\
\text { estrutura entre diferentes entes federativos. }\end{array}$ & 1) Aspectos do sistema de saúde. \\
\hline $\begin{array}{l}\text { Necessidade de fortalecer mecanismos gerenciais para } \\
\text { o bom acompanhamento das ações de saúde no SUS }\end{array}$ & 1) Aspectos do sistema de saúde. \\
\hline $\begin{array}{l}\text { Desconhecimento dos PCDT por alguns prescritores, } \\
\text { dificultando a padronização dos tratamentos e a } \\
\text { padronização dos procedimentos. }\end{array}$ & 5) Aspectos da padronização de protocolos. \\
\hline $\begin{array}{l}\text { Dificuldade em acessar os prescritores e divulgar os } \\
\text { PCDT para o preenchimento adequado da } \\
\text { documentação de solicitação de medicamentos do } \\
\text { CEAF/PNAF, bem como para que a própria prescrição } \\
\text { esteja de acordo com os protocolos. }\end{array}$ & 5) Aspectos da padronização de protocolos. \\
\hline $\begin{array}{l}\text { Ações judiciais individuais concorrentes às ações em } \\
\text { saúde coletivas. }\end{array}$ & 8) Aspectos da judicialização da saúde. \\
\hline $\begin{array}{l}\text { Necessidade ainda existente de trabalho conjunto com } \\
\text { o sistema judiciário frente à judicialização da saúde. }\end{array}$ & (8) Aspectos da judicialização da saúde. \\
\hline $\begin{array}{l}\text { Burocracia do sistema de saúde que gera lentidão para } \\
\text { a resposta às ações judiciais deferidas. }\end{array}$ & (8) Aspectos da judicialização da saúde. \\
\hline
\end{tabular}

Fonte: Da autora.

\subsection{Síntese dos resultados das categorias do Caso 01 - Assistência Farmacêutica - CEAF/PNAF}

A fim de proporcionar uma visão geral da análise do primeiro Caso, em função da riqueza de informações e aspectos que o objeto apresenta, tem-se, a seguir, o Quadro 4.7, que evidencia uma síntese dos resultados de todas as categorias e subcategorias. 
Quadro 4.7 - Síntese dos resultados das categorias do Caso 01 - Assistência Farmacêutica - Componente Especializado da Assistência Farmacêutica/Política Nacional de Assistência Farmacêutica (continua).

\begin{tabular}{|c|c|c|}
\hline Categoria & Subcategoria & Resultado \\
\hline Natureza do problema (NP) & - & $\begin{array}{l}\text { Problema: Garantir o acesso a } \\
\text { medicamentos pelo Sistema Único de } \\
\text { Saúde (SUS). } \\
\text { Dimensão: Residentes no território } \\
\text { nacional. } \\
\text { Ação: implementação do Componente } \\
\text { Especializado da Assistência } \\
\text { Farmacêutica/Política Nacional de } \\
\text { Assistência Farmacêutica } \\
\text { (CEAF/PNAF) pelo Poder Executivo. }\end{array}$ \\
\hline $\begin{array}{l}\text { Contexto Social, Econômico e } \\
\text { Político (CSEP) }\end{array}$ & - & $\begin{array}{l}\text { Evolução da assistência farmacêutica } \\
\text { com uma organização com pouca } \\
\text { regulamentação, estruturação } \\
\text { operacional e financeira, para a } \\
\text { criação de componentes bem } \\
\text { definidos, monitorados e avaliados } \\
\text { constantemente. Destes, o } \\
\text { CEAF/PNAF se destaca pela } \\
\text { sistematização operacional e previsão } \\
\text { sobre o financiamento pactuado entre } \\
\text { os entes federativos. }\end{array}$ \\
\hline \multirow[t]{2}{*}{ Aparato Normativo (AN) } & Normas embasadoras & $\begin{array}{l}\text { Leis, Decretos, Resoluções e Portarias } \\
\text { publicados entre a década de } 1970 \text { até } \\
\text { os dias atuais. }\end{array}$ \\
\hline & Discricionariedade normativa & $\begin{array}{l}\text { Abertura normativa para a } \\
\text { regionalização das ações e serviços de } \\
\text { saúde, percebida: } \\
\text { 1) Na elaboração dos planos de saúde; } \\
\text { 2) Na criação e revisão das listas de } \\
\text { medicamentos e dos protocolos } \\
\text { clínicos; } \\
\text { 3) Na disponibilização de recursos } \\
\text { financeiros (cumprindo os valores } \\
\text { mínimos); } \\
\text { 4) No planejamento das rotinas de } \\
\text { execução das ações do CEAF/PNAF } \\
\text { (cumprindo as etapas mínimas). }\end{array}$ \\
\hline
\end{tabular}


Quadro 4.7 - Síntese dos resultados das categorias do Caso 01 - Assistência Farmacêutica - Componente Especializado da Assistência Farmacêutica/Política Nacional de Assistência Farmacêutica (continuação).

\begin{tabular}{|c|c|c|}
\hline Categoria & Subcategoria & Resultado \\
\hline \multirow[t]{5}{*}{ Aparato Administrativo (AA) } & Estrutura organizacional & $\begin{array}{l}\text { Ministério da Saúde (MS), Secretaria } \\
\text { de Estado de Saúde do Distrito } \\
\text { Federal (SES/DF), Comissão } \\
\text { Intergestores Tripartite (CIT) e } \\
\text { Conselhos e Conferências de Saúde. }\end{array}$ \\
\hline & Recursos Humanos & $\begin{array}{l}\text { Previsão da participação de diferentes } \\
\text { atores no processo de gestão e } \\
\text { execução do CEAF/PNAF, } \\
\text { envolvendo representantes do } \\
\text { governo, de instituições prestadoras } \\
\text { de serviços, de entidades empresariais } \\
\text { da área da saúde, dos usuários e dos } \\
\text { profissionais de saúde, incluída a } \\
\text { comunidade científica. }\end{array}$ \\
\hline & Atividades, fluxos e rotinas & $\begin{array}{l}\text { Previsão normativa federal das etapas } \\
\text { de cadastro, avaliação, autorização, } \\
\text { dispensação e renovação. }\end{array}$ \\
\hline & Recursos financeiros & $\begin{array}{l}\text { Competências compartilhadas entre a } \\
\text { União e o Distrito Federal, de acordo } \\
\text { com os Grupos de medicamentos ( } 1 \mathrm{~A} \text {, } \\
1 \mathrm{~B} \text { e } 2 \text { ). }\end{array}$ \\
\hline & Discricionariedade operacional & $\begin{array}{l}\text { Aplicação da discricionariedade em } \\
\text { todas as possibilidades previstas pelos } \\
\text { atos normativos: } \\
\text { 1) Na elaboração dos planos de saúde; } \\
\text { 2) Na criação e revisão das listas de } \\
\text { medicamentos e dos protocolos } \\
\text { clínicos; } \\
\text { 3) Na disponibilização de recursos } \\
\text { financeiros (cumprindo os valores } \\
\text { mínimos); } \\
\text { 4) No planejamento das rotinas de } \\
\text { execução das ações do CEAF/PNAF } \\
\text { (cumprindo as etapas mínimas). }\end{array}$ \\
\hline
\end{tabular}


Quadro 4.7 - Síntese dos resultados das categorias do Caso 01 - Assistência Farmacêutica - Componente Especializado da Assistência Farmacêutica/Política Nacional de Assistência Farmacêutica (conclusão).

\begin{tabular}{|c|c|c|}
\hline Categoria & Subcategoria & Resultado \\
\hline $\begin{array}{l}\text { Aspectos conflituosos entre a } \\
\text { execução do CEAF/PNAF e a } \\
\text { execução de demandas judiciais } \\
\text { (AC) }\end{array}$ & - & $\begin{array}{l}\text { Identificação de características do } \\
\text { funcionamento do sistema de saúde } \\
\text { que não são consideradas ou } \\
\text { respeitadas no processo de } \\
\text { judicialização dos medicamentos: } \\
\text { 1) Organização normatizada das } \\
\text { ações em redes; } \\
\text { 2) Mecanismos gerenciais de } \\
\text { acompanhamento das ações em } \\
\text { saúde; } \\
\text { 3) CEAF/PNAF com ampla cobertura } \\
\text { e integralidade de tratamento para os } \\
\text { casos previstos nos Protocolos } \\
\text { Clínicos e Diretrizes Terapêuticas } \\
\text { (PCDT); } \\
\text { 4) Ações para promoção do uso } \\
\text { racional de medicamentos; } \\
\text { 5) Tecnologias em saúde ncorporadas } \\
\text { ao SUS seguindo critérios técnicos } \\
\text { objetivos; } \\
\text { 6) Protocolos clínicos elaborados } \\
\text { seguindo racionalidade e consistência } \\
\text { científica para os tratamentos; e } \\
\text { 7) Busca pela sustentabilidade } \\
\text { financeira do sistema pela compra } \\
\text { centralizada de medicamentos. }\end{array}$ \\
\hline
\end{tabular}

Fonte: Da autora. 


\section{ANÁLISE DO CASO 02}

O Caso 02 aqui apresentado se refere à judicialização da saúde no Brasil, com enfoque nas demandas por acesso aos medicamentos. A apresentação do presente caso seguirá o mesmo padrão e as mesmas categorias do Caso 01, referente à Assistência Farmacêutica (AF) no Sistema Único de Saúde (SUS) e o Componente Especializado da Assistência Farmacêutica/Política Nacional de Assistência Farmacêutica (CEAF/PNAF).

Neste sentido, tem-se, a seguir, a discussão dos resultados das categorias Natureza do Problema (NP), Contexto Social, Econômico e Político (CSEP), Aparato Normativo (AN) e suas subcategorias normas embasadoras e discricionariedade normativa, Aparato Administrativo (AA) e suas subcategorias estrutura organizacional, recursos humanos, recursos financeiros, atividades, fluxos e rotinas e discricionariedade operacional e, por fim, aspectos conflituosos entre a execução do CEAF/PNAF e a execução de demandas judiciais $(\mathrm{AC})$.

\subsection{Natureza do Problema}

A categoria NP remete à definição da problemática alvo da judicialização do acesso aos medicamentos, da sua extensão e de como se propõe lidar com a questão. No caso 02 aqui em destaque, a análise dos dados apresentou o embasamento do direito à saúde e, mais especificamente, do direito de acesso aos medicamentos.

Neste ínterim, tem-se a Figura 5.1, a seguir, que reúne os principais aspectos relacionados à caracterização do problema identificado para o caso em questão. 


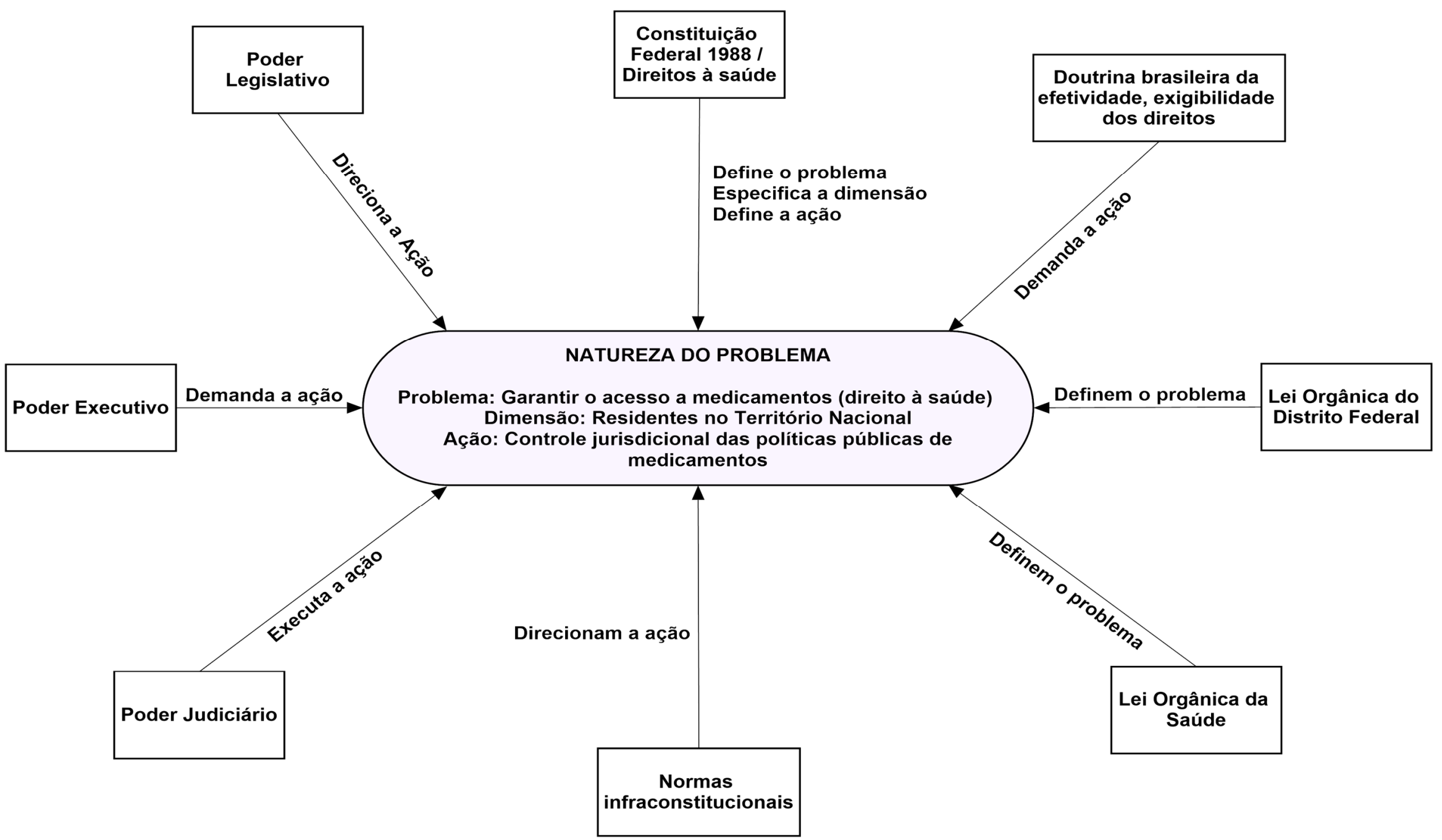

Figura 5.1 - Diagrama proposto quanto aos principais elementos envolvidos na identificação da natureza do problema do Caso 02.

Fonte: Da autora. 
A Constituição Federal (CF) de 1988 e o Estado constitucional de direito têm como aspectos centrais a dignidade da pessoa humana e os direitos fundamentais. A dignidade da pessoa humana é considerada o núcleo dos direitos fundamentais. Os direitos fundamentais incluem como princípios, conforme o documento $2 \mathrm{AR}$ apresenta, in verbis:

a) a liberdade, isto é, a autonomia da vontade, o direito de cada um eleger seus projetos existenciais;

b) a igualdade, que é o direito de ser tratado com a mesma dignidade que todas as pessoas, sem discriminações arbitrárias e exclusões evitáveis;

c) o mínimo existencial, que corresponde às condições elementares de educação, saúde e renda que permitam, em uma determinada sociedade, o acesso aos valores civilizatórios e a participação esclarecida no processo político e no debate público (BARROSO, 2016, p. 11) (grifo meu).

De acordo com a Carta Magna de 1988, a saúde é um direito fundamental, social, de todos, e um dever do Estado (documento 1LN) (BRASIL, 1988). Algumas características para a compreensão do direto à saúde são apresentadas por inúmeros autores, sendo esclarecidas nas linhas que se seguem.

A princípio, o documento $12 \mathrm{AR}$ explica que os direitos sociais possuem caráter positivo. Logo, o Estado deve atuar na garantia de tais direitos (MAGALHÃES, 2012). Sobre a questão, Gnata (2011) ratifica que, de acordo com a CF de 1988, os direitos sociais são positivos e fundamentais, e que existem tratados internacionais que os colocam como direitos humanos de acatamento obrigatório (documento 13AR).

Para uma melhor compreensão, uma investigação sobre a tipologia dos direitos evidencia a classificação dos direitos em dimensões (também denominado por alguns autores de gerações) (documento 14AR) (BONAVIDES, 2009). A referida classificação foi estabelecida em função dos direitos não terem sido criados em um mesmo momento, em uma mesma época histórica. Porém, apesar da criação sequencial dos direitos, os mesmos coexistem e não houve extinção dos primeiros conforme o surgimento daqueles que se seguiram. Neste senido, a classificação teve por base a percepção de dimensões que coexistem (documento 15AR) (NOVELINO, 2009).

Os direitos denominados de primeira dimensão são aqueles relacionados à liberdade, e envolvem os direitos civis e políticos. São direitos individuais e garantidos pela não ação do Estado (caráter negativo), justamente para que o cidadão desperte em sua individualidade de forma livre (MAGALHÃES, 2012; NOVELINO, 2009). Os direitos fundamentais de segunda dimensão são relacionados à igualdade e possuem caráter positivo, pois, o poder público deve atuar para sua garantia. Estes possuem titularidade coletiva e envolvem os direitos sociais, 
econômicos e culturais. Os direitos de terceira dimensão são ligados aos valores de solidariedade ou fraternidade, e são transindividuais (destinados à proteção do gênero humano), como, por exemplo, o direito de comunicação e aqueles associados ao meio ambiente e ao progresso (NOVELINO, 2009). Por fim, os direitos de quarta dimensão são aqueles referentes à democracia e ao pluralismo (BONAVIDES, 2009; NOVELINO, 2009).

Como abordado por Magalhães, Novelino e Bonavides, e explicado por Gnata (2011) no documento 13AR, os direitos podem ainda deter faceta individual ou coletiva. No primeiro caso têm-se os direitos que têm como titular o indivíduo e que não envolvem a prestação Estatal, mas sim, a abstenção. Tais direitos - civis e políticos - marcam um momento de resistência entre a sociedade e o Estado (Absolutista). Em respeito às liberdades individuais, espera-se que o Estado tenha seus poderes limitados. Como exemplo da questão tem-se o direito à vida, à propriedade, à liberdade de religião, entre outros. Já os direitos coletivos surgem no contexto da Revolução Industrial e na busca do proletariado pelos direitos sociais, visando garantir a existência e o bem estar da sociedade. Aqui se tem como exemplos os direitos à saúde, à educação, à previdência social, à assistência social, ao trabalho, entre outros (GNATA, 2011).

No documento 16AR destacam-se duas questões. A primeira refere-se aos direitos sociais serem coletivos e individuais ao mesmo tempo, uma vez que o bem jurídico protegido tem caráter individual e coletivo; e além de se preocupar com o indivíduo enquanto pessoa, também se preocupam com a relação do indivíduo com a comunidade. Empreende-se que o sujeito titular do direito é a coletividade (MAZZA; MENDES, 2014). Já a segunda consideração aponta que os direitos fundamentais são universais. Neste sentido, independente de não constar de forma explícita na CF de 1988, o princípio da universalidade se relaciona ao da igualdade. Logo, o direito à saúde é universal e as ações e serviços de saúde devem ter seu acesso garantido de forma universal e igualitária (documentos 17AR e 16AR) (MAZZA; MENDES, 2014; MACEDO; LOPES; BARBERATO-FILHO, 2011).

Um aspecto importante da Carta Magna de 1988 é que, por meio da força normativa máxima que ela possui, há o entendimento de eficácia ${ }^{8}$, aplicabilidade $^{9}$ e exigibilidade ${ }^{10}$ dos

\footnotetext{
${ }^{8}$ A eficácia jurídica significa que a norma tem potencialidade para aplicação em casos concretos (SARLET, 2006).

${ }^{9}$ A aplicabilidade remete à prática de uma norma de forma concreta. Ou seja, a aplicação em situações às quais as normas se referem de fato. A aplicabilidade é vista como um fenômeno conexo à eficácia jurídica (SARLET, 2006).

${ }^{10}$ A exigibilidade está relacionada à possibilidade de agir conforme as normas jurídicas (SARLET, 2006).
} 
direitos ali existentes (GNATA, 2011). Neste sentido, o direito à saúde possui um aspecto de interesse que se refere à exigibilidade individual e coletiva deste direito. Assim, ambos os entendimentos são importantes.

De fato, o indivíduo é entendido enquanto alvo de destaque e como base para a existência da sociedade. Neste sentido, deve-se dar atenção às necessidades individuais. Em contrapartida, não há indivíduo isolado, mas o indivíduo no contexto da sociedade. Então não se deve considerar somente o coletivo e anular o indivíduo, bem como não se deve dar predomínio ao indivíduo, em detrimento ao coletivo (MAZZA; MENDES, 2014).

Ao passo que o direito à saúde é considerado coletivo, este remete à prestação pelo Estado de garantias de condições dignas de vida e acesso universal e igualitário às ações e serviços de saúde, considerando a proteção e o desenvolvimento do cidadão em sua individualidade (documentos 17AR e 18AR) (MEDRADO, 2016; MACEDO; LOPES; BARBERATO-FILHO; 2011).

É importante destacar que, em termos técnicos jurídicos, os significados de "direito" e de "garantia" são diferentes. Apesar dos referidos termos poderem se equivaler em outras áreas, na área jurídica estes são detentires de peculiaridades. O termo "direito" se relaciona às prerrogativas dos indivíduos, dispostos na CF de 1988. Já a "garantia" se refere à ação de assegurar a efetividade dos direitos. Logo, o termo "direitos e garantias fundamentais" remete às prerrogativas constitucionais e à concretização destas, os direitos dos indivíduos que devem ser implementados (documento 4AR) (RODRIGUES, 2016).

O direito à saúde, portanto, é um direito de cunho coletivo, positivo e ligado ao valor de igualdade, ou seja, tratamento semelhante entre todos os cidadãos, a fim de garantir uma qualidade de vida e nível mínimo de dignidade humana.

O sistema judiciário entende que os três poderes governamentais (Executivo, Legislativo e Judiciário) devem materializar os direitos fundamentais o máximo possível, sendo que o limite mínimo que os direitos devem garantir é o núcleo essencial destes, que remete à dignidade humana (documento 2AR) (BARROSO, 2016).

Além disso, entre os três poderes, os Poderes Legislativo e Executivo devem concretizar estes direitos por meio de previsão orçamentária e de ações, isto é, por intermédio de Políticas Públicas (MAGALHÃES, 2012).

Nesta perspectiva, o Poder Executivo é responsável pela formulação de Políticas Públicas, pelo planejamento de ações e serviços e pela execução destes (documentos 11AR e 19AR) (OLIVEIRA, 2013; VIEIRA, 2008), e o Poder Legislativo é responsável pela elaboração de leis e pela alocação de recursos. O chefe do Poder Executivo e os membros do 
Poder Legislativo são escolhidos pelo voto popular, enquanto os membros do Poder Judiciário são designados por critérios técnicos, e não por eleição. Então, a democracia se materializa pela atuação dos Poderes Executivo e Legislativo, refletindo um governo da maioria (BARROSO, 2016).

A própria CF de 1988, em sua seção II (que trata da saúde), estabelece em seu art. 197, in verbis:

Art. 197. São de relevância pública as ações e serviços de saúde, cabendo ao Poder Público dispor, nos termos da lei, sobre sua regulamentação, fiscalização e controle, devendo sua execução ser feita diretamente ou através de terceiros e, também, por pessoa física ou jurídica de direito privado (BRASIL, 1988).

Diante do exposto, têm-se as responsabilidades do Poder Público sobre a regulamentação (Poder Legislativo), a execução (Poder Executivo) e o controle (Poder Judiciário) das ações e serviços de saúde.

A Carta Magna de 1988 dispõe sobre os direitos fundamentais, e o Estado deve provêlos por atividade dos Poderes Legislativo e Executivo. Na ausência do cumprimento de seus papéis e no desamparo do cidadão, o Poder Judiciário deve atuar - atuação que deve buscar reparar imediatamente a lesão, garantindo o essencial: a dignidade humana, nas áreas consideradas o mínimo existencial, como, por exemplo, a saúde. Tem-se, então, a compreensão do papel do sistema judiciário no controle de Políticas Públicas e da atuação do governo.

A CF de 1988 ganhou força normativa a partir de um movimento denominado "doutrina brasileira da efetividade". Anterior ao fato, não se tinha força política com a intenção de dar cumprimento à Constituição. A fim de superar o problema, o movimento em questão criou a normatividade constitucional. Ou seja, tornaram "as normas constitucionais aplicáveis direta e imediatamente, na extensão máxima de sua densidade normativa" (BARROSO, 2016, p. 5). A esta característica da Carta Magna, o documento 2AR denomina doutrina da efetividade.

Sobre a questão têm-se dois entendimentos discutidos por magistrados quanto à aplicação da Constituição. Há uma linha que defende a aplicação direta e imediata dos direitos. Ou seja, que entende a eficácia constitucional como a possibilidade de se ter uma imediata reivindicação e observância destes direitos. Uma segunda vertente de pensamento considera que não basta somente o texto constitucional ou até mesmo as normas infraconstitucionais. Aqui se entende que deve haver uma análise da factibilidade da 
aplicação dos direitos, inclusive sob aspectos políticos e jurídicos. Porém, a maioria dos estudos considera a força normativa como máxima constitucional, com a exigibilidade dos direitos, independente de análise prévia (GNATA, 2011).

As normas constitucionais contém comandos (p. ex. sugerem, recomendam) e possuem um atributo denominado imperatividade. Ou seja, as normas são de obrigatoriedade inafastável. E se não houver respeito a uma norma, os sistemas constitucional e infraconstitucional devem restaurar a ordem jurídica por meios que garantam a tutela do direito ou do bem jurídico afetados. São consideradas situações de desrespeito à imperatividade de uma norma a omissão do Estado ou uma ação que seja contrária ao objetivo da norma (BARROSO, 2016).

A CF de 1988 estabelece em seu art. 196 que a saúde é um direito de todos e um dever do Estado (documentos 1LN e 11J) (PROCURADORIA-GERAL DO DISTRITO FEDERAL, 1999; BRASIL, 1988). Tal fundamentação se opõe ao modelo anterior de sistema de saúde, e todos os brasileiros passam a ter o direito de acesso universal e igualitário às ações e aos serviços de saúde (documentos 9AR, 7SI e 11AR) (CONSELHO NACIONAL DE SECRETÁRIOS DE SAÚDE, 2016a; MINISTÉRIO PÚBLICO DO DISTRITO FEDERAL E TERRITÓRIOS, 2016a; OLIVEIRA, 2013).

Para a saúde pública brasileira, além da Carta Magna de 1988, existem normas infraconstitucionais que determinam como deve ser a organização do sistema público de saúde (SUS) e os meios para a oferta de medicamentos. Algumas das normas infraconstitucionais sobre os temas são listadas a seguir:

1) Lei n. 8.080, de 19 de setembro de 1990 (BRASIL, 1990a);

2) Lei Orgânica do Distrito Federal, de 08 de junho de 1993 (BRASIL, 1993b);

3) Portaria n. 3.916/GM/MS, de 30 de outubro de 1998 (BRASIL, 1998);

4) Resolução CNS/MS n. 338, de 06 de maio de 2004 (BRASIL, 2004);

5) Portaria GM/MS n. 204, de 29 de janeiro de 2007 (BRASIL, 2007a);

6) Portaria n. 2.981, de 26 de novembro de 2009 (BRASIL, 2009b);

7) Lei Complementar (LC) n. 141, de 13 de janeiro de 2012 (BRASIL, 2012c);

8) Portaria GM/MS n. 1.554, de 30 de julho de 2013 (BRASIL, 2013a);

As normas supramencionadas se relacionam e determinam regras que definem em conjunto a AF no SUS. E a partir do art. 23 da CF de 1988 e o art. $4^{\circ}$ da Lei Orgânica da Saúde (LOS) (1), determina-se que o SUS é de competência das três esferas do governo, da União, dos Estados, dos Municípios e do Distrito Federal. Porém, o inc. XII do art. 24 da 
Carta Magna registra que a competência de legislar sobre a defesa à saúde é da União (de forma geral), dos Estados e do Distrito Federal. Porém, os Municípios e o Distrito Federal poderão legislar sobre assuntos locais, conforme predisposto no art. 30 da CF de 1988 e, segundo a LOS e a Lei Orgânica do Distrito Federal (2), em seu art. 205, terão responsabilidade sobre a administração do SUS, diante da descentralização do sistema (documentos 1LN, 2LN e 21LN) (BRASIL, 1988; 1990a; 1993b).

Ainda sobre a LOS, tem-se aí a normatização da assistência terapêutica integral, a AF e a formulação de políticas de medicamentos. Por consequência, tais ações compõem a execução do sistema de saúde por serem consideradas importantes para a proteção deste direito, e devem ser implementadas pelo Poder Executivo (BRASIL, 1988; 1990a).

As Portarias GM/MS n. 3.916/1998 (3) e a Resolução CNS/MS n. 338/2004 (4) são as normas que direcionam a AF no SUS (documentos 11LN e 4LN) (BRASIL, 1998; 2004). A primeira Portaria se refere à primeira Política brasileira de medicamentos (Política Nacional de Medicamentos - PNM), que contém diretrizes importantes, porém, ainda gerais e iniciais. A segunda Portaria já regulamenta uma Política mais ampla, voltada não somente aos medicamentos, mas à AF como um todo. Neste sentido, a PNAF versa sobre as ações em saúde que envolve o medicamento como insumo principal; logo, tem caráter mais amplo. Estas normas são importantes, pois caracterizarão o direito à saúde quanto ao acesso aos medicamentos e normatização de sua execução.

A Portaria GM/MS n. 204/2007 (5) e a LC n. 141/2012 (7) dispõem sobre a organização financeira do sistema de saúde e da AF. O ditame de 2012 especifica os valores mínimos que devem ser alocados por cada um dos entes federativos nas ações e nos serviços de saúde, bem como os critérios de divisão dos recursos da União a serem transferidos aos Estados, aos Municípios e ao Distrito Federal. Já a Portaria de 2007 é mais específica e sistematiza a forma de transferência dos recursos federais em blocos de financiamento da saúde, incluindo como $4^{\circ}$ bloco a AF (documentos 5LN e 16LN) (BRASIL, 2007a; 2012c). Tais dispositivos precedem a implementação das ações e se referem a uma Lei e a uma norma de natureza infralegal. Porém, ambos são importantes para a prestação do direito à saúde. No caso da AF, cabe ainda destacar uma organização deste bloco em três componentes com 
lógica própria de financiamento. E esta sistematização objetivou melhorar o planejamento, a gestão e a eficácia ${ }^{11}$ das ações relacionadas à oferta de medicamentos.

Por fim, como alguns exemplos importantes de normas infraconstitucionais que embasam o direito à saúde, no que tange o acesso aos medicamentos, tem-se as Portarias n. 2.981/2009 (6) e GM/MS n. 1.554/2013 (8). Estes se referem especificamente à regulamentação do CEAF/PNAF. A estrutura de funcionamento do Componente é definida pela Portaria de 2009 e atualizada pela Portaria de 2013. E seguindo o entendimento de que tais normas corroboram para com o cumprimento do aspecto positivo do direito à saúde, o CEAF/PNAF é uma estratégia de ampliação do acesso aos medicamentos, para garantir a integralidade do tratamento dos indivíduos que o necessitem. Os ditames supramencionados também definem as responsabilidades de financiamento de cada um dos entes sobre o Componente aqui analisado (documentos 7LN e 8LN) (BRASIL, 2009b; 2013a).

Em suma, todas as normas supramencionadas são essenciais, uma vez que o sistema de saúde é muito complexo e sua operacionalização precisa ser muito bem descrita para lograr o devido sucesso em suas ações. E no tocante aos medicamentos disponíveis pelo SUS, existem diversas normativas que orientam o Estado na prestação das ações e dos serviços para a garantia do direito fundamental à saúde.

O documento 2AR explica que, se um direito ou um bem jurídico forem afetados, têmse duas formas de restauração da ordem. Os meios são denominados ação e jurisdição, ou seja, a reparação pode ser reclamada pelo titular do direito ou por algum responsável legítimo para proteger este direito. E ainda, existem mecanismos de tutela individual e de tutela coletiva de direitos (BARROSO, 2016). E a iniciativa de reclamar por seus direitos é legítima, conforme documento 11AR, que analisa o art. 5 , inc. XXV, da CF de 1988 (a lesão ou ameaça à um direito poderão ser apreciados pelo Poder Judiciário). Logo, o acesso irrestrito à justiça pelo cidadão é constitucional e de ordem fundamental (OLIVEIRA, 2013).

Os direitos constitucionais são direta e imediatamente exigíveis, do poder público ou do particular, por meio dos sistemas constitucional e infraconstitucional do ordenamento

\footnotetext{
${ }^{11}$ Os termos "eficácia”, "efetividade" e "eficiência” também são utilizados para a área administrativa e, apesar da proximidade dos significados, cabe discorrer sobre a utilização destes mesmos nesta outra área. A eficácia também se refere, na área jurídica, ao atingimento dos objetivos propostos (para uma ação estatal), não importando os meios utilizados para a obtenção do resultado. A eficiência também se aproxima nas duas áreas, e se refere à utilização do meio mais econômico e viável para atingir o objetivo da ação. Por fim, a efetividade, na perspectiva jurídica, se refere ao quanto de benefício a ação gerou para a população. Ou seja, não se trata do alcance dos objetivos ou dos meios para tal, mas sim, se isto acarretou em melhorias para o grupo receptor da ação (CASTRO, 2006).
} 
jurídico. Para tanto, o Poder Judiciário tem papel ativo na concretização da CF de 1988. Assim, se um direito está na Constituição, ele deve ser cumprido, até mesmo por meio de ação judicial. Aliás, os direitos fundamentais devem ser reparados, principalmente se o fato prejudicar o princípio do mínimo existencial de um direito.

O documento 12AR reforça que em muitas situações se tem a omissão ou prestação parcial de ações pelo poder público em prol dos direitos, acarretando em falha na concretização destes e na atuação da justiça (MAGALHÃES, 2012). Como exemplo, há uma distância entre a oferta de serviços e ações em saúde e as demandas da população. Assim, é crescente o número de indivíduos que buscam a via judicial para que o Estado assegure os seus direitos (documento 11AR) (OLIVEIRA, 2013). Logo, se as Políticas de saúde não conseguem cobrir a todos de forma universal e igualitária, o direito à saúde é pretendido por meio do Poder Judiciário, caracterizando o exercício democrático de cidadania pela efetividade dos direitos constitucionais. E como o caso da saúde envolve um direito fundamental, o sistema judiciário defere a maior parte dos casos em que é convocado a atuar (MAZZA; MENDES, 2014).

O direito à saúde se dá nos arts. $6^{\circ}$ e 196 a 200 da CF de 1988. No Título VIII (que trata da ordem social), seção II (que trata da saúde) e no art. 196, tem-se, in verbis:

\footnotetext{
A saúde é direito de todos e dever do estado, garantido mediante políticas sociais e econômicas que visem à redução do risco de doenças e de outros agravos e ao acesso universal e igualitário às ações e serviços para sua promoção, proteção e recuperação (BRASIL, 1988).
}

Também consta no art. $2^{\circ}$ da LOS uma menção de reforço ao previsto na Carta Magna de 1988, in verbis:

\footnotetext{
Art. $2^{\circ}$ A saúde é um direito fundamental do ser humano, devendo o Estado prover as condições indispensáveis ao seu pleno exercício.

$\S 1^{\circ} \mathrm{O}$ dever do Estado de garantir a saúde consiste na formulação e execução de políticas econômicas e sociais que visem à redução de riscos de doenças e de outros agravos e no estabelecimento de condições que assegurem acesso universal e igualitário às ações e aos serviços para a sua promoção, proteção e recuperação (BRASIL, 1990a).
}

A observância deste direito gera duas consequências sobre o Estado. A primeira é a responsabilidade de cunho ético e legal do Estado em formular Políticas Públicas que garantam o acesso às ações e aos serviços de proteção, promoção e recuperação da saúde. A segunda consequência é a prerrogativa do indivíduo em reclamar pelo reparo de direitos não 
cumpridos, de forma individual e coletiva (MACEDO; LOPES; BARBERATO-FILHO; 2011).

O documento 12J destaca a existência de um grande número de ações judiciais relacionadas às ações em saúde em trâmite no sistema judiciário (BRASIL, 2010c).

Já o documento 11AR reforça que há um número crescente de demandas no Brasil, principalmente em prol ao acesso de medicamentos ou serviços não ofertados pelo SUS (OLIVEIRA, 2013). O bem tutelado, nestes casos, é a saúde, por ser um direito social constitucional. Tal fenômeno é denominado judicialização da saúde e decorre do aumento das demandas judiciais pelo direito à saúde em função da iniquidade no acesso aos bens e serviços de saúde, incluindo os medicamentos (documento 20AR) (SANT'ANA et al, 2011).

Como exemplo importante de cenário crítico no contexto da judicialização da saúde, está o grupo de medicamentos aqui explorado: o Componente Especializado de medicamentos - por ser o grupo de insumos de maior custo, e também o mais sensível de toda a PNAF. Tal fato se dá em função de alguns elementos, como, por exemplo, os gastos elevados com tais produtos, a grande pressão proveniente da demanda dos pacientes e a competição comercial derivada do alto desenvolvimento dos laboratórios farmacêuticos nos últimos anos. Logo, estes elementos trarão algumas características para o processo de judicialização destes medicamentos, tais como: a preocupação orçamentária, a aquisição individualizada de medicamentos e a tentativa de padronização destes medicamentos, tendo como porta de entrada a judicialização (documento 2LM) (BRASIL, 2010a).

Os dados aqui obtidos, de fato, evidenciam o entendimento de que os direitos sociais devem ser cumpridos, pelo menos em seu mínimo existencial, e de acordo com o princípio da dignidade humana. $\mathrm{O}$ direito à saúde se enquadra nestes preceitos e deve ter observância independente de justificativa orçamentária por parte do governo.

Para o Caso 02, os dados apontam que, como no Caso 01, o problema em questão também é a garantia do acesso aos medicamentos pelo governo, de acordo com o direito à vida e à saúde. A dimensão do problema também envolve todos os residentes no território nacional (brasileiros e estrangeiros). Porém, o que muda é a ação e o agente. Assim, no caso em questão, a ação é exercer o controle jurisdicional das Políticas Públicas de medicamentos, garantindo o seu fornecimento - ação executada pelo Poder Judiciário, e não pelo Poder Executivo. 


\subsection{Contexto social, econômico e político}

Nesta categoria foi descrito o contexto da judicialização da saúde no Brasil. O foco desta seção está na judicialização de direitos e com detalhes relacionados à judicialização da saúde em específico.

Como síntese dos principais achados, foi elaborada a figura 5.2. 




Onde: SUS - Sistema Único de Saúde; DF - Distrito Federal; STA - Suspensão de Tutela Antecipada; STF - Supremo Tribunal Federal; CNJ - Conselho Nacional de Justiça; CEAF - Componente Especializado da Assistiência Farmacêutica; PNAF - Política Nacional de Assistência Farmacêutica; TJDFT - Tribunal de Justiça do Distrito Federal e Territórios; DPDF - Defensoria Pública do Distrito Federal; CAMEDIS - Câmara de Mediação em Saúde; SES-DF - Secretaria do Estado de Saúde do Distrito Federal; DPU - Defensoria Pública da União; TCU - Tribunal de Contas da União; CONASS - Conselho Nacional de Secretários de Saúde; NATs - Núcleos de Apoio Técnico.

Figura 5.2 - Diagrama com principais elementos identificados do contexto social, econômico e político da judicialização da saúde.

Fonte: Da autora. 
Um período importante para os direitos sociais, em função dos avanços previdenciários e trabalhistas se deu entre os anos 1930 e 1945. É importante realizar este resgate para compreender que posteriormente houve momentos de regimes liberais e regimes autoritários, como o regime militar que causou uma extinção dos direitos civis e políticos. Em todos estes momentos o direito à saúde estava integrado aos outros direitos da seguridade social (documento 21AR) (CARVALHO, 2002).

A Constituição de 1934 (Estado Social de Getúlio Vargas) previa assistência médica e sanitária somente aos trabalhadores. E a Constituição do Estado Novo de 1937 ainda agravava mais a situação da saúde no Brasil, já que era omissa quanto à este direito. Já o texto constitucional de 1967 responsabilizou a União à execução do plano nacional de saúde e a Emenda Constitucional de 1969 acrescentou que a prestação de serviços de Previdência Social somente seriam operacionalizados se houvesse fonte de financiamento. E, somente com a CF de 1988, o direito à saúde foi reconhecido separadamente dos direitos da seguridade social (documento 6AR) (CORREA; MASSAFRA, 2004).

Como citado, nos artigos $5^{\circ}$ e 196 da Constituição da República Federativa do Brasil de 1988, o direito à saúde é enfim apresentado como um direito autônomo (BRASIL, 1988).

Há de se respeitar, ainda, as diretrizes determinadas em 1990 pela Lei Orgânica da Saúde e em 1993 pela Lei Orgânica do DF. Estes dispositivos legais acrescentaram à CF as minúcias para a prestação das ações e serviços de saúde, que determinam o foco de controle pelo Poder Judiciário (documentos 2LN e 21LN) (BRASIL, 1990a; BRASIL, 1993b).

Em paralelo às definições do sistema público de saúde brasileiro, a CF também especificou em seu Capítulo III, Seção I, Disposições Gerais as normas gerais para organização do Poder Judiciário e do Ministério Público (BRASIL, 1988). Neste contexto é relevante o destaque para a atuação autônoma do Ministério Público da União e dos Ministérios Públicos dos estados e Distrito Federal dentro da organização do Estado.

E, em 1997, o Ministério Público do Distrito Federal e Territórios - MPDFT criou a Promotoria de Justiça de Defesa da Saúde - PROSUS, para lidar especificamente com as questões de saúde (documento 67LN) (BRASIL, 1997b). Isto é importante pois denota que a matéria saúde estava em pauta nas questões investigadas pelo Ministério Público.

Em paralelo às mudanças no Poder Judiciário e no Ministério Público, a área da saúde dentro do Poder Executivo também evoluía. Especificamente quanto ao fornecimento de medicamentos, em 1998 foi publicada a primeira portaria relacionada, com a Política Nacional de Medicamentos (BRASIL, 1998). 
E em 2001, o Distrito Federal normatiza os direitos dos usuários dos serviços e das ações de saúde local (documento 68LN) (BRASIL, 2001). Esta norma não só é importante para a regulamentação dos direitos, mas principalmente para a divulgação destes aos usuários dos sistemas. Então este foi um passo importante para a garantia dos direitos, conhecimento destes e posterior reforço para àqueles que recorrem ao controle feito pela justiça.

Avançando na assistência farmacêutica do SUS, em 2004 foi formulada a segunda política relacionada à medicamentos, agora denominada Política Nacional de Assistência Farmacêutica e com disposições mais amplas, acerca dos serviços que envolvem um adequado fornecimento de medicamentos (documento 4LN) (BRASIL, 2004).

Em uma análise realizada pelo Consultório Jurídico da SES-DF, foram verificados processos julgados na $2^{\text {a }}$ Vara de Fazenda Pública Privativa do TJDFT, no período entre os 2005 e 2010. Esta análise apresentou o contexto experienciado no Distrito Federal quanto às ações em saúde e demonstrou que 95,06\% das ações foram encaminhadas pela Defensoria Pública do Distrito Federal - DPDF e que 95,32\% dos casos argumentavam pelo direito à vida e à saúde. Algo comum à muitos processos e que era sustentado em 20,52\% das ações deste estudo, é que o motivo da ação era a pobreza dos requerentes. Como resultado da ação propriamente dita, somente $8,05 \%$ foram indeferidas, por ausência de comprovação da urgência do caso (documento 5NS) (CORREIO BRAZILIENSE, 2015).

Um pesquisador realizou um outro estudo referente à esfera federal, quanto às decisões judiciais feitas pelo STF no período de 2000 a 2007. Porém o foco do estudo era identificar os processos judiciais nos quais havia menção à preocupação com a ordem financeira do sistema, em função da vigência da ação judicial e seu financiamento paralelo. Logo, o estudo tratava da escassez de recursos e dos custos dos direitos. Ao realizar esta análise, foi verificado se os processos também continham, em meio à análise jurídica, a preocupação dos ministros com o impacto econômico destas ações. E o resultado foi a percepção de uma mudança nas análises e decisões relacionadas à saúde a partir do julgamento da Suspensão de Tutela Antecipada 91 de 2007 (STA 91) (MAZZA; MENDES, 2014).

Este julgamento ocorreu em fevereiro de 2007 e a ministra responsável (Ellen Gracie) decidiu pelo indeferimento da ação de solicitação de medicamento. Esta ação foi a pioneira quanto à decisão pelo não fornecimento do insumo. Anteriormente à esta ação, a questão econômica não fazia parte da análise dos ministros, apesar da limitação dos recursos ser uma realidade e um potencial limite ao cumprimento de todas as ações. Após o referido julgamento, houve uma aparente melhora na compreensão das consequências econômicas. 
Porém, apesar do assunto estar presente em algumas ações, no discurso das decisões, há critérios subjetivos e não padronizados para a tomada de decisão. Logo, não há clareza sobre o peso que estes tem em cada caso e para cada ator do processo (documento 16AR) (MAZZA; MENDES, 2014).

Conforme documento 16AR, em março de 2009, o mesmo órgão, STF, convocou uma audiência pública sobre as ações em saúde. Esta convocação denota a extensão da discussão sobre os direitos e a judicialização da saúde. E esta preocupação tem por base o aumento no número de ações, que reflete a transição demográfica do país, o crescente aumento das opções terapêuticas existentes e a escassez de recursos disponíveis. Tem-se como resultado desta tríade o complexo cenário de ações judiciais no país. Um ponto importante colocado neste audiência pública foi a coexistência do aspecto individual e do aspecto coletivo do direito à saúde, a depender da relação jurídica em questão (MAZZA; MENDES, 2014).

Cabe ressaltar que o documento 69LN, do Conselho Nacional de Justiça, registra que a audiência pública citada, de $n^{\circ} 4$, do Supremo Tribunal Federal, foi realizada nos meses de abril e maio de 2009. E acrescenta que as questões de judicialização relacionadas à assistência à saúde foram discutidas com 50 (cinquenta) especialistas na matéria (BRASIL, 2009e).

No mesmo ano, no mês de agosto, foi publicada a lei relacionada aos direitos e deveres dos usuários da saúde, em âmbito nacional, outra importante publicação que reforça os alcances e os limites do direito, de forma prática (documento 70LN) (BRASIL, 2009f).

Em novembro de 2009, ainda, nota-se uma inovação na área jurídica, diante das discussões anteriores pelo STF envolvendo a preocupação com a saúde pública. Uma portaria construída pelo Conselho Nacional de Justiça - CNJ, determinou a criação de um grupo de trabalho para estudo e proposta de medidas para as demandas judiciais relacionadas à assistência à saúde (BRASIL, 2009e). Este grande avanço parte de uma das vertentes de discussão do problema que sugere a ampla discussão sobre os casos e um melhor embasamento para os julgamentos, já que a área da saúde tem as suas peculiaridades técnicas, que podem não ser de conhecimento dos magistrados.

Ao longo de todos estes anos descritos, os poderes públicos apresentam preocupação quanto ao aumento do número de ações judiciais e colocam a necessidade de aprofundar estudos que suportem uma adequada gestão dos processos em tramitação e reduza o surgimento de novos processos. O CNJ é um dos órgãos que desenvolve estratégias para este fim, como a Portaria $n^{\circ}$ 650/2009 que criou o grupo de trabalho citado anteriormente (BRASIL, 2009e). 
$\mathrm{Na}$ área farmacêutica, é no mesmo mês de novembro de 2009 que desenvolve-se o Componente Especializado da Assistência Farmacêutica, substituindo seu precursor, denominado de medicamentos excepcionais. A nova portaria trouxe muitos avanços quanto à organização do componente, ao seu financiamento compartilhado entre os entes e à ampliação do elenco ofertado (documento 7LN) (BRASIL, 2009b).

Como panorama nacional, no ano de 2010 um estudo contabilizou 240.980 ações ajuizadas e em tramitação relacionadas à saúde. E, em paralelo ao aumento constante no número de ações, também ocorre um aumento da estrutura envolvida e dos custos relacionados. E, apesar deste crescimento, não observa-se redução do tempo de tramitação dos processos (documento 11AR) (OLIVEIRA, 2013).

Ainda no ano de 2010, o CNJ publicou uma nova recomendação que visava gerar maior eficiência na deliberação das demandas judiciais envolvendo a assistência à saúde (documento 18AR) (MEDRADO, 2016). Esta recomendação foi direcionada aos Tribunais, com o intuito de que adotem medidas de subsídio aos magistrados e aos demais operadores do direito. O objetivo, como já mencionado, era de melhorar a solução das demandas judiciais da saúde (documento 12J) (BRASIL, 2010c).

Em abril de 2010, seguindo a mesma preocupação com o crescimento de demandas judiciais em saúde, o Conselho Nacional de Justiça instituíu o Fórum Nacional do Judiciário para monitoramento e resolução das demandas de assistência à saúde. Foi uma iniciativa nacional pioneira, idealizada para ampliar o debate e garantir melhores análises e decisões. E, dentre estas demandas estão o fornecimento de medicamentos, produtos, leitos hospitalares, entre outros (documentos 71LN e 1NJ a 8NJ) (BRASIL, 2010b; TRIBUNAL DE JUSTIÇA DO DISTRITO FEDERAL E TERRITÓRIOS, 2011a; 2011b; 2011c; 2011d; 2011e; 2011f; 2011g; 2011h).

Ao final deste ano de 2011, no mês de novembro, o Fórum já promoveu o I Encontro do Fórum Nacional do Judiciário para a Saúde, onde a participação do Estado e da sociedade deliberou sobre o início das atividades dos Comitês Estaduais (documento 13J) (CONSELHO NACIONAL DE JUSTIÇA, 2016b).

Outra informação interessante, conforme documento 17J é de que, no momento da criação do Fórum, havia no país 240.980 processos judiciais relacionados à saúde, nos Tribunais de Justiça e nos Tribunais Regionais Federais (com exceção de 3 tribunais cujos dados não foram levantados) (CONSELHO NACIONAL DE JUSTIÇA, 2016c).

O ano de 2011 foi importante para avançar com a inovação anterior de criação do Fórum Nacional do Poder Judiciário para a Saúde, pois definiu os membros para os Comitês 
Executivos Estaduais e proporcionou o início efetivo do trabalho (documento 72LN) (BRASIL, 2011g).

Também foi criado em 2011 o Comitê Executivo de Saúde do Distrito Federal, em atenção à Resolução no 107 de 2010 do CNJ (documento 1NJ) (TRIBUNAL DE JUSTIÇA DO DISTRITO FEDERAL E TERRITÓRIOS, 2011a).

No Distrito Federal em particular, a judicialização também estava em fluxo crescente no ano de 2011 e afetava de forma importante o orçamento e planejamento das ações públicas. Em função da grande quantidade de demandas judiciais, a SES-DF criou, no ano citado, um Núcleo de Judicialização. Este departamento passou a ser responsável pelo atendimento das demandas judiciais e dos requerimentos administrativos que solicitam medicamentos ou serviços de saúde. Este setor é de extrema importância, pois a margem de crescimento das demandas judiciais na SES/DF é de aproximadamente 30\% a cada ano (documento 22AR) (PAIM; MARQUETTO; LOPES, 2016).

No ano de 2011 um julgamento do STF (STA 175) foi de grande importância para a judicialização da saúde pois se tratava de um recurso processual no qual a União declarava ilegitimidade como polo passivo $^{12}$ de demandas que abordavam o fornecimento de medicamentos pelo Poder Público Federal. Ou seja, a União sustentava que não seria legítimo a União ser réu em processos judiciais por acesso a medicamentos, considerando que, enquanto agente implementador da PNAF, o Ministério da Saúde não faz a entrega dos medicamentos aos usuários. Na verdade, o MS executa o repasse de recursos e de alguns medicamentos de compra centralizada. Porém toda a assistência farmacêutica básica é realizada pelos estados e municípios. Portanto, este processo tinha o objetivo de criar uma jurisprudência de não responsabilização da União para ações de acesso a medicamentos, mantendo somente os estados e municípios enquanto entes susceptíveis às ações. Porém, o Ministro Gilmar Mendes reforçou o aspecto de responsabilidade solidária dos entes federativos em matéria de saúde, afirmando que qualquer um dos entes (União, estados e municípios) pode figurar como polo passivo, isoladamente ou em conjunto (documento 16J) (DEFENSORIA PÚBLICA DA UNIÃO, 2016e).

Ao encontro das ações já descritas, o TJDFT publica em 2011 uma lista de recomendações aos juízes de direito deste Tribunal. As recomendações seguem o preconizado

12 Segundo o documento fonte, o polo passivo de uma demanda judicial é o réu da ação (DEFENSORIA PÚBLICA DA UNIÃO, 2016e). 
pelo CNJ em 2010 e também dispõe sobre a observância de critérios para garantir a tão desejada eficiência na solução das demandas judiciais envolvendo a saúde pública. Estas recomendações foram publicadas por meio de um ato interno, organizado como uma instrução normativa da Corregedoria do TJDFT (documentos 73LN e 9NJ) (BRASIL, 2011f; TRIBUNAL DE JUSTIÇA DO DISTRITO FEDERAL E TERRITÓRIOS, 2011i).

Como exemplo de uma das recomendações, acerca da aproximação do Poder Executivo e do Poder Judiciário, em fevereiro de 2012 a Escola Superior de Ciências da Saúde (ESCS) promoveu um evento com esta característica. A aula inaugural da Escola teve como tema "A judicialização da saúde sob o olhar do Supremo Tribunal Federal”, com o ministro do STF, Gilmar Mendes, como convidado (documento 6NS) (AGENCIA BRASÍLIA, 2012b).

Ainda em 2012, o documento 7NS mostra uma iniciativa da Defensoria Pública do Distrito Federal - DPDF para orientação jurídica dos cidadãos. A Defensoria promoveu um mutirão na cidade de Taguatinga, em outubro de 2012. Um dos focos da DPDF é a orientação dos cidadãos sobre os seus direitos constitucionais e, quando necessário, promover o apoio necessário para a consolidação destes direitos (AGENCIA BRASÍLIA, 2012c).

O documento 8NS apresenta um exemplo de atuação do Ministério Público no direito à saúde. O exemplo de ação se refere à um serviço de saúde, o acesso à leitos de UTI. Porém o documento relata que o Ministério Público do Distrito Federal e Territórios (MPDFT) investiga a situação das ações e serviços de saúde e, se necessário, gera denúncias quanto ao mal funcionamento do SUS. É apresentado no documento, ainda, a existência de um promotor de Defesa dos Usuários de Saúde (CORREIO BRAZILIENSE, 2012).

Conforme documentos 10NJ a 20NJ, em 2012 o Comitê Executivo Distrital da Saúde seguiu discussões práticas relacionadas ao controle de medicamentos, ao processo de compra, aos protocolos de tratamento, à manutenção de estoques de segurança dos medicamentos, à avaliação da Comissão de Judicialização da SES-DF e à outras questões que exigiam ações práticas para melhora da política e redução das ações judiciais (TRIBUNAL DE JUSTIÇA DO DISTRITO FEDERAL E TERRITÓRIOS, 2012a; 2012b; 2012c; 2012d; 2012e; 2012f; 2012g; 2012h; 2012i; 2012j; 20121).

Neste mesmo ano, o Comitê organizou o $1^{\circ}$ Encontro Público Distrital sobre Saúde e Direito, que teve a participação da Defensoria Pública do Distrito Federal - DPDF (documentos 39NJ a 41NJ) (DEFENSORIA PÚBLICA DO DISTRITO FEDERAL, 2012a; $2012 b ; 2012 c)$. 
A DPDF contabilizou para o primeiro semestre do ano de 2012 o atendimento de 5.338 pessoas com demandas relacionadas à área da saúde pública. As duas principais reclamações foram a falta de medicamentos e a falta de leitos para a internação (documentos 42NJ e 43NJ) (DEFENSORIA PÚBLICA DO DISTRITO FEDERAL, 2012d; 2012e).

Paim, Marquetto e Lopes (2016) apresentam a Figura 5.3 com um gráfico sobre o quantitativo das ações judiciais no DF entre os anos de 2012 e 2014 (até outubro deste último ano e sem considerar as ações por leitos de UTI).

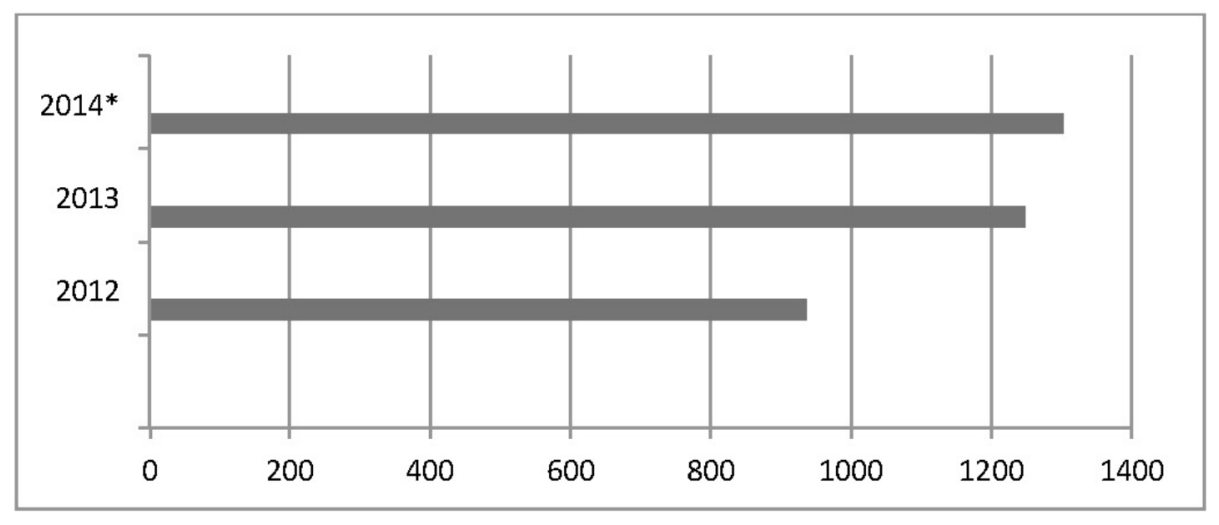

Figura 5.3 - Gráfico da quantidade de ações judiciais em saúde por ano, na SES-DF Fonte: Paim, Marquetto e Lopes (2016).

O ano de 2013 foi marcado por outra iniciativa de destaque, neste caso para o Distrito Federal novamente. Neste ano houve a instituição da Câmara Permanente Distrital de Mediação em Saúde, denominada CAMEDIS, que passou a ser responsável pela mediação entre a SES-DF e usuários que pleiteiam as ações judiciais no DF (BRASIL, 2013m). Esta portaria foi assinada em 26 de fevereiro de 2013. E trata-se de um espaço para conciliação entre os usuários do sistema de saúde e o governo (SES-DF), conforme explicado, e visa a não abertura de processos judiciais (documento 9NS, 44NJ a 46NJ; 24NJ) (AGÊNCIA BRASÍLIA, 2013; DEFENSORIA PÚBLICA DO DISTRITO FEDERAL, 2013a; 2013b; 2013c; TRIBUNAL DE JUSTIÇA DO DISTRITO FEDERAL E TERRITÓRIOS, 2013d).

Como exemplo do cenário crítico, em 2013 o governo do Distrito Federal foi réu e perdeu 900 ações judiciais. No ano de 2014, este número aumentou para 2 mil ações favoráveis aos usuários do sistema de saúde (documento 5NS) (CORREIO BRAZILIENSE, 2015).

O Comitê Distrital também segue o ano de 2013 com reuniões periódicas e seu site institucional noticia pelos documentos $21 \mathrm{NJ}$ a $33 \mathrm{NJ}$, que (TRIBUNAL DE JUSTIÇA DO 
DISTRITO FEDERAL E TERRITÓRIOS, 2013a; 2013b; 2013c;2013d; 2013e; 2013f; 2013g; 2013h; 2013i; 2013j; 20131; 2013m; 2013n).:

\begin{abstract}
As reuniões do Comitê acontecem mensalmente e têm por objetivo atender à determinação da Resolução 107/10, do CNJ, que instituiu o Fórum Nacional do Judiciário para monitoramento e resolução das demandas de assistência à saúde. A resolução responde ao elevado número e à ampla diversidade de litígios referentes ao direito à saúde e ao impacto que acarretam sobre os orçamentos públicos.
\end{abstract}

E reforçam que o Comitê tem responsabilidades, como:

O órgão deverá elaborar estudos e propor medidas concretas e normativas voltadas
ao aprimoramento de procedimentos, ao reforço à efetividade dos processos
judiciais, à prevenção de conflitos e à definição de estratégias nas questões de
direito sanitário.

Neste ano de 2013, os documentos $25 \mathrm{NJ}$ e $26 \mathrm{NJ}$ informaram que no mês de março estava sendo assinado um termo de cooperação entre o TJDFT e a SES-DF. Este acordo tinha por objetivo o fornecimento de apoio técnico aos magistrados para auxiliar nas decisões judiciais em saúde e também o acesso à sistemas informatizados da Secretaria, relacionados às demandas judiciais, como por exemplo, ao sistema de ocupação de leitos de UTI (TRIBUNAL DE JUSTIÇA DO DISTRITO FEDERAL E TERRITÓRIOS, 2013e; 2013f).

Ainda em maio de 2013, o TJDFT lançou uma página eletrônica do Comitê Distrital, ampliando a divulgação sobre as atividades do grupo e dando maior publicidade ao trabalho realizado sobre a judicialização da saúde (documento 29NJ) (TRIBUNAL DE JUSTIÇA DO DISTRITO FEDERAL E TERRITÓRIOS, 2013h).

No âmbito da União, entre os anos de 2010 e 2014 os gastos com ações judiciais pelo Ministério da Saúde cresceram cerca de 500\% (documento 1NS) (MINISTÉRIO DA SAÚDE, 2015).

Em 2014, o CNJ publica uma atualização do Comitê Organizador do Fórum Nacional do Poder Judiciário para monitoramento e resolução das demandas de assistência à saúde, mostrando a manutenção das ações propostas (documento 74LN) (BRASIL, 2014h).

Em atendimento ao trabalho do Fórum Nacional de Saúde, o documento 18J apresenta um relatório com o quantitativo de ações judiciais em saúde no ano de 2014. Nos Tribunais Federais haviam 62.291 e nos Tribunais Estaduais haviam 330.630 processos (CONSELHO NACIONAL DE JUSTIÇA, 2016d).

Ainda em 2014, o Comitê Executivo Distrital da Saúde teve várias reuniões que abordaram a problemática do desabastecimento de medicamentos padronizados. E, apesar do 
assunto central de trabalho do Comitê ser a judicialização, já é compreendido que a situação de desabastecimento destes medicamentos seria um potencial causador de novas demandas judiciais. Logo o comitê realizou reuniões sobre este problema, além da necessidade de atualização da Relação de Medicamentos Padonizados do DF (documentos 34Nj a 37NJ) (TRIBUNAL DE JUSTIÇA DO DISTRITO FEDERAL E TERRITÓRIOS, 2014a; 2014b; 2014c; 2014d).

A DPDF noticiou sua participação no Comitê Distrital no ano de 2014 e também tornou público o estudo que o Conselho Nacional de Justiça e a Universidade Estadual do Rio de Janeiro fariam neste mesmo ano sobre a iniciativa inovadora da DPDF e da SES-DF: a CAMEDIS (documentos 47NJ e 48NJ) (DEFENSORIA PÚBLICA DO DISTRITO FEDERAL, 2014a; 2014b).

A DPU é um órgão que auxilia o cidadão quando este se depara com problemas na saúde pública, assim como a DPDF, em seu território (documento 53JN) (DEFENSORIA PÚBLICA DA UNIÃO, 2016c). E, diante disto, a DPU convidou uma processualista e doutrinadora, professora da Universidade de São Paulo, para palestrar em um curso de formação de novos defensores públicos. Sobre a ocasião, a DPU divulgou o evento e posicionamento da referida professora (documento $76 \mathrm{NJ}$ ) :

\footnotetext{
Para a professora, a via coletiva permite que as políticas públicas sejam moldadas pelo controle judicial, ao passo que a ação individual não beneficia outros interessados com pretensões semelhantes. "O acesso individual ao direito não tem nada a ver com políticas públicas. Se um paciente consegue um remédio, a política pública para fornecimento desse medicamento pelo SUS não muda. Se consegue um transplante, a política pública continuará inacessível para os outros”, explicou. De acordo com Ada Pellegrini, as ações individuais conseguem mudar as políticas públicas somente pela reiteração, como ocorreu com relação ao fornecimento de remédios para aids. De outro lado, reclama do que chama de "efeito pernicioso" das ações individuais, quando se dá destinação para uma única pessoa de recursos que deveriam servir a todos. "Se alguém ganha preferência em uma fila de transplante, os outros que esperam são prejudicados", lembrou (DEFENSORIA PÚBLICA DA UNIÃO, 2015g, p. 1).
}

No ano de 2015 a União solicitou novamente a mudança no entendimento de solidariedade dos entes federativos para a oferta de medicamentos judicializados. Porém, a Defensoria Pública da União - DPU apresentou contrarrazões ao Supremo Tribunal Federal STF para que a decisão de legitimidade passiva da União nas ações de saúde não fosse alterada. Isto porque esta questão já havia sido decidida no Plenário Virtual do STF. Porém a Advocacia-geral da União solicitou retirada deste ponto de pauta, no final do ano de 2015, 
antes do julgamento da matéria (documentos 54NJ, 62NJ, 71NJ e 75NJ) (DEFENSORIA PÚBLICA DA UNIÃO, 2015e; 2015f; 2016j; 2016t).

Segundo os documentos 49NJ e 50NJ, no mês de setembro de 2015 a DPDF conseguiu prevenir a judicialização de 11 casos relacionados à saúde do DF, somente com a mediação. Além disso, neste mesmo mês, a DPDF assinou com a Câmara Legislativa do DF um termo de cooperação técnica para a troca de informações sobre a saúde, em prol da melhoria destes serviços (DEFENSORIA PÚBLICA DO DISTRITO FEDERAL, 2015a; 2015b).

No dia 15 de outubro de 2015, o ministro da saúde à época, Marcelo Castro, esteve presente em um evento do Tribunal de Contas da União (TCU) voltado para a judicialização da saúde. O evento foi intitulado "Diálogo Público: Judicialização da Saúde no Brasil" (MINISTÉRIO DA SAÚDE, 2015).

Em fevereiro de 2016, houve a atualização do comitê de organização do Fórum Nacional do Poder Judiciário. Como coloca o próprio documento 75LN, havia necessidade de organização e planejamento, para que o fórum se tornasse mais efetivo em suas atividades (BRASIL, 2016c).

Em março de 2016 o Ministério Público do Distrito Federal e Territórios - MPDFT noticiou que até aquele momento haviam sido executados $14 \%$ do orçamento previsto para a saúde e que o orçamento para esta área e para a educação, juntas, era de 6,3 bilhões de reais. Além desta atividade, o MPDFT realiza fiscalização constante dos serviços do SUS, por meio da Promotoria de Justiça de Defesa da Saúde - PROSUS. Faz parte da atuação desta promotoria o contato com a SES-DF por meio de reuniões com o secretario em exercício, de auditorias cívicas (realizadas por cidadãos voluntários em unidades de saúde) e o órgão refere como objetivos desta atuação a melhora da gestão do SUS, com mais eficiência, transparência, economicidade e moralidade (documentos 77NJ a 83NJ) (MINISTÉRIO PÚBLICO DO DISTRITO FEDERAL E TERRITÓRIOS, 2016b; 2016c; 2016d; 2016e; 2016f; 2016g; 2016h).

Em 27 de abril de 2016, o Conselho Nacional de Secretários de Saúde (CONASS) realizou um encontro entre os gestores estaduais de saúde e os representantes do Fórum Nacional do Poder Judiciário, do CNJ. Neste evento, com o objetivo de aproximar os poderes executivo e jurídico e aprofundar a discussão sobre a judicialização da saúde, os gestores explanaram sobre as suas dificuldades, como a falta de orçamento para o cumprimento das ações judiciais. Por outro lado, os magistrados comentam sobre as preocupações no 
julgamento de casos que envolvem potencialmente o risco de óbito (documento 4NS) (CONSELHO NACIONAL DE SECRETÁRIOS DE SAÚDE, 2016c).

Ainda em abril de 2016, a DPDF já tinha realizado quase 2 mil atendimentos. E, no ano de 2014 totalizou 18 mil atendimentos e no ano de 2015, 19 mil atendimentos. E a DPDF acrescenta que o número continua aumentando diariamente. Além dos inúmeros atendimentos, o Núcleo de Saúde também promoveu um seminário sobre Direito e Saúde, pela Escola da Defensoria (documentos 51NJ e 52NJ) (DEFENSORIA PÚBLICA DO DISTRITO FEDERAL, 2016b; 2016c).

A DPU também contabiliza inúmeros atendimentos para defesa do direito à saúde do cidadão, porém com unidades por todo o território nacional. Os documentos $56 \mathrm{NJ}$ a $60 \mathrm{NJ}$ e $63 \mathrm{NJ}$ a $70 \mathrm{NJ}$ retratam notícias sobre o atendimento da população e a resolução de problemas relacionados à falta de acesso à ações e serviços de saúde (DEFENSORIA PÚBLICA DA UNIÃO, 2016e; 2016f; 2016g; 2016h; 2016i; 2016l; 2016m; 2016n; 2016o; 2016p; 2016q; 2016r; 2016s).

Em 03 de junho de 2016, o conselheiro do Conselho Nacional de Justiça, Arnaldo Hosseplan, reuniu-se com o ministro da saúde, Ricardo Barros para discutirem a proposta de criação dos NATs - Núcleos de Apoio Técnico do Poder Judiciário. Estes núcleos têm o propósito de qualificar as ações judiciais e auxiliar na compreensão destas demandas tão específicas da saúde. Será considerado um assessoramento técnico de especialistas em Saúde para os magistrados de todo o país. Esta parceria poderá proporcionar ao Judiciário o conhecimento sobre os medicamentos já disponíveis no SUS, além de evidências científicas e médicas para cada caso (documentos 93NJ e 2NS) (CONSELHO NACIONAL DE JUSTIÇA, 2016c; MINISTÉRIO DA SAÚDE, 2016e).

Como exemplo, o Tribunal de Contas do Estado de Minas Gerais, como outros estados, busca alternativas para lidar com o problema da judicialização da saúde em excesso. Atualmente o órgão realiza uma auditoria para fiscalizar os gastos públicos com o setor da saúde. Além disto, este Tribunal criou um Fórum permanente, juntamente com a Secretaria de Estado de Saúde de Minas Gerais, com as Defensorias da União e do Estado de Minas Gerais e com a Advocacia-Geral do Estado de Minas Gerais. Este fórum tem o objetivo de promover debates periódicos acerca da Judicialização da saúde no Estado (documento 18AR) (MEDRADO, 2016).

Em junho de 2016, no DF, o Ministério Público Federal - MPF solicitou abertura de um processo penal contra o secretário de saúde em exercício no DF e dos dois secretários anteriores. A denúncia se referiu à um possível desabastecimento de medicamentos para 
pacientes hemofílicos. Porém o secretário informou que tanto os pacientes do SUS quanto os pacientes que entraram com ações judiciais estavam recebendo os medicamentos regularmente. Este documento apresenta o trabalho do MPF também na vigilância do cumprimento do direito à saúde (documento 10NS) (AGENCIA BRASÍLIA, 2016).

O documento 11NS, em complementação ao anterior, informa que uma decisão do STF determinou que somente os medicamentos disponíveis pelo SUS, para pacientes hemofílicos, fossem distribuídos. Esta decisão se deu por não haver diferença em termos de eficácia entre os medicamentos disponíveis pela política pública e aqueles solicitados pela via judicial (CORREIO BRAZILIENSE, 2016).

Em 2016, o documento $38 \mathrm{Nj}$ do TJDFT retoma os registros sobre as reuniões do Comitê Executivo Distrital de Saúde. Isto porque não há notícias do TJDFT datadas do ano de 2015, porém as atas das reuniões do Comitê mostram que houve atividade ininterrupta (TRIBUNAL DE JUSTIÇA DO DISTRITO FEDERAL E TERRITÓRIOS, 2016c).

Também no ano de 2016, no mês de setembro, o STF iniciou um julgamento relacionado ao fornecimendo de medicamentos de alto custo pelos estados. A matéria do julgamento versa sobre a possível definição de diretrizes para o fornecimento de medicamentos de alto custo ou, até mesmo, da impossibilidade futura deste fornecimento. E a discussão inclui como ficará a situação da judicialização dos medicamentos sem registro pela Agência Nacional de Vigilância Sanitária. Após iniciado o julgamento este foi suspenso por duas vezes, até o final do mês de setembro (documentos 12NS, 13NS e 14NS (AGÊNCIA BRASIL, 2016; FOLHA DE SÃO PAULO, 2016a; 2016b).

A título de explicação, em função da vigência do processo no STF sobre a judicialização de medicamentos de alto custo e sem registro na ANVISA, uma notícia do jornal Folha de São Paulo explica que o funcionamento da Farmácia de Alto Custo não faz parte da decisão do STF. Pelo possível equívoco relacionado à terminologia "alto custo", a notícia explica que o julgamento se refere aos medicamentos que não estão padronizados pelo SUS ou que não possuem registro na ANVISA. Logo, o funcionamento da farmácia do SUS se manterá, sem relação direta com a decisão judicial (documento 15NS) (FOLHA DE SÃO PAULO, 2016c).

Ainda como notícia atual, em outubro de 2016 foi veiculado que o governo federal tem um custeio extremamente alto com medicamentos judicializados que não possuem registro na ANVISA. A informação é de grande impacto, pois refere haver um crescimento de 220 vezes de gastos comparando-se o ano de 2010 e o ano de 2015. Em 2010 o gasto anual total do MS com a judicialização de medicamentos teria sido de 122 milhões de reais, sendo 
2,4 milhões a parcela de medicamentos sem registro. Já em 2015 o gasto anual foi de 1,1 bilhão de reais e a parcela de medicamentos sem registro foi de 50\%, ou seja, de 545 milhões de reais (ESTADAO, 2016a). Não só os valores gastos com os medicamentos não registrados na agência reguladora são alarmantes, mas também os valores globais gastos somente pelo MS com a judicialização. Pois deve-se lembrar que os demais entes também são alvos passivos de ações por medicamentos.

Um último comunicado divulgou que o MS está realizando uma investigação interna com os dados das ações judiciais em saúde impetradas contra a União. Esta investigação está sendo executada por sua equipe jurídica e objetiva analisar se há relação entre as ações no que tange os médicos prescritores, os pacientes, os advogados e os juízes envolvidos nos casos. A hipótese é de que haja relação entre os indivíduos, em alguns casos, e que estes estariam agindo indevidamente para a obtenção de vantagem por meio destas ações. A informação é de que o relatório final desta análise será encaminhado à Polícia Federal para apreciação. E a mesma notícia ainda informa que o CNJ também está realizando um estudo com o mesmo propósito (ESTADAO, 2016b). Esta informação e estas investigações são importantes pois alguns entrevistados desta pesquisa relataram a repetição de nomes de cidadãos que ajuízam ações e dos médicos prescritores que assinam os receituários presentes nos processos judiciais.

Atualmente, no DF, a maior parte dos casos de demandas judiciais na saúde envolvem um serviço ou um medicamento não padronizado pelo SUS. Há a percepção por parte da SESDF, de que este grande número de ações causam um desequilíbrio nas políticas públicas de saúde e nos recursos alocados para tal finalidade. E, de forma contrária ao esperado para o sistema, este cenário acaba prejudicando a igualdade de acesso à saúde, que embasa o próprio direito à saúde. Há também o entendimento e a opinião de que o mais adequado seria inserir este paciente no próprio sistema de saúde por meio de mediação e acordo prévio à judicialização (documento 22AR) (PAIM; MARQUETTO; LOPES, 2016).

\subsection{Aparato normativo}

A codificação dos documentos para a categoria AN acompanhou os mesmo critérios utilizados para o caso 01 na identificação das normas embasadoras e da discricionariedade normativa.

São apresentadas a seguir as normas embasadoras e a discricionariedade normativa relacionadas ao caso 02 - Judicialização da Saúde. 


\subsubsection{Normas embasadoras}

Assim como para o caso 01, para melhor organização das normas e compreensão por parte do leitor, serão apresentados Quadros que reúnem algumas publicações por períodos. E, após esta apresentação, são descritos os conteúdos dos regulamentos.

Inicia-se com a exposição de documentos do período entre 1980 e 2005 (Apêndice X).

Como já abordado com mais detalhes nas categorias anteriores, em termos dos aspectos judiciais, a Constituição da república federativa do Brasil de 1988 também foi um marco com as diretrizes basais do Poder Judiciário. É o texto constitucional que desvela os órgãos que compõem o sistema judiciário nacional, os detalhes da carreira dos magistrados, a composição dos órgãos, as competências de cada órgão, entre outros. Além disto, como já explicado, a Constituição também traz os direitos fundamentais, incluindo o direito central deste estudo, à saúde (documento 1LN) (BRASIL, 1988).

Após a apresentação do direito fundamental à saúde e das definições sobre o funcionamento do sistema judiciário, duas leis seguintes proporcionaram o delineamento dos ações e serviços em saúde: a Lei $\mathrm{n}^{\circ}$ 8.080, de 19 de setembro de 1990 e a Lei Orgânica do Distrito Federal. A primeira estrutura o SUS e define as ações e condições para a promoção, proteção e recuperação da saúde. A LOS regula as ações em saúde em todo o Brasil, executadas por entidades jurídicas de direito público ou privado e pessoas físicas (documento 2LN) (BRASIL, 1990a). A segunda, publicada três anos depois, trata do arcabouço normativo do DF, em suas diversas áreas. Uma delas é a saúde (Capítulo II, artigos 204 ao 216) e apresenta as diretrizes para o SUS local, porém respeitando os princípios da CF (documento 21LN) (BRASIL, 1993b). Estas diretrizes se apresentam bem gerais, estabelecendo demanda por políticas públicas que definam as ações e serviços. Porém reforça os preceitos constitucionais e mantém as mesmas perspectivas para a análise das demandas judiciais nesta área.

Em 1997, a portaria número ${ }^{\circ}$ 653/PGJ criou a Promotoria de Justiça de Defesa da Saúde - PROSUS. Esta promotoria faz parte do Ministério Público do Distrito Federal e Territórios e atua, portanto, de forma independente do restante da estrutura do Estado. Esta publicação é de extrema importância pois tem muita influência para os avanços do sistema de saúde. Como a promotoria atua em prol do cidadão e do próprio direito à saúde, por mecanismos próprios, acaba por ser uma via de proteção ao funcionamento adequado do sistema em paralelo ao sistema judiciário. Ou seja, também defende os interesses dos 
cidadãos e, no caso da promotoria da saúde, especificamente nesta área (documento 67LN) (BRASIL, 1997b).

Voltando às especificidades da área da saúde, a portaria $n^{\circ} 3.916 / G M / M S$, de 30 de outubro de 1998 e a Resolução CNS/MS nº 338, de 6 de maio de 2004 versam sobre a PNM e a PNAF (documentos 11LN e 4LN) (BRASIL, 1998; BRASIL, 2004). Ambas as políticas são importantes para a assistência farmacêutica no Brasil e devem ser consideradas nas análises judiciais. Por refletirem uma área específica da saúde, seus conteúdos apresentam aspectos técnicos importantes para o julgamento de ações relacionadas aos medicamentos. Por exemplo, pela apresentação do próprio conceito de assistência farmacêutica, passa a ser do conhecimento de profissionais que não são da área da saúde que são realizadas várias etapas técnicas para a gestão de medicamentos. Além destes apontamentos, as próprias diretrizes da política e os objetivos colocados podem aproximar o sistema judiciário à realidade da gestão de medicamentos.

Em 2001, a lei no 2.804 apresenta os direitos dos usuários sobre as ações e serviços em saúde no Distrito Federal (documento 68LN) (BRASIL, 2001). E o Ministério Público do Distrito Federal e Territórios - MPDFT, por atividade da Promotoria de Justiça de Defesa da Saúde - PROSUS, que trabalha especificamente com a área da saúde, disponibiliza à público uma orientação sobre os direitos dos usuários do SUS. Ao mesmo tempo em que o órgão é do DF e se coloca para esta população, as orientações são aplicáveis à todo o sistema nacional, já que o mesmo é único e baseado nos mesmos princípios e diretrizes. As orientações colocam que os pacientes têm direito, conforme documento 7SI, in verbis:

\footnotetext{
- Ao acesso universal, isto quer dizer que todos os hospitais públicos ou conveniados do SUS (nas especialidades garantidas) não poderão negar atendimento a qualquer pessoa, seja esta de qualquer classe social, sexo, cor, crença, idade ou proveniente de qualquer lugar do país;

- ao acesso igualitário, ou seja, deverá ser fornecido o mesmo tratamento a todo indivíduo que procurar atendimento junto aos estabelecimentos do SUS;

- ao acesso totalmente gratuito às ações e aos serviços de saúde pública, até mesmo junto aos hospitais particulares prestadores de serviços contratados pelo SUS. Qualquer cobrança de complementação de pagamento, seja a que título for, corresponde a crime, que deve ser denunciado às autoridades (Ministério Público ou Polícia) (MINISTÉRIO PÚBLICO DO DISTRITO FEDERAL E TERRITÓRIOS, 2016a).
}

O Apêndice Y apresenta as normas publicas entre os anos 2007 e 2009.

Reforçando as normas a serem seguidas para o adequado funcionamento do SUS, a portaria GM/MS n $n^{\circ} 204$, de 29 de janeiro de 2007 dispõe sobre o financiamento e a transferência dos recursos federais para as ações e serviços de saúde. Novamente este norma é 
importante pois objetiva manter o equilíbrio financeiro para o bom funcionamento do SUS. E os arranjos propostos por esta portaria e outras também relacionadas ao financiamento do SUS merecem atenção para que a avaliação das demandas judiciais considere os critérios econômicos nas análises realizadas. Esta portaria, ainda, reforça a ação conjunta dos entes federativos e a operacionalização da descentralização, já que fortalece a ação dos demais entes, por meio do financiamento organizado (documento 5LN) (BRASIL, 2007a).

A portaria $\mathrm{n}^{\circ} 1.820$, de 13 de agosto de 2009 regulamenta os direitos e deveres dos usuários da saúde. Assim como o caso do DF, porém de amplitude nacional, o Ministério da Saúde leva a público um documento com os direitos e deveres dos usuários do SUS. Seguindo o princípio democrático constitucional, é dada publicidade aos direitos dos cidadãos no que tange a prestação do direito à saúde. Este documento reforça aos usuários o conhecimento sobre a extensão dos serviços que lhe deveriam ser prestados, conforme CF e políticas locais. Além da importância de qualificar os próprios serviços do SUS, também auxilia o poder judiciário na compreensão mais objetiva de como os direitos se operacionalizam (considerando que os direitos não deixam de ser matérias subjetivas) (documento 70LN) (BRASIL, 2009f).

Já no ano de 2009, especificamente na área jurídica, diante da complexidade da análise e julgamento de matérias da área da saúde, uma portaria (nº 650 de 20 de novembro de 2009) especifica a criação de um grupo de trabalho para estudo e proposta de medidas concretas e normativas para as demandas judiciais envolvendo a assistência à saúde. Diante da carência de uma estrutura mínima para a discussão dos casos em saúde, esta portaria merece destaque na evolução da judicialização da saúde. O objetivo da criação do grupo de trabalho era de ampliar a proposta de ações práticas para o ajuste dos problemas do SUS, detectados a partir das ações judiciais interpostas (documento 69LN) (BRASIL, 2009e).

E, reforçando a sistematização da oferta de serviços pelo executivo, a portaria $n^{\circ}$ 2.981, de 26 de novembro de 2009, avança e detalha a organização do CEAF/PNAF. Por ser um grupo de medicamentos de alto custo, o conhecimento sobre esta norma e seus desdobramentos é essencial para a compreensão de como estes medicamentos são dispensados no SUS e a razão dos critérios mínimos a serem cumpridos pelos pacientes incluídos no programa. Pois, somente com estes esclarecimentos técnicos, as análises jurídicas se aproximarão mais do cenário complexo em saúde e da importância do uso da medicina baseada em evidências (documento 7LN) (BRASIL, 2009b).

Continuando a exposição de normas, o Apêndice $\mathrm{Z}$ foi organizado com as regulamentações dos anos 2010 e 2011. 
Após a criação da portaria $n^{\circ}$ 650/2009 o CNJ continuou avançando na discussão sobre as demandas da saúde e elaborou uma recomendação aos Tribunais de todo o país. O documento propõe a adoção de medidas que objetivam melhor subsidiar os magistrados e demais operadores do direito, a fim de assegurar maior eficiência na solução das demandas judiciais envolvendo a assistência à saúde. Este ato administrativo é um exemplo pertinente de ação em prol da análise das matérias em saúde (recomendação no 31 do CNJ, de 30 de março de 2010 - documento 12J) (BRASIL, 2010c).

E, seguindo esta iniciativa, em 06 de abril de 2010, o CNJ divulga a resolução 107 do CNJ, de 06 de abril de 2010. Por meio desta o Conselho criou o Fórum Nacional do Judiciário para monitoramento e resolução das demandas de assistência à saúde (documento 71LN) (BRASIL, 2010b). Esta resolução é posterior à criação e atuação do grupo de trabalho que possuía os mesmos objetivos do fórum. Ou seja, fruto do grupo de estudos criado, uma das ações foi a institucionalização de um grupo com atividade permanente. E especificou que este fórum seria formado por Comitês Executivos Estaduais, para a discussão das demandas locais. E também publicou, então, a portaria de designação de membros para compor os Comitês Executivos Estaduais no âmbito do Fórum Nacional do Judiciário para a Saúde. (portaria n 25 do CNJ, de 22 de março de 2011 - documento 72LN) (BRASIL, 2011g).

A portaria $\mathrm{n}^{\mathrm{o}} 49$ do $\mathrm{CNJ}$, de 6 de junho de 2011 somente ajusta a portaria anterior de definição dos componentes dos comitês executivos estaduais (documento 76LN) (BRASIL, 2011h).

Assim como o CNJ em 2010, o TJDFT compartilha a mesma iniciativa e elabora a instrução normativa 06 da Corregedoria do TJDFT, de 23 de dezembro de 2011. Esta norma também apresenta recomendações aos juízes de direito do TJDFT para a observância de critérios para assegurar maior eficiência na solução das demandas judiciais envolvendo a saúde pública (documento 73LN) (BRASIL, 2011f).

Por fim, o último grupo de normas (Apêndice AA) desta subseção apresenta documentos de 2012 a 2016.

Além das normas quanto às competências financeiras de cada ente sobre o financiamento de serviços de saúde, a lei complementar $n^{\circ} 141$, de 13 de janeiro de 2012 especifica os valores mínimos a serem alocados anualmente pela União, estados, Distrito Federal e municípios em ações e serviços públicos de saúde (documento 16LN) (BRASIL, 2012c). Uma análise mais profunda sobre os valores necessários para o funcionamento do SUS e os valores envolvidos com a judicialização pode gerar uma provável preocupação para com a sustentabilidade a longo prazo do sistema de saúde. Por isto é essencial uma análise 
econômica por parte do Poder Judiciário para a melhor qualificação do problema e uma tomada de decisões mais adequada frente a judicialização.

Os documentos 77LN, 78LN e 79LN alteram a composição do Comitê Executivo do Distrito Federal no âmbito do Fórum Nacional do Poder Judiciário para a Saúde e dispõem outras questões relacionadas ao Fórum Nacional (portaria GPR n ${ }^{\circ} 464$ do TJDFT, de 17 de abril de 2012, portaria GPR n ${ }^{0} 1.423$ do TJDFT, de 25 de outubro de 2012 e portaria GPR ${ }^{\circ}$ 1735 do TJDFT, de 14 de outubro de 2014) (BRASIL, 2012d; 2012e; 2014).

No Distrito Federal, o sistema judiciário ganha destaque ao instituir a Câmara Permanente Distrital de Mediação em Saúde - CAMEDIS (portaria conjunta $n^{\circ} 01$, de 26 de fevereiro de 2013 - documento 80LN) (BRASIL, 2013m). A CAMEDIS, como já citado no contexto histórico deste segundo caso, foi criada como uma parceria e, segundo o entrevistado $11 E N$, é importante no sentido de resolver inúmeros conflitos por meio de atos administrativos, sem a necessidade de encaminhamento de ações judiciais.

\footnotetext{
Mas, a Defensoria atua primordialmente - a doutora já viu isso -, administrativamente. Tanto que 90 por cento da nossa demanda, ela se esvai no administrativo, não se leva ao judiciário essa demanda. O DF consegue um índice de 90 por cento de resoluções extra-judiciais. Então, um índice altíssimo qualquer outro lugar. Isso, graças à atuação da Defensoria e do próprio Estado para tentar resolver o problema do paciente.
}

Como atualização e melhoria da estruturação do CEAF/PNAF, tem-se a portaria GM/MS $\mathrm{n}^{\circ} 1.554$, de 30 de julho de 2013, que sistematiza as regras de financiamento e execução do Componente Especializado da Assistência Farmacêutica no âmbito do Sistema Único de Saúde (SUS) e substitui a portaria $\mathrm{n}^{\mathrm{o}}$ 2.981, de 26 de novembro de 2009 (documento 8LN) (BRASIL, 2013a).

As duas últimas portarias, de 2014 e 2016, atualizam a composição do Comitê Organizador do Fórum Nacional do Poder Judiciário para monitoramento e resolução das demandas de assistência à saúde, foram elas a portaria $\mathrm{n}^{\circ} 40$ de 25 de março de 2014 e a portaria $\mathrm{n}^{\circ} 8$ de 2 fevereiro de 2016 (documentos 74LN e 75LN) (BRASIL, 2014h; 2016c). 


\subsubsection{Discricionariedade normativa}

Para o caso 02, a subcategoria discricionariedade 'normativa' se aplica a partir de conceito equivalente ao de discricionariedade utilizado para o caso 01. Porém, a consideração a ser feita para este caso é de que a discricionariedade pode ser compreendida também como inerente à atuação do juiz. Então a discricionariedade deste caso se dará por meio das normas e premissas para a atuação do profissional do direito e também pela liberdade de atuação que as normas aplicadas aos casos judiciais permitem.

A própria da atuação do profissional juiz é discricionária, a ser usufruída no julgamento dos casos e processos. Faz-se então matéria desta subseção compreender o que seria esta liberdade de ação, também conceituada na área de direito como discricionariedade jurídica.

Além desta diferenciação, também cabe pontuar que há outros textos jurídicos que têm como foco dos estudos a atuação do poder judiciário no controle das políticas públicas, sendo estas frutos da discricionariedade administrativa do gestor. Porém esta outra percepção será abordada no capítulo de comparação entre os casos 01 e 02.

Quanto à discricionariedade no direito, os autores da área primeiramente ponderam que aceitar a sua existência vai além de discutir a atuação do juiz em sua função. Na verdade, aceitar a discricionariedade jurídica embasa a concepção da natureza do direito. Ou seja, a compreensão que o jurista possui sobre a existência ou não da discricionariedade irá refletir nas premissas que ele traz consigo para a discussão das jurisprudência (documento 23AR) (ALMEIDA 2013).

O documento 24AR define a discricionariedade como a liberdade de opção que o juiz possui, em determinados casos, porém limitada aos interesses objetivos da "eficácia da prestação jurídica”. O resultado desta liberdade não seria a simples escolha entre duas conclusões e ou condutas possíveis, mas sim a escolha da opção apropriada aos anseios da justiça. Ou melhor, a escolha feita será aquela que contribui para a preservação da democracia e para a reflexão entre os magistrados (ALMEIDA JUNIOR, 2005, p.3).

Porém, para o judiciário, a discricionariedade não seria equivalente à liberdade de atuação da administração, pois a escolha judicial levará à correta solução. Logo, há um processo de investigação, porém finalizado pela melhor solução dentre as diversas possibilidades.

É observado, também, que o fato de juízes terem diferentes opiniões sobre um caso não nega o fato de haver uma verdade jurídica. Porém, se esta verdade não for aplicada ao 
caso concreto ou não foi tomada a decisão justa no primeiro momento, isso ainda pode acontecer em grau de recurso (ALMEIDA JUNIOR, 2005).

Almeida Júnior (2005) ainda explica que, na história do direito, o juiz ganhou voz em seu próprio papel ao final do século XIX. Pois, antes disso, exercia uma atribuição mais passiva e menos direcionadora nos processos. Naturalmente, a atuação dos juízes passou a ser mais participante, em busca da efetividade jurídica.

Como nos dias atuais os juízes têm postura mais ativa diante dos processos, há o questionamento por parte de alguns especialistas sobre os juízes desempenharem também a função legislativa. Esta hipótese considera que o juiz ultrapassa a função de intérpreteaplicador do direito e passa a criar o direito (documento 24AR) (ALMEIDA JUNIOR, 2005).

Esta diferença é sutil e, na teoria, as leituras consideram que o juiz participaria da atividade legislativa. Porém, a interpretação da constituição e demais normas seria o mesmo que criá-las ou, como é da função do magistrado, interpretá-las?

Diante deste questionamento, o documento $25 \mathrm{AR}$ explica que qualquer norma, por mais simples e clara que seja, quando em uma linguagem legislativa, possui lacunas que deixam margem à interpretação do juiz. E não haveria diferença entre o uso do termo interpretação ou criação do Direito. Mas a preocupação deve estar na extensão da “criatividade e dos modos, limites e aceitabilidade da criação do Direito pelos tribunais" (CAPPELLETTI, 1993, p. 20).

Ainda neste documento, é reforçado que o sistema jurídico coloca limites à esta liberdade judicial, tanto processuais quanto substanciais. Um exemplo importante para este trabalho é o de que quando um juiz elabora uma decisão baseada na equidade, o grau de criatividade usado na conduta é maior. Porém, quando a decisão baseia-se em alguma lei ou precedente, o grau é menor (CAPPELLETTI, 1993). Para o presente estudo este entendimento é importante e está relacionado aos achados que mostram o poder judiciário buscando alternativas para melhorar a solução das demandas judiciais envolvendo a assistência à saúde, como justificado na criação do próprio Fórum Nacional do Poder Judiciário para monitoramento e resolução das demandas de assistência à saúde (documento 71LN) (BRASIL, 2010b).

Estes argumentos demonstram que, nos últimos anos, o juiz realmente se apropriou de uma significativa autonomia e tornou-se participante do processo no sentido de buscar a solução que lhe parecer mais justa, dentre as possíveis. Neste momento ele interage com a legislação, a interpreta e o faz sem infringir um espaço que seja do Poder Legislativo (ALMEIDA JUNIOR, 2005). 
O documento 26AR acrescenta um ponto de vista importante para esta análise. As políticas públicas podem ser entendidas como mandatos constitucionais a serem cumpridos pelo gestor público. E, diante deste entendimento, as ações derivadas destas políticas poderão sofrer controle judicial. A partir disto, voltando a discussão anterior, deve-se delimitar os critérios para esta intervenção do Poder Judiciário. E este documento ressalta que se a demanda constitucional prevista não constituir em uma discricionariedade administrativa, esta será potencial alvo de questionamento judicial (LIMBERGER; SOARES, 2010).

A partir do texto compreende-se que, no caso dos direitos sociais, a previsão existente na CF é ampla e remete à obrigatoriedade do Estado prestar estes direitos. Isto é diferente de uma lei infraconstitucional que direciona para a aplicabilidade das ações para a prestação dos direitos. No casos das leis e demais normas, em muitos casos há discricionariedade presente. Mas interpretando o direito constitucional, a demanda é clara e simples no que toca a garantia do direito.

O mesmo documento 26AR ainda complementa citando que a falta de critério do sistema judiciário aliado aos problemas na saúde pública brasileira ocasiona

decisões extravagantes ou até mesmo emocionais, as quais condenam a
Administração Pública ao custeio de tratamentos descabidos, ou mesmo ao
fornecimento de medicamentos experimentais, de eficácia duvidosa, associados a
terapias alternativas (LIMBERGER; SOARES, 2010, p. 53).

Os dados mostram que a intervenção do Poder Judiciário deve seguir critérios, pois as demandas em saúde possuem grande complexidade e múltiplas facetas. E a própria organização do SUS já requer elaboração e critérios para a escolha das ações. Logo, ao julgar casos nesta matéria, esta complexidade não pode ser desconsiderada, gerando o deferimento de toda ação relacionada à saúde.

Além disso, o julgamento inapropriado pode ferir ao texto da própria Constituição que diz que o direito à saúde será garantido por meio de políticas sociais e econômicas. Pois, na vigência de demandas julgadas difíceis de serem implementadas, o déficit financeiro causado sobre o sistema poderá impedir que as políticas coletivas sejam implementadas adequadamente (LIMBERGER; SOARES, 2010).

Entende-se também a discricionariedade como as capacidades investigatórias dos juízes, limitadas pelos dispositivos legais. Porém, há de se considerar que essas capacidades não estão isentas de pressupostos. Os juízes trazem consigo premissas sociais, econômicas e religiosas. Então, diante destes pressupostos, muitos juízes, com receio de que suas decisões 
sejam consideradas parciais fiquem mais passivos no processo do julgamento. E isto tem sido associado ao mau funcionamento do sistema. Nestas situações é necessário que o magistrado não se limite em suas interpretações e aja objetivamente na decisão, sem a inclusão de outros elementos neste processo (ALMEIDA JUNIOR, 2005).

Algumas definições de discricionariedade e poder discricionário, de diferentes autores da área, são apresentadas no documento 24AR, de Almeida Júnior (2005):

\footnotetext{
"o autêntico poder discricionário é atribuído pelo direito e pela lei quando a decisão última sobre o justo (correto, conveniente, apropriado) no caso concreto é confiada à responsabilidade de alguém, é deferida à concepção (em particular, à valoração) individual da personalidade chamada a decidir em concreto, porque se considera ser melhor solução aquela em que, dentro de determinados limites, alguém olhando como pessoa consciente da sua responsabilidade, faça valer o seu próprio ponto de vista".

“sem sombra de dúvida, o ato judicial é discricionário, em nada se confundindo com um ato arbitrário, pois a discricionariedade está calcada dentro da legalidade e exige, obrigatoriamente, uma motivação na tomada da decisão considerada mais justa ao caso concreto; fundamentação esta que inocorre no ato arbitrário, pois é adotada uma posição não permitida pelo ordenamento jurídico para aquele caso em concreto."
}

"Na norma genérica está contudo prevista a intenção clara de que essa aplicação se faça a melhor possível, a mais certa possível, justa e adequada, às exigências do caso. Eis por que discrição não se confunde com arbítrio desordenado ou com arbitrariedade" (ALMEIDA JUNIOR, 2005, p.6-7)

Alguns autores descrevem que muitas ações são deferidas caracterizando quase que um acolhimento absoluto das ações em saúde e uma certa automação no julgamento (documento 20AR) (SANT'ANA et al, 2011).

Ao aceitar a discricionariedade, Almeida (2013), argumenta que não é possível fazê-lo sem considerar que o Direito possui limites. Até porque, a discricionariedade trata da liberdade limitada (documento 23AR).

Porém, dentro desta liberdade, deve-se exercer o papel de investigador e não manterse como receptor passivo dos processos, reforçando a percepção de Sant'Ana et al (2011) e possibilitando que as políticas públicas sejam prejudicadas pela má avaliação dos casos, conforme pensam Limberger e Soares (2010).

Sobre estes aspectos de aplicação prática da discricionariedade a discussão será realizada na subcategoria discricionariedade prática.

Esta subcategoria se propôs, portanto, à compreensão da liberdade de julgamento do Poder Judiciário ao realizar o controle das políticas públicas. E, para este trabalho, assume-se que a atuação do juiz é dotada de discricionariedade inerente ao próprio Direito e ao ato de 
julgar e interpretar a legislação. Dessa forma, a discricionariedade será a liberdade do magistrado de, diante das evidências do caso, tomar a melhor decisão judicial.

Resumindo a discricionariedade aplicada ao sistema jurídico, apresenta-se no Apêndice $\mathrm{AB}$ a síntese dos principais elementos desta concepção.

\subsection{Aparato administrativo}

Todas as categorias foram analisadas nos dois casos, seguindo o mesmo modelo proposto para a investigação. Desta forma, similar ao que foi feito no caso 01, esta seção também será subdividida em (1) estrutura organizacional, (2) recursos humanos, (3) recursos financeiros, (4) atividades, fluxos e rotinas e (5) discricionariedade operacional.

\subsubsection{Estrutura organizacional}

Os resultados da pesquisa demonstraram que o cenário relacionado ao controle jurisdicional da saúde, no Distrito Federal e na União, pode ser pensado em um conjunto com três partes. A primeira parte é constituída pelos órgãos que compõem o Sistema Jurídico e estão envolvidos com a problemática estudada. A segunda parte é composta pelos órgãos do Sistema de Saúde, que participam dos processos e executam as decisões judiciais. E o terceiro componente é formado por órgãos independentes dos três poderes, mas que fazem parte do Estado. Estes são identificados na CF de 88 como órgãos de funções essenciais à justiça. Quer dizer, para cada ente federativo, a pesquisa possibilitou este achado e esta proposta de organização para o claro entendimento do contexto.

É importante comentar aqui que, de forma indireta, o Sistema Legislativo também tem participação no objeto de pesquisa. Porém, para este estudo e sua proposta de investigação, o papel do Legislativo não está incorporado no foco da pesquisa.

A partir desta organização proposta, a estrutura organizacional será inicialmente apresentada por meio de um diagrama, que inclui o nível federal e o nível distrital (Figura 5.4). É importante ressaltar que as relações estabelecidas nos diagramas não são de hierarquia, de acordo com a organização das imagens. Na verdade são somente relações dentro e entre órgãos. Porém são relações contínuas, estabelecidas em organograma ou da qual dependem o funcionamento do órgão ou setor. 


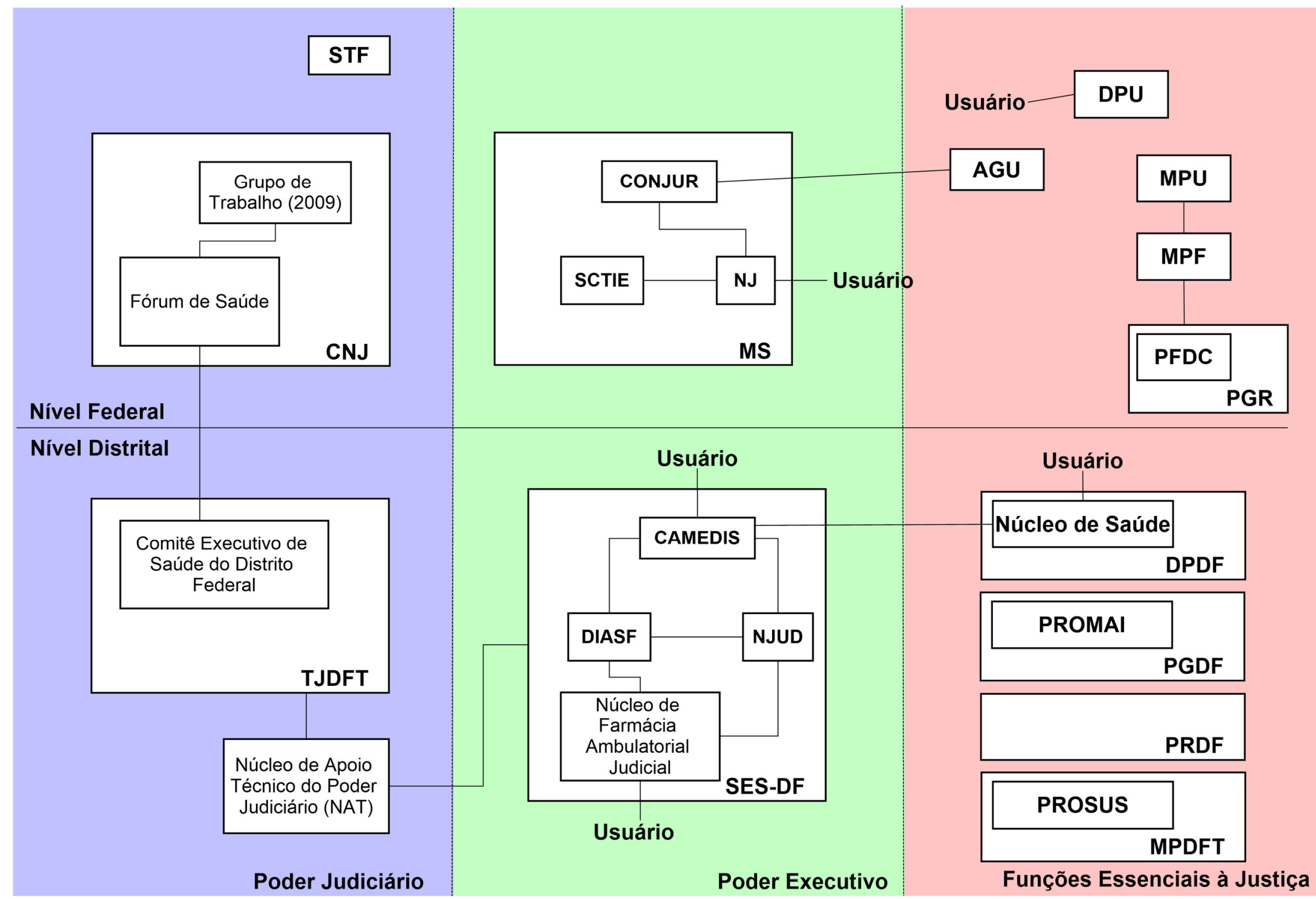

Figura 5.4 - Estrutura organizacional do controle jurisdicional exercido no DF e na União

Fonte: Da autora. 


\section{União}

\section{a. Poder Judiciário - Sistema Judiciário}

Os dados mostraram um importante envolvimento do Conselho Nacional de Justiça CNJ, com o controle de políticas de saúde. O CNJ foi instituído pela Emenda Constitucional $\mathrm{n}^{\mathrm{o}} 45$, de 30 de dezembro de 2004. Esta emenda gerou a inclusão do artigo 103-B na CF. E é da competência deste órgão o controle administrativo, o controle processual, a transparência e o desenvolvimento dos órgãos do Poder Judiciário. Além disto o CNJ trabalha com ações voltadas especificamente para a discussão da proteção do direito à saúde e como isso poderia ser melhor realizado no que tange às decisões dos juízes (documento 11AR) (OLIVEIRA, 2013).

Em 2009, como exemplo da preocupação do CNJ, esta instituição criou um grupo de trabalho para o estudo de estratégias de ações quanto à judicialização da saúde. Este grupo, de cunho temporário, também tem destaque como componente anterior da estrutura nacional de atuação na temática (documento 69LN) (BRASIL, 2009e).

Como já identificado na história da judicialização da saúde no Brasil (categoria CSEP), o CNJ também foi responsável por outro espaço importante, o Fórum Nacional do Poder Judiciário para monitoramento e resolução das demandas de assistência à saúde. Instituído em 2010 e com a organização dos comitês estaduais em 2011, esta ação tenta combater o elevado número de litígios na área da saúde e os crescentes custos decorrentes destas ações. Os comitês compõe a estrutura atual da judicialização, com a proposta de ações concretas para aperfeiçoar os procedimentos realizados pela justiça brasileira (documentos 71LN e 72LN) (BRASIL, 2010b; 2011g).

O documento 11AR cita que o Supremo Tribunal Federal - STF foi criado após a proclamação da República e é considerado o guardião da CF de 1988. Suas responsabilidades estão incluídas na própria Constituição, em seu artigo 102. O STF, como protetor da CF, o é também dos direitos que nela constam. Consequentemente, este tribunal atua quando há ameaça à $\mathrm{CF}$ ou ao direito à saúde. $\mathrm{O}$ mesmo documento cita que uma das maneiras que o STF encontrou para proteger este direito e ampliar a discussão sobre ele foi realizar mais audiências públicas (OLIVEIRA, 2013).

O entrevistado 14EN confirma o motivo pelo qual o STF foi apontado pelos dados da pesquisa como atuante na discussão da matéria em questão: 
[...] existem dispositivos relacionados à saúde na Constituição. Então se o dispositivo que você está analisando é constitucional, então de fato deve-se focar no STF, pois é esta a matéria que o STF analisa.

O estudo da CF de 1988 (artigo 92) demonstrou que o Poder Judiciário é composto por outros órgãos (documento 1LN) (BRASIL, 1988), porém, em função da sistematicidade da pesquisa, são incluídos no estudo aqueles citados em entrevistas ou em documentos relacionados à judicialização da saúde.

\section{b. Poder Executivo - Sistema de Saúde}

Em complementação ao item anterior, o sistema de saúde representa então o Poder Executivo. Foi identificado para o sistema de saúde, no nível federal, dois departamentos no MS, envolvidos com as demandas judiciais em saúde. Primeiramente, com atuação ampla neste Ministério, tem-se a Consultoria Jurídica - CONJUR/MS.

A CONJUR/MS é um órgão da Advocacia Geral da União - AGU, porém os advogados atuantes no MS possuem vínculo administrativo com o Ministério. Por este motivo a escolha de incluir este departamento como integrante do sistema de saúde (documento 8SI) (MINISTÉRIO DA SAÚDE, 2016e).

Além da Consultoria Jurídica, o MS possui um Núcleo Jurídico identificado por esta pesquisa, subordinado à Secretaria de Ciência Tecnologia e Insumos Estratégicos SCTIE/MS (NJ/SCTIE/MS). Diferentemente à CONJUR/MS que defende o MS como um todo, o núcleo jurídico de interesse defende os interesses da SCTIE, que é a secretaria responsável pela formulação e implementação de política nacionais em ciência e tecnologia e em assistência farmacêutica, além de estimular e fomentar a pesquisa, o desenvolvimento e a inovação no que tange a saúde pública (documento 9SI) (MINISTÉRIO DA SAÚDE, 2016f).

Sobre estes dois departamentos, o entrevistado 1EN confirma as informações documentais:

A judicialização tem... no Ministério quem coordena é a Conjur. Nós temos na nossa secretaria, também, o núcleo jurídico, que também fornece as orientações. 


\section{c. Funções Essenciais à Justiça}

A CF de 1988, em seu artigo 127, prevê a institucionalização do Ministério Público da União - MPU como um órgão permanente e com independência e autonomia frente aos três poderes. A independência é importante para o órgão para que ele possa defender os direitos dos cidadãos, quando não cumpridos. O regime democrático é ratificado com a ação deste órgão, que pode até agir contra o próprio Estado, caso ele seja omisso quanto à operacionalização dos direitos (documento 7SI) (MINISTÉRIO PÚBLICO DO DISTRITO FEDERAL E TERRITÓRIOS, 2016a).

O MPU é composto pelos Ministérios Públicos Federal, do Trabalho, Militar e do Distrito Federal e Territórios. Para facilitar a compreensão, apresenta-se o organograma da Figura 5.5 (documento 10SI) (MINISTÉRIO PÚBLICO DA UNIÃO, 2016).

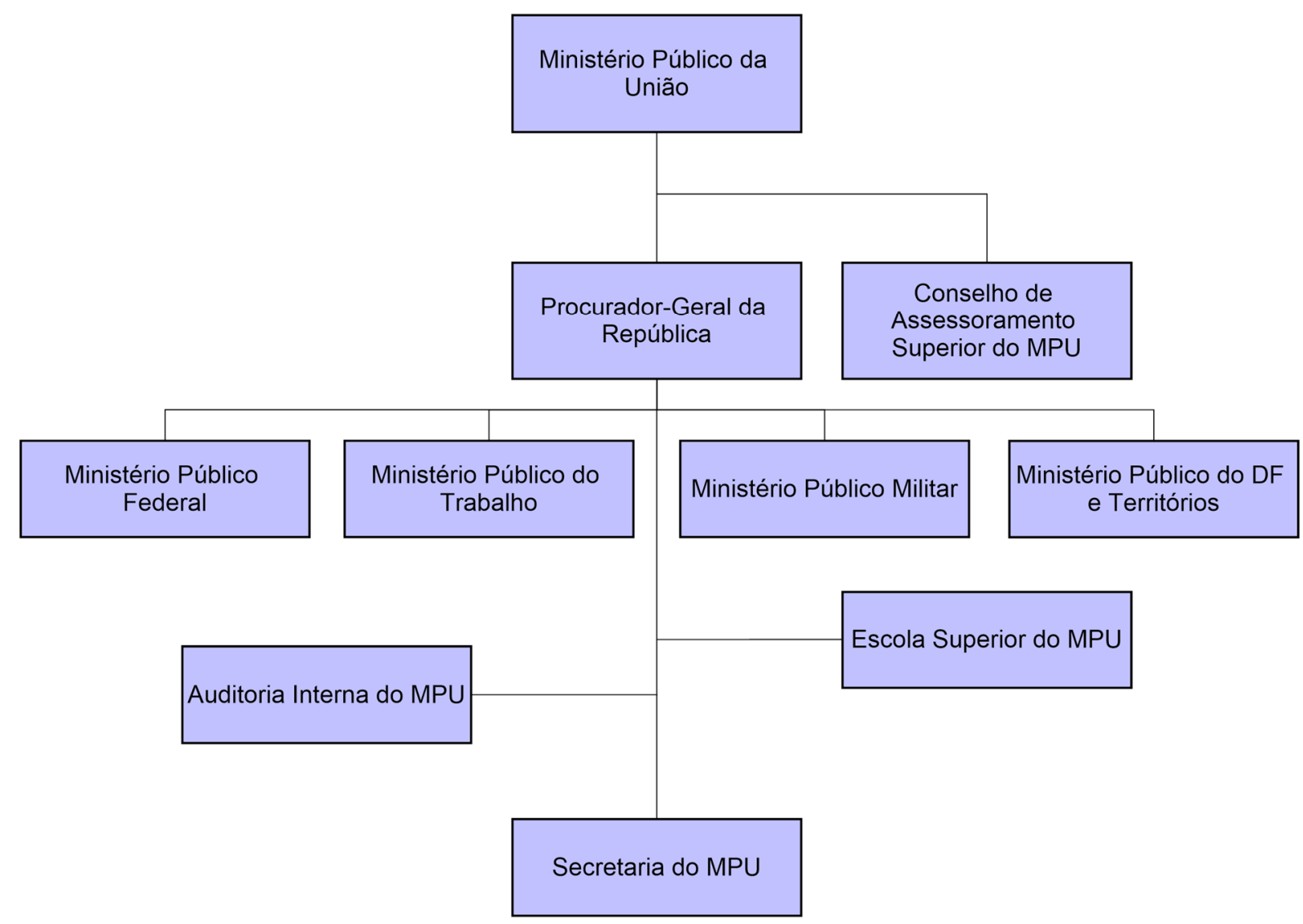

Onde: MPU - Ministério Público da União

Figura 1.5 - Organograma do Ministério Público da União

Fonte: Ministério Público da União (2016). 
Sendo o MPU constituído pelo Ministério Público Federal - MPF, estes dois órgãos tem como chefe o Procurador-Geral da República (documento 11SI) (MINISTÉRIO PÚBLICO FEDERAL, 2016).

O MPF é apresentado também pela CF, mas em seu artigo 128, no mesmo capítulo IV, da Funções Essenciais à Justiça, Seção I, do Ministério Público. Logo, incorpora a mesma independência e autonomia e também o mesmo dever de prezar pelos direitos constitucionais que o MPU, como órgão maior, possui. Quanto ao MPF, interessa ao tema a ProcuradoriaGeral da República e, submetida à esta, a Procuradoria Federal dos Direitos dos Cidadãos (BRASIL, 1988).

O entrevistado 13EN explica um pouco sobre a estrutura do MPF e das procuradorias:

\begin{abstract}
O MPF, que, por sua vez, é um ramo do Ministério Público da União. O MPU, composto pelos Ministérios Públicos do Trabalho, Militar, do Distrito Federal e Territórios e, como já explicado, o MPF. O MPF também é dividido em diversos órgãos em níveis de atuação perante o Poder Judiciário Federal, podendo, inclusive, atuar nas instâncias superiores, entenda-se Superior Tribunal de Justiça, o STJ e Supremo Tribunal Federal, o STF. Essa divisão no âmbito do MPF é a seguinte: Procuradorias da República nos Estados e no DF - PR's (atuação perante Varas Federais de primeiro grau, portanto), Procuradorias Regionais da República - PRR's (atuação perante Tribunais Regionais federais em caso de recurso ou Ação Originária, neste último caso em que a $\mathrm{CF}$ determina competência inicial nesta $2^{\circ}$ instância) e Procuradoria-Geral da República para atuação nas instâncias especial (STJ) ou extraordinária (STF). Então esta Procuradoria da República no DF - PRDF atua perante as Varas Federais com Jurisdição no Distrito Federal. Essas informações foram extraídas da leitura da Lei Complementar $n^{\circ} 75$, de 20 de maio de 1993, LC 75/1993.
\end{abstract}

Além do MPU, a União também apresenta a Defensoria Pública da União - DPU. A DPU também atua na defesa dos direitos dos cidadãos e o faz atendendo e representando o cidadão com renda familiar de até três salários mínimos (grupos de até cinco pessoas) ou quatro salários mínimos (grupos com seis ou mais pessoas) reais gratuitamente. O sítio eletrônico institucional cita que há casos relacionados à saúde pública com muita frequência para os defensores (documento 12SI) (DEFENSORIA PÚBLICA DA UNIÃO, 2016a). 


\section{Distrito Federal}

\section{a. Poder Judiciário - Sistema Judiciário Distrital}

O documento 1LN apresenta em seu Capítulo III, do Poder Judiciário, Seção I, Disposições Gerais a o composição do Poder Judiciário e nesta está incluído o Tribunal de Justiça do Distrito Federal e Territórios - TJDFT (BRASIL, 1988). Este tribunal é formado pela presidência, pela $1^{\mathrm{a}}$ vice-presidência, pela $2^{\mathrm{a}}$ vice-presidência, pelos órgãos da $1^{\mathrm{a}}$ Instância e pelos órgãos da $2^{\mathrm{a}}$ instância e por diversas secretarias e unidades administrativas. Quanto ao TJDFT, esta pesquisa identificou como sendo o foco do trabalho com a saúde um comitê interno, de interesse para a judicialização da saúde no DF e no Brasil (documento 13SI) (TRIBUNAL DE JUSTIÇA DO DISTRITO FEDERAL, 2016a)

Em resposta à demanda colocada pela instituição do Fórum Nacional do Judiciário, do CNJ, o TJDFT organizou o Comitê Executivo de Saúde do Distrito Federal, sob coordenação de um juiz do Tribunal de Justiça do Distrito Federal e Territórios. Este comitê foi instituído em 2011, a partir da preocupação do CNJ com o aumento das demandas individuais por acesso à saúde e pelo consequente impacto destas sobre a sociedade. É colocado pelo CNJ que as demandas individualizadas não devem ser prejudicadas, porém a discussão entre os setores e instituições envolvidas com a problemática deve ser realizada para tentar identificar soluções alternativas (documentos 39NJ e 14SI) (DEFENSORIA PÚBLICA DO DISTRITO FEDERAL, 2012a; TRIBUNAL DE JUSTIÇA DO DISTRITO FEDERAL, 2016b).

A mais recente inserção no sistema jurídico brasileiro para lidar com a problemática deste estudo foram os Núcleos de assessoria técnica ou Núcleos de Apoio Técnico do Poder Judiciário (NATs), conforme nomeados pelos documentos 27AR e 2NS, respectivamente (FERREIRA; COSTA, 2013; MINISTÉRIO DA SAÚDE, 2016c). Ferreira e Costa (2013) discorre sobre a criação pioneira destes núcleos no estado do Rio de Janeiro.

Os núcleos têm, como base normativa para suas criações a Recomendação no 31/2009 e a Resolução $n^{0}$ 107/2010, do CNJ, que estimulavam a celebração de convênios para apoio técnico de médicos e farmacêuticos (FERREIRA; COSTA, 2013).

E o Ministério da Saúde (2016c) divulga a retomada desta iniciativa e uma ampliação da mesma para o nível nacional. O documento cita esta parceria entre o Conselho Nacional de Justiça e o Ministério da Saúde, anunciada em junho de 2016 e formalizada em 22 agosto de 2016. Esta parceria se fez em prol da formação dos NATs, a ser operacionalizado por meio das universidades públicas e centros de excelência já existentes (MINISTÉRIO DA SAÚDE, 
2016c). O documento 27AR explica que o núcleo exemplo do Rio de Janeiro é operacionalizado pelo Tribunal de Justiça estadual e a Secretaria Estadual de Saúde. Logo, a execução da proposta será realizada nos níveis estaduais e distrital (FERREIRA; COSTA, 2013).

\section{b. Poder Executivo - Sistema de Saúde Distrital}

Alguns dados da pesquisa fazem menção à um setor de judicialização de saúde do DF, o Núcleo de Judicialização da SES-DF - NJUD/SES-DF, como os documentos 22AR, 1NJ e 12SI (PAIM; MARQUETTO; LOPES, 2016; TRIBUNAL DE JUSTIÇA DO DISTRITO FEDERAL E TERRITÓRIOS, 2011a; 2016b).

Porém, a pesquisa identificou este núcleo inicialmente a partir do entrevistado 2EN, que o citou na entrevista quando questionado sobre a estrutura da SES-DF para lidar com judicialização:

Acho que quando a gente criou o Núcleo de Judicialização em torno de...que eu não vi, eu estava na Secretaria. Então, o Núcleo de Judicialização, eu acho que ele é de 2009.

Anterior à constituição do Núcleo de Judicialização, este serviço foi iniciado com o Comitê de Judicialização da SES-DF, conforme explicado pelo chefe da Assessoria Jurídica, à época. Pelo documento 2AT consta o registro de que o Comitê iniciou suas atividades ao final de 2010, com um médico, um farmacêutico e um advogado. O objetivo de sua instituição era estabelecer um canal de comunicação com o Poder Judiciário e com a Defensoria Pública e o Ministério Público (TRIBUNAL DE JUSTIÇA DO DISTRITO FEDERAL E TERRITÓRIOS, 20111).

Além do NJUD/SES-DF, os dados do caso 01 já havia permitido identificação do Núcleo de Farmácia Ambulatorial Judicial/DIASF/SES-DF. O documento 28AR confirma que este último núcleo participa do processo administrativo de resolução das demandas judiciais quando a decisão é favorável à entrega do medicamento (KARNIKOWSKI et al, 2016).

O entrevistado 8EN também explica que o Núcleo de Farmácia Ambulatorial Judicial: 
Segundo o Comitê Executivo Distrital da Saúde (documento 92NJ), sob coordenação do TJDFT, foi criada a partir das discussões deste grupo a Câmara Permanente Distrital de Mediação em Saúde - CAMEDIS (TRIBUNAL DE JUSTIÇA DO DISTRITO FEDERAL, 2016c). Esta câmara tem atuação de aspecto mediador e foi instituída em 2013, por meio da portaria conjunta entre a SES-DF e a DPDF (BRASIL, 2013m; PAIM; MARQUETTO; LOPES, 2016). A CAMEDIS recebe suporte administrativo e material da SES-DF para o seu funcionamento e, por este motive está descrita como parte do sistema de saúde. Diz Paim, Marquetto e Lopes (2016) que a Câmara é coordenada pela SES-DF.

\section{c. Funções Essenciais à Justiça no DF}

O artigo 128 da CF diz que o Ministério Público da União é constituído pelo Ministério Público Federal, pelo Ministério Público do Trabalho, pelo Ministério Público Militar e pelo Ministério Público do Distrito Federal e Territórios - MPDFT (BRASIL, 1988).

E, segundo o artigo 129, cabe ao Ministério Público:

\footnotetext{
II - zelar pelo efetivo respeito dos Poderes Públicos e dos serviços de relevância pública aos direitos assegurados nesta Constituição, promovendo as medidas necessárias a sua garantia (BRASIL, 1988).
}

Este órgão tem papel importante no controle jurisdicional do Estado, atuando na proteção democrática e dos direitos individuais e coletivos (documento 15J) (PROCURADORIA-GERAL DO DISTRITO FEDERAL, 1999). No que cabe à proteção da saúde pública, o MPDFT divide suas competências em duas Promotorias: Promotoria de Justiça de Defesa da Saúde - PROSUS e Promotoria de Justiça Criminal de Defesa dos Usuários dos Serviços de Saúde - Pró-vida (documento 7SI) (MINISTÉRIO PÚBLICO DO DISTRITO FEDERAL E TERRITÓRIOS, 2016a).

A PROSUS, foi criada em 1997 (portaria 653/PGJ, de 1 de setembro de 1997) e sua portaria definiu seu papel para o MPDF quanto ao cumprimento da Lei Orgânica da Saúde. Já a Pró-vida é uma promotoria que atua na defesa dos usuários que sofrem algum dano causado pelos profissionais de saúde, por ação ou por omissão (documento 7NS) (AGÊNCIA BRASÍLIA, 2012c). 
Para este trabalho, a Pró-vida não se enquadra nos objetivos de proteção e defesa dos usuários do SUS nos aspectos de interesse, que envolvem o acesso aos medicamentos. Por este motivo foi apresentada, como fruto da pesquisa, porém não será analisada nas próximas subcategorias.

Ainda no Capítulo IV, Das Funções Essenciais à Justiça, mas na Seção II, da Advocacia Pública, há a previsão da Procuradoria-Geral do Distrito Federal. E, nesta procuradoria, está sistematizada a Procuradoria do Meio Ambiente, Patrimônio Urbanístico e Imobiliário e Saúde - PROMAI (documentos 1LN e 15SI) (BRASIL, 1988; PROCURADORIA-GERAL DO DISTRITO FEDERAL, 2016).

Somente para esclarecimento, diante das evidências da participação de promotorias e procuradorias no cenário da pesquisa, o entrevistado 14EN explica:

\begin{abstract}
Os procuradores são os advogados públicos, que irão defender o interesse do Estado. Então são advogados dos órgãos estatais mesmo. Os promotores... Vou falar Ministério Público. O Ministério Público não é constituído de advogados, quero dizer, não há essa equivalência de função. $O$ promotor está ali para defender o interesse público. [...] No âmbito civil, o MP atua como a gente fala de custus legis, ou seja, ele é fiscal da lei. Então ele intervém em processos dos quais ele não participa, mas ele intervém para ver se está sendo cumprida a lei.
\end{abstract}

Voltando para a estrutura organizacional, o documento 16SI apresenta ainda para o cenário distrital a Defensoria Pública do Distrito Federal - DPDF, atua nos casos relacionados à área da saúde por meio do Núcleo da Saúde. Conforme o próprio órgão, a responsabilidade da DPDF versa sobre a garantia da efetivação do direito à saúde. E a Defensoria apresenta-se aos cidadãos por meio do seguinte texto institucional:

A Defensoria Pública do DF atua na garantia de direitos à saúde de qualquer cidadão, independente da condição financeira ou pagamento de impostos, que comprove com declaração, fornecida durante o atendimento, a condição atual de hipossuficiência de renda. Estrangeiros que residem no Brasil ou visitam nosso país gozam também desse direito.

É principalmente no acesso aos serviços de saúde que a Defensoria Pública do DF pode auxiliar você. Consultas médicas, medicamentos, cirurgias e tratamentos em geral muitas vezes não são acessíveis a toda população. No entanto, a saúde é tão importante, que é assegurada na própria Constituição de nosso país como um direito social fundamental.

Assim, se você (ou algum familiar) não conseguiu atendimento no SUS ou lhe foi negado acesso ao tratamento indicado pelo seu médico, a Defensoria Pública poderá agir para que seu direito à saúde seja respeitado.

Para isso, basta procurar o Núcleo de Saúde munido de documentos pessoais, relatórios de profissionais do SUS e outros documentos que demonstrem a necessidade do tratamento (DEFENSORIA PÚBLICA DO DISTRITO FEDERAL, 2016a). 
Conforme determinada pela $\mathrm{CF}$ de 88 , as defensorias públicas possuem independência funcional e administrativa. A Seção IV dispõe especificamente sobre a defensoria pública, em seus artigos 134 e 135. E, assim como o Ministério Público, é um órgão importante para o controle jurisdicional das políticas públicas e para assegurar a efetiva prestação dos direitos constitucionais e da democracia no país (BRASIL, 1988).

Os achados da pesquisa apresentados nesta categoria foram organizados e sintetizados no Apêndice AC. 


\subsubsection{Recursos Humanos}

Para a descrição desta subcategoria, segue-se a organização das informações apresentadas na subseção anterior, sobre a estrutura organizacional relacionada ao caso.

\section{União}

\section{a. Poder Judiciário - Sistema Judiciário}

O sistema judiciário se refere então à um dos três poderes e, pelos achados da pesquisa, tem os seguintes órgãos, comissões e afins envolvidos no processo de judicialização da saúde no nível federal: o Conselho Nacional de Justiça (CNJ); Grupo de Trabalho para estudo das ações em saúde; Fórum Nacional do Poder Judiciário para monitoramento e resolução das demandas de assistência à saúde e o Supremo Tribunal Federal - STF.

Para simplificar, assim como designado pelo $\mathrm{CNJ}$, o Fórum acima citado será referenciado como Fórum da Saúde.

Segundo o documento 69LN, o grupo de trabalho do CNJ para estudos das ações em saúde, de 2009, teve como componentes os seguintes representantes nacionais:

(1) juiz da $5^{\text {a }}$ Vara da Fazenda Pública do Estado da Bahia;

(2) juiz da $10^{\text {a }}$ Vara da Fazenda Pública do Estado do Rio de Janeiro;

(3) juiz da $5^{\text {a }}$ Vara Federal de Pernambuco;

(4) desembargador do Tribunal Regional Federal da $4^{\mathrm{a}}$ Região; e

(5) especialista em direito sanitário (BRASIL, 2009e).

À época, era possível a participação de outros interessados, como autoridades e especialistas nas matérias de discussão (BRASIL, 2009e).

Já o Fórum da Saúde é coordenado pelos Conselheiros integrantes da Comissão de Relacionamento Institucional e Comunicação do CNJ. Além desta coordenação, o fórum é composto pelos comitês executivos. Estes comitês serão compostos por magistrados das unidades jurisdicionais e outros especialistas. E o fórum pode ainda receber a participação de autoridades e especialistas, assim como o grupo de trabalho de 2009, bem como representantes do Conselho Nacional do Ministério Público, do Ministério Público Federal, dos Estados e do Distrito Federal, das Defensorias Públicas, da Ordem dos Advogados do Brasil, de universidades e outras instituições de pesquisa (documento 71LN) (BRASIL, 2010b). 
Para reavivar o Fórum da Saúde, em 2016 foi constituído novo Comitê Organizador permanente deste fórum nacional. Este é composto por:

(1) Juiz Auxiliar da Presidência do CNJ;

(2) Um conselheiro representante do Conselho Nacional do Ministério Público (CNMP);

(3) Promotor de Justiça do Ministério Público do Estado de São Paulo;

(4) Desembargador do Tribunal Regional Federal da 4a Região;

(5) Desembargador do Tribunal de Justiça do Estado de Minas Gerais;

(6) Juiz do Tribunal de Justiça do Estado da Paraíba;

(7) Defensor Público da Defensoria Pública do Distrito Federal;

(8) Diretor substituto do Departamento de Atenção Especializada do Ministério da Saúde;

(9) Secretário-Geral da Agência Nacional de Saúde Suplementar (ANS);

(10) Diretor da Agência Nacional de Vigilância Sanitária (Anvisa);

(11) Assessora Jurídica do Conselho Nacional de Secretários de Saúde (CONASS);

(12) Assessora Jurídica do Conselho Nacional de Secretarias Municipais de Saúde (CONASEMS);

(13) Médico e Professor da Faculdade de Medicina da Universidade de São Paulo; e

(14) Médico e Professor da Faculdade de Medicina da Universidade de São Paulo (documento 75LN) (BRASIL, 2016c).

Quanto ao STF, a composição deste tribunal, segundo o documento 1LN, é de onze ministros, que sejam referência quanto ao conhecimento e atuação jurídica. Além disso, os candidatos devem ter mais de trinta e cinco anos e menos de sessenta e cinco anos de idade. A escolha se dá pela maioria absoluta de votos do Senado Federal e a posterior nomeação parte da Presidência da República (BRASIL, 1988).

\section{b. Poder Executivo - Sistema de Saúde}

Conforme documento 8SI, a Consultoria Jurídica do MS tem como composição, no momento desta pesquisa:

(1) Consultor - Advogado da União - direção e gestão-geral das ações da CONJUR;

(2) Coordenador-geral de acompanhamento jurídico - Advogado da União coordenação-geral das atividades de defesa do MS em matérias judicializadas; 
(3) Responsável pelo Núcleo em matérias de saúde e atos normativos - procurador federal - coordenação-geral das atividades de elaboração de atos normativos e manifestações consultivas em matérias de saúde;

(4) Responsável pelo Núcleo de Gestão - NUGEST/MS - procurador federal coordenação-geral das atividades estratégicas e de gestão administrativa da CONJUR;

(5) Chefe de gabinete: organização das atividades de gabinete; e

(6) Assessores do Núcleo de Gestão - NUGEST/MS - coordenação das atividades de planejamento estratégico da CONJUR (MINISTÉRIO DA SAÚDE, 2016e).

Conforme documentos e sítio institucional, o Núcleo Jurídico da SCTIE/MS está ligado à uma área técnica do MS, diferentemente da CONJUR/MS, que é uma Consultoria Jurídica para todo o Ministério. O Núcleo Jurídico tem interface com a Comissão Nacional de Incorporação de Tecnologias do SUS - CONITEC e com o Núcleo Técnico de Farmacêuticos - NUT/CONJUR. Logo, a equipe é composta dos advogados competentes, aliados às comissões do NUT/CONJUR e da CONITEC (documento 9SI) (MINISTÉRIO DA SAÚDE, 2016f).

\section{c. Funções Essenciais à Justiça}

Quanto ao Ministério Público Federal - MPF, parte do MPU, ele é composto por servidores analistas que fornecem apoio jurídico ao órgão, servidores técnicos para suporte técnico-administrativo e membros procuradores da república (documento 11SI) (MINISTÉRIO PÚBLICO FEDERAL, 2016).

Ainda sobre o MPF, porém quanto à Procuradoria-Geral da República, além do Procurador-Geral da República, tem-se como membros 73 subprocuradores-gerais da República. E, como servidores, há os cargos de analista para apoio jurídico, apoio técnicoadministrativo, técnico-especializado, médico, perito, saúde e técnico da informação e comunicação. Além dos cargos para analistas, há os técnicos em apoio técnico-administrativo e saúde (documento 15SI) (PROCURADORIA-GERAL DO DISTRITO FEDERAL, 2016).

Conforme documento 12SI, a DPU tem dois defensores públicos atuantes na área da saúde. Cada um deles atua em uma unidade da DPU e, estas, possuem um defensor públicochefe e um defensor público-chefe substituto (DEFENSORIA PÚBLICA DA UNIÃO, 2016a). 


\section{Distrito Federal}

\section{a. Poder Judiciário - Sistema Judiciário Distrital}

Quanto ao TJDFT, já foi citado que o espaço de trabalho específico com a saúde é desenvolvido por meio do Comitê Executivo Distrital da Saúde/TJDFT (Fórum da Saúde). Então, quanto à sua composição, assim como os demais comitês estaduais, é bem diversa. Este grupo não possui membros do DF somente, mas também da União. Este comitê é constituído por integrantes do sistema judiciário, do sistema de saúde e por outras instituições de interesse. Da parte jurídica, são participantes alguns magistrados do TJDFT e da Justiça Federal, defensores públicos do DF e também da União e advogados da OAB. Da parte da saúde, compõem o comitê gestores da SES/DF, membros do Conselho Regional de Medicina do DF e pesquisador da FIOCRUZ. Além destes, há também representantes de planos de saúde, de empresas de seguro, de cooperativas e outras instituições que tenham interesse na temática (documento 12SI) (TRIBUNAL DE JUSTIÇA DO DISTRITO FEDERAL, 2016b).

O último documento disponível sobre a alteração da composição do Comitê é a portaria GPR $\mathrm{n}^{\mathrm{o}}$ 1.735, de 14 de outubro de 2014 (documento 79LN). Esta apresenta a seguinte composição para o Comitê:

(1) Dois juízes de direito do TJDFT;

(2) Secretário-adjunto de saúde - SES;

(3) Corregedor geral, da Corregedoria da Saúde, da SES/DF;

(4) Chefe do Núcleo de Judicialização $d a$ SES/DF;

(5) Subsecretário de administração geral - SUAG/SES;

(6) Diretora de regulação da SES;

(7) Subsecretário de atenção à saúde - SAS/SES.

(8) Defensora pública Federal;

(9) Defensor público Federal;

(10) Quatro defensores públicos do DF;

(11) Promotor de justiça de Defesa da Saúde;

(12) Dois promotores de justiça do MPDFT;

(13) Três procuradores gerais do DF;

(14) Advogado - OAB/DF;

(15) Conselheiro seccional da OAB/DF;

(16) Pesquisador da FIOCRUZ e coordenador do Programa de Direito Sanitário;

(17) Presidente do Conselho Regional de Medicina-CRM/DF; 
(18) Representante do Sindicato Brasiliense de Hospitais Privados;

(19) Coordenador de apoio técnico da Agência Nacional de Saúde Suplementar ANS/DF;

(20) Secretário-Geral da Agência Nacional de Saúde Suplementar - ANS/DF;

(21) Superintendente executivo do Instituto de Estudos de Saúde Suplementar - IESS;

(22) Representante da União Nacional das Instituições de Autogestão em Saúde UNIDAS;

(23) Representante da Agência Nacional de Vigilância Sanitária, ANVISA;

(24) Representante do CASSI;

(25) Representante da UNIMED do Brasil;

(26) Representante da Unimed do Brasil/Unimed Cerrado;

(27) Dois representantes do Golden Cross;

(28) Representante do AMIL;

(29) Representante da Associação Médica de Brasília - AMBr;

(30) Representante da Associação Brasileira de Medicina de Grupo- ABRAMGE;

(31) Dois representantes da FENASAÚDE (BRASIL, 2014i).

Por fim, como a portaria data de 2014, cabe acrescentar a relação de presentes na última reunião do Comitê, de 16 de junho de 2016: (1) Juiz de Direito Titular da 21 a Vara Cível de Brasília (coordenação), (2) Secretário de Saúde do DF, (3) 1ª PROSUS/MPDFT; (4) Subsecretário de Atenção Integral à Saúde, (5) Assessoria Jurídica da SES/DF, (6) Coordenador da Pediatria da SES/DF; (7) Diretor de Assistência Farmacêutica-DIASF/SES, (8) Promotor de Justiça do MPDFT, (9) Coordenador de Fiscalização do CRM/DF, (10) Cons. Jurídica do CRM/DF, (11) PGDF, (12) Defensor Público Federal, (13) Gerente da Assistência Intensiva - GEAI/SAS/SES, (14) Defensor Público do DF, (15) Diretora de Regulação da SES/DF - DIREG/SUPRAC/SES/DF, (16) Diretoria de Atenção Especializada CATES/SAIS/SES/DF, (17) PGDF, (18) Assessoria da Diretoria de Regulamentação da SES/DF, (19) Assessoria de Comunicação da SES/DF (documento 33AT) (TRIBUNAL DE JUSTIÇA DO DISTRITO FEDERAL E TERRITÓRIOS, 2016d).

A composição do Comitê varia nos diferentes documentos, mas pode-se perceber que há uma diversidade nos órgãos de origem dos componentes e isto enriquece e qualifica a discussão sobre as demandas da saúde.

Como nova proposta, já aprovada, estão os NATs, citados na subcategoria anterior. Estes núcleos serão compostos de forma multidisciplinar, se seguirem os modelos já 
existentes em alguns estados brasileiros. Sua composição poderá envolver: funcionários administrativos; farmacêuticos; nutricionistas; enfermeiros, médicos (documento 27AR) (FERREIRA; COSTA, 2013).

\section{b. Poder Executivo - Sistema de Saúde Distrital}

O Núcleo Jurídico da SES-DF - NJUD/SES-DF tem, conforme o decreto $\mathrm{n}^{\circ} 36.918$, de 26 de novembro de 2015 (documento 66LN) um cargo de chefia de confiança (BRASIL, 2015g). Além disto, conforme entrevistas realizadas, verificou-se que o Núcleo é composto por advogados da SES/DF, um farmacêutico e outros funcionários administrativos.

O entrevistado 9EN explica que há somente um farmacêutico atualmente no Núcleo e que o mesmo tem jornada de trabalho de 20 horas semanais. E cita que anteriormente havia outro farmacêutico, que foi transferido para outro setor da SES-DF.

Este outro profissional, o entrevistado 6EN comenta também:

Sem brincadeira, eu acho que passavam mais de 100 processos por mim por semana. Medicamentos. Então, assim, é um volume muito grande, mas a maioria... eu fazia pareceres mesmo e o [...] era o responsável pela compra. E quando eu saí de lá, ele está com tudo agora.

Na SES-DF há, ainda, o Núcleo de Farmácia Ambulatorial Judicial, submetido à DIASF/SES-DF (documentos 29AR e 1SI) (CONTI et al, 2015; SECRETARIA DE ESTADO DE SAÚDE DO DISTRITO FEDERAL, 2016a). De acordo com visita e entrevista realizada no núcleo, o mesmo estava em funcionamento com um profissional farmacêutico na chefia e quatro outros farmacêuticos realizando atividades administrativas e de atendimento ao público, no turno visitado.

A CAMEDIS é composta por um representante da SES-DF e por outro da Defensoria Pública do Distrito Federal (documento 9NS) (AGÊNCIA BRASÍLIA, 2013). Os documentos 22AR e 79NJ ainda acrescentam que a SES-DF coordena a câmara (PAIM; MARQUETTO; LOPES, 2016; TRIBUNAL DE JUSTIÇA DO DISTRITO FEDERAL, 2013a) e que há um membro titular e um suplente para cada instituição (documento 80LN) (BRASIL, 2013m). 


\section{c. Funções Essenciais à Justiça no DF}

A PROSUS, do MPDFT, é integrada por promotores de justiça e promotores de justiça adjuntos (documento 15SI) (PROCURADORIA-GERAL DO DISTRITO FEDERAL, 2016).

Já a PROMAI, da Procuradoria-Geral do DF, é constituída por um procurador-chefe e duas assessoras, um procurador-coordenador de saúde, um procurador-coordenador de meioambiente e um diretor de suporte administrativo (PROCURADORIA-GERAL DO DISTRITO FEDERAL, 2016).

Conforme documento $1 \mathrm{LN}$, cada unidade jurisdicional deve ter o número de defensores públicos adequado para que seja atendida a demanda de cada população (BRASIL, 1988). E os documentos 9 NS e 16SI informam que, no Distrito Federal, há dois locais de atendimento em saúde da DPDF e dois defensores coordenadores para o atendimento de demandas da saúde. Uma das localidades atende no horário comercial e é responsável de fato pelo Núcleo da Saúde, recebendo a maioria dos atendimentos. Este serviço possui um defensor público coordenador. O outro núcleo realiza os atendimentos no período da noite, finais de semana e feriados e possui outro defensor coordenador (AGÊNCIA BRASÍLIA, 2013; DEFENSORIA PÚBLICA DO DISTRITO FEDERAL, 2016a).

Pela entrevista realizada na DPDF, Núcleo da Saúde, complementa-se a informação de que há vários voluntários executando o trabalho administrativo do Núcleo, bem como há um trabalho inédito sendo realizado por um profissional farmacêutico voluntário do Conselho Regional de Farmácia do Distrito Federal.

Em entrevista foi citado pelo entrevistado 11EN sobre a possível atuação de um farmacêutico na DPDF:

Inclusive, com presença de especialistas do Conselho Regional de Farmácia. Que todos eles se manifestassem para verificar, "esse medicamento, realmente, atende esse paciente?", "ele é uma exceção ao caso concreto ou ele deveria ser padronizado e retirado o outro que teria menos, menor eficiência?".

Em complementação, o entrevistado 12EN explica:

Que a sociedade precisa do farmacêutico. E eu vim, a gente veio, o conselho veio atrás da Defensoria, justamente, para a gente agregar essa atribuição.

Os dados desta subcategoria foram sistematizados no Apêndice AD. 


\subsubsection{Recursos Financeiros}

Com relação à subcategoria dos recursos financeiros, assim como para o caso 01, cabe aqui também dois tipos de informações relevantes. O primeiro deles seria o panorama dos gastos públicos com as ações judiciais em saúde e o segundo tipo envolveria as normas relacionadas à estes gastos.

O CNJ, assim como outros envolvidos com a judicialização da saúde, reconhecem a grande quantidade de ações relacionadas à assistência à saúde em tramitação e, de interesse para esta subcategoria, o expressivo dispêndio de recursos financeiros que é gerado para o governo (documento 12J) (BRASIL, 2010c).

Há um entendimento de que somente os direitos sociais acarretam gastos para o governo. Este raciocínio é elaborado pela própria definição destes direitos envolver a prestação de serviços por parte do governo para a sua garantia. Porém, para que os direitos de primeira dimensão possam ser garantidos ao cidadão, algumas condições mínimas de suporte também são necessárias. Por exemplo, para haver liberdade, são necessárias a segurança pública, a manutenção dos espaços públicos, entre outros. E estas condições exigem serviços governamentais. Logo, havendo grandes gastos por parte do governo, a administração pública tem que determinar prioridades para a garantia dos direitos sociais. E, por extensão, a intervenção do Poder Judiciário também deverá ter critérios pois estes gastos se somarão aos demais pré-existentes (documento 26AR) (LIMBERGER; SOARES, 2010).

Porém, em muitos casos, o STF tem decidido manter as decisões dos tribunais quanto à execução de medidas que garantam o cumprimento do direito à saúde, ainda que em ações individualizadas. Quer dizer, em função do direito Constitucional e das normas infraconstitucionais que o organizam, é papel do Poder Judiciário garantir o seu cumprimento, ainda que atinja a esfera orçamentária. Por outro lado, considerando a previsão legal da lei orçamentária, legitimada pelo Poder Legislativo, não caberia ao Poder Judiciário ou ao Poder Executivo, interferir nesta regulamentação. Pois, a partir de uma decisão judicial e da sua execução, os gastos realizados terão ferido a previsão orçamentária inicial e o trabalho do Legislativo (documento 16AR) (MAZZA; MENDES, 2014).

A rigor, nesta seara dos custos relacionados às ações judiciais, o gestor público poderia ser punido pela Lei de Crimes Fiscais em função da ordenação de despesas não previstas em lei ou, ainda, por crime de responsabilidade fiscal, também por executar despesa não prevista ou por gasto superior ao previsto. Há também a problemática de realocar recursos para executar as decisões judiciais e retirar de outras políticas de saúde ou mesmo de 
políticas de outras áreas, prejudicando outros cidadãos que receberiam os outros serviços (MAZZA; MENDES, 2014). Percebe-se a complexidade de um cenário no qual a execução de uma decisão judicial legítima, de efetivação de um direito constitucional, fere outras normas da administração pública ou pode prejudicar a coletividade.

A realidade para a União, estados e municípios é de que, apesar do aumento anual do montante investido com a aquisição de medicamentos, as ações judiciais por estes produtos também está em fase crescente. Ou seja, ainda que o governo amplie seu poder de compra por meio da realização das políticas públicas, a prática da judicialização continua crescendo. $\mathrm{O}$ documento 17AR mostra que o percentual investido pelo Ministério da Saúde com medicamentos, em 2002 era de 5,4\%. Já em 2007 este percentual passou para 10,7\%. E mesmo diante do aumento do investimento, em 2007 foram gastos R \$ 500.000.000,00 (quinhentos milhões) no país (esferas federal, estadual e municipal) (MACEDO; LOPES; BARBERATO-FILHO; 2011).

Ainda no âmbito da União, entre os anos de 2010 e 2014 os gastos com ações judiciais pelo Ministério da Saúde cresceram cerca de 500\%, totalizando mais de 2,1 bilhões de reais neste período. Esta ações incluem procedimentos, equipamentos, medicamentos e depósitos judiciais. No ano de 2010 os gastos foram de 139,6 milhões de reais e atingiu um valor de 838,4 milhões de reais somente no ano de 2014 (documento 1NS) (MINISTÉRIO DA SAÚDE, 2015).

Já os documentos 1NS, 2SI e 2NS informam que entre 2010 e maio de 2016 os custos foram de 3,9 bilhões de reais de recursos da União com ações judiciais em saúde. Em 2010, o valor utilizado para as ações foi de 139,6 milhões de reais. Em 2014 chegou à 838,4 milhões de reais. E, em 2015, os gastos foram de 1,2 bilhão de reais. E somente no ano de 2016 já foram gastos 686,4 milhões de reais (MINISTÉRIO DA SAÚDE, 2015; 2016a; 2016c).

Compreende-se dos dados que em quase seis anos e meio (2010 a maio de 2016) os custos com a judicialização pela esfera Federal foi aproximadamente três vezes o valor do total gasto somente no ano de 2015. E somente neste início de 2016 os gastos já foram superiores a meio milhão de reais. Logo, nos últimos anos, o crescimento desta prática tem aumentado surpreendentemente e os gastos acompanham o volume de ações. A comparação entre os gastos de 2010 a 2014 (2,1 bilhões de reais) e os gastos do ano 2015 sozinho (1,2 bilhão de reais) também retrata a proporção dos custos para os últimos anos.

Um documento (30AR) da pesquisa ilustra o impacto orçamentário da judicialização de medicamentos de alto custo para o país. Foram exploradas as ações de três medicamentos, impetradas contra a União entre 2006 e 2010. Logo, o responsável pela execução das decisões 
de fornecimento foi o Ministério da Saúde, no âmbito federal. Tratava-se da judicialização de três medicamentos para doenças hereditárias raras, o laronidase, o idursulfase e o galsulfase. As ações foram abertas por 195 indivíduos, em um total de 196 processos (DINIZ; MEDEIROS; SCHWARTZ, 2012). Os custos e a distribuição por pacientes foram organizadas na Tabela 5.1 .

Tabela 5.1 - Custos de três medicamentos de alto custo, por ações judiciais ao MS, entre 2006 e 2010.

\begin{tabular}{ccc}
\hline Medicamento & N de pacientes & Custos (R\$) \\
\hline (1) Laronidase & 24 & $9.262 .981,00$ \\
(2) Idursulfase & 68 & $86.985 .457,00$ \\
(3) Galsulfase & 103 & $123.416 .039,00$ \\
\hline TOTAL & 195 & $219.664 .476,00$
\end{tabular}

Fonte: Da autora.

Ainda sobre este caso, um a cada vinte pacientes faleceram durante o tratamento. E, quanto aos custos, houve uma variação significativa no valor de compra destes medicamentos ao longo dos anos de aquisição. Para o medicamento (1) a variação foi de $28 \%$, para o medicamento (2) foi de $716 \%$ e, para o (3), foi de 146\%. Não há justificativa registrada para a variação de preço, mas o estudo entende que a capacidade de controle do preço de compra é perdido pelo MS em função das pequenas compras e pelo monopólio de alguns laboratórios sobre a venda. Percebe-se, então, uma grande variação nos preços dos medicamentos e se as compras tivessem sido realizadas pela média dos cinco menores preços pagos, teria havido uma economia de $\mathrm{R} \$ \mathbf{8 4 . 0 0 0 . 0 0 0 , 0 0}$ (oitenta e quatro milhões) durante os cinco anos analisados. Os autores observaram que foi uma iniciativa do MS a compra em lotes a cada oito meses (DINIZ; MEDEIROS; SCHWARTZ, 2012).

Com o mesmo objetivo de ampliar o volume de compra e reduzir os preços, o entrevistado 9EN explica que as compras de medicamentos judicializados são realizadas pela SES-DF com uma programação de seis meses. E, três meses antes do término dos produtos, o grupo de compras do próprio NJUD/SES-DF já realiza uma nova compra, em função da demora neste processo, para evitar o desabastecimento e a falta de continuidade do tratamento destes pacientes judicializados. O mesmo entrevistado explica que para os tratamentos crônicos, a ação judicial garante o recebimento do medicamento continuamente, por toda a vida, sem necessidade de renovação de algum documento ou abertura de novo processo. 
O ministro da saúde em exercício em 2015, Marcelo Casto, comentou no documento 1NS:

\begin{abstract}
O caráter imediatista do cumprimento das decisões judiciais pode levar ao desperdício de recurso público uma vez que a aquisição dos medicamentos e insumos não é feita de maneira planejada e nem por meio de processo criterioso. Precisamos nos organizar de modo a não sobrecarregar um orçamento já subfinanciado (MINISTÉRIO DA SAÚDE, 2015).
\end{abstract}

O documento 31AR, do Conselho Nacional de Secretários de Saúde, registra a preocupação para com o orçamento da saúde, que está sendo reduzido em função do ajuste fiscal. O aumento da insuficiência orçamentária, nos últimos anos, está gerando esta redução no orçamento da saúde. Há então uma apreensão quanto a necessidade de novas fontes para o financiamento do SUS. Comparativamente, em 2014 foram gastos R $\$ 1.063,00$ per capita pelo SUS e R \$ 2.818,00 per capita pelos planos privados de saúde. E estes planos possuem clientela quatro vezes menor, além de isenções fiscais e empréstimos a juros subsidiados (CONSELHO NACIONAL DE SECRETÁRIOS DE SAÚDE, 2016b).

Estes dados mostram que o orçamento da saúde já está em situação difícil, mesmo sem considerar os gastos não previstos com as ações judiciais. Consequentemente, uma das medidas importantes para reorganizar os gastos públicos deve ser a criticidade com a análise das ações judiciais e outras ações possíveis para a redução dos custos com o processo de judicialização e com o financiamento das ações e serviços requeridos pelas ações.

A prática da mediação é uma das medidas que gera uma redução das ações judiciais. E, no campo orçamentário, acaba por gerar uma importante redução de gastos públicos. De acordo com um dado do Ipea, o custo médio de uma ação judicial é de $\mathrm{R} \$$ 5.606,67 (cinco mil, seiscentos e seis reais e sessenta e sete centavos). No cenário do DF, com a atividade da CAMEDIS que já totalizou até o ano de 2016 aproximadamente 260 mediações, foram economizados cerca de $\mathrm{R} \$ 1.500 .000,00$ (um milhão e quinhentos mil) dos gastos públicos (documento 22AR) (PAIM; MARQUETTO; LOPES, 2016).

E, de acordo com o documento 2AT, o promotor que compõe o Comitê Executivo de Saúde do DF;

Indaga se a Comissão de Judicialização está acompanhando o custo da Judicialização, através da execução dos “empenhos”. Dr. Luis Guilherme informa, em resposta, que Dra. Lucimar detém a tabela de custos de cada ordem judicial. Dra. Lucimar, a seu tempo, esclarece que o primeiro estudo realizado foi o custo para a SES/DF das horas dos inúmeros profissionais envolvidos nas ações judiciais (por volta de R\$ 10.000,00), sem contar produto, preço da cirurgia e material. No que pertine à indagação da Dra. Maria Célia, diz que dispõe de alguns preços por categoria de material. (TRIBUNAL DE JUSTIÇA DO DISTRITO FEDERAL E TERRITÓRIOS, 20111, p. 9) 
Estes dados retratam que a judicialização gera não só os gastos da aquisição dos produtos ou serviços requeridos, mas o processo em si também onera o poder público pela necessidade de estabelecimento de novos fluxos operacionais.

Além do panorama dos custos das ações judiciais, outro foco de análise seria voltado para a questão prática do processo, quanto aos aspectos da operacionalização das compras do medicamentos judicializados, da proveniência dos recursos, entre outros aspectos.

Os impactos da judicialização sobre o orçamento público também é pauta das reuniões do Comitê Executivo de Saúde do Distrito Federal. No documento 1AT tem-se o registro do coordenador do comitê, um juiz de Direito do TJDFT, questionando como estaria o andamento das ações judiciais por medicamentos. O subsecretário de atenção à saúde informa que há demora no processo licitatório, pela própria natureza burocrática deste, e isto dificultava a aquisição dos medicamentos e o cumprimento das ações judiciais. Também afirma que iria propor ao governador do DF uma ampliação do fundo de judicialização para atendimento das demandas judiciais relativas a medicamentos (TRIBUNAL DE JUSTIÇA DO DISTRITO FEDERAL E TERRITÓRIOS, 2011m).

Apesar deste registro, de 2011, não houve menção atual sobre um fundo específico para a judicialização. Na verdade, o explicado pela SES-DF é que os recursos são deslocados de políticas e programas de saúde, sem um fundo específico para a judicialização.

$\mathrm{O}$ entrevistado 2EN, pela SES-DF, explicou quando questionado se a DIASF planejaria o orçamento para as compras relativas aos medicamentos judicializados:

\begin{abstract}
Não. Então, assim, a gente acredita que com...o que a gente coloca a mais, considerando o aumento da população e o aumento do consumo anual, já cobriria. Só que a judicializaçao, eu não posso colocar ela no PLOA, primeiro porque o orçamento, ele não é de gestão da DIASF. Eu faço a previsão da DIASF. E outra coisa, a judicialização, ela tem uma prerrogativa de que ela pode usar o orçamento de qualquer programa de trabalho. Então, atender ação judicial, eu posso usar... aqui, eu estou definindo as ações orçamentárias da assistência farmacêutica, certo? Mas, eu tenho uma ação orçamentária que não é da assistência farmacêutica, é da nossa Subcretaria. Que são assim, Desenvolvimento de Ações de Atenção à Saúde. É uma ação orçamentária bem ampla. Se não tem dinheiro na assistência farmacêutica, a judicialização pega dinheiro lá. Só que assim, eu não posso pegar dinheiro lá, porque o meu está todo programado.
\end{abstract}

Já o entrevistado 1EN, pelo MS, informou que no caso da União os recursos deslocados para cobrir os gastos com as ações judiciais de medicamentos saem do próprio Departamento de Assistência Farmacêutica (DAF/SCTIE/MS): 
Para cada componente, nós temos uma funcional programática, um orçamento definido que é carimbado. Esse orçamento é para financiamento de medicamentos do CEAF, a nível nacional, anual. A própria LOA. Então, normalmente, a maior parte da ação judicial pega o nosso orçamento. Mas, por exemplo, medicamentos oncologógicos e de oftalmologia, que não faz parte do bloco da assistência farmacêutica, porque ele é competência de uma outra política que é da SAS (Secretaria de Atenção à Saúde), sai do orçamento deles, porque são eles os responsáveis.

E, ao encontro disto, a ata da reunião seguinte (2AT) cita a preocupação com "criação de um suprimento de fundos maior para as aquisições emergenciais" (TRIBUNAL DE JUSTIÇA DO DISTRITO FEDERAL E TERRITÓRIOS, 20111, p). Ou seja, na verdade, em função das ações terem um prazo exíguo de 24 horas para a execução, para o cumprimento das ações era utilizado um fundo emergencial.

Ainda em 2011, o Comitê ou Comissão de Judicialização discute com o restante do Comitê Executivo de Saúde do DF sobre a aquisição de medicamentos e outros produtos demandados pela via judicial. Foi registrado que o diretor da Comissão, à época:

\begin{abstract}
alude às "atas de registros de preço", bem assim às "notas de empenho". Dr. Luis Guilherme noticia a existência de algumas "atas", mas não sabe ao certo como se daria o registro de preços para os medicamentos não padronizados ou se haverá interesse. Em suma, aponta a criação de um suprimento de fundos maior para as aquisições emergenciais. Em aparte, Dr. Paulo informa a tramitação de 6 (seis) processos de compras. Ainda, continua Dr. Luis Guilherme, nas dispensas, acelerar os procedimentos de pagamento (TRIBUNAL DE JUSTIÇA DO DISTRITO FEDERAL E TERRITÓRIOS, 20111).
\end{abstract}

Percebe-se que, a partir desta época iniciou-se a ideia da adoção das atas de registro de preços e das notas de empenho para as compras. E este dado é notável pois já em 2016 estes trâmites são utilizados pelo atual NJUD/SES-DF.

Nas anotações da conversa com o entrevistado 9EN, consta a informação de que tanto para medicamentos padronizados quanto para os não padronizados, se o produto já foi comprado anteriormente, já existem as atas de compra para agilizar o trabalho. Caso não seja o caso, é procedimento usual a abertura de um processo de Dispensa de Licitação - DL - e que, para este caso, ainda há uma demora de 30 a 60 dias para a aquisição. E, ainda que o juiz especifique um período curto para o fornecimento de medicamentos mais urgentes, os processos acabam demorando. Nestes casos, o NJUD/SES-DF informa ao juiz que não há ata de preço e que o procedimento de compra seria mais demorado que o prazo determinado para o cumprimento da ação. 
O entrevistado 10EN explica a rotina para a criação de uma ata de preço:

\begin{abstract}
Aí as meninas me mandam periodicamente, geralmente de seis em seis meses, elas me mandam a relação dos medicamentos. E dentro daqueles medicamentos, a quantidade...a média, o custo médio mensal daqueles medicamentos. Aí ele chega aqui para mim, aí que eu vou elaborar solicitações de registro de preço com a intenção de que isso vire ata, vire uma ata de registro de preço. E com a ata, a gente compra mais barato. Enfim, aí ele vem para cá, vem essa solicitação, eu consulto no nosso sistema e é uma consulta meio manual assim, eu tenho que ir de um a um, código por código. Para eu ver o que está em ata, se ele não está em ata, ele está numa solicitação de registro de preço. Porque se ele não tiver, eu tenho que colocar numa nova. Aí eu vou, faço a filtragem disso, emito as minhas solicitações de registro de preço, geralmente aí para medicamentos que não são padronizados, eu devo ter aí umas 10 a 15 solicitações, cada uma com 20 medicamentos. Então, são bastante, assim, que tem uso contínuo. E assim, constantemente está entrando medicamento, entrando paciente e esse número só aumenta. Aí eu faço essas solicitações de registro de preço, mando, ele segue o fluxo normal para que ele vire uma ata de registro de preço. Quando eu tenho uma ata, ela vale pelo período de um ano.
\end{abstract}

E o entrevistado 8EN reforça a explicação:

Às vezes, sim. Tem um negócio chamado Ata. Quando o medicamento, ele está em Ata, aí é mais rápido. Por exemplo, é como se fosse assim, a Secretaria já fez um pré-contrato de 20 mil comprimidos, aí a gente vai tirando de pouquinho em pouquinho. Essa ata tem validade, sei lá, de um ano, dois anos. Aí a gente vai tirando de pouquinho em pouquinho. Aí é rápido. Mas, quando não tem nem ata, não tem nada, demora demais. Importado então, "nossa senhora".

O documento $10 \mathrm{NJ}$ informa que o Ministério Público já questionou as compras com DL e a SES-DF explicou que o processo licitatório possui 66 passos para a sua realização e isto não permite agilidade ao processo. E acrescentou explicando que muitos medicamentos não têm grande disponibilidade no mercado ou o preço está defasado no mercado, razões que levam à não cotação por parte das empresas (TRIBUNAL DE JUSTIÇA DO DISTRITO FEDERAL E TERRITÓRIOS, 2012a).

Sobre o procedimento de compra, considerando a informação de que este pode demorar de 30 a 60 dias, para casos até de resolução mais rápida, o entrevistado 9EN também explica que as aquisições são iniciadas entre dois a três meses antes do término do tratamento já disponível. Ou seja, as compras são realizadas para um período extenso de tempo e as novas compras são iniciadas com grande antecedência para evitar o desabastecimento.

Este estudo identificou, ainda, quatro tipos de ações judiciais diferentes relacionadas a medicamentos, no que tange o réu da ação: 
(1) Ação única contra a União;

(2) Ação única contra o estado;

(3) Ação contra a União e o estado, como corréus;

(4) Ações paralelas, separadas, uma contra a União e outra contra o estado, com a mesma reclamação.

A observação destes casos é importante para a discussão da responsabilidade solidária apresentada pelos entes federativos (caso 1, 2 e 3, a depender do tipo de medicamento) e também da possibilidade de dois entes cumprirem duas ações judiciais separadas (caso 4) porém com a mesma requisição.

Recentemente, no final de 2015, a União pleiteou em um Recurso Extraordinário, junto ao STF, que não fosse mais tratada como polo passivo de ações em saúde. Ou seja, que não fosse mais acionada como réu em processos judiciais de saúde. Porém, foi colocado por entidades interessadas na questão que a União é a responsável pela padronização dos medicamentos no nível nacional, logo, deve ser responsabilizada também nas ações em saúde (documento 72NJ) (DEFENSORIA PÚBLICA DA UNIÃO, 2015a).

Sobre a questão, a DPU defende a manutenção da União como polo passivo e apresentou sua preocupação de que haja um amplo debate caso a responsabilidade solidária seja aberta à nova votação (documento 73NJ) (DEFENSORIA PÚBLICA DA UNIÃO, 2015b).

O documento 74NJ também reforça a informação:

\footnotetext{
A Proposta de Súmula Vinculante 4 (PSV-4) apresentada pela Defensoria Pública da União pedindo a fixação de responsabilidade solidária entre os Entes da Federação no fornecimento de medicamento e tratamento de saúde foi incluída na pauta desta quinta-feira (12) do Supremo Tribunal Federal (STF). Os ministros ainda retomam a votação dos Embargos no Recurso Extraordinário (RE) 855.178, processo que também trata do tema.

Os embargos de declaração propostos pela Advocacia-Geral da União no RE 855.178 começaram a ser votados em 5 de agosto passado, mas o processo foi interrompido com pedido de vista do ministro Edson Fachin, após o relator Luiz Fux votar pela rejeição. O recurso tenta reverter decisão do Plenário Virtual do STF que encerrou a questão reconhecendo a existência de ampla jurisprudência dominante da Corte Suprema pela legitimidade passiva da União nas ações de saúde (DEFENSORIA PÚBLICA DA UNIÃO, 2015c).
} 
A DPU argumentou (documento 55NJ), à época que:

Deixar a solidariedade constitucional sucumbir frente à repartição infraconstitucional de competências equivaleria a retroceder a tempos anteriores à metade da década de 1990, quando o Poder Judiciário adotava postura tímida na judicialização da política e na própria efetividade do direito à saúde (DEFENSORIA PÚBLICA DA UNIÃO, 2015d, p. 1).

E o Plenário Virtual acrescentou, in verbis:

A conclusão inexorável é no sentido de que negar a solidariedade de União, estados, distrito federal e municípios às prestações de saúde frustrará o direito de muitos cidadãos que vivem em regiões pobres, aumentando as desigualdades regionais. A solidariedade reduz as discrepâncias, uma vez que obriga a União a sanar as falhas locais, mais frequentes e intensas em regiões carentes (DEFENSORIA PÚBLICA DA UNIÃO, 2015d, p.1).

E, para tal Súmula Vinculante, o ministro Ricardo Lewandowski sugeriu a redação de manutenção das responsabilidades: "É solidária a responsabilidade dos entes federativos para o fornecimento de medicamento e tratamento médico das pessoas carentes". A PGR deu parecer favorável e ainda propôs a inclusão do bloqueio de verbas públicas para garantir o cumprimento das decisões judiciais (documento 74NJ) (DEFENSORIA PÚBLICA DA UNIÃO, 2015c, p. 1).

Além desta discussão, a DPU também sustenta, já no ano de 2016, a importância do bloqueio das verbas públicas para os casos de descumprimento de ações judiciais por parte dos entes federativos, no documento $61 \mathrm{NJ}$.

\footnotetext{
No mérito, o documento assinala que a decisão de bloqueio de verbas não viola o princípio da separação de poderes, arrolando jurisprudência do STF favorável à intervenção judicial por opções administrativas que afrontam os princípios constitucionais da administração pública, ainda mais se tratando de direitos indisponíveis assegurados pela Constituição e em favor de pessoa hipossuficiente nos processos relacionados ao direito à saúde. "Assim, entende a Defensoria Pública da União que o Supremo Tribunal Federal deve negar provimento ao recurso, fixando a tese no sentido de ser possível o bloqueio de verbas públicas para o custeio de tratamento de saúde, no caso de descumprimento de ordem judicial por parte do Ente Federado", requer a instituição, por meio do documento (DEFENSORIA PÚBLICA DA UNIÃO, 2016b).
}

Porém, em contraponto, é apresentado o argumento de que este bloqueio causaria desequilíbrio orçamentário.

Como exemplos de processos judiciais no STF de participação da DPU estão (DEFENSORIA PÚBLICA DA UNIÃO, 2016b): 
- Proposta de Súmula Vinculante 4 (PSV-4), de autoria da DPU: sobre a fixação de responsabilidade solidária entre os Entes da Federação nas prestações de saúde.

- Recurso Extraordinário 855.178: também sobre a fixação de responsabilidade solidária entre os Entes da Federação nas prestações de saúde.

- Recurso Extraordinário 566.471: fornecimento de remédio de alto custo fora da lista do Sistema Único de Saúde (SUS).

- RE 657.718: fornecimento de remédios não registrados pela Agência Nacional de Vigilância Sanitária (Anvisa).

Sobre a discussão de solidariedade nas ações em saúde, o documento 14J e 15J explica que a União responsabilizou os estados e municípios pelo fornecimento de medicamentos via ações judiciais e a posição final da DPU é de apoio à tese atual de responsabilidade compartilhada (DEFENSORIA PÚBLICA DA UNIÃO, 2016c; 2016d).

O entrevistado 1EN confirma a atual responsabilidade solidária e comenta:

Que eu me lembro, tem um entendimento do STF, que os tais entes são solidários. Quando uma ação judicial, principalmente, envolve pedido no Tribunal Federal. [...] E muitas vezes, tem se pedido quando tem mais de um ente que está envolvido na ação, que, por exemplo, o estado faça o repasse, entregue o medicamento e depois ele cobra uma parcela da União.

A responsabilidade compartilhada sobre os gastos já era usual para a compra de medicamentos do CEAF/PNAF.

Exemplo, para os medicamentos do CEAF/PNAF, há a organização já apresentada do financiamento:

- Grupo 1A - financiamento pelo MS.

- Grupo 1B - financiamento pelo MS.

- Grupo 2 - financiamento pelo DF (estados).

Cabe informar que, quando a SES-DF cria um novo protocolo e inclui novos medicamentos em sua relação local de medicamentos padronizados, estes serão custeados somente pelo DF.

No caso da judicialização, o financiamento de medicamentos dos grupos do CEAF/PNAF será realizado da mesma forma, pelas mesmas normas de repasse. E o mesmo ocorre para outros medicamentos dos outros componentes, de acordo com a previsão de financiamento prévia. 
Sobre a questão, o documento 16J exemplifica o caso já citado de STA 175:

\begin{abstract}
REPERCUSSÃO GERAL NO RECURSO EXTRAORDINÁRIO 855.178 SERGIPE

RECURSO EXTRAORDINÁRIO. CONSTITUCIONAL E ADMINISTRATIVO. DIREITO À SAÚDE. TRATAMENTO MÉDICO. RESPONSABILIDADE SOLIDÁRIA DOS ENTES FEDERADOS. REPERCUSSÃO GERAL RECONHECIDA. REAFIRMAÇÃO DE JURISPRUDÊNCIA. O tratamento médico adequado aos necessitados se insere no rol dos deveres do Estado, porquanto responsabilidade solidária dos entes federados. O polo passivo pode ser composto por qualquer um deles, isoladamente, ou conjuntamente.

[...] ementa do referido julgado:

Suspensão de Segurança. Agravo Regimental. Saúde pública. Direitos fundamentais sociais. Art. 196 da Constituição. Audiência Pública. Sistema Único de Saúde SUS. Políticas públicas. Judicialização do direito à saúde. Separação de poderes. Parâmetros para solução judicial dos casos concretos que envolvem direito à saúde. Responsabilidade solidária dos entes da Federação em matéria de saúde. Fornecimento de medicamento: Clopidrogrel 75 mg. Fármaco registrado na ANVISA. Não comprovação de grave lesão à ordem, à economia, à saúde e à segurança pública. Possibilidade de ocorrência de dano inverso. Agravo regimental a que se nega provimento (STA 175-AgR, Rel. Min. Gilmar Mendes, Plenário, DJe 30/04/2010) (DEFENSORIA PÚBLICA DA UNIÃO, 2016e).
\end{abstract}

Para outros medicamentos, o financiamento será realizado pelo ente que recebe a ação judicial. Por este motivo, por exemplo, a importância de conferir se foi iniciada alguma outra ação judicial pelo mesmo requerente, com a mesma solicitação. Pois, se o DF responde à uma ação realizando a entrega de um medicamento e o paciente fez a mesma solicitação no âmbito da União, o MS pode também executar a mesma decisão e realizar a compra duplicada do produto.

Para melhor compreensão dos casos, cabe apresentar uma informação do documento 20J, relacionado ao MS:

O cumprimento das decisões judiciais pela União se dá das seguintes maneiras

1) Aquisição pelo próprio Ministério da Saúde do medicamento/insumo pleiteado;

2) Depósito do valor necessário à aquisição, pelo próprio paciente, do medicamento/tratamento médico demandado; ;sêp?

3) Repasse aos Estados ou Municípios de parcela do valor do medicamento/tratamento, quando o paciente é por eles atendido e/ou quando a decisão assim determina (MINISTÉRIO DA SAÚDE, 2016g, p.3). 
Ou seja, a prioridade de atendimento das ações é dos estados e municípios, com repasse do recurso pelo MS, quanto à parte que lhe cabe. Se o medicamento não estiver previsto por estes entes e a ação for direcionada à União, o MS realiza a compra do produto ou o depósito em conta bancária. Logo, no caso dos estados e munícipios serem os réus das ações, eles devem cumpri-las e receber o repasse de recursos, quando aplicado ao caso.

Outro aspecto importante, por fim, é a forma de aquisição dos produtos pelos entes federativos. De acordo com os documentos 32AR e 20J, existem diferentes modalidades de compra de medicamentos judicializados. Estas modalidades seriam a dispensa de licitação e a inexigibilidade de licitação. Além destas opções, para o MS há ainda a opção de depósito em conta judicial (INTERFARMA, 2016; MINISTÉRIO DA SAÚDE, 2016g).

A Tabela 5.2 apresenta os valores gastos pelo MS por compras ou por depósito judicial, entre os anos de 2005 a 2012 e tem por base o conteúdo do documento 20J.

Tabela 5.2 - Valores, em reais, gastos pelo Ministério da Saúde para o atendimento de decisões judiciais, de 2005 a 2012.

\begin{tabular}{ccc}
\hline ANO & Compras* & $\begin{array}{c}\text { Depósitos judiciais e repasses aos } \\
\text { estados e municípios }\end{array}$ \\
\hline $\mathbf{2 0 0 5}$ & $2.441 .041,95$ & $116.504,54$ \\
$\mathbf{2 0 0 6}$ & $7.600 .579,92$ & $1.572 .541,17$ \\
$\mathbf{2 0 0 7}$ & $17.530 .346,45$ & $2.417 .575,47$ \\
$\mathbf{2 0 0 8}$ & $47.660 .885,03$ & $6.848 .820,40$ \\
$\mathbf{2 0 0 9}$ & $83.1165 .223,93$ & $12.622 .944,44$ \\
$\mathbf{2 0 1 0}$ & $124.103 .206,10$ & $15.682 .922,20$ \\
$\mathbf{2 0 1 1}$ & $243.954 .000,00$ & $22.106 .705,99$ \\
$\mathbf{2 0 1 2}$ & $287.844 .968,16$ & $68.002 .152,43$ \\
\hline
\end{tabular}

* Compras - se refere à aquisição de medicamentos, equipamentos e insumos concedidos por decisões judiciais. Fonte: Da autora.

Já a Tabela 5.3 apresenta um detalhamento por modalidade de compra, entre os anos de 2012 e 2014. 
Tabela 5.3 - Valores, em reais, gastos pelo Ministério da Saúde para o atendimento de decisões judiciais, de 2012 a 2014.

\begin{tabular}{|c|c|c|c|c|c|}
\hline ANO & $\begin{array}{l}\text { Dispensa de } \\
\text { Licitação (1) }\end{array}$ & $\begin{array}{l}\text { Inexigibilidade } \\
\text { de Licitação (2) }\end{array}$ & $\begin{array}{c}\text { Subtotal } \\
\text { Compras } \\
\text { DELOG }(1+2) \\
\end{array}$ & $\begin{array}{c}\text { Subtotal } \\
\text { Depóstio em } \\
\text { conta Judicial } \\
\end{array}$ & Totais \\
\hline $\begin{array}{l}2012 \\
\%\end{array}$ & $\begin{array}{c}191.651 .854 \\
(52.09)\end{array}$ & $\begin{array}{c}132.802 .071 \\
(36.10)\end{array}$ & $\begin{array}{c}324.453 .925 \\
(88.19)\end{array}$ & $\begin{array}{c}43.442 .024 \\
(11.81)\end{array}$ & 367.895 .949 \\
\hline $\begin{array}{l}2013 \\
\%\end{array}$ & $\begin{array}{l}435.804 .141 \\
(78.82)\end{array}$ & $\begin{array}{l}3.018 .656 \\
\quad(0.55)\end{array}$ & $\begin{array}{c}438.822 .767 \\
(79.37)\end{array}$ & $\begin{array}{c}114.054 .087 \\
(20.63)\end{array}$ & 552.876 .854 \\
\hline $\begin{array}{l}2014 \\
\%\end{array}$ & $\begin{array}{c}628.573 .684 \\
(74.46)\end{array}$ & $\begin{array}{c}74.818 .979 \\
(8.86)\end{array}$ & $\begin{array}{c}703.392 .663 \\
(83.32)\end{array}$ & $\begin{array}{c}140.822 .280 \\
(16.68)\end{array}$ & 844.214 .943 \\
\hline $\begin{array}{l}\text { Variação } \\
\text { 2014/2012 (\%) }\end{array}$ & 227.98 & -43.66 & 116.79 & 224.16 & 129.47 \\
\hline $\begin{array}{l}\text { Acumulado } \\
2012-2014\end{array}$ & $\begin{array}{c}1.256 .029 .679 \\
(71.16)\end{array}$ & $\begin{array}{c}210.639 .676 \\
(11.93)\end{array}$ & $\begin{array}{c}1.466 .669 .355 \\
(83.10)\end{array}$ & $\begin{array}{c}298.318 .391 \\
(16.90)\end{array}$ & 1.764 .987 .746 \\
\hline
\end{tabular}

A análise do impacto orçamentário é importante pois, mesmo considerando demandas justas, em um cenário no qual as políticas fossem o mais eficientes possível, estas ações judiciais teriam impacto financeiro. Por este motivo este aspecto deve ser considerado nas análises judiciais e deve haver o debate para a definição de medidas concretas para remediação. O documento 30AR ainda acrescenta dois impactos de cunho financeiro: a ineficiência causada pelas compras individualizadas (não realizadas em grande escala) e a dificuldade do controle do consumo e estoque destes medicamentos (pois não são geridos pela estrutura da assistência farmacêutica usual do poder executivo) (DINIZ; MEDEIROS; SCHWARTZ, 2012).

O Apêndice AE apresenta uma síntese das responsabilidades com o custeio da judicialização de medicamentos pelos entes Federal e Distrital.

Cabe ainda, pelo conteúdo identificado nesta subcategoria, a elaboração de um Quadro (5.1, a seguir), com a reunião de informações importantes de cunho orçamentário. 
Quadro 5.1 - Aspectos dos impactos orçamentários relacionadas à judicialização de medicamentos.

\begin{tabular}{|c|}
\hline IMPACTOS ORÇAMENTÁRIOS DA JUDICIALIZAÇÃO DA SAÚDE \\
\hline Custos não previstos pela Lei Orçamentária Anual (LOA). \\
\hline Orçamento desviado de outras políticas de saúde ou de outras pastas do governo. \\
\hline Ineficiência causada pelas compras individualizadas, perda da larga escala. \\
\hline Dificuldade do controle do consumo e estoque destes medicamentos. \\
\hline Investimento em estrutura para gerir a execução das ações judiciais. \\
\hline Risco de dois entes cumprirem duas ações judicias independentes, porém sobre a mesma reclamação. \\
\hline
\end{tabular}

Fonte: Da autora.

\subsubsection{Atividades, fluxos e rotinas}

A análise do aparato administrativo segue com a subcategoria das atividades, fluxos e rotinas. E esta acompanhará a mesma organização desenvolvida na primeira subcategoria, da estrutura organizacional. E tem-se como foco desta subseção a apresentação das atividades dos órgãos, departamentos, comissões e outros grupos envolvidos com a judicialização da saúde.

\section{União}

\section{a. Poder Judiciário - Sistema Judiciário}

Como já apresentado pela pesquisa, o Poder Judiciário tem competência essencial sobre a efetivação dos direitos sociais da CF de 1988. Porém, não depende só do controle jurisdicional esta efetivação, pois os aspectos econômicos, culturais e educacionais influenciam no processo de julgamento das demandas e concretização das decisões judiciais. $\mathrm{O}$ documento 6AR ainda acrescenta que, à medida que se investe em serviços de aconselhamento jurídico ao cidadão, aumenta-se a quantidade de litígios e, consequentemente, a necessidade por mais investimento público na resolução destes processos. Estes investimentos envolvem a prestação jurisdicional ampliada e também o investimento social relacionado às ações (CORREA; MASSAFRA, 2004).

O CNJ compõe o Poder Judiciário e é o responsável por controlar a atuação administrativa e financeira dos demais órgãos do mesmo poder. Além disso também supervisiona o "cumprimento dos deveres funcionais dos juízes" com o debate e deliberação. 
A atuação deste órgão é realizada por meio do julgamento de processos de questões administrativas e do recebimento de reclamações, petições ou representações contra o próprio judiciário. Desta forma objetiva garantir a transparência e celeridade aos processos, além de instruir os cidadãos sobre os seus direitos (documento 11AR) (OLIVEIRA, 2013, p. 84).

Um exemplo de atuação do CNJ foi a elaboração e publicação da Recomendação $\mathrm{n}^{\circ}$ 31, de 30 de março de 2010. Esta é uma orientação voltada aos tribunais, para que os julgamentos de ações em saúde possam ter maior agilidade e eficiência (documento 12J) (BRASIL, 2010c). E este documento será investigado na subcategoria discricionariedade operacional.

Há também a portaria $n^{\circ}$ 650/2009 que criava o grupo de trabalho já citado para discussão da judicialização da saúde. Esta norma considera o CNJ um órgão estimulador de políticas institucionais para o próprio Poder Judiciário e isto mostra a importância do órgão para este sistema (documento 69LN) (BRASIL, 2009e).

As atividades do CNJ, portanto, objetivam a garantia dos direitos e da cidadania, a correta prestação jurisdicional, a celeridade nesta prestação jurisdicional, o combate à corrupção e à improbidade administrativa, entre outros. E, como exemplos significativos para o caso tratado, o CNJ busca adotar soluções para os conflitos e para gerir demandas repetitivas (documento 17SI) (CONSELHO NACIONAL DE JUSTIÇA, 2016a). Estes dois últimos objetivos retratam bem as preocupações que o órgão tem para com o caso da saúde pública brasileira e explicam a iniciativa de criação dos grupos de trabalho e do Fórum da Saúde.

Quanto às ações em saúde, o grupo de trabalho formado em 2009 teve como atividades elaborar estudos e propor medidas concretas e normativas referentes às demandas judiciais envolvendo a assistência à saúde (BRASIL, 2009e).

Novamente quanto ao Fórum Nacional do Poder Judiciário para monitoramento e resolução das demandas de assistência à saúde, este tem como atividades (documento 71LN):

I - o monitoramento das ações judiciais que envolvam prestações de assistência à saúde, como o fornecimento de medicamentos, produtos ou insumos em geral, tratamentos e disponibilização de leitos hospitalares;

II - o monitoramento das ações judiciais relativas ao Sistema Único de Saúde;

III - a proposição de medidas concretas e normativas voltadas à otimização de rotinas processuais, à organização e estruturação de unidades judiciárias especializadas;

IV - a proposição de medidas concretas e normativas voltadas à prevenção de conflitos judiciais e à definição de estratégias nas questões de direito sanitário;

V - o estudo e a proposição de outras medidas consideradas pertinentes ao cumprimento do objetivo do Fórum Nacional (BRASIL, 2010b). 
E, o Comitê Organizador deste Fórum, que teve sua composição republicada no ano de 2016 (documento 75LN), tem como funções:

I - conduzir as atividades, organizar a instalação e o funcionamento;

II - elaborar e fazer cumprir o programa de trabalho;

III - organizar encontros nacionais de membros do Poder Judiciário, com ou sem a participação de outros segmentos do poder público, da sociedade civil e de comunidades interessadas, para a discussão de temas relacionados às suas atividades e para a proposição de medidas que contribuam para a solução de questões relacionadas às demandas de assistência à saúde;

IV - promover a realização de seminários e outros eventos regionais, com a participação de membros do Poder Judiciário, de estudiosos e especialistas, e de tantos quantos tenham envolvimento com os temas de seu interesse, para o estudo e o desenvolvimento de soluções práticas voltadas para a superação das questões relacionadas às demandas de assistência à saúde;

V - coordenar os trabalhos dos Comitês Estaduais, propondo ações concretas de interesse local, regional ou estadual;

VI - realizar reuniões periódicas ordinárias ou extraordinárias, sempre que for necessário, para a condução dos trabalhos do Fórum;

VII - participar de outros eventos promovidos por entes públicos ou entidades privadas, sempre que isso se mostrar próprio e adequado à sua integração institucional ou contribuir para a concretização dos objetivos do Fórum;

VIII - indicar membros dos Comitês Estaduais ou Regionais para representar o Fórum em eventos locais ou mesmo de caráter nacional, sempre que isso se mostrar mais conveniente e adequado para o interesse publico;

IX - manter a Comissão Permanente de Acesso à Justiça e Cidadania informada de suas atividades (BRASIL, 2016c).

Por fim, ainda com relação ao Poder Judiciário no âmbito federal, tem-se o STF e suas atribuições. Quanto ao STF, sua importância para a judicialização da saúde é ressaltada pelo documento 11AR, que explica que este órgão é a instância maior do Poder Judiciário apta a garantir à população o cumprimento de seu direito à saúde (OLIVEIRA, 2013).

De acordo com a CF, seu artigo 102 estabelece que este tribunal é responsável pela guarda da Constituição e, para isto, tem como atividades processar e julgar litígios de inconstitucionalidade, de infrações penais comuns, de crimes de responsabilidade, habeas corpus de autoridades descritas no artigo 102 da CF; julgar recursos ordinários; e julgar recursos extraordinários, em única ou última instância relacionados à inconstitucionalidade (documento 1LN) (BRASIL, 1988).

O entrevistado 14EN ainda explica que existe a justiça comum, de alcance estadual e municipal e existe a justiça federal, que é uma justiça especializada. Em entrevista foi dito que:

Com relação às ações que forem propostas contra a União, elas não serão propostas na justiça comum, mas sim na justiça federal, que é uma justiça especializada para assuntos de interesse da União. [...] Ações de interesse da União devem ser propostas na justiça federal, e não no TJDFT, que faz parte da justiça comum. 


\section{b. Poder Executivo - Sistema de Saúde}

A CONJUR/MS é responsável pelas seguintes atividades de natureza jurídica:

(1) assessorar o Ministro da Saúde;

(2) coordenar as atividades jurídicas do MS;

(3) explicar a interpretação da $\mathrm{CF}$ de 88 e das demais normas, garantindo a legalidade administrativa das atividades do Ministério; e

(4) examinar os editais de licitação, contratos e instrumentos congêneres; os atos de inexigibilidade ou de dispensa de licitação (documento 8SI) (MINISTÉRIO DA SAÚDE, 2016e).

Ainda, um representante da Consultoria Jurídica do Ministério da Saúde, Advogado Geral da União, informa que a AGU (vinculada ao MS pela CONJUR) apresenta divisão de funções muito clara - consultivo e contencioso (documento 1NJ) (TRIBUNAL DE JUSTIÇA DO DISTRITO FEDERAL E TERRITÓRIOS, 2011a).

A CONJUR/MS, para garantir os direitos individuais e as demandas da coletividade, apoia juridicamente o Ministério para que sejam respeitadas a Constituição Federal, a Lei Orgânica da Saúde e a Lei de Licitações e Contratos. Isto é realizado por meio de projetos estruturantes do departamento, a saber:

GRUPO 1 - ESTRUTURA FUNCIONAL - Estabelecer organograma, fluxos e rotinas das unidades.

GRUPO 2 - SISTEMAS DE PROCESSOS DIGITAIS E ELETRÔNICOS -

Estabelecer rotinas de trabalho que envolva os sistemas operacionais. (SAPIENS/PEC).

GRUPO 3 - PARECERES REFERENCIAIS - Estruturar processos de pareceres referenciais;

GRUPO 4 - ARQUIVO DIGITAL - Sistematizar o arquivo digital da CONJUR;

GRUPO 5 - ATOS NORMATIVOS - Revisar os atos normativos internos da CONJUR e do MS;

GRUPO 6 - GESTÃO DE PESSOAS - Gerir a força de trabalho e qualificar a mão de obra;

GRUPO 7 - LOGISTICA OPERACIONAL - Garantir a infraestrutura operacional; GRUPO 8 - MONITORAMENTO GERENCIAMENTO/METAS - Gerenciar metas;

GRUPO 9 - AÇÕES DE CONVIVÊNCIA - Integração da equipe;

GRUPO 10 - MANUAL DE REFERÊNCIA DA GESTÃO - Elaborar manual de orientação (MINISTÉRIO DA SAÚDE, 2016e). 
Por fim, a CONJUR/MS é, ainda, responsável pela elaboração de notas técnicas sobre os medicamentos demandados judicialmente, como apoio à defesa da União contra litígios em que o Estado se configura como parte passiva do processo (documento 8SI) (MINISTÉRIO DA SAÚDE, 2016e).

O NJ/SCTIE/MS tem função de assessorar a Secretaria de Ciência, Tecnologia e Insumos Estratégicos no que tange as demandas judiciais relacionadas às tecnologias em saúde e, para este trabalho, em especial os medicamentos (MINISTÉRIO DA SAÚDE, 2016e).

O entrevistado 1EN confirma a presença do NJ na SCITE:

Nós temos na nossa secretaria, também, o núcleo jurídico, que também, fornece as orientações da parte judicial, do orçamento...

\section{c. Funções Essenciais à Justiça}

O MPU, como já mencionado, tem como objetivo proteger a sociedade e, para isto, executa atividade de fiscalização do Estado, em prol do cumprimento da Lei e da oferta dos direitos constitucionais. O MPU protege a coletividade e, se necessário, interpondo ações contra o Estado (documento 7SI) (MINISTÉRIO PÚBLICO DO DISTRITO FEDERAL E TERRITÓRIOS, 2016a).

O entrevistado 13EN informa as responsabilidades do Ministério Público, de acordo com a CF e pertinentes à judicialização da saúde:

\footnotetext{
Inicialmente as funções institucionais do Ministério Público estão contidas no art. 129 da Constituição Federal e, na hipótese do quesito em questão, destacamos os incisos I e II: "Art. 129. São funções institucionais do Ministério Público: [...] II zelar pelo efetivo respeito dos Poderes Públicos e dos serviços de relevância pública aos direitos assegurados nesta Constituição, promovendo as medidas necessárias a sua garantia; III - promover o inquérito civil e a ação civil pública, para a proteção do patrimônio público e social, do meio ambiente e de outros interesses difusos e coletivos.
}

Já o MPF possui Procuradores da República que atuam junto aos juízes federais. Logo, há uma procuradoria da república no DF, envolvida com ações para o âmbito federal. $\mathrm{O}$ artigo 102 da CF de 1988 (documento 1LN) apresenta sobre quais competências o MPF é responsável por julgar e processar e são elas, in verbis: 
I - as causas em que a União, entidade autárquica ou empresa pública federal forem interessadas na condição de autoras, rés, assistentes ou oponentes, exceto as de falência, as de acidentes de trabalho e as sujeitas à Justiça Eleitoral e à Justiça do Trabalho;

II - as causas entre Estado estrangeiro ou organismo internacional e Município ou pessoa domiciliada ou residente no País;

III - as causas fundadas em tratado ou contrato da União com Estado estrangeiro ou organismo internacional;

IV - os crimes políticos e as infrações penais praticadas em detrimento de bens, serviços ou interesse da União ou de suas entidades autárquicas ou empresas públicas, excluídas as contravenções e ressalvada a competência da Justiça Militar e da Justiça Eleitoral;

$\mathrm{V}$ - os crimes previstos em tratado ou convenção internacional, quando, iniciada a execução no País, o resultado tenha ou devesse ter ocorrido no estrangeiro, ou reciprocamente;

$\mathrm{V}-\mathrm{A}$ as causas relativas a direitos humanos a que se refere o $\S 5^{\circ}$ deste artigo;(Incluído pela Emenda Constitucional no 45, de 2004)

VI - os crimes contra a organização do trabalho e, nos casos determinados por lei, contra o sistema financeiro e a ordem econômico-financeira;

VII - os habeas corpus, em matéria criminal de sua competência ou quando o constrangimento provier de autoridade cujos atos não estejam diretamente sujeitos a outra jurisdição;

VIII - os mandados de segurança e os habeas data contra ato de autoridade federal, excetuados os casos de competência dos tribunais federais;

IX - os crimes cometidos a bordo de navios ou aeronaves, ressalvada a competência da Justiça Militar;

$\mathrm{X}$ - os crimes de ingresso ou permanência irregular de estrangeiro, a execução de carta rogatória, após o "exequatur", e de sentença estrangeira, após a homologação, as causas referentes à nacionalidade, inclusive a respectiva opção, e à naturalização; XI - a disputa sobre direitos indígenas (BRASIL, 1988, grifo meu).

Pelo item I observa-se que o MPF poderá se envolver em ações relacionadas à União, quando esta for autora ou ré do processo, sendo este último posicionamento a causa mais comum das ações em saúde.

Além disso, o entrevistado 13EN explica no que a atuação do MPF se baseia na busca por direitos coletivos, e não individuais:

\begin{abstract}
Além disso, é importante ressaltar o teor do art. 15 da LC 75/1993, verbis: Art. 15. É vedado aos órgãos de defesa dos direitos constitucionais do cidadão promover em juízo a defesa de direitos individuais lesados. $\S 1^{\circ}$ Quando a legitimidade para a ação decorrente da inobservância da Constituição Federal, verificada pela Procuradoria, couber a outro órgão do Ministério Público, os elementos de informação ser-lhe-ão remetidos. $\S 2^{\circ}$ Sempre que o titular do direito lesado não puder constituir advogado e a ação cabível não incumbir ao Ministério Público, o caso, com os elementos colhidos, será encaminhado à Defensoria Pública competente.
\end{abstract}

O entrevistado ainda explana sobre como se dá o contato com o cidadão para as demandas em saúde e qual a extensão da ação da procuradoria da república do MPF no Distrito Federal: 
Desses dispositivos, conclui-se que essa Procuradoria da República atuará em casos envolvendo órgãos públicos, entidades autárquicas e empresas públicas no âmbito federal, ou seja, como exemplo, deve envolver o Hospital Universitário de Brasília, o Hospital Geral do Exército Brasileiro, o Hospital das Forças Armadas, o Ministério da Saúde, o Programa Farmácia Popular. Diante desses dispositivos o cidadão dirige-se à Procuradoria da República e relata o seu problema que será posto a termo pelo atendente da Sala de Atendimento ao Cidadão, o SAC ou poderá ser feito o relato por conta do noticiante e protocolado na sede da Procuradoria. Após isso, a reclamação será distribuída a um Procurador da República que detém competência de analisar se a matéria é de atribuição do MPF ou de outro órgão público ou é de direito individual. Portanto, o papel da Procuradoria nos citados feitos devem estar de acordo com os regramentos Constitucionais e Legais e será analisado caso a caso pelo Procurador sorteado para atuar naquele problema específico.

Por último, o entrevistado 13EN ainda apresenta um panorama dos procedimentos instaurados, tanto judicialmente quanto extrajudicialmente, pelo órgão. As informações foram sistematizadas a seguir:

(1) Processos judiciais

2013: 101

2014: 108

2015: 88

$2016\left(1^{\circ}\right.$ semestre $): 33$

(2) Processos extrajudiciais

2013: 16

2014: 25

2015: 37

2016 ( $1^{\mathrm{o}}$ semestre): 12

Sobre a PGR, fisicamente ela é a sede administrativa do MPF. Cabe informar também, que a PGR indica os subprocuradores-gerais da República para atuar no STF (documento 17SI) (PROCURADORIA-GERAL DA REPÚBLICA, 2016).

E, como percebido em alguns documentos, a Procuradoria Federal dos Direitos dos Cidadãos - PFDC solicita, em diversas oportunidades, informações sobre atividades administrativas do Ministério da Saúde, no que tange a gestão da Política Nacional de Medicamentos e seus desdobramentos. E esta atividade objetiva a defesa dos direitos à vida $\mathrm{e}$ à saúde dos cidadãos (documento 21J) (MINISTÉRIO DA SAÚDE, 2016h).

A Defensoria Pública da União - DPU atende a população que necessita de representação jurídica, de forma gratuita. Além disso, organiza atendimentos itinerantes nas 
comunidades do interior, que não têm acesso à uma das setenta e uma unidades da DPU no Brasil. Por fim, realiza atividade de estímulo dos alunos das escolas públicas sobre os direitos, por meio de um concurso de redação (documento 12SI) (DEFENSORIA PÚBLICA DA UNIÃO, 2016a).

O documento $11 \mathrm{AR}$ complementa as atividades da DPU dizendo que é constatada uma grande demanda judicial em saúde de responsabilidade dos defensores públicos (OLIVEIRA, 2013).

\section{Distrito Federal}

\section{a. Poder Judiciário - Sistema Judiciário Distrital}

O TJDFT é responsável, com órgão do Poder Judiciário, por defender os direitos individuais e coletivos garantindo a aplicação da lei. E, para esta pesquisa, interessa as ações voltadas ao direito à saúde. Conforme documento 13SI, observa-se que este tribunal possui estrutura complexa com $1^{\mathrm{a}}$ e $2^{\mathrm{a}}$ instâncias (TRIBUNAL DE JUSTIÇA DO DISTRITO FEDERAL, 2016a). Isto é interessante, pois caracteriza uma peculiaridade do Distrito Federal, pois o entrevistado $14 \mathrm{EN}$ esclareceu que a justiça comum possui as varas, com a $1^{\text {a }}$ instância de entrada de processos, assim como os Tribunais de Justiça Estaduais, com a $2^{\text {a }}$ instância, para recursos dos processos. Explicou também que após o recurso em $2^{\mathrm{a}}$ instância, o processo ainda pode ser encaminhado aos tribunais superiores. E, a depender da matéria da ação, este "terceiro nível” processual será realizado pelo STF, Supremo Tribunal de Justiça, Tribunal Superior Eleitoral Estadual, Tribunal Superior do Trabalho ou Superior Tribunal Militar. No caso da judicialização da saúde, por serem processos relacionados à Constituição e ao direito à saúde, o tribunal envolvido é o STF, como os dados da pesquisa demonstram.

Voltando ao Comitê Executivo Distrital da Saúde, suas atividades se referem ao acompanhamento das ações judiciais em saúde do DF e o debate para que se consiga criar um novo contexto acerca destas demandas. Ou seja, o Comitê monitora as ações, discute sobre elas, tenta coordenar e executar ações para a resolução dos problemas que levaram às ações e ainda procura estabelecer um diálogo produtivo com as partes envolvidas com as ações e serviços de saúde (tanto públicas quanto privadas, como com as operadoras de planos de saúde). Deve-se lembrar que as instituições envolvidas com a judicialização da saúde lidam com ações de fornecimento de medicamentos, mas também relacionadas à outros produtos, ao acesso à exames, cirurgia, leitos, entre outros (documento 14SI) (TRIBUNAL DE JUSTIÇA DO DISTRITO FEDERAL, 2016b). 
A portaria $n^{0}$ 25/2011 (documento 72LN), que designa alguns dos comitês executivos estaduais, também dispõe sobre as competências destes. São estas:

I. Promover a integração dos Tribunais Estaduais, Regionais Federais e do Trabalho com o Comitê Executivo Nacional do Fórum;

II. Manter permanente interlocução com o Comitê Executivo Nacional;

III. Realizar e cooperar nos trabalhos relacionados as objetivos do Fórum no âmbito de seus Estados e Regiões, sob a coordenação do Comitê Executivo Nacional;

IV. Propor, ao Comitê Executivo Nacional, ações concretas e soluções que busquem a realização dos objetivos do Fórum;

V. Participar das reuniões nacionais e realizar reuniões locais periódicas (BRASIL, 2011g, p. 9).

No documento 1AT, o promotor de justiça Dr. Jairo Bisol, da PROSUS, manifesta a preocupação de definir o:

objeto de discussão do Comitê que, no seu entender, não está centrado na natureza do Direito à Saúde, mas em imprimir o máximo de "racionalidade" na judicialização do problema. Solicita a participação da Comissão de Judicialização da Secretaria de Estado de Saúde do DF (TRIBUNAL DE JUSTIÇA DO DISTRITO FEDERAL E TERRITÓRIOS, $2011 \mathrm{~m}, \mathrm{p} .1)$.

Esta consideração é pertinente pois recai sobre o papel do próprio comitê, pois aplica maior praticidade às suas ações e reduz as possíveis discussões teóricas sobre a legitimidade ou não da judicialização. E cabe explicar que a citação à "Comissão de Judicialização da Secretaria de Estado de Saúde do DF” se refere ao NJUD/SES-DF.

Desde a criação do Comitê Executivo de Saúde do Distrito Federal foram realizadas 33 reuniões do grupo para a discussão sobre as ações judiciais interpostas sobre a saúde do DF (documento 33AT). O registro de atas das reuniões realizadas até o momento deu orígem à organização do Apêndice $\mathrm{AF}$, com a relação de datas e reuniões realizadas (TRIBUNAL DE JUSTIÇA DO DISTRITO FEDERAL E TERRITÓRIOS, 2016d).

Percebe-se que, no ano de 2011, a considerar a criação do comitê e início dos trabalhos no mês de junho, houve uma média de uma reunião por mês (sete reuniões em 2011). No ano de 2012 a frequência de reuniões foi menor, se comparado ao ano anterior. Pois foram realizadas também sete reuniões, porém durante todo o ano. Em 2013 foram realizadas somente três reuniões, sendo que duas foram realizadas em abril e um em dezembro. Porém, a segunda reunião do mês de abril foi de cunho extraordinário e teve como assunto de urgência uma discussão relacionada à um problema de um hospital regional do DF, ocorrido à época. 
No ano de 2014, parece-se reestabelecer a frequência das reuniões, tendo ocorrido 9 encontros. Houve quase uma frequência mensal de reuniões e demonstrou ser um ano de maior atividade por parte do comitê, além do ano de sua instituição. Já em 2015 foram registradas quatro reuniões, com reuniões bimensais até maio e uma última reunião em agosto. Por fim, em 2016, até o momento de elaboração deste trabalho havia a contagem de 3 reuniões, realizadas no primeiro semestre de 2016.

Apesar da variação na frequência das reuniões, é fato que o Comitê mantém-se em atividade desde a sua criação. E, pelas anotações em atas, o trabalho executado reflete em resultado prático, pois consegue agregar diversas partes interessadas na judicialização da saúde e as deliberações são importantes para a resolução de problemas a curto e longo prazo. Como exemplos de resultados obtidos pelo Comitê, o documento 14SI cita que já foram conseguidas soluções administrativas para conflitos relacionados à medicamentos, exames e leitos de unidade de terapia intensiva - UTI, ampla comunicação com os atores envolvidos com os problemas deflagrados nas ações, melhor comunicação com os gestores públicos do sistema de saúde, melhora do acesso à medicamentos e serviços, criação da CAMEDIS e outras soluções importantes (TRIBUNAL DE JUSTIÇA DO DISTRITO FEDERAL, 2016b).

Quanto aos Núcleos de Apoio Técnico do Poder Judiciário (NATs), estes desenvolvem atividades de suporte aos magistrados nas decisões de ações judiciais relacionadas ao direito à saúde. Este apoio é dado por meio da disponibilização de conhecimento técnico, para melhor embasar o julgamento das demandas (documentos 27AR e 2NS) (FERREIRA; COSTA, 2013; MINISTÉRIO DA SAÚDE, 2016c).

Tendo como exemplo de pioneirismo o estado do Rio de Janeiro, as atividades dos NATs existentes neste estado foram crescentes nos anos relatados pelo documento 27AR. O impacto de sua implementação foi significativo a ponto do número de pareceres produzidos ter sido de 987 em 2009, 1448 em 2010 (FERREIRA; COSTA, 2013).

$\mathrm{Na}$ pesquisa desta tese verificou-se a prévia existência e disponibilização deste tipos de pareceres nos sítios eletrônicos oficiais do CNJ e do MS (nível federal). Em ambos os órgãos eles são denominados notas técnicas. Isto demonstra a preocupação com este embasamento técnico-científico para a tomada de decisões em saúde. Há uma quantidade significativa de pareceres de tipos específicos de medicamentos. No caso do CNJ, os pareceres são assinados pelo Núcleo de Avaliação de Tecnologias em Saúde do Hospital das Clínicas da Universidade Federal de Minas Gerais. No caso do MS, as notas são elaboradas pela Consultoria Jurídica do próprio órgão, como já (documentos 17SI e 8SI) CONSELHO NACIONAL DE JUSTIÇA, 2016a; MINISTÉRIO DA SAÚDE, 2016e). 
Ainda sobre as notas técnicas do CNJ, esta informação documental foi depois revisitada pelo entrevistado $1 \mathrm{EN}$ :

\begin{abstract}
A judicialização é antiga, esse processo. Tanto, que até em 2009 teve audiência pública no STF sobre isso. Mas, eu acho que aos poucos, está havendo maiores aproximações entre judiciário e os próprios gestores do SUS. Tanto que tem até um grupo específico no Conselho Nacional de Justiça, no CNJ, que tem a participação do Ministério da Saúde, em considerar elaborar recomendações para que os juízes sigam alguns ritos, pelo menos. Se chega uma ação judicial, você vai apenas analisar? Ou tem... qual recomendação?
\end{abstract}

O MS explica, ainda, que as notas da CONJUR/MS são produzidas por médicos e farmacêuticos seguindo as diretrizes do SUS e em resposta às demandas judiciais em saúde. Estas notas têm o objetivo de serem utilizadas para subsidiar processos judiciais contra a União (documento 8SI) (MINISTÉRIO DA SAÚDE, 2016e).

Ainda sobre os pareceres, o entrevistado 7EN relata sua experiência com as ações judiciais:

Tinha um relatório, tinha a receita e o relatório do médico. Não, parecer farmacêutico, não. Inclusive, nessa época, que foi em 2012, estavam começando. Tiveram alguns casos no Brasil. Então, no Rio de Janeiro foi um deles. Em Goiânia, a gente teve um outro também. Que eram tribunais que já tinham farmacêuticos sendo parecerista e utilizando a saúde baseada em evidências para poder auxiliar a tomada de decisão do juiz. Porque, assim, como tem risco de vida, risco à vida, o médico quando ele coloca se o paciente não usar, tem risco à vida. Pronto, aí o juiz, ele já defere. Inclusive, lá em Goiânia existiam um plantonista, um procurador plantonista. Mas, tinha a equipe de pareceristas também, juntos. Eu participei de seminários lá que eles estavam apresentando qual era esse modelo e que era um modelo novo e que estava surtindo muito efeito.

\title{
b. Poder Executivo - Sistema de Saúde Distrital
}

Originalmente, o NJUD/SES-DF (antigo Comitê ou Comissão de Judicialização da SES-DF) iniciou suas atividades organizando os procedimentos relacionados às ações judiciais que envolviam a SES-DF. O documento 2AT apresenta um registro importante sobre isto:

No início, observou que as ordens judiciais não obedeciam a um fluxo, porquanto havia várias portas de entrada, a saber: Diretor do Hospital, Secretário, Procuradoria, Jurídico etc. Nesse sentir, o primeiro passo foi tentar centralizar apenas num lugar o recebimento das ordens judiciais, com vistas a agilizar o cumprimento, o que de fato interessa para o paciente. Verificou, ainda, que, entre o recebimento da ordem e o seu encaminhamento para a Secretaria de Saúde, perdiam-se dois, quatro, por vezes até cinco meses, quando o tempo para cumprimento não passava de 24 (vinte e quatro) horas, sem olvidar dos mandados de prisão e arresto de orçamento (TRIBUNAL DE JUSTIÇA DO DISTRITO FEDERAL E TERRITÓRIOS, 20111, p. 8). 
Sobre suas atividades, o documento complementa que:

a Comissão de Judicialização não constitui um instrumento público, tampouco justificativa do gestor, mas instrumento de resolução. Isto significa, arremata, "matar o problema na origem". Nas suas atividades, estabeleceu grande parceria com a Defensoria Pública. Em termos numéricos, noticia, de 700 (setecentos) requerimentos, 40 (quarenta) ou 50 (cinquenta) dão origem a ordens judiciais. Conta com uma equipe pequena, frisa (TRIBUNAL DE JUSTIÇA DO DISTRITO FEDERAL E TERRITÓRIOS, 20111, p. 8).

Atualmente, o NJUD/SES-DF, além de receber e lidar com as demandas judiciais impostas sobre a SES-DF, também desenvolve atividades de melhoria do fornecimento de serviços do SUS, ampliando a informação dos usuários, para que os mesmos acessem as ações e serviços pelo próprio sistema de saúde, quando disponível. Para estes casos, são repassadas informações sobre o tipo de tratamento, a disponibilidade na rede e o local de acesso, e isto é feito por ligação telefônica ou documentos administrativos. Cabem nestes casos não só os pacientes que possuem o tratamento necessário pelo SUS, mas também para aqueles casos em que há alternativas terapêutica disponíveis. E, quando esta substituição está disponível, não só é benéfico para o sistema de saúde, que evita a judicialização, como também o é para o paciente, pois a compra dos medicamentos judicializados leva, em média, 45 dias para a sua conclusão (documento 22AR) (PAIM; MARQUETTO; LOPES, 2016).

Este trabalho, segundo análise das informações coletadas por entrevistas, é equivalente ao trabalho realizado pela DPDF. Ou seja, ambos os órgãos divulgam seus papéis com atividades de mediação. Porém há a diferença de que a DPDF pode realizar uma mediação que evita a abertura da ação judicial enquanto o Núcleo de Judicialização tenta reverter a ação já aberta, pois só participa do processo quando recebe a ação com a decisão do juiz.

O entrevistado 9EN, do Núcleo de Judicialização, comentou que é atividade do NJUD/SES-DF o contato com os prescritores das ações judiciais quando há a possibilidade de indicar a substituição do medicamento prescrito por um outro padronizado ou por algum que já tenha sido comprado pelo núcleo e haja ata de compra prévia. O objetivo é evitar a judicialização, ainda que o processo já tenha sido iniciado, ou facilitar o processo de compra. Para o primeiro caso, havendo a substituição da prescrição, este ato seria incorporado ao processo judicial, pois somente o prescritor pode realizar a substituição de qualquer medicamento da prescrição. 


\section{O entrevistado 10EN explica a rotina do departamento:}

Ou essa demanda vem como se fosse uma primeira compra que vem direto da justiça. Vindo de lá, esse processo passa aqui por nós, a gente digitaliza esse processo e tudo. E informa a Farmácia de Ações Judiciais, eles cadastram esse paciente. Aí depois do cadastro, tudo mais, eles demandam para a gente a confecção do pedido, que é o PAM. Aí com esse PAM, eu elaboro aqui também o projeto básico desse medicamento. Aí ele segue o trâmite, isto se for em caso de dispensa de licitação, quando não tem ata para esse medicamento. [...]

\section{$\mathrm{O}$ entrevistado 8EN também tenta explicar a rotina do NJUD/SES-DF e a posterior} interlocução com a Farmácia para a dispensação dos medicamentos:

\begin{abstract}
É bom você entender assim, quais são as etapas, os passos. O que acontece? Por exemplo, paciente novo, chegou a ação lá, o DF fez todo o - como é que fala? -, recorreu da forma como pôde, mas o juiz deu lá a decisão interlocutória, antecipou a tutela falando, "não, o paciente tem direito a esse medicamento". Aí o que a gente faz? O NJUD ele manda para mim ou o processo físico ou ele digitaliza, que a gente tem uma rede compartilhada. Aí eu cadastro esse paciente aqui, entendeu? Aí daqui sai o meu despacho falando assim, "sim, cadastrei esse paciente, solicito a compra". Aí volta para o NJUD, aí ele faz o PAM, que é o Pedido de Aquisição de Medicamento, que gera um número que vai abrir um processo de compra mesmo do medicamento. Aí o que acontece? Aí depois, beleza, aí fez essa compra, tudinho, a primeira vez para o paciente. Aí a gente liga para o paciente, o paciente comparece aqui na farmácia portando a receita atualizada, tudo, para gente fazer a dispensação. E aí depois quando ele...uns três meses antes de terminar o medicamento dele, a gente já solicita novo pedido de compra, que é o PAM de continuidade. Que a gente solta um memorando para o NJUD de novo, aí para ele abrir um processo. [...] (memorando) de controlar o estoque, de ver o que está precisando pedir ou não. Porque até...assim, tem casos da gente comprar para paciente, geralmente, o PAM é para seis meses de tratamento. Aí tem casos da gente comprar para o para paciente, ele nunca comparecer, a gente não conseguir contato com o paciente, entendeu?
\end{abstract}

Sobre a continuidade dos tratamentos determinados por ações judiciais, este mesmo entrevistado explica:

Os pacientes que, por exemplo, que o paciente, normalmente, ele não vem só para...tipo assim, ele não consegue só tratamento dele e pronto, acabou. Normalmente, ele tem...tem paciente que tem continuidade. Tem muitos medicamentos, a maioria inclusive, que ele vai continuar utilizando por um determinado tempo. O que orienta a gente nesse sentido, é a prescrição médica e a própria decisão judicial. Que, às vezes, o judicial fala, "não, determino o tratamento para seis meses". Então, a gente se limita por isso. Ou então, ele fala, "não, até enquanto durar a necessidade". Aí quando tem esse processo de continuidade, por isso que a gente faz aquele primeiro passo de mandar, de remeter esse processo quando ele é a primeira compra. A gente remete para a farmácia de ações para que conste o cadastro dele lá, porque a partir da segunda compra, eles já pegam a pasta do paciente que tem lá e falam, "pô, esse paciente aqui vai continuar utilizando, então, eu tenho que emitir, eu tenho que fazer um novo pedido". E geralmente, isso acontece assim, emitir hoje um pedido e tal, daqui a mais ou menos três meses, que tem durado...para comprar, está um pouco 
complicado as compras, assim. Mas, mais ou menos, daqui uns três meses, esse medicamento ainda não, de repente, não foi comprado. Ou se ele foi comprado, a gente sabe que o paciente vai continuar utilizando, as meninas lá da farmácia de ações me mandam uma nova demanda, fala, "o paciente vai utilizar e tal, tal". E aí eu já emito um novo processo. Porque a minha ideia é que ele não tenha descontinuidade (Entrevistado 10EN).

Paim, Marquetto e Lopes (2016) ainda acrescentam que o NJUD/SES-DF é responsável por elaborar informações sobre as políticas do SUS para os magistrados, a fim de colaborar com um melhor embasamento para as decisões judiciais. Estas informações são elaboradas por médicos e farmacêuticos e tratam, por exemplo, de dados sobre as alternativas terapêuticas disponíveis no SUS, para substituição ao requerido pelas ações.

Porém, em entrevista ao Núcleo, foi informado que atualmente não está sendo possível realizar a elaboração destes pareceres, pelo menos por parte do farmacêutico responsável. Isto porque, no passado haviam dois farmacêuticos no setor e, no período desta pesquisa, somente um farmacêutico ainda estava atuante. Logo, esta situação inviabiliza a redação dos pareceres ou notas técnicas, em função do volume de trabalho relacionado à demandas por medicamentos e, portanto, de responsabilidade técnica deste único profissional do setor.

O entrevistado 10EN comenta ainda, que os pareceres elaborados por este núcleo não eram aqueles que poderiam auxiliar na decisão do juiz. Isto porque o Núcleo de Judicialização da SES-DF só passa a fazer parte do processo após a decisão de deferimento de um pedido, quando o processo é encaminhado para o núcleo. O entrevistado explica:

Ele (parecer) entra no processo da Secretaria de Saúde, porque ele não entra no processo judicial. O que vem para mim aqui é só a decisão final. A decisão e geralmente a gente pede a petição inicial para montar o processo e um relatório médico com receita. Então, assim, esse parecer, ele não entra no processo judicial. [...] Ele não reverte o processo, a não ser que o médico decida reverter. Eu posso informar ao juiz. Posso informar o juiz e tal, "olha, esse aqui não é indicado". Mas, ele vai perguntar para o médico prescritor. Porque, assim, o médico, ele que tem autonomia para prescrever aquilo e tem a justificativa para tal. Então, se o médico fala (inint) mesmo a gente informando o juiz e o juiz chega e fala para o médico, ele vai fazer um parecer dizendo que não, que ele tem fundamentação para aquilo e vai manter. Teoricamente, ele vai manter aquela decisão. Ele vai informar o juiz para que mantenha aquela decisão.

O entrevistado 8EN também comenta sobre a questão e dá o entendimento de que os pareceres do NJUD/SES-DF não têm aplicabilidade como defesa do governo frente ao processo judicial. E que, mesmo com a existência de pareceres, os médicos são autônomos na prescrição: 


\begin{abstract}
Às vezes, o que acontece? Esse parecer é mais a parte burocrática em si, que meio que a Secretaria ela tenta responder falando assim, "que tem medicamento padronizado, que tem outras vias de tratamento que não, necessariamente, deveria ser aquele que não é padronizado". Eu acho que é mais formal. Porque no final das contas, por exemplo, a gente entra com um para a próstata. Por exemplo, aí tem um rol, assim, de mais de 30 quimioterápicos que tem no Base, muitas vezes tem em estoque, também. Só que o médico não prescreve. E muitas vezes é um médico do Base, é um médico da rede, é um médico do HUB, por exemplo. Só que, por exemplo, o HUB é na União, só que recai sobre o DF, quando o paciente for do DF. Então, assim, apesar das existências dos pareceres farmacêuticos que saem lá da judicialização, que tem o [...], que é o farmacêutico de lá. Ele faz esse parecer.
\end{abstract}

Uma prática relacionada à maioria das ações em saúde, em função da urgência da matéria em questão, é a elaboração de pedidos judiciais com concessão de tutela antecipada (liminar). Ou seja, quando deferido o pedido, o Poder Executivo deve proceder com a entrega imediata do medicamento. E esta providência administrativa de compra do produto e entrega ao reclamante da ação deve ser feita antes mesmo que o gestor seja ouvido como parte acusada da ação (documento 33AR) (PEPE et al, 2010).

Com base nos dados obtidos, percebe-se que o gestor deve responder à demanda judicial, ao mesmo tempo que mantém em funcionamento as atividades do serviço (implementação da política pública) e tenta seguir as diretrizes e princípios do SUS em ambas as vias de fornecimento de medicamentos (executiva e judiciária). E estas atividades fazem parte das funções do NJUD/SES-DF, pois os dados deixam claro que todos os processos administrativos relacionados à ações judiciais em saúde, no DF, são realizados por este núcleo. Ou seja, as compras de medicamentos são dissociadas do restante da assistência farmacêutica do GDF. Então tem-se a estrutura que foi apresentada no caso 01, no capítulo 4 da pesquisa, para administrar a gestão dos componentes de medicamentos da PNAF, a Diretoria de Assistência Farmacêutica - DIASF. Em paralelo - com outra estrutura, funcionários e atividades - há a gestão dos medicamentos judicializados pelo NJUD/SES-DF. Ou seja, dentro do Poder Executivo, na SES-DF, há duas equipes que trabalham paralelamente para gerir, respectivamente, os medicamentos da política de assistência farmacêutica e os medicamentos judicializados. Há de se ressaltar que existe uma única estrutura que integra os dois serviços, a Farmácia Ambulatorial de Ações Judiciais. Isto porque este núcleo de farmácia está submetido à DIASF, porém só dispensa aos usuários medicamentos judicializados. E toda a logística destes medicamentos é realizada separadamente dos demais, independente da DIASF, pelo setor de compras do Núcleo de Judicialização e pela Farmácia Ambulatorial de Ações Judiciais.

Em geral, a relação entre a DIASF e o NJUD/SES-DF ocorre por meio da Farmácia Ambulatorial de Ações Judiciais. Porém, além deste contato, o NJUD/SES-DF também faz 
contato com a DIASF para elaborar os pedidos de compra de medicamentos. Então há um documento denominado "Termo de referência" que deve ser emitido para cada tipo de medicamento, a cada compra, que é emitido pela DIASF, em função da sua especialidade e responsabilidade farmacêutica.

Seguindo este entendimento, o Núcleo de Farmácia Ambulatorial Judicial da SES-DF é responsável por receber os medicamentos do NJUD/SES-DF, gerenciar seu estoque, estabelecer e seguir rotinas de contato e recepção dos pacientes e dispensar os medicamentos aos usuários, requerentes das ações judiciais (documento 29AR) (CONTI et al, 2015). Estas atividades são também explicadas pelo entrevistado 8EN:

\begin{abstract}
O que acontece? Por exemplo, paciente novo, chegou a ação lá (NJUD/SES-DF), o DF fez todo o - como é que fala? -, recorreu da forma como pôde, mas o juiz deu lá a decisão interlocutória, antecipou a tutela falando, "não, o paciente tem direito a esse medicamento". Aí o que a gente faz? O [...] (NJUD/SES-DF), ele manda para mim ou o processo físico ou ele digitaliza, que a gente tem uma rede compartilhada. Aí eu cadastro esse paciente aqui, entendeu? Aí daqui sai o meu despacho falando assim, "sim, cadastrei esse paciente, solicito a compra". Aí volta para o [...], aí o [...], ele faz o PAM, que é o Pedido de Aquisição de Medicamento, que gera um número que vai abrir um processo de compra mesmo do medicamento. Entendeu? $[\ldots]$

Aí a gente liga para o paciente, o paciente comparece aqui na farmácia portando a receita atualizada, tudo, para gente fazer a dispensação. E aí depois quando ele...uns três meses antes de terminar o medicamento dele, a gente já solicita novo pedido de compra, que é o PAM de continuidade. Que a gente solta um memorando para o [...] (NJUD/SES-DF) de novo, aí para ele abrir um processo.
\end{abstract}

Como citado na categoria de estrutura organizacional, a CAMEDIS é um espaço de mediação. Ou seja, antes da abertura de uma ação judicial, a defensoria estabelece uma relação de debate com o usuário e o sistema de saúde, como uma prática extrajudicial, para resolução de conflitos (documentos 11AR e 22AR) (OLIVEIRA, 2013; PAIM; MARQUETTO; LOPES, 2016).

São atividades da CAMEDIS definidas por portaria (documento 80LN):

I. promover mediação em demandas por serviços ou produtos de saúde a serem fornecidos pelo SUS no Distrito Federal;

II. buscar conciliação e propor soluções para demandas judiciais em trâmite;

III. tomar conhecimento das demandas judiciais e administrativas levadas à ciência da CAMEDIS por qualquer de seus membros integrantes indicados no artigo $3^{\circ}$;

$I V$. propor à órgãos e entidades da Administração Pública do Distrito Federal, responsáveis pela elaboração e execução de políticas públicas associadas à saúde pública no DF, medidas para melhorias e cooperação (BRASIL, 2013m, p.2). 
A CAMEDIS está instituída como uma das portas de entrada para o controle judiciário, porém tem o objetivo de evitá-lo, quando possível. Esta instância tem atuação como mediadora para com os interesses dos usuários do sistema de saúde nacional e objetiva resolver os problemas em saúde por meio de diálogo, sem o início de um processo judicial. Esta Câmara deve, então, pensar em soluções para as demandas da sociedade sobre os serviços públicos de saúde. Caracteriza-se como uma articulação entre os dois sistemas já que é composta por um representante da SES-DF e por outro da Defensoria Pública do Distrito Federal (documento 9NS) (AGÊNCIA BRASÍLIA, 2013).

O fluxo prático funciona com o recebimento dos casos pelo Núcleo da Saúde da DPDF e encaminhamento para a apreciação da CAMEDIS, segundo documento 22AR. A Câmara poderá decidir entre três resultados possíveis (PAIM; MARQUETTO; LOPES, 2016):

(1) atendimento total da demanda;

(2) atendimento parcial da demanda; e

(3) não atendimento da demanda.

No caso do atendimento parcial significa que houve uma solicitação e a SES/DF ofereceu um alternativa de tratamento para tal. Quando há esta possibilidade, é realizada uma reunião com as duas partes para a mediação do conflito e proposta de solução. Esta proposta de trabalho é relevante pois esclarece ao usuário quais as alternativas disponíveis no SUS, explicando o funcionamento das políticas públicas. E, no caso da mediação ser bem sucedida, a resolução do problema permanece no campo administrativo, sem abertura de ação judicial (PAIM; MARQUETTO; LOPES, 2016).

As principais demandas atendidas pela CAMEDIS envolvem medicamentos, consultas e materiais. Ainda de acordo com o documento 22AR, de Paim, Marquetto e Lopes (2016), a mediação pela Câmara já evitou $20 \%$ de novas ações judiciais no DF.

E, de forma independente da CAMEDIS, o próprio NJUD/SES-DF também tenta evitar a continuidade do processo judicial, Quer dizer, mesmo após deferido o processo, o Núcleo ainda tenta uma abordagem com o prescritor, quando adequado, para que não seja necessária a judicialização. Sobre isto o entrevistado 10EN comenta:

$\mathrm{Eu}$ andava com dois processos em paralelo. O processo chegava aqui para mim, um processo novo, eu copiava esse processo. Copiava. E aí eu duplicava. A gente tinha um processo, digamos, principal. E um processo complementar que a gente chamava. E esse processo principal que eu já...fazer aquele processo que eu já te falei, fazer o PAM e tudo mais, remeter lá para as meninas e tal. Para depois emitir o 
PAM e seguir a compra. E o outro eu emitia para o médico ou então para a coordenação aqui, para poder pegar essas informações. E os dois andando juntos, porque o normalmente da compra, ele tem demorado. Ele tem demorado aí uns dois, três meses. Então, era o prazo mais ou menos desse processo retornar com a resposta. Então, assim, se mesmo que eu tivesse já descartado o processo de compra, dava tempo de eu falar...se o médico falasse, se ele aceitasse a indicação de substituição, dava tempo de eu parar esse processo, o processo principal e tal. E daí ia arquivar, porque a gente sempre sugere que ele troque, que ele substitua esse medicamento por que esteja padronizado. Aí a grande maioria, assim, são medicamentos de protocolo muito específicos, assim. Então, são pacientes que realmente já...mnormalmente que já passaram pela sequência do protocolo, "ah, usou tal. Na falha desse você usa o próximo". Então, normalmente, já chega dessa forma. A gente, às vezes, manda assim tentando uma rejeição. Normalmente, não acontece, é muito difícil. [...] A gente informa se o médico acatar. Aí a gente informaria para o juiz. Se ele concordasse, a gente informaria o juiz. Porque o médico, provavelmente, iria fazer um relatório médico, uma prescrição a cerca disso, aí a gente informaria para o juiz e se fosse o caso, alterasse a decisão e tal.

Muito difícil, muito difícil de acontecer.

\section{c. Funções Essenciais à Justiça no DF}

Faz parte das atribuições do MPDFT a investigação e relatoria sobre os aspectos de gestão do sistema de saúde que possam impactar na qualidade do atendimento ao cidadão (documento 8NS) (CORREIO BRAZILIENSE, 2012).

O MPDFT, alinhado às suas responsabilidades, criou o "Portal Direito e Saúde do MPDFT". Este sítio eletrônico cumpre com o objetivo de ampliar o conhecimento do cidadão sobre os seu direito à saúde e também auxiliar os profissionais envolvidos com a judicialização. Estão disponíveis neste espaço algumas normas relacionadas, alguns exemplos de jurisprudências, pesquisas e notícias. Esta página foi criada pela $4^{\mathrm{a}}$ Câmara de Coordenação e Revisão da Ordem Jurídica Cível Especializada em Saúde, Idoso e Deficiente, do MPDFT (documento 19SI) (MINISTÉRIO PÚBLICO DO DISTRITO FEDERAL E TERRITÓRIOS, 2016i).

Como parte do MPDFT ativa na justiça da saúde, a PROSUS tem como atividades (documento 7SI) (MINISTÉRIO PÚBLICO DO DISTRITO FEDERAL E TERRITÓRIOS, 2016a):

(1) Acompanhar e fiscalizar o atendimento ao cidadão oferecido pelo SUS;

(2) Acompanhar a execução de convênios e de contratos firmados entre o SUS e entidades sem fins lucrativos, filantrópicas e de iniciativa privada;

(3) Fiscalizar as atividades de vigilância sanitária e epidemiológica, de saúde do trabalhador, de assistência terapêutica e farmacêutica;

(4) Fiscalizar o seguimento dos princípios constitucionais da gratuidade, da integralidade e da universalidade das ações e serviços de saúde; 
(5) Verificar a abertura de processo de sindicância e/ou administrativo para apurar as responsabilidades, quando puder ter havido erro ou negligência por parte dos profissionais da área da saúde;

(6) Verificar os cuidados adequados de descarte de resíduos de saúde;

(7) Fiscalizar a atuação dos profissionais de saúde;

(8) Fiscalizar clínicas médicas, hospitais públicos e outros serviços para a saúde;

(9) Elaborar normas educativas e regulamentadoras na área de saúde.

Percebe-se que as atividades de números (1), (3) e (4) estão diretamente relacionadas ao caso em questão, que envolve as demandas por medicamentos.

Cabe dizer que, desde 1997, há disponíveis 49 documentos referentes às Recomendações da Procuradoria de Justiça de Defesa da Saúde (PROSUS) com relação à demandas relacionadas à saúde sendo, dentre estes documentos, somente um se refere à medicamentos (documento 20SI) (MINISTÉRIO PÚBLICO DO DISTRITO FEDERAL E TERRITÓRIOS, 2016j). Esta recomendação será apresentada na subcategoria discricionariedade prática (PROCURADORIA-GERAL DO DISTRITO FEDERAL, 1999).

Ainda sobre o papel do MPDFT na defesa dos direitos coletivos, o procurador-geral de justiça, Leonardo Bessa, explicou que o Ministério deve assumir as ações que envolvam causas com importância para a sociedade, em casos em que o requerente desista da ação (documento $84 \mathrm{NJ})$ :

"Há um reforço da importância do MP no processo civil, para atuar em questões que possuam importância social” (MINISTÉRIO PÚBLICO DO DISTRITO FEDERAL E TERRITÓRIOS, 20161, p. 1)

Quanto à PGDF, a PROMAI desenvolve as atividades de planejamento, orientação, coordenação e controle das ações relativas à tutela ambiental, de patrimônio urbanístico, imobiliário e de saúde (documento 18SI) (PROCURADORIA-GERAL DA REPÚBLICA, 2016).

A DPDF, em seu Núcleo da Saúde, tem como responsabilidade a orientação do cidadão e a prestação de assistência jurídica em todas as áreas. Além disso, o documento 7NS destaca a preocupação dos defensores em explicar à população sobre seus direitos e sobre a importância da resolução dos conflitos sem a abertura de ações judiciais (AGÊNCIA BRASÍLIA, 2012c). Esta conduta é também confirmada pelo entrevistado 11EN, que afirma: 


\begin{abstract}
A Defensoria, ela tem o papel de garantir o tratamento do cidadão carente à princípio. Assim, todo aquele que necessita de um tratamento, não recebe, o Estado não fornece, procura a Defensoria para viabilizar esse tratamento. A discussão até onde vai o direito desse tratamento, é uma discussão jurídica. E isso a gente procura trabalhar perante o judiciário. Mas, a Defensoria atua primordialmente - a doutora já viu isso -, administrativamente. Tanto que 90 por cento da nossa demanda, ela se esvai no administrativo, não se leva ao judiciário essa demanda. O DF consegue um índice de 90 por cento de resoluções extra-judiciais. Então, um índice altíssimo qualquer outro lugar. Isso, graças à atuação da Defensoria e do próprio estado para tentar resolver o problema do paciente.
\end{abstract}

No documento 44NJ, é apresentado o ponto de vista do Defensor-geral do DF, Jairo Lourenço:

"A iniciativa de conversar e discutir é o melhor caminho para buscar soluções"
(DEFENSORIA PÚBLICA DO DISTRITO FEDERAL, 2013a).

O entrevistado 9EN também comenta que grande parte dos processos direcionados à SES-DF eram provenientes da DPDF, sendo esta uma atividade essencial da Defensoria quando o artifício da mediação não é solucionador.

O AG apresenta então uma síntese das atividades identificadas no estudo.

Além da apresentação do Apêndice AG com uma síntese textual sobre as atividades desempenhadas por cada órgão, departamento, setor, comitê ou afins, propõe-se a Figura 5.6 com o estabelecimento de relações e da natureza destas relações entre estas entidades. Esta Figura é importante pois responde ao objetivo desta pesquisa de identificar quais as partes do sistema judiciário estão envolvidas com a judicialização de medicamentos no DF e na União, bem como quais seriam as naturezas destas relações. Este objetivo está esquematizado na Figura 3.2 da seção de metodologia. 


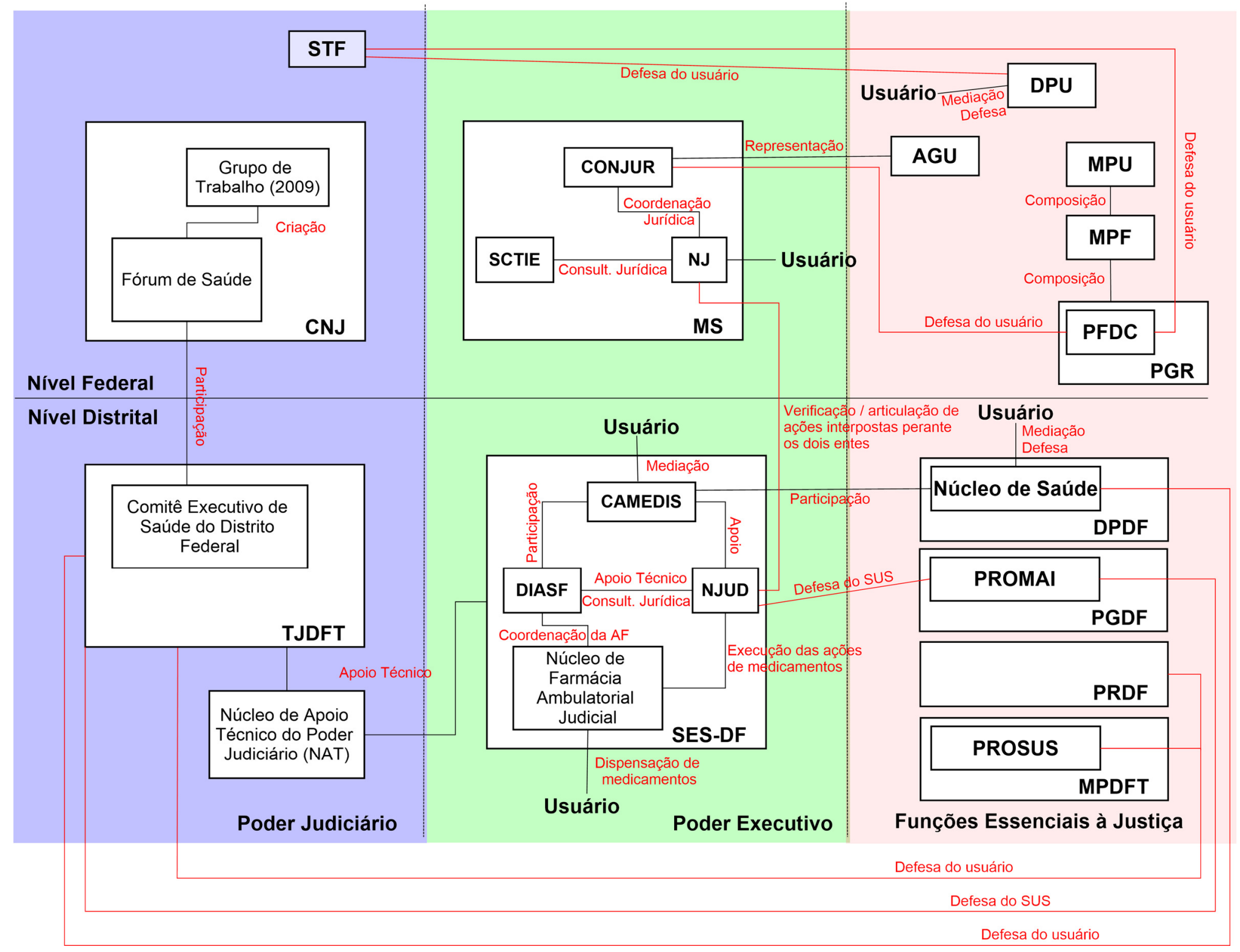

Figura 5.6 - Relações estabelecidas diante da judicialização de medicamentos - nível federal e distrital. Fonte: elaborado pela autora (2016). 
Apresentadas as atividades dos órgãos envolvidos com a judicialização da saúde, passa-se ainda nesta subcategoria, a analisar alguns aspectos práticos e operacionais dos processos judiciais em saúde, apresentados em documentos e explicados por entrevistados. A partir desta análise, propõe-se uma tipificação dos casos judiciais por acesso a medicamentos e propõe-se alguns fluxos do fornecimento destes medicamentos nos níveis federal e/ou distrital, assim como foi apresentado no caso 01 (Figuras 4.6, 4.7 e 4.8).

Este trabalho de construção se torna necessário pois, diferentemente da política e do CEAF que são bem organizados e que possuem fluxos de atividades bem definidos para a sua operacionalização nos níveis fedeal e distrital, o processo de fornecimento via judicialização não apresenta o mesmo quadro. Para o fenômeno da judicialização as estruturas organizacionais são muito recentes e não bem registradas e divulgadas. Até mesmo quanto ao organograma e as funções definidas para os órgãos e os departamentos envolvidos percebe-se que estes dados, quando existentes, são melhor registrados e publicizados para o caso da União. Para o Distrito Federal, existem ainda menos registros, conforme pesquisa documental e conforme relatos dos próprios entrevistados. Desta forma os fluxos das operações no fornecimento de medicamentos do componente especializado ainda não foram desenhados, bem como não foi feita uma organização conceitual quanto aos tipos de ações judiciais provocadas (entende-se como tipos o status do medicamento solicitado frente à sua situação na própria RENAME, SES-DF ou ANVISA).

A caracterização das ações em saúde é importante para a adequada análise e discussão dos procedimentos e critérios adotados no julgamento destas. E, a partir disso, para a proposta de ações concretas para a garantia de possíveis avanços na área.

É explorado pelo documento 22AR que grande parte das ações judiciais em saúde do DF requerem algum tipo de ação ou serviço não prestados pelo governo. São exemplos os medicamentos não padronizados e as indicações clínicas não aprovadas para o uso (PAIM; MARQUETTO; LOPES, 2016). Ao contrário destes dados, o documento 34AR informa que outra parte das ações se referem à solicitação de medicamentos listados nas relações de medicamentos dos componentes da assistência farmacêutica. Esses fatos demonstram algum problema na execução das políticas (SANTOS; BLIACHERIENE; UETA, 2011).

Um outro documento (35AR) acrescenta que um problema em potencial para o usuário do SUS buscar a via judicial para acesso à medicamentos é a falta destes produtos nas farmácias públicas em função de falhas de gestão. Outra causa apontada é o desconhecimento dos prescritores do conteúdo das listas de medicamentos padronizados (MACHADO et al, 2011). Ou seja, muitos prescritores não têm conhecimento dos medicamentos disponíveis 
Machado (2011) ainda explica que algumas ações judiciais demandam mais de um medicamento por envolver todos os medicamentos prescritos para o paciente. Então, se pelo menos um deles não estiver disponível no SUS e for iniciado um litígio com a prescrição múltipla de medicamentos, todos serão solicitados, ainda que os demais estejam padronizados. E isto é comum para medicamentos de baixo custo, da atenção básica da saúde, que não requerem cumprimento de protocolos. Logo, muitas vezes estes produtos são comprados por via judicial, mesmo havendo disponibilidade no sistema de saúde.

O documento 20AR discute a mesma problemática e cita que há um predomínio de prescrições do próprio SUS como originárias de ações judiciais. Observa-se como fatores estimuladores da judicialização o atraso na incorporação de novos medicamentos nas listas padronizadas e o não seguimento destas listas pelos prescritores (SANT’ANA et al, 2011).

Por outro ponto de vista, as próprias ações podem apresentar problemas. Por exemplo, uma questão importante observada na análise de processos judiciais foi a baixa qualidade de algumas prescrições medicamentosas. Existem regras de boas práticas de prescrição e, diante destas, muitas das receitas analisadas não seguiam estas orientações e, no processo judicial, foram deferidas sem exigência de adequação por parte do Poder Judiciário. Ou seja, se o foco das ações é a saúde do usuário, seria coerente a preocupação com a elaboração de prescrições seguras e adequadas, conforme argumentam Sant'Ana et al (2011). Alguns dos problemas em potencial relacionados à erros de prescrições são:

troca do medicamento e/ou substituição das formas farmacêuticas na dispensação, administração do medicamento pela via errada, na dose errada, uso do medicamento além ou aquém do tempo necessário ou não-adesão ao tratamento (SANT'ANA et al, 2011, p. 719).

$\mathrm{O}$ entrevistado 9EN comenta ainda que alguns prescritores, mesmo tendo conhecimento quanto à relação de medicamentos padronizados ou quanto aos protocolos de tratamento, optam por prescrever sem o seguimento das indicações da SES-DF. Ou seja, definem tratamentos que não estão padronizados ou não seguem a ordem de primeira, segunda e até terceira escolha de tratamento. Para este segundo caso, muitas vezes o medicamento prescrito não segue a sequência correta indicada e, para estes casos em que o paciente não se enquadra ao PCDT, o SUS não disponibiliza o medicamento pela via regular de acesso.

Outros problemas comuns são a desobediência à norma que determina a prescrição de medicamentos por seu nome genérico, ou seja, pelo nome do fármaco (Lei Federal n. ${ }^{\circ}$ 
9.787/1999) e a apresentação de um relatório médico somente com a definição da doença. Neste último caso não é incluída justificativa para a prescrição ou outras informações importantes, como o histórico do paciente, exames realizados, entre outros. Nestes casos, quando há alternativa terapêutica no SUS, não há justificativa que explique o porquê desta outra opção terapêutica. Cita-se neste mesmo documento, ainda, que não foi observado nos processos quaisquer consultas à profissionais técnicos da saúde, que muitos medicamentos judicializados não possuem registro na ANVISA (1\% a $10 \%$ dos casos), que destaca-se a judicialização de medicamentos do CEAF/PNAF (SANT'ANA et al, 2011).

Já em 2011 havia também a preocupação do Comitê de Judicialização da SES-DF (documento 2AT) com os adequados registros médicos que embasavam as ações judiciais. E, considerando esta problemática, sugerem a organização de uma outra comissão para avaliar a procedência do pedido médico:

Ciente de que algumas prescrições médicas são extremamente danosas, adverte, tem buscado o entendimento no sentido de que o médico justifique o pedido, nos casos de medicamentos não padronizados. Aventa a possibilidade de criar uma Comissão para avaliar a eficácia da droga receitada, no lugar de punir o médico (TRIBUNAL DE JUSTIÇA DO DISTRITO FEDERAL E TERRITÓRIOS, 20111, p. 8).

As entrevistas realizadas apontaram para a existência de uma comissão de especialistas na via regular de acesso, para a verificação do enquadramento do paciente dentro dos protocolos de tratamento. E também de uma comissão responsável por verificar a prescrição médica que compõe a ação judicial. Conforme entrevistado 9EN, o processo judicial chega ao NJUD/SES-DF e a prescrição é encaminhada à este equipe de especialistas, denominada Coordenação Técnica, para um parecer de acordo ou não com a adequada indicação do medicamento e, possivelmente, gerar a indicação de substituição.

O entrevistado 11EN, da DPDF também comenta sobre esta possibilidade de análise dos processos por comissão de especialistas:

Mas, a gente leva a todos eles que entram a preocupação com o medicamento padronizado. É que quando houver uma indicação médica de um medicamento não padronizado, que ele fosse avaliado por uma comissão de médicos formada pela Secretaria de Saúde ou pelo CRM. Inclusive, com presença de especialistas do Conselho Regional de Farmácia. Que todos eles se manifestassem para verificar, “esse medicamento, realmente, atende esse paciente?”, “ele é uma exceção ao caso concreto ou ele deveria ser padronizado e retirado o outro que teria menos, menor eficiência?". Só que isso só fica na conversa. E nunca...o que iniciou um trabalho, foi o antigo subsecretário, doutor Robson. Ele começou, mas eu não sei se esse trabalho deu continuidade. Eu vi que o doutor Daniel estava dando um trabalho nisso, mas eu não sei em que nível está. Para que fosse formada essas comissões para reavaliar uma prescrição médica. Exatamente a preocupação da Defensoria não 
dá uma despesa desnecessária ao estado para buscar um tratamento eficiente. Não estou dizendo melhor, porque o melhor pode ser um de ponta no exterior. Mas, se ele consegue um tratamento eficiente no Brasil, não deveria...o estado, o SUS não teria condições de pagar o melhor. Nem é obrigação. Para mim, teria que pagar o tratamento para o paciente, dentro das condições. E essa preocupação, ela foi se alimentando. Até que surgiu uma conversa informal aqui da doutora dela e de um outro farmacêutico aqui, que deu a ideia e foi amadurecida, foi provocado o conselho. E trouxeram essa demanda para gente tentar uma farmacêutica dentro da Defensoria, que iria cuidar do medicamento. E só depois dela me dar uma autorização, para mim entrar com ação judicial. As dificuldades são imensas. Ela está encontrando as dificuldades. Aquilo que eu tinha falado anteriormente para a doutora, esse problema já verificou isso in loco nos casos concretos da possibilidade de substituição. Mas, falta ainda uma atuação de estado, sim, de criar uma comissão para reavaliar essa prescrição. $O$ que não necessariamente um medicamento seria uma exceção, o fornecimento do medicamento não padronizado deveria ser sempre exceção.

Ainda sobre estas comissões, o entrevistado 11EN defende bem esta estratégia:

E nós estamos tentando trabalhar nisso. Só que para isso, nós precisamos que seja criada essas comissões, para reavaliação. Existe um trabalho andando na Secretaria de Saúde, mas não houve conclusão. E seria interessante, sim, esse trabalho que, talvez, buscasse alternativas para que nós viabilizássemos o SUS mais equilibrado. E principalmente, na área de medicamentos. Que a Defensoria no DF, ao contrário, há uma tendência nossa é sempre evitar qualquer tipo de judicialização e principalmente, de medicamento não padronizado. É uma preocupação. Mas, sempre com uma visão bem clara da instituição garantir o atendimento e o tratamento eficiente para esse paciente. Se eu não tenho uma contraprova de que outro medicamento padronizado é eficiente para ele, nós não iramos deixar, a Defensoria, jamais de buscar esse tratamento para ele. Mas, para isso, nós precisamos do que? De um embasamento legal para isso. Nós temos que buscar, sim, um tratamento eficiente e o mais econômico possível. E para isso nós contamos...

Alguns pareceres da CONJUR/MS apresentam algumas situações relacionadas às ações judiciais por acesso a medicamentos que demandam a União. Estes pareceres foram elaborados para auxiliar no procedimento jurídico de defesa da União nos autos de alguns processos, com os seguintes tipos de situações:

(1) Caso no qual o medicamento está contido na RENAME e está disponível no SUS se não houver comprovação da recusa administrativa em fornecer o medicamento ao autor da ação, esta deve ser extinta. Este caso caracteriza a falta de interesse de agir por parte do autor da ação (art. 267, inc. VI, do CPC). O fundamento é de que o Poder Judiciário só deveria agir se houvesse omissão pela política pública (documento 7J) (MINISTÉRIO DA SAÚDE, 2016i). Logo, se não for comprovado que o usuário buscou o SUS e não foi atendido, orientase para que a ação não seja deferida. Um exemplo de ação para este caso é aquela na qual o paciente não se enquadra em um PCDT e não recebe o medicamento disponível, porém com indicação clínica e critérios clínicos pré-definidos. 
Como exemplo, conforme julgamento do STF (STA 175/CE):

O primeiro dado a ser considerado é a existência, ou não, de política estatal que abranja a prestação de saúde pleiteada pela parte. [...] O segundo dado a ser considerado é a existência de motivação para o não fornecimento de determinada ação de saúde pelo SUS (MINISTÉRIO DA SAÚDE, 2016i).

(2) Caso no qual o medicamento não é padronizado, mas há alternativas terapêuticas disponíveis no SUS para o tratamento solicitado. Se a intervenção do Poder Judiciário deve ocorrer em virtude de omissão ou deficiência pela política pública, a existência de alternativa terapêutica não caracteriza este aspecto. Logo, a ação não procede como adequada, pois há a possibilidade de acesso pelo SUS (documentos 8J e 9J) (MINISTÉRIO DA SAÚDE, 2016j; 20161). Porém o acesso será por outro medicamento equivalente quanto à indicação clínica.

(3) Caso no qual o medicamento não é padronizado e não possui registro na ANVISA, mas há alternativas terapêuticas disponíveis no SUS para o tratamento solicitado. É apontado que a ausência de tratamento disponível no SUS não significa necessariamente omissão ou deficiência da política. Pois, pode não haver tratamento devidamente comprovado para a finalidade deflagrada ou haver outros tratamentos além do que está sendo judicializado. Assim como o registo do medicamento na ANVISA não significa imediatamente a incorporação deste produto no sistema de saúde. Isto porque o registro é feito mediante documentação de estudos do próprio laboratório produtor. Então o medicamento registrado pode não ser a melhor alternativa para determinada finalidade clínica. E, no caso de medicamentos sem registro na ANVISA a situação se agrava, pois isso significa que este produto não pode ser produzido, comercializado ou consumido no território brasileiro (documento 10J) (MINISTÉRIO DA SAÚDE, 2016m).

Alguns entrevistados corroboram estas informações citando experiências que exemplificam os casos citados. O entrevistado 7EN, por exemplo, comenta sobre o perfil das ações judiciais no DF:

Então, se era um medicamento não padronizado, significava então que, em tese, a judicialização ocorreu porque ele não estava disponível. Mas, o que descobri foi que a maior parte dos medicamentos demandados já eram padronizados, independente do componente, seja o básico, estratégico ou especializado, ele já era padronizado o medicamento. Então, na verdade, as demandas por medicamentos não padronizados eram menores do que aquelas pelos já padronizados. Dentro dos padronizados agora eu não lembro quantos que eram do componente especializado -, mas tinha uma grande parte que também era do componente especializado. Então, o que reflete assim, que tem a demanda mesmo, assim, seja do componente básico, estratégico ou especializado, existe uma demanda judicial por eles. E como no componente 
especializado tem os protocolos, então muitas vezes...essa parte eu não analisei mais a fundo. Mas, às vezes, os próprios protocolos não cobriam a doença ou até a gravidade. Às vezes, por exemplo, alguns medicamentos só podiam ser indicados se tivesse uma doença com uma determinada gravidade ou refratariedade a um tratamento anterior. E aí muitas vezes não tinha. Então, eles já entravam com esse processo.

\section{O mesmo entrevistado (7EN) também cita exatamente uma situação apresentada} anteriormente:

Outra coisa que eu observei também, é que muitos processos traziam mais de um medicamento. E esses medicamentos, às vezes, acontecia assim, do médico prescrever, por exemplo, um medicamento que não tinha padronização. Mas, como na receita já tinha o medicamento não padronizado, ele já incluía outros medicamentos e outros insumos, também. Então, às vezes, aparecia, por exemplo, um processo com cinco medicamentos. Mas, às vezes, um era não padronizado e aí todos os outros já eram padronizados, inclusive, já estavam disponíveis na Secretaria, não estava nem em falta. [...] Aí o juiz deferia. A maior parte dos processos era deferido, assim, não tinha defesa e ele já era deferido. E sem nenhum argumento, assim. “Ah, mas não tem eficácia, não tem nada”, mas não interessa, ele já era deferido.

\section{O entrevistado 11EN comenta também sua experiência, pela DPDF:}

Mas, nós encontramos uma dificuldade muito grande com medicamentos não padronizados e de alto custo, principalmente, em tratamentos oncológicos. Nesses casos, com a dificuldade, muitas vezes...inclusive, medicamentos sem autorização da Anvisa para comercialização no país. Nesses casos da Anvisa, muitas vezes, a gente vai verificar nas resoluções da Anvisa a possibilidade de realizar o tratamento com esse medicamento. E as hipóteses em que esse medicamento é autorizado sua utilização no Brasil. Quando se busca essas resoluções? Com o relatório médico, a gente viabiliza que esse tratamento seja realizado e, muitas vezes, via judiciário. Só que isso dá um custo para o estado elevado. E muitas vezes, há uma quebra de protocolo, porque o estado tem um protocolo que indica os medicamentos para determinados tipos de doenças. E quando nós entramos via judicial para que esse medicamento seja disponibilizado, nós estamos quebrando o protocolo, com base num médico que indicou o medicamento e fundamentou, realmente, ele fundamenta corretamente a necessidade daquele medicamento. Mas, até onde vai esse entendimento, eficácia e eficiência desse medicamento? Nós buscamos através de estudos no exterior e, muitas vezes, só tem no...não sei, não tem nem no Brasil. Não autorização na Anvisa. Então, nós buscamos essa comprovação científica para convencer, para mostrar para o juiz que esse medicamento, realmente, vai atingir...tem eficácia, tem eficiência. Só que algumas vezes, esse medicamento tem o custo muito mais elevado. E nós temos ainda...muitas vezes, não há uma contraprova fornecida no processo de que esse medicamento, realmente, poderia ser substituído pelo outro.

\section{O entrevistado 12EN também comenta:}

E eu observei que os medicamentos não padronizados, os que vem geral e chegam a questão da ação judicial, são medicamentos além de alto custo, caros, são para poucos. Não tem tanto volume. E é um valor muito alto. E que o governo, às vezes, 
acaba não dando nem adesão para o tratamento, porque conseguiu-se naquele momento e até quando? Então, a preocupação chega até a esse fato de já termos um medicamento já com a ação, com a judicializaçao, e já ter conseguido até ser favorável, a certidão ser positiva. Mas, não teve adesão.

Diante destes exemplos de ações judiciais e aliado às informações repassadas pelos entrevistados destes estudo, procede-se com as propostas de tipificação de demandas por medicamentos e dos fluxos de fornecimento pela via judicial. Relembrando que tratam-se de propostas derivadas do presente estudo e visam contribuir para a compreensão da operacionalização da judicialização da saúde no Brasil.

A CAMEDIS e as Defensorias Públicas do Distrito Federal e da União já foram apresentadas nesta pesquisa, na categoria das estruturas organizacionais. Cabe aqui relembrar que a tentativa inicial para os processos em saúde é de mediar o conflito. Logo, sendo a questão mediada com sucesso, o usuário terá acesso à tecnologia em saúde ou ao serviço solicitado por meio do próprio SUS, sem a judicialização. Então os tipos de situação identificados a seguir se referem aos casos nos quais não houve a tentativa de mediação ou a tentativa foi falha. Isto porque, no caso de haver, por exemplo, uma alternativa terapêtica disponível no SUS, a mediação poderia evitar a judicialização e levar à substituição da prescrição por parte do profissional prescritor responsável. Logo, para os casos que virão a seguir, o cidadão buscou na Justiça a prestação do seu direito à saúde, foi aberta uma ação judicial e esta foi deferida. Para cada tipo de caso identificado, corresponde um fluxo específico da operacionalização do acesso ao medicamento exigido.

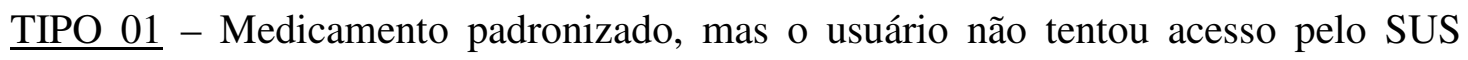
primeiramente.

Este tipo de judicialização envolve alguns usuários que não passaram por um serviço do SUS antes de requerer o medicamento pela via judicial. Isto pode ocorrer tanto para cidadãos que iniciaram suas ações por meio de advogados particulares quanto pela defensoria pública. É claro que, pela defensoria, há uma intenção já detectada por esta pesquisa para a verificação prévia quanto à existência do tratamento ou de alternativas terapêuticas no próprio SUS. Porém, quando não é feito, pode ocorrer a abertura de uma ação por medicamento já disponível no sistema.

Cabem também neste tipo de caso, as ações nas quais judicializa-se um medicamento não padronizado, por exemplo, mas no processo é incluída toda a prescrição medicamentosa com outros medicamentos que fazem parte da relação de padronizados. Por vezes até por 
comodismo, conforme relatos, o usuário opta por solicitar todos os medicamentos pela via judicial para ter o acesso por uma única via. Nestes casos, os medicamentos que estavam disponíveis no SUS passam por aquisição judicial individualizada sem haver necessidade.

Para todos os casos deste tipo, mesmo havendo a abertura de uma ação judicial, é possível, ainda, reencaminhar o usuário para o SUS garantindo que o paciente tenha recebido o tratamento corretamente e notificar isto ao juiz, no próprio processo. Porém, ressalta-se que, para o caso de tratamentos de medicamentos do CEAF/PNAF, o paciente deve se enquadrar nos PCDT, assim como os demais usuários do sistema. Se o paciente não se enquadrar no PCDT, ele se caracteriza como um caso do Tipo 04, fora do protocolo.

No caso excepcional de desabastecimento, passa-se a configurar o Tipo 02 de ação.

A sistematização dos fluxos de operacionalização de acesso de casos do Tipo 01, é apresentada na Figura 5.7.

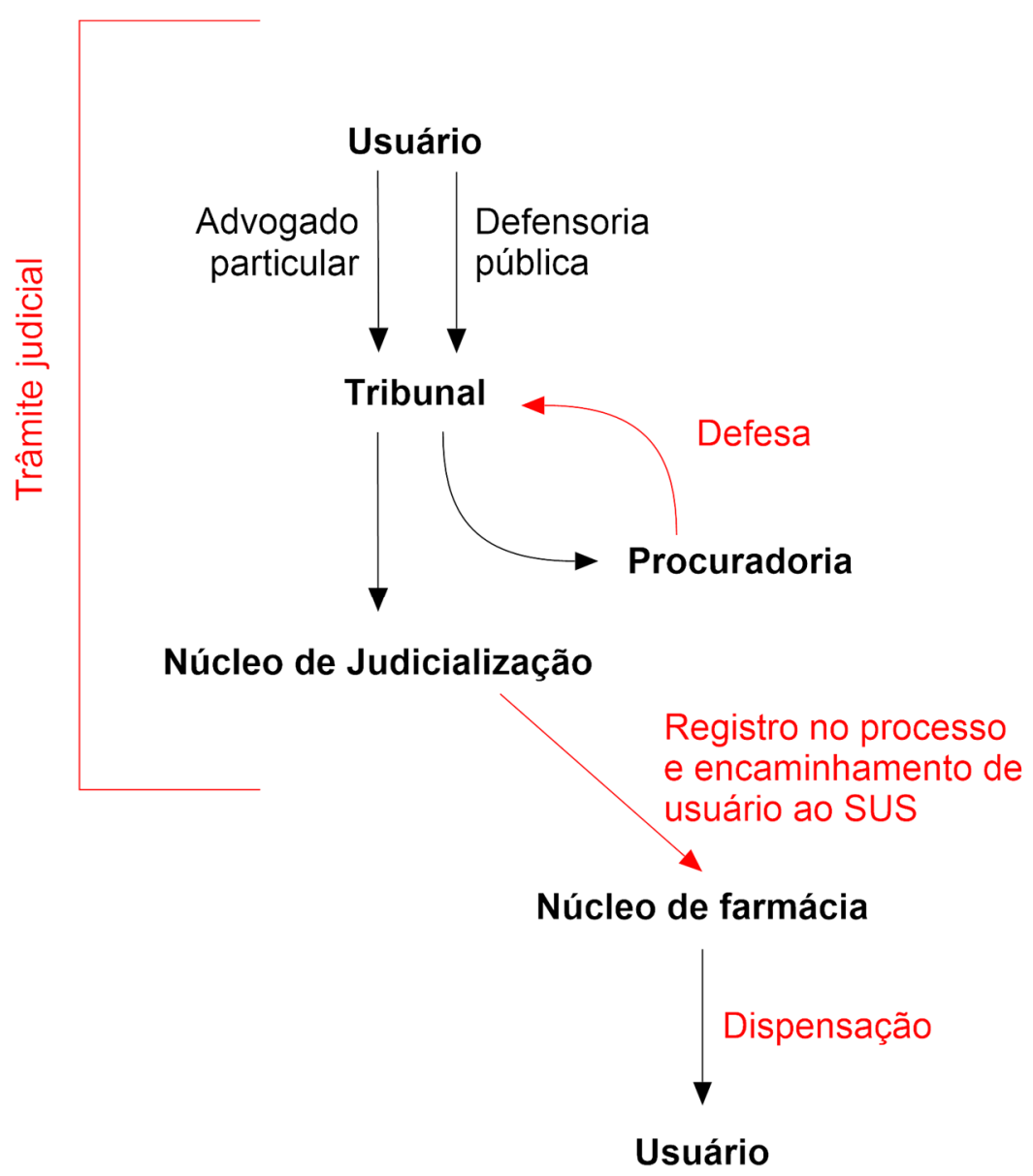

Figura 5.7 - Fluxo da operacionalização de acesso a medicamentos por via judicial - Casos do Tipo 01. Fonte: Da autora. 
TIPO 02 - Medicamento padronizado, em desabastecimento.

Esta situação também trata de medicamento padronizado pelo SUS, mas em falta no momento da abertura do processo judicial. Para este caso o mais comum é iniciar a primeira compra pelo núcleo de judicialização, em função da antecipação de tutela do direito. E, após a aquisição do medicamento para o fornecimento do primeiro mês, reencaminha-se o usuário para a via regular do sistema e ele recebe o tratamento pelo SUS, pela via regular da política.

Porém, podem ocorrer ainda duas situações. A primeira ocorre quando o medicamento continuar em desabastecimento na rede e o Núcleo Jurídico continuar com a responsabilidade da compra nos meses seguintes. A segunda seria a ocorrerência de uma lentidão da resolução da ação judicial e o abastecimento ser reestabelecido antes mesmo da primeira compra ser iniciada pela via judicial. Nesta última situação, encaminha-se o usuário para o SUS e garante-se a oferta do tratamento, notificando-se no processo judicial este encaminhamento.

O fluxo de operacionalização de acesso dos casos do tipo 02 está esquematizado na Figura 5.8.
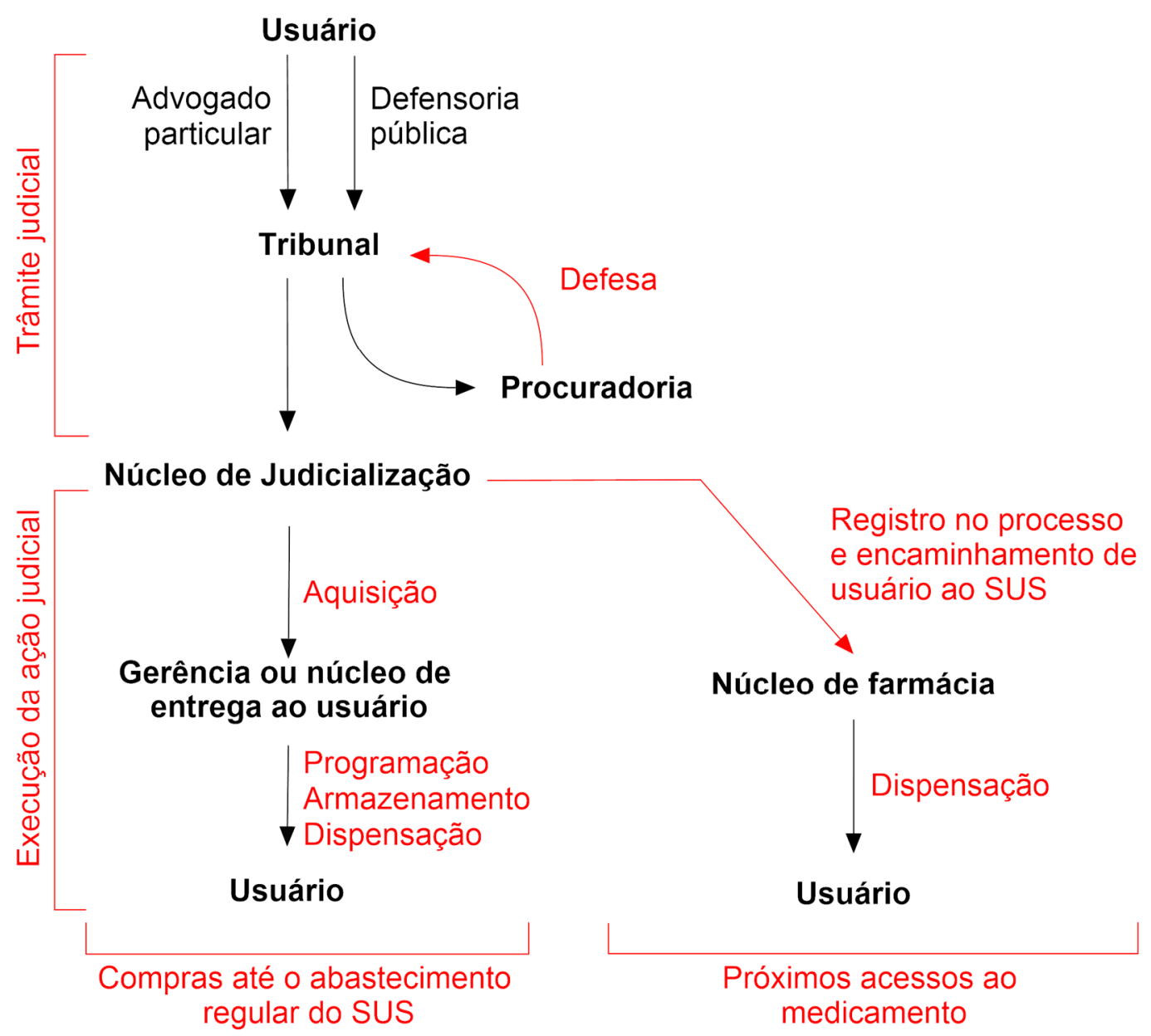

Figura 5.8 - Fluxo da operacionalização de acesso a medicamentos por via judicial - Casos do Tipo 02. Fonte: Da autora. 


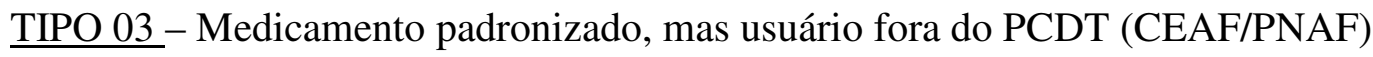

Algumas situações deste caso equivalem ao tipo 04, em termos clínicos. Pois, mesmo que o medicamento seja padronizado na rede, se o paciente não cumpre os critérios do PCDT este pode não ser o melhor tratamento para ele. Ou pode não ser o melhor tratamento para aquele nível de agravo da doença. Quer dizer, por vezes há outras alternativas terapêuticas para o estágio da doença em que o paciente esteja e, em outra etapa, o tratamento solicitado já seria o mais adequado.

De qualquer forma, clinicamente, ele não está no momento adequado para receber este tratamento ou não possui o quadro necessário para tal. Mesmo o medicamento sendo padronizado no sistema de saúde, este tipo de ação tem respaldo clínico para a sua ocorrência, pois o tratamento solicitado não pôde ser acessado por meio do SUS por não ser indicado para o caso.

Porém, como já colocado, trata-se do caso já deferido pela justiça, então o medicamento é fornecido independentemente do cumprimento destes critérios clínicos. Mas o detalhe essencial do caso é que este paciente não é encaminhado ao SUS, mesmo havendo a padronização do medicamento. Isto porque os medicamentos adquiridos pela via regular de acesso, ou seja, pela implementação da política de medicamentos, tem financiamento previsto pelos respectivos programas de saúde. Consequentemente, o acesso fora do protocolo descaracteriza o cumprimento da política e não está previsto no orçamento programado. Para esta situação, o andamento do processo é equivalente ao do Tipo 04, para medicamentos não padronizados.

Outra questão peculiar à este caso é de que os PCDT são publicações do MS. Deve-se lembrar, então, que no caso 01 foi descrita a discricionariedade administrativa do poder executivo em criar Protocolos Estaduais de tratamento. Dessa forma, as ações do tipo 03 podem se dividir em dois subtipos: (a) aquelas referentes à medicamentos cujo requerente está fora dos protocolos do MS e dos protocolos estaduais; e (b) aquelas em que o usuário está incluído no Protocolo Estadual e não no PCDT do MS. E, nesta última situação, ele receberá o medicamento pela via regular, da política.

Para tal fornecimento, segue-se o fluxo proposto na Figura 5.9. 


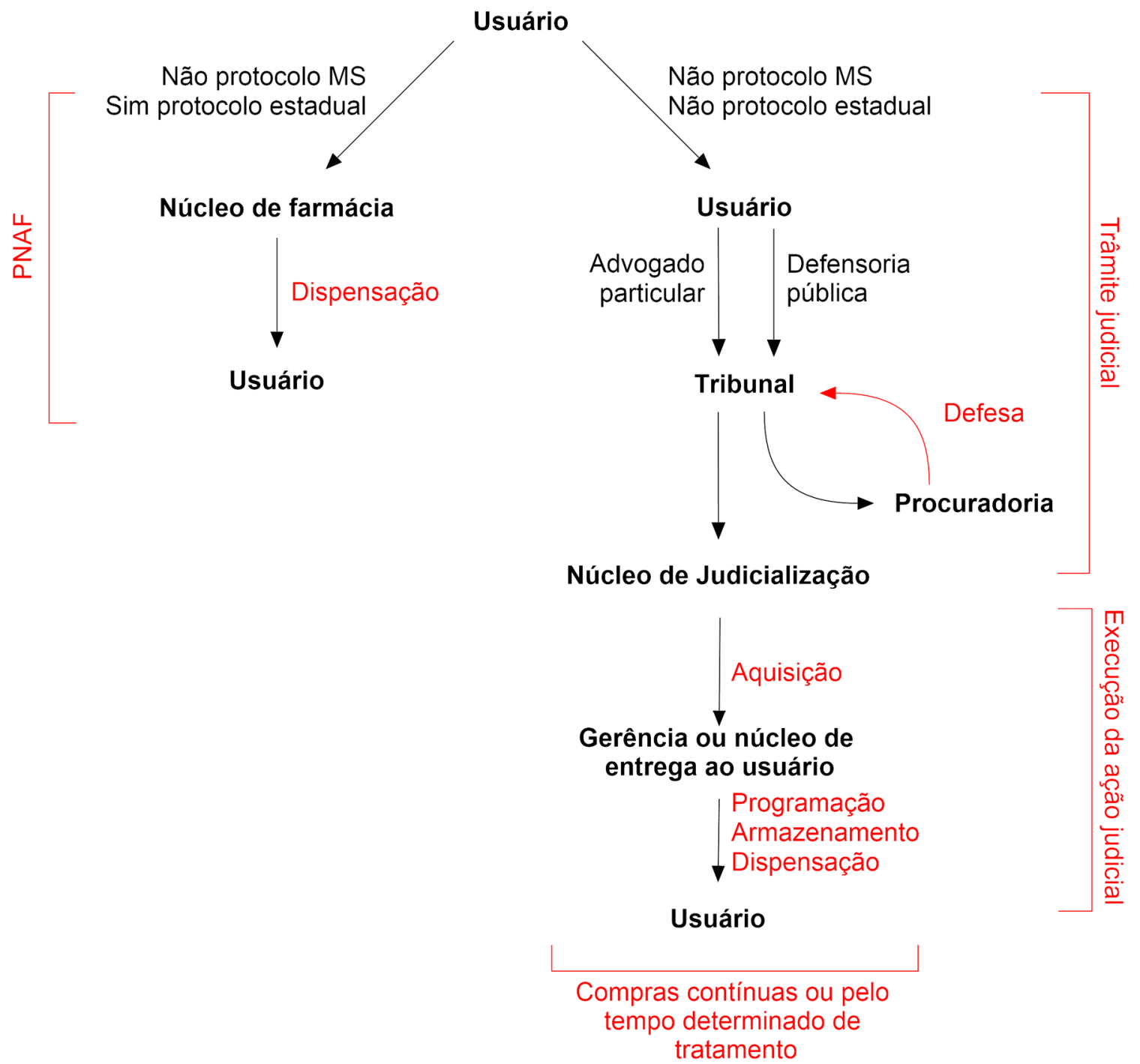

Figura 5.9 - Fluxo da operacionalização de acesso a medicamentos por via judicial - Casos do Tipo 03. Fonte: Da autora.

\section{TIPO 04 - Medicamento não padronizado}

Os casos de usuários que requerem um medicamento não padronizado no SUS, se solicita um tratamento que não está previsto para as doenças mais prevalentes da população, para as doenças raras ou mesmo para os diversos estágios das doenças com cobertura de tratamento pelo SUS. Para este tipo de ação judicial (04), normalmente há duas outras variáveis a levar em consideração: a existência ou não de registro na ANVISA do medicamento e a comprovação ou não de sua eficácia para o fim proposto. Porém, como se trata de casos já deferidos pela justiça, quanto à execução destas ações, a análise quanto à existência do registro ou de eficácia deverá ou deveria ter sido realizada antes da decisão judicial. Logo, estas análises não cabem posteriormente à decisão do juiz. E é relevante 
destacar que o medicamento pode ter eficácia e segurança comprovadas para outras indicações clínicas, e não para aquela a qual está sendo solicitado.

Para estas situações do tipo 04, lembrando que o pedido já foi deferido judicialmente, o medicamento será fornecido continuamente (ou pelo tempo determinado na ação) pela estrutura do poder executivo criada especificamente para dar andamento às ações judiciais e já escrita em subseção anterior.

Como proposta do fluxo para o tipo 04, tem-se o esquema criado na Figura 5.10.

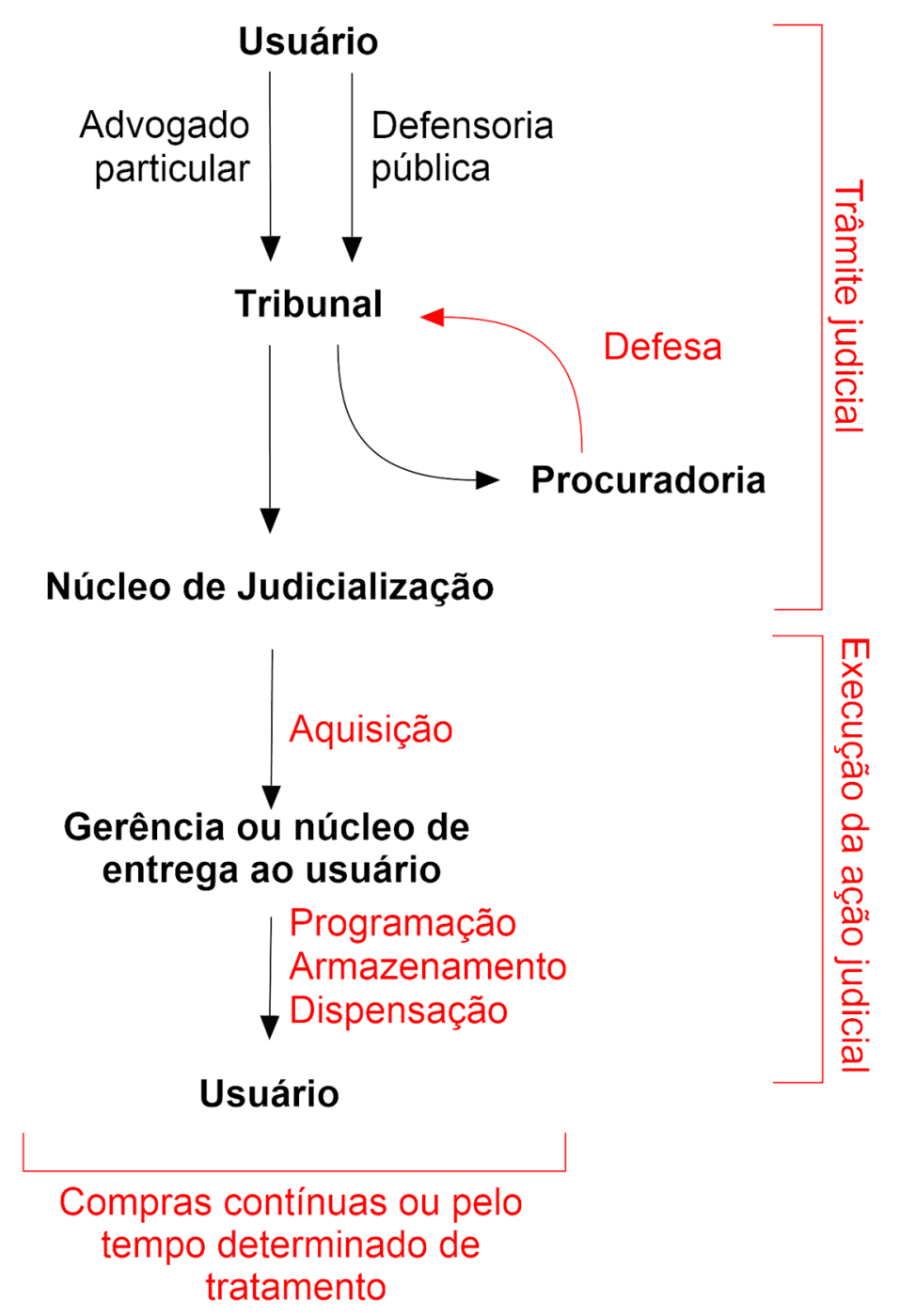

Figura 5.10 - Fluxo da operacionalização de acesso a medicamentos por via judicial - Casos do Tipo 04. Fonte: Da autora.

Em paralelo aos quatro tipos de situações apresentadas, deve-se considerar que as ações podem ser interpostas ao Distrito Federal (ou estados) e à União, conforme citado na subcategoria recursos financeiros. Logo, para todos os tipos de caso há ainda duas possíveis 
situações: o usuário interpõe uma única ação tendo os dois entes federativos como réus (ou tem somente um, sendo o outro solidário ao caso) ou o usuário interpõe duas ações separadas, uma contra cada um dos entes federativos citados.

Subtipo A: usuário interpõe uma ação tendo a União e o DF (estado) como corréus.

Para esta situação, dá-se preferência para o estado ou o Distrito Federal executar a ação judicial e a União participa transferindo os recursos da parte que lhe cabe.

$\underline{\text { Subtipo B: }}$ usuário interpõe duas ações separadas, uma contra a União e outra contra o DF (estado), com respeito à mesma solicitação.

No subtipo B, como são impetradas duas ações separadamente, os Núcleos Jurídicos do MS e do estado ou SES-DF precisam manter comunicação para confirmar se quando há duplicidade de ações, conforme informaram os entrevistados 1EN, 8EN, 9EN e 10EN. Ou, ainda, verificar nos sistemas online os números de cadastro de pessoa física (CPF) dos autores das ações, para confirmação quanto à existência de ações equivalentes. Ocorrendo esta comunicação, há ainda dois possíveis procedimentos. Um primeiro processo seria a execução da ação pela SES-DF (ou pelo estado). Neste caso, o MS transfere os recursos da parte que lhe cabe no financiamento, quando for o caso. Nas outras duas situações, o MS executa a ação e pode fazê-lo por meio de compra e entrega do medicamento ou por depósito do valor do produto direto na conta do usuário, como já explicado.

Sobre isto, o entrevistado 1EN comentou:

Então, normalmente, eu sei que tem uma articulação do nosso núcleo jurídico com os núcleos estaduais, justamente para ver se alguém já forneceu um medicamento ou não, para não ter esse duplo envio do medicamento. E muitas vezes, tem se pedido quando tem mais de um ente que está envolvido na ação, que, por exemplo, o estado faça o repasse, entregue o medicamento e depois ele cobra uma parcela da União.

O entrevistado 8EN também expõe sua experiência no Núcleo de Farmácia Ambulatorial Judicial quanto à esta questão:

Tanto o DF, quanto a União. Aí esses casos da União, a maioria que a gente pega aqui é de paciente já recebendo em casa. E eu também recebo muito e-mail da União, do povo lá, se você quiser também o contato para conversar com eles, do Ministério. E aí eles perguntando, "paciente fulano de tal, ação tal, medicamento tal. Vocês estão entregando?", aí a gente fala, "não", "estou”. Porque aí já é uma comunicação para cruzar os dados, falando "olha, o paciente está pegando aí, aquì". $[\ldots]$

E a gente sempre fica olhando na União para ver se a União está entregando. Mas, é difícil, a gente não tem muita resposta, entendeu? Mas, tem gente que chega aqui, por exemplo, desde que está a Defensoria Pública do DF, chega à Defensoria 
Pública da União. Aí a gente já bate o olho e pergunta, "mas, será que o NJUD viu isso?", "será que o NJUD viu sera ele está recebendo por lá ou não está?". Esse aqui é do DF, mas tem uns que são Defensoria Pública da União, entendeu? E aí fala assim, "réu não sei o que", aí está lá União, DF e outros. É uma coisa assim, entendeu? Aí nunca assim...tem uns assim que fica no limbo, a gente não sabe se está recebendo pela União ou não está.

Para cada uma destas situações foram criadas Figuras para melhor explicar os casos. Para o Subtipo A, foi elaborada a Figura 5.11. Para o Subtipo B, foi criada a Figura 5.12.

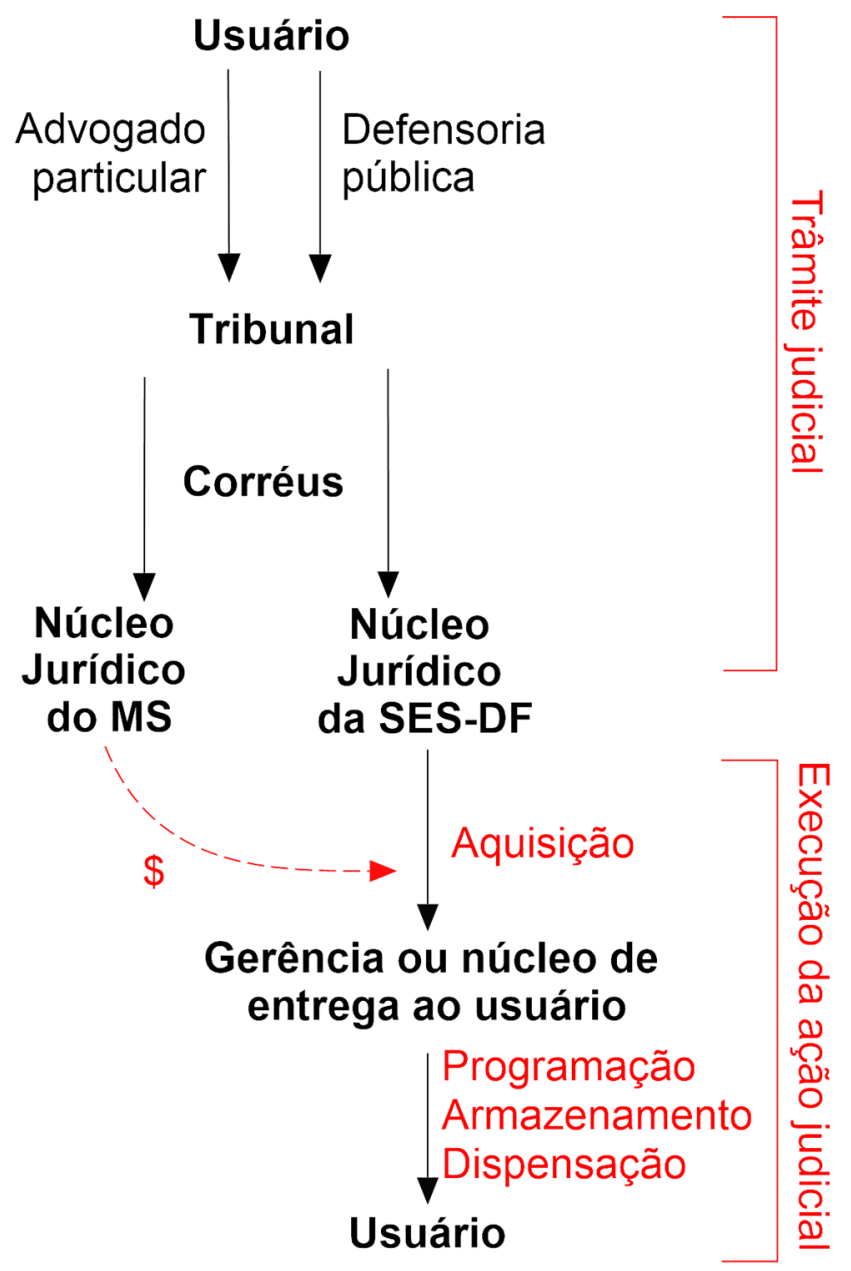

Figura 5.11 - Fluxo da operacionalização de acesso a medicamentos por via judicial - Casos do Subtipo A. Fonte: Da autora. 


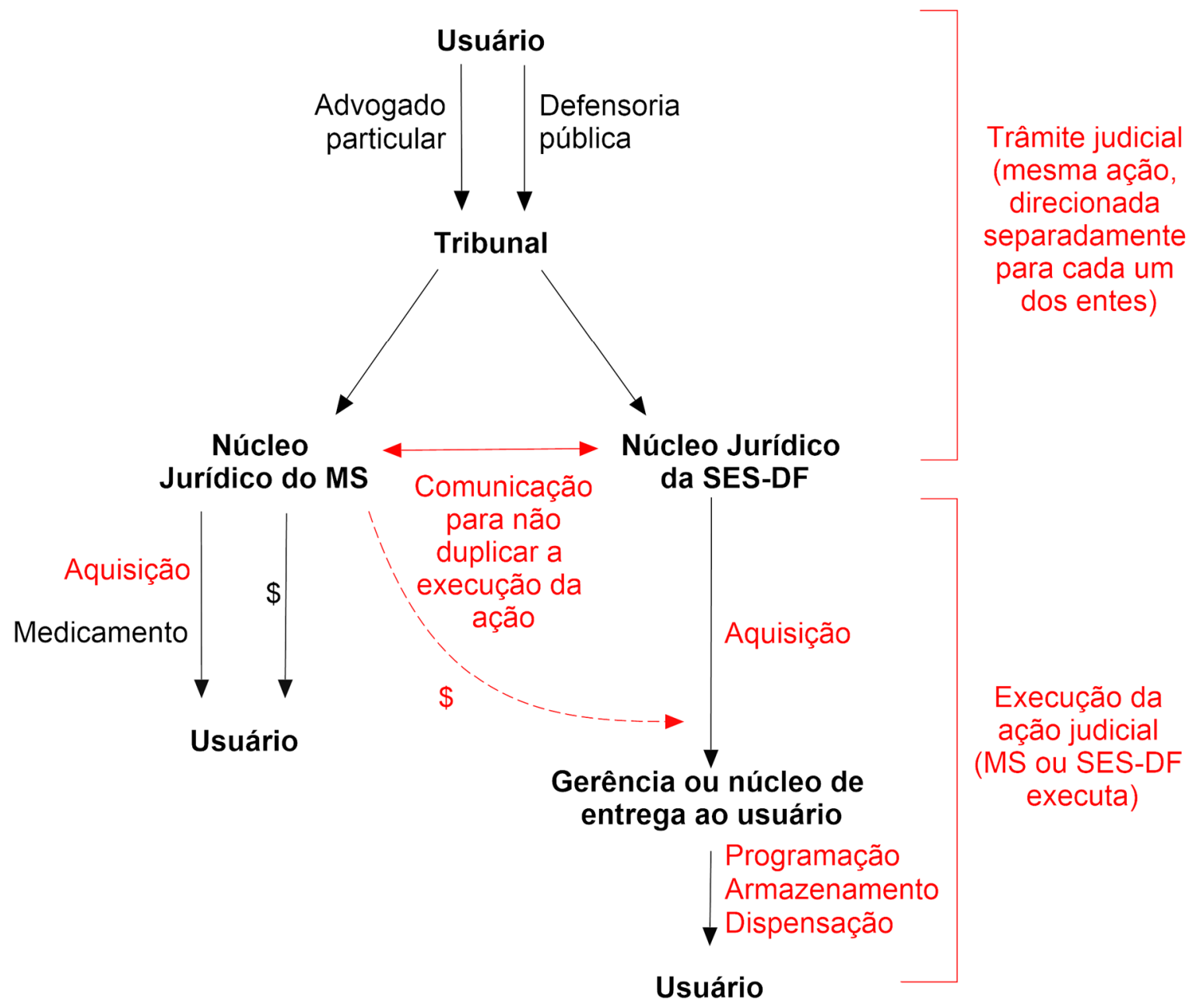

Figura 5.12 - Fluxo da operacionalização de acesso a medicamentos por via judicial - Casos do Subtipo B. Fonte: Da autora.

É importante registrar que o entrevistado 9EN explicou que o tempo de resolução das decisões judiciais, em geral, é menor para o Ministério da Saúde se comparado à SES-DF. Desta forma, a abertura de um processo contra a União, normalmente tem um tempo de execução menor.

Alguns pontos processuais importantes para todos os casos são os seguintes:

Os processos judiciais tratados por este trabalho tem uma matéria comum que é a reclamação pelo fornecimento de medicamentos. Além disso, são caracterizados por ações individualizadas, que podem ser direcionadas ao DF e/ou à União.

O documento 20AR acrescenta que os processos jurídicos relacionados à saúde podem tramitar em $1^{\mathrm{a}}$ e $2^{\mathrm{a}}$ instâncias, a depender da abertura de recurso ou não contra a primeira decisão judicial (SANT'ANA et al, 2011).

Para o início dos processos, a demanda precisa ser encaminhada à um tribunal de $1^{\mathrm{a}}$ instância e, havendo recurso por parte do governo, por representação pela procuradoria, a 
ação passa para a $2^{\mathrm{a}}$ instância. No caso do DF o TJDFT possui como $1^{\mathrm{a}}$ instância 175 órgãos instalados (varas e juizados). Já para a $2^{\text {a }}$ instância o Tribunal de Justiça é formado por 40 desembargadores (documento 13SI) (TRIBUNAL DE JUSTIÇA DO DISTRITO FEDERAL, 2016a).

Ainda sobre as características dos processos, já que as ações judiciais tratam da solicitação de medicamentos e o assunto central remete ao direito à saúde e ao direito à vida, estes litígios são encaminhados com solicitação de antecipação de tutela. Logo, há a decisão judicial provisória antes mesmo da defesa, que seria o governo, ser chamada. Mas processualmente, apesar do governo ter que cumprir esta decisão de imediato, há uma decisão posterior final, caso seja identificado algum problema que inviabilize o deferimento da ação. Mas isto não é comum para as ações em saúde. E, conforme entrevistado 14EN, um indeferimento posterior ocorreria, por exemplo, se fosse descoberta alguma fraude na solicitação realizada. Por isso, em geral, a decisão judicial final é a mesma do momento da antecipação da tutela.

Sobre esta questão geral, o entrevistado 14EN explica:

[...] o procedimento básico seria: você entra com uma ação e eles citam a outra parte, dizendo "fulano, entraram com uma ação contra você. Venha se defender." Então a outra parte se defende, tem a produção de prova, terá a audiência, a perícia, o que for necessário e aí teria a sentença. Isto é o usual, o básico, o procedimento comum. Só que o que é que acontece... tem as exceções e a saúde é uma delas. Às vezes aquele processo demora, pois deve-se chamar a outra parte, ela responder e ter produção de prova para que o juiz possa decidir. E tem situações que são urgentes e que existe a antecipação de tutela.

Para melhor esclarecer as particularidades jurídicas, o entrevistado 14EN continua explanando sobre a antecipação de tutela:

E o que é esse pedido de antecipação de tutela: você tem um problema e vai ao juiz e fala que tem "esse problema" e que está "acontecendo isso". Mas eu não terei tempo de esperar até o outro cara citar, porque "senão eu vou morrer". Então eu preciso desse remédio para hoje, preciso dessa operação para hoje. E então geralmente, é super razoável, o juiz defere. Ele fala "diante da urgência eu obrigo o estado, o hospital a dar o remédio, a fazer a cirurgia. E aí, depois, eu vou analisar a situação com mais calma”. Então geralmente o juiz dá uma decisão em antecipação de tutela e geralmente as pessoas conseguem o remédio, não é? E então o processo continua, ele não termina aí. E aí pode ter a defesa. $\mathrm{O}$ estado, depois disso, pode se defender. Mas ele foi citado para cumprir a ação e se defender depois. Então a antecipação de tutela... é meio complicado... mas em tese teria uma decisão posterior, que seria a decisão definitiva. Porque esta decisão de antecipação de tutela em tese é provisória. É uma decisão de urgência que até poderia ser revertida ao final. No caso da saúde é complicado. Por exemplo, no final descobre que o autor estava mentindo e que ele pegou este remédio e revendeu. 
Em concordância ao explicado e conforme informação dada pelo entrevistado 9EN, as ações, quando deferidas, recebem esta decisão judicial e já são encaminhadas ao núcleo jurídico responsável. Em paralelo à isto, uma cópia do processo é recebida pela Procuradoria, que irá providenciar a análise para a representação e defesa do governo frente ao Judiciário.

Mas o entrevistado 8EN apresenta uma ressalva para a questão colocada:

Cada paciente vai com a sua receita e a decisão judicial. Receita e a decisão judicial.
Porque? Porque, às vezes, o juiz, ele volta atrás. E como a maioria é antecipação de
tutela, quando sai a sentença, o juiz fala, "não, eu não vejo necessidade em dar". Aí
a gente tem que ficar de olho, também, porque a judicialização é meio falha nessa
parte. Então, sempre que a gente vai fazer um pedido de compra, a gente tenta olhar
as decisões atualizadas no TJ, ver se mudou alguma coisa. A gente imprime, coloca
receita atualizada e vai juntando, para cada paciente, faz um memorando só. Mas,
cada paciente tem o seu documento.

O documento 22AR acrescenta que a aplicação de liminar dificulta o cumprimento das ações em saúde, pois determina prazos muito curtos para a prestação do direito e os trâmites burocráticos da administração pública por vezes não permite a aquisição do medicamento à tempo (PAIM; MARQUETTO; LOPES, 2016).

Como já descrito na subcategoria recursos financeiros, no caso de medicamentos cujo financiamento é de responsabilidade compartilhada por mais de um ente federativo, mantémse a solidariedade no custeio destes. Logo, se um ente realizou a compra, depois é feito o repasse de recursos ou o ajuste das contas.

Como ferramenta de síntese das informações apresentadas na discussão dos tipos de ações judiciais por medicamentos, foi elaborado o Quadro 5.2.

Quadro 5.2 - Síntese de aspectos relacionados às ações judiciais por medicamentos (continua)

Síntese de aspectos relacionados às ações judiciais por medicamentos

São matérias das ações por acesso a medicamentos: (1) medicamentos não padronizados; (2) medicamentos com indicações clínicas não aprovadas para uso pelo SUS ou pela ANVISA (padronizados, porém para outras indicações clínicas); (3) medicamentos padronizados (problema na execução da política); (4) medicamentos padronizados (por estarem na mesma prescrição que o medicamento de fato responsável pela judicialização)

São causas que incitam a abertura de processo judicial: (1) falta do medicamento nas farmácias públicas; (2) desconhecimento dos prescritores sobre a lista de medicamentos padronizados; (3) não seguimento pelos prescritores da lista de medicamentos padronizados; e (4) atraso na incorporação de novos medicamentos nas listas padronizadas;

Muitas prescrições de processos judiciais apresentam como problemas: (1) não adequação aos critérios de boas práticas de prescrição; (2) fármacos não prescritos pelo nome genérico; (3) prescrições não acompanhadas por relatórios médicos robustos; e (4) medicamentos sem registro na ANVISA. 
Quadro 5.2 - Síntese de aspectos relacionados às ações judiciais por medicamentos (conclusão)

Para as ações de medicamentos padronizados, porém com o usuário fora do PCDT ou do Protocolo Estadual, o processo judicial exige o indeferimento do acesso via SUS para que o trâmite da ação prospere.

Para as ações de medicamentos padronizados, porém com o usuário fora do PCDT ou do Protocolo Estadual, os critérios clínicos baseados em evidências dos PCDT não estão sendo seguidos no caso de deferimento deste acesso.

Para ações de medicamentos padronizados, porém em desabastecimento, após a regularização do fornecimento o usuário é encaminhado novamente para o SUS.

Para acesso aos medicamentos padronizados pela política, após fim do desabastecimento, o usuário deve se enquadrar nos critérios dos PCDT, no caso do CEAF/PNAF.

Para ações de medicamentos não padronizados, a aprovação do fornecimento muitas vezes desrespeita os critérios de existência de registro na ANVISA para comercialização no país e de comprovação científica de eficácia e segurança para a indicação clínica proposta.

Para medicamentos de financiamento solidário entre os entes, o custeio dos medicamentos judicializados também deve ser compartilhado.

Os núcleos jurídicos dos diferentes entes federativos devem manter comunicação constante para evitar a execução de ações judiciais equivalentes e duplicadas, direcionadas à mais de um ente.

Fonte: Da autora.

\subsubsection{Discricionariedade operacional}

Nesta subcategoria, complementando e avançando no que foi discutido quanto à liberdade de atuação do magistrado no controle jurisdicional, os dados da pesquisa apresentam variados exemplos de situações em que esta oportunidade de ação se mostra. Então foram organizados os exemplos encontrados nos documentos de demandas judiciais e suas decisões. E, antes desta exposição, há dois depoimentos relacionados às preocupações de se compreender e julgar um caso da área da saúde.

O defensor público do Tribunal de Justiça do Distrito Federal e dos Territórios, Ramiro Nóbrega Sant'Ana, no documento 4NS, citou as limitações que um defensor público possui em conhecer os aspectos particulares das políticas públicas de saúde. Ele cita que "Entender uma Política Pública a partir de portarias e compreendê-las é o principal, mas essa é uma linguagem que nós não aprendemos na faculdade" (CONSELHO NACIONAL DE SECRETÁRIOS DE SAÚDE, 2016c). Ou seja, na prática, com casos da saúde, os magistrados não estão empoderados de conhecimento da área o suficiente para se sentirem seguros e realizarem um bom julgamento. 
Em contraponto à defesa das decisões melhor embasadas, como outro exemplo de preocupação de um magistrado, tem-se a fala do juiz do Tribunal de Justiça do Estado da Paraíba, Marcos Salles. Este diz não querer ter em sua consciência a culpa por um óbito (CONSELHO NACIONAL DE SECRETÁRIOS DE SAÚDE, 2016c). Esta opinião retrata uma postura de deferimento frente às ações desta natureza. Isto porque, diante da dificuldade de análise de um caso envolvendo risco à vida, o receio de um óbito em função da negação ao pedido judicial pode limitar a capacidade ou vontade de interpretação dos fatos e uma possível decisão de indeferimento, a depender do caso em específico.

Nos casos relatados por Sant'Ana et al (2011) no documento 20AR, em geral os pedidos liminares de antecipação de tutela foram deferidos e os réus não apresentaram o padrão de recorrer, em sua maioria. Para estes casos relacionados ao acesso à medicamentos, a vigência das ações era de meses e, de forma majoritária, o paciente mantinha o recebimento dos produtos sem necessidade de uma nova prescrição ou avaliação médica. E isto foi verificado nos autos dos processos, confirmando a não exigência de acompanhamento posterior.

Em um cenário em que se observa a judicialização excessiva do direito à saúde, também ocorre o deferimento em massa de demandas que exigem do governo o financiamento de tratamentos irracionais e a realocação de recursos por parte do gestor, conforme documento 35AR. Este ato pode até ocasionar dano ao cumprimento do princípio de equidade e dificultar o acesso à saúde por outros, em função do desvio de verbas de outras políticas de saúde. E, especificamente para o contexto da assistência farmacêutica, isto pode ainda ocasionar o uso irracional de medicamentos, desarticulando as ações da área (MACHADO et al, 2011).

O documento 20AR explica que nos casos em que se notou deferimento dos processos sem análise individual, entende-se que pode ocorrer uma falha por não serem demonstradas inadequações de algumas prescrições apresentadas nos casos, ou que há alternativas terapêuticas disponíveis no SUS para os casos relatados ou, por fim, que há possíveis malefícios que o medicamento solicitado pode causar para o paciente requerente (SANT'ANA et al, 2011).

Diniz, Medeiros e Schwartz (2012) apresentam no documento 30AR que nos casos analisados em suas pesquisas foram detectadas incertezas quanto à relevância científica dos medicamentos solicitados em ações judiciais. E, diante do deferimento destes casos, o Poder Judiciário determinou a compra dos medicamentos. Estes medicamentos cuja eficácia e segurança são questionáveis para determinada finalidade terapêutica não seriam incorporados 
pelo SUS, comprovadas estas condições, e não seriam fornecidos aos usuários. Logo, o deferimento de uma ação com este pleito e o fornecimento deste tipo de medicamento seria o equivalente à incorporar uma tecnologia não apropriada no SUS. Porém, ao invés disto estar ocorrendo, somente os pacientes das ações judicializadas estão recebendo esses produtos, que clinicamente e cientificamente não seriam os mais adequados. Logo, pela premissa de que o sistema de saúde omitiu o atendimento à estes pacientes, a decisão de deferimento seria uma proteção e resgate do que, no entendimento do juiz, deveria ter sido feito anteriormente. Porém a qualidade do tratamento e a segurança do paciente devem ser resguardadas.

Um caso simbólico para o Brasil e que atingiu o âmbito internacional, envolve a substância fosfoetanolamina. No documento 36AR, o autor destaca que esta substância foi demandada judicialmente e teve suas solicitações acatadas pelo judiciário independente da realização de ensaios clínicos de comprovação da eficácia e segurança de uso no tratamento de câncer. E foi a corte de São Paulo que interrompeu a distribuição da fosfoetanolamina sob estas condições (LEDFORD, 2015). Este caso demonstra que, antes da decisão do tribunal de São Paulo, inúmeros outros tribunais haviam deferido as solicitações de acesso à substância citada, apesar da ausência de critérios técnicos objetivos que indicassem a eficácia e segurança desta aplicação clínica.

Como outros exemplos de casos da área da saúde e que demonstram a discricionariedade nas decisões, apresenta-se alguns exemplos abaixo. São casos de jurisprudência do Tribunal de Justiça do Distrito Federal e Territórios e versam sobre casos de acesso à medicamentos. Nestes casos evidenciam-se algumas situações de indeferimento de ações de apelação do Estado.

Como primeiro caso, tem-se o disposto no documento $1 \mathrm{~J}$, in verbis:

CONSTITUCIONAL - PACIENTE HIPOSSUFICIENTE - MEDICAÇÃO, NECESSIDADE - ASSISTÊNCIA À SAÚDE, DEVER DO ESTADO

(Reg. Ac. 318.983). Relator: Des. Lecir Manoel da Luz. Apelante: Distrito Federal (Adv. Dr. Murilo de Almeida Nobre Júnior - Procurador do DF). Apelada: Selma Maria de Oliveira (Defensoria Pública). [iç]

Decisão: Conhecer. Rejeitar preliminar. Negar provimento. Unânime.

Constitucional. Processual civil. ação cominatória. Paciente acometida de reumatismo. necessidade de medicação. Carência de recursos financeiros por parte da enferma. Preliminar. Perda superveniente do objeto. inocorrência. ilegitimidade passiva ad causam. Competência. Justiça Comum. mérito. Prestação de assistência à saúde aos necessitados. dever do Estado. sentença mantida. recurso improvido. 1 se a autora tivesse logrado êxito em obter os remédios e materiais necessários para o tratamento de sua enfermidade diretamente da secretaria de saúde do distrito Federal, não haveria necessidade de recorrer ao Judiciário. da mesma forma, se a pretensão da autora é o recebimento de remédios e materiais médicos por prazo indeterminado, enquanto perdurar o tratamento, percebe-se que o pleito não foi satisfeito integralmente, razão pela qual não há que se falar em perda superveniente 
do objeto. 2- não há que se falar em competência da Justiça Federal para o processamento do feito, tendo em vista que a Lei orgânica do dF determina a competência do distrito Federal para prestar assistência social aos necessitados. demais disso, o artigo 198 da Constituição Federal prevê que o sistema de saúde é descentralizado, com direção única em cada esfera de governo. 3- a par das deficiências das políticas públicas em gerir adequadamente os recursos destinados à saúde pública, o seu acesso, que deve ser universal e igualitário, carrega em seu bojo, ainda, as conquistas e avanços disponibilizados pela ciência médica. assim, a alegação de que o Estado não tem como suportar pedidos individualizados ou coletivos de fornecimento de medicamento, sob pena de resultar na inviabilização dos serviços públicos não merece acolhida, uma vez que cabe ao Estado realocar os recursos suficientes a fim de assegurar ao administrado a proteção de sua saúde. 4 Entre proteger o direito à vida e à saúde ou fazer prevalecer, contra essa prerrogativa fundamental, um interesse financeiro e secundário do Estado, impõe-se ao julgador privilegiar o respeito inviolável à vida e à saúde humana, especialmente daqueles que tem direito à distribuição gratuita de medicamentos.

(APELAÇÃO CÍVEL No 2004011 126614-6; 5ª T. CÍVEL; PUBL. EM 08/09/08; DJ 3, PÁG. 114) (TRIBUNAL DE JUSTIÇA DO DISTRITO FEDERAL E TERRITÓRIOS, 2008).

Observa-se pelo primeiro caso apresentado, que é praxe do sistema judiciário a elaboração de uma ementa de apresentação dos elementos jurídicos principais do caso. Por se tratar de direito à saúde, os casos apresentados são "constitucionais". Neste caso, também cita-se que o paciente não tem condições financeiras para a aquisição do medicamento, que este é necessário como assistência à saúde e de que este fornecimento é dever do Estado. $\mathrm{Na}$ análise jurídica consta que a paciente possui uma doença crônica e deveria receber o medicamento pela Secretaria de Estado de Saúde do Distrito Federal, enquanto responsável pelas políticas de saúde e, mesmo diante do argumento de falta de recursos suficientes para responder à ação primeira, é decidido que o direito à vida é superior à esta argumentação e o DF deve se responsabilizar pelo fornecimento de medicamentos. Trata-se de uma ação de apelação por parte do DF, então esta ação foi indeferida, no sentido de dar ganho de causa à usuária do SUS, demandante de um tratamento para reumatismo.

O segundo caso apresentado versa sobre é apresentado pelo documento $2 \mathrm{~J}$ :

CONSTITUCIONAL - MEDICAMENTO DE ALTO CUSTO - PORTADORES DE DOENÇA GRAVE, HIPOSSUFICIÊNCIA - DIREITO À VIDA E À SAÚDE, DEVER DO ESTADO - RESERVA DO POSSÍVEL, INAPLICABILIDADE (Reg. Ac. 333.366). Relator: Des. Natanael Caetano. Apelante: Distrito Federal (Adva. Dra. Dina Oliveira de Castro Alves - Procuradora do DF). Apelada: Neide Cristina de Araújo Chiminelli (Defensoria Pública).

Decisão: Conhecer e negar provimento, unânime.

Ação Cominatória. Fornecimento de medicamento de alto custo a portadores de doença grave que não tem recursos para sua aquisição. direito à vida e à saúde. dever do Estado. reserva do possível. não aplicação. a saúde e a vida humana representam prerrogativas indisponíveis, tuteladas pela Constituição Federal de 1988, à qual o Poder Público deve obediência. É possível aplicar o princípio da reserva do possível, para admitir que o Poder Público deixe de adimplir prestações positivas que foram impostas pela Constituição Federal. Todavia, não se admite seja 
invocado, quando o tema é de alta relevância social - direito à vida e à saúde, cuja implicação da omissão do estado em implementar políticas públicas consequentes e responsáveis seja a ruptura da dignidade da pessoa humana com o comprometimento de um mínimo existencial do indivíduo. segundo precedentes desta Corte de Justiça, o distrito Federal deve fornecer aos enfermos que não disponham de recursos para custear os remédios necessários para o tratamento da sua saúde, os quais foram indicados por prescrição médica.

(APELAÇÃO CÍVEL No 2007011 023783-4; 1 T. CÍVEL; PUBL. EM 01/12/08; DJ 3, PÁG. 62) (TRIBUNAL DE JUSTIÇA DO DISTRITO FEDERAL E TERRITÓRIOS, 2009a).

Este caso também se refere ao direito constitucional à vida e ao direito à saúde, que são deveres do Estado frente ao cidadão brasileiro. Trata-se de um caso envolvendo a solicitação de um medicamento de alto custo para portadores de doenças raras. $\mathrm{Na}$ apelação o DF apresenta novamente a justificativa econômica para a revisão da decisão judicial anterior e a resposta aponta que o direito à saúde e à vida tem prerrogativas indisponíveis, tuteladas pela CF e isto exige execução por parte do Poder Público. E ainda cita que a omissão desta prestação de serviços compromete o cerne dos direitos que é a dignidade da pessoa humana.

Mais um caso é apresentado a seguir, conforme documento 3J, in verbis:

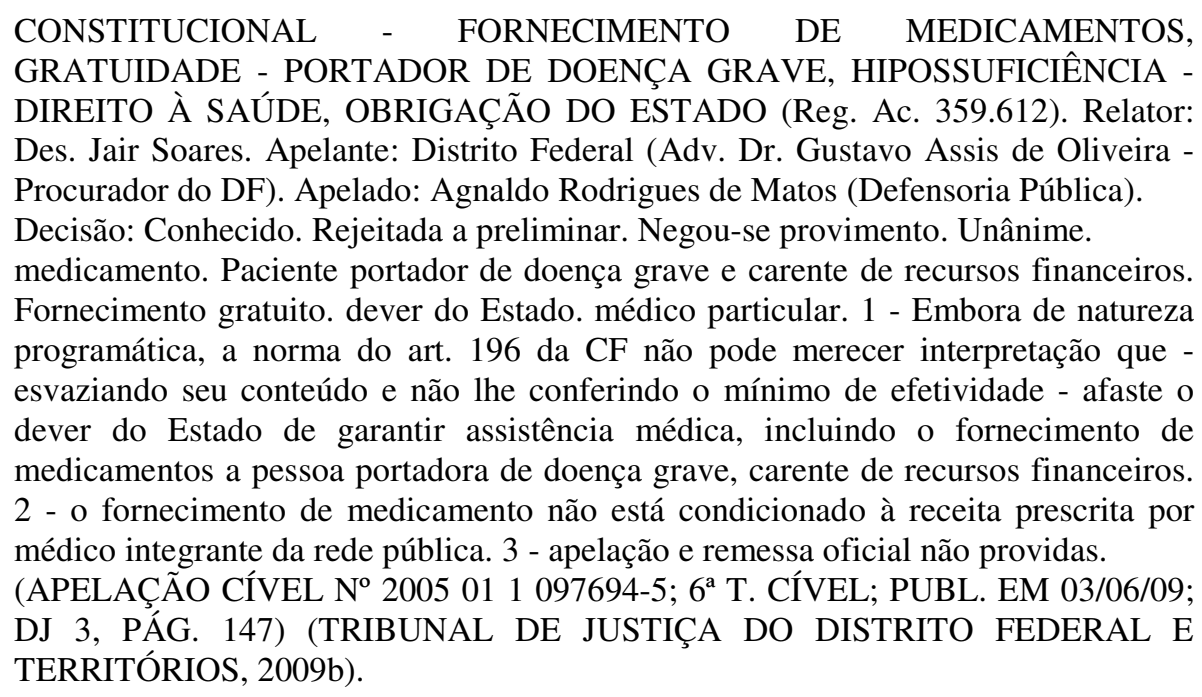

Assim como os casos anteriores, trata-se de apelação do DF em caso de solicitação de acesso à medicamentos. Refere-se ao fato do paciente não ter recursos para arcar com o tratamento ser um caso de direito à saúde e de prestação obrigatória pelo Estado. Uma informação diferente apresentada é de que o médico prescritor é particular, e não do SUS. Novamente é decidido pela efetividade da Constituição e fornecimento dos medicamentos solicitados, independente da prescrição não ser de médico da rede pública.

Como quarto caso, tem-se, conforme documento $4 \mathrm{~J}$ : 
CONSTITUCIONAL - FORNECIMENTOS DE MEDICAMENTOS - AÇÃO COMINATÓRIA - ACESSO GRATUITO Á MEDICAÇÃO - FALTA DE DOTAÇÃO ORÇAMENTÁRIA, IRRELEVÂNCIA (Reg. Ac. 400.183). Relator: Des. Otávio Augusto. Apelante: Distrito Federal (Adv. Dr. Ewerton Azevedo Mineiro - Procurador do DF). Apelado: Camel Nackle Massuh (Defensoria Pública). Decisão: conhecido. Negou-se provimento. Unânime.

Constitucional. Administrativo. Apelação. Remessa oficial. Ação cominatória. Fornecimento de medicamento. Preliminar de ausência de interesse de agir. Rejeição. Mérito. Medicamento não cadastrado no protocolo clínico e diretrizes terapêuticas do Ministério da Saúde. Desnecessidade. Limitação financeira e de políticas públicas. Inadmissibilidade. Prevalência dos direitos à vida e à saúde. Direito assegurado pela Constituição Federal (art. 196) e pela Lei Orgânica do Distrito Federal (arts. 204 e 207). Ofensa a princípios da isonomia e da impessoalidade. Inocorrência. Avaliação por profissional da rede pública. Prescindibilidade. Manutenção da sentença. A saúde é direito de todos e dever do Estado, constitucionalmente assegurado e disciplinado, que implica a garantia, em especial à população carente, de acesso gratuito a medicamentos. Precedentes do Supremo Tribunal Federal e do Superior Tribunal de Justiça. O interesse de agir está presente não somente na utilidade da ação, mas também na necessidade do processo como remédio apto a fornecer ao autor o medicamento que precisa para continuar seu tratamento de saúde, independentemente do local onde este se realize. O fornecimento de medicamento pelo Sistema Único de Saúde decorre de imposição legal, artigo $9^{\circ}$, inciso II, da Lei n. 8.080/90 e artigo 207, inciso XXIV, da Lei Orgânica do Distrito Federal, sendo dever do Estado assegurar a todos os cidadãos, indistintamente, o direito à saúde, oferecendo aos que não possam arcar com o seu tratamento os medicamentos necessários, de tal forma que não pode o Distrito Federal se furtar do ônus que lhe é imposto. O fato de determinado medicamento não estar cadastrado no "protocolo clínico diretrizes terapêuticas do Ministério da Saúde" não afasta a obrigatoriedade de o Distrito Federal fornecê-lo àqueles que dele necessitem. A falta de dotação orçamentária não constitui óbice ao fornecimento de medicamentos pelo Distrito Federal, uma vez que o direito fundamental à vida e à saúde sobrepõe-se a quaisquer entraves administrativos. Recursos improvidos. Unânime. (APELAÇÃO CÍVEL No $2007011123300-9 ; 6^{\text {a }}$ T. CÍVEL; PUBL. EM 20/01/10; DJ 3, PÁG. 161) (TRIBUNAL DE JUSTIÇA DO DISTRITO FEDERAL E TERRITÓRIOS, 2009c).

No quarto caso, também relacionado ao direito à vida e ao acesso à medicamento indisponível no SUS, o DF apresenta que o medicamento não está incluído nos protocolos clínicos e diretrizes terapêuticas do Ministério da Saúde, além da limitação orçamentária existente pelos recursos escassos. Porém estes dois argumentos foram considerados improvidos e o recurso foi negado. Novamente a decisão judicial se embasou na supremacia da Constituição Federal.

Como próximo caso, apresenta-se (documento 5J):

CIVIL - COMINATÓRIA - FORNECIMENTO DE REMÉDIO INDISPENSÁVEL - DEVER DO PODER PÚBLICO

(Reg. Ac. 475.052). Relator: Des. Antoninho Lopes. Autora: Kamilla Pereira Alves rep. por Cristiano Messias Alves da Cunha (Defensoria Pública). Réu: Distrito Federal (Advs. Dr. Rogério Andrade Cavalcanti Araújo e Dr. Valdson Gonçalves de Amorim - Procuradores do DF). istep:

Decisão: negar provimento ao recurso, unânime.

Constitucional e Civil. ação cominatória. Fornecimento gratuito de medicamento indispensável. dever do Poder Público. Verba honorária. 1. o direito à vida e à saúde 
deve ser obrigatoriamente garantido pelo Estado, a quem cabe colocar em favor da população os meios a tanto necessários, em cumprimento das normas constitucionais. 2. nas demandas patrocinadas pela defensoria Pública do distrito Federal, não pode haver imposição de verba honorária quando o acionado é o distrito Federal, pela confusão entre credor e devedor. 3. remessa improvida.

(REMESSA DE OFÍCIO No $2008011028115-4 ; 4^{a}$ T. CÍVEL; PUBL. EM 26/01/11; DJ 3, PÁG. 93) (TRIBUNAL DE JUSTIÇA DO DISTRITO FEDERAL E TERRITÓRIOS, 2011s).

Nesta ação mostra-se que houve a solicitação de um medicamento por uma paciente, contra o Distrito Federal. A oferta do medicamento em si foi deferida. Porém, nesta outra ação, relacionada à sanção da Defensoria Pública, mostra-se que não pode haver a imposição de verba honorária quando o caso envolver o DF como réu. Pois, neste caso, o mesmo ente deveria o pagamento para si próprio. Mas, ademais esta outra questão, o caso é significativo para apresentar mais uma situação de jurisprudência favorável ao cidadão.

Tem-se no sexto caso a seguinte situação, de acordo com o documento 6J, in verbis:

CONSTITUCIONAL - FORNECIMENTO DE FÁRMACO AUSENTE DA
RELAÇÃO DE MEDICAMENTOS DO DF - RELATÓRIO MÉDICO,
SUFICIÊNCIA - MATERIAIS PROFILÁTICOS - SUBSTITUIÇÃO POR
HIGIENE ADEQUADA, IMPOSSIBILIDADE
(Reg. Ac. 499.557). Relatora: Desa. Carmelita Brasil. Apelante: Nilson de Souza
Rocha (Defensoria Pública). Apelado: Distrito Federal (Adv. Dr. Rubem Dario
França Brisolla - Procurador do DF). iš́l:
Decisão: dar provimento. Unânime.
Ação Cominatória. Fornecimento de fármaco ausente da relação de medicamentos
do Distrito Federal. Possibilidade. Relatório médico. Prova suficiente. Materiais
profiláticos. Substituição por higiene adequada. Ausente indicação medica neste
sentido. Impossibilidade. O fato de não se tratar de medicamento padronizado pela
Secretaria de Estado de Saúde não constitui óbice à determinação de seu
fornecimento ao paciente, tendo em vista que é autorizado pela ANVISA e outro
não foi indicado com igual eficácia para o tratamento da enfermidade. O relatório
médico é a prova suficiente da função a ser desempenhada pelo medicamento. A
substituição de materiais profiláticos por higiene adequada só possível mediante
indicação expressa de profissional da área de saúde. Apelação provida.
(APELAÇÃO CÍVEL No 2007 01 $1087521-6 ; 2^{2}$ T. CÍVEL; PUBL. EM 29/04/11;
DJ 3, PÁG. 107) (TRIBUNAL DE JUSTIÇA DO DISTRITO FEDERAL E
TERRITÓRIOS, 2011t).

Para este caso, a peculiaridade está na citação da ausência do fármaco solicitado na relação de medicamentos padronizados do DF. Coloca-se também, na análise judicial, que o relatório médico apresentado foi suficiente para a compreensão e julgamento do caso. Para o caso do medicamento solicitado, portanto, a ação foi deferida, por entender que mesmo sem constar na relação de medicamentos, se o mesmo possui registro na ANVISA e não houve indicação de outro melhor para o tratamento necessário, o Estado deve novamente cumprir com o provimento.

Por fim, apresenta-se um último exemplo de jurisprudência (documento 6J): 
CONSTITUCIONAL - FORNECIMENTO DE MEDICAÇÃO - MEDICAMENTO REGULARMENTE PRESCRITO - MIELOMA MÚLTIPLO E CARDIOPATIA DIREITO CONSTITUCIONAL À SAÚDE

(Reg. Ac. 496.773). Relator: Des. Humberto Adjuto Ulhôa. Impetrante: Maria das Dores da Silva Gama (Defensoria Pública). Informante: Secretário de Estado da Saúde do Distrito Federal.

Decisão: negou-se provimento. Decisão unânime.

Mandado de Segurança. Mieloma múltiplo e cardiopatia. Medicamento regularmente prescrito ao paciente. Bortezomibe (velcade). Deferimento da liminar. Agravo regimental interposto pelo Distrito Federal. Fundamentos inabalados. Decisão mantida. 1 - A concessão de liminar em mandado de segurança demanda a demonstração inequívoca dos requisitos insertos no art. 7. ${ }^{\circ}$, III, da Lei 12.016/2009 relevância no fundamento invocado e se do ato impugnado pode resultar a ineficácia da medida, caso seja deferida apenas ao final. 2 - É firme o entendimento desta eg. Corte de Justiça no sentido de que, sendo o Secretário de Estado de Saúde responsável pela implementação de políticas públicas hábeis à efetivação do direito constitucional à saúde, detém tal agente público legitimidade para figurar como autoridade coatora em mandado de segurança destinado à obtenção de medicamentos. 3 - Presente a prova do diagnóstico da doença de que é portadora a impetrante (mieloma múltiplo e cardiopatia) bem como da necessidade do medicamento indicado, regularmente prescrito por médico da Secretaria de Estado de Saúde do GDF (bortezomibe - velcade), rejeita-se a alegação do Distrito Federal de que inexiste direito líquido e certo a ser amparado por mandado de segurança ante a ausência de prova pré-constituída. 4 - Na hipótese vertente, o maior requisito para a concessão da liminar é a própria extirpação do mal que acomete a impetrante, com a urgência que o caso requer. À evidência, eventual ausência de formalidade burocrática não pode obstar a concessão da medida buscada, porquanto não retira a gravidade de sua situação. Não se pode admitir entrave ao cumprimento de garantia constitucional que preserva a própria dignidade humana. 5 - Recurso conhecido e não provido.

(AGRAVO REGIMENTAL NO(A) MANDADO DE SEGURANÇA No 2011002 003769-6; C. ESPECIAL; PUBL. EM 19/04/11; DJ 3, PÁG. 36) (TRIBUNAL DE JUSTIÇA DO DISTRITO FEDERAL E TERRITÓRIOS, 2011t).

Neste último caso, apesar da apelação pelo DF, a decisão foi mantida e a liminar deferida. A decisão é reforçada pela comprovação da doença da paciente, da necessidade decorrente então, do tratamento, e pela prescrição ainda ser proveniente de médico da própria SES-DF. Diante do dever do Estado de prestar o direito à saúde, por meio de políticas públicas, a decisão final exige do DF o repasse do medicamento solicitado.

Ao encontro do ponto de vista de que é necessário embasamento técnico auxiliar para o julgamento de casos da área da saúde, o ministro da saúde do atual ano (2016), Ricardo Barros, diz que (documento 4NS):

É uma excelente iniciativa. Todos os procedimentos e medicamentos que estão fora da regulação do SUS e tudo que está incorporado ao sistema será avaliado por juízes com o auxílio de pareceres técnicos. [...] Vale ressaltar que o material vai servir para uma consulta voluntária do magistrado dentro de sua autonomia (CONSELHO NACIONAL DE SECRETÁRIOS DE SAÚDE, 2016c). 
E desde 2010 já havia o entendimento de que o suporte técnico é importante. A Recomendação $n^{\circ} 31$, de 30 de março de 2010 foi emitida pelo CNJ para todos os tribunais do Brasil. E este documento (12J) propunha medidas para subsidiar os magistrados no julgamento das demandas em saúde. São recomendações propostas pelo CNJ:

(1) que os tribunais celebrem convênios para oportunizar apoio técnico de médicos e farmacêuticos para a apreciação das questões clínicas dos casos;

(2) que os magistrados solicitem embasamento técnico para os casos por meio de relatórios médicos, descrição e CID da doença, prescrições adequadas;

(3) que as decisões evitem o fornecimento de medicamentos não registrados pela ANVISA;

(4) que os gestores sejam consultados antes das decisões (preferencialmente por meio eletrônico);

(5) que seja verificado se os cidadãos das ações fazem parte de programas de pesquisa clínica pois, se assim o for, o programa deve arcar com o tratamento todo;

(6) que incluam os cidadãos no SUS, caso eles estejam requerendo e recebendo medicamentos já padronizados por meio da ação judicial (isso objetiva que após o problema existente com a política, o paciente passe a receber o tratamento pela via regular de acesso);

(7) que os magistrados visitem os órgãos de gestão e de serviço da saúde pública;

(8) que o Direito Sanitário seja ensinado durante a formação dos magistrados; e

(9) que sejam realizados mais eventos multidisciplinares, para aproximação entre magistrados e gestores (BRASIL, 2010c).

Com o mesmo objetivo, já no ano de 2011 foi publicada a Instrução Normativa 06, de 23 de dezembro de 2011, pela Corregedoria do TJDFT. Este documento (73LN) apresenta, em seu início, a preocupação com a falta de informações clínicas prestadas nos processos judiciais, com a exigência de registro dos medicamentos pela ANVISA para uso no Brasil e com a necessidade de garantir-se a sustentabilidade do SUS. A partir destas e outras premissas, o TJDFT institui recomendações semelhantes ao CNJ, por seguimento à estas recomendações do órgão superior. E ainda inclui outras orientações de:

(1) consultar o Ministério Público quanto a possibilidade de abertura de ação coletiva quando houver pedido de inclusão de medicamento na lista da ANVISA;

(2) exigir comprovação de incapacidade financeira do requerente; 
(3) quando a ação envolver o acesso de leitos de UTI, acessar a Central de Regulação de Leitos de UTI para verificar se o cidadão já está na lista de espera e se há pacientes mais graves a sua frente; conversar com equipe técnica multidisciplinar para a análise do caso e da classificação técnica dos pacientes e ordem de gravidade; e

(4) quando a ação exigir serviço pela rede privada, registrar que o tratamento deve ser acompanhado por médico da rede pública (BRASIL, 2011f).

As recomendações específicas do TJDFT sobre as ações por leitos de UTI apresentam um aspecto interessante que é o de respeitar o seguimento do serviço e da política pública. Pois, ao orientar que deve ser respeitada a ordem de gravidade dos pacientes, este é um aspecto da regulação do próprio serviço. E, se existe esta organização que prioriza a condição de saúde, o requerimento de acesso pela via judicial tem o potencial de priorizar o acesso de um cidadão com quadro de menor gravidade. Este é um exemplo de situação que mostra como a judicialização pode beneficiar um indivíduo, desconsiderando a coletividade.

Portanto o julgamento se mostra um processo discricionário e, peculiar à área da saúde, carente de embasamento suficiente para a compreensão dos casos e julgamento justo, por vezes. Além de que, as recomendações propostas denotam que o processo de formação de juízo de valor pode ser mais ou menos crítico, a depender das ferramentas que o magistrado possui e sua iniciativa em exigir mais informações para os casos. Então a discricionariedade existe para a decisão final, porém o atingimento desta decisão pode ser melhor orientada para maior eficiiencia do processo.

Se o ato de julgar e sentenciar é subjetivo, os elementos trazidos à auxílio dos juízes devem contribuir para que, independente de quem seja o magistrado, todos sejam capazes de chegar à verdade jurídica, como já apresentado nesta pesquisa. Ou seja, as alegações e aspectos devem estar aptos a serem valorados da mesma forma, por diferentes juízes e, para isto, os dados mostram que os próprios profissionais demonstram receio neste tipo de julgamento e carecem de informações e auxílio para tal.

Os aspectos apresentados do uso da discricionariedade foram organizados no Quadro 5.3. 
Quadro 5.1: Síntese do uso da discricionariedade jurídica na saúde.

\section{CONCEPÇÕES ACERCA \\ DA DISCRICIONARIEDADE JURÍDICA}

Duas concepções:

(1) discricionariedade relativa à liberdade de atuação e decisão pelo profissional do direito no julgamento dos casos; e (2) discricionariedade relativa à liberdade de atuação que as normas aplicadas aos casos judiciais permitem.

\section{USO DA DISCRICIONARIEDADE JURÍDICA NAS AÇÕES EM} SAÚDE

Cada caso tem aspectos muito particulares, há então demandas por medicamentos deferidas e indeferidas, em jurisprudências passadas.

Dificuldade de compreensão das portarias e do planejamento das ações em saúde, por parte dos magistrados.

As ações em saúde têm uma característica comum de referenciar risco à vida do autor pela ausência do tratamento. Logo, a falta de embasamento clínico e uma compreensão clara dos riscos acrescenta maior preocupação aos magistrados na investigação.

A ausência de análise individual dos casos pode gerar deferimento de ações com prescrições inadequadas ou com alternativas terapêuticas disponíveis no SUS.

O uso da discricionariedade e o deferimento de ações sem embasamento científico é o mesmo que incorporar tecnologias no SUS, para indivíduos, e não para o todo. Porém, sem seguir os critérios técnicos e científicos necessários.

Para o argumento de falta de recursos financeiros para a implementação das políticas públicas, a discricionariedade possibilita o deferimento da ação, pela compreensão de que este aspecto da gestão não justifica a não prestação do direito.

Para medicamentos não incluídos em PCDT ou, por extensão, para pacientes não incluídos nos critérios dos PCDT, a discricionariedade possibilita o deferimento da ação, pela compreensão de que este aspecto não justifica a não prestação do direito.

Para medicamentos não incluídos na relação de medicamentos padronizados, a discricionariedade possibilita o deferimento da ação, pela compreensão de que este aspecto não justifica a não prestação do direito.

O julgamento busca a efetividade constitucional, independente da prescrição ser ou não de médico da rede pública.

Fonte: Da autora. 


\subsection{Aspectos conflituosos entre a execução do CEAF/PNAF e a execução de demandas judiciais}

Conforme explicado nesta mesma categoria, para o caso 01, a interpretação e a análise dos resultados da pesquisa revelaram questões problemáticas quanto a atuação dos dois poderes em prol da garantia do mesmo direito constitucional. Ou seja, há aspectos da prática do Poder Judiciário que se misturam com aspectos da prática do Poder Executivo.

Foram percebidos elementos relevantes para a gestão da política de medicamentos, para o caso do CEAF/PNAF, especificamente. E embora fosse evidenciado que estes elementos até são reconhecidos pelo sistema judiciário, a preocupação que é, de fato, demonstrada por alguns órgãos não garante que as decisões por todos os magistrados considerem estas questões.

A análise desta dos conflitos de interesse revelados no caso 01 apresentou os pontos importantes para a boa gestão da assistência farmacêutica e a garantia de um tratamento com eficácia e segurança comprovados. Para o caso 02, muitos aspectos foram explorados nos documentos que discutem a judicialização da saúde e foram abordados como sendo pontos frágeis ou pontos fortes do processo de judicialização.

Como uma síntese dos elementos deflagrados em meio à judicialização da saúde, elaborou-se o Quadro 5.4. 
Quadro 5.4: Fortalezas e fragilidades do contexto da judicialização da saúde.

\section{Fortalezas do contexto da judicialização}

Previsão constitucional para a ação do Poder Judiciário no controle jurisdicional das políticas públicas.

Garantia do direito à saúde como objetivo da judicialização.

Preocupação de melhorar a estrutura envolvida com a judicialização da saúde nos níveis federal e distrital.

Criação de recomendações e instruções para tentar trazer efetividade para as decisões judiciais.

Estratégias de trabalho conjunto com o sistema judiciário (implantação de núcleos técnicos da saúde no judiciário; realização de eventos conjuntos; propostas de trabalho integrado entre SES e conselhos de justiça).

Criação de sistemas compartilhados com as informações das Secretarias de Saúde sobre a disponibilidade do objeto da ação judicial (medicamento e leitos de hospitais, por exemplo).

\section{Fragilidades do contexto da judicialização}

Não cumprimento dos princípios e diretrizes do SUS: desrespeito à responsabilidade tripartite, descentralizada.

Não cumprimento dos princípios e diretrizes do SUS: prejuízo à integralidade.

Não cumprimento dos princípios e diretrizes do SUS: prejuízo à equidade.

Não cumprimento dos princípios e diretrizes do SUS: prejuízo à universalização.

Ações judiciais individuais concorrentes às ações em saúde coletivas.

Não cumprimento das diretrizes terapêuticas do SUS: deferimento de medicamentos com pouca evidências quanto à eficácia e segurança

Não cumprimento das diretrizes terapêuticas do SUS: deferimento de medicamentos não registrados na ANVISA.

Não cumprimento das diretrizes terapêuticas do SUS: não cumprimento dos PCDT.

Não cumprimento das diretrizes terapêuticas do SUS: estímulo ao uso irracional de medicamentos.

Judicialização dos medicamentos do CEAF/PNAF, apesar do aumento da cobertura dos últimos anos.

Necessidade de fortalecer mecanismos gerenciais para o bom acompanhamento e execução das açõesjudiciais de saúde no SUS.

Dificuldades orçamentárias: perda do poder de compra em larga escala.

Dificuldades orçamentárias: variação de custos durante o período de compra para a ação, principalmente de medicamentos com poucos fornecedores.

Dificuldades orçamentárias: deslocamento de verba das políticas de saúde ou de outras pastas.

Burocracia do sistema de saúde que gera lentidão para a resposta às ações judiciais deferidas.

Reclamação de demora na revisão da relação de tecnologias incorporadas pelo sistema.

Reclamação de demora na revisão e criação de novos PCDT.

Não seguimento dos PCDT por alguns prescritores, dificultando a padronização dos tratamentos e a padronização dos procedimentos.

Elaboração de pareceres muito tecnicistas no trabalho conjunto da saúde com o sistema judiciário.

Judicialização excessiva.

Fonte: Da autora. 
E, para melhor explicar esta problemática, optou-se por seguir a mesma organização proposta para o caso 01, com a inclusão de uma última nova dimensão. Foram então adequados os aspectos encontrados às dimensões elaboradas no caso anterior.

1) Aspectos do sistema de saúde

2) Aspectos da Assistência Farmacêutica e do CEAF/PNAF

3) Aspectos técnicos farmacêuticos

4) Aspectos da padronização de medicamentos

5) Aspectos da padronização de protocolos

6) Aspectos da atuação do farmacêutico

7) Aspectos da judicialização da saúde

Logo, a análise dos documentos levou a seguinte organização destes dados (Quadro $5.5)$

Quadro 5.5: Fortalezas e fragilidades do contexto da judicialização da saúde e respectivas dimensões. (Continua)

\begin{tabular}{|l|l|}
\hline Fortalezas do contexto da judicialização & Dimensões do contexto \\
\hline $\begin{array}{l}\text { Previsão constitucional para a ação do Poder Judiciário } \\
\text { no controle jurisdicional das políticas públicas. }\end{array}$ & (7) Aspectos da judicialização da saúde \\
\hline $\begin{array}{l}\text { Garantia do direito à saúde como objetivo da } \\
\text { judicialização. }\end{array}$ & (7) Aspectos da judicialização da saúde \\
\hline $\begin{array}{l}\text { Preocupação de melhorar a estrutura envolvida com a } \\
\text { judicialização da saúde nos níveis federal e distrital. }\end{array}$ & (1) Aspectos do sistema de saúde \\
\hline $\begin{array}{l}\text { Criação de recomendações e instruções para tentar } \\
\text { trazer efetividade para as decisões judiciais. }\end{array}$ & (7) Aspectos da judicialização da saúde \\
\hline $\begin{array}{l}\text { Estratégias de trabalho conjunto com o sistema } \\
\text { judiciário (implantação de núcleos técnicos da saúde no } \\
\text { judiciário; realização de eventos conjuntos; propostas } \\
\text { de trabalho integrado entre SES e conselhos de justiça) }\end{array}$ & (7) Aspectos da judicialização da saúde \\
\hline $\begin{array}{l}\text { Criação de sistemas compartilhados com as } \\
\text { informações das Secretarias de Saúde sobre a } \\
\text { disponibilidade do objeto da ação judicial } \\
\text { (medicamento e leitos de hospitais, por exemplo). }\end{array}$ & (7) Aspectos da judicialização da saúde \\
\hline
\end{tabular}


Quadro 5.5: Fortalezas e fragilidades do contexto da judicialização da saúde e respectivas dimensões. (Continuação)

\begin{tabular}{|c|c|}
\hline Fragilidades do contexto da judicialização & Dimensões do contexto \\
\hline $\begin{array}{l}\text { Não cumprimento dos princípios e diretrizes do SUS: } \\
\text { desrespeito à responsabilidade tripartite, } \\
\text { descentralizada. }\end{array}$ & (1) Aspectos do sistema de saúde \\
\hline $\begin{array}{l}\text { Não cumprimento dos princípios e diretrizes do SUS: } \\
\text { prejuízo à integralidade. }\end{array}$ & (1) Aspectos do sistema de saúde \\
\hline $\begin{array}{l}\text { Não cumprimento dos princípios e diretrizes do SUS: } \\
\text { prejuízo à equidade. }\end{array}$ & (1) Aspectos do sistema de saúde \\
\hline $\begin{array}{l}\text { Não cumprimento dos princípios e diretrizes do SUS: } \\
\text { prejuízo à universalização. }\end{array}$ & (1) Aspectos do sistema de saúde \\
\hline $\begin{array}{l}\text { Ações judiciais individuais concorrentes às ações em } \\
\text { saúde coletivas. }\end{array}$ & (1) Aspectos do sistema de saúde \\
\hline $\begin{array}{l}\text { Não cumprimento das diretrizes terapêuticas do SUS: } \\
\text { deferimento de medicamentos com poucas evidências } \\
\text { quanto à eficácia e segurança }\end{array}$ & (4) Aspectos da padronização de medicamentos \\
\hline $\begin{array}{l}\text { Não cumprimento das diretrizes terapêuticas do SUS: } \\
\text { deferimento de medicamentos não registrados na } \\
\text { ANVISA. }\end{array}$ & (4) Aspectos da padronização de medicamentos \\
\hline $\begin{array}{l}\text { Não cumprimento das diretrizes terapêuticas do SUS: } \\
\text { não cumprimento dos PCDT. }\end{array}$ & (5) Aspectos da padronização de protocolos \\
\hline $\begin{array}{l}\text { Não cumprimento das diretrizes terapêuticas do SUS: } \\
\text { estímulo ao uso irracional de medicamentos. }\end{array}$ & (6) Aspectos da atuação do farmacêutico \\
\hline $\begin{array}{l}\text { Judicialização dos medicamentos do CEAF/PNAF, } \\
\text { apesar do aumento da cobertura dos últimos anos. }\end{array}$ & $\begin{array}{l}\text { (2) Aspectos da Assistência Farmacêutica e do } \\
\text { CEAF/PNAF }\end{array}$ \\
\hline $\begin{array}{l}\text { Necessidade de fortalecer mecanismos gerenciais para } \\
\text { o bom acompanhamento e execução das ações } \\
\text { judiciais de saúde no SUS. }\end{array}$ & (1) Aspectos do sistema de saúde \\
\hline $\begin{array}{l}\text { Dificuldades orçamentárias: perda do poder de compra } \\
\text { em larga escala. }\end{array}$ & (3) Aspectos técnicos farmacêuticos \\
\hline $\begin{array}{l}\text { Dificuldades orçamentárias: variação de custos durante } \\
\text { o período de compra para a ação, principalmente de } \\
\text { medicamentos com poucos fornecedores. }\end{array}$ & (3) Aspectos técnicos farmacêuticos \\
\hline $\begin{array}{l}\text { Dificuldades orçamentárias: deslocamento de verba } \\
\text { das políticas de saúde ou de outras pastas. }\end{array}$ & (3) Aspectos técnicos farmacêuticos \\
\hline $\begin{array}{l}\text { Burocracia do sistema de saúde que gera lentidão para } \\
\text { a resposta às ações judiciais deferidas. }\end{array}$ & (1) Aspectos do sistema de saúde \\
\hline $\begin{array}{l}\text { Reclamação de demora na revisão da relação de } \\
\text { tecnologias incorporadas pelo sistema. }\end{array}$ & (4) Aspectos da padronização de medicamentos \\
\hline $\begin{array}{l}\text { Reclamação de demora na revisão e criação de novos } \\
\text { PCDT. }\end{array}$ & (5) Aspectos da padronização de protocolos \\
\hline
\end{tabular}


Quadro 5.5: Fortalezas e fragilidades do contexto da judicialização da saúde e respectivas dimensões.

(Conclusão)

\begin{tabular}{|l|l|}
\hline Fragilidades do contexto da judicialização & Dimensões do contexto \\
\hline $\begin{array}{l}\text { Não seguimento dos PCDT por alguns prescritores, } \\
\text { dificultando a padronização dos tratamentos e a } \\
\text { padronização dos procedimentos. }\end{array}$ & (5) Aspectos da padronização de protocolos \\
\hline $\begin{array}{l}\text { Elaboração de pareceres muito tecnicistas no trabalho } \\
\text { conjunto da saúde com o sistema judiciário. }\end{array}$ & (7) Aspectos da judicialização da saúde \\
\hline Judicialização excessiva. & (7) Aspectos da judicialização da saúde \\
\hline
\end{tabular}

Fonte: Da autora.

A discussão dos pontos apresentados no Quadro 5.5 obedece a mesma ordem utilizada para o caso 01 .

1) Aspectos do sistema de saúde

Conforme análise, os documentos da pesquisa que discutem a judicialização da saúde entendem que este fenômeno interfere na eficácia das políticas públicas.

A posição do documento $1 \mathrm{AR}$, por exemplo, é de que a utilização da via judicial para acesso aos medicamentos apresenta elementos contrários às diretrizes do SUS. É explicado que a requisição de medicamentos pode violar a organização descentralizada do sistema. Por exemplo, se for solicitado à um município um medicamento que faz parte da lista estadual, o réu da ação deverá realizar a aquisição do produto. Pode ocorrer também de um estado ou um município ser obrigado à adquirir um medicamento para um cidadão de outro estado ou de outro munícipio (VIEIRA; ZUCCHI, 2007). Para estes dois casos exemplificados percebe-se que não há o seguimento das regras de descentralização administrativa e o ente federativo acaba realizando a função do outro ente. Nestes casos não se trata das responsabilidades previstas para o Poder Executivo, mas sim de atendimentos às ordens impostas pelo Poder Judiciário.

Este mesmo documento ainda explica que muitas ações judiciais provêm de prescrições de médicos da rede privada de saúde, ferindo o princípio da integralidade do SUS (VIEIRA; ZUCCHI, 2007). Isto quer dizer que o SUS está preparado para ofertar desde serviços de prevenção, até serviços de maior complexidade, para que o usuário seja atendido de forma integral, ampla, completa, em todas as condições de agravos. Logo, o entendimento 
de que as prescrições de médicos particulares não respeita este princípio se refere ao usuário não estar sendo acompanhado pelo sistema e, de forma garantida, da forma adequada para cada nível de seu agravo em saúde.

O documento 17AR lembra que o Poder Executivo é então responsável pela provisão de medicamentos eficazes, seguros, efetivos e custo-efetivos para a população. Ou seja, é responsável pelo fornecimento de medicamentos seguros e que atingem os objetivos terapêuticos propostos, nas condições reais e não experimentais, e o fazem ao menor custo. Em contraste à isto, a judicialização dos medicamentos passa a ser um problema para o cumprimento destes critérios. Isto ocorre pois muitas vezes o medicamento judicializado pode não ser o melhor em termos de custo/benefício, pode haver alternativa terapêutica no próprio SUS ou a ação pode infringir algum princípio do SUS ou lei relacionada ao mercado farmacêutico (MACEDO; LOPES; BARBERATO-FILHO; 2011). Todas estas possibilidades, além de outras não exemplificadas, demonstram haver situações nas quais o tratamento judicializado pode não ser o melhor ou o mais custo-efetivo. E a necessidade de resposta imediata da ação judicial e da compra individualizada destes medicamentos acarreta custos ao sistema e pode prejudicar a equidade, pela oferta do próprio SUS para os demais usuários.

Em acordo ao explicado, o documento $11 \mathrm{AR}$ cita explicitamente que a judicialização afeta a universalização da saúde pois causa desigualdades entre os cidadãos (OLIVEIRA, 2013). Ou seja, este fornecimento individual pode causar uma alocação não prevista de verbas e prejudicar a própria política de medicamentos ou outras políticas, trazendo potenciais prejuízos à cobertura integral de serviços à todos os demais cidadãos que também precisam. $\mathrm{Na}$ vigência desta situação, compreende-se que as ações individuais competem com a sustentabilidade de um sistema coletivo.

Além disso, há prescrições de ações judiciais que trazem não somente o medicamento fruto da judicialização, mas também todos os outros medicamentos do paciente que, entretanto, estão disponíveis pelo SUS. O entrevistado 6EN exemplifica:

E não vem só o medicamento, vem assim, do medicamento do postinho, do posto de saúde, como aspirina até o nosso. Entende? Vem cinco, seis medicamentos juntos. Vem tudo.

Este seria mais um exemplo de situação que gera uma compra individualizada, neste caso desnecessária pois já haveria a oferta pelo sistema de saúde, e isto afeta o poder de compra dos componentes da assistência farmacêutica e pode prejudicar os demais usuários do sistema de saúde. 
Um outro aspecto do sistema de saúde frente à judicialização tem sido o desenvolvimento e a melhoria da estrutura que lida com as demandas judiciais dentro do Poder Executivo. Ou seja, a estrutura que coloca em prática as decisões judiciais.

No caso do DF, atualmente há o já apresentado NJUD/SES-DF. Mas originalmente existia somente uma Comissão de Judicialização (TRIBUNAL DE JUSTIÇA DO DISTRITO FEDERAL E TERRITÓRIOS, 20111). O documento 2AT e o depoimento dos entrevistados 6EN e 10EN mostram que há uma preocupação com a melhoria constante da organização deste núcleo e que o próprio aumento das demandas judiciais acarreta o crescimento da equipe e da organização do setor.

E, para o MS, a mesma relação é verdadeira e isto é exemplificado pela organização de um Núcleo de Judicialização para a SCTIE, além do departamento maior de Consultoria Jurídica - CONJUR/MS que assessora o MS enquanto órgão.

Porém, os dados mostram que se o aumento da complexidade e da quantidade de ações judiciais exigiu uma maior organização do Poder Executivo, se este aumento se mantém, como os dados demonstram, a necessidade de melhora da organização também será uma realidade constante.

E, além desta questão, há de se trabalhar nos procedimentos de resposta às ações judiciais. Pois, conforme documento já apresentado (10NJ), há cerca de 66 passos para o processo licitatório de compra de medicamentos. Ou seja, o processo de aquisição se mostra muito burocrático para um contexto que exige maior agilidade e efetividade das respostas (TRIBUNAL DE JUSTIÇA DO DISTRITO FEDERAL E TERRITÓRIOS, 2012a).

\section{2) Aspectos da Assistência Farmacêutica e do CEAF/PNAF}

Vieira e Zucchi (2007) consideram que a judicialização vai de encontro à Política Nacional de Medicamentos, sob alguns aspectos. Um deles se refere à ampliação do elenco de medicamentos do CEAF/PNAF nos últimos anos e, ainda assim, a judicialização destes e de outros medicamentos é crescente.

A portaria GM/MS n 2.981/2009 apresentava 147 fármacos em 314 apresentações farmacêuticas para compor o CEAF/PNAF. Estes medicamentos têm indicação de tratamento na forma de linhas de cuidado definidas nos PCDT para as doenças especificadas no Componente (BRASIL, 2010a).

$\mathrm{Na}$ RENAME atual, de 2014, a lista do CEAF/PNAF ampliava para 265 os medicamentos padronizados. Nesta lista existem 140 fármacos diferentes e há variações na 
apresentação farmacêutica (a apresentação se refere à dose ou à forma farmacêutica ${ }^{13}$ do medicamento), que totalizam os 265 produtos (BRASIL, 2015f).

Para comparação, a relação do DF para o CEAF/PNAF possui atualmente 234 medicamentos (SECRETARIA DE ESTADO DE SAÚDE DO DISTRITO FEDERAL, 2016b). Destes 234 medicamentos, há 133 fármacos.

Os dados mostram então uma grande quantidade de medicamentos padronizados para o Componente Especializado e uma ampliação significativa desde a publicação da Portaria original, em 2009, até os dias atuais desta pesquisa, de 2016. Desta forma, o aumento da judicialização verificado nas categorias anteriores da pesquisa, inclusive na seção de recursos financeiros, tem fatores mais complexos e que persistem em função da grande quantidade de tratamentos medicamentosos existente. Ou seja, ainda que se amplie o elenco de medicamentos padronizados, a política sempre estará realizando a priorização de tratamentos e medicamentos, em função do limite de recursos que sempre existirá para o governo. Tem-se então uma realidade complexa e conflituosa, pois a política de assistência farmacêutica, por melhor planejada que seja, não conseguirá envolver todos os tratamentos existentes e disponíveis. Diante disto a judicialização deve ser pensada enquanto meio para que o governo tenha que ofertar todo e qualquer medicamento, sem consideração ao limite orçamentário e à racionalidade que embasa a PNAF.

\section{3) Aspectos técnicos farmacêuticos}

Um outro ponto de conflito entre os dois Poderes se refere às aquisições dos medicamentos, que são realizadas mediante aspectos técnicos farmacêuticos. Nesta etapa de aquisição ou compra de medicamentos, o preço dos produtos é um dos critérios considerados, mas os fatores essenciais são a eficácia e a segurança dos medicamentos. Ou seja, somente a partir destas premissas é que se considera o custo-efetividade do produto.

${ }^{13}$ Forma farmacêutica é estado final de apresentação que os princípios ativos farmacêuticos possuem após uma ou mais operações farmacêuticas [...] com características apropriadas a uma determinada via de administração (BRASIL, 2011n, p. 9-10). São formas farmacêuticas as sólidas, líquidas, semissólidas e gasosas (BRASIL, 2011n). 
O entrevistado 6EN comenta sobre as ações direcionadas à SES-DF, mas que se referem à medicamentos financiados pelo MS na execução da política:

\begin{abstract}
Por exemplo, isso acontece. Então, se o paciente der entrada num medicamento que é de posto, ele vai receber pelo posto. Se houver falta, aí ele vai acionar. Isso é um problema sob certos aspectos, porque? Faltou um medicamento nosso, sei lá, era um medicamento do Ministério, por exemplo. Deu atraso, não sei o que. Esse paciente, se ele acionar, é responsabilidade da Secretaria pegar e dar conta. [...]

Judicialização só tem um núcleo. Então, ele que tem que ser responsável pelo todo. Então, assim, a gente não tem conhecimento. Chegou uma ação judicial aqui esses dias, que a gente ligou para a paciente, ela disse que ela já tinha finalizado o tratamento. E aí a gente perguntou, "quem forneceu?", ela, "ah, o Ministério da Saúde". Só que aí a gente sabe onde a gente procura, a hora que a gente digitou o nome da mulher, estava lá todo o fornecimento de medicamento para ela do tempo do tratamento dela.

Porque assim, uma falha que tem...uma falha, porque esse paciente, às vezes, ele entra pelas duas, pela SES e pelo Ministério. E muitas vezes...ou melhor, acho que todas as vezes o Ministério é muito mais rápido. A política do Ministério é diferente, eles entregam.
\end{abstract}

No exemplo citado, se o medicamento é solicitado judicialmente em dois processos paralelos, tendo como réus a União e o DF e isto não é observado é possível que as duas ações sejam deferidas e o paciente receba o tratamento duas vezes. Isto seria uma situação extrema de complicação econômica, pois haveria disponibilização dobrada de um tratamento individualizado.

Percebe-se no exemplo acima que se o medicamento estava previsto no rol dos padronizados, significa que ele teve de ser comprado pela via judicial e deixou de compor o quantitativo que seria adquirido por meio da política e isto reduz o poder de compra do ente federativo.

O documento 30AR, já apresentado, ainda apresenta uma segunda variável quanto às compras via judicialização. Esta variável trata-se da variação de preços de um mesmo produto ao longo dos anos de aquisição. Ou seja, tendo a ação uma duração longa de cobertura de tratamento ou, até mesmo, tempo indeterminado, se houver uma pequena quantidade de laboratórios produtores do medicamento em questão, aumenta-se a chance do mercado regular o preço com grandes variações. Diante da garantia de compra do medicamento por parte do governo, a área de oferta muitas vezes abusa do preço de venda, por considerar garantida a compra pelo governo (DINIZ; MEDEIROS; SCHWARTZ, 2012).

Além deste segundo tipo de conflito orçamentário, o terceiro aspecto é na verdade o mais básico e inerente à todas as ações e se trata do financiamento dos produtos das ações judiciais. Para a judicialização os recursos financeiros são provenientes das demais políticas de saúde e não estão previstos na programação orçamentária elaborada no ano anterior da 
gestão, como é feito com as políticas regulares. Os entrevistados 1EN e 2EN explicaram isto, tanto para o âmbito Federal quanto para o Distrital.

4) Aspectos da padronização de medicamentos

O documento 1AR explica que as ações judiciais que obrigam a aquisição de medicamentos não relacionados nas listas de padronizados faz com que a judicialização vá de encontro com as políticas de medicamentos e com o próprio SUS (VIEIRA; ZUCCHI, 2007).

Isto ocorre em função do aspecto de não seguimento aos critérios de padronização de medicamentos: eficácia e segurança dos fármacos. Ou seja, a judicialização fere a PNAF quanto permite o fornecimento de medicamentos sem eficácia ou segurança comprovadas ou, ainda, que não sejam indicados para a finalidade clínica apresentada na ação judicial ou que possuam alternativa terapêutica disponível no SUS. Logo, é importante considerar os critérios usados para a padronização de medicamentos, como considerar os próprios medicamentos já padronizados e disponíveis.

Trazendo estes elementos, o entrevistado 7EN explica:

\begin{abstract}
Então, primeiro revisar a lista e no DF, especificamente, a gente tinha mais de mil medicamentos padronizados. Sendo que na RENAME, que é nacional, tinha 700. Então, assim... inclusive, agora nesse ano de 2016, está sendo revista a REME-DF no sentido de diminuir o número de itens. Hoje tem 1050 e eles estão querendo reduzir. E os que forem mantidos, assim, alguns itens, colocar a especificação assim de protocolo mesmo, de indicação.

[...] Eu não cheguei a comparar com os outros estados, assim, em número de processos. Mas...e também, não observei assim um padrão. Tinha muitos medicamentos que eram do componente especializado quando eu olhei, e que não estavam padronizados na época. Por exemplo, 2009 não lembro Trastuzumabe, por exemplo. Tinha muita demanda, aí em 2010 já não quase nenhuma demanda. E aí eu fui olhar, tinha sido padronizado.
\end{abstract}

E acrescenta que há uma reclamação quanto à periodicidade de revisão das listas de medicamentos padronizados e solicitação de incorporações mais ágeis às listas de medicamentos:

Então, o que eu observei também, é que tinha uma pressão pela padronização da judicialização. A judicialização pressiona a padronização. E muitas vezes, ela não tem avaliação da evidência científica. Então, assim, isso eu consegui observar, do Trastuzumabe especificamente. Mas, para outros medicamentos, assim, não tinha. 
Um outro critério importante é a existência de registro do medicamento na ANVISA. Pois isto garante a autorização de comercialização do medicamento no país, que será concedida após a comprovação de atendimento de aspectos sanitários mínimos, pelo produto.

Sobre este aspecto e os demais já citados, é importante apresentar a descrição dos votos já proferidos até a data de coleta de dados desta pesquisa, dos ministros do STF no processo judicial em andamento sobre o provimento ou não de medicamentos de alto custo por parte do Poder Público, por meio de demandas judiciais (documento 13NS) (FOLHA DE SÃO PAULO, 2016b):

\section{(1) Ministro: Marco Aurélio Mello}

Sobre os medicamentos de alto custo: a favor, considerando que o paciente não tenha condições financeiras e que os familiares devem ajudar quando for possível.

Sobre a ausência de registro na ANVISA: a favor do custeio da importação, desde que o medicamento tenha registro em outros países, que tenha eficácia comprovada e que não existam medicamentos substitutivos no Brasil.

\section{(2) Ministro: Luís Roberto Barroso}

Sobre os medicamentos de alto custo: contra a judicialização dos medicamentos não padronizados, exceto nas situações nas quais o paciente comprovar que não pode arcar com os custos, a CONITEC não tiver apresentado recusa em incluir o medicamento na RENAME e a União for solidária no custeio.

Sobre a ausência de registro na ANVISA: contra a disponibilização, exceto em caso de medicamento com eficácia comprovada em testes e importação já solicitada à ANVISA, mas que ainda não tenha sido analisado pela agência no prazo de um ano ou mais.

\section{(3) Ministro: Edson Fachin}

Sobre os medicamentos de alto custo: a favor para medicamentos não padronizados, porém com a apresentação de prescrição médica, ser a única alternativa de tratamento existente ou demonstrar problema ou demora na incorporação do medicamento na rede pública.

Sobre a ausência de registro na ANVISA: contra, exceto quando os processos da ANVISA desrespeitarem a lei ou demorarem a acontecer. 
Sobre o voto do ministro Luís Roberto Barroso (2), o documento 14NS apresenta (AGÊNCIA BRASIL, 2016, p.1):

\begin{abstract}
Em seu voto, o ministro disse que é preciso retirar do Judiciário a discussão sobre políticas públicas para a saúde. A judicialização, segundo Barroso, traz consequências negativas e graves, como a desorganização administrativa do governo, ampla ineficiência da aplicação de recursos públicos e a seletividade no sistema de saúde.

"A verdade é que, como os recursos são limitados e precisam ser distribuídos entre fins alternativos, a ponderação termina sendo entre o direito à vida de uns e o direito à vida de outros. A vida e a saúde de quem tem condições de ir a juízo não tem mais valor dos muitos que são invisíveis para o sistema de Justiça”, disse Barroso.
\end{abstract}

Apreende-se da fala do ministro que o sistema judiciário preocupa-se com a discussão da judicialização de medicamentos e da saúde, como um todo, e que a mesma traz inúmeras consequências ao sistema de saúde. Logo, é importante continuar o debate, para que a judicialização não acabe com a sustentabilidade do próprio sistema.

\title{
5) Aspectos da padronização de protocolos
}

Assim como para a padronização de medicamentos, os PCDT são resultado de análises técnicas quanto à adequada indicação clínica dos medicamentos e quanto aos critérios de inclusão dos pacientes para cada tratamento. Ou seja, os medicamentos de alto custo são indicados para os usuários que se adequam à um protocolo que transcende os critérios farmacêuticos, mas é na verdade um protocolo geral clínico, que envolve todos os aspectos de tratamento e acompanhamento de cada agravo à saúde.

Sendo assim, o não cumprimento dos PCDT e fornecimento de medicamentos por via judicial ademais o seguimento dos protocolos significa o não cumprimento dos critérios baseados em evidências. Com isto, a estrutura de segurança prevista pela política de saúde não é respeitada.

$\mathrm{O}$ entrevistado 7EN é quem coloca a questão do não seguimento dos protocolos existentes e a pressão pela revisão e abertura dos protocolos, seguida de grande impacto orçamentário:

[...] se for a questão judicial, mais uma vez há a pressão por ampliação do protocolo. Ou às vezes, é porque quem está à frente da coordenação, muitas vezes entende que tem que ampliar e aí incorpora. Então, assim, mesmo que o medicamento tenha um protocolo pelo Ministério, no DF se ele tiver o protocolo expandido, o GDF arca sozinho com aquele medicamento. Então, assim, se tem judicialização para esses outros casos, para essas outras indicações ou no caso só de ampliação do tempo do 
tratamento, então o GDF arca sozinho. E tudo isso tem um gasto muito grande, assim, em termos do impacto no orçamento. Hoje, na assistência farmacêutica do DF, a gente tem previsão... a gente teria que ter no orçamento uma previsão de 700 milhões por ano para comprar tudo de medicamento. Tudo para não deixar faltar nada. [...] E o que a gente viu é que a gente só tinha um orçamento de 130 milhões no mês. Isso já contando com o repasse do Ministério, do Fundo de Saúde e tudo. Sem considerar a judicialização. Então, assim, se fosse para comprar tudo que é padronizado no consumo médio mensal, na verdade, anual, para tudo, a gente tinha que ter no mínimo 700 milhões, considerando todos os recursos.

O entrevistado 2EN acrescenta a decisão dos médicos de prescreverem fora dos protocolos:

Eu acho que sim, eu não diria nem a questão dos usuários, porque eu acho que está no papel deles conseguir o acesso ao medicamento. Mas, eu acho que daí a gente entra mais na questão de médicos e nas próprias decisões que são tomadas à revelia, enfim, dos pareceres. Essa é a questão.

E o entrevistado 6EN ainda comenta que estes prescritores podem não ter conhecimento sobre os protocolos da própria SES-DF.

Outra coisa que a gente tem relacionado aos medicamentos daqui, são ações judiciais por falta de informação do prescritor. Porque ele não sabe que o medicamento está disponível, que tem a farmácia de dispensa, que é só ligar no 160 e preencher a documentação.

Percebe-se, então, que não há o seguimento dos PCDT por parte de alguns prescritores do Sistema Único de Saúde, dificultando que a padronização dos tratamentos e a padronização dos procedimentos resulte em segurança dos tratamentos. E isto é um aspecto conflituoso importante da judicialização pois deve ser analisado previamente à decisão judicial até que ponto o tratamento solicitado não potencializa mais riscos do que o tratamento já disponível pelo SUS, quando for este o caso.

6) Aspectos da atuação do farmacêutico

Um conflito percebido nos dados da pesquisa quanto à atuação do farmacêutico se refere à não consideração da importância deste profissional no processo de judicialização. $\mathrm{Na}$ verdade, todos os procedimentos relacionados ao planejamento da PNAF envolvem a atuação e o conhecimento farmacêutico, porém especificamente quanto à atuação deste profissional na judicialização, há vozes que afirmam que sua participação traga ganhos para além da gestão dos medicamentos judicializados. 
A favor deste entendimento e como correção deste conflito a recomendação $\mathrm{n}^{0} 31$ de 2010 do CNJ afirma a importância do farmacêutico no processo de embasamento técnico dos magistrados. O documento coloca que:

a) Os Tribunais devem celebrar convênios com entidades para que os Juízes possam ter acesso a técnicos (médicos e farmacêuticos) que lhes possam auxiliar na apreciação de questões clínicas relativas à saúde (BRASIL, 2010c; OLIVEIRA, 2013).

Logo, além da participação dos farmacêuticos na elaboração de pareceres pelos Núcleos Jurídicos no momento posterior à decisão judicial, mais importante ainda é a participação no momento anterior à decisão. E é este posicionamento que pode auxiliar para decisões mais justas e até coerentes com as políticas.

7) Aspectos da judicialização da saúde

$\mathrm{O}$ documento 11AR reforça que atualmente tem ganho mais força o grupo que considera que os direitos sociais devem ser garantidos imediatamente, ou seja, que deve-se garantir efetividade aos direitos constitucionais. E, a partir disto, que é legítima a atuação do Poder Judiciário para esta efetivação de direitos, diante da omissão de uma política pública. Mas, por outro lado, há também a preocupação de que esta intervenção seja realizada de forma arbitrária. Nesta situação, teme-se que os resultados das decisões judiciais sejam desfavoráveis para o sistema como um todo em função dos magistrados não possuírem embasamento técnico suficiente para um bom julgamento dos casos. Dentro desta discussão está a preocupação com a priorização das ações individuais frente às políticas de cunho coletivo (OLIVEIRA, 2013).

A própria discussão da legitimidade da atuação do Poder Judiciário é conflituosa e, ainda mais, sobre a forma pela qual será realizada esta atuação. Em contraponto à essa preocupação, nas quais os magistrados muitas vezes não possuem embasamento técnico para a tomada de decisões, o CNJ publicou algumas recomendações relacionadas às demandas em saúde (documento 12J) (BRASIL, 2010c).

Estas recomendações foram direcionadas aos Tribunais de Justiça dos estados e aos Tribunais Regionais Federais, para a orientação dos magistrados se aprofundarem mais em cada caso e não realizar as decisões com base somente na prescrição médica isolada (OLIVEIRA, 2013). 
Outra questão importante no cenário da judicialização, justamente proposta para reduzir os conflitos de interesse entre os dois poderes e tentar alinhar as ações paralelas é a definição de estratégias de trabalho conjunto entre o Poder Executivo e o Poder Judiciário.

As próprias recomendações do $\mathrm{CNJ}$, já citadas, orientam para que haja integração entre os órgãos dos dois poderes:

a) Os Tribunais devem celebrar convênios com entidades para que os Juízes possam ter acesso a técnicos (médicos e farmacêuticos) que lhes possam auxiliar na apreciação de questões clínicas relativas à saúde.

b) Os juízes devem instruir os processos que lhes chegam tanto quanto possível com relatórios médicos contendo a descrição da doença, inclusive com a aposição da Classificação Internacional de Doenças (CID).

c) Devem os magistrados ouvir os gestores do Sistema Unificado de Saúde (SUS) antes da aplicação de medidas de urgência.

g) Os Tribunais devem promover visitas dos magistrados, para fins de conhecimentos técnicos, aos Conselhos Municipais e Estaduais de Saúde, bem como às unidades de saúde pública ou conveniadas com o SUS [...] (OLIVEIRA, 2013, p. 85).

Estas recomendações são importantes pois até o Sistema de Justiça questiona a conduta dentro do próprio sistema, como mostrado no trecho (documento 19J):

\begin{abstract}
Observa-se que as instâncias anteriores basearam-se, para deferirem as liminares acatadas, tão somente na opinião de uma hematologista, qual seja, a da Dra. Jussara Oliveira Santa Cruz, e, segundo consta dos autos, a profissional médica seria a única no País a prescrever o tratamento nos termos questionados, o que vai de encontro aos protocolos do Ministério da Saúde e de outros países tidos como referências quanto a esse tratamento. (SUPREMO TRIBUNAL FEDERAL, 2016d, p.39).
\end{abstract}

Outro exemplo é o Ministério da Saúde que explica no documento 2NS que auxilia o sistema judiciário provendo informações sobre os tratamentos disponibilizados pelo SUS, os tratamentos viabilizados por ações judiciais e outras informações importantes para elucidar a formatação constitucional e legal do SUS. Ainda nesta nota da imprensa, afirma-se que o MS mantém diálogo com os envolvidos com a judicialização da saúde, como os juízes, desembargadores, ministros, promotores, procuradores e advogados (MINISTÉRIO DA SAÚDE, 2016c).

Por parte do Poder Judiciário, um exemplo de atuação conjunta vem da DPDF, que promove reuniões com a Secretaria de Saúde e com a Procuradoria Geral (ambos órgãos distritais) para propor melhorias à gestão pública. E, além destas reuniões, o melhor exemplo de trabalho conjunto se refere à CAMEDIS e à mediação realizada entre o cidadão e a SESDF (documento 11AR) (OLIVEIRA, 2013). 
Um depoimento do secretário de estado de saúde de Minas Gerais, Fausto Pereira dos Santos, sobre a problemática da judicialização vai ao encontro da ideia de que a interação entre as instituições é benéfica:

\footnotetext{
"Não existe mágica para resolver esse problema. É só definitivamente a questão do diálogo, das diversas experiências exitosas que podem ser estendidas para o país e adequadas às realidades das regiões. Esse é o caminho a meu ver" (CONSELHO NACIONAL DE SECRETÁRIOS DE SAÚDE, 2016, p. 4).
}

Este autor defende a mesma ideia apresentada pelo CNJ de que os órgãos do sistema judiciário precisam de uma base técnica para as decisões. Logo, seria bom para este contexto a parceria com universidades, por exemplo (CONSELHO NACIONAL DE SECRETÁRIOS DE SAÚDE, 2016).

Também ao encontro disto está a parceria firmada em junho de 2016 e já apresentada neste trabalho entre o Ministério da Saúde e o Conselho Nacional de Saúde, para a formação dos Núcleos de Apoio Técnico do Poder Judiciário - NATs (MINISTÉRIO DA SAÚDE, 2016c).

Sobre os NATs o Ministro da Saúde em exercício, Ricardo Barros e o conselheiro do CNJ e supervisor do Fórum Nacional do Judiciário para a Saúde, Arnaldo Hossepian, comentam:

\footnotetext{
É uma excelente iniciativa. Todos os procedimentos e medicamentos que estão fora da regulação do SUS e tudo que está incorporado ao sistema será avaliado por juízes com o auxílio de pareceres técnicos", afirma Barros. "Vale ressaltar que o material vai servir para uma consulta voluntária do magistrado dentro de sua autonomia (Ministro Ricardo Barros) (MINISTÉRIO DA SAÚDE, 2016c, p. 1).

É importante que fique claro que o CNJ não interfere na jurisdição. A proposta é conferir ao juiz de direito a possibilidade de que, em tempo rápido, lhe seja fornecido um parecer técnico em Saúde para que ele possa deliberar adequadamente. Numa área como essa, qualquer utilização do orçamento de forma inadequada acaba prejudicando um número maior de beneficiários do SUS (conselheiro Arnaldo Hossepian) (MINISTÉRIO DA SAÚDE, 2016c, p. 1).
}

$\mathrm{O}$ entrevistado $2 \mathrm{EN}$ apresenta uma percepção interessante sobre este trabalho conjunto está sendo percebido atualmente no DF:

Se a gente tiver um núcleo técnico auxiliando o judiciário, porque o judiciário, ele...apesar da nossa resposta (parecer) ser técnica, ele enxerga a resposta como sendo parcial. [...] A Secretaria é polo passivo na ação. É claro que a Secretaria vai se defender. Então, ele não enxerga que a análise técnica é desvinculada. Mas, na visão dos juízes, é que o parecer técnico, ele está meio que defendendo a Secretaria, entendeu? Ele para ser técnico teria que estar lá dentro do judiciário, para o juiz enxergá-lo de forma desvinculada. [...] E querendo ou não, o parecer é do nosso especialista, nosso aqui do DIASF. Nós somos órgãos da Secretaria, então, ele não 
enxerga... A solução para isso era que tivesse... já há em alguns estados o que eles chamam de NAT, o núcleo de avaliação dentro do judiciário.

Outro exemplo de colaboração é explicado pelo entrevistado $6 \mathrm{EN}$ e se refere ao contato entre a DPDF e a SES-DF. O entrevistado explica que antes da abertura do processo judicial a DPDF faz contato com a Diretoria de Assistência Farmacêutica - DIASF e solicita a justificativa do não atendimento da demanda do usuário que buscou a defensoria.

Já é a ação. Antes disso, a Defensoria questiona a DIASF através de ofício. Daí muitas vezes, o que acontece? A DIASF faz um trabalho excelente que é ignorado. A verdade é essa. Que era uma coisa que eu monitorava junto com a [...]. Eu tinha todo esse - a gente chamou de pasta compartilhada -, onde ficavam todos os processos que eles da DIASF faziam, as respostas ao ofício de questionamento. Eu via e colocava "virou ação", "não virou ação".

Explicando melhor o que seria o questionamento da DPDF:

Porque não tem o medicamento? [...] Que são motivos simples, desabastecimento, fora do protocolo, medicamento não padronizado... então, assim, é meio complicado. Eles não entendem...

Outra questão importante e que se apresentou como um conflito para o cenário da judicialização da saúde é a elaboração de pareceres técnicos para embasamento dos magistrados. Ao passo que os pareceres são estratégias para melhorar o processo decisório, os entrevistados 1EN e 7EN comentam sobre o problema dos pareceres serem muito tecnicistas.

Muitas vezes que eu noto, daí é percepção minha. Tem muitos pareceres de farmacêutico, mas, as informações ainda continuam muito técnicas. [...] Isso dificulta, muitas vezes. Pelo entendimento do juiz... Você tem lá "revisões sistemáticas mostram que...". Ele está lá com a receita do médico falando que se o paciente não receber, ele vai morrer. Mas, a tradução do conhecimento para a parte prática, eu acho que a gente precisa aprimorar um pouco mais isso. Não adianta você ter muitos núcleos que dão resposta, mas a informação continua sendo muito técnica. E dá trabalho fazer um parecer muito bem embasado, com certeza. Só que se você não conseguir traduzir isso para o ponto de vista do juiz que está lá, você tem um trabalho perdido, infelizmente (Entrevistado 1EN).

O entrevistado 1EN amplia a zona de conflito para o papel do prescritor na judicialização e reforça a importância:

Eu acho que assim, a gente tem que resolver a nossa questão interna, aqui na saúde. Porque a ação judicial, ela não começa no judiciário, ela começa na saúde, ela começa com a caneta do médico. Então, eu acho que é a maior proximidade, comunicação e responsabilização dos profissionais de saúde. Então, eu acho que é esse ninho de aproximação no sistema. [...] Organizar. E eu acho que muitas vezes, até mesmo, ter uma maior sensibilidade dos gestores para, muitas vezes, entender a 
própria prescrição. Por exemplo, porque que o médico prescreveu tal medicamento? Lógico, não adianta ele só prescrever e levar o paciente lá. O paciente é que sempre está no meio do caminho. O maior problema é a comunicação do gestor de saúde com ao profissional de saúde. Se ele está prescrevendo aqui, embase quais são os mecanismos que... o que está levando ele a prescrever esse medicamento e não o medicamento que está na RENAME, quais são as evidências. Mas, ter um foco, um grupo local em nível de gestão que consiga verificar, justamente, essa pertinência. [...] Então, é criado um grupo específico que vai analisar caso a caso. Mas, para isso, o médico, ele deve embasar muito bem porque que está recomendando aquele medicamento.

Porém, apesar de qualificar parte do problema inicial da judicialização, que é a prescrição médica, o entrevistado 1EN complementa especificando a responsabilidade do judiciário na resolução do problema:

Só que daí também, tem que ter um outro comprometimento do judiciário. Não adianta a gente fazer todo esse caminho, se no final fala que não é pertinente e vai lá e judicializa. É um trabalho perdido. Então, é um processo conjunto.

Daí qual que é o entendimento constitucional do que é a saúde? É um direito público da população ou é individual? Então, nós temos diferentes conceitos e diferentes interpretações.

Eu acho que se tiver muito bem clara, realmente, a necessidade... para você prescrever um medicamento que não está padronizado e embasar isso, muitas vezes, já vai inibir. Porque a gente sabe da influência da prescrição que nós temos. Todos os mecanismos que influenciam que o médico prescreva determinado medicamento. Nós temos bons e maus médicos, isso não tem jeito. Sempre vai ter. Mas, a princípio, o que realmente for ação deve ser uma exceção. Porque se não for exceção, é uma falha de sistema. E para isso que solicite a CONITEC para incorporar, oficialmente, o medicamento.

O entrevistado 7EN também expõe sua opinião sobre os pareceres farmacêuticos, a assessoria técnica de apoio aos magistrados e a coordenação de especialistas médicos que também emitem pareceres, no caso da SES-DF:

Porque, na verdade, o parecer dos farmacêuticos não...assim, quem prescreve é o médico. Então, ele prescreveu, o parecer é só dizendo assim, "tem esse, esse e esse para substituir". Mas, aí o médico é quem vai falar, "não, mas no caso do paciente, esse não....". Então, assim, o parecer é no sentido que existe esse, esse que são medicamentos....mas, aí a prescrição é...

A não ser que ele tivesse assessor técnico lá com ele. Técnico no sentido, ou farmacêutico, ou médico ou alguma coisa assim. Ele só manda comprar, ele não tem a análise técnica daquilo. Como ele saberá que esse medicamento realmente é indicado? Será que ele conseguiu o protocolo da doença que é estabelecido pela Sociedade Brasileira [...].

Ela (coordenação de especialistas) fala embasada principalmente nos protocolos, fala, "olha, o paciente foi indicado aqui o budesonida. Mas, o budesonida ele passou primeiro pelo medicamento tal, tal e tal para aquela doença e tudo. Então, assim, eles fazem basicamente isso. Aí eles concluem no final, fala, "não, realmente é indicado" ou eles falam, "não, o medicamento não é indicado". Ainda assim, segue o processo de compra. Ainda assim, com o parecer... 
Além dos pareceres técnicos, uma outra estratégia para solucionar um conflito relacionado às decisões judiciais é o compartilhamento de informações entre os Poderes Executivo e Judiciário. Por meio da Instrução Normativa 06 de 2011, o TJDFT recomenda aos magistrados que acessem o sistema de informações sobre leitos de UTI para o conhecimento destes dados no momento das decisões judiciais (documento 73LN) (BRASIL, 2011f).

O documento 22AR também comenta sobre a troca de informações entre os dois Poderes:

\begin{abstract}
Uma ferramenta utilizada pelo Núcleo de Judicialização foi disponibilizar aos magistrados, informações acerca das Políticas Públicas oferecidas pela SES/DF, prestadas por profissionais médicos e farmacêuticos com intuito de subsidiá-los nas decisões. As informações prestadas pelo Núcleo de Judicialização sobre alternativas terapêuticas ofertadas pelo SUS (com base nos Protocolos Clínicos e Diretrizes terapêuticas do Ministério da Saúde e da SES/DF), quando ignoradas ou desconsideradas pelo Judiciário, causam ingerências nas Políticas Públicas (PAIM; MARQUETTO; LOPES, 2016, p.4).
\end{abstract}

Por fim, o documento 1AT há uma discussão sobre o acesso aos sistema de regulação de leitos de UTI, ao encontro do colocado pelo documento 73LN. Porém, quanto aos medicamentos, é afirmado em reunião que a PGDF possuía acesso ao "Sistema de Módulo de Medicamentos", da SES-DF. E, por meio deste sistema era possível verificar os medicamentos disponíveis em estoque. É colocado em reunião do Comitê Executivo Distrital de Saúde a sugestão de maior compartilhamento de informações entre o sistema judiciário e o NJUD/SES-DF (TRIBUNAL DE JUSTIÇA DO DISTRITO FEDERAL E TERRITÓRIOS, $2011 \mathrm{~m})$

Uma outra fonte de conflitos entre os dois poderes se refere às ações judiciais entendidas como desnecessárias e que, ainda assim, são deferidas em juízo. O Entrevistado $10 \mathrm{EN}$ comenta sobre isto:

Um caso emblemático que a gente tem de questão de medicamento, assim, de prescrição. O quanto que a prescrição se sobressai e ainda, o juiz, ele permanece, é a questão do fator 9. A gente tem uma médica aqui em Brasília que só ela que prescreve Fator 9 e combinados. Só ela prescreve, entendeu? E assim, as ações são mais antigas, a gente manda a defesa, mas o juiz ele permanece. Permanece e a gente tem que comprar o fator recombinante. A DIASF, os médicos do Hemocentro, todos.

Normalmente, o médico que indica. Fala, "olha, esse aqui você não vai conseguir na rede pública, mas você precisa usar esse medicamento. Então, assim, ou procura um advogado particular ou então vai na Defensoria." 
Sobre este mesmo caso de conflito, já no ano de 2016, coloca o Ministério Público Federal como iniciador de uma ação penal contra o Secretário de Saúde em cargo e os dois secretários de saúde anteriores, sob a suspeita da não disponibilização dos Fatores 8 e 9 (hemoderivados) para os hemofílicos do Distrito Federal. Estes medicamentos são de aquisição centralizada pelo MS, como já citado anteriormente, então o Distrito Federal realiza o papel de repassador do medicamento ao usuário do SUS, por meio do Hemocentro. Porém, o Secretário de Saúde do DF, Humberto Fonseca, afirma que: "A ação é absurda, indignante, infamante". E comenta que os pacientes estavam recebendo regularmente os medicamentos do repasse (AGÊNCIA BRASÍLIA, 2016, p.2).

Sobre esta mesma questão, o entrevistado 6EN comenta:

\begin{abstract}
Inclusive, as ações judiciais, elas vem dizendo que a Secretaria tenta recorrer para dar morosidade ao processo. E não é. Então, assim, até a própria Procuradoria, ela tem uma dificuldade. Porque você tem uma constituição que fala que o paciente tem direito. Mas, ele não tem direito a qualquer coisa. Ação judicial tem casos extremos, paciente que pede protetor solar.
\end{abstract}

Exemplificando com mais detalhes, o mesmo entrevistado 6EN expõe uma situação relacionada à judicialização excessiva:

\begin{abstract}
Sim, teve uma paciente que foi excelente. Ela entrou com uma ação judicial de medicamentos padronizados e abastecidos. Aí eu falei "porque você entrou com uma ação judicial?", “ah, porque eu não quero mais ser atendida no componente especializado e eu não quero ser atendida no Adolescentro. Eu quero buscar os meus medicamentos num lugar só". Eu falei, "então, mas infelizmente, eu vou direcionar o seu processo para os locais que tem o medicamento", "uai, mas eu entrei na justiça porque eu quero uma coisa diferente". Aí eu falei, "na sua ação está descrito medicamentos, se todos são padronizados você vai para lá do mesmo jeito". Então, você tem assim, mãe e filho que... observa-se o sobrenome...que são coisas famosas de anos, que todo mundo já sabe. Que são pacientes realmente difíceis. Então, assim, você aprende quem são rapidinho.
\end{abstract}

Por outro lado, é importante destacar os dados que mostram também o alinhamento de alguns órgãos, em alguns casos específicos, como o já descrito referente ao Fator 9 recombinante, para pacientes hemofílicos.

O STF compreende que, não havendo superioridade no tratamento oferecido pelos fatores recombinantes, o tratamento deve ser realizado com os medicamentos já previstos (CORREIO BRAZILIENSE, 2016; SUPREMO TRIBUNAL FEDERAL, 2016d). Segundo o ministro Ricardo Lewandowski, em sua decisão judicial: "Defiro em parte a medida liminar pleiteada a fim de determinar que os pacientes hemofílicos recebam tratamento conforme o 
Protocolo do Ministério da Saúde, ressalvada a necessidade de terapia diversa, desde que comprovada por junta médica oficial" (CORREIO BRAZILIENSE, 2016).

Isto é importante também para fortalecer o pressuposto da gestão destes medicamentos no SUS, seguindo a PNAF, pois há racionalidade desde a seleção dos medicamentos, até a aquisição e disponibilização, incluindo todas as etapas deste gestão. Ou seja, como registrado em pela SES-DF, a decisão judicial fortalece e confirma a retidão destes processos, muitas vezes não considerada ou investigada nas demais ações judiciais deferidas a favor do acesso. Conforme nota: “A decisão do Supremo Tribunal Federal refere-se apenas aos casos citados, mas reforça a correção dos parâmetros que são utilizados pelo Ministério da Saúde e pela Secretaria de Saúde. São 17 os pacientes judicializados" (CORREIO BRAZILIENSE, 2016, p.1).

Ainda quanto à judicialização e seus pontos conflituosos, algumas outras opiniões de atores envolvidos neste processo são importantes para a compreensão deste fenômeno e seus pontos de conflito.

O entrevistado 1EN expõe a preocupação nas análises bem embasadas quanto ao funcionamento da política e as características da ação judicial, para que não haja ações injustas e que privilegiem somente o individual:

\begin{abstract}
A motivação da ação judicial, ela é complexa. Nós temos várias motivações. Motivações que eu acho que, às vezes, ainda tem uma lacuna no SUS, para algumas situações que o SUS ainda não conseguiu construir. O SUS ainda é um sistema em construção, em permanente construção. Mas, nós temos muitos casos que ainda são irracionais, e que não levam em consideração a própria construção da política como um todo. Então, é muito do sistema, do nível de organização. Muitas vezes, o medicamento está padronizado no SUS, ele está disponível e tem motivações que a gente não sabe que é pedido por ação judicial. Tem momentos que deveria estar disponível, mas por falta de gestão ele não está e que também tem motivação. Então, é um conjunto de causas muito complexas. E a própria construção da política que leva em consideração um nível coletivo, não um nível individual. Então, muitas vezes, eu acho que tem aquela divisão do próprio Max Webber, da ética de convicção e da ética de responsabilidade. Em que você tem um nível individual, que por ser o paciente que está ali, realmente pode ser que seja o melhor medicamento para ele. Muitas vezes pela própria facilidade de aderência ao tratamento. Mas, em um nível de sistema de saúde, pode ser que não seja o mais custo-efetivo. Ele tem a mesma efetividade, mas o custo é maior. Então, são alguns aspectos que são, que devem ser considerados.
\end{abstract}

O entrevistado 3EN complementa mostrando que há casos sim para os quais a via judicial pode ser a única opção de acesso à tratamento. Porém, deve-se respeitar a política de base e a racionalidade por trás da suas elaboração: 
Eu não sou contra a judicialização. Eu acho que tem casos que, realmente, você não tem uma política voltada e você não vai ter protocolos que tem que ter o acesso. Mas, é complicado.

\section{$\mathrm{O}$ entrevistado 7EN expõe sua opinião quanto às possíveis melhorias a serem} incorporadas no cenário da judicialização da saúde:

$\mathrm{Na}$ verdade, várias coisas. Uma delas é a conscientização do próprio judiciário... a própria conscientização do judiciário. Mas, isso já tem sido feito, assim, muito. Essa questão da conscientização, muitos juízes, magistrados, eles se posicionam assim, eles não têm competência técnica. E se o médico que está acompanhando o paciente, fala que o paciente vai morrer, quem é ele para falar que não vai? Ele tem que julgar a lei e o que já existe que é universalidade, integralidade e equidade. É isso que ele julga. Assim, claro, diversas diretrizes do SUS, etc., mas ele julga isso. O que está na Constituição, que a saúde é um dever do estado, pronto. Então, ele vai julgar isso, ele não vai julgar o mérito em si. Ele vai julgar o que está escrito lá e o que o médico está falando. Então, assim, tem que ter essas câmeras mesmo de assessoria técnica, tem que ter maior conscientização do magistrado. Mas, isso já está sendo feito.

O entrevistado ainda completa caracterizando as ações judiciais e, com isso, mostrando quão complexo é analisar a judicialização, pois seus principais objetos são medicamentos do próprio SUS e solicitados por via judicial por prescritores também do próprio SUS.

Como identifiquei que a maior parte dos medicamentos já são padronizados, primeiro. Ah, outra coisa que eu observei, que grande parte das receitas, dos requerimentos, eram feitos por médicos do SUS. Então, assim, capacitar e ter protocolos internos do SUS. Porque se o médico do SUS está prescrevendo fora do protocolo, aí que o juiz vai falar, "meu filho, não tem a menor condição". Então, assim, ter esses protocolos institucionalizados, ter... capacitação, divulgação e adoção desses protocolos, fiscalização dos protocolos que não são atendidos. A gente teve relato de representante de indústria, de laboratório farmacêutico que ficava na porta do laboratório, principalmente dos reumatologistas, no Hospital de Base. Ficava lá na porta, quando o paciente saía, "você está com prescrição assim, assim? A gente pode entrar na justiça para conseguir esse medicamento e tal, você não quer tentar?". Então, assim, o próprio laboratório fica fazendo essa pressão para judicializar... o próprio laboratório fica fazendo essa pressão para judicializar no sentido de pressionar pela via judicial, porque aí depois é fácil de padronizar porque tem muita demanda. Então, assim, divulgar essa questão, não só para os médicos, mas para toda a equipe profissional. Até para a própria farmácia, para os farmacêuticos. [...] E a própria Procuradoria questiona isso, quando eu estava fazendo o trabalho, "ah, mas os médicos do SUS fazem isso, prescrevem desse jeito. Como é que a gente vai defender? Se é o próprio médico do GDF que está prescrevendo. Como é que a gente vai defender? Se é o nosso próprio ator é que está levando essa demanda?”. E aí ficam essas questões (Entrevistado 7EN). 
O entrevistado ainda apresenta sua preocupação com a melhoria da execução da

PNAF, como meio de redução e controle das ações judiciais:

E outra parte que eu acho mais importante além de capacitar a equipe profissional da saúde, é garantir a disponibilidade por meio de todo o ciclo da assistência farmacêutica, dos medicamentos já padronizados. Considerando que a maior parte são medicamentos padronizados. [...] A programação tem uma dificuldade muito grande porque não tem...o consumo, ele é muito variável, extremamente variável. Então, quando está faltando, por exemplo, Captopril de 50, usa mais o de 25. Mas, o sistema não faz essa análise.

Seguindo as opiniões sobre pontos conflituosos da judicialização, o entrevistado 8EN acrescenta aos dados da pesquisa sua impressão sobre o aumento das ações judiciais nos últimos anos:

Eu acho que sim, porque hoje em dia as pessoas estão mais informadas de tudo. E a mídia está muito em cima. Então, por exemplo, se a pessoa olhar lá na televisão, "ah, faltou meu medicamento, eu tenho ação judicial", ela vai falar, "pô, porque que eu não posso entrar com uma ação judicial?". Então, a pessoa também vai atrás. Então, hoje em dia, por mês, eu acho que eu cadastro mais ou menos uns vinte a trinta pacientes novos. Mas, também, tem muitos que falecem. Porque tem muito medicamento que é oncológico, medicamento oncológico do Base (Hospital de Base). Então, assim, é uma rotatividade muito grande. Hoje, a gente não tem um número muito alto de pacientes, é em torno de quase 600. Não é alto.

[...] O problema é que os médicos, muitos deles têm envolvimento com a indústria farmacêutica. Tem envolvimento em pesquisa, essas coisas. Então, eu acredito que sim, usem alguns pacientes como cobaias, essas coisas. E aí vai... e tem muito uso off-label aqui, também. Então, assim, eu acho que a partir do momento que o médico, ele está na rede, ele deveria sim, usar até a última escolha do medicamento padronizado. Ele não deveria ficar trabalhando contra a Secretaria. Porque é trabalhar contra a Secretaria. [...] Então, eu acho assim, que deveria utilizar todos os meios que tivesse. E se não der aquele, beleza, entrou com a ação, é a única escolha mesmo. E às vezes, entrar numa CFT para ver se não tem como padronizar o medicamento dele, já que tem muita demanda.

Por fim, o entrevistado 10EN coloca a sua opinião sobre a análise técnica da ação judicial enquanto filtro das ações que se referem à medicamentos já disponíveis na SES-DF:

Porque hoje é assim: o médico prescreveu, normalmente vai comprar. Se tiver um filtro, alguém que fale assim, "não, mas porque? Isso realmente passou pelas etapas de protocolo e tal"? Pelo menos dar uma filtrada assim. Pelo menos eu acho que vai... talvez, não reduza tanto a quantidade e tudo. Mas, pelo menos, vai qualificar isso. Que realmente aquilo é indicado e tal, tal. Porque hoje em dia, para você ter uma ideia, tem ação, decisão judicial que já chegou para a gente para comprar Zerocal para uma paciente que é diabética. Então, vem de tudo assim. Tem uma paciente aqui que ela usa seringa para...eu não sei exatamente para que ela usa seringas estéreis. Ela quer que compra da marca [...]. Aí o juiz defere, "porque da marca Bebê?". Então, tem essas coisas assim. Mas, tem a decisão judicial, a gente tem que cumprir. [...] Até os juízes reclamam disso, que ele fala assim, "eu não sei se realmente aquele paciente precisa. Mas, tem um relatório médico, eu vou contra?" 
As opiniões apresentadas acrescentam ao trabalho o ponto de vista de alguns entrevistados que estão envolvidos com a judicialização e cujas percepções são extremamente importantes para a análise do objeto em questão e para a proposta de melhorias concretas aos procedimentos executados no momento de realização desta pesquisa.

\subsection{Síntese dos resultados das categorias do Caso 02 - Judicialização da saúde}

Com a padronização proposta para o caso 01, segue-se a mesma sistemática de apresentação da análise do segundo caso. O Quadro 5.6 apresenta uma síntese dos resultados de todas as categorias e subcategorias desta segunda análise.

Quadro 5.6: Síntese dos resultados das categorias do caso 02 - Judicialização da saúde (continua).

\begin{tabular}{|c|c|c|}
\hline Categoria & Subcategoria & Resultado \\
\hline $\begin{array}{l}\text { Natureza do } \\
\text { problema (NP) }\end{array}$ & -1 & $\begin{array}{l}\text { Problema: garantir o acesso à medicamentos (direito } \\
\text { à saúde, direito à vida). } \\
\text { Dimensão: residentes no território nacional. } \\
\text { Ação: controle jurisdicional das políticas públicas } \\
\text { de saúde. }\end{array}$ \\
\hline $\begin{array}{l}\text { Contexto social, } \\
\text { econômico e } \\
\text { político (CSEP) }\end{array}$ & - & $\begin{array}{l}\text { Contexto de significativo aumento de demandas em } \\
\text { saúde e, especificamente, por medicamentos. Junto } \\
\text { ao crescimento do número de ações, os sistemas } \\
\text { judiciário e executivo avançam em estrutura e } \\
\text { organização de processos para as decisões e } \\
\text { execuções dos litígios. }\end{array}$ \\
\hline & Normas embasadoras & $\begin{array}{l}\text { Leis, decretos, resoluções, portarias e } \\
\text { recomendações publicadas desde a Constituição } \\
\text { Federal de } 1988 \text { até os dias atuais. }\end{array}$ \\
\hline $\begin{array}{l}\text { Aparato } \\
\text { normativo (AN) }\end{array}$ & Discricionariedade normativa & $\begin{array}{l}\text { Discricionariedade relativa à liberdade de atuação e } \\
\text { decisão pelo profissional do direito no julgamento } \\
\text { dos casos e discricionariedade relativa à liberdade } \\
\text { de atuação que as normas aplicadas aos casos } \\
\text { judiciais permitem. }\end{array}$ \\
\hline \multirow{4}{*}{$\begin{array}{l}\text { Aparato } \\
\text { administrativo } \\
\text { (AA) }\end{array}$} & Estrutura organizacional & $\begin{array}{l}\text { Órgãos do sistema judiciário, órgãos do sistema de } \\
\text { saúde e órgãos essenciais à justça dos níveis federal } \\
\text { e distrital. }\end{array}$ \\
\hline & Recursos Humanos & $\begin{array}{l}\text { Participação de magistrados do sistema judiciário e } \\
\text { de atores do sistema de saúde na prática da } \\
\text { judicialização e de representantes das instituições } \\
\text { interessadas, no contexto da discussão da } \\
\text { judicialização da saúde. }\end{array}$ \\
\hline & Atividades, fluxos e rotinas & $\begin{array}{l}\text { Atividade inicial de julgamento e decisão sobre os } \\
\text { litígios em saúde e atividades voltadas à execução } \\
\text { da decisão de fornecimento de medicamentos. }\end{array}$ \\
\hline & Recursos financeiros & $\begin{array}{l}\text { Recursos provenientes de políticas de saúde } \\
\text { variadas, sem programação prévia para alocação de } \\
\text { recursos para a judicialização e princípio da } \\
\text { responsabilidade solidária entre os entes } \\
\text { federativos, no custeio dos medicamentos } \\
\text { judicializados. }\end{array}$ \\
\hline
\end{tabular}


Quadro 5.6: Síntese dos resultados das categorias do caso 02 - Judicialização da saúde (continuação).

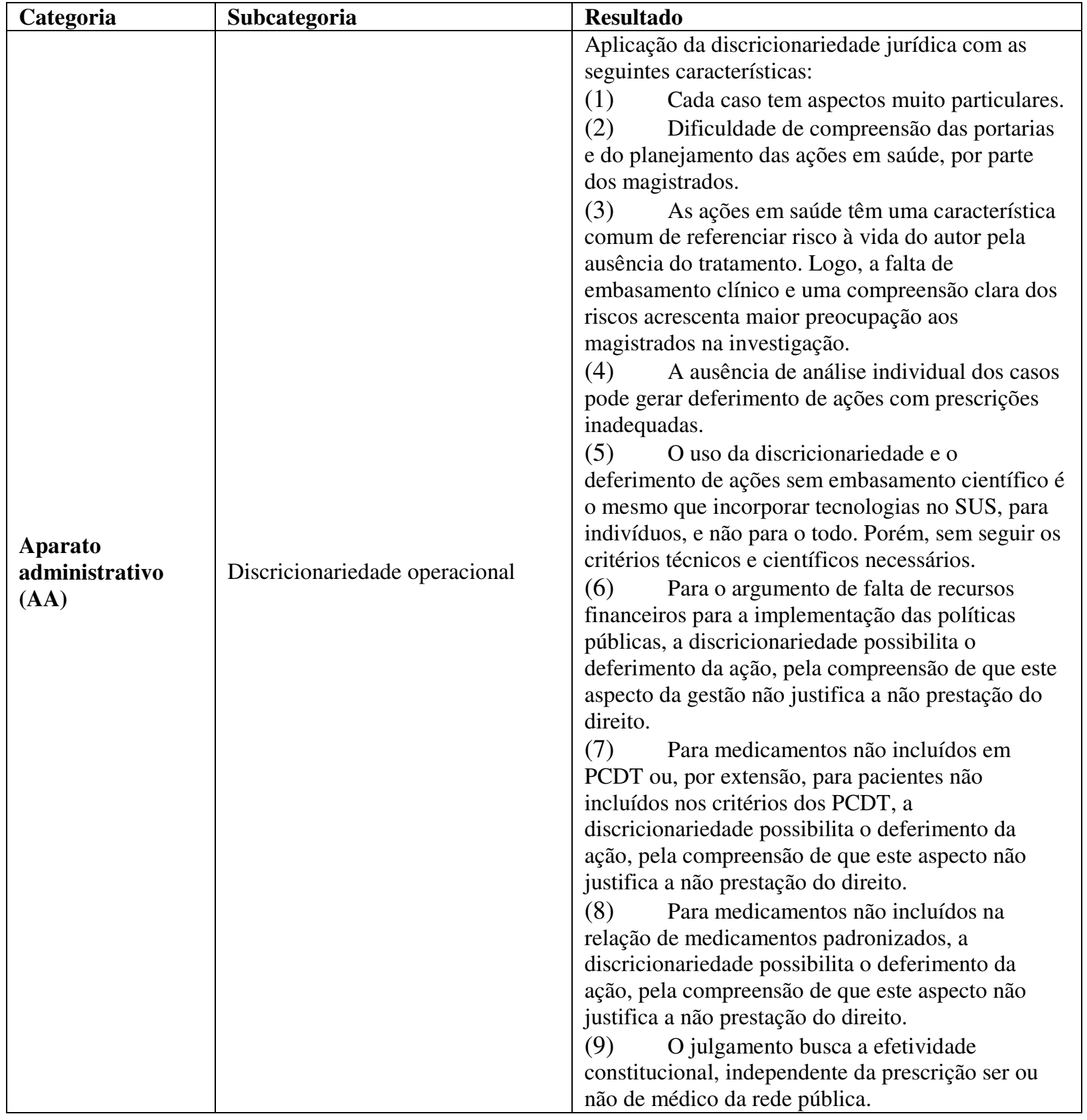


Quadro 5.6: Síntese dos resultados das categorias do caso 02 - Judicialização da saúde (conclusão).

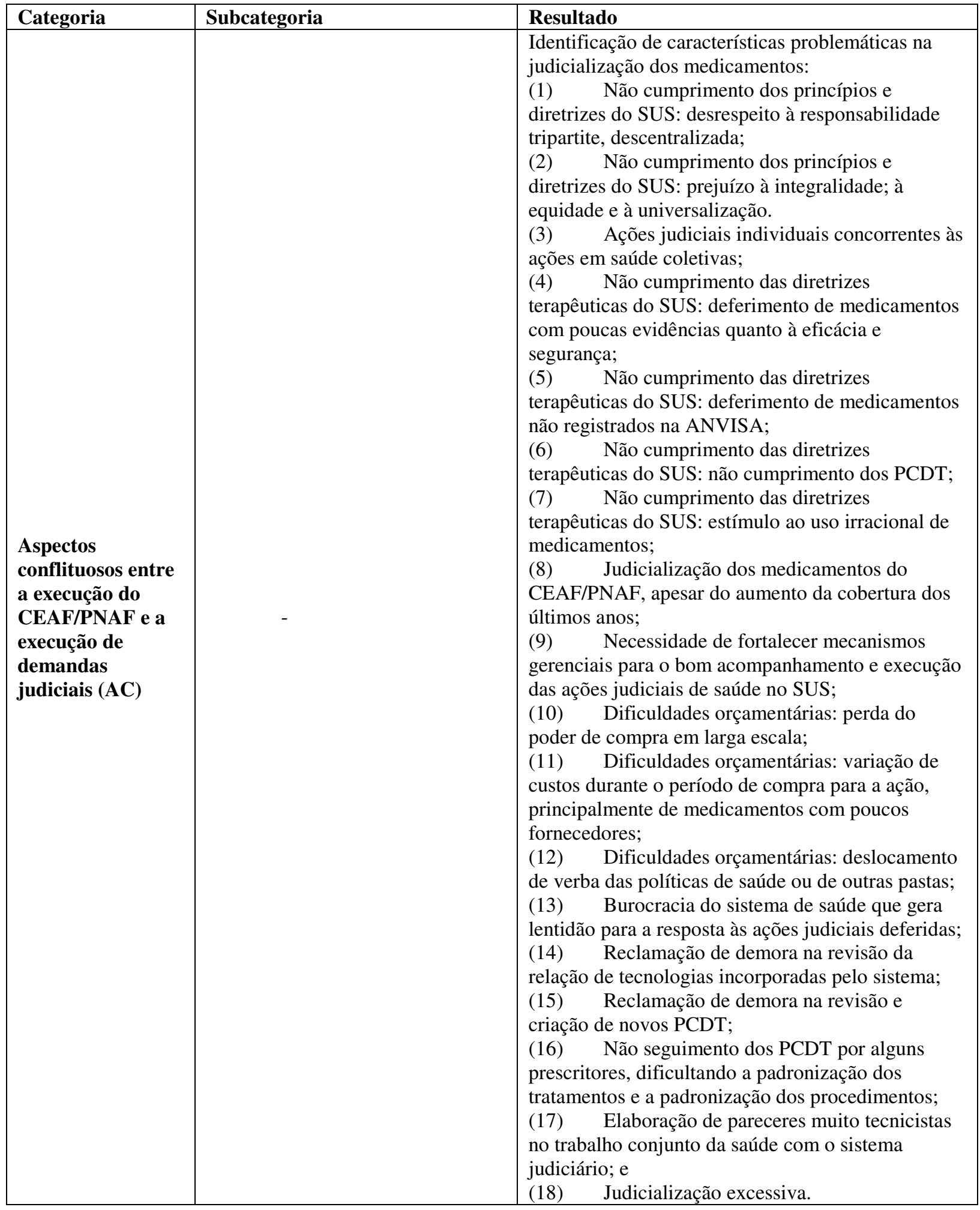

Fonte: Da autora.

Os dados apresentados nos capítulos 4 e 5 foram analisados para construir os casos 01 e 02, na perspectiva de uma pesquisa exploratória e descritiva. Logo, as informações foram sistematizadas para que os dois cenários fossem compreendidos e detalhados. A partir destas informações, o capítulo 6 se propõe à uma discussão final sobre o cenário atual da 
judicialização de medicamentos no DF e à construção de um modelo prático que reúna os elementos identificados neste estudo. 


\section{ANÁLISE INTEGRATIVA DOS CASOS}

Neste capítulo, os dois casos são revistos sob a perspectiva analítica da gestão governamental. E, por serem casos não exatamente equiparáveis, a análise feita foi integrativa entre os dois fenômenos previamente explorados para melhor expor o que os dados revelam com respeito à implementação do direito a acesso a medicamentos.

Este capítulo segue a mesma estrutura de categorias e subcategorias utilizada nos dois capítulos anteriores. E, além de seções que tratam das respectivas categorias e subcategorias, foram incluídos dois novos tópicos que apresentam as proposições elaboradas a partir dos resultados deste trabalho. A primeira delas se refere à uma linha histórica sobre o Componente Especializado da Assistência Farmacêutica da Política Nacional de Assistência Farmacêutica - CEAF/PNAF e a judicialização da saúde, ambos em âmbitos federal e distrital. O segundo tópico se refere à proposição de um modelo operacional para a judicialização de medicamentos, que reúne os pontos fortes do modelo existente e as sugestões de melhorias para os pontos identificados como frágeis do modelo atual.

Como início da análise e antes da apresentação das categorias, o panorama geral dos resultados da codificação demonstra a diferença de padrão da distribuição dos dados para as categorias nos dois casos.

Utilizando as ferramentas de análise do software $\mathrm{Nvivo}^{\circledR}$, foram criados mapas visuais, um para cada caso da pesquisa, com a apresentação dos resultados da codificação dos documentos (documentos oficiais, reportagens jornalísticas, artigos e entrevistas transcritas). Os mapas mostram a distribuição proporcional dos trechos codificados para cada categoria e subcategoria, para cada caso. Esta visualização é útil para a compreensão da quantidade proporcional de informações codificada para cada categoria dentro de todo o conjunto de codificações do caso.

A Figura 6.1 mostra esta distribuição referente ao caso 01 e a Figura 6.2 se refere ao caso 02 . 


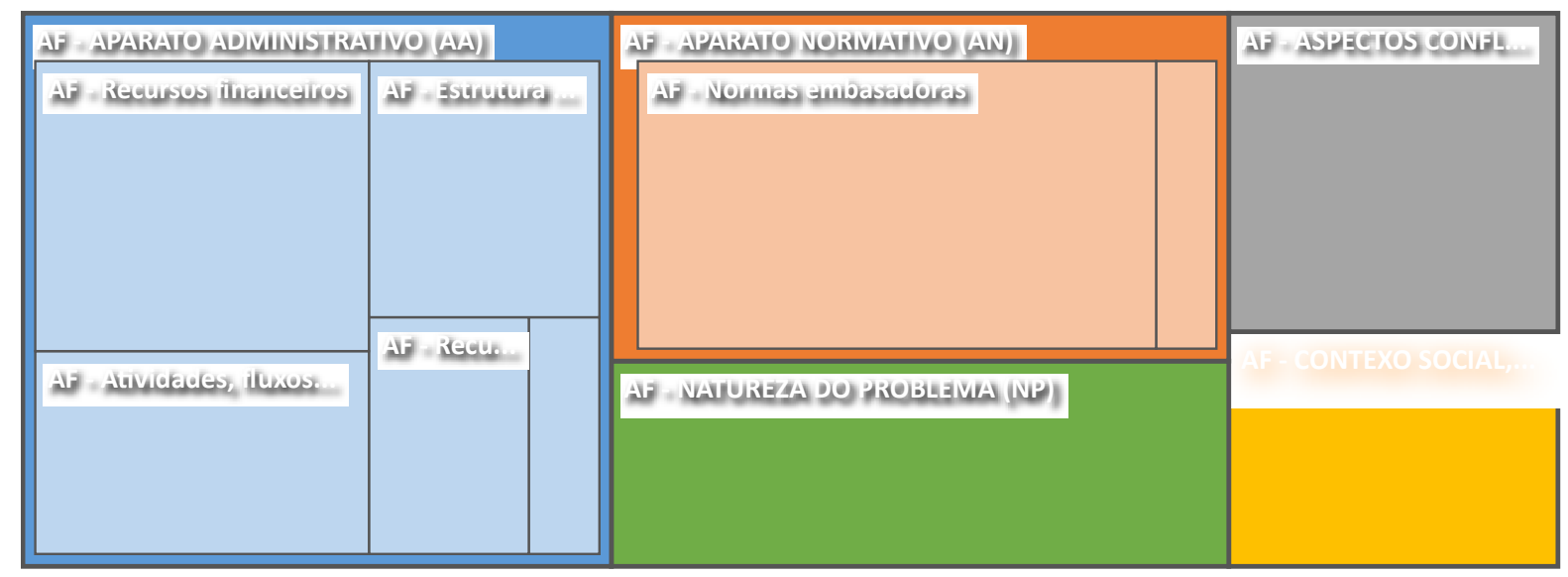

Figura 6.1: Distribuição visual dos códigos por categorias para o caso 01 - Assistência Farmacêutica CEAF/PNAF

Fonte: Da autora.

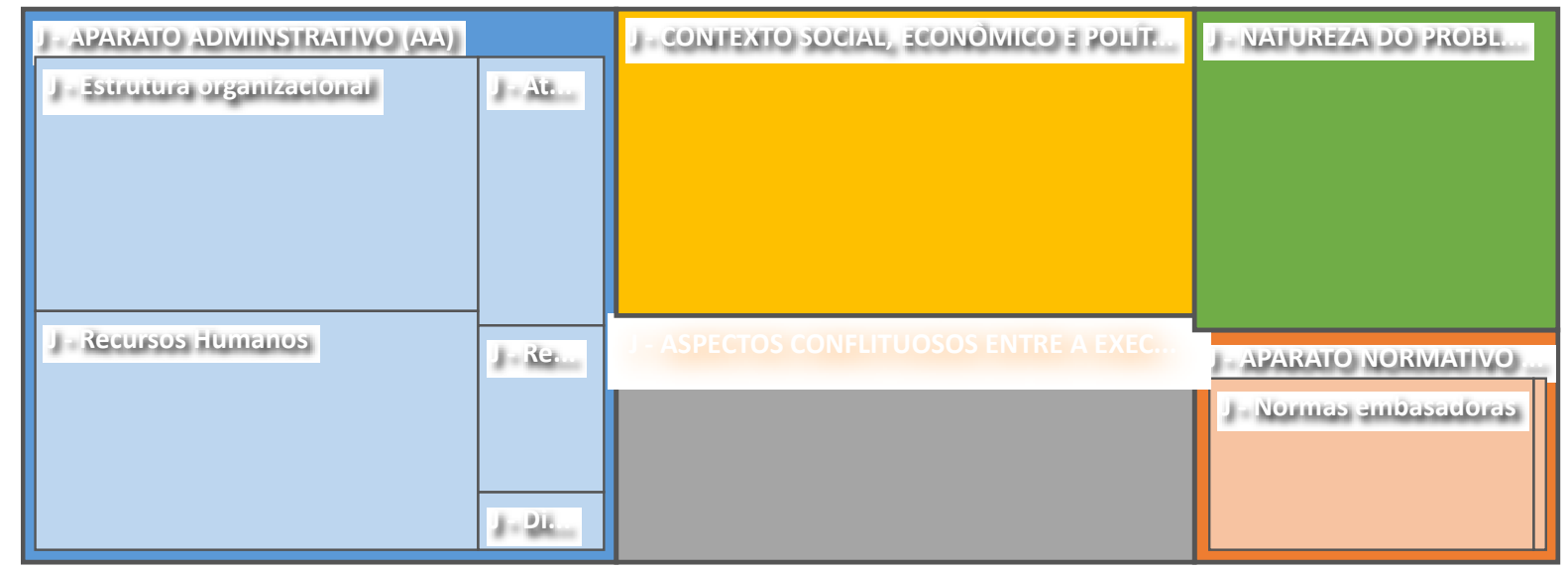

Figura 6.2: Distribuição visual dos códigos por categorias para o caso 02 - Judicialização da saúde Fonte: Da autora.

Primeiramente cabe ressaltar que, de acordo com a quantidade absoluta de códigos para cada categoria, o caso 02 teve uma quantidade muito maior se comparada ao caso 01 , como será apresentado nas Tabelas 6.1 e 6.2. Logo, os mapas expõe a proporção da codificação dentro do respectivo caso e permite inferências gerais sobre os padrões.

De início, percebe-se um padrão oposto em quase todas as categorias e subcategorias dos respectivos casos em termos de quantidade proporcional de trechos codificados. Ou seja, as categorias e subcategorias que tiveram maior quantidade de códigos para um caso, tiveram a menor quantidade de códigos para o outro caso. As exceções à esta observação são as subcategorias discricionariedade operacional, discricionariedade normativa e normas embasadoras, que apresentaram o mesmo padrão. As duas primeiras subcategorias tiveram 
poucos códigos identificados nos dois casos e isto pode ser compreendido em função de ser um assunto muito específico e que não é explícito nos documentos. Na verdade, a interpretação das informações leva à identificação do aspecto discricionário. E como a discricionariedade normativa teve menor proporção dentro da categoria aparato normativo, consequentemente espera-se que as normas embasadoras exponham padrão oposto, tendo maior expressão na mesma categoria. De fato a presença de informações relacionadas às normas é muito mais comum do que de conteúdo pelo qual extraímos a ideia de discricionariedade.

A observação dos resultados de codificação quanto ao aparato administrativo é interessante pois mostra uma padrão oposto de volume de informações quanto às subcategorias recursos financeiros e atividades, fluxos e rotinas se comparadas à estrutura organizacional e recursos humanos. As duas primeiras têm maior projeção para o caso 01, enquanto as duas últimas tiveram maior proporção de categorização para o caso 02 . E ambos os casos tiveram menor quantidade de códigos para a subcategoria discricionariedade operacional.

De fato a descrição do caso 02 desvela uma grande quantidade de organizações envolvidas com o fenômeno da judicialização e, de forma proporcional, também houveram mais citações relacionadas aos recursos humanos, como apresentado no Capítulo 5. Também observa-se que nos dados para o caso 01 , há descrição robusta sobre o financiamento dos medicamentos da política de medicamentos e sobre os gastos históricos com a política. Em contraste, , para o caso 02, as informações sobre os recursos financeiros são escassas e, de forma geral, se referem aos gastos históricos com a judicialização e discussão sobre a responsabilidade solidária entre os entes para o custeio da judicialização. Refletindo as características do caso, não havia conteúdo referente à previsão orçamentária para a judicialização.

A natureza do problema e o contexto social, econômico e político tiveram proporções de codificação diferentes para cada um dos casos também. Para a codificação de trechos sobre a natureza do problema foram identificadas mais informações sobre a assistência farmacêutica (caso 01). Isto também está refletido nos resultados pois a discussão desta categoria, no Capítulo 4, que foca a implementação da política, possui mais elementos e detalhes do que a discussão da mesma categoria no Capítulo 5, que trata da via judicial. Para o caso 02, a natureza do problema é mais concisa e versa sobre a definição do controle jurisdicional. Sobre os contextos históricos, ambos os s tiveram uma boa base de evidências, porém, de fato, o 
caso 02 apresentou um corpus de evidências mais robusto relacionados à judicialização da saúde.

Por fim, as categorias aparato normativo e aspectos conflituosos entre a execução do CEAF/PNAF e de demandas judiciais também oostentaram padrão contrário quanto à proporção de códigos nos respectivos casos.. De fato é perceptível pela descrição das normas embasadoras o caso 01, no Capítulo 04, que há muito mais dados referentes à normatização da política. Isso ocorre pois a normatização da judicialização remete à Constituição Federal $\mathrm{CF}$ - e às normas relacionadas à própria política, porém com uma seleção reduzida, frente aos aspectos técnicos que impactam na definição de medicamentos para o Sistema Único de Saúde - SUS.

Por fim, quanto aos aspectos conflituosos, também foi notável a existência de mais informações voltadas diretamente ao contexto da judicialização. Isto porque, para o caso 01, os aspectos conflituosos se referem às questões preocupantes do ponto de vista da saúde e que devem ser consideradas no processo de judicialização. Já para o caso 02, há questões semelhantes às do caso 01, acrescidas de exemplos de casos judiciais específicos e suas jurisprudências. E isto amplia as informações de casos conflituosos em função dos julgamentos judiciais que ocorrem sem apoio técnico da área da saúde ou mesmo que ocorrem desarticulados com o que é preconizado pela política e pelo sistema de saúde.

A análise apresentada nos mapas é reforçada pela apresentação da quantidade de códigos associada a cada caso. As Tabelas 6.1 e 6.2 condensam, para os respectivo casos, a quantidade de fontes documentais e de trechos codificados para cada categoria e subcategoria.

Cabe ressaltar para a interpretação destas Tabelas, que apesar da quantidade de documentos ter sido de 309, os mesmos documentos com códigos em uma categoria podem ser contados novamente nas demais categorias. Assim, o número total de documentos reportados pode ser superior à 309. Cabe também ressaltar um só documento podia conter trechos relevantes a cada um dois casos. Logo, documentos que tratavam tanto de acesso via política e acesso via judicial puderam ter trechos codificados para um ou outro dos dois casos. 
Tabela 6.1: Distribuição do número de códigos por categorias para o caso 01 - Assistência Farmacêutica -CEAF/PNAF

\begin{tabular}{|c|c|c|c|c|c|c|c|c|c|c|c|c|c|c|c|c|c|c|c|c|}
\hline \multirow[b]{2}{*}{ CASO } & \multirow{2}{*}{\multicolumn{2}{|c|}{$\begin{array}{c}\text { Categoria } \\
\text { NP }\end{array}$}} & \multirow{2}{*}{\multicolumn{2}{|c|}{$\begin{array}{l}\text { Categoria } \\
\text { CSEP }\end{array}$}} & \multicolumn{4}{|c|}{ Categoria AN } & \multicolumn{10}{|c|}{ Categoria AA } & \multirow{2}{*}{\multicolumn{2}{|c|}{ Categoria CI }} \\
\hline & & & & & \multicolumn{2}{|c|}{ NE } & \multicolumn{2}{|c|}{ DN } & \multicolumn{3}{|c|}{$\mathbf{E}$} & & \multicolumn{2}{|c|}{$\mathbf{R F}$} & \multicolumn{2}{|c|}{ AFR } & \multicolumn{2}{|c|}{ DP } & & \\
\hline \multirow{2}{*}{ (1) Assistência Farmacêutica } & QF & QT & QF & QT & $\begin{array}{l}\mathrm{Q} \\
\mathrm{F}\end{array}$ & $\begin{array}{l}\mathrm{Q} \\
\mathrm{T}\end{array}$ & $\begin{array}{l}\mathrm{Q} \\
\mathrm{F}\end{array}$ & $\begin{array}{l}\mathrm{Q} \\
\mathrm{T}\end{array}$ & $\mathrm{F}$ & $\mathrm{T}$ & $\mathrm{F}$ & $\mathrm{T}$ & $\mathrm{QF}$ & QT & QF & QT & $\mathrm{QF}$ & $\mathrm{T}$ & QF & QT \\
\hline & 21 & 46 & 15 & 28 & 25 & 68 & 6 & 8 & 5 & 5 & & 6 & 15 & 41 & 11 & 29 & 4 & & 15 & 38 \\
\hline TOTAL & \multicolumn{8}{|c|}{ Fontes: 133} & \multicolumn{12}{|c|}{ Trechos: 306} \\
\hline
\end{tabular}

Fonte: Da autora.

Onde: NP - Natureza do problema; CSEP - Contexto social, econômico e político; $A N$ - Aparato normativo; NE - Normas embasadoras; DN - Discricionariedade normativa; AA - Aparato administrativo; EO - Estrutura organizacional; RH - Recursos humanos; RF - Recursos financeiros; AFR - Atividades, fluxos e rotinas; DP - Discricionariedade operacional; CI - Conflitos de interesse; QF - quantidade de fontes documentais que tiveram trechos codificados para esta categoria e caso; QT - quantidade de trechos codificados para esta categoria e caso.

Tabela 6.2: Distribuição do número de códigos por categorias para o caso 02 - Judicialização da saúde

\begin{tabular}{|c|c|c|c|c|c|c|c|c|c|c|c|c|c|c|c|c|c|c|c|c|}
\hline \multirow{3}{*}{$\frac{\text { CASO }}{\text { Judicialização da saúde }}$} & \multirow{2}{*}{\multicolumn{2}{|c|}{ Categoria NP }} & \multirow{2}{*}{\multicolumn{2}{|c|}{ Categoria CSEP }} & \multicolumn{4}{|c|}{ Categoria AN } & \multicolumn{6}{|c|}{ Categoria AA } & \multirow{2}{*}{\multicolumn{2}{|c|}{ AFR }} & \multirow{2}{*}{\multicolumn{2}{|c|}{ DP }} & \multirow{2}{*}{\multicolumn{2}{|c|}{ Categoria CI }} \\
\hline & & & & & \multicolumn{2}{|c|}{ NE } & \multicolumn{2}{|c|}{ DN } & \multirow[b]{2}{*}{$\mathrm{F}$} & \multicolumn{2}{|c|}{ EO } & \multirow{2}{*}{$\begin{array}{r}\mathbf{R H} \\
\mathrm{T}\end{array}$} & \multicolumn{2}{|c|}{ RF } & & & & & & \\
\hline & QF & QT & QF & QT & $\mathrm{QF}$ & QT & QF & QT & & $\mathrm{T}$ & $\mathrm{F}$ & & $\mathrm{F}$ & $\mathrm{T}$ & $\mathrm{F}$ & $\mathrm{T}$ & $\mathrm{F}$ & $\mathrm{T}$ & $\mathrm{F}$ & $\mathrm{T}$ \\
\hline & 59 & 156 & 141 & 238 & 57 & 108 & 6 & 15 & 02 & 77 & 10 & 66 & 6 & 3 & 0 & 3 & & 1 & 5 & 92 \\
\hline TOTAL & & & & tes: 633 & & & & & & & & & & & rech & & & & & \\
\hline
\end{tabular}

Fonte: Da autora.

Onde: NP - Natureza do problema; CSEP - Contexto social, econômico e político; $A N$ - Aparato normativo; NE - Normas embasadoras; DN - Discricionariedade normativa;

AA - Aparato administrativo; EO - Estrutura organizacional; RH - Recursos humanos; RF - Recursos financeiros; AFR - Atividades, fluxos e rotinas; DP - Discricionariedade prática; CI - Conflitos de interesse; QF - quantidade de fontes documentais que tiveram trechos codificados para esta categoria e caso; QT - quantidade de trechos codificados para esta categoria e caso. 


\subsection{Natureza do problema}

Identificou-se que a judicialização da saúde envolve a reclamação por um direito amplo e que não se restringe somente ao acesso a medicamentos. Porém, este trabalho se propôs a focar neste objeto específico da judicialização e os dados confirmaram que acesso a medicamentos é, de fato, um dos principais alvos do controle jurisdicional no Brasil, em função de sua grande demanda. Na literatura, Medeiros, Diniz e Schwartz (2013) também afirmam que os medicamentos são o principal objeto das demandas em saúde.

Para os dois casos pesquisados foi identificado o problema "garantir o acesso a medicamentos pelo SUS", sendo este então o objetivo final das ações do Poder Executivo e do Poder Judiciário, no estudo em questão. Lembrando que a NP é composta por três elementos e remete ao problema em questão, à sua extensão e à ação para sua resolução.

Como ponto de partida da problemática tem-se a Constituição Federal de 1988 (BRASIL, 1988) e a sua previsão do direito à vida e do direito à saúde, conforme apresentado na categoria NP dos dois casos. Este direito fundamental e constitucional deve ser garantido à todos os residentes do território nacional, incluindo os estrangeiros (extensão). É, então, dever do Estado e direito do cidadão o acesso às ações e serviços de saúde, incluindo o fornecimento de medicamentos enquanto estratégia e tecnologia terapêuticas.

Foi identificado pelo estudo que, fundamentalmente, a provisão destas ações e serviços é dever conjunto dos Poderes Legislativo e Executivo, como explicou Magalhães (2012). O primeiro deve garantir a previsão orçamentária a partir de lei específica e o segundo deve planejar e executar as ações em saúde. A partir desta informação, uma pesquisa complementar da literatura identificou que o binômio executivo-legislativo é comumente estudado no Brasil. Alguns dos focos destes estudos residem no aspecto democrático da atuação dos dois poderes, no partidarismo, na previsão orçamentária governamental, nos atores envolvidos nesta relação e em outros aspectos (ALVES, 2009; BARBOSA, 2015; BITTENCOURT, 2012; FELISBINO, 2009; MORAES, 2001). Logo, a literatura mostra que esta relação é bem estudada e que considera-se que estes dois Poderes são os responsáveis pelas políticas públicas. Inclusive, conforme os dados levantados, por muito tempo a ação do Poder Judiciário foi considerada uma interferência no campo das políticas públicas e somente eram aceitas como legítimas as atuações dos dois outros Poderes.

De acordo com o entendimento de que os Poderes Legislativo e Executivo são os responsáveis pela previsão orçamentária e pela prestação das ações em saúde, respectivamente, surge a discussão sobre qual será o papel do Poder Judiciário nesta seara. 
No contexto desta discussão, Pereira (2016) explica que a administração pública é submetido a três tipos de controles e que todos os três são de extrema importância, principalmente no cenário atual. Estas formas de controle se baseiam nos três Poderes da União. O primeiro deles é o controle administrativo, exercido pelo próprio Poder Executivo. Remete à um controle interno de fiscalização e ocorre quando um órgão hierarquicamente superior fiscaliza um órgão inferior. Já o segundo controle é denominado controle legislativo ou parlamentar, que se caracteriza como externo e é realizado sobre os Poderes Executivo e Legislativo, do ponto de vista político (leis que obedecem à CF) ou financeiro (leis, aplicadas por meio do Tribunal de Contas). O último é o controle judicial ou judiciário ou jurisdicional, que se refere aos atos de fiscalização e correção do Poder Judiciário sobre os atos administrativos dos demais Poderes. Por fim, cabe ressaltar que o controle administrativo não impede uma posterior intervenção pelo controle judiciário. Pois, se houver ilegalidade, o Poder Judiciário ainda pode intervir, independente da ocorrência de todos os procedimentos administrativos possíveis.

Compreende-se então que o sistema judiciário se faz presente no caso 02 em função da sua atividade de controle sobre os atos do sistema executivo que, neste estudo, se refere à implementação de uma política de medicamentos.

Logo após a criação da CF de 1988, o texto constitucional era considerado mais retórico e menos prático. Então, com a era neoconstitucional e com a "doutrina brasileira da efetividade" explicada por Barroso (2016), os magistrados mudaram a percepção e passaram a garantir uma "força" à Constituição. Esta corrente de efetividade máxima para os direitos constitucionais passou a exigir a prestação dos direitos ditos positivos, independente da existência de um dispositivo infraconstitucional. Como já foi mostrado, é sobre esta base teórica que a Política Nacional de Assistência Farmacêutica (BRASIL, 2004) e a judicialização da saúde se apoiam.

A partir deste ponto diferenciaram-se as ações referentes à solução do problema para os casos 01 e 02. Para o primeiro, a ação identificada é a execução de uma política: a implementação de um componente de medicamentos, o CEAF/PNAF. Para o segundo caso, a ação é o controle jurisdicional desta política.

Há então os aspectos específicos que caracterizam a natureza do problema do caso 01 e os que caracterizam à natureza do problema do caso 02. Para melhor compreensão destes aspectos, são apresentadas primeiramente as considerações para o caso 02 .

Para o caso 02, como foi dito, prevê-se uma atividade de controle jurisdicional. Ou seja, o sistema judiciário realizará um controle das políticas públicas, conforme descrito na 
literatura (CHIEFFI, BARATA, 2009; DINIZ, MACHADO, PENALVA, 2014; PEREIRA, 2016; PERLINGEIRO, 2012) e previsto pela própria CF no artigo 5º, inciso XXV. Esta literatura aponta que atualmente o controle das políticas públicas é um desafio para o direito, que deve basear-se nos paradigmas atuais do direito administrativo para a avaliação da política. A saber, o judiciário deve avaliar a legitimidade, a finalidade, a eficiência e os resultados da política judicializada. A aplicação jurídica deverá então investigar se a política está seguindo estes quatro pressupostos (LIMBERGER; SOARES, 2010).

A ação do judiciário na área da saúde será guiada pela $\mathrm{CF}$ e pelas normas infraconstitucionais, como as Leis Orgânicas da Saúde e do Distrito Federal, por exemplo.

Em resumo, os dados mostram que o judiciário deve seguir a supremacia da $\mathrm{CF}$, deve interpretar as leis mais específicas elaboradas pelo legislativo e deve aplicá-las diante da não prestação do direito à saúde pelo executivo. Neste entendimento, o judiciário deve resolver o problema de omissão da política pública para com o cidadão, que reflete em um conflito de interesses entre o requerente e o réu da ação. Portanto, a constante falha no acesso ao sistema de saúde desencadeia o recurso à tutela jurisdicional e a cada dia provoca uma maior atividade judiciária nesta área, como relatado por Sant’Ana et al (2011).

Para a organização desta análise dos casos, em cada seção serão identificados no texto os principais pontos, por meio de numeração. E estes elementos serão apresentados posteriormente em Quadros síntese.

Um primeiro ponto sobre a NP do caso 02 se refere à (1) existência da própria judicialização, pois este processo ocorre no Brasil em prol da garantia do direito à saúde, como já explicado. No entanto, a literatura revisada indica que os demais países que também possuem o sistema universal de saúde garantem o direito aos serviços de saúde, e não o direito à saúde, de forma ampla e sem delimitação. Isto reflete em diferenças práticas quanto ao que é fornecido pela via judicial e isto acaba sendo o motivo da crescente judicialização da saúde no Brasil. Aliado à isto, as ações pelo direito à saúde muitas vezes não visam o direito à vida, mas sim à dignidade humana. E, neste sentido, a saúde seria um meio para ter a dignidade (PEPE et al, 2010). Este entendimento pode ser definidor de decisões judiciais pois até mesmo tratamentos que não possuem comprovação de eficácia e para os quais não há comprovação para a garantia à saúde e à vida, são aprovados indiscriminadamente por via judicial. Ou seja, receber o tratamento é compreendido como uma situação mínima para que se respeite a dignidade do cidadão. E isto pode inibir o ato de analisar a viabilidade e validade do tratamento indicado. 
Um segundo assunto a ser revisto é o questionamento da (2) legitimidade da ação do Poder Judiciário sobre as políticas públicas. Como já mencionado, atualmente, na era neoconstitucional, espera-se que os direitos constitucionais sejam efetivados. Neste sentido, Barroso (2016) reafirma que a CF deixou de ser vista como um documento político e ganhou força normativa, com aplicabilidade direta. Os direitos passaram a ser direitos subjetivos em sentido pleno. A judicialização dos medicamentos, então, responde ao entendimento constitucional de oferta universal de serviços de saúde e do direito à saúde.

Em defesa da legitimidade da ação do Judiciário, há (i) a jurisprudência do Supremo Tribunal Federal - STF, contrária à ideia anterior de que o Judiciário realizava interferência inadequada sobre o trabalho do Executivo. Esta jurisprudência determina que "o judiciário, em situações excepcionais, pode determinar que a administração pública adote medidas assecuratórias de direitos constitucionais" (BARROS, 2016, p. 1).

Outra base que sustenta essa legitimidade é que, conforme os resultados mostraram, (ii) a própria CF especifica que é atividade do Poder Judiciário a garantia destes direitos, quando os mesmos forem omitidos pela política pública. E, diante disto, o Judiciário é quem não deve se omitir do seu dever caso um direito não seja prestado.

Um terceiro alicerce ao argumento da legitimidade é de que, apesar poder judiciário não ser eleito, sua atuação sobre a execução das políticas públicas não fere os princípios democráticos. Primeiramente porque o Poder Judiciário está previsto constitucionalmente e também há a previsão de que o gestor público não pode agir em desacordo ou optar por não cumprir a constituição. Além disso, (iii) sem a prestação do direito à saúde não se garante a dignidade humana. E sem este mínimo existencial não há democracia.

Por fim, a atuação judicial se legitima pelo (iv) princípio da separação dos três poderes alinhado ao princípio da inafastabilidade de acesso ao Judiciário. Logo, todo cidadão tem o acesso ao Judiciário garantido e isto legitima a atuação deste terceiro Poder. No Brasil a interferência do Judiciário é prevista e isto não fere o princípio da separação dos três poderes, porém deve ocorrer dentro de parâmetros da razoabilidade e proporcionalidade (MAGALHÃES, 2012).

Reichert e Schwartz (2011) reconhecem que em situações emergenciais que exijam a prestação de um direito e nas quais uma negativa possa causa danos à saúde, deve-se considerar o direito individual e torná-lo objeto de uma demanda em juízo. Esta ideia aborda outro elemento importante da discussão da judicialização que se refere à cobertura dos direitos individuais versus os direitos coletivos. Pois, ao passo que o caso 01 mostra a complexa estrutura da política e sua cobertura universal e integral, o caso 02 mostra situações 
de fornecimento de medicamentos para casos individuais; e os resultados da pesquisa apontaram a sobrecarga financeira que a via judicial acarreta sobre o governo em função desta previsão individualizada.

Outra particularidade referente ao caso 02 é (3) a percepção genérica de que ocorre o deferimento absoluto ou da grande maioria dos pedidos judiciais, permitindo a inferência que existe um privilégio para aqueles que podem demandar pela via judicial, em detrimento daqueles que não podem. Ou seja, restringem-se os serviços à alguns, ferindo o princípio da integralidade e ferindo o fornecimento de serviços aos demais cidadãos que se beneficiariam. Pepe (2010) e Mazza e Mendes (2014) exprimem esta percepção e consideram que este seria um dos efeitos negativos da judicialização e que possui o risco de impossibilitar o exercício coletivo. Porém explicam também que o STF tem compreendido que o direito à saúde é um direito individual e pode ser buscado separadamente por cada indivíduo.

Consta, então, que o controle jurisdicional deve fiscalizar se a política está seguindo os pressupostos da legitimidade, da finalidade, da eficiência e dos resultados da política judicializada (LIMBERGER; SOARES, 2010). Ao mesmo tempo pela análise da NP do caso 01, foi evidenciado o esforço de seguir destes paradigmas pela gestão do CEAF/PNAF. A política apresenta legitimidade e finalidade previstas pela $\mathrm{CF}$ e trabalha com critério e cuidado a ampliação do componente em prol do ganho de eficiência e resultados. No entanto, se o número de ações judiciais a favor dos cidadãos está aumentando, apesar das ações tomadas na implementação da política, isto significa que os resultados não estão sendo alcançados como esperado.

Comprovada, então, a legitimidade da atuação do Judiciário no Brasil, continua a preocupação com a maneira em que o controle jurisdicional é realizado mediante os problemas com o acesso aos medicamentos. Parte-se, portanto, a uma análise da natureza da implementação do CEAF/PNAF que leva em consideração que este cenário é cada vez mais objeto da intervenção jurídica. Logo, sugere-se um olhar não à implementação em si, mas sim aos aspectos da implementação que devem ser considerados ou, ao menos, que devem ser reconhecidos pelos magistrados para as decisões judiciais.

Neste ponto da análise, antes de dar seguimento à discussão dos aspectos do problema do caso 01, propõe-se pensar a problemática da judicialização da saúde de outra forma. Como citado no parágrafo anterior, os resultados auferidos com respeito ao caso 1 e caso 2 levaram à reflexão de que faz sentido a partir de agora, focar na relação entre o fornecimento de medicamentos pela via judicial e pela via regular da política (do CEAF/PNAF). Ou seja, o olhar integrativo aos dois casos permite vislumbrar um grande sistema que é o fornecimento 
de medicamentos ao cidadão brasileiro, levando ao atingimento de seu direito à saúde (pelo menos no que tange à necessidade de tratamento medicamentoso). Este grande sistema, já em funcionamento nos dias atuais, é composto pela ação do sistema executivo e pela ação do sistema judiciário. Por existir a relação de controle do judiciário sobre o executivo, o primeiro exerce influência sobre a atividade do segundo, de implementação do CEAF/PNAF. A partir deste entendimento, o que os dados desta pesquisa demonstram é que há uma complexa relação entre os dois Poderes já citados: Executivo e Judiciário, neste contexto do fornecimento de medicamentos.

E como a relação Executivo-Judiciário no contexto da garantia do direito de acesso a saúde não foi estudada do ponto de vista da operacionalização das atividades que compõem esta relação, será proposta neste trabalho uma abordagem para tal conduta. Nesta tarefa, por perceber que a complexidade do cenário se diz respeito a aspectos teóricos e conceituais tradicionalmente abordados pela administração pública, este trabalho resgata as funções propostas por Gulick e Urwick (2005), no acrônimo POSDCORB.

Estas funções foram elaboradas, originalmente, sob a perspectiva do trabalho do chefe do executivo. Como a relação executivo-jurídico até agora não tem sido abordado pela perspectiva da administração pública, propõe-se utilizar este referencial conceitual para entender como pode ser administrada a relação em questão. Para isto, a análise se apropria dos elementos propostos por Gulick e Urwick (2005) para a análise da NP do caso 01 e para a análise das próximas categorias a partir de então.

São sete os elementos descritos por Gulick e Urwick (2005) e identificáveis nos dados desta pesquisa: planejamento, organização, assessoria/apoio/pessoal (staffing), direção, coordenação, informação e orçamento.

Chama a atenção, em primeiro lugar, a função de coordenação, que se refere à atividade de promover o harmonização entre as várias partes de um trabalho que se realiza por vários atores distintos. A implementação do direito a acesso a medicamentos, como já evidenciado, envolve a atuação dos Poderes Executivo e Judiciário e exige que estes Poderes se relacionem na garantia desse direito. Como o estudo da relação destes dois poderes não está bem estabelecido na literatura e, portanto, não há abordagens teóricas já estabelecidas para sua investigação, escolheu-se realizar a análise a partir da perspectiva da coordenação intergovernamental, seguindo as classificações de Alexander (1998).

Conforme apresentado na fundamentação teórica da pesquisa, Alexander (1998) classifica as relações entre as organizações em três tipos: hierárquica, de mercado e por associação solidária. Estruturas de coordenação podem ser observadas nos níveis de análise 
meta, meso e micro. As estruturas de coordenação no nível micro se dizem respeito aos mecanismos formais ou informais pelos quais se operacionaliza o contato entre as organizações.

Ao longo da análise estas características serão melhor evidenciadas. Aqui, como apresentação e caracterização inicial das estruturas de coordenação, observa-se que a judicialização da saúde pode ser vista como um sistema interorganizacional interpoderes que apresenta elementos de uma meta-estrutura de associação solidária em que a base da coordenação é o compartilhamento de valores, e uma meso-estrutura com elementos de rede solidária cujo propósito é de melhorar o acesso (na matéria específica deste estudo) a medicamentos de alto custo e de coordenar os trabalhos de interesse geral. Este sistema já conta com várias microestruturas de coordenação, ou seja, mecanismos formais e informais de estabelecimento e manutenção das relações.

Cabe explicar que no processo de análise a observação de cada um dos poderes, evidencia que, separadamente, o Poder Executivo (sistema de saúde) e o Poder Judiciário, apresentam, de forma semelhante, meta-estrutura hierárquica, meso-estrutura também hierárquica e microestruturas de coordenação formal e informal. No entanto, a análise revela, ainda, um sistema interorganizaconal interpoderes em formação que, reconhecido como tal, poderia ser conscientemente fomentado. É este 'sistema interorganizacional' que se caracteriza por meta-estrutura de associação solidária, meso-estrutura de rede solidária e micro-estruturas específicas para coordenar a relação entre os Poderes Executivo e Judiciário.

Estas caracterizações auxiliam não só a compreensão do problema, como também a elaboração de medidas adequadas de ajuste aos procedimementos atuais para lidar com ele. -È essencial destacar que a análise realizada leva em consideração que o sistema final da judicialização da saúde possui características diferentes das dos respectivos sistemas interorganizacionais dos dois poderes, quando observados separadamente. Assim, as qualificações da meta, meso e microestruturas se dizem respeito às características da relação entre os já existentes sistemas interorganizacionais dos dois poderes.

Retomando a análise em questão, a descrição da natureza do problema a ser resolvido pela política de saúde mostra que trata-se de um contexto de grande complexidade. Ou seja, a organização do CEAF/PNAF é feita sob um complexo rol de normas específicas e sob aspectos técnicos da área da saúde. Logo, se o judiciário irá controlar esta política, ele irá atuar em uma outra área técnica, com peculiaridades que não fazem parte das discussões regulares da área do direito. Vários outros pontos que contribuirão à confecção do modelo a 
ser proposto como produto desta tese serão sinalizados ao longo desta discussão com uso de fonte itálica.

Como visto no caso 01, a atividade final de fornecimento de medicamentos se embasa em uma política pública da área farmacêutica, que está alinhada à Política Nacional de Saúde e aos princípios e diretrizes do SUS. Logo, a estrutura responsável por esta atividade segue a mesma estrutura descentralizada e hierarquizada do SUS, respeitando as competências de cada ente federativo. E cabe relembrar que, para esta pesquisa, a atividade de fornecimento de medicamentos se refere especificamente aos medicamentos especializados, também denominados medicamentos de alto custo.

As normas gerais relacionadas à estrutura da saúde pública brasileira e as normas específicas sobre a estrutura da assistência farmacêutica remetem à função de organização (POSDCORB) do executivo. Esta classificação se refere à como se dá a estruturação formal da subdivisão das atividades, ou seja, como elas se organizam e são definidas (GULICK; URWICK, 2005).

E, observando qual seria a característica da coordenação entre as partes, em cada sistema isoladamente, percebe-se que entre os entes federativos (União, estados e municípios) há uma definição bem clara e distinta das competências, estruturadas com base em uma organização hierárquica. O mesmo sistema de organização hierárquico é percebido entre os departamentos e gerências dos órgãos envolvidos. Porém, quando trata-se do sistema entre o Poder Judiciário e o Poder Executivo, a relação na meta-estrutura se caracteriza como uma associação solidária, pois baseia-se no compartilhamento de valores comuns (direito à vida, direito à saúde e garantia da dignidade humana) em prol da garantia do acesso à medicamentos. É perceptível que estes dois poderes trabalham independentemente e que não há relação hierárquica entre eles. Logo, não há relação de comando entre os órgãos de um sistema e outro. E há de se destacar que, baseado na análise dos dados deste estudo, considera-se como diferentes o comando administrativo e hierárquico da gestão pública versus a peculiaridade do controle jurisdicional em demandar a execução das ações judiciais. Esta atividade do judiciário é justamente o elo de relação entre os dois sistemas e se refere à competência do Poder Judiciário no controle das políticas públicas. Porém não é considerado aqui como fruto de uma autoridade hierárquica do Poder Judiciário sobre o Poder Executivo, pois estes dois Poderes atuam paralelamente na constituição do Estado brasileiro.

Sobre a meso-estrutura, classificada como uma rede solidária, o sistema também é compreendido a partir do trabalho coordenado entre os atores do sistema judiciário e do 
sistema de saúde, que são indepententes, porém trabalham em prol do objetivo comum que é garantir o acesso a medicamentos.

Por fim, para as microestruturas, vários aspectos de relações formais e informais serão destacados mais à frente, nesta análise.

A NP do caso 01 identificou que o CEAF/PNAF responde às demandas pactuadas com a Comissão Intergestores Tripartite - CIT, às portarias criadas pelo Ministério da Saúde, às normas pré-definidas pela Comissão Nacional de Incorporação de Tecnologias no SUS CONITEC, às especificações da Relação Nacional de Medicamentos - RENAME e às delimitações dos Protocolos Clínicos e Diretrizes Terapêuticas - PCDT.

Logo, como estas normas delimitam regras para a realização das atividades ou mesmo definem que atividades serão necessárias, este arcabouço constitui parte da função planejamento das ações. Pois, como descrito por Gulick e Urwick (2005), o planejamento envolve não só a elaboração das coisas que devem ser feitas, mas também os métodos para fazê-las e alcançar os objetivos existentes.

Entende-se que as decisões do judiciário sobre a matéria em questão, ou seja, sobre o deferimento ou não das solicitações de acesso à medicamentos, deverá ter por base o conhecimento destes aspectos que alicerçam o próprio CEAF/PNAF. Pois entende-se, $a$ priori, que o julgamento de um fato requer o conhecimento mínimo sobre como os sistemas de saúde e de fornecimento de medicamentos operam. Se a política é implementada na base de critérios específicos para o fornecimento de medicamentos, faz sentido que as ações judiciais também sejam julgadas visando a aplicação de critérios que garantam o melhor tratamento ao requerente. Pois, se não o for, qual seria a necessidade de estruturar uma política primeiro? Poderia simplesmente haver o fornecimento pelo governo de quaisquer medicamentos para quaisquer pessoas. Se há critérios clínicos para a utilização segura de medicamentos, estes critérios continuam existindo para os pacientes, ocorrendo o acesso pela via regular da política ou pela via judicial. Se há riscos envolvidos ou se o tratamento não é o melhor para determinado caso, esta situação se manterá ainda que o paciente utilize a via judicial para solicitar o tratamento medicamentoso.

Logo, se há critérios para a segurança do usuário e estes critérios não são de conhecimento da área jurídica, é razoável que haja algum mecanismo de coordenação entre os dois sistemas, para que o trabalho da judicialização seja feito com cooperação das partes, em benefício final do cidadão.

Enquanto os serviços de saúde funcionam embasados nas normas e orientações já elencadas no caso 01, o sistema judiciário funciona, quanto à essência de sua atuação, 
embasado no arcabouço normativo da CF e nas jurisprudências estabelecidas, também já apresentadas. Esta é a percepção geral obtida pelos resultados da pesquisa, já que a maior parte da discussão teórico-conceitual sobre a judicialização da saúde se refere à explicação do que seja o direito à saúde e à explicação sobre a legitimidade da atuação do Poder Judiciário para controlar as políticas públicas.

Foram os documentos de recomendações para atuação dos magistrados frente as demandas da saúde (CNJ e TJDFT) (BRASIL, 2010c; 2011f), identificados neste trabalho, que chamaram atenção para a importância do embasamento técnico do judiciário.,Em geral, os documentos científicos que discutem as particularidades da saúde na judicialização são produzidos pela própria área da saúde. Observou-se que enquanto há documentos normativos oficiais, assim como outros documentos institucionais que abordam pormenores da judicialização da saúde, divulgados em sítios eletrônicos, a revisão de literatura realizada neste estudo revela que na produção científica de autores do direito, a abordagem mais comum reside na análise da legitimidade do controle jurisdicional de políticas públicas.

A partir da NP do caso 01, extrai-se como elementos importantes a serem considerados pelo judiciário, os seguintes:

(i) Princípios e diretrizes estruturantes do SUS: descentralização; universalidade; integralidade e equidade (4).

Ainda que seja inerente à judicialização a abertura de litígios individualizados, o fato da decisão judicial beneficiar o indivíduo impacta o funcionamento do sistema. O SUS prevê a disponibilização de serviços à todos (universal) e em todos os níveis de assistência (integralidade), de acordo com a necessidade de cada um (equidade). Porém, como já apresentado, quanto mais demandas judiciais forem executadas pela União e pelas Secretarias de Saúde, mais recursos serão alocados para estas provisões individuais e retirados das políticas de saúde coletivas.

A literatura revisada permite a inferência de que ocorre uma desigualdade indireta a partir das ações individuais. Isto é considerado pelo fato de ocorrer o desvio da verba de outras políticas, que atingiriam outros cidadãos. E também é identificado pelo fato de que quem acessa a justiça, recebe a tutela e quem não acessa, não a recebe. Porém é acrescido à análise que o direito possui a sua faceta individual e que deve ser realizado quando o assunto em questão não caracterizar um direito difuso (GNATA, 2011). Ou seja, apesar de impactar, sim, no SUS, o uso de medicamentos se refere à uma necessidade individual e por isso há o entendimento de que esta deva ser atendida. 
Importante relembrar também que o SUS é operacionalizado de forma descentralizada e que a resposta às ações judiciais pode ferir à divisão de competências entre os três entes federativos. Por exemplo, se uma ação ajuizada em um município se refere ao residente de um outro município, o primeiro terá que arcar com o custeio do tratamento. Significa que se a União é acionada à fornecer medicamentos, ela estará executando a atividade de outro ente federativo e, como agravante, passa a ser responsabilizada por uma atividade que não concerne às suas competências. Pois, conforme descentralização administrativa do sistema, são os estados e os municípios que entregam os medicamentos aos usuários e a União somente repassa o financiamento ou os produtos, a depender do componente da AF. Então, com a judicialização, a União teve que desenvolver estruturas e mecanismos não previamente existentes para este novo manejo de aquisição de medicamentos e de entrega ao paciente, desconsiderando o princípio da descentralização.

Outra situação evidenciada pelos resultados da pesquisa é a duplicação da entrega de medicamentos judicializados quando mais de um ente é acionado pela justiça.

Sobre estes casos, o acesso ao sistema judiciário não poderá ser controlado ou negado ao cidadão. Porém, se houver medidas administrativas ou mesmo alguma espécie de filtro com determinados critérios para as ações judiciais consideradas adequadas, o impacto destes tipos de problemas será reduzido.

E, quando se propõe uma espécie de filtro para os casos, se quer dizer que a análise dos dados desta pesquisa levou à compreensão de que muitos eventos poderiam ter resolução administrativa prévia à via judicial, conforme será especificado ao longo da discussão das categorias seguintes.

Sobre os princípios do SUS, como já foi citado anteriormente, estes podem ser vistos como elementos que estruturam a função organização do fenômeno estudado. Destaca-se que estes elementos que estabelecem a estrutura formal do sistema de saúde são os mesmos que este trabalho propõe para serem considerados na atividade do sistema judiciário. Quer dizer, uma das principais sugestões de coordenação entre os sistemas feitas aqui é a de que o judiciário reconheça as características do sistema de saúde em seus julgamentos de controle da política. Até é possível argumentar que estas características de organização do SUS têm base constitucional e se uma decisão judicial não as respeita, isto poderia ser considerado uma afronta ao direito à saúde dos demais cidadãos. Porém este raciocínio envolve elementos muito complexos e atualmente não há consenso para tal.

Voltando à análise, se observa que os elementos de organização do sistema de saúde podem compor um dos conjuntos de informações importantes para as decisões judiciais e, 
portanto, podem servir, também, a função de coordenação (do POSDCORB) da relação executivo-judiciária.

Algumas considerações são necessárias para compreender .esta proposição. Em primeiro lugar, os elementos de organização a que se refere aqui e que equivalem à elementos informacionais importantes para a coordenação executivo-judiciário não são aspectos técnicos dos tratamentos e medicamentos - que serão tratados mais adiante - mas sim aspectos constitucionais e legais (CF e Lei Orgânica da Saúde) do sistema de saúde. Em segundo lugar, as funções do POSDCORB foram idealizadas para as relações interorganizacionais executivo-executivo, logo, sua aplicação nas proposições feitas por este trabalho requer alguns ajustes, para algumas situações.

A seguir se apresenta o segundo elemento de relevância ao judiciário na tomada de suas decisões.

(ii) Objetivo da Assistência Farmacêutica - AF - de garantir o uso racional de medicamentos pela PNAF (5).

Conforme definição de AF, o objetivo final das ações de promoção, proteção e recuperação da saúde é o uso racional dos medicamentos. E para que isto seja alcançado as atividades desenvolvidas dentro do contexto da AF devem ser respeitadas, pois há uma razão para a incorporação de cada uma delas. Ou seja, a oferta de medicamentos do CEAF/PNAF, tal qual é executada pela política, é estruturada sobre princípios técnicos. Com base no próprio conceito, percebe-se que a definição dos protocolos e do elenco de medicamentos objetiva o uso de insumos adequados, para condições clínicas adequadas, nas doses corretas e em tempo oportuno. Além disso, esta definição é realizada por profissionais competentes e prevendo a atuação do profissional farmacêutico em diversos momentos da política.

No caso da via judicial, percebe-se que muitas decisões são proferidas sem a análise dos aspectos da saúde, pois não se alinham aos critérios ou às definições construídas pelos profissionais competentes da área da saúde. E, quanto à avaliação dos tratamentos judicializados, atualmente não há participação do profissional farmacêutico nos contextos da União e do DF. Porém, há a recente assinatura de termo de compromisso para a cooperação técnica do MS e das Secretarias de Estado de Saúde.

Sobre o uso racional de medicamentos, primeiramente infere-se que, se é um aspecto que garante qualidade e segurança ao tratamento do usuário, é um elemento que deve ser garantido pela PNAF e pelo controle jurisdicional. Ou seja, para a garantia do direito à saúde, são necessárias qualidade e segurança do tratamento, logo, é necessário viabilizar isto ao cidadão por meio das ferramentas disponíveis de assistência farmacêutica. Sendo uma das 
principais dessas ferramentas a atuação do profissional farmacêutico com a sua expertise, o elemento inovador proposto é que as estratégias para a participação deste profissional no processo de implementação da política via CEAF/PNAF sejam também incorporadas na execução da decisão judicial. Pois, é fato que ambas são vias de acesso à medicamentos.

Assim, são propostas duas frentes de atuação paraeste profissional: sua participação nas atividades de gestão dos medicamentos pela via regular e pela via judicial; e sua participação enquanto prestador de informações técnicas (logísticas e clínicas) aos magistrados, durante o processo de decisão jurídica.

$\mathrm{O}$ primeiro tipo de participação proposto diz respeito à atividades de planejamento (função planejamento do POSDCORB), pois se refere à atividades logísticas, de forma geral. O segundo se refere à troca de informações (função informação) e também pode-se inferir que trata-se da função planejamento, pois o assessoramento técnico irá auxiliar a tomada de decisões judicial. Pois, como explicado por Gulick e Urwick (2005), a função planejamento também envolve os métodos para se realizar uma atividade e atingir determinado objetivo.

(iii) Critérios de padronização dos medicamentos - RENAME e REME do DF (6).

Como apontado na exploração do caso 01 e do caso 02 existem uma lista de medicamentos padronizados nacionalmente (Relação Nacional de Medicamentos Essenciais RENAME) e, derivadas desta, as listas regionais (Relação de Medicamentos Essenciais do Distrito Federal - REME-DF). Para que o Estado cumpra com seu dever de fornecer atendimento em saúde à população, ele deve organizar o fornecimento de medicamentos, que é parte importante da assistência à saúde.

Pela complexidade que cabe à esta atividade, a seleção dos medicamentos é um dos instrumentos da gestão. Esta etapa irá garantir a oferta dos melhores tratamentos, segundo os critérios já apresentados de eficácia, de efetividade e de eficiência, e possibilitar que sejam feitas a programação, a cotação dos preços, a aquisição, o armazenamento e as demais atividades de gestão. Isto porque é a padronização dos produtos e esta limitação no número de itens que possibilita uma boa gestão, do ponto de vista administrativo, e previsão dos melhores tratamentos, do ponto de vista da saúde.

Para o caso específico do CEAF há ainda de se considerar que o componente abrange os tratamentos para as doenças de baixa prevalência. Portanto, além do SUS fornecer medicamentos para as doenças mais comuns, também vem ampliando sua lista de medicamentos padronizados de forma significativa no últimos anos, conforme identificado no caso 01. Em contrapartida, a judicialização da saúde também vêm crescendo. Isto significa 
que apesar da ampliação do elenco, as ações por medicamentos de alto custo se mantiveram e até aumentaram em quantidade.

Neste cenário crescente da judicialização, considera-se que se há critérios clínicos importantes para a definição de quais medicamentos estarão disponíveis no SUS e se este processo é executado por grupos de profissionais qualificados na matéria, a aprovação de ações judiciais que vão de encontro às listas elaboradas estará potencialmente ferindo a racionalidade dos componentes da PNAF. É claro que cada caso individual deve ser analisado em suas peculiaridades. Porém deve-se ter atenção sobre a judicialização de medicamentos não padronizados.

A elaboração de listas de medicamentos padronizados faz parte então do planejamento de ações em saúde e sugere-se que a maneira de sua confecção seja levada ao conhecimento dos magistrados do sistema judiciário, que participarão da tomada de decisões nos litígios em saúde. Quanto às listas, não somente são conteúdos importantes o elenco final de medicamentos padronizados e disponíveis no SUS, o que pode contribuir a não determinar a entrega por via judicial do que já existe por via regular, mas também os critérios técnicos de padronização, que fornecem ao magistrado insumos para uma decisão balizada em aspectos clínicos.

(iv) Critérios de elaboração dos Protocolos Clínicos e Diretrizes Terapêuticas $\operatorname{PCDT}(7)$.

O CEAF/PNAF foi estruturado para que os medicamentos de alto custo fossem disponibilizados somente para os pacientes que cumprissem os requisitos clínicos dos PCDT (do Ministério da Saúde ou estaduais). Esta premissa foi instituída por tratarem de doenças complexas ou cujos tratamentos são complexos. Então, para que houvesse segurança para o paciente, os tratamentos mais adequados foram organizados de acordo com a clínica do paciente, em cada estágio das doenças. Logo, os protocolos existem por razões clínicas e para serem a melhor linha de tratamento disponível ao cidadão. Fugir aos protocolos, na ausência de razão plausível, é indicar um tratamento que não segue as evidências científicas disponíveis.

Mas, por outro lado, se houver um paciente que não se enquadra no protocolo por se tratar de uma exceção clínica, entende-se que será uma circunstância que admitiria a judicialização do tratamento. É claro que não é adequado para este estudo proferir uma espécie de "classificação" sobre quais casos seriam ou não adequados para a judicialização. $\mathrm{Na}$ verdade pretende-se exemplificar, de forma geral e passível de individualidades para cada caso real, o que viria a ser uma ação judicial de um caso não previsto de fato pela política 
vigente e que merece atenção judicial e o que viria a ser uma ação relacionada à política vigente e que não requer via judicial.

Como ponto importante para a manutenção da sustentabilidade do sistema de saúde, é necessário organizar este entendimento quanto à critérios mínimos que admitem a judicialização ou que geram um tratamento de risco ou um tratamento equivalente que poderia ter sido feito pela própria política. Para isto, propõe-se que a relação entre o Poder Executivo e o Poder Judiciário seja desenvolvida, a ponto de poderem trabalhar em conjunto e organizar o fluxo das demandas para que algumas situações possam ser resolvidas administrativamente, sem inibir a prerrogativa do cidadão de lutar por seus direitos.

Os critérios que fundamentam os PCDT também fazem parte do planejamento de ações em saúde e também poderiam ser reconhecidos pelo sistema judiciário (quanto ao protocolos existentes e seus conteúdos e quanto aos critérios técnicos que embasaram a elaboração).

(v) Processo de revisão da RENAME e dos PCDT pela CONITEC (8).

Para qualificar a AF, o Ministério da Saúde - MS, os estados e os munícipios revisam periodicamente as listas de medicamentos padronizados e os protocolos de tratamento dos medicamentos de alto custo. E esta operação é essencial para a qualidade do fornecimento de medicamentos, pois sem a atualização a PNAF não responderia às necessidades da população e, com isto, não estaria cumprindo seu papel em garantir o direito à saúde.

Entretanto, ao passo que o governo realiza esta revisão e adequa os tratamentos disponíveis da melhor forma compreendida pelos especialistas da área, de acordo com evidências científicas, a judicialização considera que as listas e protocolos não estão adequados ou atualizados com os medicamentos solicitados judicialmente. Ou seja, o judiciário infere que a padronização não está acompanhando às necessidades de tratamentos. Mas cabe ressaltar que cada caso será peculiar pois, muitas vezes, o tratamento não está disponível por não ser julgado o mais adequado para o caso em questão.

Sobre isto, pode-se sugerir um meio termo para a correção do problema. Pois, por um lado o processo de revisão das listas e protocolos pode e deve se preocupar em verificar os casos que estão sendo judicializados em grande volume e, diante disto, emitir um parecer de incorporação ou não da tecnologia. E, por outro lado, os magistrados devem se informar quanto às listas existentes e o porquê da não incorporação de algum medicamento, quando for o caso. Com esta base, teriam uma autonomia consciente para as decisões judiciais.

Estas atividades por parte de cada Poder poderiam fazer parte das estratégias de coordenação entre os dois sistemas. Mas, para dar certo, estas atividades precisam ser 
reconhecidos pelo judiciário e pelo executivo, respectivamente, como operações que colaboram com todo o processo de judicialização. O judiciário conheceria e reconheceria os procedimentos realizados pelo Poder Executivo e a partir deste conhecimento, proferiria as decisões. Quer dizer, a partir do momento que concordarem com os procedimentos a serem realizados, os dois sistemas podem cumprir com as partes que lhe cabem e respeitar o fluxo pré-determinado nesses procedimentos.

Ao realizar esta revisão dos casos 01 e 02, foi identificado um outro elemento importante de discussão. É citado por Barros (2016), no relato da jurisprudência sobre o papel do judiciário que (9) o controle jurisdicional ocorrerá em “situações excepcionais”. Quanto à isto, considerando que a NP do caso 02 já identificou o crescente número de demandas judiciais, supõe-se em função da falha ou omissão da política de assistência farmacêutica, nos dias atuais, questiona-se até quando existirá o perfil de excepcionalidade para estas situações. $\mathrm{Ou}$, ainda, atualmente a quantidade de demandas ainda remete à situações extraordinárias ou o impacto sobre o sistema de saúde já aponta que as ações deixaram de ser excepcionais?

Os dados levantados neste trabalho sugerem que a intervenção jurídica está caminhando a passos rápidos para um cenário em que deixe de ser extraordinária e tenha uma posição de extremo impacto sobre o funcionamento regular do sistema de saúde. Ressalta-se que atualmente o contexto já é preocupante, conforme descrito nas demais categorias dos capítulos anteriores do estudo.

Uma última questão relevante a considerar sobre a judicialização é que a área do direito expõe a percepção de que (10) o controle das políticas públicas pode, ao final, proporcionar um avanço e um aparelhamento das ações e serviços prestados (BARROS, 2016). Sobre isto, apesar de ser compreensível que o objetivo maior do controle judiciário é corrigir um problema da gestão pública e forçar o executivo a melhorar as suas ações e garantir a efetivação do direito, para que isto não se traduzir somente em ações isoladas mas contribuir à melhora permanente dos serviços, é necessário pensar e estabelecer meios para coordenar os fluxos de informação entre os dois poderes, visando, entre outros, diminuir a carga de trabalho e retrabalho dos dois ao redor do acesso de medicamentos e, consequentemente, os custos relacionados a isso. 
Ventura et al (2010, p. 77) também afirmam que a judicialização da saúde pode ser um instrumento de melhoria da AF:

\begin{abstract}
As demandas judiciais não podem ser consideradas como principal instrumento deliberativo na gestão da assistência farmacêutica no SUS, mas admitidas como um elemento importante na tomada de decisão dos gestores e, muitas vezes, na melhoria do acesso aos medicamentos no âmbito do SUS.
\end{abstract}

A partir destes dois últimos pontos (9 e 10) percebe-se a importância para a administração pública de repensar a judicialização da saúde dos pontos de vista teórico, conceitual e prático. Com o crescimento da judicialização da saúde e o aumento da intervenção do Poder Judiciário à uma extensão não esperada, o impacto disto será cada vez maior sobre as políticas de saúde. Logo, se não houver ordenamento da relação executivojudiciário com um olhar para as consequências de sua interação para o alcance dos princípios e objetivos constitucionais, os impactos não serão previstos, controlados e/ou evitados.

Baseado neste entendimento, aliado às evidências de que o próprio judiciário concebe a cooperação técnica entre os dois poderes e que isto não fere a autonomia decisória do magistrado (BRASIL, 2010c; 2011f), este trabalho propõe que deva haver coordenação entre as atividades do Executivo e do Judiciário ao redor da questão de direito à saúde e acesso a medicamentos. E considerando que os dois poderes possuem competências acerca desta questão, sugere-se que as atividades devam ser planejadas e executadas considerando a atuação dos dois Poderes.

Os dados demonstram que a complexidade inerente à saúde demanda cuidado com as ações desta área e que, até o momento, não tem sido dado o olhar administrativo para a gestão do sistema inter-organizacional inter-poderes como um todo.

A implementação da política já demanda a coordenação de ações (GOMES, 2010), pois o fornecimento de medicamentos é executado pelos três entes federativos e pela interação de instituições em cada nível federativo, como demonstrado no caso 01. E, além disso, ainda existe a atuação de um segundo sistema que impacta sobre o funcionamento do primeiro, como revelado no caso 02 . Por estes motivos é necessário pensar em novas formas de realizar estas ações do ponto de vista da gestão pública, o que requer dar atenção às funções administrativas representadas pelo POSDCORB de Gulick e Urwick (2005). Pois, apesar de não ser papel do Sistema Judiciário a implementação das políticas, sua atividade tem influência sobre este processo. Então ainda que a relação executivo-judiciário não caracterize um caso clássico de coordenação executiva, se torna relevante repensar os 
conceitos e propor novas perspectivas que garantam diálogo entre os poderes visando o melhor atendimento das demandas dos cidadãos.

A literatura corrobora este posicionamento ao explicar que a prática da judicialização garante o direito constitucional e é um avanço para a cidadania, porém gera problemas de gestão, pois influencia na forma de implementação das políticas de saúde e acarreta gastos não previstos (MEDRADO, 2016).

Magalhães (2012, p. 2878) também confirma os dados deste estudo dizendo que as ações em saúde possuem características particulares e, por isso, deve haver tratamento cuidadoso e que requer (11) diálogo entre os diferentes Poderes:

\footnotetext{
Admite-se, sem dúvidas, que se realize um verdadeiro diálogo institucional entre os três poderes. Ademais, o caráter aberto e fluído das normas consagradoras dos direitos sociais exige a sua concretização a partir das peculiaridades das situações particulares, o que pode ser levado a efeito pelo órgão jurisdicional.
}

A natureza do problema exposta nos dois casos deixa patente, então, a relevância à sociedade brasileira compreender como a relação executivo-judiciário se operacionaliza atualmente e quais poderiam ser as estratégias factíveis a serem implementadas neste contexto para melhorar o sistema de saúde judicializada que, de fato, existe no país.

Para a sistematização das informações importantes para a proposição de um modelo final prático para a judicialização, elaborou-se os Quadros 6.1 e 6.2 O primeiro (Quadro 6.1) reúne os pontos levantados na análise que sustentam a necessidade de criação deste modelo de organização da relação executivo-judiciário e o segundo (Quadro 6.2) sistematiza os pontos fortes e fracos do modelo atual de operacionalização da judicialização.

Apresentados inicialmente aqui com os resultados da análise da categoria Natureza do Problema (NP), estes dois Quadros serão revisados e reapresentados ao final da discussão de cada categoria deste capítulo, acrescentando os outros pontos identificados como relevantes. Assim, os Quadros que sucedem conterão os aspectos já identificados na(s) categoria(s) anterior(es), com destaque para diferenciação do que estiver sendo incorporado. A partir deste conjunto de informações derivadas primeiramente da exploração, descrição e interpretação dos dois casos (capítulos 4 e 5) e depois da revisitação destes dados (neste capítulo 6), será elborado e proposto o modelo final. 
Quadro 6.1: Aspectos que justificam a organização da relação executivo-legislativo nas demandas de saúde $-1^{\mathrm{a}}$ versão parcial

\begin{tabular}{|c|l|}
\hline $\mathbf{N}$ & Aspectos que justificam a organização da relação executivo-judiciário nas demandas de saúde \\
\hline $\mathbf{1}$ & $\begin{array}{l}\text { (1)* Necessidade de maior objetividade para as decisões judiciais, pautada pelo consenso de que o } \\
\text { direito à vida deve ser operacionalizado sob critérios técnicos e racionais. }\end{array}$ \\
\hline $\mathbf{2}$ & $\begin{array}{l}\text { (2) Atuação legítima do Poder Judiciário e que se constitui uma relação perene entre este Poder e o } \\
\text { Executivo. }\end{array}$ \\
\hline $\mathbf{3}$ & (3) Deferimento judicial majoritário de ações em saúde sem critério técnico norteador. \\
\hline $\mathbf{4}$ & (9) Aumento do número de ações de controle jurisdicional e do consequente impacto sobre a PNAF \\
\hline $\mathbf{5}$ & (10) Potencial de avanço e aparelhamento das ações e serviços de saúde a partir da ação do judiciário \\
\hline
\end{tabular}

*Os números no início de cada sentença se referem à numeração apresentada no texto, para organização dos elementos em meio ao texto descritivo.

Fonte: Da autora.

Quadro 6.2: Aspectos do planejamento do CEAF/PNAF e da judicialização importantes para o processo de judicialização de medicamentos $-1^{\mathrm{a}}$ versão parcial (continua)

\begin{tabular}{|c|c|c|c|c|}
\hline $\mathbf{N}$ & $\begin{array}{l}\text { Aspectos do } \\
\text { planejamento do } \\
\text { CEAF/PNAF e do } \\
\text { controle jurisdicional } \\
\text { importantes para o } \\
\text { processo de } \\
\text { judicialização de } \\
\text { medicamentos }\end{array}$ & Situação atual & Situação sugerida & $\begin{array}{l}\text { Funções da } \\
\text { administração }\end{array}$ \\
\hline 1 & $\begin{array}{l}\text { (4) Princípios e } \\
\text { diretrizes estruturantes } \\
\text { do SUS: } \\
\text { descentralização; } \\
\text { universalidade; } \\
\text { integralidade e } \\
\text { equidade }\end{array}$ & $\begin{array}{l}\text { Não cumprimento das } \\
\text { diretrizes e } \\
\text { princípios. }\end{array}$ & $\begin{array}{l}\text { Resolução extrajudicial } \\
\text { quando adequado e judicial } \\
\text { somente para casos não } \\
\text { cobertos e que admitam o } \\
\text { fornecimento de } \\
\text { medicamentos pelo } \\
\text { governo. }\end{array}$ & $\begin{array}{l}\text { Organização - } \\
\text { sistema } \\
\text { executivo } \\
\text { Coordenação - } \\
\text { executivo- } \\
\text { judiciário }\end{array}$ \\
\hline 2 & $\begin{array}{l}\text { (5) Objetivo da } \\
\text { Assistência } \\
\text { Farmacêutica - AF - } \\
\text { de garantir o uso } \\
\text { racional de } \\
\text { medicamentos - } \\
\text { PNAF. }\end{array}$ & $\begin{array}{l}\text { Não cumprimento das } \\
\text { diretrizes e } \\
\text { princípios. }\end{array}$ & $\begin{array}{l}\text { Conhecimento por parte } \\
\text { dos magistrados sobre os } \\
\text { preceitos da AF e } \\
\text { assimilação deste para as } \\
\text { decisões judiciais, por } \\
\text { meio da atuação do } \\
\text { farmacêutico como } \\
\text { prestador de informações. } \\
\text { E participação do } \\
\text { farmacêutico nos cuidados } \\
\text { com os medicamentos } \\
\text { judicializados. }\end{array}$ & $\begin{array}{l}\text { Planejamento - } \\
\text { sistema } \\
\text { executivo } \\
\text { Informação - } \\
\text { executivo- } \\
\text { judiciário } \\
\text { Coordenação - } \\
\text { executivo- } \\
\text { judiciário }\end{array}$ \\
\hline 3 & $\begin{array}{l}\text { (6) Critérios de } \\
\text { padronização dos } \\
\text { medicamentos - } \\
\text { RENAME e REME do } \\
\text { DF }\end{array}$ & $\begin{array}{l}\text { Não conhecimento e } \\
\text { reconhecimento dos } \\
\text { critérios para a } \\
\text { escolha de } \\
\text { medicamentos para } \\
\text { uma política coletiva. }\end{array}$ & $\begin{array}{l}\text { Conhecimento por parte } \\
\text { dos magistrados sobre os } \\
\text { critérios de padronização e } \\
\text { assimilação destes para as } \\
\text { decisões judiciais. }\end{array}$ & $\begin{array}{l}\text { Planejamento - } \\
\text { sistema } \\
\text { executivo } \\
\text { Coordenação - } \\
\text { executivo- } \\
\text { judiciário }\end{array}$ \\
\hline
\end{tabular}


Quadro 6.2: Aspectos do planejamento do CEAF/PNAF e da judicialização importantes para o processo de judicialização de medicamentos $-1^{\mathrm{a}}$ versão parcial (conclusão)

\begin{tabular}{|c|c|c|c|}
\hline $\begin{array}{l}\text { Aspectos do } \\
\text { planejamento do } \\
\text { CEAF/PNAF e do } \\
\text { controle jurisdicional } \\
\text { importantes para o } \\
\text { processo de } \\
\text { judicialização de } \\
\text { medicamentos }\end{array}$ & Situação atual & Situação sugerida & $\begin{array}{l}\text { Funções da } \\
\text { administração }\end{array}$ \\
\hline $\begin{array}{l}\text { (7) Critérios de } \\
\text { elaboração dos } \\
\text { Protocolos Clínicos e } \\
\text { Diretrizes Terapêuticas } \\
\text { - PCDT }\end{array}$ & $\begin{array}{l}\text { Não conhecimento e } \\
\text { reconhecimento dos } \\
\text { critérios para a } \\
\text { organização dos } \\
\text { cuidados em saúde } \\
\text { para uma política } \\
\text { coletiva. }\end{array}$ & $\begin{array}{l}\text { Conhecimento por parte dos } \\
\text { magistrados sobre os critérios } \\
\text { de organização dos cuidados } \\
\text { em saúde e assimilação destes } \\
\text { para as decisões judiciais. }\end{array}$ & $\begin{array}{l}\text { Planejamento - } \\
\text { sistema } \\
\text { executivo } \\
\text { Coordenação - } \\
\text { executivo- } \\
\text { judiciário }\end{array}$ \\
\hline $\begin{array}{l}\text { (8) Processo de revisão } \\
\text { da RENAME e dos } \\
\text { PCDT pela CONITEC }\end{array}$ & $\begin{array}{l}\text { Não conhecimento } \\
\text { sobre o processo de } \\
\text { revisão das listas e } \\
\text { dos protocolos ou não } \\
\text { concordância com } \\
\text { estes processos. }\end{array}$ & $\begin{array}{l}\text { Adequação do processo de } \\
\text { revisão das listas e dos } \\
\text { protocolos, pactuado e } \\
\text { reconhecido pelos Poderes } \\
\text { Executivo e Judiciário (sistema } \\
\text { executivo verificando os casos } \\
\text { judicializados ao realizar a } \\
\text { revisão das listas e sistema } \\
\text { judiciário reconhecendo os } \\
\text { documentos como instrumentos } \\
\text { técnicos para as decisões). }\end{array}$ & $\begin{array}{l}\text { Coordenação - } \\
\text { executivo- } \\
\text { judiciário }\end{array}$ \\
\hline $\begin{array}{l}\text { (11) Diálogo aberto } \\
\text { entre as instituições } \\
\text { dos dois Poderes em } \\
\text { estudo. }\end{array}$ & $\begin{array}{l}\text { Pouco diálogo entre } \\
\text { os dois Poderes na } \\
\text { rotina das decisões } \\
\text { judiciais, porém com } \\
\text { previsão atual de } \\
\text { cooperação técnica. }\end{array}$ & $\begin{array}{l}\text { Efetivação da cooperação } \\
\text { técnica e de outros canais de } \\
\text { comunicação para que haja o } \\
\text { conhecimento por parte dos } \\
\text { magistrados sobre os preceitos } \\
\text { da AF. }\end{array}$ & $\begin{array}{l}\text { Coordenação - } \\
\text { executivo- } \\
\text { judiciário }\end{array}$ \\
\hline
\end{tabular}

Fonte: Da autora.

\subsection{Contexto social, econômico e político}

Para a melhor compreensão da judicialização de medicamentos, o entendimento dos contextos históricos do CEAF/PNAF e da judicialização da saúde foram essenciais para a adequada interpretação dos cenários atuais. $\mathrm{O}$ conhecimento sobre os fatos já ocorridos e a identificação das iniciativas que se consolidaram ou não, fortalece o entendimento do objeto em questão.

$\mathrm{Na}$ discussão desta categoria, assim como de todas as outras categorias a serem apresentadas mais adiante, os pontos principais identificados para a construção do modelo final a ser proposto são sinalizados, seguindo a sequência numérica e padrão de destaque em itálicoutilizados na discussão da primeira categoria. 
Para o caso da saúde, quanto ao CEAF/PNAF, é notável que houve uma evolução na saúde pública como um todo e que a AF tem acompanhado um movimento de organização e estruturação do SUS. Por exemplo, antes mesmo da legalização e da consolidação do SUS, já havia uma relação de medicamentos considerados essenciais para o país, criada em 1964. Porém não havia um sistema público com a organização de hoje em dia e que fornecesse cobertura total para todos os cidadãos. Logo, a AF também não era estruturada sobre a premissa da cobertura total pelo sistema.

Ainda antes da instituição do SUS é interessante observar que a prática da padronização de medicamentos já mostrava que a gestão é muito dinâmica e que muitas vezes somente os medicamentos da lista vigente não eram capazes de atender todas as demandas da saúde. Este fato é observado pela criação do termo "medicamentos excepcionais" de 1982. Ou seja, a administração pública já mostrava flexibilidade na gestão dos medicamentos e abertura para o fornecimento de medicamentos que por ventura fossem necessários, porém não estivessem selecionados na lista principal.

Cabe neste ponto refletir que o fornecimento de medicamentos, assim como de outros produtos, somente terá adequada gestão se houver previsão sobre os insumos a serem disponibilizados. Como para qualquer controle de estoque, é necessário o conhecimento dos medicamentos que deverão ser programados para compra, adquiridos, recebidos, armazenados e dispensados à população. Do ponto de vista administrativo, é de extrema importância a padronização dos itens, principalmente em função da quantidade expressiva de itens que um município, um estado ou mesmo o Ministério da Saúde deve gerir.

Ao encontro disto, os autores Mota e colaboradores (2003) e Simonetti e colaboradores (2007) explicam que a etapa de seleção de medicamentos é essencial para a boa manutenção do ciclo de assistência farmacêutica, que inclui a própria seleção e as demais etapas de programação, aquisição, armazenamento e distribuição/dispensação.

Mas não é somente o olhar administrativo que importa ao caso. As discussões e as análises para este objeto de estudo são muito delicadas por envolver a saúde humana. E, por este motivo, além da preocupação gerencial com a seleção prévia dos medicamentos, há um cuidado particular por se tratar da seleção de um dispositivo para a saúde. Então o processo de seleção também é mais complexo do que a seleção de qualquer outro produto de um estoque. Como foi apresentado nos casos 01 e 02, os requisitos básicos para a padronização de um fármaco são ter a eficácia e a segurança comprovadas. Deve-se, por isto, ter registros científicos disponíveis com esta comprovação. Então, além destes critérios, um deles será o custo-efetividade, como identificado também nos casos. 
A (12) análise econômica é realizada, até mesmo em função da limitação de recursos, porém é precedida pela comprovação das evidências clínicas para o uso. Assim, diante destas particularidades, a incorporação de um medicamento, como já abordada na categoria NP deste capítulo, deve ser realizada por profissionais competentes para reduzir os risco de um escolha inadequada para a população brasileira. E este raciocínio acompanha a literatura que explora as exigências para a etapa de seleção de medicamentos pelas comissões responsáveis (MOTA; FERNANDES; COELHO, 2003; SIMONETTI; NOVAES; GONÇALVES, 2007) e as diretrizes para a definição de elenco da própria RENAME (2012a), que devem ser seguidas não somente para a relação nacional, como para as relações regionais. E o MS ainda complementa inserindo a necessidade da avaliação econômica comparativa dos benefícios e dos custos de cada medicamento sugerido para a incorporação na lista (MINISTÉRIO DA SAÚDE, 2016c).

Após esta reflexão e o exame da história do CEAF/PNAF, observa-se que, historicamente, apesar da lista nacional padronizada, desde o início houve a sensibilidade de também garantir o acesso aos tratamentos não padronizados. E é importante reforçar que a ausência de padronização pode ocorrer em função de uma lentidão do processo de incorporação, que ainda poderia vir a acontecer se houvesse entendimento de que a padronização era necessária, ou da existência de casos para os quais a padronização não é de interesse e a aquisição deveria ser esporádica. Com base nisto, a etapa de seleção tem grande importância e deve ser considerada no cenário da judicialização da medicamentos.

Com a estruturação do SUS, a AF também seguiu seus princípios e diretrizes para sua organização e culminou na política atual de AF (PNAF). Junto à ela os medicamentos excepcionais passaram a ser um dos componentes de medicamentos previstos: o CEAF. E ao longo dos anos a comissão de padronização destes medicamentos foi sendo melhor estruturada, gerando a formação da CONITEC e de diretrizes para a composição da RENAME (BRASIL, 2011c; 2012a).

Ao longo desta evolução, os medicamentos de alto custo passaram de medicamentos de uso excepcional para medicamentos previstos na lista nacional, de aquisição regular e de cobertura de inúmeros casos de doenças de baixa prevalência. Conforme apresentado nos resultados do trabalho, esta lista recebe bastante atenção por parte do Ministério da Saúde, em função do perfil destes medicamentos quanto ao custo elevado, quanto às características tecnológicas destas terapias e quanto à complexidade dos tratamentos. Neste ponto cabe ressaltar que (13) este componente apresenta complexidade tamanha que somente para ele foram elaborados protocolos específicos de tratamento. E, conforme explicado pelo 
entrevistado 1EN no caso 01, estes protocolos não envolvem somente o tratamento medicamentoso, mas todo o cuidado em saúde que o paciente deva receber.

Ainda quanto ao CEAF/PNAF, um último dado importante são as evidências de ampliação desta lista no últimos anos. Esta informação qualifica mais uma vez o cuidado do MS para com estes medicamentos. Justamente por cobrirem doenças de baixa prevalência, apesar das constantes reclamações da população e do judiciário de demora no processo de atualização da lista de padronizados, ainda assim a revisão periódica destes produtos é uma atividade frequente e divulgada pelo órgão.

No tocante à judicialização da saúde, destaca-se o julgamento da Suspensão de Tutela Antecipada 91 - STA 91, de 2007. Dois anos antes da primeira portaria do CEAF/PNAF, este julgamento foi inovador por ter (14) incluído na análise do caso o aspecto financeiro das ações judiciais, aliado à outros critérios. A decisão foi a primeira de indeferimento pelo fornecimento do medicamento judicializado. É claro que deve-se considerar que neste ano o quantitativo de ações e o impacto orçamentário destes processos eram extremamente inferiores aos valores atuais, como os dados já apresentaram. Porém, é necessário que haja jurisprudências como esta, com bom embasamento, para que sirvam de modelo e garantam a abertura necessária para as mudanças que precisam começar a ocorrer.

Este aspecto financeiro da judicialização se refere à função orçamento, do POSDCORB que, por sua vez, pode ter aspectos do planejamento orçamentário, da contabilidade e do controle fiscal (GULICK; URWICK, 2005).

Sobre as jurisprudências, os autores Almeida Júnior (2005) e Magalhães (2012) explicam que estas têm papel na construção do direito e o pensar de cada juiz sobre os diferentes processos contribui para a construção da verdade jurídica.

Unindo este caso (STA 91) ao aumento das demandas judiciais entre 2007 e 2009, o Supremo Tribunal Federal - STF - teve a iniciativa de convocar a audiência pública de 2009. Esta audiência foi importante para estabelecer o diálogo entre o Poder Judiciário, o Poder Executivo e outros atores interessados nesta temática. Infere-se que esta iniciativa representa a preocupação do STF em ampliar a discussão para melhorar as decisões judiciais na área. Considerando que esta audiência ocorreu em 2009, não foi evidenciado nos dados da pesquisa avanço nas decisões se comparado ao aumento da judicialização que vem ocorrendo nos últimos anos. Ou seja, se houve avanço na área, não conseguiu conter o aumento da judicialização.

Mas é claro que as evidências mostram explicitamente que há a (15) preocupação e a movimentação do Poder Judiciário em prol de medidas concretas de melhoria. 
Principalmente porque a maior parte dos documentos identificados por esta pesquisa foram emitidos por este Poder e são de cunho técnico ou de divulgação.

O Conselho Nacional de Justiça - CNJ, o STF e o Tribunal de Justiça do Distrito Federal - TJDFT são exemplos de órgãos que mantém algum tipo de atividade de discussão na área, pois os dados mostraram o envolvimento destas organizações na organização de eventos interdisciplinares, a convocação de reuniões com representantes de diferentes áreas, a criação e a manutenção dos Comitês e do Fórum Nacional, o estabelecimento de termos de cooperação, entre outros. Estas atividades são exemplos de meios para a coordenação das atividades entre os sistemas executivo e judiciário e, com isto, são exemplos de mecanismos formais de coordenação. Como já citado, foi identificado para o fenômeno estudado a existência de algumas microestruturas formais e informais de coordenação de ação. Estes exemplos são de estruturas formais de interação.

Duas iniciativas de grande importância são as recomendações apresentadas pelo CNJ (2010) e pelo TJDFT (2011). Como já discutido no caso 02, estas recomendações trazem elementos essenciais para um trabalho conjunto com o Poder Executivo e explicitam pontos importantes que devem ser considerados no julgamento dos casos. Dentre as recomendações cabe destacar o incentivo da (16) cooperação entre o judiciário e os profissionais de saúde do executivo, médicos e farmacêuticos. Com base no entendimento de que os casos em saúde devem ser decididos judicialmente respeitando os critérios clínicos para garantir o sucesso do tratamento (eficácia) e a segurança aos pacientes, esta recomendação fomenta esta articulação de operadores do judiciário com os do executivo. Talvez esta atividade seja uma das mais importantes para a melhoria das decisões em saúde. Primeiramente porque tem o potencial de garantir a eficácia e segurança dos tratamentos conforme evidências científicas e em segundo lugar porque pode ajudar na identificação dos tipos de ações judiciais, conforme proposta de tipificação que este trabalho apresentou no caso 02, na subcategoria de atividades, fluxos e rotinas do AA. Ou seja, o apoio técnico da saúde presta informações sobre o funcionamento do SUS e pode identificar se o caso pode ser resolvido extrajudicialmente ou se requer ação judicial, do ponto de vista administrativo.

Ainda sobre as recomendações, este mesmo raciocínio anterior cabe para a proposta do CNJ de que (17) os magistrados contatem os gestores públicos antes de proferirem as decisões judiciais. E a razão para esta outra recomendação segue a da proposta de cima, pela qual o gestor poderá contribuir com informações sobre o funcionamento da política e se o pleito é justificado ou se pode ser resolvido encaminhando o paciente ao SUS. 
E uma terceira recomendação que merece destaque é a indicação de evitar o deferimento de ações cujos medicamentos não tenham registro na Agência Nacional de Vigilância Sanitária - ANVISA. E, sobre isto, a problemática envolve inicialmente o entendimento de que o registro na ANVISA pressupõe o cumprimento das exigências sanitárias e clínicas, comprovadas cientificamente. Porém, cabe considerar neste trabalho, que a falta de registro pode se referir tanto à casos de registros negados quanto a solicitações de registro não apreciadas, mas que não cumprem os requisitos sanitários necessários. E, por outro lado, pode haver situações nas quais o processo de registro ainda está em andamento e não foi aprovado ou não houve solicitação de registro, mas o medicamento cumpre os critérios sanitários. Então, para estes dois últimos casos ou outras (18) situações particulares cujos medicamentos têm o potencial de registro, a apreciação judicial poderá ser particularizada.

Neste ponto, a consideração sobre a individualidade de cada litígio também remete à aspectos de coordenação. Pois para cada caso serão necessárias a análise apropriada e a solicitação do apoio técnico, inclusive para os casos em que há ou não registro do medicamento na ANVISA.

A cooperação técnica, além de evidenciar um elemento de coordenação entre o Executivo e o Judiciário, também representa um elemento de direção do CNJ e do TJDFT. Pois, conforme Gulick e Urwick (2005), a função de direção envolve a tarefa de tomar decisões e empenhá-las em ordens ou instruções.

No âmbito do DF a cooperação técnica foi assinada por termo entre o TJDFT e a SESDF, em 2011. Porém, apesar da existência deste documento de apoio técnico, esta pesquisa identificou a atuação do Poder Executivo somente na etapa após a decisão judicial de deferimento. Ou seja, somente foram encontrados indícios da atuação da SES-DF em elaborar parecer em sua defesa, e não como colaboração para a análise do caso. No caso 02 foi identificado que o farmacêutico do Núcleo de Judicialização elaborava pareceres que contribuíam com a defesa da SES-DF por meio da Procuradoria, mas somente após a antecipação da tutela. Também foi identificada uma comissão de médicos especialistas que às vezes são chamados à dar um parecer sobre a adequação do tratamento indicado. Porém, novamente oscasos reportados se referem à ações após a chegada do litígio com decisão favorável, esperando cumprimento da ação.

A cooperação técnica é discutida na literatura como uma estratégia que pode ser utilizada pelo poder judiciário para solucionar as demandas judiciais da área da saúde de forma mais eficiente. O ponto de partida para este entendimento é de que a participação de 
especialistas em grupos de trabalho pode viabilizar estudos e sugestões de medidas de aperfeiçoamento do controle jurisdicional. E a primeira recomendação quanto à isto, expedida pelo CNJ, baseou-se nos resultados da já citada Audiência Pública no 4, de 2009 (FERREIRA; COSTA, 2013). E de fato é consenso na fala dos entrevistados da pesquisa que um dos pontos críticos do processo, atualmente, é a inexistência deste apoio técnico.

É importante relembrar, neste ponto do trabalho, que a análise da literatura realizada revela que este cenário da relação entre o Poder Executivo e o Poder Judiciário não está descrito para outros países e tampouco foi estudado do ponto de vista da gestão pública ou da operacionalização do controle do Poder Jurídico. Logo, além de não haver precedente de estudo do objeto em questão (operacionalização da judicialização da saúde), há também uma lacuna teórica. Ou seja, em função do Brasil ter um modelo de sistema de saúde particular e a relação entre o Executivo e o Judiciário ao redor de acesso à saúde também ser particular, a análise dos dados, além de seu aspecto descritivo, possui também um aspecto exploratório. E para entender os dados da pesquisa, a adaptação dos modelos de POSDCORB de Gulick e Urwick (2005) e de Coordenação Interorganizacional de Alexander (1998) se apresentou como a abordagem mais adequada para a análise deste tipo de interação.

A criação do Fórum Nacional do Judiciário para a Saúde e dos Comitês Executivos Estaduais é uma excelente estratégia para a discussão dos problemas da saúde pública entre representantes dos diferentes segmentos envolvidos com a área. A iniciativa do Fórum Nacional e dos Comitês envolve a discussão da situação da saúde em cada localidade e as propostas de melhorias práticas e rápidas para os problemas identificados. O (19) espaço do Fórum e dos Comitês se presta então à discutir os problemas do SUS e as possíveis medidas interventivas. Em contraste, mas sendo atuações complementares e igualmente importantes no cenário da judicialização, a cooperação entre os magistrados e os profissionais do sistema de saúde é estabelecida para a análise dos casos judiciais individuais. Ao invés de analisarem as condições coletivas da saúde, é uma segunda estratégia, mas para o estudo das características individuais de cada demanda.

Outras iniciativas importantes e que aproximam diferentes atores do processo foram a criação da CAMEDIS em 2013 e a determinação de criação dos Núcleos de Apoio Técnico NATs, em 2016.

Cabe mostrar que a CAMEDIS e os NATs, ao passo que são estratégias de coordenação dos sistemas, também compõe a organização do sistema interorganizacional (executivo-judiciário), pois são estruturas formais e com atividades próprias. 
A CAMEDIS, como já descrita no caso 02, aproxima a Defensoria Pública do Distrito Federal - DPDF à Secretaria de Estado de Saúde do Distrito Federal - SES-DF. E esta iniciativa é importante por estabelecer o (20) canal de mediação entre os usuários do SUS e o gestor local deste sistema, a SES-DF. Com o conhecimento do cenário da judicialização e dos casos mais comuns de solicitação de medicamentos por esta via, é possível notar que a prática da mediação tem potencial de reduzir de forma significativa o uso da via judicial. Pois pela tipificação dos casos judicializados proposta nesta tese é possível identificar que grande parte das ações se refere à medicamentos já padronizados ou que possuem alternativa terapêutica disponível no SUS. Diante disto, se a mediação for bem executada e, como proposta deste trabalho, também estiver estruturada para as contemplar as ações provenientes de advogados particulares, grande parte da judicialização poderá ser evitada e parte dos conflitos poderá ser resolvida administrativamente.

A proposta de uma outra (21) estrutura de mediação independente das defensorias é pertinente pois é necessário atingir também os cidadãos que não buscam a assessoria jurídica da Defensoria Pública. Sabe-se que a maioria da ações judiciais provém da defensoria pública (95\% para o caso do DF), de acordo como Paim, Marquetto e Lopes (2016). Porém, ainda assim, sugere-se a criação de espaços de mediação entre os usuários e o sistema de saúde, semelhante à proposta da CAMEDIS. Ou seja, recomenda-se a indicação de membros dos tribunais e da SES-DF (um titular e um suplente de cada órgão) e a atuação destes diante de casos sujeitos à mediação provenientes de outras fontes que não a defensoria pública. Com isto tem-se a cobertura das ações passíveis de mediação, antes de serem inicializadas.

A mediação judicial é bastante defendida pelos autores da área jurídica, que explicam que trata-se de um mecanismo de solução de conflitos eficiente, que resulta em redução considerável da ações judiciais. E acrescentam que além de evitar as ações judiciais, tentando resolver os problemas por meio de requerimentos administrativos, o grupo de mediação também pode trabalhar propondo soluções àquelas ações em trâmite (PAIM; MARQUETTO; LOPES, 2016).

Finaliza-se a discussão sobre os espaços de cooperação com uma das informações mais atuais da categoria CSEP. Foi identificado pela pesquisa o acordo de junho de 2016 entre o CNJ e o MS. Esta proposta relaciona-se ao tipo de cooperação técnica já descrita e incentivada pelas recomendações do próprio CNJ, em âmbito nacional, e do TJDFT, em âmbito distrital. Este acordo visa a (22) criação dos NATs. Estes núcleos objetivam formalizar as parcerias entre magistrados e profissionais do sistema de saúde (médicos e farmacêuticos) para a análise das ações judiciais individualizadas. 
Os NATs também partem de uma decisão do CNJ que reflete a função de direção deste órgão, dentro do sistema Judiciário.

Por fim, dois outros julgamentos se mostram importantes e merecem destaque nesta revisão histórica dos casos estudados. O primeiro deles foi a STA 175, de 2011. Este caso foi importante para estimular o debate sobre a responsabilidade solidária entre os entes no financiamento e na execução das ações em saúde. Neste julgamento, a União solicita a suspensão da participação na responsabilidade solidária. Ou, ainda, que não possa mais figurar como polo passivo em ações de saúde. Pois, apesar da impressão inicial do caso parecer se tratar somente da divisão da responsabilidade no custeio dos medicamentos judicializados, os dados da pesquisa revelam que se tornou necessário à União estabelecer uma estrutura não prevista no PNAF, específica para atender as decisões judiciais. Nesta estrutura paralela, também se desenvolve toda a logística de aquisição dos medicamentos judicializados, recebimento, entrega aos pacientes e demais atividades necessárias para a execução das ações. Observa-se, ainda, que parte dos medicamentos a serem compradas e distribuídas pela estrutura paralela não era de responsabilidade da União na via regular de oferta de medicamentos (implementação da PNAF). Então infere-se que há um (23) impacto orçamentário não somente pelos custos dos produtos judicializados, mas também pelos custos da gestão da estrutura paralela necessária a lidar com o crescente número de ações judiciais.

O segundo julgamento do STF, ao qual foi feita menção no parágrafo anterior, ainda estava em andamento no momento de finalização deste trabalho. Este se refere à definição de jurisprudência quanto às ações pelo fornecimento de medicamentos de alto custo. Como visto por este trabalho, o STF é o órgão do sistema judiciário responsável pela guarda da Constituição Federal - CF. Logo, sobre ele incidirão os casos que afligem a CF, como o acesso aos medicamentos, que remete à garantia do direito à saúde. Este julgamento irá definir orientações para as futuras decisões sobre o fornecimento de medicamentos de alto custo e/ou sem registro na ANVISA.

O STF, enquanto órgão decisor de jurisprudências sobre casos que envolvem a União, exerce a função de direção sobre os demais órgãos do judiciário.

Para o tema e objetivo deste trabalho, este julgamento é de extrema importância como possível medida de redução de grande parte dos casos judiciais. A depender do veredito final, parte do trabalho que os Tribunais precisariam realizar em parceria com o Poder Executivo, para filtrar as ações que poderiam ser evitadas, já o será feito a partir desta jurisprudência. 
Os dois Quadros (Quadros 6.1 e 6.2) previamente apresentados neste capítulo de análise foram atualizados para incluir os elementos relevantes apontados nesta discussão sobre a categoria CSEP dos casos 01 e 02, conforme apresentado, a seguir, nos Quadros 6.3 e 6.4 .

Quadro 6.3: Aspectos que justificam a organização da relação executivo-legislativo nas demandas de saúde $-2^{\text {a }}$ versão parcial

\begin{tabular}{|c|c|}
\hline $\mathbf{N}$ & $\begin{array}{l}\text { Aspectos que justificam a organização da relação executivo-judiciário nas demandas de } \\
\text { saúde }\end{array}$ \\
\hline 1 & $\begin{array}{l}\text { Necessidade de maior objetividade para as decisões judiciais, pautada pelo consenso de que o } \\
\text { direito à vida deve ser operacionalizado sob critérios técnicos e racionais. }\end{array}$ \\
\hline 2 & $\begin{array}{l}\text { Atuação legítima do Poder Judiciário e que se estabelece uma relação perene entre este Poder e o } \\
\text { Executivo. }\end{array}$ \\
\hline 3 & Deferimento majoritário de ações em saúde sem critério técnico norteador. \\
\hline 4 & Aumento do controle jurisdicional e do consequente impacto sobre a PNAF. \\
\hline 5 & Potencial avanço e aparelhamento das ações e serviços de saúde a partir da ação do judiciário. \\
\hline 6 & (13) Complexidade do CEAF/PNAF e necessidade de respeito à esta condição e aos PCDT. \\
\hline 7 & $\begin{array}{l}\text { (15) Preocupação e movimentação do Poder Judiciário em prol de medidas concretas de melhoria } \\
\text { da judicialização da saúde. }\end{array}$ \\
\hline 8 & $\begin{array}{l}\text { (23) Impacto orçamentário e de gestão sobre o MS a partir da grande quantidade de ações } \\
\text { judiciais que o acionam como réu. }\end{array}$ \\
\hline
\end{tabular}

Fonte: Da autora.

Diante da importância atual do controle jurisdicional para a saúde pública, pensa-se que o histórico dos dois casos investigados nesta tese pode contribuir para a compreensão inicial deste fenômeno. Por conseguinte, se mostra na Figura 6.3 uma linha histórica que reúne os principais fatos divulgados sobre o CEAF/PNAF e sobre a judicialização da saúde, nos âmbitos federal e distrital. 
Quadro 6.4: Aspectos do planejamento do CEAF/PNAF e da judicialização importantes para o processo de judicialização de medicamentos $-2^{\mathrm{a}}$ versão parcial (continua)

\begin{tabular}{|c|c|c|c|c|}
\hline $\mathbf{N}$ & $\begin{array}{l}\text { Aspectos do } \\
\text { planejamento do } \\
\text { CEAF/PNAF e do } \\
\text { controle jurisdicional } \\
\text { importantes para o } \\
\text { processo de } \\
\text { judicialização de } \\
\text { medicamentos } \\
\end{array}$ & Situação atual & Situação sugerida & $\begin{array}{l}\text { Funções da } \\
\text { administração }\end{array}$ \\
\hline 1 & $\begin{array}{l}\text { Princípios e diretrizes } \\
\text { estruturantes do SUS: } \\
\text { descentralização; } \\
\text { universalidade; } \\
\text { integralidade e } \\
\text { equidade }\end{array}$ & $\begin{array}{l}\text { Não } \\
\text { cumprimento } \\
\text { das diretrizes e } \\
\text { princípios. }\end{array}$ & $\begin{array}{l}\text { Resolução extrajudicial } \\
\text { quando adequado e judicial } \\
\text { somente para casos não } \\
\text { cobertos e que admitam o } \\
\text { fornecimento de } \\
\text { medicamentos pelo governo. }\end{array}$ & $\begin{array}{l}\text { Organização - sistema } \\
\text { executivo } \\
\text { Coordenação - } \\
\text { executivo-judiciário }\end{array}$ \\
\hline 2 & $\begin{array}{l}\text { Objetivo da } \\
\text { Assistência } \\
\text { Farmacêutica - AF - } \\
\text { de garantir o uso } \\
\text { racional de } \\
\text { medicamentos - } \\
\text { PNAF. }\end{array}$ & $\begin{array}{l}\text { Não } \\
\text { cumprimento } \\
\text { das diretrizes e } \\
\text { princípios. }\end{array}$ & $\begin{array}{l}\text { Conhecimento por parte dos } \\
\text { magistrados sobre os preceitos } \\
\text { da AF e assimilação deste } \\
\text { para as decisões judiciais, por } \\
\text { meio da atuação do } \\
\text { farmacêutico como prestador } \\
\text { de informações. E } \\
\text { participação do farmacêutico } \\
\text { nos cuidados com os } \\
\text { medicamentos judicializados. }\end{array}$ & $\begin{array}{l}\text { Planejamento - sistema } \\
\text { executivo } \\
\text { Informação - } \\
\text { executivo-judiciário } \\
\text { Coordenação - } \\
\text { executivo-judiciário }\end{array}$ \\
\hline \multirow[b]{2}{*}{3} & \multirow{2}{*}{$\begin{array}{l}\text { Critérios de } \\
\text { padronização dos } \\
\text { medicamentos - } \\
\text { RENAME e REME do } \\
\text { DF }\end{array}$} & \multirow{2}{*}{$\begin{array}{l}\text { Não } \\
\text { conhecimento e } \\
\text { reconhecimento } \\
\text { dos critérios } \\
\text { para a escolha } \\
\text { de } \\
\text { medicamentos } \\
\text { para uma } \\
\text { política coletiva. }\end{array}$} & $\begin{array}{l}\text { Conhecimento por parte dos } \\
\text { magistrados sobre os critérios } \\
\text { de padronização e assimilação } \\
\text { destes para as decisões } \\
\text { judiciais. }\end{array}$ & \multirow{2}{*}{$\begin{array}{l}\text { Planejamento - sistema } \\
\text { executivo } \\
\text { Coordenação - } \\
\text { executivo-judiciário }\end{array}$} \\
\hline & & & $\begin{array}{l}\text { (12) São critérios mínimos } \\
\text { para o fornecimento de um } \\
\text { med. a eficácia, a segurança e } \\
\text { o custo-efetividade; e o } \\
\text { processo deve ser } \\
\text { acompanhado por profissional } \\
\text { competente. }\end{array}$ & \\
\hline 4 & $\begin{array}{l}\text { Critérios de elaboração } \\
\text { dos Protocolos } \\
\text { Clínicos e Diretrizes } \\
\text { Terapêuticas - PCDT }\end{array}$ & $\begin{array}{l}\text { Não } \\
\text { conhecimento e } \\
\text { reconhecimento } \\
\text { dos critérios } \\
\text { para a } \\
\text { organização dos } \\
\text { cuidados em } \\
\text { saúde para uma } \\
\text { política coletiva. }\end{array}$ & $\begin{array}{l}\text { Conhecimento por parte dos } \\
\text { magistrados sobre os critérios } \\
\text { de organização dos cuidados } \\
\text { em saúde e assimilação destes } \\
\text { para as decisões judiciais. }\end{array}$ & $\begin{array}{l}\text { Planejamento - sistema } \\
\text { executivo } \\
\text { Coordenação - } \\
\text { executivo-judiciário }\end{array}$ \\
\hline 5 & $\begin{array}{l}\text { Processo de revisão da } \\
\text { RENAME e dos } \\
\text { PCDT pela CONITEC }\end{array}$ & $\begin{array}{l}\text { Não } \\
\text { conhecimento } \\
\text { sobre o processo } \\
\text { de revisão das } \\
\text { listas e dos } \\
\text { protocolos ou } \\
\text { não } \\
\text { concordância } \\
\text { com estes } \\
\text { processos. }\end{array}$ & $\begin{array}{l}\text { Adequação do processo de } \\
\text { revisão das listas e dos } \\
\text { protocolos, pactuado e } \\
\text { reconhecido pelos Poderes } \\
\text { Executivo e Judiciário } \\
\text { (sistema executivo verificando } \\
\text { os casos judicializados ao } \\
\text { realizar a revisão das listas e } \\
\text { sistema judiciário } \\
\text { reconhecendo os documentos } \\
\text { como instrumentos técnicos } \\
\text { para as decisões). }\end{array}$ & $\begin{array}{l}\text { Coordenação - } \\
\text { executivo-judiciário }\end{array}$ \\
\hline
\end{tabular}


Quadro 6.4: Aspectos do planejamento do CEAF/PNAF e da judicialização importantes para o processo de judicialização de medicamentos - $2^{\mathrm{a}}$ versão parcial (conclusão)

\begin{tabular}{|c|c|c|c|c|}
\hline $\mathbf{N}$ & $\begin{array}{l}\text { Aspectos do } \\
\text { planejamento do } \\
\text { CEAF/PNAF e do } \\
\text { controle jurisdicional } \\
\text { importantes para o } \\
\text { processo de } \\
\text { judicialização de } \\
\text { medicamentos }\end{array}$ & Situação atual & Situação sugerida & $\begin{array}{l}\text { Funções da } \\
\text { administração }\end{array}$ \\
\hline \multirow{4}{*}{6} & \multirow{4}{*}{$\begin{array}{l}\text { Diálogo aberto entre } \\
\text { as instituições dos dois } \\
\text { Poderes em estudo. }\end{array}$} & \multirow{4}{*}{$\begin{array}{l}\text { Pouco diálogo } \\
\text { entre os dois } \\
\text { Poderes na } \\
\text { rotina das } \\
\text { decisões } \\
\text { judiciais, porém } \\
\text { com previsão } \\
\text { atual de } \\
\text { cooperação } \\
\text { técnica (por } \\
\text { meio dos NATs) } \\
\text { e com existência } \\
\text { atual do Fórum } \\
\text { Nacional e os } \\
\text { Comitês } \\
\text { Estaduais em } \\
\text { Saúde, do } \\
\text { Judiciário. }\end{array}$} & $\begin{array}{l}\text { - Conhecimento por parte dos } \\
\text { magistrados dos preceitos da } \\
\text { AF por meio de canais de } \\
\text { comunicação entre os dois } \\
\text { Poderes: }\end{array}$ & \multirow{4}{*}{$\begin{array}{l}\text { Organização - } \\
\text { executivo-judiciário } \\
\text { (NATs) } \\
\text { Coordenação - } \\
\text { executivo-judiciário } \\
\text { Direção - sistema } \\
\text { judiciário }\end{array}$} \\
\hline & & & $\begin{array}{l}\text { - (16) e (22) Efetivação da } \\
\text { cooperação técnica entre } \\
\text { magistrados e médicos e } \\
\text { farmacêuticos, por meio dos } \\
\text { NATs, para análise das } \\
\text { demandas judiciais } \\
\text { individuais. }\end{array}$ & \\
\hline & & & $\begin{array}{l}\text { - (17) Efetivação da } \\
\text { cooperação entre magistrados } \\
\text { e gestores públicos, para } \\
\text { análise das demandas judiciais } \\
\text { individuais. }\end{array}$ & \\
\hline & & & $\begin{array}{l}\text { - (19) Efetivação da } \\
\text { cooperação entre interessados } \\
\text { no SUS, por meio de reuniões } \\
\text { (comitês e fóruns), para } \\
\text { problemas de gestão. }\end{array}$ & \\
\hline 7 & $\begin{array}{l}\text { (14) Manutenção da } \\
\text { sustentabilidade } \\
\text { financeira das políticas } \\
\text { de saúde (SUS). }\end{array}$ & $\begin{array}{l}\text { O discurso } \\
\text { reconhece o } \\
\text { problema } \\
\text { financeiro, } \\
\text { porém aceito-o } \\
\text { como motivo } \\
\text { para impedir a } \\
\text { judicialização. }\end{array}$ & $\begin{array}{l}\text { Execução das demais medidas } \\
\text { propostas e consequente } \\
\text { redução da judicialização e de } \\
\text { seu impacto orçamentário. }\end{array}$ & $\begin{array}{l}\text { Orçamento - sistema } \\
\text { executivo (política e } \\
\text { judicialização) }\end{array}$ \\
\hline 8 & $\begin{array}{l}\text { (18) Critérios para o } \\
\text { registro dos } \\
\text { medicamentos na } \\
\text { ANVISA e } \\
\text { características deste } \\
\text { processo. }\end{array}$ & $\begin{array}{l}\text { Há ações } \\
\text { deferidas e } \\
\text { indeferidas de } \\
\text { medicamentos } \\
\text { sem registro e } \\
\text { baixo índice de } \\
\text { avaliação } \\
\text { adequada. }\end{array}$ & $\begin{array}{l}\text { Avaliação individual dos } \\
\text { casos de medicamentos sem } \\
\text { registro na ANVISA. }\end{array}$ & $\begin{array}{l}\text { Coordenação - } \\
\text { executivo-judiciário }\end{array}$ \\
\hline 9 & $\begin{array}{l}(20) \text { e }(21) \\
\text { Estabelecimento de } \\
\text { processo de mediação } \\
\text { efetiva, com cobertura } \\
\text { integral dos casos. }\end{array}$ & $\begin{array}{l}\text { Há a mediação } \\
\text { somente para os } \\
\text { casos entre } \\
\text { DPDF e SES- } \\
\text { DF como réu } \\
\text { (CAMEDIS). }\end{array}$ & $\begin{array}{l}\text { Manter a estrutura de } \\
\text { mediação na SES-DF/DPDF } \\
\text { e estabelecer estrutura na } \\
\text { DPU, para as defensorias } \\
\text { públicas (20). Estabelecer uma } \\
\text { estrutura no TJDFT e no STF } \\
\text { para ações iniciadas por } \\
\text { advogados particulares (21). }\end{array}$ & $\begin{array}{l}\text { Organização - } \\
\text { executivo-judiciário } \\
\text { (CAMEDIS) } \\
\text { Coordenação - } \\
\text { executivo-judiciário } \\
\text { Direção - sistema } \\
\text { judiciário }\end{array}$ \\
\hline
\end{tabular}



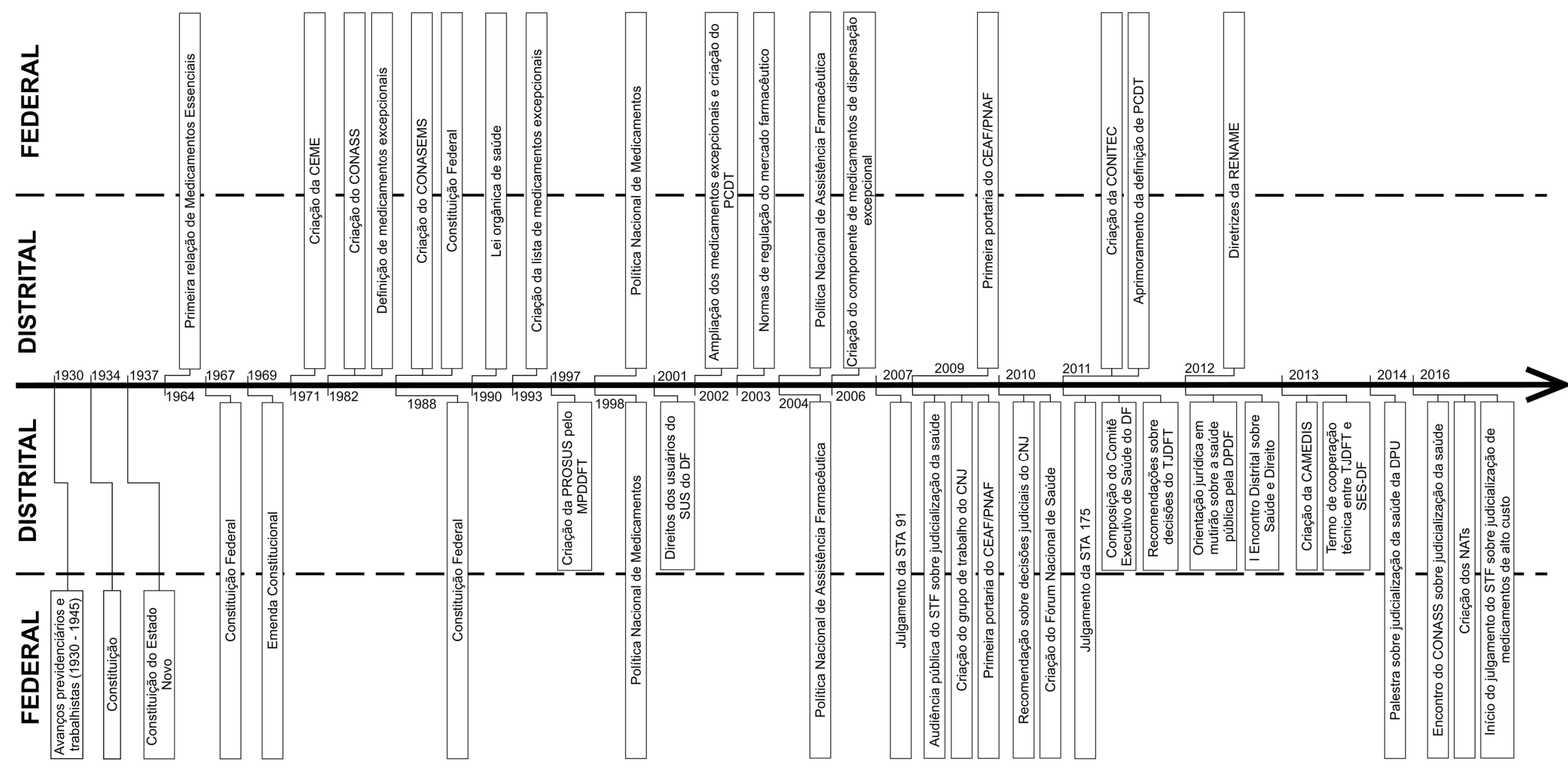

Figura 6.3: Linha histórica sobre o CEAF/PNAF e a judicialização da saúde no Brasil, nos níveis Federal e Distrital Fonte: Da autora. 


\subsection{Aparato normativo}

Dando seguimento à análise integrativa dos casos estudados, apresenta-se a categoria AN com suas duas subcategorias: as normas embasadoras e a discricionariedade 'normativa'. Seguindo a mesma proposta de análise, os pontos identificados como importantes sobre o modelo operacional atual da judicialização e os pontos frágeis que merecem ser revistos serão numerados, conforme sequência iniciada na primeira categoria, e serão destacados em itálico.

\subsubsection{Normas embasadoras}

Foram muitas as normas evidenciadas tanto para a área da saúde quanto para a judicialização da saúde. Uma primeira observação é a de que, pelo sistema único de saúde ser bastante normatizado, é de se esperar que as políticas de medicamentos sejam bem estruturadas a partir da organização do SUS. E, de fato, a descrição do caso 01 mostra o atendimento desta expectativa, já que o componente especializado da assistência farmacêutica não só é dotada de um sólido arcabouço de normas, como também é executado em concordância à estas normas. Avalia-se este fato como sendo um ponto positivo, pois a tarefa de fornecer medicamentos seguros e eficazes para uma população grande e com tantas variações regionais epidemiológicas, como é a brasileira, é muito complexa.

Observa-se, no caso 01, um arcabouço normativo extenso e detalhista, conforme apresentado no capítulo 03, pois atende às especificidades do SUS e garante um maior controle das ações e dos riscos envolvidos no fornecimento de medicamentos. São estas normas que definem a microestrutura formal de coordenação das atividades do sistema interorganizacional do Poder Executivo na área de saúde.

A partir deste entendimento de que (24) a área da saúde é complexa e sua operacionalização não é feita de forma arbitrária, retomam-se alguns questionamentos: sendo necessárias tantas diretrizes para o bom funcionamento da saúde pública, em que base estas normas poderiam ser ignoradas ou superadas nos casos em que o fornecimento de medicamentos ocorrerá pela via judicial? Em quais circumstâncias se justificaria a efetivação do direito à saúde, por meio da via judicial, sem seguir o planejamento das ações em saúde? A partir da observação de que o acesso pela via judicial muitas vezes não segue o planejamento já existente na saúde, em quais circunstâncias as evidências e garantias de eficácia e segurança dos tratamentos podem não ser levadas em consideração nas decisões via judicialização? 
É claro que as respostas não são simples e únicas, pois os casos são variados e individuais. Mas, a considerar a utilidade que há no planejamento governamental, incluindo o controle dos riscos para os pacientes e a garantia da sustentabilidade do sistema de saúde, sugere-se um equilíbrio entre (25) o reconhecimento destas normas e a apropriação de seus conteúdos para a prática da judicialização. Isto inclusive remete à discussão sobre a discricionariedade.

Com respeito às normas e seus conteúdos, é possível notar que algumas delas se fazem presentes nos dois casos analisados, fornecendo uma boa base para a coordenação interpoderes ao redor das matérias da saúde. Um Quadro que relaciona estas normas se encontra no Apêndice AH.

Basicamente as normas relacionadas se referem à $\mathrm{CF}$ e sua previsão dos direitos fundamentais, à Lei Orgânica da Saúde e sua normatização sobre o funcionamento do SUS, à Lei Orgânica do Distrito Federal e às normas inferiores de organização da AF e do CEAF/PNAF. Entende-se que o conhecimento destas normas é importante para uma boa avaliação das ações judiciais e emissão de decisões mais embasadas pelos juízes.

Nas demais categorias da pesquisa e mesmo na categoria AN, na subcategoria discricionariedade normativa, ficam evidentes diversos aspectos do sistema de saúde que não são considerados em algumas decisões judiciais. Novamente lembrando, não é o intuito deste trabalho propor um fluxo para a decisão judicial em si, no sentido de pré-determinar as situações que devam ser deferidas ou indeferidas, mas sim propor que estas decisões sejam tomadas na base de informação adequada com respeito a aspectos importantes para a segurança do usuário do sistema. A apropriação de normas da área da saúde, pela atuação do judiciário, parece ser uma medida válida para qualificar as decisões judiciais em questão.

Os dados do estudo mostram que não há padronização na forma de trabalho do judiciário, podendo existir casos nos quais os aspectos técnicos, os aspectos econômicos, entre outros aspectos, são mais ou menos considerados pelo magistrado em sua análise. Ressalta-se a menção do termo "forma de trabalho do judiciário" e não "decisões judiciais". Pois, essas decisões não podem são suscetíveis a padronização justamente pela existência da discricionariedade jurídica.

A partir desta constatação, foi criado o Quadro que apresentado na Apêndice AI com a reunião de normas cujo reconhecimento pelo judiciário é considerado importante.

Com um maior enfoque para os medicamentos de alto custo, foi interpretado que as normas versam sobre: 
(i) o controle sanitário de medicamentos e a necessidade de registro pela agência reguladora, a ANVISA, como já abordado em categoria anterior deste capítulo de análise;

(ii) as regras para o acesso aos medicamentos do CEAF/PNAF, quanto aos formulários, laudos, autorizações e aos critérios exigidos por estes documentos (pois estes critérios são, na verdade, os critérios da padronização dos medicamentos e dos PCDT);

(iii) a importância da incorporação de novos fármacos nas listas e do seguimento dos PCDT, como já abordado em categoria anterior deste capítulo de análise;

(iv) a pactuação das ações pelos três entes federativos, caracterizando um planejamento bem estruturado e articulado entre os níveis. Logo, a tendência é de que não haja discordância entre as regiões ou mesmo sobreposição desnecessária de ações. E isto não deixa de ser um respeito aos princípios e diretrizes do próprio sistema de saúde; e

(v) algumas regras de financiamento do CEAF/PNAF, que mostram uma organização em prol da eficiência da política, em prol da melhor organização para a operacionalização e em prol da sustentabilidade do sistema.

Então, por não haver uma prerrogativa teórica de estudo da relação entre os Poderes Executivo-Judiciário, como já explicado anteriormente, uma das sugestões deste estudo é de que as normas que embasam a área judicializada (no caso, saúde) sejam consideradas no processo de tomada de decisão judicial. Isto porque, a considerar que o magistrado não possui expertise em aspectos da área da saúde, que é a matéria central deste estudo, as normas que sustentam o objeto da ação judicial serão importantes guias para o entendimento de como as políticas estão organizadas e o porquê desta organização para a garantia do direito à saúde, que é o objetivo maior das ações. Com esta conduta de reconhecer as normas, os magistrados passariam a ter maior embasamento para os julgamentos. Para o caso específico objeto desta pesquisa, sugere-se que as normas embasadoras do CEAF/PNAF sejam reconhecidas pelo judiciário para a análise dos medicamentos judicializados (coordenação executivo-judiciário).

Fundamentados nos pontos apresentados nesta subcategoria, os Quadros 6.5 e 6.6 refletirão a atualização dos pontos a serem levados em consideração para a sugestão do novo modelo de judicialização. Esta atualização será apresentada ao final da categoria AN, após a subcategoria discricionariedade normativa. 


\subsubsection{Discricionariedade normativa}

A proposta de divisão da subcategoria discricionariedade em duas, a normativa e a prática, se mostrou adequada tanto para o estudo do caso do CEAF/PNAF, quanto para o estudo da judicialização. E, de forma interessante, a própria pesquisa desvelou diferentes entendimentos de discricionariedade para cada área, ainda que pautados na mesma base conceitual.

Apesar da conceituação de discricionariedade encontrada na literatura ser apresentada com uma dimensão de análise somente, após a análise inicial dos dados foi percebida a possibilidade e, possivelmente, a necessidade de focar a discussão do conceito em dois aspectos distintos. Inicialmente foi constatado que existe um conceituação de discricionariedade para a administração e outra afim para o direito. Mas além desta diferenciação entre a conceituação das áreas, os dados demandavam uma separação de cada um destes conceitos em duas dimensões: a 'normativa' e a 'prática' (ou 'operacional').

As duas dimensões do conceito e os termos escolhidos 'normativa' e 'prática' para diferenciá-las são propostas conceituais deste trabalho. Considera-se que esta distinção possa ser útil em outros estudos futuros, também. De toda maneira, neste estudo ,independente da aplicação ocorrer para a área de administração, para a área do direito ou qualquer outra área, a concepção das dimensões é a mesma.

A análise dos dados mostrou que para a administração pública a discricionariedade remete à atuação do administrador dentro dos limites pré-estabelecidos para a referida atividade. Ou seja, remete à liberdade limitada para a atuação do administrador, conforme Mello (2005).

Já para o direito, o entendimento de discricionariedade tem relação direta com a própria atividade de julgamento. Ou seja, a atuação inerente ao juiz é discricionária por sua natureza própria. Nos julgamentos dos litígios a decisão do juiz será discricionária, no sentido deste profissional ter liberdade de julgamento, conforme Almeida (2013).

Estes dois conceitos têm em comum dois elementos implícitos: os limites préestabelecidos para a atuação do profissional ou, de outro ponto de vista, a margem de liberdade para a atuação do profissional e as opções de ações realizadas de fato pelo profissional.

Cabe ressaltar que a proposta de uma dimensão prática ou operacional do conceito é importante do ponto de vista da análise do uso da discricionariedade. Logo, se o objetivo da pesquisa for outro, como a compreensão específica das normas que regem a atuação de um 
profissional, não é necessária a separação do conceito em diferentes dimensões. Porém, para este estudo e potencialmente para diversos outros que se interessam pela implementação de uma política, são duas informações diferentes o grau de liberdade que as normas permitem ao profissional e a escolha da atuação que ele faz.

Logo, a partir da importância da compreensão dos limites de atuação do gestor público e do magistrado na seara da judicialização da saúde, verificou-se que a liberdade do administrador é pautada por normas que versam sobre o produto final da ação do gestor. Ou seja, as normas que limitam a sua atividade na verdade limitam ou descrevem os resultados das ações. Por exemplo, a portaria define que o gestor local pode elaborar protocolos estaduais de cuidado à saúde, além de adotar os protocolos do Ministério da Saúde. Esta portaria descreve o resultado final da ação, que será a elaboração ou não de protocolos estaduais.

Já no caso dos magistrados, a adequação do conceito de discricionariedade para a área do direito fez com que a liberdade de atuação deste profissional fosse pautada por normas que regulam o objeto da ação do magistrado e não a ação dele. Ou seja, para este segundo caso, as normas que limitam a sua atividade na verdade limitam ou descrevem o direito à saúde (no caso do fenômeno em questão). Por exemplo, a CF determina que o direito à saúde deve ser cumprido por meio de ações da gestão pública que o efetivem. Então a discricionariedade do administrador se refere às normas para estas ações e a discricionariedade do magistrado se refere à determinação inicial de fazer cumprir o direito à saúde. Nesta perspectiva, nem a própria Constituição Federal limita a discricionariedade, porque a CF simplesmente normatiza que a saúde é direito de todos.

Então a discricionariedade no direito se refere à concepção do próprio direito, ou seja, a função do magistrado de julgar. E este ato é discricionário por si só, sem seguir normas.

Então, ao passo que para os administradores há normas previstas para serem seguidas (dentro da liberdade de execução de cada uma), para os magistrados não há normas a seguir. $\mathrm{Na}$ verdade, para estes últimos, eles é que farão o polo passivo seguir as normas (quando for este o veredito).

Porém, dito tudo isto, apesar de não haver previsão do seguimento de normas para a atuação jurídica e não contrapondo à esta essência da atuação judiciária, um dos elementos já evidenciados neste capítulo de análise é o reconhecimento das normas das políticas por parte dos magistrados. Mais do que isso, não somente há o reconhecimento, mas a incorporação das informações incorporadas nas normas em algumas análises e decisões. Dito de outra maneira, a atividade jurídica não terá limites estabelecidos pelas normas das políticas públicas, mas 
estas normas poderão embasar ou mesmo constituir o objeto de análise do processo para a tomada de decisão, que será a aplicação da discricionariedade inerente aos juízes.

Cappelletti (1993) e Almeida Júnior (2005) entendem que cada caso tem a sua decisão adequada e que os juízes irão decidir sempre pelo melhor veredito possível. Sendo assim, a (26) sugestão de incorporação dos elementos das normas da saúde para melhor elucidar os casos apresentados por via judicial tende à auxiliar no alcance da melhor decisão.

Quanto às normas identificadas no caso 01 e que delimitam as margens para a discricionariedade dos gestores em saúde, o conteúdo especificado já foi abordado nas categorias anteriores, que seriam: (i) descentralização administrativa e decisões de planejamento locais, como dos planos de saúde; (ii) confecção de listas de medicamentos regionais e protocolos estaduais; (iii) responsabilidades dos entes para com o financiamento dos componentes da AF.

A partir da análise desta subseção, os Quadros 6.5 e 6.6 foram atualizados com os elementos das duas subcategorias do AN.

Quadro 6.5: Aspectos que justificam a organização da relação executivo-legislativo nas demandas de saúde $-3^{\text {a }}$ versão parcial

\begin{tabular}{|c|c|}
\hline $\mathbf{N}$ & $\begin{array}{l}\text { Aspectos que justificam a organização da relação executivo-judiciário nas demandas de } \\
\text { saúde }\end{array}$ \\
\hline 1 & $\begin{array}{l}\text { Necessidade de maior objetividade para as decisões judiciais, pautada pelo consenso de que o } \\
\text { direito à vida deve ser operacionalizado sob critérios técnicos e racionais. }\end{array}$ \\
\hline 2 & $\begin{array}{l}\text { Atuação legítima do Poder Judiciário e que se estabelece uma relação perene entre este Poder e o } \\
\text { Executivo. }\end{array}$ \\
\hline 3 & Deferimento majoritário de ações em saúde sem critério técnico norteador. \\
\hline 4 & Aumento do controle jurisdicional e do consequente impacto sobre a PNAF. \\
\hline 5 & Potencial avanço e aparelhamento das ações e serviços de saúde a partir da ação do judiciário. \\
\hline 6 & Complexidade do CEAF/PNAF e necessidade de respeito à esta condição e aos PCDT. \\
\hline 7 & $\begin{array}{l}\text { Preocupação e movimentação do Poder Judiciário em prol de medidas concretas de melhoria da } \\
\text { judicialização da saúde. }\end{array}$ \\
\hline 8 & $\begin{array}{l}\text { Impacto orçamentário e de gestão sobre o MS a partir da grande quantidade de ações judiciais que } \\
\text { o acionam como réu. }\end{array}$ \\
\hline 9 & (24) Complexidade de organização da saúde pública e do CEAF/PNAF em seus vários aspectos. \\
\hline 10 & $\begin{array}{l}\text { (26) Necessidade de subsídios para a intervenção do Poder Judiciário nas demandas em saúde, em } \\
\text { função da complexidade dos casos. }\end{array}$ \\
\hline
\end{tabular}

Fonte: Da autora. 
Quadro 6.6: Aspectos do planejamento do CEAF/PNAF e da judicialização importantes para o processo de judicialização de medicamentos $-3^{\mathrm{a}}$ versão parcial (continua)

\begin{tabular}{|c|c|c|c|c|}
\hline $\mathbf{N}$ & $\begin{array}{l}\text { Aspectos do } \\
\text { planejamento do } \\
\text { CEAF/PNAF e do } \\
\text { controle } \\
\text { jurisdicional } \\
\text { importantes para o } \\
\text { processo de } \\
\text { judicialização de } \\
\text { medicamentos }\end{array}$ & Situação atual & Situação sugerida & $\begin{array}{l}\text { Funções da } \\
\text { administração }\end{array}$ \\
\hline 1 & $\begin{array}{l}\text { Princípios e diretrizes } \\
\text { estruturantes do SUS: } \\
\text { descentralização; } \\
\text { universalidade; } \\
\text { integralidade e } \\
\text { equidade }\end{array}$ & $\begin{array}{l}\text { Não cumprimento } \\
\text { das diretrizes e } \\
\text { princípios. }\end{array}$ & $\begin{array}{l}\text { Resolução extrajudicial } \\
\text { quando adequado e } \\
\text { judicial somente para } \\
\text { casos não cobertos e que } \\
\text { admitam o fornecimento } \\
\text { de medicamentos pelo } \\
\text { governo. }\end{array}$ & $\begin{array}{l}\text { Organização - sistema } \\
\text { executivo } \\
\text { Coordenação - } \\
\text { executivo-judiciário }\end{array}$ \\
\hline 2 & $\begin{array}{l}\text { Objetivo da } \\
\text { Assistência } \\
\text { Farmacêutica - AF - } \\
\text { de garantir o uso } \\
\text { racional de } \\
\text { medicamentos - } \\
\text { PNAF. }\end{array}$ & $\begin{array}{l}\text { Não cumprimento } \\
\text { das diretrizes e } \\
\text { princípios. }\end{array}$ & $\begin{array}{l}\text { Conhecimento por parte } \\
\text { dos magistrados sobre os } \\
\text { preceitos da AF e } \\
\text { assimilação deste para as } \\
\text { decisões judiciais, por } \\
\text { meio da atuação do } \\
\text { farmacêutico como } \\
\text { prestador de informações. } \\
\text { E participação do } \\
\text { farmacêutico nos cuidados } \\
\text { com os medicamentos } \\
\text { judicializados. }\end{array}$ & $\begin{array}{l}\text { Planejamento - sistema } \\
\text { executivo } \\
\text { Informação - executivo- } \\
\text { judiciário } \\
\text { Coordenação - } \\
\text { executivo-judiciário }\end{array}$ \\
\hline \multirow[b]{2}{*}{3} & \multirow{2}{*}{$\begin{array}{l}\text { Critérios de } \\
\text { padronização dos } \\
\text { medicamentos - } \\
\text { RENAME e REME } \\
\text { do DF }\end{array}$} & \multirow{2}{*}{$\begin{array}{l}\text { Não } \\
\text { conhecimento e } \\
\text { reconhecimento } \\
\text { dos critérios para } \\
\text { a escolha de } \\
\text { medicamentos } \\
\text { para uma política } \\
\text { coletiva. }\end{array}$} & $\begin{array}{l}\text { Conhecimento por parte } \\
\text { dos magistrados sobre os } \\
\text { critérios de padronização e } \\
\text { assimilação destes para as } \\
\text { decisões judiciais. }\end{array}$ & \multirow{2}{*}{$\begin{array}{l}\text { Planejamento - sistema } \\
\text { executivo } \\
\text { Coordenação - } \\
\text { executivo-judiciário }\end{array}$} \\
\hline & & & $\begin{array}{l}\text { São critérios mínimos para } \\
\text { o fornecimento de um } \\
\text { med. a eficácia, a } \\
\text { segurança e o custo- } \\
\text { efetividade; e o processo } \\
\text { deve ser acompanhado por } \\
\text { profissional competente. }\end{array}$ & \\
\hline 4 & $\begin{array}{l}\text { Critérios de } \\
\text { elaboração dos } \\
\text { Protocolos Clínicos e } \\
\text { Diretrizes } \\
\text { Terapêuticas - PCDT }\end{array}$ & $\begin{array}{l}\text { Não } \\
\text { conhecimento e } \\
\text { reconhecimento } \\
\text { dos critérios para } \\
\text { a organização dos } \\
\text { cuidados em } \\
\text { saúde para uma } \\
\text { política coletiva. }\end{array}$ & $\begin{array}{l}\text { Conhecimento por parte } \\
\text { dos magistrados sobre os } \\
\text { critérios de organização } \\
\text { dos cuidados em saúde e } \\
\text { assimilação destes para as } \\
\text { decisões judiciais. }\end{array}$ & $\begin{array}{l}\text { Planejamento - sistema } \\
\text { executivo } \\
\text { Coordenação - } \\
\text { executivo-judiciário }\end{array}$ \\
\hline
\end{tabular}


Quadro 6.6: Aspectos do planejamento do CEAF/PNAF e da judicialização importantes para o processo de judicialização de medicamentos $-3^{\mathrm{a}}$ versão parcial (continuação)

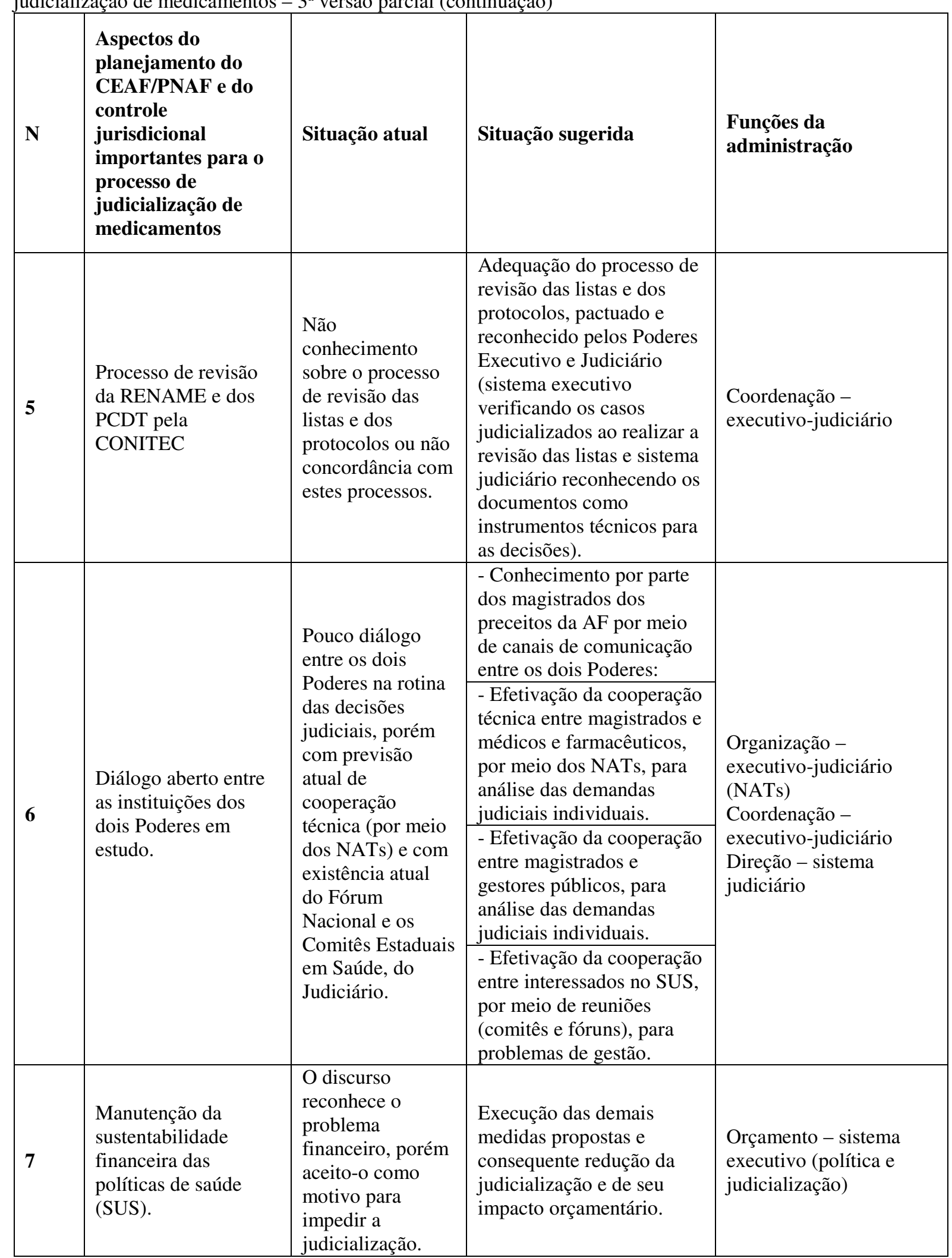


Quadro 6.6: Aspectos do planejamento do CEAF/PNAF e da judicialização importantes para o processo de judicialização de medicamentos $-3^{\mathrm{a}}$ versão parcial (conclusão).

\begin{tabular}{|c|c|c|c|c|}
\hline $\mathbf{N}$ & $\begin{array}{l}\text { Aspectos do } \\
\text { planejamento do } \\
\text { CEAF/PNAF e do } \\
\text { controle } \\
\text { jurisdicional } \\
\text { importantes para o } \\
\text { processo de } \\
\text { judicialização de } \\
\text { medicamentos }\end{array}$ & Situação atual & Situação sugerida & $\begin{array}{l}\text { Funções da } \\
\text { administração }\end{array}$ \\
\hline 8 & $\begin{array}{l}\text { Critérios para o } \\
\text { registro dos } \\
\text { medicamentos na } \\
\text { ANVISA e } \\
\text { características deste } \\
\text { processo. }\end{array}$ & $\begin{array}{l}\text { Há ações } \\
\text { deferidas e } \\
\text { indeferidas de } \\
\text { medicamentos } \\
\text { sem registro e } \\
\text { baixo índice de } \\
\text { avaliação } \\
\text { adequada. }\end{array}$ & $\begin{array}{l}\text { Avaliação individual dos } \\
\text { casos de medicamentos } \\
\text { sem registro na ANVISA. }\end{array}$ & $\begin{array}{l}\text { Coordenação - } \\
\text { executivo-judiciário }\end{array}$ \\
\hline 9 & $\begin{array}{l}\text { Estabelecimento de } \\
\text { processo de mediação } \\
\text { efetiva, com } \\
\text { cobertura integral dos } \\
\text { casos. }\end{array}$ & $\begin{array}{l}\text { Há a mediação } \\
\text { somente para os } \\
\text { casos entre DPDF } \\
\text { e SES-DF como } \\
\text { réu (CAMEDIS). }\end{array}$ & $\begin{array}{l}\text { Manter a estrutura de } \\
\text { mediação na SES- } \\
\text { DF/DPDF e estabelecer } \\
\text { estrutura na DPU, para as } \\
\text { defensorias públicas. } \\
\text { Estabelecer uma estrutura } \\
\text { no TJDFT e no STF para } \\
\text { ações iniciadas por } \\
\text { advogados particulares } \\
(21) \text {. }\end{array}$ & $\begin{array}{l}\text { Organização - } \\
\text { executivo-judiciário } \\
\text { (CAMEDIS) } \\
\text { Coordenação - } \\
\text { executivo-judiciário } \\
\text { Direção - sistema } \\
\text { judiciário }\end{array}$ \\
\hline 10 & $\begin{array}{l}\text { (25) Normatização do } \\
\text { CEAF/PNAF e da } \\
\text { judicialização da } \\
\text { saúde. }\end{array}$ & $\begin{array}{l}\text { Há seguimento da } \\
\text { CF e de } \\
\text { jurisprudências, } \\
\text { por parte do } \\
\text { judiciário, porém } \\
\text { falta } \\
\text { reconhecimento } \\
\text { das normas da } \\
\text { saúde. }\end{array}$ & $\begin{array}{l}\text { O reconhecimento das } \\
\text { normas da saúde e a } \\
\text { apropriação de seus } \\
\text { conteúdos para prática da } \\
\text { judicialização. }\end{array}$ & $\begin{array}{l}\text { Organização - sistema } \\
\text { executivo } \\
\text { Coordenação - } \\
\text { executivo-judiciário }\end{array}$ \\
\hline
\end{tabular}

Fonte: Da autora.

\subsection{Aparato administrativo}

Os resultados das subcategorias do aparato administrativo têm em sua essência um conteúdo bastante descritivo e extenso. Logo, a análise visa caracterizar os aspectos de destaque da judicialização de medicamentos e identificar os elementos importantes para a construção do modelo a ser proposto.

Em concordância à investigação feita nas categorias anteriores, objetiva-se identificar elementos que já estão implementados e são positivos para o andamento dos processos de judicialização e elementos não presentes ou frágeis ao processo. A partir desta identificação é possível propor os ajustes ao modelo atual da judicialização, haja visto como os processos de 
fato ocorrem. Pois o objetivo maior deste trabalho, frente à lacuna observada nos estudos da área, é desenvolver recomendações práticas ao cenário da judicialização, com orientações que facilitem os processos, de ponto de vista da administração.

Assim como para a categoria AN, na categoria AA os Quadros com os principais elementos desta análise serão apresentados ao final da discussão de todas as subcategorias. E, conforme padrão estabelecido, os elementos que comporão o Quadro serão destacados no texto com itálico e serão numerados de acordo com a mesma sequência já iniciada.

\subsubsection{Estrutura organizacional}

A observação dos resultados referentes à estrutura organizacional mostra que no caso 01 os órgãos e departamentos estão bem estruturados quanto à implementação do CEAF/PNAF. Em primeiro lugar, o SUS já possui uma estrutura de base, e a AF vem se desenvolvendo nos últimos anos e aprimorando sua organização. Então, como as atividades da política já estavam previstas e parte da estrutura já existia, a estrutura para o CEAF/PNAF está muito bem definida, tanto para o âmbito do Distrito Federal quanto para o Federal.

Para o caso 02, foi evidenciado que sua estrutura atual é complexa para todos os trâmites que envolvem as ações judiciais em saúde. Desde a reclamação inicial pelo direito de acesso ao medicamento até o recebimento deste produto, foi identificado o envolvimento de diversas organizações no nível federal e no nível distrital. Além da separação pelos entes federativos de origem das organizações, observado também no caso 01 , há no caso 02 a separação pelos Poderes públicos: Judiciário e Executivo. Tem, ainda, no caso 02, a participação de entidades não vinculadas à nenhum dos três Poderes do governo, mas igualmente previstos pela CF de 1988..São os chamados "órgãos essenciais à justiça", que não estão submetidos à outras estruturas do governo e são dotados de liberdade e autonomia de ação.

Em suma, para o caso 01, as estruturas envolvidas em disponibilizar os medicamentos do componente especializado são somente do sistema executivo (implementação do CEAF/PNAF). Já para o caso 02, as estruturas envolvidas são dos órgãos das funções essências à justiça (recebimento das ações, participação do processo enquanto fiscalizadores, requerentes ou defensores do cidadão), dos órgãos do sistema judiciário (recebimento das reclamações, decisão sobre as ações) e dos órgãos do sistema executivo, de saúde (execução das ações judiciais). Para todos estes três subsistemas, há os órgãos do nível Distrital e do nível Federal. 
Uma das contribuições relevantes desta pesquisa foi a identificação de estruturas criadas no sistema de saúde para lidar com as demandas judiciais. Pois foi evidenciado que o sistema executivo tem estruturas diferentes para lidar com a política e com a execução das ações de medicamentos. Aliás, ressalta-se que o segundo tipo de estrutura lida não somente com as demandas de medicamentos concedidas via judicial, mas também com as que dizem respeito a outras tecnologias ou procedimentos em saúde. Significa que a execução tanto das ações de implementação do CEAF/PNAF quanto das ações aprovadas judicialmente são operacionalizadas pelo Poder Executivo. Em suma, a entrega do serviço, por via regular ou por via judicial, é da responsabilidade do poder executivo. No caso da via regular, toda a operacionalização é realizada pelas estruturas da área de Assistência Farmacêutica (tanto do MS, quanto da SES-DF). Já para a via judicial, há uma estrutura intermediária específica da judicialização, que são os núcleos judiciais, que realizam a gestão logística para todas as tecnologias em saúde. Para o MS, o Núcleo de Judicialização finaliza o processo de entrega do medicamento ou repasse de recursos. Para SES-DF, o Núcleo de Judicialização finaliza o processo de compra do medicamento, mas o Núcleo de Farmácia Ambulatoria de Ações Judiciais finaliza a entrega ao paciente.

Cabe, ainda, destacar que enquanto os órgãos essenciais à justiça e os órgãos do sistema judiciário já possuem nos propósitos intrínsecos às suas atuações, a competência de lidar com as questões judiciais, não parece inerente à atuação dos órgãos do sistema de saúde ter estruturas planejadas para a execução de decisões judiciais. Foi necessário criar as estruturas necessárias para dar andamento às decisões judiciais.

De um lado, pode-se argumentar que o controle jurisdicional está previsto em Constituição, a judicialização é natural, faz parte da atuação do governo e é até previsível, ainda que de forma extraordinária. Sendo assim, é previsível a necessidade de haver estrutura para a execução das ações que resultam dos litígios. Porém, por outro lado, como a judicialização deveria ocorrer excepcionalmente e somente mediante omissão da política, atender os casos excepcionais, mesmo que requeresse alguma estrutura, não exigiria uma estrutura significativa para resolução das decisões judiciais.

De qualquer forma, é importante notar que o crescimento das demandas judiciais requer uma organização e investimentos cada vez maiores para a sua gestão. E, do ponto de vista administrativo, ao passo que o aumento das demandas amplia o volume de produtos a serem adquiridos e amplia os investimentos, um planejamento efetivo dos fluxos e estruturas da judicialização tende à reduzir os custos associados, tanto por parte do poder executivo quanto por parte do poder judiciário. 
Conforme Van de Ven e Walker (1984), uma forma de melhorar os processos que envolvem múltiplas organizações é a mobilização de arranjos de estruturas formais de coordenação. Logo, tanto para o sistema executivo quanto para o sistema judiciário, que enfrentam juntos a tarefa de resolver um número crescente de ações judiciais, a formação de arranjos de cooperação potencialmente trará eficiência para os processos.

O importante, além de definir bem as estruturas e suas interrelações, é fazer com que todos os subsistemas (executivo, judiciário e órgãos essenciais à justiça) reconheçam a estrutura final e atuem em consonância com as atividades pactuadas entre todos os componentes do sistema interorganizacional.

Tomando os resultados por partes, nota-se primeiramente que as estruturas envolvidas com a judicialização da saúde são evidenciadas com maior clareza para o Poder Judiciário e para os órgãos independentes (essenciais à Justiça). Mas, como já dito, isso pode ocorrer em função das competências naturais destes órgãos na Justiça brasileira. Porém, para o sistema executivo, foram identificadas estruturas na União (MS) e no Distrito Federal (SES-DF) que lidam com a judicialização diferentes das estruturas que lidam com a PNAF.

Os departamentos do MS envolvidos com a judicialização estão explicitamente apresentados e divulgados ao público, não sendo difícil sua identificação. A nível distrital houve dificuldade em identificar os departamentos da SES-DF envolvidos com a judicialização nos documentos oficiais e informações nos sítios eletrônicos da Secretaria de Saúde. . Porém estruturas que lidam com as ações via judicial são bem conhecidas pelos profissionais que atuam na própria Secretaria. Foi observado, então, uma falta de registro ou mesmo publicidade das informações ao respeito. Enqjuanto há muitos (27) registros e, inclusive, organogramas e fluxos, para as atividades da SES-DF relacionadas ao CEAF/PNAF, não o há para o Núcleo de Judicialização. Assim, o reconhecimento inicial da existência deste Núcleo partiu dos relatos de entrevistados da SES-DF e somente após estes relatos e minuciosa examinação das fontes escritas foram encontrados alguns dados documentais.

Em se tratar da estrutura organizacional do executivo para a judicialização, então, há melhores registros por parte do MS e registros mais escassos pela SES-DF, sendo estes elementos relevantes às funções organização e informação (reporting) do POSDCORB (GULICK; URWICK, 2005).

Apesar dos profissionais da SES-DF reconhecerem o NJUD/SES-DF e de haver menção à este departamento desde a sua criação em atas do Comitê Executivo Distrital da Saúde, é importante a sua melhor divulgação à público. Este Núcleo serve como meio de 
coordenação entre o executivo e o judiciário (microestrutura) e é reconhecido formalmente pela SES-DF, apesar da falta de divulgação dos registros oficiais.

Outro ponto, também observado, com destaque para o sistema executivo do DF, é o aparente desenvolvimento das estruturas sem um planejamento prévio. Quer dizer, há dois relatos importantes dos entrevistados da SES-DF: um primeiro de que não há fluxos de trabalho estabelecidos e formalizados, e um segundo de que a quantidade de funcionários não é suficiente para as demandas encaminhadas.

Entende-se que o cenário da judicialização mudou rapidamente em pouco tempo, conforme os dados quantitativos de ações judiciais e do impacto financeiro destas, e que também que é comum o surgimento de departamentos sem um planejamento formal prévio. Barbosa e Medeiros (2005) explicam que, na administração pública, os sistemas de planejamento e controle envolvem o estabelecimento de metas e objetivos comuns. Para o sistema interorganizacional pleiteado por este trabalho, o planejamento é função essencial para que as atividades possam ser coordenadas e os resultados que dependem da cooperação possam ser atingidos. Desta forma, uma das melhorias importantes para todo o sistema é a pactuação de planejamento para as estruturas, recursos humanos e atividades.

Portanto é essencial que o organograma da SES-DF seja atualizado e divulgado em sua versão atual; que o departamento tenha fluxos claros, registrados e de conhecimento de todos; que os processos realizados e a história do setor também sejam registrados; entre outras condutas que visem a organização da estrutura. E isto se faz ainda mais necessário por causa do caráter das atividades realizadas, pois estas envolvem um custo alto para o governo. Como é sabido, a função administrativa de organizar tende à melhorar os processos de trabalho e isso, potencialmente, poderia trazer soluções para parte dos problemas apresentados pela quantidade de ações judiciais.

Como estruturas do Poder Judiciário foram detectados dois tribunais (STF e TJDFT) e o CNJ como órgãos envolvidos com o objeto do estudo. Sabe-se que a estrutura do Poder Judiciário é mais complexa do que isto, porém estas foram as estruturas presentes nos documentos e que se destacaram no contexto das demandas em saúde.

No nível federal executivo, detectou-se a existência de um departamento de consultoria jurídica que atende todo o MS e de um núcleo jurídico que atende a Secretaria de Ciência, Tecnologia e Insumos Estratégicos. A organização de núcleos pelas Secretarias chama a atenção para a divisão das atividades de apoio jurídico, principalmente em função do grande volume de ações, a necessidade de otimizar as respostas institucionais nos processos e 
também para lidar com as questões que devam ser melhor analisadas, como a prevenção às ações judiciais.

O MS desenvolveu e possui atualmente uma estrutura para a gestão das demandas judiciais em saúde. Ressalta-se que apesar do MS não distribuir medicamentos para o usuário enquanto implementador da política de medicamentos, ele teve de estruturar setores que fizessem este fornecimento para atender as ações via judicialização.

O mesmo ocorreu para a SES-DF, pois há uma estrutura específica para a implementação da AF e do CEAF/PNAF e outra estrutura para a execução das ações judiciais, já que envolvem procedimentos distintos, o que significa centros de compras duplicados e mecanismos de entrega dos medicamentos aos pacientes (farmácias ambulatoriais), também duplicados.

Foi evidenciado na pesquisa que CNJ e TJDFT costumam disponibilizar muita informação sobre suas participações no contexto da judicialização da saúde. Na verdade, observou-se que o poder judiciário é novamente o principal divulgador da judicialização e das atividades que estão sendo realizadas para a sua melhoria. Em segundo lugar, os dois já mencionados, alguns órgãos essenciais à justiça também divulgam suas participações nesta atividade, como a DPDF, a DPU e o MPDFT. Por último, na divulgação de suas atividades relacionadas à judicialização do acesso a medicamentos, tem-se o poder executivo. $\mathrm{O}$ levantamento realizado mostrou que o MS também publica alguns documentos demonstrando a existência de processos envolvendo a via judicial. No entanto, a SES-DF ainda precisa aprimorar os canais de comunicação com o cidadão e de divulgação de informações atualizadas sobre a judicialização.

Gulick e Urwick (2005) argumentam que a função de informação é importante para manter os interessados no assunto atentos ao andamento dos processos e à situação do objeto em questão. No caso da judicialização da saúde, é importante manter os registros atualizados para o conhecimento dos demais órgãos do próprio sistema de coordenação, quanto para o conhecimento público, dos cidadãos.

O STF, ainda não citado, também foi uma estrutura muito presente na análise do caso 02, em diversas categorias, em função das jurisprudências emitidas por este órgão. O STF é um dos tribunais que podem julgar as causas civis relacionadas aos medicamentos, porém é acessado não como primeira instância para os casos individuais de direito à saúde do cidadão. E também é o tribunal responsável quando a matéria envolve caso contra a União.

Resumindo, o TJDFT, o CNJ e o MS apresentaram maior transparência de informações e melhor perfil comunicador das discussões e deliberações sobre o assunto em 
pauta. Todos os três órgãos disponibilizam informação sobre a judicialização em seus sítios eletrônicos.

De todas as estruturas, as que estabelecem contato com o usuário, no sentido de haver atividade fim relacionada à esta interação, são o NJ/STIE/MS (pois foi preciso estabelecer atividades de contato com o usuário para a entrega do medicamento ou depósito do valor em conta para a compra do produto), a CAMEDIS para a tentativa de mediação e prevenção da judicialização no DF; o Núcleo de Farmácia Ambulatorial Judicial (criado para dispensar o medicamento ao paciente judicializado); as Defensorias Públicas da União e do Distrito Federal (recebem as reclamações, tentam identificar uma solução administrativa e, quando necessário, iniciam o processo judicial em defesa do usuário) e, em última análise, os tribunais, no sentido de receberem as demandas provenientes dos usuários e julgá-las.

Conforme Alexander (1998) é importante que as relações dos departamentos e instituição estejam bem descritas, para que todos tenham a mesma informação dos fluxos e de outros aspectos importantes para a coordenação das ações.

A parceria entre o CNJ e o MS que gerou a criação dos Núcleos de Apoio Técnico do Poder Judiciário (NATs) é importante para qualificar as decisões judiciais em saúde e estes Núcleos servem como pontes entre os dois sistemas (MINISTÉRIO DA SAÚDE, 2016a).

Sobre estes núcleos, o ministro da saúde, Ricardo Barros, afirmou em documento da pesquisa:

\footnotetext{
"É uma excelente iniciativa. Todos os procedimentos e medicamentos que estão fora da regulação do SUS e tudo que está incorporado ao sistema será avaliado por juízes com o auxílio de pareceres técnicos." [...] "Vale ressaltar que o material vai servir para uma consulta voluntária do magistrado dentro de sua autonomia" (MINISTÉRIO DA SAÚDE, 2016a, p. 1).
}

Já o conselheiro Arnaldo Hosseplan, do CNJ, ressaltou: "é importante que fique claro que o CNJ não interfere na jurisdição" (MINISTÉRIO DA SAÚDE, 2016a, p. 1). Esta postura é explicada pelo fato de que o juiz de direito poderá avaliar a ação judicial para cada caso de forma individualizada. Porém a iniciativa irá proporcionar ao magistrado um parecer técnico em tempo oportuno para sua avaliação e deliberação. O conselheiro também concorda que: "Numa área como essa, qualquer utilização do orçamento de forma inadequada acaba prejudicando um número maior de beneficiários do SUS" (MINISTÉRIO DA SAÚDE, 2016a, p. 1).

Quanto às relações entre as estruturas, foram identificados dois aspectos: as relações usuais entre os órgãos/departamentos de um mesmo ente federativo ou entre entes federativos 
diferentes, e o contato entre judiciário e executivo (em termos de atividades e não de subordinação).

É importante destacar também que esta pesquisa exploratória e descritiva foi capaz de identificar as estruturas que existem atualmente, a incluir as estruturas mais recentes (CAMEDIS, Farmácia de Ações judiciais, NATs, Fórum da saúde, NJUD/SES-DF).

Para contribuir à esperada eficiência da política pública e do controle jurisdicional, é necessário compreender a relação entre as estruturas dos dois Poderes, de acordo com as ações de cada uma delas, e mostrar como podem ser organizadas em um sistema interorganizacional planejado.

Além da investigação das estruturas realizada nesta subseção, também devem ser analisados os aspectos de recursos humanos, recursos financeiros e atividades, à luz da interação entre os dois sistemas. Logo, nas próximas subseções serão abordados estes outros aspectos para uma percepção mais completa deste sistema interorganizacional identificado pela pesquisa.

\subsubsection{Recursos Humanos}

Como será lembrado, a análise dos recursos humanos nos dois casos acompanhou a ordem da análise da estrutura organizacional permitindo identifcar não somente a variedade de órgãos e departamentos envolvidos com o fenômeno, mas também o perfil dos profissionais envolvidos.

Do ponto de vista administrativo, cabe pensar que alguns órgãos tem como função primária lidar com a judicialização (Poder Judiciário e Órgãos Essenciais à Justiça) e outros agregam esta função sobre a função primária de executar as políticas (Poder Executivo). Os dados evidenciam que, no caso do sistema de saúde, assim como a criação de setores que operacionalizam as decisões judiciais não tiveram o planejamento necessário pois as demandas judiciais cresceram rapidamente em curto período de tempo, o pessoal alocado para estas atividades também não têm, necessariamente, formação apropriada para lidar com tal demanda.

É claro que parte da atuação dos recursos humanos na área da saúde exige como requisitos os conhecimentos técnicos da própria área da saúde, principalmente da área farmacêutica. No entanto, é possível inferir que para lidar com a judicialização que afeta as atividades da área seriam requeridos conhecimentos próprios a outros campos de estudo. Diante deste contexto, quanto aos recursos humanos, para um bom planejamento de ações e 
aprimoramento do modelo de gestão do sistema interorganizacional, cabe realizar um diagnóstico quanto à quantidade existente e a quantidade necessária para as responsabilidades de cada órgão e quanto ao perfil dos funcionários e as competências quedevem possuir para o trabalho em questão. Com isto, pode-se decidir, se necessário, pelo ajuste no número de funcionários e pelo desenvolvimento de competências por meio de capacitação adequada.

O tema de recursos humanas se relaciona à função denominada staffing, que trata da seleção e capacitação dos recursos humanos e a manutenção de um bom ambiente de trabalho e clima organizacional (GULICK; URWICK, 2005).

A pergunta que se levanta ao redor desta função no contexto da judicialização de acesso a medicamentos especializados, então, é sobre os profissionais adequados à realização das atividades necessárias.

Como já foi apresentado, apesar do controle jurisdicional ser uma atividade de responsabilidade do Poder Judiciário, muitas instituições diferentes acabam participando do processo de judicialização em algum momento, inclusive órgãos ligados ao Poder Executivo. Dessa forma, não é só o Poder Judiciário que precisa contar com seus fluxos organizados e profissionais conscientes do processo. Muitos profissionais que executam o CEAF/PNAF precisam lidar com algum aspecto da judicialização no dia-a-dia e por isso fazem parte do cenário total, assim como pessoas da área de saúde que detêm informações pertinentes sobre a política e podem colaborar com apoio técnico para a melhoria da judicialização. Logo, os recursos humanos da área da saúde podem contribuir ao processo se envolvendo com a execução das ações judiciais ou prestando assessoria sobre os aspectos técnicos das demandas judiciais por medicamentos.

$\mathrm{Na}$ verdade todos os envolvidos precisam estar alinhados, tendo consciência de todo o cenário e das funções de cada parte. Por isto para o planejamento é tão importante (i) estruturar uma nova organização do sistema interorganizacional, (ii) registrar e formalizar esta organização, (iii) comunicar à todos os envolvidos ou mesmo fazer a organização com a participação dos envolvidos, na medida do possível, (iv) definir e capacitar os recursos humanos necessários (28), e (v) manter a comunicação entre os participantes continuamente (29). 


\subsubsection{Recursos Financeiros}

A análise dos recursos financeiros revelou aspectos relevantes nos dois casos investigados. No caso da política de saúde a organização do financiamento do CEAF/PNAF é bem delineada $\mathrm{O}$ embasamento legal orçamentário e a estrutura executora da política somam uma organização planejada para a execução das respectivas competências financeiras, em que o financiamento do componente é é baseado na contribuição pelos entes federativos, de acordo com cada um dos grupos do componente de alto custo (grupos 1A, 1B e 2).

Esta previsão é seguida conforme planejado, a não ser diante de imprevistos. Foi observado que departamentos responsáveis da SES-DF e MS realizam a previsão dos custos no ano anterior à execução orçamentária e trabalham para seguir o planejado. No caso da relação União e Distrito Federal, para o CEAF/PNAF existe o repasse de medicamentos (grupo 1A) e o repasse de recursos (grupo 1B) por parte da União e existe por parte do DF o recebimento de medicamentos, o uso de recursos que lhe cabe e a compra de medicamentos por orçamento próprio e compartilhado. De forma muito resumida, relembra-se que o custeio dos medicamentos pela política é feita segundo repartição prevista em normas.

Da mesma forma, foi apreendido pelos dados da pesquisa que existe o princípio da responsabilidade solidária entre os entes da federação para com o custeio da judicialização de medicamentos. Logo, se havia previsão de custeio compartilhado do medicamento na política do CEAF/PNAF, isto se mantém também na judicialização. Porém, se o medicamento judicializado não é padronizado, o polo passivo da ação (o réu) irá arcar com os custos. Por exemplo, a pesquisa demonstrou que o DF pode padronizar medicamentos que não estejam presentes na RENAME ou mesmo elaborar um protocolo estadual e incluir medicamentos em um novo protocolo. Em ambas as situações, como não havia previsão nacional (pelo MS) ou de divisão de responsabilidades entre a União e o DF, o ente judicializado (DF, neste caso) arca com os gastos do produto judicializado.

Além da questão da responsabilidade sobre o custeio, outra questão importante é a fonte dos recursos. Foi explicado pelos entrevistados que não há planejamento orçamentário no ano anterior para a judicialização, nem por parte da União nem port parte do DF. Logo, o MS ou a SES-DF realizam no ano anterior uma programação orçamentária para o andamento das políticas de saúde que não contempla a ocorrência de ações judiciais. Assim, durante o ano consecutivo, conforme as ações judiciais são interpostas e recaem para o órgão do executivo resolver a demanda, se torna necessário financiar e resolver a decisão judicial em curto prazo de tempo. 
Além dos custos dos medicamentos, em si, cabe ainda chamar a atenção para os custos relacionados às estruturas criadas e mantidas nos sistemas executivos da União (MS) e do DF (SES-DF) para atender às demandas por via judicial. Como já explicado, além da estrutura e dos recursos empregados para a implementação da política de medicamentos, a judicialização exige uma segunda estrutura, paralela, para a execução das ações judiciais em saúde. Logo, além dos gastos com a compra propriamente dita dos medicamentos, há os demais custos associados à todo este processo de gestão (estrutura física, recursos humanos, logística dos medicamentos, entre outros aspectos).

Convém incluir os aspectos financeiros, junto à preocupação com a segurança do paciente, como já explicado anteriormente, nas considerações sobre como repensar o sistema como um todo.

Para Gulick e Urwick (2005), a função orçamento (budgeting) para a Administração Pública envolve tanto as atividades de planejamento orçamentário (que não estão claramente evidentes para a judicialização da saúde), como de fiscalização e controle contábil.

Diante do aumento do quantitativo de ações judiciais nos últimos anos de forma expressiva e, consequentemente, dos gastos com a execução destas ações, é possível aos gestores preverem parte dos gastos com a judicialização. Mesmo não sendo uma previsão orçamentária semelhante aos demais gastos, justamente porque não há como prever a iniciativa de busca por esta via, os últimos anos têm apresentado padrão de aumento desta conduta e aumento dos gastos. Diante disto, mesmo não havendo fundo específico para a judicialização, em termos de orçamento (função administrativa) propõe-se um (30) monitoramento cuidadoso destes gastos e a realização de uma previsão mínima dos gastos. Pelos resultados da pesquisa, além da percepção pelo aumento constante do volume de ações, também foi identificado que os tratamentos crônicos judicializados são fornecidos aos pacientes durante toda sua vida. Logo, é possível uma previsão logística e financeira sobre os casos já existentes e que deverão ser continuados nos anos seguintes.

Além desta sugestão de previsão orçamentária mínima com as compras de medicamentos, entende-se que (31) as demais sugestões sobre os outros aspectos (estrutura, atividades e recursos humanos necessários para viabilizar a judicialização) irão impactar sobre os custos. Tanto no sentido de haver uma previsão e isto poder trazer eficiência aos processos quanto no sentido de que, ao implementar outros ajustes, a redução do número de ações judiciais poderá impactar positivamente o orçamento dos sistemas Distrital e Federal, por consequência. 


\subsubsection{Atividades, fluxos e rotinas}

Seguindo a mesma perspectiva já abordada, os órgãos do judiciário e os essenciais à justiça já possuíam a competência de lidar com litígios e, por isto, suas atividades, fluxos e rotinas já se alinham com a natureza do problema da judicialização da saúde. Diferentemente dos órgãos do judiciário, o executivo costuma lidar somente com a execução da política. Foi em função do crescente número de ações judiciais que se tornou necessário se organizar, estabelecendo novas atividades, fluxos e rotinas aos que já existiam.

Em muitos casos, para o estabelecimento de novas competências e o desenvolvimento de novas atividades, foi necessária a formação de novas relações, entre departamentos de um mesmo órgão ou entre órgãos diferentes. Para este último caso, foi identificado inclusive a necessidade de criar relações entre poderes diferentes, como é desejado para os trabalhos de cooperação técnica, por exemplo.

Dentre estas relações, algumas se destacaram como relações formais (contato entre o Comitê Executivo Distrital em Saúde e o Fórum Nacional, do CNJ; contato entre DPDF e a SES-DF, por meio da CAMEDIS) e outras se destacaram como relações informais (contato entre o NJ/SCTIE/MS e NJUD/SES-DF para identificarem se o outro ente já respondeu à determinada demanda judicial; contato entre a DPDF e a Farmácia Ambulatorial de Ações Judiciais para esclarecer dúvidas sobre os processos judiciais em andamento). Estas relações se caracterizam como microestruturas de coordenação entre entidades do sistema estudado.

Algumas características relevantes das atividades desenvolvidas no contexto da judicialização da saúde são:

(i) alguns órgãos desenvolvem atividade de defesa do usuário, em prol de seu direito à saúde, por meio da oferta do medicamento necessário. Foram identificados pelo estudo o Núcleo da Saúde da DPDF, a Procuradoria da República no DF - PRDF, a Procuradoria do Sistema Único de Saúde - PROSUS (do Ministério Público do Distrito Federal e Territórios MPDFT) e, no nível nacional, a Procuradoria Federal dos Direitos do Cidadão - PFDC, da Procuradoria-Geral da República - PGR;

(ii) outros órgãos atuam como defensores do governo e, no caso específico, do órgão da saúde, como a Procuradoria do Meio Ambiente, Patrimônio Urbanístico e Imobiliário e Saúde - PROMAI, da Procuradoria-Geral do Distrito Federal - PGDF;

(iii) alguns departamentos estabelecem atividades que exigem relacionamento com outros departamentos do mesmo órgão, como o NJ/SCTIE/MS e a CONJUR/MS, o NJUD/SES-DF e a CAMEDIS, a DIASF e o Núcleo de Farmácia Ambulatorial Judicial; e 
(iv) alguns departamentos ou órgãos estabelecem atividades entre outros órgãos, como o NJ/SCTIE/MS e o NJUD/SES-DF, a CONJUR/MS e a PFDC/PGR, o NAT e a SES-DF, a CAMEDIS e o Núcleo de Saúde da DPDF, o Comitê Executivo de Saúde do DF e o Fórum Nacional da Saúde do Poder Judiciário.

Estes aspectos reforçam a necessidade de uma (32) boa articulação e previsão destas atividades, sempre de forma coordenada, para garantir eficiência para a resolução das demandas judiciais em saúde.

Como citado, existem órgãos que têm como atividade representar o governo em sua defesa nos julgamentos e, para o caso das demandas por medicamentos, a antecipação de tutela determina que a defesa deva ser realizada após o deferimento imediato do caso, quando desta decisão judicial. Estes órgãos estudam cada ação interposta e analisam as condições de oferta dos serviços pela política, as características clínicas do caso da ação interposta, consultam o órgão demandado pela ação judicial e elaboram a defesa.

Há os órgãos que atuam em defesa do usuário e, para estes casos, há dois tipos de atuações. Um primeiro caso se refere às Defensorias Públicas da União e do DF que agem recebendo a queixa do cidadão, tentando intervir extrajudicialmente e, se necessário, abrem a ação judicial. Um segundo caso seria dos órgãos independentes, que atuam como fiscalizadores do sistema de saúde, em defesa do seu bom funcionamento e, consequentemente, da oferta dos serviços à população. Para este caso os órgãos seriam os Ministérios Públicos (da União, Federal e do Distrito Federal e Territórios).

As funções de planejamento, organização, direção, coordenação, informação, orçamento e gestão de pessoal podem ser identificadas em meio às atividades específicas de cada órgão e também podem se dizer respeito a atividades coordenadas entre órgãos de diferentes Poderes.

Exploradas as atividades, a partir um olhar mais geral, há de se ressaltar que, mesmo com o modelo geral a ser proposto para o sistema interorganizacional, ainda haverá o momento de avaliação das ações judiciais e de interpretação de cada caso individual, para posterior decisão do juiz. Então, em paralelo ao modelo de operacionalização da judicialização da saúde, cabe ainda o usufruto dos modelos de fluxos elaborados para cada tipo de ação judicial identificado por esta pesquisa. Este trabalho se refere à atividades específicas do julgamento das ações. Porém, quanto mais embasamento técnico houver disponível, melhor a decisão final, tanto para o usuário, quanto à eficácia e segurança do tratamento pleiteado, quanto para os sistemas de saúde e judiciário (logo, para o Estado). 


\subsubsection{Discricionariedade operacional}

Como já explicado na seção 6.3.2, os exemplos de situações nas quais o gestor público do CEAF/PNAF pode aplicar sua liberdade de ação já foram incorporadas aos Quadros da análise. Desta forma, cabe complementar a discussão sobre discricionariedade abordando a dimensão 'prática' ou 'operacional' proposta.

Para o caso do administrador público o uso da discricionariedade refletirá na decisão de ação dentro dos limites estabelecidos pela norma da 'discricionariedade normativa'. Ou seja, exercer a discricionariedade pelo gestor público é escolher como irá agir dentro de normas que dizem os resultados finais que ele deve obter para ter uma política eficaz, efetiva e eficiente.

Já para o juiz, a escolha que ele pode realizar para usufruir de sua 'discricionariedade prática' envolve o deferimento total, deferimento parcial ou o indeferimento de uma ação. Suas opções de atuação são reduzidas, se comparada às do gestor, porém a característica de sua atuação profissional é que as difere, em essência. Mas, apesar das decisões poderem ser dos três tipos, os conteúdos poderão variar. E, a depender do tribunal ao qual pertence o juiz, a decisão poderá ter algum impacto sobre as demais decisões da área, dentro do Brasil. Ou, ainda, se a decisão é proferida pelo STF, o impacto será na verdade a definição de resultado. Essas decisões prévias do STF são denominadas jurisprudências para casos posteriores e semelhantes.

As jurisprudências do STF não dão margem à discricionariedade, pois não criam liberdade para a ação do magistrado, mas sim definem as ações, garantindo um só resultado para alguns tipos de casos.

No caso da discricionariedade operacional, como já dito, os exemplos que impactam a judicialização já foram incorporados aos Quadros de análise. Porém, para o caso 02 da pesquisa, cabe considerar como resultados da discricionariedade as jurisprudências deliberadas.

Os dados da pesquisa apontam como características pertinentes ao exercício da discricionariedade operacional jurídica:

(i) dificuldade de compreensão das portarias e do planejamento das ações em saúde, por parte dos magistrados (33);

(ii) as ações em saúde têm uma característica comum de referenciar risco à vida do autor pela ausência do tratamento. Logo, a falta de embasamento clínico e de uma 
compreensão clara dos riscos acrescenta maior preocupação aos magistrados na investigação e tendência ao deferimento total das ações (34); e

(iii) o julgamento busca a efetividade constitucional, independente da prescrição ser ou não ser de médico da rede pública (35).

Os elementos de todas as subcategorias do aparato administrativo foram então incorporados aos Quadros 6.7 e 6.8.

Quadro 6.7: Aspectos que justificam a organização da relação executivo-legislativo nas demandas de saúde - $4^{\mathrm{a}}$ versão parcial

\begin{tabular}{|c|c|}
\hline $\mathbf{N}$ & $\begin{array}{l}\text { Aspectos que justificam a organização da relação executivo-judiciário nas demandas de } \\
\text { saúde }\end{array}$ \\
\hline 1 & $\begin{array}{l}\text { Necessidade de maior objetividade para as decisões judiciais, pautada pelo consenso de que o } \\
\text { direito à vida deve ser operacionalizado sob critérios técnicos e racionais. }\end{array}$ \\
\hline 2 & $\begin{array}{l}\text { Atuação legítima do Poder Judiciário e que se estabelece uma relação perene entre este Poder e o } \\
\text { Executivo. }\end{array}$ \\
\hline 3 & Deferimento majoritário de ações em saúde sem critério técnico norteador. \\
\hline 4 & Aumento do controle jurisdicional e do consequente impacto sobre a PNAF. \\
\hline 5 & Potencial avanço e aparelhamento das ações e serviços de saúde a partir da ação do judiciário. \\
\hline 6 & Complexidade do CEAF/PNAF e necessidade de respeito à esta condição e aos PCDT. \\
\hline 7 & $\begin{array}{l}\text { Preocupação e movimentação do Poder Judiciário em prol de medidas concretas de melhoria da } \\
\text { judicialização da saúde. }\end{array}$ \\
\hline 8 & $\begin{array}{l}\text { Impacto orçamentário e de gestão sobre o MS a partir da grande quantidade de ações judiciais que } \\
\text { o acionam como réu. }\end{array}$ \\
\hline 9 & Complexidade de organização da saúde pública e do CEAF/PNAF em seus vários aspectos. \\
\hline 10 & $\begin{array}{l}\text { Necessidade de subsídios para a intervenção do Poder Judiciário nas demandas em saúde, em } \\
\text { função da complexidade dos casos. }\end{array}$ \\
\hline 11 & $\begin{array}{l}\text { (33) Dificuldade de compreensão das portarias e do planejamento das ações em saúde, por parte } \\
\text { dos magistrados. }\end{array}$ \\
\hline 12 & $\begin{array}{l}\text { (34) A falta de embasamento clínico e uma compreensão clara dos riscos acrescenta maior } \\
\text { preocupação aos magistrados na investigação dos casos em saúde. }\end{array}$ \\
\hline 13 & $\begin{array}{l}\text { (35) As prescrições que originam as ações são de profissionais da rede pública e rede privada, } \\
\text { sendo necessárias ações que alcancem estes dois grupos. }\end{array}$ \\
\hline
\end{tabular}

Fonte: Da autora. 
Quadro 6.8: Aspectos do planejamento do CEAF/PNAF e da judicialização importantes para o processo de judicialização de medicamentos $-4^{\mathrm{a}}$ versão parcial (continua)

\begin{tabular}{|c|c|c|c|c|}
\hline $\mathbf{N}$ & $\begin{array}{l}\text { Aspectos do } \\
\text { planejamento do } \\
\text { CEAF/PNAF e do } \\
\text { controle } \\
\text { jurisdicional } \\
\text { importantes para o } \\
\text { processo de } \\
\text { judicialização de } \\
\text { medicamentos }\end{array}$ & Situação atual & Situação sugerida & $\begin{array}{l}\text { Funções da } \\
\text { administração }\end{array}$ \\
\hline 1 & $\begin{array}{l}\text { Princípios e } \\
\text { diretrizes } \\
\text { estruturantes do } \\
\text { SUS: } \\
\text { descentralização; } \\
\text { universalidade; } \\
\text { integralidade e } \\
\text { equidade }\end{array}$ & $\begin{array}{l}\text { Não cumprimento } \\
\text { das diretrizes e } \\
\text { princípios. }\end{array}$ & $\begin{array}{l}\text { Resolução extrajudicial } \\
\text { quando adequado e judicial } \\
\text { somente para casos não } \\
\text { cobertos e que admitam o } \\
\text { fornecimento de } \\
\text { medicamentos pelo } \\
\text { governo. }\end{array}$ & $\begin{array}{l}\text { Organização - sistema } \\
\text { executivo } \\
\text { Coordenação - } \\
\text { executivo-judiciário }\end{array}$ \\
\hline 2 & $\begin{array}{l}\text { Objetivo da } \\
\text { Assistência } \\
\text { Farmacêutica - AF - } \\
\text { de garantir o uso } \\
\text { racional de } \\
\text { medicamentos - } \\
\text { PNAF. }\end{array}$ & $\begin{array}{l}\text { Não cumprimento } \\
\text { das diretrizes e } \\
\text { princípios. }\end{array}$ & $\begin{array}{l}\text { Conhecimento por parte } \\
\text { dos magistrados sobre os } \\
\text { preceitos da AF e } \\
\text { assimilação deste para as } \\
\text { decisões judiciais, por } \\
\text { meio da atuação do } \\
\text { farmacêutico como } \\
\text { prestador de informações. } \\
\text { E participação do } \\
\text { farmacêutico nos cuidados } \\
\text { com os medicamentos } \\
\text { judicializados. }\end{array}$ & $\begin{array}{l}\text { Planejamento - sistema } \\
\text { executivo } \\
\text { Informação - executivo- } \\
\text { judiciário } \\
\text { Coordenação - } \\
\text { executivo-judiciário }\end{array}$ \\
\hline \multirow[b]{2}{*}{3} & \multirow{2}{*}{$\begin{array}{l}\text { Critérios de } \\
\text { padronização dos } \\
\text { medicamentos - } \\
\text { RENAME e REME } \\
\text { do DF }\end{array}$} & \multirow{2}{*}{$\begin{array}{l}\text { Não conhecimento e } \\
\text { reconhecimento dos } \\
\text { critérios para a } \\
\text { escolha de } \\
\text { medicamentos para } \\
\text { uma política } \\
\text { coletiva. }\end{array}$} & $\begin{array}{l}\text { Conhecimento por parte } \\
\text { dos magistrados sobre os } \\
\text { critérios de padronização e } \\
\text { assimilação destes para as } \\
\text { decisões judiciais. }\end{array}$ & \multirow{2}{*}{$\begin{array}{l}\text { Planejamento - sistema } \\
\text { executivo } \\
\text { Coordenação - } \\
\text { executivo-judiciário }\end{array}$} \\
\hline & & & $\begin{array}{l}\text { São critérios mínimos para } \\
\text { o fornecimento de um } \\
\text { med. a eficácia, a } \\
\text { segurança e o custo- } \\
\text { efetividade; e o processo } \\
\text { deve ser acompanhado por } \\
\text { profissional competente. }\end{array}$ & \\
\hline 4 & $\begin{array}{l}\text { Critérios de } \\
\text { elaboração dos } \\
\text { Protocolos Clínicos } \\
\text { e Diretrizes } \\
\text { Terapêuticas - } \\
\text { PCDT }\end{array}$ & $\begin{array}{l}\text { Não conhecimento e } \\
\text { reconhecimento dos } \\
\text { critérios para a } \\
\text { organização dos } \\
\text { cuidados em saúde } \\
\text { para uma política } \\
\text { coletiva. }\end{array}$ & $\begin{array}{l}\text { Conhecimento por parte } \\
\text { dos magistrados sobre os } \\
\text { critérios de organização } \\
\text { dos cuidados em saúde e } \\
\text { assimilação destes para as } \\
\text { decisões judiciais. }\end{array}$ & $\begin{array}{l}\text { Planejamento - sistema } \\
\text { executivo } \\
\text { Coordenação - } \\
\text { executivo-judiciário }\end{array}$ \\
\hline
\end{tabular}


Quadro 6.8: Aspectos do planejamento do CEAF/PNAF e da judicialização importantes para o processo de judicialização de medicamentos $-4^{\mathrm{a}}$ versão parcial (continuação)

\begin{tabular}{|c|c|c|c|c|}
\hline $\mathbf{N}$ & $\begin{array}{l}\text { Aspectos do } \\
\text { planejamento do } \\
\text { CEAF/PNAF e do } \\
\text { controle } \\
\text { jurisdicional } \\
\text { importantes para o } \\
\text { processo de } \\
\text { judicialização de } \\
\text { medicamentos }\end{array}$ & Situação atual & Situação sugerida & $\begin{array}{l}\text { Funções da } \\
\text { administração }\end{array}$ \\
\hline 5 & $\begin{array}{l}\text { Processo de revisão } \\
\text { da RENAME e dos } \\
\text { PCDT pela } \\
\text { CONITEC }\end{array}$ & $\begin{array}{l}\text { Não conhecimento } \\
\text { sobre o processo de } \\
\text { revisão das listas e } \\
\text { dos protocolos ou } \\
\text { não concordância } \\
\text { com estes processos. }\end{array}$ & $\begin{array}{l}\text { Adequação do processo de } \\
\text { revisão das listas e dos } \\
\text { protocolos, pactuado e } \\
\text { reconhecido pelos Poderes } \\
\text { Executivo e Judiciário } \\
\text { (sistema executivo } \\
\text { verificando os casos } \\
\text { judicializados ao realizar a } \\
\text { revisão das listas e sistema } \\
\text { judiciário reconhecendo os } \\
\text { documentos como } \\
\text { instrumentos técnicos para } \\
\text { as decisões). }\end{array}$ & $\begin{array}{l}\text { Coordenação - } \\
\text { executivo-judiciário }\end{array}$ \\
\hline \multirow{4}{*}{6} & \multirow{4}{*}{$\begin{array}{l}\text { (28) Diálogo aberto } \\
\text { entre as instituições } \\
\text { dos dois Poderes em } \\
\text { estudo. }\end{array}$} & \multirow{4}{*}{$\begin{array}{l}\text { Pouco diálogo entre } \\
\text { os dois Poderes na } \\
\text { rotina das decisões } \\
\text { judiciais, porém } \\
\text { com previsão atual } \\
\text { de cooperação } \\
\text { técnica (por meio } \\
\text { dos NATs) e com } \\
\text { existência atual do } \\
\text { Fórum Nacional e os } \\
\text { Comitês Estaduais } \\
\text { em Saúde, do } \\
\text { Judiciário. }\end{array}$} & $\begin{array}{l}\text { - Conhecimento por parte } \\
\text { dos magistrados dos } \\
\text { preceitos da AF por meio } \\
\text { de canais de comunicação } \\
\text { entre os dois Poderes: }\end{array}$ & \multirow{4}{*}{$\begin{array}{l}\text { Organização - } \\
\text { executivo-judiciário } \\
\text { (NATs) } \\
\text { Coordenação - } \\
\text { executivo-judiciário } \\
\text { Direção - sistema } \\
\text { judiciário }\end{array}$} \\
\hline & & & $\begin{array}{l}\text { - Efetivação da cooperação } \\
\text { técnica entre magistrados e } \\
\text { médicos e farmacêuticos, } \\
\text { por meio dos NATs, para } \\
\text { análise das demandas } \\
\text { judiciais individuais. }\end{array}$ & \\
\hline & & & $\begin{array}{l}\text { - Efetivação da cooperação } \\
\text { entre magistrados e } \\
\text { gestores públicos, para } \\
\text { análise das demandas } \\
\text { judiciais individuais. }\end{array}$ & \\
\hline & & & $\begin{array}{l}\text { - Efetivação da cooperação } \\
\text { entre interessados no SUS, } \\
\text { por meio de reuniões } \\
\text { (comitês e fóruns), para } \\
\text { problemas de gestão. }\end{array}$ & \\
\hline \multirow{2}{*}{7} & \multirow{2}{*}{$\begin{array}{l}\text { Manutenção da } \\
\text { sustentabilidade } \\
\text { financeira das } \\
\text { políticas de saúde } \\
\text { (SUS). }\end{array}$} & \multirow{2}{*}{$\begin{array}{l}\text { O discurso } \\
\text { reconhece o } \\
\text { problema financeiro, } \\
\text { porém não é aceito } \\
\text { como motivo para } \\
\text { impedir a } \\
\text { judicialização. }\end{array}$} & $\begin{array}{l}\text { (30) Instituir } \\
\text { monitoramento cuidadoso } \\
\text { dos gastos e a realizar de } \\
\text { uma previsão mínima dos } \\
\text { gastos }\end{array}$ & \multirow{2}{*}{$\begin{array}{l}\text { Orçamento - sistema } \\
\text { executivo (política e } \\
\text { judicialização) }\end{array}$} \\
\hline & & & $\begin{array}{l}\text { (31) Execução das demais } \\
\text { medidas propostas e } \\
\text { consequente redução da } \\
\text { judicialização e de seu } \\
\text { impacto orçamentário. }\end{array}$ & \\
\hline
\end{tabular}


Quadro 6.8: Aspectos do planejamento do CEAF/PNAF e da judicialização importantes para o processo de judicialização de medicamentos $-4^{\mathrm{a}}$ versão parcial (continuação)

\begin{tabular}{|c|c|c|c|c|}
\hline $\mathbf{N}$ & $\begin{array}{l}\text { Aspectos do } \\
\text { planejamento do } \\
\text { CEAF/PNAF e do } \\
\text { controle } \\
\text { jurisdicional } \\
\text { importantes para o } \\
\text { processo de } \\
\text { judicialização de } \\
\text { medicamentos }\end{array}$ & Situação atual & Situação sugerida & $\begin{array}{l}\text { Funções da } \\
\text { administração }\end{array}$ \\
\hline 8 & $\begin{array}{l}\text { Critérios para o } \\
\text { registro dos } \\
\text { medicamentos na } \\
\text { ANVISA e } \\
\text { características deste } \\
\text { processo. }\end{array}$ & $\begin{array}{l}\text { Há ações deferidas e } \\
\text { indeferidas de } \\
\text { medicamentos sem } \\
\text { registro e baixo } \\
\text { índice de avaliação } \\
\text { adequada. }\end{array}$ & $\begin{array}{l}\text { Avaliação individual dos } \\
\text { casos de medicamentos } \\
\text { sem registro na ANVISA. }\end{array}$ & $\begin{array}{l}\text { Coordenação - } \\
\text { executivo-judiciário }\end{array}$ \\
\hline 9 & $\begin{array}{l}\text { Estabelecimento de } \\
\text { processo de } \\
\text { mediação efetiva, } \\
\text { com cobertura } \\
\text { integral dos casos. }\end{array}$ & $\begin{array}{l}\text { Há a mediação } \\
\text { somente para os } \\
\text { casos entre DPDF e } \\
\text { SES-DF como réu } \\
\text { (CAMEDIS). }\end{array}$ & $\begin{array}{l}\text { Manter a estrutura de } \\
\text { mediação na SES- } \\
\text { DF/DPDF e estabelecer } \\
\text { estrutura na DPU, para as } \\
\text { defensorias públicas. } \\
\text { Estabelecer uma estrutura } \\
\text { no TJDFT e no STF para } \\
\text { ações iniciadas por } \\
\text { advogados particulares. }\end{array}$ & $\begin{array}{l}\text { Organização - } \\
\text { executivo-judiciário } \\
\text { (CAMEDIS) } \\
\text { Coordenação - } \\
\text { executivo-judiciário } \\
\text { Direção - sistema } \\
\text { judiciário }\end{array}$ \\
\hline 10 & $\begin{array}{l}\text { Normatização do } \\
\text { CEAF/PNAF e da } \\
\text { judicialização da } \\
\text { saúde. }\end{array}$ & $\begin{array}{l}\text { Há seguimento da } \\
\text { CF e de } \\
\text { jurisprudências, por } \\
\text { parte do judiciário, } \\
\text { porém falta } \\
\text { reconhecimento das } \\
\text { normas da saúde. }\end{array}$ & $\begin{array}{l}\text { O reconhecimento das } \\
\text { normas da saúde e a } \\
\text { apropriação de seus } \\
\text { conteúdos para prática da } \\
\text { judicialização. }\end{array}$ & $\begin{array}{l}\text { Organização - sistema } \\
\text { executivo } \\
\text { Coordenação - } \\
\text { executivo-judiciário }\end{array}$ \\
\hline 11 & $\begin{array}{l}\text { (27) Organização } \\
\text { dos órgãos } \\
\text { envolvidos. }\end{array}$ & $\begin{array}{l}\text { Existência dos } \\
\text { departamentos, } \\
\text { porém muitos sem } \\
\text { registro formal das } \\
\text { estruturas e fluxos. }\end{array}$ & $\begin{array}{l}\text { Necessidade de registros, } \\
\text { como a formalização de } \\
\text { organogramas e fluxos } \\
\text { atualizados. }\end{array}$ & $\begin{array}{l}\text { Organização - sistema } \\
\text { executivo-judiciário } \\
\text { Informação - sistema } \\
\text { executivo-judiciário } \\
\text { Coordenação - sistema } \\
\text { executivo-judiciário } \\
\end{array}$ \\
\hline \multirow{3}{*}{12} & \multirow{3}{*}{$\begin{array}{l}\text { (28) Recursos } \\
\text { humanos de } \\
\text { qualidade e em } \\
\text { quantidade } \\
\text { suficiente. }\end{array}$} & \multirow{3}{*}{$\begin{array}{l}\text { Poucos profissionais } \\
\text { trabalhando com a } \\
\text { judicialização, } \\
\text { principalmente no } \\
\text { sistema de saúde. }\end{array}$} & $\begin{array}{l}\text { Recursos humanos em } \\
\text { quantidade necessária para } \\
\text { a resolução das demandas. }\end{array}$ & \multirow{3}{*}{$\begin{array}{l}\text { Apoio, pessoal - sistema } \\
\text { executivo-judiciário }\end{array}$} \\
\hline & & & $\begin{array}{l}\text { Capacitação adequada para } \\
\text { os recursos humanos } \\
\text { envolvidos com a } \\
\text { judicialização, para } \\
\text { manutenção da } \\
\text { funcionalidade do sistema. }\end{array}$ & \\
\hline & & & $\begin{array}{l}\text { Orientação dos prescritores } \\
\text { sobre as regras de } \\
\text { prescrição no SUS. }\end{array}$ & \\
\hline 13 & $\begin{array}{l}\text { (32) Sistematização } \\
\text { das atividades } \\
\text { coordenadas. }\end{array}$ & $\begin{array}{l}\text { Atividades } \\
\text { dissociadas, } \\
\text { executadas pelo } \\
\text { órgão responsável, } \\
\text { sem articulação ou } \\
\text { conhecimento dos } \\
\text { demais envolvidos. }\end{array}$ & $\begin{array}{l}\text { Reconhecimento das } \\
\text { atividades do sistema por } \\
\text { todas as partes e } \\
\text { articulação entre os órgãos, } \\
\text { na medida do necessário. }\end{array}$ & $\begin{array}{l}\text { Planejamento - sistema } \\
\text { executivo-judiciário } \\
\text { Direção - sistema } \\
\text { executivo-judiciário } \\
\text { Coordenação - sistema } \\
\text { executivo-judiciário } \\
\text { Informação - sistema } \\
\text { executivo-judiciário }\end{array}$ \\
\hline
\end{tabular}


Quadro 6.8: Aspectos do planejamento do CEAF/PNAF e da judicialização importantes para o processo de judicialização de medicamentos $-4^{\mathrm{a}}$ versão parcial (conclusão)

\begin{tabular}{|c|c|c|c|c|}
\hline $\mathbf{N}$ & $\begin{array}{l}\text { Aspectos do } \\
\text { planejamento do } \\
\text { CEAF/PNAF e do } \\
\text { controle } \\
\text { jurisdicional } \\
\text { importantes para o } \\
\text { processo de } \\
\text { judicialização de } \\
\text { medicamentos }\end{array}$ & Situação atual & Situação sugerida & $\begin{array}{l}\text { Funções da } \\
\text { administração }\end{array}$ \\
\hline 14 & $\begin{array}{l}\text { (35) Origem das } \\
\text { prescrições de ações } \\
\text { judiciais das redes } \\
\text { pública e privada. }\end{array}$ & $\begin{array}{l}\text { Não há ações em } \\
\text { busca da } \\
\text { conscientização dos } \\
\text { prescritores sobre a } \\
\text { judicialização; da } \\
\text { divulgação dos } \\
\text { protocolos e ações } \\
\text { de educação ou } \\
\text { repreensão pelas } \\
\text { prescrições fora dos } \\
\text { protocolos do } \\
\text { próprio local de } \\
\text { trabalho (caso da } \\
\text { rede pública). }\end{array}$ & $\begin{array}{l}\text { Definição de ações de } \\
\text { conscientização dos } \\
\text { prescritores sobre a } \\
\text { judicialização; de } \\
\text { divulgação dos protocolos } \\
\text { e de educação ou } \\
\text { repreensão pelas } \\
\text { prescrições fora dos } \\
\text { protocolos do próprio local } \\
\text { de trabalho (rede pública) } \\
\text { realizada por comissões } \\
\text { locais de análise das } \\
\text { prescrições dissidentes dos } \\
\text { protocolos. }\end{array}$ & $\begin{array}{l}\text { Planejamento - sistema } \\
\text { executivo-judiciário } \\
\text { Apoio, pessoal - sistema } \\
\text { executivo-judiciário }\end{array}$ \\
\hline
\end{tabular}

Fonte: Da autora.

\subsection{Aspectos conflituosos entre a execução do CEAF/PNAF e a execução de demandas judiciais}

Analisar os aspectos conflituosos para o acesso de medicamentos entre a via regular da política e a via judicial identificados nos casos 01 e 02 , após revisitar as demais categorias, é um trabalho fácil. Isto porque as questões apresentadas nos dois capítulos anteriores acabaram sendo abordadas nas demais categorias desta análise.

Portanto é importante rever os conflitos identificados e confirmar se estes aspectos estão sendo abordados e possuem suas sugestões de melhoria inclusas para o modelo final.

Eram os aspectos conflituosos do caso 01:

(1) Organização normatizada das ações em redes - foi abordado neste capítulo de análise na categoria NP.

(2) Mecanismos gerenciais de acompanhamento das ações em saúde (36) - faz parte das atividades coordenadas, da categoria AA, porém cabe inclusão explícita deste aspecto de direção e coordenação das ações. Pois é necessário o acompanhamento das ações de forma 
articulada entre os sistemas de saúde e judiciário. Este tópico deve ser então incluído no Quadro final da análise (item 6).

(3) CEAF/PNAF com ampla cobertura e integralidade de tratamento para os casos previstos nos PCDT - foi abordado neste capítulo de análise na categoria NP.

(4) Ações para promoção do uso racional de medicamentos - foi abordado neste capítulo de análise na categoria NP.

(5) Tecnologias em saúde incorporadas ao SUS seguindo critérios técnicos objetivos foi abordado neste capítulo de análise na categoria NP.

(6) Protocolos clínicos elaborados seguindo racionalidade e consistência científica para os tratamentos - foi abordado neste capítulo de análise na categoria NP.

(7) Busca pela sustentabilidade financeira do sistema pela compra centralizada de medicamentos - foi abordado neste capítulo de análise na categoria RF.

E eram as características problemáticas na judicialização dos medicamentos (caso 02):

(19) Não cumprimento dos princípios e diretrizes do SUS: desrespeito à responsabilidade tripartite, descentralizada - foi abordado neste capítulo de análise na categoria NP.

(20) Não cumprimento dos princípios e diretrizes do SUS: prejuízo à integralidade; à equidade e à universalização - foi abordado neste capítulo de análise na categoria NP.

(21) Ações judiciais individuais concorrentes às ações em saúde coletivas - foi abordado neste capítulo de análise na categoria NP.

(22) Não cumprimento das diretrizes terapêuticas do SUS: deferimento de medicamentos com poucas evidências quanto à eficácia e segurança - foi abordado neste capítulo de análise na categoria NP.

(23) Não cumprimento das diretrizes terapêuticas do SUS: deferimento de medicamentos não registrados na ANVISA - foi abordado neste capítulo de análise na categoria NP.

(24) Não cumprimento das diretrizes terapêuticas do SUS: não cumprimento dos PCDT foi abordado neste capítulo de análise na categoria NP.

(25) Não cumprimento das diretrizes terapêuticas do SUS: estímulo ao uso irracional de medicamentos - foi abordado neste capítulo de análise na categoria NP.

(26) Judicialização dos medicamentos do CEAF/PNAF, apesar do aumento da cobertura dos últimos anos - foi abordado neste capítulo de análise na categoria NP.

(27) Necessidade de fortalecer mecanismos gerenciais para o bom acompanhamento e execução das ações judiciais de saúde no SUS - foi abordado neste capítulo de análise na categoria AA.

(28) Dificuldades orçamentárias: perda do poder de compra em larga escala - os aspectos financeiros foram abordados neste capítulo de análise na categoria RF. 
(29) Dificuldades orçamentárias: variação de custos durante o período de compra para a ação, principalmente de medicamentos com poucos fornecedores - os aspectos financeiros foram abordados neste capítulo de análise na categoria RF.

(30) Dificuldades orçamentárias: deslocamento de verba das políticas de saúde ou de outras pastas - os aspectos financeiros foram abordados neste capítulo de análise na categoria RF.

(31) Burocracia do sistema de saúde que gera lentidão para a resposta às ações judiciais deferidas - a melhora das atividades foi abordada neste capítulo de análise na categoria AA.

(32) Reclamação de demora na revisão da relação de tecnologias incorporadas pelo sistema - aspecto da padronização foi abordado neste capítulo de análise na categoria NP.

(33) Reclamação de demora na revisão e criação de novos PCDT - aspecto do PCDT foi abordado neste capítulo de análise na categoria NP.

(34) Não seguimento dos PCDT por alguns prescritores, dificultando a padronização dos tratamentos e a padronização dos procedimentos - foi abordado neste capítulo de análise na categoria DP.

(35) Elaboração de pareceres muito tecnicistas no trabalho conjunto da saúde com o sistema judiciário (37) - este aspecto deve ser inserido no Quadro final (no item 13), enquanto observação importante para a cooperação técnica entre o sistema de saúde e judiciário.

(36) Judicialização excessiva - foi abordado neste capítulo de análise na categoria NP.

É possível perceber, ao final desta etapa, que a categoria dos aspectos conflituosos acabava por identificar os pontos frágeis e os pontos fortes que deveriam receber atenção na seara da judicialização da saúde. Desta forma, os elementos identificados e organizados em dimensões na categoria dos conflitos, fazem parte de alguma outra categoria do estudo, com a característica de serem questões mais delicadas e que exigem cuidado.

A revisão dos elementos identificou então que todos estão abordados nos Quadros finais e serão contemplados no modelo operacional final.

Com a inclusão das informações desta última categoria, os Quadros 9 e 10, apresentados na próxima subseção, sintetizam os principais elementos deste capítulo de análise. 


\subsection{Propostas de modelos quanto às atividades entre o Poder Executivo e o Poder Judiciário}

Nesta seção são propostos dois modelos que atendem o objetivo geral deste estudo, integrando os diversos resultados da pesquisa.

Primeiramente são reapresentadas as duas Figuras dos modelos conceituais iniciais da pesquisa. Após a realização do estudo e compreensão dos fenômenos, foi possível prencher as lacunas presentes nestas Figuras originais.

$\mathrm{Na}$ sequência, na base das análises apresentadas ao longo do presente capítulo, apresenta-se o modelo operacional proposto por esta pesquisa.

Por fim, com o intuito de contribuir com o campo de pesquisa em políticas públicas, propõe-se um modelo de investigação de relações entre sistema executivo e sistema judiciário, quanto ao controle jurisdicional.

As Figuras 6.4 e 6.5 tomaram como base os modelos propostos no capítulo de metodologia (Figuras 3.1 e 3.2 respectivamente), nos quais questionava-se, antes da realização desta pesquisa, quais seriam os processos e a natureza das relações entre os órgãos do Poder Executivo na execução do CEAF/PNAF e entre os Poderes Executivo e Judiciário quanto à execução da judicialização de medicamentos, no DF e na União. Logo, estas novas Figuras representam uma integração dos resultados quanto ao modelo atualmente executado para a política e para a judicialização de medicamentos.

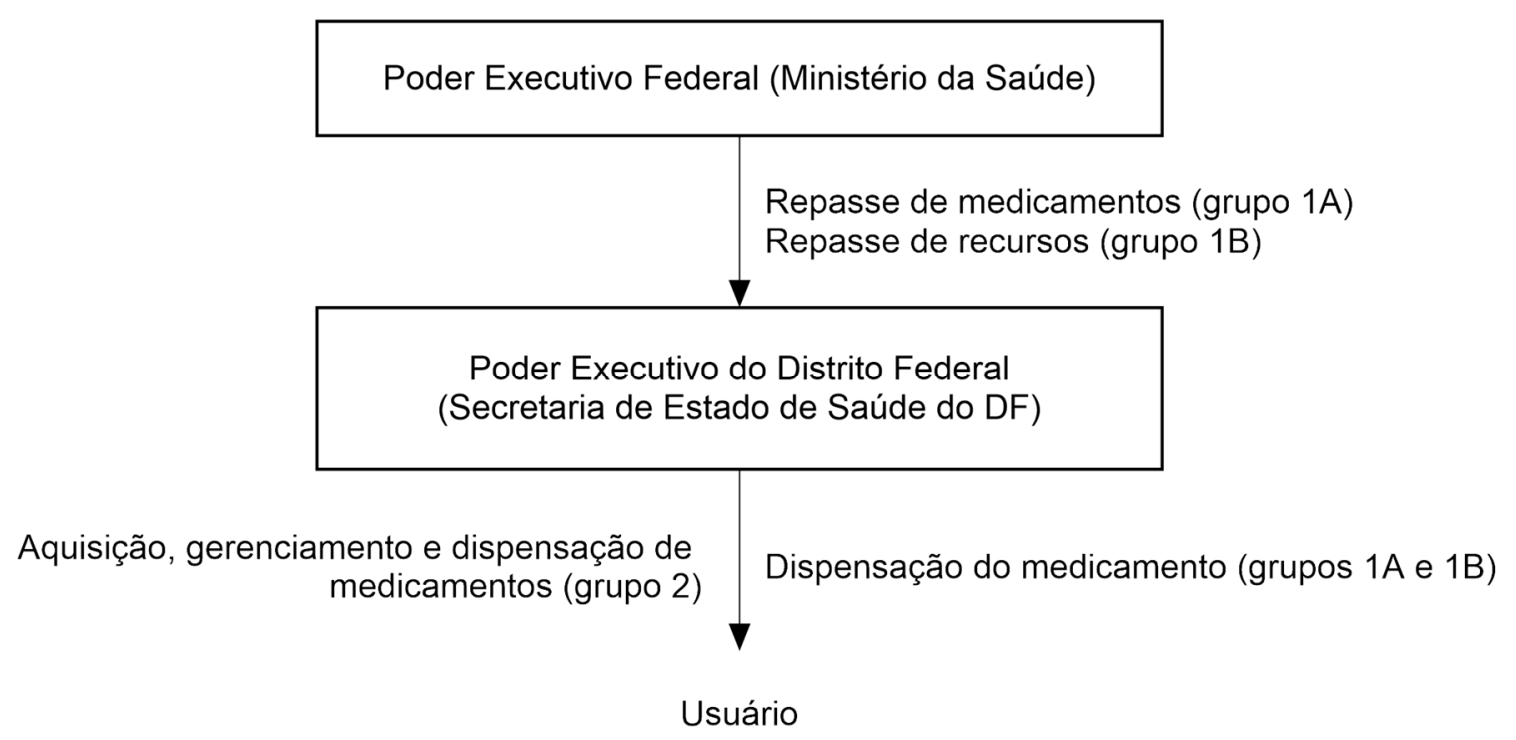

Figura 6.4 - Modelo da implementação do CEAF/PNAF.

Fonte: Da autora. 


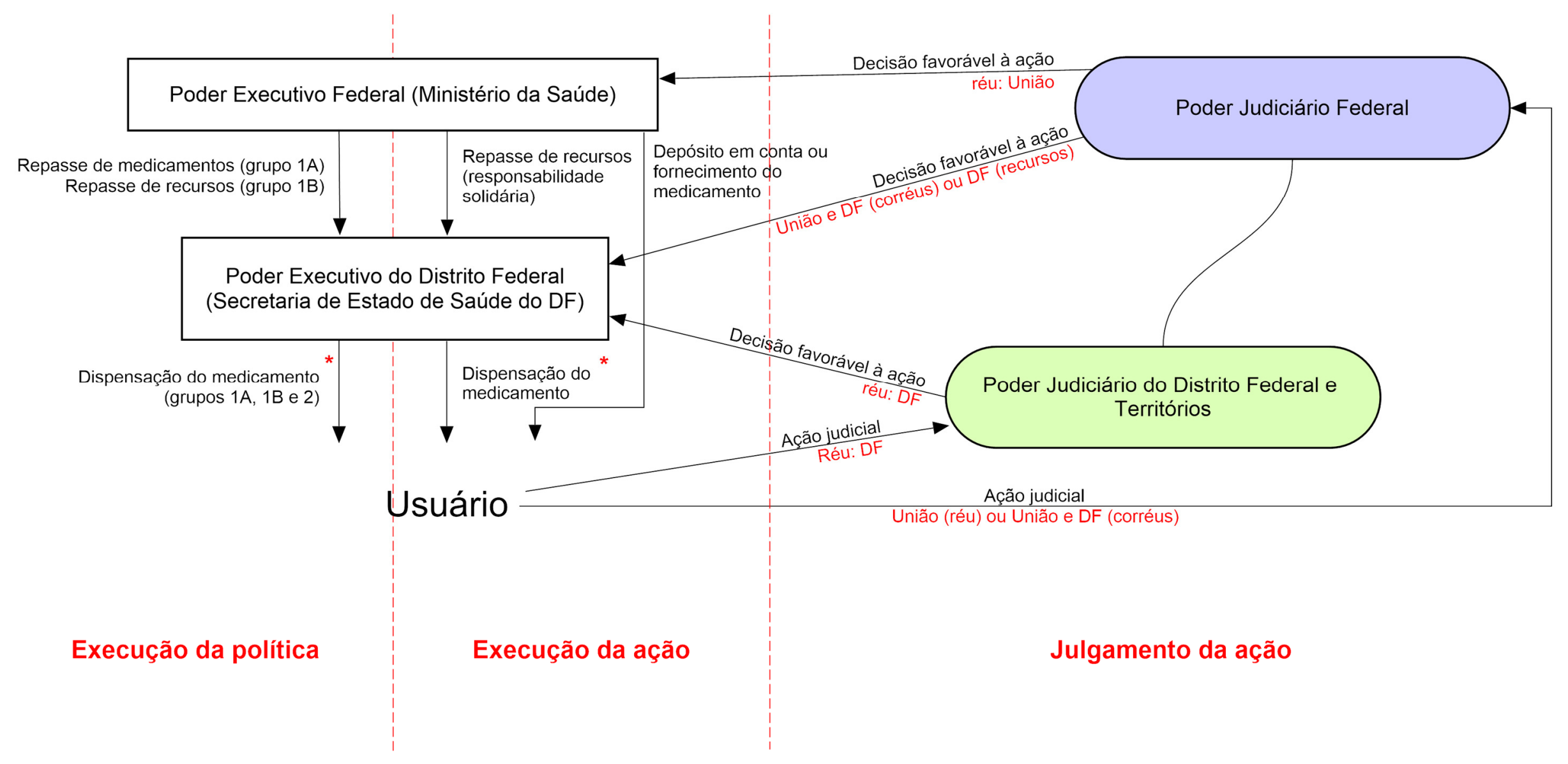

* O termo "dispensação" de medicamentos difere do ato de fornecimento, pois o primeiro envolve a entrega do produto acompanhada de orientação farmacêutica. Figura 6.5 - Modelo da operacionalização da judicialização de medicamentos.

Fonte: Da autora. 
Após a análise integrada dos dois casos, com relação à todas as categorias do estudo, as versões finais dos dois Quadros expõem os pontos que justificam e que orientam uma melhor organização do sistema interorganizacional da judicialização da saúde nos âmbitos federal e distrital.

Os elementos de todas as subcategorias do aparato administrativo foram então incorporados aos Quadros 6.9 e 6.10.

O Quadro 6.9 sintetiza os principais aspectos problemáticos, que justificam a preocupação em melhorar a gestão da judicialização da saúde. E o Quadro 6.10 representa então a síntese final dos elementos a serem considerados na proposta do modelo operacional da judicialização da saúde.

Quadro 6.9 - Aspectos que justificam a organização da relação executivo-legislativo nas demandas de saúde versão final

\begin{tabular}{|c|c|}
\hline $\mathbf{N}$ & $\begin{array}{l}\text { Aspectos que justificam a organização da relação executivo-judiciário nas demandas de } \\
\text { saúde }\end{array}$ \\
\hline 1 & $\begin{array}{l}\text { Necessidade de maior objetividade para as decisões judiciais, pautada pelo consenso de que o } \\
\text { direito à vida deve ser operacionalizado sob critérios técnicos e racionais. }\end{array}$ \\
\hline 2 & $\begin{array}{l}\text { Atuação legítima do Poder Judiciário e que se estabelece uma relação perene entre este Poder e o } \\
\text { Executivo. }\end{array}$ \\
\hline 3 & Deferimento majoritário de ações em saúde sem critério técnico norteador. \\
\hline 4 & Aumento do controle jurisdicional e do consequente impacto sobre a PNAF. \\
\hline 5 & Potencial avanço e aparelhamento das ações e serviços de saúde a partir da ação do judiciário. \\
\hline 6 & Complexidade do CEAF/PNAF e necessidade de respeito à esta condição e aos PCDT. \\
\hline 7 & $\begin{array}{l}\text { Preocupação e movimentação do Poder Judiciário em prol de medidas concretas de melhoria da } \\
\text { judicialização da saúde. }\end{array}$ \\
\hline 8 & $\begin{array}{l}\text { Impacto orçamentário e de gestão sobre o MS a partir da grande quantidade de ações judiciais que } \\
\text { o acionam como réu. }\end{array}$ \\
\hline 9 & Complexidade de organização da saúde pública e do CEAF/PNAF em seus vários aspectos. \\
\hline 10 & $\begin{array}{l}\text { Necessidade de subsídios para a intervenção do Poder Judiciário nas demandas em saúde, em } \\
\text { função da complexidade dos casos. }\end{array}$ \\
\hline 11 & $\begin{array}{l}\text { Dificuldade de compreensão das portarias e do planejamento das ações em saúde, por parte dos } \\
\text { magistrados. }\end{array}$ \\
\hline 12 & $\begin{array}{l}\text { A falta de embasamento clínico e uma compreensão clara dos riscos acrescenta maior } \\
\text { preocupação aos magistrados na investigação dos casos em saúde. }\end{array}$ \\
\hline 13 & $\begin{array}{l}\text { As prescrições que originam as ações são de profissionais da rede pública e rede privada, sendo } \\
\text { necessárias ações que alcancem estes dois grupos. }\end{array}$ \\
\hline
\end{tabular}

Fonte: Da autora. 
Quadro 6.10 - Aspectos do planejamento do CEAF/PNAF e da judicialização importantes para o processo de judicialização de medicamentos - versão final (continua)

\begin{tabular}{|c|c|c|c|c|}
\hline $\mathbf{N}$ & $\begin{array}{l}\text { Aspectos do } \\
\text { planejamento do } \\
\text { CEAF/PNAF e do } \\
\text { controle } \\
\text { jurisdicional } \\
\text { importantes para o } \\
\text { processo de } \\
\text { judicialização de } \\
\text { medicamentos }\end{array}$ & Situação atual & Situação sugerida & $\begin{array}{l}\text { Funções da } \\
\text { administração }\end{array}$ \\
\hline 1 & $\begin{array}{l}\text { Princípios e } \\
\text { diretrizes } \\
\text { estruturantes do } \\
\text { SUS: } \\
\text { descentralização; } \\
\text { universalidade; } \\
\text { integralidade e } \\
\text { equidade }\end{array}$ & $\begin{array}{l}\text { Não cumprimento } \\
\text { das diretrizes e } \\
\text { princípios. }\end{array}$ & $\begin{array}{l}\text { Resolução extrajudicial } \\
\text { quando adequado e } \\
\text { judicial somente para } \\
\text { casos não cobertos e que } \\
\text { admitam o fornecimento } \\
\text { de medicamentos pelo } \\
\text { governo. }\end{array}$ & $\begin{array}{l}\text { Organização - sistema } \\
\text { executivo } \\
\text { Coordenação - } \\
\text { executivo-judiciário }\end{array}$ \\
\hline 2 & $\begin{array}{l}\text { Objetivo da } \\
\text { Assistência } \\
\text { Farmacêutica - AF - } \\
\text { de garantir o uso } \\
\text { racional de } \\
\text { medicamentos - } \\
\text { PNAF. }\end{array}$ & $\begin{array}{l}\text { Não cumprimento } \\
\text { das diretrizes e } \\
\text { princípios. }\end{array}$ & $\begin{array}{l}\text { Conhecimento por parte } \\
\text { dos magistrados sobre os } \\
\text { preceitos da AF e } \\
\text { assimilação deste para as } \\
\text { decisões judiciais, por } \\
\text { meio da atuação do } \\
\text { farmacêutico como } \\
\text { prestador de informações. } \\
\text { E participação do } \\
\text { farmacêutico nos cuidados } \\
\text { com os medicamentos } \\
\text { judicializados. }\end{array}$ & $\begin{array}{l}\text { Planejamento - } \\
\text { sistema executivo } \\
\text { Informação - } \\
\text { executivo-judiciário } \\
\text { Coordenação - } \\
\text { executivo-judiciário }\end{array}$ \\
\hline \multirow[b]{2}{*}{3} & \multirow{2}{*}{$\begin{array}{l}\text { Critérios de } \\
\text { padronização dos } \\
\text { medicamentos - } \\
\text { RENAME e REME } \\
\text { do DF }\end{array}$} & \multirow{2}{*}{$\begin{array}{l}\text { Não conhecimento } \\
\text { e reconhecimento } \\
\text { dos critérios para a } \\
\text { escolha de } \\
\text { medicamentos para } \\
\text { uma política } \\
\text { coletiva. }\end{array}$} & $\begin{array}{l}\text { Conhecimento por parte } \\
\text { dos magistrados sobre os } \\
\text { critérios de padronização e } \\
\text { assimilação destes para as } \\
\text { decisões judiciais. }\end{array}$ & \multirow{2}{*}{$\begin{array}{l}\text { Planejamento - } \\
\text { sistema executivo } \\
\text { Coordenação - } \\
\text { executivo-judiciário }\end{array}$} \\
\hline & & & $\begin{array}{l}\text { São critérios mínimos para } \\
\text { o fornecimento de um } \\
\text { med. a eficácia, a } \\
\text { segurança e o custo- } \\
\text { efetividade; e o processo } \\
\text { deve ser acompanhado por } \\
\text { profissional competente. }\end{array}$ & \\
\hline 4 & $\begin{array}{l}\text { Critérios de } \\
\text { elaboração dos } \\
\text { Protocolos Clínicos e } \\
\text { Diretrizes } \\
\text { Terapêuticas - PCDT }\end{array}$ & $\begin{array}{l}\text { Não conhecimento } \\
\text { e reconhecimento } \\
\text { dos critérios para a } \\
\text { organização dos } \\
\text { cuidados em saúde } \\
\text { para uma política } \\
\text { coletiva. }\end{array}$ & $\begin{array}{l}\text { Conhecimento por parte } \\
\text { dos magistrados sobre os } \\
\text { critérios de organização } \\
\text { dos cuidados em saúde e } \\
\text { assimilação destes para as } \\
\text { decisões judiciais. }\end{array}$ & $\begin{array}{l}\text { Planejamento - } \\
\text { sistema executivo } \\
\text { Coordenação - } \\
\text { executivo-judiciário }\end{array}$ \\
\hline
\end{tabular}


Quadro 6.10 - Aspectos do planejamento do CEAF/PNAF e da judicialização importantes para o processo de judicialização de medicamentos - versão final (continuação)

\begin{tabular}{|c|c|c|c|c|}
\hline $\mathbf{N}$ & $\begin{array}{l}\text { Aspectos do } \\
\text { planejamento do } \\
\text { CEAF/PNAF e do } \\
\text { controle } \\
\text { jurisdicional } \\
\text { importantes para o } \\
\text { processo de } \\
\text { judicialização de } \\
\text { medicamentos }\end{array}$ & Situação atual & Situação sugerida & $\begin{array}{l}\text { Funções da } \\
\text { administração }\end{array}$ \\
\hline 5 & $\begin{array}{l}\text { Processo de revisão } \\
\text { da RENAME e dos } \\
\text { PCDT pela } \\
\text { CONITEC }\end{array}$ & $\begin{array}{l}\text { Não conhecimento } \\
\text { sobre o processo de } \\
\text { revisão das listas e } \\
\text { dos protocolos ou } \\
\text { não concordância } \\
\text { com estes } \\
\text { processos. }\end{array}$ & $\begin{array}{l}\text { Adequação do processo de } \\
\text { revisão das listas e dos } \\
\text { protocolos, pactuado e } \\
\text { reconhecido pelos Poderes } \\
\text { Executivo e Judiciário } \\
\text { (sistema executivo } \\
\text { verificando os casos } \\
\text { judicializados ao realizar a } \\
\text { revisão das listas e sistema } \\
\text { judiciário reconhecendo os } \\
\text { documentos como } \\
\text { instrumentos técnicos para } \\
\text { as decisões). }\end{array}$ & $\begin{array}{l}\text { Coordenação - } \\
\text { executivo-judiciário }\end{array}$ \\
\hline \multirow{4}{*}{6} & \multirow{4}{*}{$\begin{array}{l}\text { Diálogo aberto entre } \\
\text { as instituições dos } \\
\text { dois Poderes em } \\
\text { estudo. }\end{array}$} & \multirow{4}{*}{$\begin{array}{l}\text { Pouco diálogo entre } \\
\text { os dois Poderes na } \\
\text { rotina das decisões } \\
\text { judiciais, porém } \\
\text { com previsão atual } \\
\text { de cooperação } \\
\text { técnica (por meio } \\
\text { dos NATs) e com } \\
\text { existência atual do } \\
\text { Fórum Nacional e } \\
\text { os Comitês } \\
\text { Estaduais em } \\
\text { Saúde, do } \\
\text { Judiciário. }\end{array}$} & $\begin{array}{l}\text { - Conhecimento por parte } \\
\text { dos magistrados dos } \\
\text { preceitos da AF por meio } \\
\text { de canais de comunicação } \\
\text { entre os dois Poderes: }\end{array}$ & \multirow{4}{*}{$\begin{array}{l}\text { Organização - } \\
\text { executivo-judiciário } \\
\text { (NATs) } \\
\text { Coordenação - } \\
\text { executivo-judiciário } \\
\text { Direção - sistema } \\
\text { judiciário }\end{array}$} \\
\hline & & & $\begin{array}{l}\text { - Efetivação da cooperação } \\
\text { técnica entre magistrados e } \\
\text { médicos e farmacêuticos, } \\
\text { por meio dos NATs, para } \\
\text { análise das demandas } \\
\text { judiciais individuais (evitar } \\
\text { pareceres muito tecnicistas } \\
\text { - 37). }\end{array}$ & \\
\hline & & & $\begin{array}{l}\text { - Efetivação da cooperação } \\
\text { entre magistrados e } \\
\text { gestores públicos, para } \\
\text { análise das demandas } \\
\text { judiciais individuais. }\end{array}$ & \\
\hline & & & $\begin{array}{l}\text { - Efetivação da cooperação } \\
\text { entre interessados no SUS, } \\
\text { por meio de reuniões } \\
\text { (comitês e fóruns), para } \\
\text { problemas de gestão. }\end{array}$ & \\
\hline \multirow[b]{2}{*}{7} & \multirow{2}{*}{$\begin{array}{l}\text { Manutenção da } \\
\text { sustentabilidade } \\
\text { financeira das } \\
\text { políticas de saúde } \\
\text { (SUS). }\end{array}$} & \multirow{2}{*}{$\begin{array}{l}\text { O discurso } \\
\text { reconhece o } \\
\text { problema } \\
\text { financeiro, porém } \\
\text { não é aceito como } \\
\text { motivo para } \\
\text { impedir a } \\
\text { judicialização. }\end{array}$} & $\begin{array}{l}\text { Instituir monitoramento } \\
\text { cuidadoso dos gastos e a } \\
\text { realizar de uma previsão } \\
\text { mínima dos gastos }\end{array}$ & \multirow{2}{*}{$\begin{array}{l}\text { Orçamento - sistema } \\
\text { executivo (política e } \\
\text { judicialização) }\end{array}$} \\
\hline & & & $\begin{array}{l}\text { Execução das demais } \\
\text { medidas propostas e } \\
\text { consequente redução da } \\
\text { judicialização e de seu } \\
\text { impacto orçamentário. }\end{array}$ & \\
\hline
\end{tabular}


Quadro 6.10 - Aspectos do planejamento do CEAF/PNAF e da judicialização importantes para o processo de judicialização de medicamentos - versão final (continuação)

\begin{tabular}{|c|c|c|c|c|}
\hline $\mathbf{N}$ & $\begin{array}{l}\text { Aspectos do } \\
\text { planejamento do } \\
\text { CEAF/PNAF e do } \\
\text { controle } \\
\text { jurisdicional } \\
\text { importantes para o } \\
\text { processo de } \\
\text { judicialização de } \\
\text { medicamentos }\end{array}$ & Situação atual & Situação sugerida & $\begin{array}{l}\text { Funções da } \\
\text { administração }\end{array}$ \\
\hline 8 & $\begin{array}{l}\text { Critérios para o } \\
\text { registro dos } \\
\text { medicamentos na } \\
\text { ANVISA e } \\
\text { características deste } \\
\text { processo. }\end{array}$ & $\begin{array}{l}\text { Há ações deferidas } \\
\text { e indeferidas de } \\
\text { medicamentos sem } \\
\text { registro e baixo } \\
\text { índice de avaliação } \\
\text { adequada. }\end{array}$ & $\begin{array}{l}\text { Avaliação individual dos } \\
\text { casos de medicamentos } \\
\text { sem registro na ANVISA. }\end{array}$ & $\begin{array}{l}\text { Coordenação - } \\
\text { executivo-judiciário }\end{array}$ \\
\hline 9 & $\begin{array}{l}\text { Estabelecimento de } \\
\text { processo de } \\
\text { mediação efetiva, } \\
\text { com cobertura } \\
\text { integral dos casos. }\end{array}$ & $\begin{array}{l}\text { Há a mediação } \\
\text { somente para os } \\
\text { casos entre DPDF e } \\
\text { SES-DF como réu } \\
\text { (CAMEDIS). }\end{array}$ & $\begin{array}{l}\text { Manter a estrutura de } \\
\text { mediação na SES- } \\
\text { DF/DPDF e estabelecer } \\
\text { estrutura na DPU, para as } \\
\text { defensorias públicas. } \\
\text { Estabelecer uma estrutura } \\
\text { no TJDFT e no STF para } \\
\text { ações iniciadas por } \\
\text { advogados particulares. }\end{array}$ & $\begin{array}{l}\text { Organização - } \\
\text { executivo-judiciário } \\
\text { (CAMEDIS) } \\
\text { Coordenação - } \\
\text { executivo-judiciário } \\
\text { Direção - sistema } \\
\text { judiciário }\end{array}$ \\
\hline 10 & $\begin{array}{l}\text { Normatização do } \\
\text { CEAF/PNAF e da } \\
\text { judicialização da } \\
\text { saúde. }\end{array}$ & $\begin{array}{l}\text { Há seguimento da } \\
\text { CF e de } \\
\text { jurisprudências, por } \\
\text { parte do judiciário, } \\
\text { porém falta } \\
\text { reconhecimento das } \\
\text { normas da saúde. }\end{array}$ & $\begin{array}{l}\text { O reconhecimento das } \\
\text { normas da saúde e a } \\
\text { apropriação de seus } \\
\text { conteúdos para prática da } \\
\text { judicialização. }\end{array}$ & $\begin{array}{l}\text { Organização - sistema } \\
\text { executivo } \\
\text { Coordenação - } \\
\text { executivo-judiciário }\end{array}$ \\
\hline 11 & $\begin{array}{l}\text { Organização dos } \\
\text { órgãos envolvidos. }\end{array}$ & $\begin{array}{l}\text { Existência dos } \\
\text { departamentos, } \\
\text { porém muitos sem } \\
\text { registro formal das } \\
\text { estruturas e fluxos. }\end{array}$ & $\begin{array}{l}\text { Necessidade de registros, } \\
\text { como a formalização de } \\
\text { organogramas e fluxos } \\
\text { atualizados. }\end{array}$ & $\begin{array}{l}\text { Organização - sistema } \\
\text { executivo-judiciário } \\
\text { Informação - sistema } \\
\text { executivo-judiciário } \\
\text { Coordenação - } \\
\text { sistema executivo- } \\
\text { judiciário }\end{array}$ \\
\hline \multirow{3}{*}{12} & \multirow{3}{*}{$\begin{array}{l}\text { Recursos humanos } \\
\text { de qualidade e em } \\
\text { quantidade } \\
\text { suficiente. }\end{array}$} & \multirow{3}{*}{$\begin{array}{l}\text { Poucos } \\
\text { profissionais } \\
\text { trabalhando com a } \\
\text { judicialização, } \\
\text { principalmente no } \\
\text { sistema de saúde. }\end{array}$} & $\begin{array}{l}\text { Recursos humanos em } \\
\text { quantidade necessária para } \\
\text { a resolução das demandas. }\end{array}$ & \multirow{3}{*}{$\begin{array}{l}\text { Apoio, pessoal - } \\
\text { sistema executivo- } \\
\text { judiciário }\end{array}$} \\
\hline & & & $\begin{array}{l}\text { Capacitação adequada para } \\
\text { os recursos humanos } \\
\text { envolvidos com a } \\
\text { judicialização, para } \\
\text { manutenção da } \\
\text { funcionalidade do sistema. }\end{array}$ & \\
\hline & & & $\begin{array}{l}\text { Orientação dos prescritores } \\
\text { sobre as regras de } \\
\text { prescrição no SUS. }\end{array}$ & \\
\hline
\end{tabular}


Quadro 6.10 - Aspectos do planejamento do CEAF/PNAF e da judicialização importantes para o processo de judicialização de medicamentos - versão final (conclusão)

\begin{tabular}{|c|c|c|c|c|}
\hline $\mathbf{N}$ & $\begin{array}{l}\text { Aspectos do } \\
\text { planejamento do } \\
\text { CEAF/PNAF e do } \\
\text { controle } \\
\text { jurisdicional } \\
\text { importantes para o } \\
\text { processo de } \\
\text { judicialização de } \\
\text { medicamentos }\end{array}$ & Situação atual & Situação sugerida & $\begin{array}{l}\text { Funções da } \\
\text { administração }\end{array}$ \\
\hline \multirow{2}{*}{13} & \multirow{2}{*}{$\begin{array}{l}\text { Sistematização das } \\
\text { atividades } \\
\text { coordenadas. }\end{array}$} & \multirow{2}{*}{$\begin{array}{l}\text { Atividades } \\
\text { dissociadas, } \\
\text { executadas pelo } \\
\text { órgão responsável, } \\
\text { sem articulação ou } \\
\text { conhecimento dos } \\
\text { demais envolvidos. }\end{array}$} & $\begin{array}{l}\text { Reconhecimento das } \\
\text { atividades do sistema por } \\
\text { todas as partes e } \\
\text { articulação entre os órgãos, } \\
\text { na medida do necessário. }\end{array}$ & \multirow{2}{*}{$\begin{array}{l}\text { Planejamento - } \\
\text { sistema executivo- } \\
\text { judiciário } \\
\text { Direção - sistema } \\
\text { executivo-judiciário } \\
\text { Coordenação - } \\
\text { sistema executivo- } \\
\text { judiciário } \\
\text { Informação - sistema } \\
\text { executivo-judiciário }\end{array}$} \\
\hline & & & $\begin{array}{l}\text { Mecanismos gerenciais de } \\
\text { acompanhamento das } \\
\text { ações em saúde (36). }\end{array}$ & \\
\hline 14 & $\begin{array}{l}\text { Origem das } \\
\text { prescrições de ações } \\
\text { judiciais das redes } \\
\text { pública e privada. }\end{array}$ & $\begin{array}{l}\text { Não há ações em } \\
\text { busca da } \\
\text { conscientização dos } \\
\text { prescritores sobre a } \\
\text { judicialização; da } \\
\text { divulgação dos } \\
\text { protocolos e ações } \\
\text { de educação ou } \\
\text { repreensão pelas } \\
\text { prescrições fora dos } \\
\text { protocolos do } \\
\text { próprio local de } \\
\text { trabalho (caso da } \\
\text { rede pública). }\end{array}$ & $\begin{array}{l}\text { Definição de ações de } \\
\text { conscientização dos } \\
\text { prescritores sobre a } \\
\text { judicialização; de } \\
\text { divulgação dos protocolos } \\
\text { e de educação ou } \\
\text { repreensão pelas } \\
\text { prescrições fora dos } \\
\text { protocolos do próprio local } \\
\text { de trabalho (rede pública) } \\
\text { realizada por comissões } \\
\text { locais de análise das } \\
\text { prescrições dissidentes dos } \\
\text { protocolos.. }\end{array}$ & $\begin{array}{l}\text { Planejamento - } \\
\text { sistema executivo- } \\
\text { judiciário } \\
\text { Apoio, pessoal - } \\
\text { sistema executivo- } \\
\text { judiciário }\end{array}$ \\
\hline
\end{tabular}

Fonte: Da autora.

Como uma segunda forma de apresentar os resultados, a partir de uma perspectiva operacional, os aspectos dos Quadros que originaram ações foram agora adaptados na Figura 6.6. Este diagrama apresenta então uma sugestão de modelo operacional para o sistema interorganizacional da judicialização da saúde na União e no Distrito Federal.

Por fim, a partir das características identificadas para o fenômeno estudado e com base no conteúdo teórico que fundamentou a pesquisa (implementação de políticas públicas, coordenação interorganizacional, funções administrativas e controle jurisdicional), foi criado um último produto do trabalho, por meio do qual propõe-se um modelo (Figura 6.7) para o estudo de sistemas interorganizacionais executivo-judiciário 


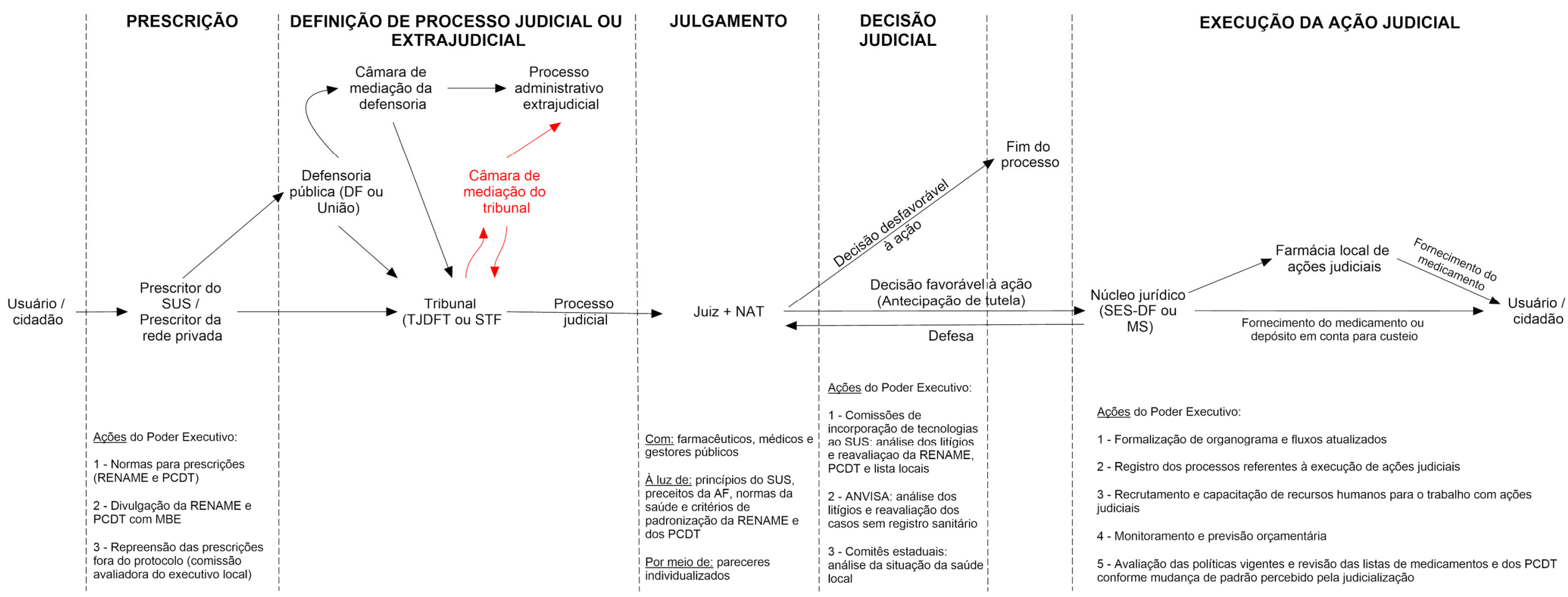

Figura 6.6 - Modelo operacional proposto para a judicialização de medicamentos no Brasil, nos níveis Federal e Distrital Fonte: Da autora. 


\section{SISTEMA INTERORGANIZACIONAL EXECUTIVO - JUDICIÁRIO}

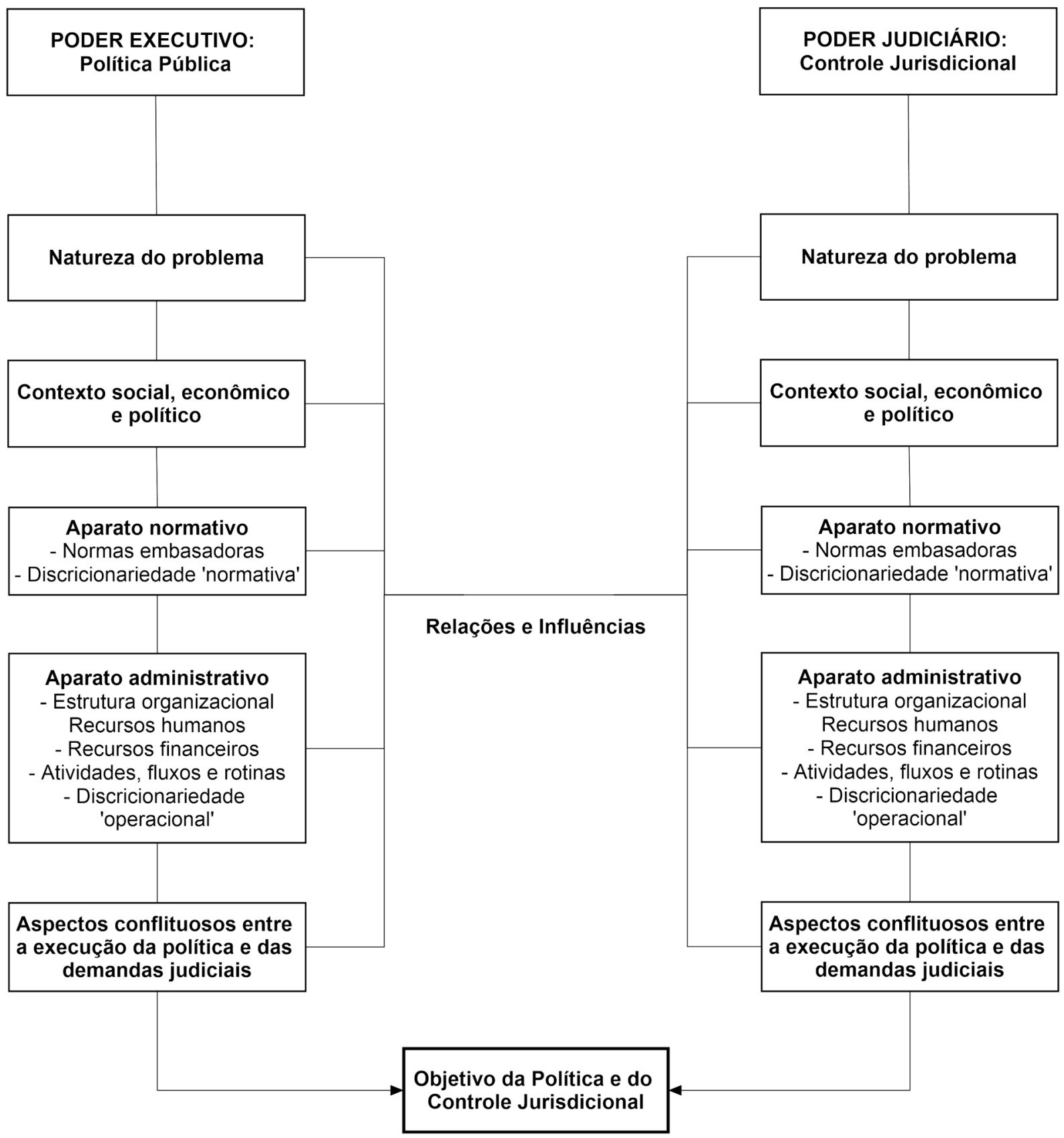

Figura 6.7: Modelo para o estudo de sistemas interorganizacionais executivo-judiciário. Fonte: Da autora. 


\section{CONCLUSÕES E RECOMENDAÇÕES}

As linhas que se seguiram tiveram por norte propor um modelo prático de implementação de Políticas Públicas de medicamentos junto ao controle jurisdicional da saúde. Para o alcance do objetivo em questão, fez-se necessário o conhecimento sobre a Política de medicamentos a ser estudada, bem como o controle do sistema judiciário sobre as Políticas de saúde. Assim, por meio de investigação exploratória e descritiva sobre os objetos supramencionados, foi possível evidenciar dois ricos sistemas para a implementação da Política e a operacionalização da judicialização - sistemas enfatizados nos Casos 01 e 02 aqui apresentados detalhadamente e em profundidade.

Para o Caso 01, referente à exploração da implementação do Componente Especializado da Assistência Farmacêutica/Política Nacional de Assistência Farmacêutica (CEAF/PNAF), foi evidenciado que se trata de uma Política bastante detalhada e bem estruturada. Em relação à questão foi possível observar uma evolução ao longo do tempo, além de avanços importantes na organização dos componentes da Assistência Farmacêutica (AF) quanto à sua execução e seu financiamento. Os resultados demonstraram a existência de aspectos técnicos que embasam o fornecimento de medicamentos aos usuários da rede pública, e que tais aspectos prezam pela eficácia e segurança dos produtos e, consequentemente, do tratamento dos pacientes. Um dado importante é que os critérios supramencionados são obtidos a partir de pesquisas científicas publicadas, e não a partir da opinião de especialistas.

Ainda sobre o Caso 01, foram levantadas as responsabilidades compartilhadas entre os Estados e os Municípios e entre estes e a União, que também participa como implementador da Política. As respectivas competências são claramente definidas em relação à operacionalização das ações e quanto às responsabilidades de custeio dos medicamentos. Foi evidenciado que nesta divisão de competências, os Estados e o Distrito Federal ganham certa autonomia para a definição de algumas atividades. E neste sentido, como estes possuem autonomia para determinar quais medicamentos padronizar e quais protocolos criar, passam a ter responsabilidade financeira sobre os produtos, tanto na oferta regular quanto na oferta judicial.

A presente pesquisa identificou várias normas que regem o sistema de saúde como um todov, bem como outros ditames voltados especificamente para a AF. São estas normas que 
garantem a boa organização das ações e os fluxos bem claros entre os órgãos envolvidos e interessados no acesso da população aos medicamentos.

No que tange ao Caso 02, que tratou do acesso aos medicamentos do componente especializado por via judicial, foi constatado que, dentro do Poder Judiciário tem-se uma grande preocupação com a matéria 'saúde'. Foi identificado o esforço por parte do sistema judiciário em estabelecer espaços de discussão sobre as ações em saúde, a fim de esclarecer as particularidades técnicas de tais ações. O julgamento vigente no Supremo Tribunal Federal (STF) quanto à decisão sobre a responsabilidade de custeio de medicamentos de alto custo, indiscriminadamente, pelo governo é um grande exemplo disto. A preocupação com a alta taxa de deferimento de ações judiciais, sem uma análise técnica quanto aos tratamentos solicitados, acarreta em elevados custos para o Estado e propicia risco ao paciente. Diante da ausência de comprovação científica sobre os riscos e benefícios de alguns medicamentos judicializados para determinadas indicações clínicas, a sua utilização nem sempre deveria ser indicada.

Quanto às questões operacionais, os fluxos do sistema jurídico seguem o proposto para todas as ações civis. Porém, notaram-se algumas iniciativas, como, por exemplo, o estabelecimento de parcerias entre o Poder Judiciário e o Poder Executivo (Conselho Nacional de Justiça - CNJ e Ministério da Saúde - MS, e Tribunal de Justiça do Distrito Federal e dos Territórios - TJDFT e Secretaria de Estado de Saúde do Distrito Federal SES/DF) no que tange aos espaços de discussão supramencionados, que visam suprir a dificuldade que os profissionais especialistas da área jurídica possuem no julgamento das matérias em saúde. E quanto aos demais órgãos do processo, identificou-se que a Defensoria Pública do Distrito Federal estruturou um Núcleo específico para a questão da saúde, com um espaço físico disponibilizado exclusivamente para este tipo de atendimento.

O fenômeno da judicialização é embasado pela Constituição Federal (CF) de 1988, do mesmo modo que as Políticas de saúde o são. A partir daí, várias questões conflituosas foram aqui identificadas, onde se faz a sugestão da consideração destas pelo Poder Judiciário na análise das demandas de saúde. Como apontado na discussão, o Sistema Único de Saúde (SUS) deve obedecer às diretrizes e aos princípios de descentralização, universalização, integralidade e equidade, e as ações judiciais interferem neste cumprimento em pelo menos três formas diferentes. Ou seja, duas destas se relacionam ao fato das ações priorizarem o indivíduo e não o coletivo: o deslocamento de recursos das ações públicas coletivas para 
ações judiciais individuais e a priorização no atendimento da demanda do indivíduo frente ao atendimento dos demais cidadãos que estão acessando pelo sistema de saúde; e a terceira diz respeito ao tipo de serviço ou produto fornecido pela via judicial. Neste último caso, pela maior parte dos julgamentos ser realizada por magistrados sem apoio técnico na área, o serviço ou o medicamento fornecido pode não ser o mais adequado ao caso e ferir o princípio do atendimento integral do paciente.

Mesmo com a constatação em questão, um ponto importante identificado pelas limhas que se seguiram e evidenciado, sobretudo, nas entrevistas com os atores do processo, é a preocupação dos Poderes Judiciário e Executivo com a garantia do direito à saúde e da sustentabilidade do SUS. Ou seja, foi evidenciado não somente que ambos os Poderes têm a competência de garantir o direito à saúde por meio do acesso aos medicamentos (e de outras ações e serviços de saúde que não foram alvos do presente estudo), mas também que é objetivo dos Poderes a sustentabilidade e sobrevivência do SUS. Mesmo que, nos casos individuais, a judicialização aparente não considerar os custos que os tratamentos judicializados acarretarão para o SUS, foi apurado que existe sim a consciência e preocupação por parte do sistema judiciário sobre a questão. De fato, o Poder Judiciário possui uma jurisprudência bem clara de que os limites orçamentários do sistema de saúde não justificam os problemas de gestão existentes e a não cobertura dos pacientes - o que não se mostra como um motivo para o indeferimento de ações. Ao mesmo tempo, o Judiciário tem discutido no STF os custos dos tratamentos judicializados, mas sob o ponto de vista dos pressupostos técnicos que limitem a judicialização.

A partir da compreensão dos Casos aqui apresentados, foi possível empreender uma análise que identificasse os elementos de interface entre a atuação do sistema judiciário e a atuação do sistema de saúde (Poder Executivo) - o terceiro objetivo específico do presente estudo. Nesta análise foram identificados diversos elementos que permeiam a $\mathrm{AF}$ e a judicialização da saúde, tanto conceituais quanto operacionais. A temática do registro de medicamentos pela Agência Nacional de Vigilância Sanitária (ANVISA), da periodicidade de revisão das listas de medicamentos padronizados pelo SUS e dos protocolos, do seguimento ou não da lista de padronizados pelos médicos do SUS, além da colaboração técnica de profissionais da saúde com os magistrados, são exemplos de questões existentes na relação entre os dois Poderes no contexto em questão. 
E é a partir da compreensão de como se dá a atual relação entre os Poderes Judiciário e Executivo que foram identificadas algumas das influências da judicialização sobre a Política aqui analisada. São vários os reflexos da judicialização sobre o sistema de saúde, desde o desenvolvimento de uma nova estrutura administrativa para lidar unicamente com a execução das ações judiciais, tanto no âmbito distrital quanto no âmbito federal, a designação de pessoal para o desenvolvimento destas novas atividades, até o custeio desta nova estrutura e dos objetos das ações. Tais pontos caracterizam a criação de uma estrutura para a operacionalização das ações aprovadas por via judicial. Além desse impacto, foi possível observar que a judicialização, ou melhor, as demandas por via judicial também pode influir na implementação em si da Política de medicamentos vigente. Um exemplo disso que emergiu dos dados obtidos na presente pesquisa seria quando a atuação do sistema judiciário provoca a reavaliação de aspectos do sistema de saúde, bem como na expectativa existente sobre a revisão da Relação Nacional de Medicamentos Essenciais (RENAME), das relações de medicamentos padronizados locais e dos Protocolos Clínicos e Diretrizes Terapêuticas, que levariam em consideração as ações judiciais movidas. A identificação destes fatores de influência atendeu o quarto objetivo específico do presente estudo.

Os achados relacionados ao atendimento dos quatro objetivos supramencionados, aliados aos do quinto e último objetivo específico (reconhecer nas características do processo atual de judicialização seus pontos fortes e falhos) sustentam a organização do modelo geral proposto para a operacionalização do controle jurisdicional na área de medicamentos do SUS. O modelo final criado reúne o fluxo padrão dos processos judiciais, porém, inclui sugestões de ações de responsabilidade dos sistemas executivo e judiciário, além dos dois sistemas, em parceria. Tais ações são propostas a partir de informações sobre mecanismos ou ações de coordenação pré-existentes e identificadas a partir da pesquisa, bem como a partir de sugestões que a análise possibilitou apontar.

O modelo proposto acrescenta um olhar voltado para os processos administrativos, o que representa uma contribuição teórico-prática das linhas que se seguiram ao cenário atual da judicialização da saúde. A base da proposta reside na constatação de que parte dos casos judiciais contra o sistema são desnecessários, e de que julgamentos informados a respeito de medicamentos e conhecimento dos critérios técnicos que tem por base evidências científicas para sua prescrição contribuiriam para decisões judiciais melhor fundamentadas. Assim, reconhecer a situação atual como um sistema interorganizacional onde a coordenação entre os 
Poderes é possível e necessária, além de abordar a gestão do sistema como um todo, permitirá a busca de soluções adequadas aos problemas existentes. A partir daí, é possível prever que a mediação entre o cidadão e o sistema de saúde, a análise técnica e científica das prescrições e tratamentos propostos nas ações judiciais, o seguimento das listas de medicamentos padronizados e de seus protocolos de cuidado e a melhora contínua das Políticas de saúde vigentes poderão reduzir as demandas por via judicial. O objetivo, de fato, não será negar o acesso aos medicamentos pleiteado pelas ações judiciais, mas sim, integrar o usuário as Política Públicas vigentes, podendo melhorar as próprias Políticas e garantir o acesso igualitário às mesmas.

Ao abordar a judicialização da saúde sob a perspectiva da Administração Pública, partindo da implementação de uma Política Pública até o entendimento de como a judicialização ocorre e influencia o sistema de saúde, a presente pesquisa se deparou com uma limitação teórica. A ausência de teoria nacional e internacional para examinar a relação Executivo-Judiciário mostrou-se um achado importante, uma vez que indicou tratar-se de um domínio não investigado a partir desta perspectiva. Tal aspecto veio à tona, pois, pouco países possuem a mesma previsão de um sistema de saúde com cobertura universal aos seus cidadãos. E enquanto a literatura jurídica brasileira se debruça sobre os temas "controle jurisdicional" e "interferência do Poder Judiciário sobre o Poder Executivo", e a literatura brasileira da saúde aborda o perfil e os impactos das ações judiciais pelo direito à saúde, o campo da Administração ainda não se apropriou do tema.

Quanto à forma de investigação da relação supramencionada, optou-se aqui tomar emprestado alguns modelos do campo da Administração. Tal abordagem pode ser útil em estudos futuros que se interessem pela relação Executivo-Judiciário no contexto de outras questões de judicialização. Porém, sendo os modelos pensados para tratar de relações Executivo-Executivo, são necessárias adaptações conforme o foco do estudo, uma vez que não há um Poder superior ao outro que possa exercer uma voz de comando sobre os demais. A autonomia das partes tem similaridades com o que se vê em outras relações interorganizacionais onde não há uma autoridade hierárquica em comum. De fato, coordenar tal relação requer parceria e cooperação voluntária entre os dois Poderes.

Fazendo uso das classificações de Alexander (1998) e de Gulick e Urwick (2005), a presente pesquisa descobriu que apesar de haver dois Poderes e dois sistemas operacionais diferentes para cada um deles, com normas e diretrizes próprias, era possível qualificar a 
interface entre os dois Poderes como um grande sistema interorganizacional ao redor da questão de acesso a medicamentos especializados. Então, a partir deste achado, é possível sugerir a utilização da classificação POSDCORB sobre as funções administrativas para entender a gestão do sistema e das partes do sistema, com o entendimento de que a função de coordenação se refere a dois Poderes públicos independentes e administrativamente distintos.

Embora a meta-estrutura de coordenação em cada um dos dois Poderes seja hierárquica, a meta-estrutura de coordenação da relação entre eles seria de associação solidária, com base no compartilhamento de valores, tais como: o direito à vida, o direito à saúde e a garantia da dignidade humana. A meso-estrutura de coordenação seria uma rede solidária, ou seja, um tipo de comuna onde se agrupam atores sociais independentes com o propósito de melhorar algo e de coordenar os trabalhos de interesse geral. Finalmente, para tocar o dia a dia da relação, tem-se as micro-estruturas ou mecanismos de coordenação caracterizadas por relações formais e informais (ALEXANDER, 1999) aqui apontadas anteriormente. Além das estruturas de coordenação da relação, a presença de todas as funções administrativas foi identificada como relevante à gestão da relação estudada (planejamento, organização, recursos humanos, direção, coordenação, informação e orçamento) (GULICK; URWICK, 2005).

Quanto ao objeto estudado, conclui-se que a CF de 1988 e a Lei Orgânica da Saúde Lei n. 8.080, de 19 de setembro de 1990 - são normas singulares que se destacam no cenário mundial, pois preveem o atendimento integral aos brasileiros e a cobertura de todos os cidadãos. A garantia do direito à saúde, no entanto, por ser um direito positivo, exige ação, ou seja, prestação de serviços por parte do Estado - o que acarreta em relevância econômica no contexto das Políticas Públicas. Enquanto são bem aceitos os papéis dos Poderes Executivo e Legislativo, há muita discussão na literatura sobre a legitimidade ou não da atuação do Poder Judiciário sobre as Políticas Públicas, apesar de sua previsão constitucional. Além disso, observou-se que o direito à saúde não está bem delimitado no plano conceitual e normativo. Quer dizer, não há aprofundamento e delimitação do que seria esse direito por normas infraconstitucionais que possam guiar os julgamentos em saúde. Logo, para tal questão, os resultados do presente estudo sugerem a utilidade do empoderamento de informações oriundas do sistema da saúde para o sistema judiciário, para o auxílio nas decisões judiciais.

Outras recomendações que emergem do cenário estudado para a atuação do Judiciário podem ser apontadas, tais como: a conveniência de conscientizar os profissionais de saúde 
(com destaque para os prescritores) e a própria população sobre o funcionamento do SUS, a normatização do sistema de saúde, a organização da AF e o conceito de cidadania e de direitos individuais versus coletivos. Aconselha-se ainda o desenvolvimento de estratégias de gestão para o SUS que envolvam a revisão da forma e da dinamicidade da padronização dos medicamentos, da criação e atualização dos protocolos de cuidado e dos processos de registro de medicamentos. Por fim, preconiza-se melhorar a comunicação entre todas as partes envolvidas com a judicialização: os Poderes Executivo e Judiciário e a população.

Como potenciais contribuições do presente estudo, apresentam-se, em primeiro lugar, as contribuições metodológicas. Uma é a organização e apresentação das categorias de pesquisa, com base na literatura de implementação de Políticas Públicas e adaptadas para o fenômeno estudado. Percebeu-se que os dois Casos aqui investigados envolvem, no campo conceitual, um processo de implementação: de Políticas, no Caso 01; e de execução de uma atividade, que seria o controle jurisdicional, no Caso 02. A aplicação das categorias da teoria de implementação de Políticas Públicas, devidamente adaptadas, se mostrou adequada para as linhas que se seguiram de como se dá a judicialização na prática, ou seja, da implementação da judicialização.

O aspecto exploratório e descritivo do estudo possibilitou a descrição em profundidade dos dois Casos. Especificamente, a abordagem exploratória do segundo Caso se mostrou inovadora, trazendo insights em todas as categorias analíticas frente às discussões sobre a judicialização da saúde existentes atualmente na literatura das áreas de Direito e Saúde. Mesmo no primeiro Caso, apesar de tratar-se de uma política bastante estudada, os olhares aqui desenvolvidos sobre o objeto identificaram características também não descritas na literatura, tais como: a identificação em profundidade das normas embasadoras, a discussão da discricionariedade administrativa, a descrição do aparato administrativo e a identificação dos aspectos conflituosos dos critérios técnicos estruturantes da Política e o contexto judicial.

Para a área do Direito, o presente estudo contribui com a identificação e análise da jurisprudência nacional relacionada ao pleito por medicamentos, realizada pela revisão de diversos casos e de recomendações documentadas. Neste sentido, como exemplo, tem-se a discussão da judicialização sob a perspectiva de ser um problema de coordenação entre Poderes.

Outro aspecto original foi a discussão da prática profissional do gestor e do juiz, sob a perspectiva da discricionariedade tal como é compreendida para cada uma das profissões e 
perfil de atuação. Neste ponto se deu a caracterização de uma diferenciação da discricionariedade tal qual ela se apresenta no âmbito conceitual e normativo para o profissional (discricionariedade 'normativa') e quais são as formas, de fato, escolhidas e executadas pelo profissional (discricionariedade 'operacional').

Também constam como produtos e contribuições da presente Tese a elaboração dos fluxos de atividades e recursos entre os órgãos envolvidos com a implementação do CEAF/PNAF (União e Distrito Federal) para cada um dos Grupos de medicamentos identificados (1A, 1B e 2). E ainda tem-se a elaboração dos fluxos entre os principais órgãos estudados do Poder Executivo (MS e SES/DF) e do Poder Judiciário (STF e TJDFT) quanto a operacionalização da judicialização da saúde.

Para a via judicial, a análise dos dados coletados possibilitou a identificação de quatro tipos diferentes de ações judiciais por acesso a medicamentos (abertura de ação sem ineficácia da política como motivo; ação por medicamento padronizado, porém em desabastecimento; ação por medicamento padronizado, porém paciente fora dos Protocolos Clínicos e Diretrizes Terapêuticas (PCDT); e, ação por medicamento não padronizado) e a organização de seus respectivos fluxos operacionais para o fornecimento destes medicamentos. Para a compreensão da judicialização, do ponto de vista operacional e administrativo, a tipicação e identificação dos fluxos respectivos é um achado importante, uma vez que não há nenhuma classificação deste tipo apontada nos documentos estudados ou proposta na literatura existente.

Em geral, podem também ser consideradas colaborações para com o campo de investigação da judicialização o levantamento do Estado da Arte sobre a judicialização da saúde no Brasil, bem como os resultados de interface e influência entre a atuação dos Poderes Judiciário e Executivo nas Políticas de medicamentos.

A linha histórica elaborada com os principais eventos relacionados à PNAF e ao controle jurisdicional da saúde pública brasileira pode auxiliar futuros estudos como um ponto de partida para a compreensão do fenômeno da judicialização.

E como última contribuição, voltada ao campo de pesquisa em Políticas Públicas, foi proposto um modelo com o delineamento de categorias para o estudo de casos envolvendo a relação Executivo-Judiciário.

Finalmente, o modelo com a descrição do fluxo operacional e das ações propostas para aprimorar o funcionamento do sistema interpoderes de judicialização de medicamentos 
consolidou todos os resultados obtidos, propiciando uma contribuição teórica para o campo do conhecimento, além de uma contribuição prática para a atuação dos dois Poderes.

A partir destes resultados e pelo fato do fenômeno caracterizar um campo de investigação um tanto quanto inexplorado, vale apontar algumas recomendações de futuras pesquisas, a saber: o desenvolvimento de propostas teóricas para o estudo da relação Executivo-Judiciário e de estratégias e mecanismos para a coordenação prática entre estes dois Poderes independentes. E ainda, faz-se por bem sugerir um aprofundamento sobre a definição de discricionariedade e as propostas conceituais aqui apresentadas, além da investigação da aplicabilidade tanto do conceito de discricionaridade normativa quanto de discrecionaridade operacional em outras realidades, ou seja, na implementação de outras Políticas Públicas.

Um achado importante do presente estudo - que até o momento não foi explorado por nenhum outro (e que, de modo preocupante, não é o ponto de discussão atual no contexto da judicialização) são os gastos associados à judicialização. Quer dizer, investigam-se os gastos que resultam do custeio dos medicamentos e demais produtos e serviços judicializados, mas não os custos relacionados da estrutura e dos processos necessários para efetivar sua entrega. Recomenda-se que futuros estudos foquem nos custos das novas estruturas administrativas que foram criadas para a execução das demandas judiciais e de sua manutenção.

Outros pontos que merecem maior atenção de pesquisa incluem: 1) averiguar se e como a Administração Pública processa e incorpora as informações provenientes da judicialização no monitoramento e avaliação das Políticas Públicas; e, 2) se e como o faz para a priorização de novos problemas, definição da agenda e formulação de novas Políticas.

Por fim, ainda em relação às sugestões de pesquisa, do mesmo modo como aqui foi possível observar - o fenômeno de judicialização sob a perspectiva de acesso a medicamentos especializados -, é relevante a exploração da atuação do sistema judiciário na defesa do direito de acesso a outros serviços de saúde ou mesmo na garantia de outros direitos e outras áreas de Políticas Públicas.

Em suma, a judicialização do direito social à saúde não é em si o problema. O problema se dá no uso desnecessário ou inadequado desta via para acessar os serviços já disponibilizados por via regular ou para o alcance de ações e serviços de saúde de qualidade questionáveis e que podem, inclusive, oferecer riscos aos cidadãos. Durante o desenvolvimento da presente pesquisa foi identificada a existência de lacunas operacionais 
para as quais existem ações possíveis para tornar melhor criterioso e técnico o julgamento em saúde. Foi a partir destas descobertas que as linhas que aqui se seguiram ganharam forma, direcionando a construção do modelo supramencionado, que objetiva a decisão judicial favorável aos casos de exceção e que garantam segurança ao tratamento dos cidadãos brasileiros. 


\section{REFERÊNCIAS}

AGÊNCIA BRASIL. STF suspende novamente julgamento sobre remédios de alto custo - 28 de setembro de 2016. Disponível em: < http://agenciabrasil.ebc.com.br/geral/noticia/201609/stf-suspende-novamente-julgamento-sobre-remedios-de-alto-custo $>$ Acesso em 7 out. 2016.

AGÊNCIA BRASÍLIA. GDF inaugura segunda Farmácia Especializada - 27 de janeiro de 2012a. Disponível em: <http://www.agenciabrasilia.df.gov.br/noticias/>. Acesso em 11 jul. 2016.

Aula inaugural da ESCS - 09 de fevereiro de 2012b. Disponível em: $<\mathrm{http}$ ///www.agenciabrasilia.df.gov.br/noticias/>. Acesso em 11 jul. 2016.

. Defensoria Pública promove mutirão em Taguatinga - 25 de outubro de 2012c.

Disponível em: <http://www.agenciabrasilia.df.gov.br/noticias/>. Acesso em 11 jul. 2016.

. Saúde ganha Câmara de Mediação - 28 de fevereiro de 2013. Disponível em:

$<\mathrm{http} / / / \mathrm{www}$.agenciabrasilia.df.gov.br/noticias/>. Acesso em 11 jul. 2016.

Rede pública está abastecida de medicamento para hemofílicos - 24 de junho de 2016. Disponível em: <http://www.agenciabrasilia.df.gov.br/2016/06/24/rede-publica-estaabastecida-de-medicamento-para-hemofilicos/ >. Acesso em 11 jul. 2016.

ALEXANDER, E. R. A structuration theory of inteorganizational coordination: cases in environmental management. International Journal of Organizational Analysis. Vol. 6, p. 334-354. Out.1998.

ALMEIDA, B. T. A. Discricionariedade judicial e teoria do direito. Revista CEI. Brasília, ano XVII, n. 60, p. 55-64. maio/ago. 2013.

ALMEIDA JUNIOR, J. E. Discricionariedade Jurídica. In: Âmbito Jurídico, Rio Grande, VIII, n. 23, out 2005. Disponível em: <http://www.ambitojuridico.com.br/site/index.php?n_link=revista_artigos_leitura\&artigo_id=282>. Acesso em 25 set 2016.

ALVES, V. A Relação entre o poder legislativo e o poder executivo no contrato social de Jean-Jacques Rousseau. Revista Synesis, v. 1, n. 2. 2009. Disponível em: < http://seer.ucp.br/seer/index.php?journal=synesis\&page=article\&op=download\&path $\% 5 \mathrm{~B} \% 5$ $\mathrm{D}=45$ \&path\%5B\%5D=44>. Acesso em 14 out. 2016.

ANDRADE, E.I.G.; MACHADO, C.D.; FALEIROS, D.R.; SZUSTER, D.A.C.; JÚNIOR, A.A.G.J.; SILVA, G.D.; CHERCHIGLIA, M.L.; ACÚRCIO, F.A. A judicialização da saúde e a política nacional de assistência farmacêutica no Brasil: gestão da clínica e medicalização da justiça. Revista de Medicina de Minas Gerais, v.18, n. 4, suplemento 4, p.46-50, 2008. 
BARBOSA, S. C. T.; MEDEIROS, J. J. Coordenação Interorganizacional na implementação de programas públicos. Revista Gestão e Planejamento, ano 6, n. 11, Salvador, jan/jun, p. 47-60. 2005.

BARBOSA, A. R. Relação Executivo-Legislativo municipal brasileiro: produção dos Projetos de Leis em Salvador. Revista Cadernos de Estudos Sociais e Políticos, v.4, n.7, jan-junho 2015. Disponível em: <

http://cadernos.iesp.uerj.br/index.php/CESP/article/view/160/135>. Acesso em 14 out. 2016.

BARROS, J. B. Separação de Poderes, controle jurisdicional de políticas públicas e Neoconstitucionalismo. Revista Âmbito Jurídico. Disponível em:

$<$ http://www.ambitojuridico.com.br/site/?n_link=revista_artigos_leitura\&artigo_id=11078\&re vista_caderno=9>. Acesso em 12 out. 2016.

BARROSO, L.R. Da falta de efetividade à judicialização excessiva: direito à saúde, fornecimento gratuito de medicamentos e parâmetros para a atuação judicial.

Disponível em: <http://www.conjur.com.br/dl/estudobarroso.pdf>. Acesso em 20 jun 2016.

BARDIN, L. Análise de conteúdo. Lisboa: Edições 70. 1979.

BAUER, M.W.; GASKELL, G. Pesquisa Qualitativa com Texto, Imagem e Som - Um Manual Prático. 7 ed. Petrópolis, RJ: Vozes, 2008.

BENBASAT, I.; GOLDSTEIN, D. K.; MEAD, M. The case research strategy in studies of information systems. MIS Quarterly, v. 11, n. 3, p. 369-386, Sept. 1987.

BENEVIDES, M. V. M. Cidadania e Democracia. Revista Lua Nova, n. 33, 1994. p. São Paulo, CEDEC, n. 33, p. 7-16, 1994.

BITTENCOURT, F. M. R. Relações executivo-legislativo no presidencialismo de coalizão: Um Quadro de Referência para Estudos de Orçamento e Controle. Núcleo de Estudos e Pesquisas do Senado - Textos para Discussão 112. Abril/2012. Disponível em: < https://www12.senado.leg.br/publicacoes/estudos-legislativos/tipos-de-estudos/textos-paradiscussao/td-112-relacoes-executivo-legislativo-no-presidencialismo-de-coalizao-um-quadrode-referencia-para-estudos-de-orcamento-e-controle>. Acesso em 14 out. 2016.

BOBBIO, N.; MATTEUCCI, N.; PASQUINO, G. Dicionário de Política. v. 2.5 ed. Brasília e Imprensa Oficial do Estado de São Paulo: Editora Universidade de Brasília, 1993.

BONAVIDES, P. Curso de Direito Constitucional. 24ª ed. São Paulo: Malheiros, 2009.

BOWEN, G. A. Naturalistic inquiry and the saturation concept: A research note. Qualitative Research, 8(1), 137-152. 2008.

BRANDÃO, C. M. R. ; GUERRA JR, A. A. ; CHERCHIGLIA, M. L. ; ANDRADE, E. I. G.; ALMEIDA, A. M.; SILVA, G. D.; QUEIROZ, . V.; FALEIROS, . R. ; ACURCIO, F. A.

Gastos do Ministério da Saúde do Brasil com medicamentos de alto custo: Uma análise centrada no paciente. Value in Health. 14, p. S71-S77, 2011. 
BRASIL. Lei $n^{0}$ 5.991, de 17 de dezembro de 1973. Dispõe sobre o Controle Sanitário do Comércio de Drogas, Medicamentos, Insumos Farmacêuticos e Correlatos, e dá outras Providências. Disponível em: < http://www2.camara.leg.br/legin/fed/lei/1970-1979/lei-599117-dezembro-1973-358064-normaatualizada-pl.pdf>. Acesso em 2 out 2015.

Ministério da Saúde.. Portaria Interministerial no 3 MPAS/MS/MEC, de 15 de dezembro de 1982. Disponível em: <http://www.jusbrasil.com.br/diarios/3569233/pg-107secao-1-diario-oficial-da-uniao-dou-de-16-12-1982>. Acesso em 2 set de 2016.

Constituição (1988). Constituição da República Federativa do Brasil: promulgada em 5 de outubro de 1988. Disponível em: <http://www.planalto.gov.br/ccivil_03/constituicao/constitui\%C3\%A7ao.htm>. Acesso em 2 out de 2015.

Lei $n^{0} 8.080$, de 19 de setembro de 1990. Dispõe sobre as condições para a promoção, proteção e recuperação da saúde, a organização e o funcionamento dos serviços correspondentes e dá outras providências. Diário Oficial da União, Brasília, DF, 20 set. 1990a. p. 018055.

Lei n. ${ }^{\circ} 8142$, de 28 de dezembro de 1990. Dispõe sobre a participação da comunidade na gestão do sistema único de saúde (SUS) e sobre as transferências intergovernamentais de recursos financeiros na área da saúde e dá outras providências. Diário Oficial da União, Brasília, DF, 31 dez. 1990b.

Lei $n^{0}$ 8.689, de 27 de julho de 1993a. Dispõe sobre a extinção do Instituto Nacional de Assistência Médica da Previdência Social (Inamps) e dá outras providências. Disponível em: <http://www.planalto.gov.br/ccivil_03/leis/L8689.htm>. Acesso em 2 out de 2015.

. Lei Orgânica do Distrito Federal (1993). Lei Orgânica do Distrito

Federal: promulgada em 08 de junho de 1993b. Disponível em:

$<$ http://www.fazenda.df.gov.br/aplicacoes/legislacao/legislacao/TelaSaidaDocumento.cfm?txt Numero $=0 \&$ txtAno $=0 \&$ txtTipo $=290 \&$ txtParte $=.>$. Acesso em 2 out de 2015.

. Ministério da Saúde. Portaria SAS/MS no 142, de 06 de outubro de 1993c.

Disponível em: < http://www.jusbrasil.com.br/diarios/1305182/pg-1-secao-1-diario-oficialda-uniao-dou-de-06-10-1993>. Acesso em 2 set de 2016.

Ministério da Saúde. Portaria SAS/MS no 204, de 06 de novembro de 1996. Disponível em: < sna.saude.gov.br/legisla/legisla/med/SAS_P204_96med.doc>. Acesso em 2 set de 2016.

. Ministério da Saúde. Portaria SAS/MS n 17, de 22 de janeiro de 1997a. Disponível em: <http://portalsaude.saude.gov.br/images/pdf/2014/abril/03/portaria-sas-ms-17-1997.pdf>. Acesso em 2 set de 2016.

. Ministério da Saúde. Portaria n 653/PGJ, de 01 de setembro de 1997b. Disponível em: <http://www.mpdft.mp.br/portal/>. Acesso em 7 set de 2016. 
BRASIL. Ministério da Saúde. Portaria no 3.916/GM, de 30 de outubro de 1998. Disponível em: < http://www.cff.org.br/userfiles/file/portarias/3916_gm.pdf >. Acesso em 5 set. 2016.

. Ministério da Saúde. Portaria SAS/MS no 409, de 05 de agosto de 1999. Disponível em: <http://portalsaude.saude.gov.br/images/pdf/2014/abril/03/portaria-sas-ms-4091999.pdf>. Acesso em 5 set. 2016.

Lei $\mathrm{n}^{0} 2.804$, de 25 de outubro de 2001.Dispõe sobre os direitos dos usuários dos serviços e das ações de saúde no Distrito Federal. Disponível em:

$<$ http://www.tc.df.gov.br/SINJ/BaixarArquivoNorma.aspx?id_norma=50760 >. Acesso em 5 set 2016.

. Ministério da Saúde. Portaria GM/MS n 1.318, de 23 de julho de 2002a. Define, para o grupo 36, medicamentos, da Tabela Descritiva do Sistema de Informações Ambulatoriais do Sistema Único de Saúde - SIA/SUS, a forma e a redação no anexo desta portaria. Disponível em: <http://u.saude.gov.br/images/pdf/2014/abril/03/pt-gm-ms-13182002.pdf>. Acesso em 5 set 2016.

Ministério da Saúde. Portaria SAS/MS n 921 , de 22 de novembro de 2002b.

Disponível em: < http://portalsaude.saude.gov.br/images/pdf/2014/julho/28/Portaria-SAS921-de-2002.pdf>. Acesso em 5 set. 2016.

Ministério da Saúde. O Sistema Público de Saúde Brasileiro. Seminário Internacional: Tendências e Desafios dos Sistemas de Saúde nas Américas. Brasília: Editora do Ministério da Saúde, 2002c. 44 p.

. Lei n. ${ }^{\circ} 10.742$, de 6 de outubro de 2003. Define normas de regulação para o setor farmacêutico, cria a Câmara de Regulação do Mercado de Medicamentos - CMED e altera a Lei $\mathrm{n}^{\circ}$ 6.360, de 23 de setembro de 1976, e dá outras providências. Disponível em: <http://www.camara.gov.br/sileg/integras/445721.pdf>. Acesso em 5 set 2016.

. Ministério da Saúde. Resolução no 338, de 06 de maio de 2004. Disponível em: < http://portal.saude.gov.br/portal/arquivos/pdf/resol_cns338.pdf>. Acesso em 5 set. 2016.

. Ministério da Saúde. Portaria SAS/MS no 203, de 19 de abril de 2005. Disponível em: <http://portalsaude.saude.gov.br/images/pdf/2014/julho/28/Portaria-SAS-203-de2005.pdf $>$. Acesso em 5 set. 2016.

. Ministério da Saúde. Assistência farmacêutica na atenção básica: instruções técnicas para sua organização - 2. ed. - Brasília : Ministério da Saúde, 2006a. 100 p.

Ministério da Saúde. Conselho Nacional de Saúde. Diretrizes nacionais para o processo de educação permanente no controle social do SUS / Ministério da Saúde, Conselho Nacional de Saúde - Brasília : Editora do, 2006b. 40 p. - (Série A. Normas e Manuais Técnicos) 
BRASIL. Conselho Nacional de Secretários de Saúde. SUS: avanços e desafios. Conselho Nacional de Secretários de Saúde. - Brasília: CONASS, 2006c. 164 p.

. Ministério da Saúde. Portaria n. ${ }^{\circ}$ 2.577, de 27 de outubro de 2006d. Aprova o Componente de Medicamentos de Dispensação Excepcional. Disponível em: $<$ http://pfdc.pgr.mpf.mp.br/atuacao-e-conteudos-deapoio/legislacao/saude/portarias/portaria_2577.2006>. Acesso em 5 set 2016.

. Ministério da Saúde. Portaria SAS/MS no 768, de 26 de outubro de 2006e.

Disponível em: <http://portalsaude.saude.gov.br/images/pdf/2014/abril/03/pt-sas-ms-7682006.pdf>. Acesso em 5 set. 2016.

Ministério da Saúde. Portaria GM/MS n. 204, de 29 de janeiro de 2007a.

Regulamenta o financiamento e a transferência dos recursos federais para as ações e os serviços de saúde, na forma de blocos de financiamento, com o respectivo monitoramento e controle. Disponível em:

<http://adcon.rn.gov.br/ACERVO/cerest/doc/DOC000000000043304.PDF>. Acesso em 5 set 2016.

Ministério da Saúde. Primeira retificação da Portaria GM/MS no 2.577, 26 de fevereiro de 2007b. Disponível em:

$<$ http://portalsaude.saude.gov.br/images/pdf/2014/abril/03/retificacao-i-pt-gm-ms-25772006.pdf>. Acesso em 5 set. 2016.

. Ministério da Saúde. Segunda retificação da Portaria GM/MS no 2.577, 26 de abril de 2007c. Disponível em:

$<$ http://portalsaude.saude.gov.br/images/pdf/2014/abril/03/retificacao-ii-pt-gm-ms-25772006.pdf>. Acesso em 5 set. 2016.

. Ministério da Saúde. Portaria GM/MS n 1.869, de 4 de setembro de 2008.

Disponível em: <http://portalsaude.saude.gov.br/images/pdf/2014/abril/03/pt-sas-ms-7682006.pdf>. Acesso em 5 set. 2016.

Ministério da Saúde. Secretaria-Executiva. Subsecretaria de Planejamento e Orçamento. Sistema de Planejamento do SUS : uma construção coletiva : organização e funcionamento. v.1. 3. ed. Brasília : Ministério da Saúde, 2009a. 100 p. - (Série B. Textos Básicos de Saúde).

. Ministério da Saúde. Portaria no 2.981, de 26 de novembro de 2009b. Aprova o Componente Especializado da Assistência Farmacêutica. Disponível em: <http://189.28.128.100/dab/docs/legislacao/portaria2982_26_11_09.pdf>. Acesso em 5 set 2016.

Ministério da Saúde. Participação social no SUS: o olhar da gestão municipal. Conasems, Brasília: Ministério da Saúde, 2009c. 28 p. 
BRASIL. Ministério da Saúde. Portaria n. ${ }^{\circ}$ 2.670, de 3 de novembro de 2009d. Aprova o Regimento Interno da Comissão Intergestores Tripartite - CIT. Disponível em <http://bvsms.saude.gov.br/bvs/saudelegis/gm/2009/prt2670_03_11_2009.html>. Acesso em 10 set. 2016.

Conselho Nacional de Justiça. Portaria n. ${ }^{\mathbf{6}} \mathbf{6 5 0}$ de 20 de novembro de 2009e. Cria grupo de trabalho para estudo e proposta de medidas concretas e normativas para as demandas judiciais envolvendo a assistência à saúde. Diário Oficial da União, Brasília, DF, 24 nov. 2009e.

Ministério da Saúde. Decreto n. ${ }^{\mathbf{1}} \mathbf{1 . 8 2 0}$, de 13 de agosto de 2009f. Dispõe sobre os direitos e deveres dos usuários da saúde. Disponível em <http://bvsms.saude.gov.br/bvs/saudelegis/gm/2009/prt1820_13_08_2009.html>. Acesso em 10 jul. 2016.

. Ministério da Saúde. Portaria GM/MS no 106, de 22 de janeiro de 2009fg Disponível em: <http://portalsaude.saude.gov.br/images/pdf/2014/abril/03/pt-sas-ms-768-2006.pdf>. Acesso em 5 set. 2016.

Ministério da Saúde. Da excepcionalidade às linhas de cuidado: o Componente Especializado da Assistência Farmacêutica. Brasília: Ministério da Saúde, 2010a. 262 p.

. Conselho Nacional de Justiça. Resolução n. ${ }^{\mathbf{0}} 107$ de 06 de abril de 2010b. Institui o Fórum Nacional do Judiciário para monitoramento e resolução das demandas de assistência à saúde. Disponível em: <http://www.cnj.jus.br/files/atos_administrativos/resoluo-n107-06-042010-presidncia.pdf>. Acesso em 10 jul 2016.

Conselho Nacional de Justiça. Recomendação n. ${ }^{\circ} 31$ de 30 de março de 2010c. Recomenda aos Tribunais a adoção de medidas visando a melhor subsidiar os magistrados e demais operadores do direito, para assegurar maior eficiência na solução das demandas judiciais envolvendo a assistência à saúde. Disponível em: < http://www.cnj.jus.br/files/atos_administrativos/recomendao-n31-30-03-2010presidncia.pdf>. Acesso em 5 set 2016.

Ministério da Saúde. Portaria GM/MS no 343, de 22 de fevereiro de 2010d.

Disponível em: <http://portalsaude.saude.gov.br/images/pdf/2014/abril/03/pt-gm-ms-3432010.pdf >. Acesso em 4 set. 2016.

. Ministério da Saúde. Retificação da Portaria GM/MS no 343, 3 de março de 2010e. Disponível em: <http://portalsaude.saude.gov.br/images/pdf/2014/abril/03/retificacao-pt-gmms-343-2010.pdf>. Acesso em 4 set. 2016.

. Ministério da Saúde. Portaria GM/MS n 743, de 8 de abril de 2010f. Disponível em: $<$ http://portalsaude.saude.gov.br/images/pdf/2014/abril/03/pt-gm-ms-743-2010.pdf >. Acesso em 4 set. 2016. 
BRASIL. Ministério da Saúde. Portaria GM/MS n 3.128, de 14 de outubro de 2010g. Disponível em: <http://portalsaude.saude.gov.br/images/pdf/2014/abril/03/pt-gm-ms-31282010.pdf >. Acesso em 4 set. 2016.

Ministério da Saúde. Portaria GM/MS no 3.439, de 11 de novembro de 2010h. Disponível em: <http://portalsaude.saude.gov.br/images/pdf/2014/abril/03/pt-gm-ms-34392010.pdf>. Acesso em 4 set. 2016.

. Ministério da Saúde. Portaria SCTIE/MS n 19, de 30 de dezembro de 2010i Disponível em: <http://portalsaude.saude.gov.br/images/pdf/2014/abril/03/pt-sctie-ms-192010.pdf >. Acesso em 4 set. 2016.

Lei n. ${ }^{\circ}$ 12.401, de 28 de abril de 2011a. Altera a Lei no ${ }^{\circ}$ 8.080, de 19 de setembro de 1990, para dispor sobre a assistência terapêutica e a incorporação de tecnologia em saúde no âmbito do Sistema Único de Saúde - SUS. Disponível em: <https://www.planalto.gov.br/ccivil_03/_ato2011-2014/2011/lei/112401.htm>. Acesso em 5 set 2016.

Decreto n. ${ }^{\mathbf{0}} \mathbf{7 . 5 0 8}$, de 28 de junho de 2011b. Regulamenta a Lei $\mathrm{n}^{\mathrm{O}} 8.080$, de 19 de setembro de 1990, para dispor sobre a organização do Sistema Único de Saúde - SUS, o planejamento da saúde, a assistência à saúde e a articulação interfederativa, e dá outras providências. Disponível em: <http://www.planalto.gov.br/ccivil_03/_ato20112014/2011/decreto/D7508.htm>. Acesso em 5 set 2016.

Decreto n. ${ }^{\circ}$ 7.646, de 21 de dezembro de 2011c. Dispõe sobre a Comissão Nacional de Incorporação de Tecnologias no Sistema Único de Saúde e sobre o processo administrativo para incorporação, exclusão e alteração de tecnologias em saúde pelo Sistema Único de Saúde - SUS, e dá outras providências. Disponível em:

<http://www.planalto.gov.br/ccivil_03/_Ato2011-2014/2011/Decreto/D7646.htm>. Acesso em 5 set 2016.

Lei n..$^{\mathbf{1 2}} \mathbf{4 6 6}$, de 24 de agosto de 2011e. Acrescenta arts. 14-A e 14-B à Lei no 8.080, de 19 de setembro de 1990, que "dispõe sobre as condições para a promoção, proteção e recuperação da saúde, a organização e o funcionamento dos serviços correspondentes e dá outras providências", para dispor sobre as comissões intergestores do Sistema Único de Saúde (SUS), o Conselho Nacional de Secretários de Saúde (Conass), o Conselho Nacional de Secretarias Municipais de Saúde (Conasems) e suas respectivas composições, e dar outras providências. Disponível em: <http://www.planalto.gov.br/CCIVIL_03/_Ato20112014/2011/Lei/L12466.htm>. Acesso em 5 set 2016.

Tribunal de Justiça do Distrito Federal e dos Territórios. Instrução n. ${ }^{\circ}$ 6, de 23 de dezembro de 2011f. Recomenda aos juízes de direito do TJDFT a observância de critérios para assegurar maior eficiência na solução das demandas judiciais envolvendo a saúde pública. Disponível em: <http://www2.tjdft.jus.br/administrativo/publicacoes/instrucoes/2011/instrucao_6.doc>. Acesso em 10 jul. 2016. 
BRASIL. Conselho Nacional de Justiça. Portaria n. ${ }^{\mathbf{2}}$ 25, de 22 de março de $2011 \mathrm{~g}$. Designa membros para compor os Comitês Executivos Estaduais no âmbito do Fórum Nacional do Judiciário para a Saúde. Disponível em:

<http://www.cnj.jus.br///images/atos_normativos/portaria/portaria_25_22032011_171020121 72730.pdf>. Acesso em 10 jul. 2016.

Conselho Nacional de Justiça. Portaria n. ${ }^{\circ}$ 49, de 6 de junho de 2011h. Acrescenta os incisos XV a XXVII à Portaria n. ${ }^{\circ}$ 25, de 22 de março de 2011, e altera dispositivos dos incisos III. VI, VII, XI e XIV da mesma norma. Disponível em:

<http://www.cnj.jus.br/images/programas/forumdasaude/Portaria\%20n\%2049-GP.pdf>. Acesso em 10 jul. 2016.

Ministério da Saúde. Portaria SCTIE/MS no 2, de 16 de março de 2011i. Disponível em: <http://portalsaude.saude.gov.br/images/pdf/2014/abril/03/pt-sctie-ms-2-2011.pdf >. Acesso em 4 set. 2016.

Ministério da Saúde. Portaria SCTIE/MS no 7, de 13 de junho de 2011j. Disponível em: <http://portalsaude.saude.gov.br/images/pdf/2014/abril/03/pt-sctie-ms-7-2011.pdf>. Acesso em 4 set. 2016.

Ministério da Saúde. Portaria GM/MS no 2.079, de 1 de setembro de 20111.

Disponível em: <http://portalsaude.saude.gov.br/images/pdf/2014/abril/03/pt-gm-ms-20792011.pdf>. Acesso em 4 set. 2016.

Ministério da Saúde. Portaria GM/MS no 2.928, de 12 de dezembro de $2011 \mathrm{~m}$.

Disponível em: <http://portalsaude.saude.gov.br/images/pdf/2014/abril/03/pt-gm-ms-29282011.pdf>. Acesso em 4 set. 2016.

Brasil. Vocabulário Controlado de Formas Farmacêuticas, Vias de Administração e Embalagens de Medicamentos, $1^{a}$ Edição / Agência Nacional de Vigilância Sanitária. Brasília: Anvisa, 2011n. Disponível em $<$ http://portal.anvisa.gov.br/documents/33836/354054/vocabulario_controlado_medicamentos _Anvisa.pdf/fd8fdf08-45dc-402a-8dcf-fbb3fd21ca75>. Acesso em 10 de out 2016.

. Ministério da Saúde. Resolução n. ${ }^{\circ}$ 1, de 17 de janeiro de 2012a. Estabelece as diretrizes nacionais da Relação Nacional de Medicamentos Essenciais (RENAME) no âmbito do Sistema Único de Saúde (SUS). Disponível em:

<http://bvsms.saude.gov.br/bvs/saudelegis/cit/2012/res0001_17_01_2012.html>. Acesso em 10 jul. 2016.

Portaria n. ${ }^{\circ}$ 533, de 2 de março de 2012b. Estabelece o elenco de medicamentos e insumos da Relação Nacional de Medicamentos Essenciais (RENAME) no âmbito do Sistema Único de Saúde (SUS). Disponível em: < http://bvsms.saude.gov.br/bvs/saudelegis/gm/2012/prt0533_28_03_2012.html>. Acesso em 10 jul. 2016. 
BRASIL. Lei complementar n. ${ }^{\circ} 141$, de 13 de janeiro de 2012c. Regulamenta o $\S 3^{\circ}$ do art. 198 da Constituição Federal para dispor sobre os valores mínimos a serem aplicados anualmente pela União, Estados, Distrito Federal e Municípios em ações e serviços públicos de saúde; estabelece os critérios de rateio dos recursos de transferências para a saúde e as normas de fiscalização, avaliação e controle das despesas com saúde nas 3 (três) esferas de governo; revoga dispositivos das Leis $\mathrm{n}^{\text {os }} 8.080$, de 19 de setembro de 1990, e 8.689, de 27 de julho de 1993; e dá outras providências. Disponível em:

<http://www.planalto.gov.br/ccivil_03/leis/LCP/Lcp141.htm>. Acesso em 5 set 2016.

. Tribunal de Justiça do Distrito Federal e dos Territórios. Portaria GPR n. ${ }^{\mathbf{0}}$

464, de 17 de abril de 2012d. Altera a composição do Comitê Executivo do Distrito Federal no âmbito do Fórum Nacional do Judiciário para a Saúde. Disponível em:

<http://www.tjdft.jus.br/publicacoes/publicacoes-oficiais/portarias-gpr/2012/00464.html>. Acesso em 5 set 2016.

. Tribunal de Justiça do Distrito Federal e dos Territórios. Portaria GPR n. ${ }^{\circ}$ 1.423, de 25 de outubro de 2012e. Altera a composição do Comitê Executivo do Distrito Federal no âmbito do Fórum Nacional do Judiciário para a Saúde - Resolução 107 CNJ, de 6 de abril de 2010. Disponível em: <http://www.tjdft.jus.br/publicacoes/publicacoesoficiais/portarias-gpr/2012/01423.html>. Acesso em 5 set 2016.

Ministério da Saúde. Portaria GM/MS n 1.091, de 28 de maio de 2012f. Disponível em: <http://portalsaude.saude.gov.br/images/pdf/2014/abril/03/pt-gm-ms-1091-2012.pdf >. Acesso em 6 set. 2016.

. Ministério da Saúde. Portaria GM/MS no 1.103, de 28 de maio de 2012g. Disponível em: <http://portalsaude.saude.gov.br/images/pdf/2014/abril/03/pt-gm-ms-1103-2012.pdf>. Acesso em 6 set. 2016.

Portaria n. ${ }^{\mathbf{1}}$ 1554, de 30 de julho de 2013a. Dispõe sobre as regras de financiamento e execução do Componente Especializado da Assistência Farmacêutica no âmbito do Sistema Único de Saúde (SUS). Disponível em: < http://bvsms.saude.gov.br/bvs/saudelegis/gm/2013/prt1554_30_07_2013.html>. Acesso em 10 jul. 2016.

Portaria n. ${ }^{\circ}$ 1.996, de 11 de setembro de 2013b. Altera a Portaria no 1.554/GM/MS, de 30 de julho de 2013. Diário Oficial da União, Brasília, DF, 12 set. 2013.

Ministério da Saúde, Portaria n. ${ }^{\circ}$ 2.135, de 25 de setembro de 2013c. Estabelece diretrizes para o processo de planejamento no âmbito do Sistema Único de Saúde (SUS). Disponível em: <http://bvsms.saude.gov.br/bvs /saudelegis/gm/2013/prt2135_25_09_2013.html>. Acesso em 10 jul. 2016.

Ministério da Saúde. Portaria SAS/MS no 257, de 12 de março de 2013d. Disponível em: <http://portalsaude.saude.gov.br/images/pdf/2014/abril/03/pt-sas-ms-257-2013.pdf>. Acesso em 6 set. 2016. 
BRASIL. Ministério da Saúde. Portaria SAS/MS no 284, de 20 de março de 2013e. Disponível em: <http://portalsaude.saude.gov.br/images/pdf/2014/abril/03/pt-sas-ms-2842013.pdf>. Acesso em 6 set. 2016.

Ministério da Saúde. Portaria SAS/MS no 745, de 5 de julho de 2013f. Disponível em: <http://portalsaude.saude.gov.br/images/pdf/2014/abril/03/pt-sas-ms-745-2013.pdf>. Acesso em 6 set. 2016.

. Ministério da Saúde. Portaria GM/MS no 2.978, de 4 de dezembro de 2013g. Disponível em: <http://portalsaude.saude.gov.br/images/pdf/2014/abril/03/pt-gm-ms-29782013.pdf>. Acesso em 6 set. 2016.

. Ministério da Saúde. Portaria GM/MS no 2.979, de 4 de dezembro de 2013h. Disponível em: <http://portalsaude.saude.gov.br/images/pdf/2014/abril/03/pt-gm-ms-29792013.pdf>. Acesso em 6 set. 2016.

. Ministério da Saúde. Portaria GM/MS no 2.981, de 4 de dezembro de 2013 i. Disponível em: <http://portalsaude.saude.gov.br/images/pdf/2014/abril/03/pt-gm-ms-29812013.pdf $>$. Acesso em 6 set. 2016.

Ministério da Saúde. Portaria SAS/MS no 1.447, de 26 de dezembro de 2013j. Disponível em: <http://portalsaude.saude.gov.br/images/pdf/2014/abril/03/pt-sas-ms-14472013.pdf>. Acesso em 6 set. 2016.

Ministério da Saúde. Portaria GM/MS no 3.293, de 26 de dezembro de 20131.

Disponível em: <http://portalsaude.saude.gov.br/images/pdf/2014/abril/03/pt-gm-ms-32932013.pdf $>$. Acesso em 6 set. 2016.

Secretaria de Estado de Saúde do Distrito Federal. Portaria Conjunta n. ${ }^{\circ}$ 01, de 26 de fevereiro de 2013m. Institui a Câmara Permanente Distrital de Mediação em Saúde (CAMEDIS). Disponível em: <http://www.tjdft.jus.br/institucional/comite-executivodistrital-da-saude/camedis/portaria-conjunta-no-01-de-26-de-fevereiro-de-2013>. Acesso em 10 jul. 2016.

Ministério da Saúde. Componente Especializado da Assistência Farmacêutica: inovação para a garantia do acesso a medicamentos no SUS. Brasília: Ministério da Saúde, 2014a. 163 p.

Ministério da Saúde. Portaria SCTIE/MS no 6, de 25 de fevereiro de 2014b. Disponível em: <http://portalsaude.saude.gov.br/images/pdf/2014/abril/03/pt-sctie-ms-62014.pdf>. Acesso em 6 set. 2016.

Ministério da Saúde. Portaria GM/MS no 799, de 5 de maio de 2014c. Disponível em: <http://portalsaude.saude.gov.br/images/pdf/2014/maio/07/Portaria-n---799-de-5-demaio-de-2014---Extens--o-prazo-Glaucoma.pdf>. Acesso em 6 set. 2016. 
BRASIL. Ministério da Saúde. Portaria SAS/MS no 683, de 06 de agosto de 2014d. Disponível em: <http://portalsaude.saude.gov.br/images/pdf/2014/agosto/08/Portaria-683-de2014-leflunomida-pramipexol-toxina-calcitriol-tocilizumabe.pdf>. Acesso em 6 set. 2016.

. Ministério da Saúde. Portaria no 2.127, de 30 de setembro de 2014e. Disponível em: $<$ http://portalsaude.saude.gov.br/images/pdf/2014/outubro/21/pt-2127-de-2014-aquisi----ocentralizada-cabergolina.pdf>. Acesso em 6 set. 2016.

. Ministério da Saúde. Portaria no 49, de 22 de dezembro de 2014f. Disponível em: $<$ http://portalsaude.saude.gov.br/images/pdf/2014/dezembro/29/Portaria-SCTIE-n-49-de2014--inclui-procedimento-para-fingolimode.pdf>. Acesso em 6 set. 2016.

Ministério da Saúde. Portaria n $\mathbf{n}^{\mathbf{2}} \mathbf{2 6 6 5}$, de 29 de dezembro de 2014g. Disponível em: $<$ http://portalsaude.saude.gov.br/images/pdf/2014/dezembro/30/Portaria-2865-de-2014.pdf>. Acesso em 6 set. 2016.

. Conselho Nacional de Justiça. Portaria n. ${ }^{\mathbf{0}} 40$ de 25 de março de 2014h. Cria o Comitê Organizador do Fórum Nacional do Poder Judiciário para monitoramento e resolução das demandas de assistência à saúde. Disponível em:

<http://www.cnj.jus.br///images/atos_normativos/portaria/portaria_40_25032014_270320141 34822.pdf>. Acesso em 10 jul. 2016.

. Tribunal de Justiça do Distrito Federal e dos Territórios. Portaria GPR n. ${ }^{\mathbf{0}}$ 1.735, de 14 de outubro de 2014i. Revoga as Portarias GPR 464 e 1423, ambas de 2012 e altera a composição do Comitê Executivo do Distrito Federal no âmbito do Fórum Nacional do Judiciário para monitoramento e resolução das demandas de assistência à Saúde Resolução 107 CNJ, de 06 de abril de 2010. Disponível em: $<$ http://www.tjdft.jus.br/publicacoes/publicacoes-oficiais/portarias-gpr/2014/portaria-gpr1735-de-14-10-2014>. Acesso em 10 jul. 2016.

em:

Ministério da Saúde. Portaria GM/MS no 410, de 13 de abril de 2015a. Disponível $<$ http://pesquisa.in.gov.br/imprensa/jsp/visualiza/index.jsp?jornal=1\&pagina=40\&data=14/04 /2015>. Acesso em 2 set. 2016.

em:

Ministério da Saúde. Portaria SAS/MS no 361, de 23 de abril de 2015b. Disponível $<$ http://pesquisa.in.gov.br/imprensa/jsp/visualiza/index.jsp?data=24/04/2015\&jornal=1\&pagi na=75\&totalArquivos=168>. Acesso em 2 set. 2016.

Ministério da Saúde. Portaria SCTIE/MS no 29, de 22 de junho de 2015c.

Disponível em:

$<$ http://pesquisa.in.gov.br/imprensa/jsp/visualiza/index.jsp?jornal=1\&pagina $=65 \&$ data $=23 / 06$ /2015\%20>. Acesso em 2 set. 2016.

. Ministério da Saúde. Portaria SAS/MS nº 583, de 8 de julho de 2015d. Disponível em: <http://pesquisa.in.gov.br/imprensa/jsp/visualiza/index.jsp? jornal=1\&pagina=60\&data=09/07/2015>. Acesso em 2 set. 2016. 
BRASIL. Ministério da Saúde. Portaria GM/MS no 1.330, de 08 de setembro de 2015e. Disponível em: <http://portalsaude.saude.gov.br/images/pdf/2015/setembro/09/Portariacentraliza----o-riluzol.pdf>. Acesso em 2 set. 2016.

Ministério da Saúde. Secretaria de Ciência, Tecnologia e Insumos Estratégicos. Departamento de Assistência Farmacêutica e Insumos Estratégicos. Relação Nacional de Medicamentos Essenciais: RENAME 2014 / Ministério da Saúde, Secretaria de Ciência, Tecnologia e Insumos Estratégicos, Departamento de Assistência Farmacêutica e Insumos Estratégicos. - 9. ed. - Brasília : Ministério da Saúde, 2015f. 228 p.

. Secretaria de Estado de Saúde do Distrito Federal. Decreto no 36.918, de 26 de novembro de 2015g. Disponível em: <http://www.jusbrasil.com.br/diarios/105185489/dodfsecao-01-27-11-2015-pg-3>. Acesso em 28 set de 2016.

Ministério da Saúde. Portaria no 1.055, de 24 de maio 2016a. Aprova o repasse de recursos para Estados e Distrito Federal, a título de financiamento, referente a abril, maio e junho de 2016, para aquisição de medicamentos do Componente Especializado da Assistência Farmacêutica conforme Tabela de Procedimentos, Medicamentos, Órteses, Próteses e Materiais Especiais do Sistema Único de Saúde. Diário Oficial da União, Brasília, DF, 27 mai. 2016. Disponível em:

$<$ http://pesquisa.in.gov.br/imprensa/jsp/visualiza/index.jsp?jornal=1\&pagina=35\&data=27/05 /2016>. Acesso em 2 set. 2016.

Conferências e os Conselhos de Saúde. Disponível em:

$<$ http://sistemaunicodesaude.weebly.com/conferecircncias-e-conselhos.html >. Acesso em 9 set. $2016 b$.

Conselho Nacional de Justiça. Portaria GPR n. 8 de 2 de fevereiro de 2016c. Cria o Comitê Organizador do Fórum Nacional do Poder Judiciário para monitoramento e resolução das demandas de assistência à saúde. Disponível em:

$<$ http://www.tjdft.jus.br/publicacoes/publicacoes-oficiais/portarias-gpr/2016/portaria-gpr1621-de-08-09-2016>. Acesso em 5 set 2016.

Ministério Público da União. Ministério Público do Distrito Federal e Territórios. Manual de atuação para a tutela dos direitos metaindividuais. Disponível em: $<$ http://www.mpdft.mp.br/pdf/unidades/camaras/ManualMetasIndividuais.pdf> Acesso em 03 de jul de 2016d.

BRYMAN, A. Quantity and quality in social research. London: Routledge, 1988.

CALADO, M. R. Controle Jurisdicional dos Atos Administrativos Discricionários. Âmbito Jurídico. Disponível em: <http://www.ambitojuridico.com.br/site/index.php?n_link=revista_artigos_leitura\&artigo_id=9517>. Acesso em 27 out 2016.

CAMBI, E. Neoconstitucionalismo e neoprocessualismo. Panóptica, v. 2, n. 2, 2007. 
CAPPELLETTI, M. Juízes Legisladores? Porto Alegre: Fabris, 1993.

CARVALHO, J. M. Cidadania no Brasil: o longo caminho. 2. ed. Rio de Janeiro: Civilização Brasileira, 2002.

CASTRO, R. B. Eficácia, Eficiência e Efetividade na Administração Pública. $30^{\circ}$ Encontro da ANPAD. Salvador/ Bahia: 2006.

CHIEFFI, A.L.; BARATA, R.B. Judicialização da política pública de assistência farmacêutica e equidade. Caderno de Saúde Pública, Rio de Janeiro, v. 25, n. 8. p. 18391849, ago. 2009.

COELHO, J. S. Construindo a Participação Social no SUS: um constante repensar em busca de equidade e transformação. Saúde e Sociedade. São Paulo, v.21, supl.1, p.138-151, 2012.

COELHO, T.C.B.; ARAÚJO, T.M.; ALMEIDA, T.S.C.; SILVA, E.A.L.; SANTOS, D.V. Discursos de trabalhadores da Estratégia Saúde da Família sobre o SUS. Revista de Saúde Coletiva. UEFS, Feira de Santana, v. 5, n. 1, p. 1-8, dez. 2015.

CONITEC. A comissão. Disponível em: <http://conitec.gov.br/entenda-a-conitec-2>. Acesso em 9 set. 2016.

CONSELHO FEDERAL DE FARMÁCIA. Busca de informação sobre medicamentos: como separar o joio do trigo? Farmacoterapêutica. Ano XIII, n. 1 a 3, jan-jun. 2008.

CONSELHO NACIONAL DE JUSTIÇA. Fórum da Saúde. Disponível em:

<http://www.cnj.jus.br/programas-e-acoes/forum-da-saude>. Acesso em 06 jul. 2016.

CNJ firma parceria com Ministério da Saúde e realiza 236 a sessão plenária. Disponível em: <http://www.cnj.jus.br/programas-e-acoes/forum-da-saude>. Acesso em 06 ago. 2016. . Relatório de demandas relacionadas à saúde nos tribunais até 2011. Disponível em: < http://www.cnj.jus.br/programas-e-acoes/forum-da-saude/quantidade-de-demandas-nostribunais>. Acesso em: 08 jul. 2016.

Relatórios de cumprimento da Resolução CNJ n. 107. Relatório de demandas relacionadas à saúde nos tribunais - dados enviados até junho de 2014. Disponível em: $<$ http://www.cnj.jus.br/images/programas/forumdasaude/demandasnostribunais.forumSaude.p df>. Acesso em: 08 jul. 2016.

Declaração do I Encontro do Fórum Nacional do Judiciário para a Saúde. Disponível em: <http://www.cnj.jus.br/programas-e-acoes/forum-da-saude/documentos>. Acesso em: 08 jul. 2016. 
CONSELHO NACIONAL DE SAÚDE. Diretrizes Aprovadas nos Grupos de Trabalho ou na Plenária Final - Por Ordem de Votação nos Eixos Temáticos - 04 de dezembro de 2015. Disponível em: < http://conferenciasaude15.org.br/wpcontent/uploads/2016/01/Diretrizes-Aprovadas-Vers\%C3\%A3o-Final.pdf>. Acesso em 20 de jun de 2016.

CONSELHO NACIONAL DE SECRETÁRIOS DE SAÚDE. O direito à saúde e a proposta de cobertura universal. Revista Consensus. Ed. 19. 2016a. Disponível em: <http://www.conass.org.br/consensus/category/edicao-19/>. Acesso em 12 jul. 2016.

O esgotamento do modelo de financiamento do SUS. Revista Consensus. Ed. 19. 2016b. Disponível em: <http://www.conass.org.br/consensus/category/edicao-19/>. Acesso em 12 jul. 2016.

Judicialização na Saúde. Revista Consensus. Ed. 19. 2016c. Disponível em: $<$ http://www.conass.org.br/consensus/category/edicao-19/>. Acesso em 12 jul. 2016.

CONTI, M. A.; FOLLE, A. D.; NAVES, J. O. S. Avaliação das demandas judiciais por acesso a medicamentos do Distrito Federal. Revista Eletrônica Gestão \& Saúde, v. 06, n. 1. p. $245-265.2015$.

CORREA, D.; MASSAFRA, C.Q. O direito à saúde e o papel do judiciário para a sua efetividade no Brasil. Editora Unijuí, ano 2, n. 3, p. 45-70, jan./jun. 2004.

CORREA, M.V.C. Controle Social na Saúde. In: MOTA, A.E. et al. Serviço Social e Saúde: Formação e Trabalho Profissional. São Paulo: Cortez, 2007. 408p

CORREIO BRAZILIENSE. 90 novos leitos de UTI - 07 de junho de 2012. Disponível em: < http://www.correiobraziliense.com.br/cidades---df/>. Acesso em 10 jul. 2016.

Saúde quer criar comissão para tentar reduzir número de derrotas judiciais - 20 de agosto de 2015. Disponível em: < http://www.correiobraziliense.com.br/cidades---df/>. Acesso em 10 jul. 2016.

Decisão do Supremo Tribunal Federal muda tratamento de hemofílicos - 11 de agosto de 2016. Disponível em: < http://www.correiobraziliense.com.br/cidades---df/>. Acesso em 22 ago. 2016.

CRESWELL, J. W. Qualitative inquiry and research design: Choosing among five approaches. 2a e. University of Nebraska, Lincoln: SAGE Publications, 2007. 395 p.

DATASUS. Estabelecimento de Saúde - Farmácia de Alto Custo Asa Sul. Disponível em: $<$ http://cnes2.datasus.gov.br/Exibe_Ficha_Estabelecimento.asp?VCo_Unidade=53001028167 41>. Acesso em 23 out. 2016. 
DEFENSORIA PÚBLICA DA UNIÃO. Repercussão geral no recurso extraordinário 855.178 Sergipe. Disponível em:

<http://www.dpu.gov.br/images/Repercuss\%C3\%A3o_geral_RE_sa\%C3\%BAde.pdf>. Acesso em 07 jul. 2016a.

Saúde. Disponível em: <http://www.dpu.gov.br/saude>. Acesso em 07 jul. 2016b.

Recurso Extraordinário 855.178/SE. Disponível em:

<http://www.dpu.gov.br/images/stories/foto_noticias/2015/Contrarraz\%C3\%B5es_RE_sa\%C 3\%BAde.pdf>. Acesso em 07 jul. 2016.

Memorando n. 186, 2008. Disponível em:

<http://www.dpu.gov.br/images/stories/foto_noticias/2015/PSV_4_solidariedade.compressed. pdf>. Acesso em 07 jul. 2016.

Medicamentos. Disponível em:

$<$ http://www.dpu.gov.br/component/search/?searchword=sa\%C3\%BAde\&searchphrase=all\&1 imit=20\&limitstart=0>. Acesso em 13 jul. 2016.

STF pode encerrar debate sobre legitimidade da União em ações de saúde - 03 Agosto 2015. Disponível em:

$<$ http://www.dpu.gov.br/component/search/?searchword=sa\%C3\%BAde\&searchphrase=all\&l imit=20\&limitstart=0>. Acesso em 13 jul. 2016.

DPU quer debate amplo se STF reabrir decisão sobre União nas ações de saúde - 26

Agosto 2015. Disponível em:

$<$ http://www.dpu.gov.br/component/search/?searchword=sa\%C3\%BAde\&searchphrase=all\&l imit $=20 \&$ limitstart $=0>$. Acesso em 13 jul. 2016.

DPU assegura medicamento para assistida com gravidez anembrionária - 07 Janeiro 2016. Disponível em:

$<$ http://www.dpu.gov.br/component/search/?searchword=sa\%C3\%BAde\&searchphrase=all\&l imit=20\&limitstart=0>. Acesso em 13 jul. 2016.

. DPU apresenta GT Catadores na Expocatadores em São Paulo - 08 Janeiro 2016.

Disponível em:

$<$ http://www.dpu.gov.br/component/search/?searchword=sa\%C3\%BAde\&searchphrase=all\&l imit=20\&limitstart=0>. Acesso em 13 jul. 2016.

Aumenta número de atendimentos e processos abertos na DPU em Florianópolis -15

Janeiro 2016. Disponível em:

$<$ http://www.dpu.gov.br/component/search/?searchword=sa\%C3\%BAde\&searchphrase=all\&l imit=20\&limitstart=0>. Acesso em 13 jul. 2016.

Ações para garantir tratamento do câncer são constantes na DPU - 18 Janeiro 2016.

Disponível em:

$<$ http://www.dpu.gov.br/component/search/?searchword=sa\%C3\%BAde\&searchphrase=all\&l imit=20\&limitstart=0>. Acesso em 13 jul. 2016. 
DEFENSORIA PÚBLICA DA UNIÃO. Estado de SC deverá tratar câncer de mama metastático com trastuzumabe - 02 Fevereiro 2016. Disponível em: $<\mathrm{http}: / / \mathrm{www}$. dpu.gov.br/component/search/?searchword=sa\%C3\%BAde\&searchphrase=all\&1 imit=20\&limitstart=0>. Acesso em 13 jul. 2016.

DPU pede atuação em processo no STF que define bloqueio de verbas públicas - 18 Fevereiro 2016. Disponível em:

$<$ http://www.dpu.gov.br/component/search/?searchword=sa\%C3\%BAde\&searchphrase=all\&l imit=20\&limitstart=0>. Acesso em 13 jul. 2016.

DPU e Secretaria de Saúde de PE debatem criação de Câmara de Conciliação - 11 Março 2016. Disponível em:

$<$ http://www.dpu.gov.br/component/search/?searchword=sa\%C3\%BAde\&searchphrase=all\&l imit=20\&limitstart=0>. Acesso em 13 jul. 2016.

. Projeto reúne Defensorias para atender comunidade carente em Salvador - 22 Março 2016. Disponível em:

$<$ http://www.dpu.gov.br/component/search/?searchword=sa\%C3\%BAde\&searchphrase=all\&l imit=20\&limitstart=0>. Acesso em 13 jul. 2016.

Justiça defere na Páscoa pedido da DPU para tratamento de fibrose pulmonar - 30 Março 2016. Disponível em:

$<$ http://www.dpu.gov.br/component/search/?searchword=sa\%C3\%BAde\&searchphrase=all\&l imit=20\&limitstart=0>. Acesso em 13 jul. 2016.

Paciente recebe medicamento após atuação conjunta de unidades da DPU - 06 Abril 2016. Disponível em:

$<$ http://www.dpu.gov.br/component/search/?searchword=sa\%C3\%BAde\&searchphrase=all\&l imit=20\&limitstart=0>. Acesso em 13 jul. 2016.

Acatada no CE ação sobre medicamento que evita rejeição em transplante renal - 12 Abril 2016. Disponível em:

$<$ http://www.dpu.gov.br/component/search/?searchword=sa\%C3\%BAde\&searchphrase=all\&l imit=20\&limitstart=0>. Acesso em 13 jul. 2016.

Pacientes renais pedem auxílio à DPU para liberação de medicamento em SC - 29 Abril 2016. Disponível em:

$<$ http://www.dpu.gov.br/component/search/?searchword=sa\%C3\%BAde\&searchphrase=all\&l imit=20\&limitstart=0>. Acesso em 13 jul. 2016.

. Reunião da Rede Intersecretarias é realizada na DPU em Porto Alegre - 16 Maio 2016. Disponível em:

$<$ http://www.dpu.gov.br/component/search/?searchword=sa\%C3\%BAde\&searchphrase=all\&l imit=20\&limitstart=0 $>$. Acesso em 13 jul. 2016. 
DEFENSORIA PÚBLICA DA UNIÃO. Defensor fala sobre judicialização da saúde para assistentes sociais - 19 Maio 2016. Disponível em:

$<$ http://www.dpu.gov.br/component/search/?searchword=sa\%C3\%BAde\&searchphrase=all\&l imit $=20 \&$ limitstart $=0>$. Acesso em 13 jul. 2016.

DPU garante tratamento a crianças com fibrose cística em Belém - 23 Maio 2016.

Disponível em:

$<$ http://www.dpu.gov.br/component/search/?searchword=sa\%C3\%BAde\&searchphrase=all\&l imit=20\&limitstart=0>. Acesso em 13 jul. 2016.

STJ rejeita chamamento ao processo da União nas ações de prestação de saúde - 06

Junho 2016. Disponível em:

$<$ http://www.dpu.gov.br/component/search/?searchword=sa\%C3\%BAde\&searchphrase=all\&l imit=20\&limitstart=0>. Acesso em 13 jul. 2016.

DPU consegue tratamento com fosfoetanolamina para paciente no Recife - 08 Junho 2016. Disponível em:

$<$ http://www.dpu.gov.br/component/search/?searchword=sa\% $\% \%$ BAde\&searchphrase=all\&l imit=20\&limitstart=0>. Acesso em 13 jul. 2016.

Câncer de mama e a realidade do SUS são debatidos na Alesp - 22 Junho 2016.

Disponível em:

$<$ http://www.dpu.gov.br/component/search/?searchword=sa\%C3\%BAde\&searchphrase=all\&l imit=20\&limitstart=0>. Acesso em 13 jul. 2016.

Mãe sul-mato-grossense tem medicamento garantido após atuação da DPU - 04 Julho 2016. Disponível em:

$<$ http://www.dpu.gov.br/component/search/?searchword=sa\%C3\%BAde\&searchphrase=all\&l imit=20\&limitstart=0>. Acesso em 13 jul. 2016.

DPU assegura medicação contra câncer para cidadão no Ceará - 15 Julho 2016.

Disponível em:

$<$ http://www.dpu.gov.br/component/search/?searchword=sa\%C3\%BAde\&searchphrase=all\&l imit=20\&limitstart=0>. Acesso em 13 jul. 2016.

Atuação extrajudicial da DPU garante tratamento fora do Acre para bebê - 22 Julho 2016. Disponível em:

$<$ http://www.dpu.gov.br/component/search/?searchword=sa\%C3\%BAde\&searchphrase=all\&l imit=20\&limitstart=0>. Acesso em 13 jul. 2016.

DPU intervém e medicamento para leucemia volta a ser fornecido no Paraná - 25

Julho 2016. Disponível em:

$<$ http://www.dpu.gov.br/component/search/?searchword=sa\%C3\%BAde\&searchphrase=all\&l imit=20\&limitstart=0>. Acesso em 13 jul. 2016.

DPU faz mutirão de atendimento em Francisco Badaró - 02 Agosto 2016. Disponível em: <http://www.dpu.gov.br/component/search/?searchword=sa\%C3\%BAde\&searchphrase $=$ all \&limit=20\&limitstart=0>. Acesso em 13 jul. 2016 . 
DEFENSORIA PÚBLICA DA UNIÃO. PPS e Anadef pedem entrada em RE sobre papel da União nas ações de saúde - 15 Setembro 2015. Disponível em: $<$ http://www.dpu.gov.br/component/search/?searchword=sa\%C3\%BAde\&searchphrase=all\&l imit $=20 \&$ limitstart $=0>$. Acesso em 13 jul. 2016.

CNBB vai apoiar debate no STF para União ser acionada em processos de saúde - 17 Setembro 2015. Disponível em: $<$ http://www.dpu.gov.br/component/search/?searchword=sa\%C3\%BAde\&searchphrase=all\&l imit=20\&limitstart=0>. Acesso em 13 jul. 2016.

STF julga proposta de súmula da DPU que fixa solidariedade na área de saúde - 11 Novembro 2015. Disponível em:

$<$ http://www.dpu.gov.br/component/search/?searchword=sa\%C3\%BAde\&searchphrase=all\&l imit=20\&limitstart=0>. Acesso em 13 jul. 2016.

STF atende a pedido da AGU e retira matérias de saúde da pauta de julgamento - 13 Novembro 2015. Disponível em:

$<$ http://www.dpu.gov.br/component/search/?searchword=sa\% $\% \%$ BAde\&searchphrase=all\&l imit=20\&limitstart=0>. Acesso em 13 jul. 2016.

Ada Pellegrini diz na DPU que ações coletivas melhoram as políticas públicas - 15 Dezembro 2015. Disponível em:

$<$ http://www.dpu.gov.br/component/search/?searchword=sa\%C3\%BAde\&searchphrase=all\&l imit=20\&limitstart=0>. Acesso em 13 jul. 2016.

DEFENSORIA PÚBLICA DO DISTRITO FEDERAL. Defensores Públicos participam do $1^{\circ}$ Encontro Público Distrital sobre Saúde e Direito - 18 abr 2012. Disponível em: $<$ http://www.defensoria.df.gov.br/?s=sa\%C3\%BAde>. Acesso em 11 jul. 2016.

Defensoria Pública participa de Encontro que reúne agentes públicos para debater a Saúde no DF - 19 abr 2012. Disponível em: <http://www.defensoria.df.gov.br/?s=sa\%C3\%BAde>. Acesso em 11 jul. 2016.

Encontro sobre Saúde e Direito destaca trabalho da Defensoria Pública do DF - 20 abr 2012. Disponível em: <http://www.defensoria.df.gov.br/?s=sa\%C3\%BAde>. Acesso em 11 jul. 2016.

. Por saúde, população apela à Defensoria - 17 ago 2012. Disponível em: <http://www.defensoria.df.gov.br/?s=sa\%C3\%BAde>. Acesso em 11 jul. 2016.

Defensoria Pública do DF se reúne com Comitê Distrital para discutir principais demandas na área de saúde - 29 out 2012. Disponível em: $<\mathrm{http}: / /$ www.defensoria.df.gov.br/?s=sa\%C3\%BAde>. Acesso em 11 jul. 2016.

Saúde ganha Câmara de Mediação - 28 fev 2013a. Disponível em: <http://www.defensoria.df.gov.br/?s=sa\%C3\%BAde>. Acesso em 11 jul. 2016. 
DEFENSORIA PÚBLICA DA UNIÃO. Defensoria Pública do DF e Secretaria de Saúde criam Câmara de Mediação - 27 fev 2013. Disponível em:

<http://www.defensoria.df.gov.br/?s=sa\%C3\%BAde>. Acesso em 11 jul. 2016.

. Comitê de Saúde do DF divulga balanço de processos - 20 mar 2013. Disponível em: $<$ http://www.defensoria.df.gov.br/?s=sa\%C3\%BAde>. Acesso em 11 jul. 2016.

DPDF participa da primeira reunião de 2014 do Comitê Executivo Distrital da Saúde $07 \mathrm{fev}$ 2014. Disponível em: <http://www.defensoria.df.gov.br/?s=sa\%C3\%BAde>. Acesso em 11 jul. 2016.

Câmara de Mediação em Saúde, fruto de parceria entre a DPDF e a SES, é tema de estudos do CNJ e da UERJ - 13 fev 2014. Disponível em:

<http://www.defensoria.df.gov.br/?s=sa\%C3\%BAde>. Acesso em 11 jul. 2016.

Defensoria consegue evitar a judicialização de 11 casos de saúde em apenas um dia 02 set 2015. Disponível em: <http://www.defensoria.df.gov.br/?s=sa\%C3\%BAde >. Acesso em 11 jul. 2016.

Defensoria Pública e Comissão de Fiscalização da CLDF assinam termo de cooperação técnica para melhorar Saúde no DF - 29 set 2015. Disponível em: $<$ http://www.defensoria.df.gov.br/?s=sa\%C3\%BAde>. Acesso em 11 jul. 2016.

Com núcleo especializado, Defensoria celebra "Dia Mundial da Saúde" - 07 abr 2016. Disponível em: <http://www.defensoria.df.gov.br/?s=sa\%C3\%BAde>. Acesso em 11 jul. 2016.

. Escola da Defensoria realiza segundo Seminário sobre Direito e Saúde - 30 maio 2016. Disponível em: <http://www.defensoria.df.gov.br/?s=sa\%C3\%BAde>. Acesso em 11 jul. 2016.

. Núcleo da Saúde. Disponível em: <http://www.defensoria.df.gov.br/?page_id=2376>. Acesso em 07 jul. 2016.

DENHARDT, J.V.; DENHARDT, R.B. The new public service: serving, not steering. Armonk, NY: M. E. Sharpe, 2007. 223p.

DENZIN, N.K.; LINCOLN, Y.S. O Planejamento da Pesquisa Qualitativa. Teorias e abordagens. 2 ed. Porto Alegre: Artmed, 2006.

DINIZ, D.; MEDEIROS, M.; SCHWARTZ, I.V.D. Consequências da judicialização das políticas de saúde: custos de medicamentos para as mucopolissacaridoses. Caderno de Saúde Pública, v. 28, n.3, p.479-489, mar. 2012.

DINIZ, D.; MACHADO, T.R.C.; PENALVA, J. A judicialização da saúde no Distrito Federal, Brasil. Ciência e Saúde Coletiva, v.19, n.2, p. 591-298. 2014. 
DRAIBE, S. Brasil: a reforma do sistema de saúde. Relatório de pesquisa, Campinas, NEPP/Unicamp, 1992.

DUARTE, C.M.R. Eqüidade na legislação: um princípio do sistema de saúde brasileiro? Ciência \& Saúde Coletiva, v.5, n.9, p. 443-463. 2000.

DUBÉ, L.; PARÉ, G. Rigor in information systems positivist case research: current practices, trends, and recommendations. MIS Quarterly, v. 27, n. 4, p. 597-635, Dec. 2003.

DYE, T.D. Understanding Public Policy. Englewood Cliffs, N.J.: Prentice-Hall. 1984.

EASTON, D. A Framework for Political Analysis. Englewood Cliffs: Prentice Hall. 1965.

ELMORE, R.F. Backward Mapping: Implementation Research and Policy Decisions. Political Science Quarterly, v. 94 n. 4, p. 601-616, Winter 1979-1980.

EISENHARDT, K. M. Building theories from case study research. Academy of Management Review, v. 14, n. 4, p. 532-550, out. 1989.

ESTADAO. Gasto do governo com remédio sem aval da Anvisa cresce 220 vezes em 5 anos- 16 de outubro de 2016a. Disponível em:

$<$ http://saude.estadao.com.br/noticias/geral,gasto-do-governo-com-remedio-sem-aval-daanvisa-cresce-220-vezes-em-5-anos,10000082399>. Acesso em 16 out. 2016.

ESTADAO. Saúde cruza dados contra suposta 'máfia da judicialização' - 16 de outubro de 2016b. Disponível em: < http://saude.estadao.com.br/noticias/geral,saude-cruza-dadoscontra-suposta-mafia-da-judicializacao,10000082413>. Acesso em 16 out. 2016.

EVANS, P.; RUESCHEMEYER, D; SKOCPOL, T. Bringing the State Back In. Cambridge: Cambridge University Press, 1985.

FARIA, M.C. Neoconstitucionalismo, neoprocessualismo, póspositivismo, formalismovalorativo... A supremacia constitucional no estudo do processo. Revista Ética e Filosofia Política, v. 2, n. 15, p. 103-117, 2012.

FELISBINO, R. A. Atores e práticas na relação executivo-legislativo municipal: o caso do município de Mogi Mirim (SP) em dois contextos democráticos (1946-1964 e pós-1988). Revista OMNIA HUMANAS, v. 2, n. 1, 27-47, Jan/Jun de 2009. Disponível em <file:///Users/samarahaddad/Downloads/31-188-1-PB.pdf>. Acesso em 14 out. 2016.

FERRAZ, M. B. Economia da saúde e sua inserção no sistema de saúde. In: BLIACHERIENE, A. C.; SANTOS, J. S. (Orgs.) Direito à vida e à saúde: impactos orçamentários e judiciais. São Paulo: Atlas. 2010.

FERREIRA, M.C. Direito à proteção da saúde pela via judicial: em busca de efetividade e equidade. Revista de Estudos Jurídicos, v. 15, n. 22, p. 237-264 , 2011. 
FERREIRA, S.L.; COSTA, A.M. Núcleos de assessoria técnica e judicialização da saúde: constitucionais ou inconstitucionais? Revista SJRJ, Rio de Janeiro, v. 20, n. 36, p. 219-240, abr. 2013.

FIOCRUZ. Equidade. Disponível em: < http://pensesus.fiocruz.br/equidade> Acesso em: 1 set. 2016.

FOLHA DE SÃO PAULO. Supremo deve definir alternativas para acesso a remédios de alto custo - 28 de setembro de 2016a. Disponível em: < http://www1.folha.uol.com.br/cotidiano/2016/09/1817488-supremo-deve-definir-alternativaspara-acesso-a-remedios-de-alto-custo.shtml>. Acesso em 7 out. $2016 .$.

Ministros do STF propõem critérios para acesso a remédio sem registro - 28 de setembro de 2016b. Disponível em:

$<$ http://www1.folha.uol.com.br/cotidiano/2016/09/1817677-relator-muda-voto-e-exigeparticipacao-familiar-no-custeio-de-tratamentos.shtml>. Acesso em 7 out. 2016.

. Farmácia de Alto Custo não entra na decisão do STF sobre medicamentos - 26 de setembro de 2016c. Disponível em:

$<$ http://www.correiobraziliense.com.br/app/noticia/cidades/2016/09/26/interna_cidadesdf,550 566/farmacia-de-alto-custo-nao-entra-na-decisao-do-stf-sobre-medicamentos.shtml>. Acesso em 7 out. 2016.

FONTANA, E. A função do Estado-Juiz na realização dos direitos fundamentais sociais: alguns aportes acerca do protagonismo judicial. In: XVIII CONGRESSO NACIONAL DO CONPEDI, 2009, São Paulo. Anais eletrônicos. Disponível em: < http://www.publicadireito.com.br/conpedi/manaus/arquivos/anais/sao_paulo/1893.pdf> Acesso em: 29 fev. 2016.

FRASER, M.T.D; GONDIM, S.M.G. Da fala do outro ao texto negociado: discussões sobre a entrevista na pesquisa qualitativa. Paidéia, v. 14, n. 28, p. 139-152, 2004.

FREY, K. Políticas públicas: um debate conceitual e reflexões referentes à prática da análise de políticas públicas no Brasil. Planejamento e Políticas Públicas, Brasília, v. 21, p. 211-59, 2000.

GEORGE, A.L.; BENNETT, A. Case studies and theory development in the social sciences. Massachusetts: BCSIA, $1^{\text {st }}$ ed., 2005. 331

GERSCHMAN, S.; SANTOS, M. A. B. O Sistema Único de Saúde Como Desdobramento das Políticas de Saúde do Século XX. Revista Brasileira de Ciências Sociais, São Paulo, v. 21, p. 177-190, 2006.

GIL, A. C. Métodos e técnicas de pesquisa social. 6a ed. São Paulo: Atlas, 2009. 216 p.

GNATA, N.P.B. Crítica aos limites do controle jurisdictional de políticas públicas em direitos sociais. Joaçaba, v. 12, n. 2, p. 181-196, jul./dez. 2011. 
GOMES, E. G. M. Políticas Públicas de Gestão e Coordenação Intra-governamental. EnAPG 2010 - Vitória/ES. 2010.

GOMES, D. C. C. Aplicação dos Princípios e Diretrizes do Sistema Único de Saúde (SUS) diante da Constituição Federal de 1988 e Legislação em Vigor. In: Judicialização da Saúde, Parte II: ética nos relacionamentos do setor saúde, IV Jornada Médico-jurídica de Saúde Suplementar, Seminário de Direito Sanitário. Rio de Janeiro: EMERJ, 2012. 238 p.

GRANDORI, A.; SODA, G. Inter-firm networks: antecedents, mechanisms and forms. Organization Studies. 1995. 16/2. p 183-214.

GULICK, L.; URWICK, L. Papers on the science of administration. In: The early sociology of management and organizations. Vol. IV. New York: Taylor \& Francis eLibrary, 2005.

HILL, M.; HUPE, P. Implementing Public Policy: Governance in Theory and in Practice. Thousand Oaks, CA: Sage Publications, 2005.

HOFLING, E. M. Estado e políticas (públicas) sociais. Cadernos Cedes, ano XXI, n. 55, p. 30-41, 2001.

INTERFARMA. Por que o brasileiro recorre à justiça para adquirir medicamentos? Junho de 2016. Disponível em: <http://www.interfarma.org.br/uploads/biblioteca/101-porque-o-brasileiro-vai-a-justiaa-em-busca-de-medicamentos-site.pdf>. Acesso em: 27 set. 2016.

KARNIKOWSKI, M. G. O.; SILVA, K. M.; SALGADO, F. X. C.; NOVAES, M. R. C. G. Aspectos farmacoeconômicos das ações judiciais impetradas à Secretaria de Estado de Saúde do Distrito Federal. Associação Médica de Brasília. Disponível em: < http://www.ambr.org.br/aspectos-farmacoeconomicos-das-acoes-judiciais-impetradas-asecretaria-de-estado-de-saude-do-distrito-federal-2/>. Acesso em: 28 set. 2016.

KIEWIET, D., RODERICK, D., MCCUBBINS M. The Logic of Delegation: Congressional Parties and the Appropriations Process. Chicago: The University of Chicago Press. 1991.

KLEIN JÚNIOR, V. H. et al. Participação e coprodução em política habitacional: estudo de um programa de construção de moradias em SC. Revista de Administração Pública, v. 46, n. 1, p. 25-47, 2012.

KORNIS, G.E.M.; BRAGA, M.H.; ZAIRE, C.E. Os marcos legais das políticas de medicamentos no Brasil contemporâneo (1990-2006). Rev APS, v.11, n.1, jan./mar. 2008. p. 85-99.

KRÜGER, T.R. O desconhecimento da reforma sanitária e da legislação do SUS na prática do Conselho de Saúde. Planejamento e Políticas Públicas, v. 22, p. 119-144, dez, 2000.

LASSWELL, H.D. Politics: Who Gets What, When, How. Cleveland, Meridian Books. 1936/1958. 264 p. 
LEDFORD, H. Brazilian courts tussle over unproven cancer treatment. Patients demand access to compound despite lack of clinical testing. Nature. V. 527, p. $420-421.2015$.

LEITE, N. R. L. de A. A Possibilidade da Interferência do Poder Judiciário no Controle de Políticas Públicas. In: Judicialização da Saúde, Parte II: ética nos relacionamentos do setor saúde, IV Jornada Médico-jurídica de Saúde Suplementar, Seminário de Direito Sanitário. Rio de Janeiro: EMERJ, 2012. 238 p.

LIMA, L.L; D’ASCENZI, L. Implementação de Políticas Públicas: perspectivas analíticas. Revista de Sociologia e Política, v. 21, n. 48, p. 101-110, dez. 2013.

LIMBERGER, T.; SOARES, H.C. Políticas públicas e o direito ao fornecimento gratuito de medicamentos: desafios ao poder judiciário. Revista de Estudos Constitucionais, Hermenêutica e Teoria do Direito (RECHTD), v. 2, n. 2, p. 50-63, jan./jun. 2010.

LINDBLOM, C. E. The Science of Muddling Through. Public Administation Review. n. 19, p. 78-88, 1959.

LINDBLOM, C. E. Still Muddling, Not Yet Through. Public Administation Review. n. 39, p. 517-526, 1979.

LIPSKY, M. Street Level Bureaucracy. New Yor: Russel Sage.sép 1980.

LYNN, L.E. Designing Public Policy: A Casebook on the Role of Policy Analysis. Santa Mônica, Calif.: Goodyear. 1980.

LOTTA, G. S.; VAZ, J. C. A contribuição dos arranjos institucionais complexos para a efetividade das políticas públicas no Brasil. XVII Congreso Internacional del CLAD sobre la Reforma del Estado y de la Administración Pública, Cartagena, Colombia, 30 oct. - 2 Nov. 2012.

MACEDO, E.I.; LOPES, L.C.; BARBERATO-FILHO S. Análise técnica para a tomada de decisão do fornecimento de medicamentos pela via judicial. Revista de Saúde Pública, v. 45, n. 4, p. 706-713, 2011.

MACHADO, M. A. A.; ACURCIO, F.A.; BRANDÃO, C.M.R.; FALEIROS, D.R.; GUERRA JR, A.A.; CHERCHIGLIA, M.L.; ANDRADE, E.I.G. Judicialização do acesso a medicamentos no Estado de Minas Gerais, Brasil. Revista de Saúde Pública (USP. Impresso), v. 45, n. 3, p. 590-598, 2011.

MACNEALY, M. S. Toward better case study research. IEEE Transactions on professional Communication, v. 40, n. 3, p. 182-195, Sept. 1997.

MAGALHÃES, G.G.C.V. A configuração pós-moderna dos direitos fundamentais sociais: uma análise da ingerência jurisdictional no âmbito de efetivação desses direitos. RIDB, n.5, ano 1, p. 2849-2889. 2012. 
MAGARINOS-TORRES, R.; PEPE, V.L.E.; OSORIO-DE-CASTRO, C.G.S. Estruturação da assistência farmacêutica: plano de ação para a seleção de medicamentos essenciais. Caderno de Saúde Coletiva, Rio de Janeiro, v. 21, n. 2. P.188-196. 2013.

MARQUES, C. A. M.; MARQUES, C. G. P. Discricionariedade administrative e conceitos jurídicos indeterminados: em busca da concretização do Interesse Público. Âmbito Jurídico. Disponível em: < http://www.ambito-

juridico.com.br/site/index.php?n_link=revista_artigos_leitura\&artigo_id=11083>. Acesso em 29 out 2016.

MARTINS, Sérgio Pinto. Direito da seguridade social. 22a ed. São Paulo: Atlas, 2005.

MATLAND, R.E. Synthesizing the Implementation Literature: The Ambiguity-Conflict Model of Policy Implementation. Journal of Public Administration Research and Theory, v. 5 n.2, p. 145-174, 1995.

MAY, P. J. \& WINTER, S. C. Politicians, Managers, and Street-Level Bureaucrats: Influences on Policy Implementation. Journal of Public Administration Research and Theory, v. 19, n. 3 p. 453-476.

MAZZA, F.F.; MENDES, A.N. Decisões judiciais e orçamento: um olhar sobre a saúde pública. Revista de Direito Sanitário, São Paulo, v. 14, n.3, p. 42-65, nov. 2013/ fev. 2014.

MEAD, L.M. Public Policy: Vision, Potential, Limits. Policy Currents, [s.l.], fev, p.1-4, 1995.

MEDEIROS, M.; DINIZ, D.; SCHWARTZ, I.V.D. A tese da judicialização da saúde pelas elites: os medicamentos para mucopolissacaridose. Ciência \& Saúde Coletiva, v.18, n.4, p. 1089-1098. 2013.

MEDRADO, R.G.; CRUZ, M.V.G.; RASO, L.M.; ROCHA, H.H.N. SOS SUS: Muita Justiça, Pouca Gestão? Estudo sobre a Judicialização da Saúde. XXXVII Encontro da ANPAD. Anais XXXVII EnANPAD. Rio de Janeiro. Disponível em:

$<$ http://www.anpad.org.br/admin/pdf/2013_EnANPAD_APB794.pdf>. Acesso em 15 jun 2016.

MELlO, C. A. B. Curso de Direito Administrativo. 18ª ed. São Paulo: Malheiros, 2005.

MENDES, E. V. Distrito Sanitário: o processo social de mudança das práticas sanitárias do Sistema Único de Saúde. São Paulo: Hucitec, 1999.

MILES, M.B.; HUBERMAN, A.M.; SALDAÑA, J. Qualitative data analysis: a method sourcebook. United States of America: Sage, 3 ed., 2014. 381 p.

MINISTÉRIO DA SAÚDE. Em cinco anos, mais de R \$ 2,1 bilhões foram gastos com ações judiciais - 05 de outubro de 2015. Disponível em:

$<$ http://portalsaude.saude.gov.br/index.php/cidadao/principal/agencia-saude>. Acesso em 11 jul. 2016. 
MINISTÉRIO DA SAÚDE. Componente Especializado da Assistência Farmacêutica. Disponível em:

$<$ http://portalsaude.saude.gov.br/index.php?option=com_content\&view=article\&id=11635\&It emid=702>. Acesso em 05 jul. 2016a.

Conselho Nacional de Saúde - Composição. Disponível em:

$<$ http://conselho.saude.gov.br/apresentacao/composicao.htm>. Acesso em 09 set. 2016b.

Ministério da Saúde firma parceria com CNJ para apoio técnico a juízes - 3 de junho de 2016c. Disponível em:

$<$ http://portalsaude.saude.gov.br/index.php/cidadao/principal/agencia-saude>. Acesso em 11 jul. 2016.

Organograma - estrutura e competências. Disponível em:

$<$ http://portalsaude.saude.gov.br/index.php/o-ministerio/estrutura-e-competencias/leia-maisestrutura-e-competencias $>$. Acesso em 11 set. 2016 d.

Consultoria Jurídica junto ao Ministério da Saúde. Disponível em: < http://portalsaude.saude.gov.br/index.php/o-ministerio/principal/conjur>. Acesso em: 07 jul. 2016e.

. Núcleo Jurídico - SCTIE. Disponível em:

$<\mathrm{http}$ ://portalsaude.saude.gov.br/index.php/o-ministerio/principal/secretarias/sctie/sctiedestaques/11758-secretaria-de-ciencia-tecnologia-e-insumos-estrategicos >. Acesso em: 25 set. $2016 f$.

. Intervenção judicial na saúde pública. Disponível em:

$<$ http://portalsaude.saude.gov.br/index.php/o-ministerio/principal/conjur/leia-maisconjur/376-12-conjur/13007-panorama-da-judicializacao>. Acesso em: 20 set. 2016g.

Aviso n ${ }^{\circ} 1210$, em resposta ao ofício no 439/2010, de 06 de setembro de 2010.

Disponível em: < http://pfdc.pgr.mpf.mp.br/institucional/grupos-de-trabalho/saude/temastrabalhados/assistencia-farmaceutica/atuacao-do-gt/aviso-1210-em-resposta-ao-oficio-4392010>. Acesso em 27 set. 2016h.

Consultoria Jurídica junto ao Ministério da Saúde. Parecer tema 15. Subtema 15.1. Falta de interesse de agir. Disponível em:

$<$ http://portalsaude.saude.gov.br/images/pdf/2014/julho/14/4.\%20exist\%C3\%AAncia\%20do $\% 20$ medicamento\%20no\%20SUS\%20para\%20a\%20doen\%C3\%A7a\%20do\%20auto.pdf $>$. Acesso em: 15 jul. 2016 i.

. Consultoria Jurídica junto ao Ministério da Saúde. Parecer tema 15. Subtema 15.1. Existência de alternativas terapêuticas disponíveis no SUS, para o tratamento sintomático da doença. Disponível em: <http://portalsaude.saude.gov.br/images/pdf/2014 /julho/14/3.\%20aus\%C3\%AAncia\%20do\%20medicamento\%20no\%20SUS, \%20mas\%20com $\% 20$ alternativa $\% 20$ terap $\%$ C3\%AAutica $\% 20$ no $\% 20$ SUS $\% 20$ apenas $\% 20$ para $\% 20$ tratamento $\%$ 20dos\%20sintomas.pdf>. Acesso em: 15 jul. 2016j. 
MINISTÉRIO DA SAÚDE. Consultoria Jurídica junto ao Ministério da Saúde. Parecer tema 15. Subtema 15.1. Existência de alternativas terapêuticas disponíveis no SUS. Disponível em:

<http://portalsaude.saude.gov.br/images/pdf/2014/julho/14/2.\%20aus\%C3\%AAncia\%20do\% 20medicamento\%20no\%20SUS.pdf>. Acesso em: 15 jul. 20161.

Consultoria Jurídica junto ao Ministério da Saúde. Parecer tema 15. Subtema 15.1 não possui registro na ANVISA. Disponível em:

$<$ http://portalsaude.saude.gov.br/images/pdf/2014/julho/14/1.\%20medicamento\%20sem\%20r egistro\%20na\%20anvisa.pdf>. Acesso em: 15 jul. 2016m.

MINISTÉRIO PÚBLICO DA UNIÃO. Organograma. Disponível em: <http://www.mpu.mp.br/navegacao/institucional/organograma>. Acesso em 28 set. 2016.

MINISTÉRIO PÚBLICO DO DISTRITO FEDERAL E TERRITÓRIOS. Núcleo divulga análises orçamentárias da saúde e da educação referentes a fevereiro de 2016 - 25 de Abril de 2016a. Disponível em: <http://www.mpdft.mp.br/portal/index.php/comunicacaomenu/noticias/noticias-2016>.Acesso em 12 jul. 2016.

Promotoria de Justiça de Defesa da Saúde - Prosus. 2016b. Disponível em: < http://www.mpdft.mp.br/portal/index.php/conhecampdft-menu/promotorias-justicamenu/promotoria-de-justia-de-defesa-da-sade-prosus-mainmenu-105>. Acesso em 07 jul. 2016.

Portal Direito e Saúde do MPDFT. 2016c. Disponível em: < http://www.mpdft.mp.br/saude/>. Acesso em 07 jul. 2016.

MPDFT divulga análise sobre execução orçamentária do GDF - 28 de Março de 2016. Disponível em: <http://www.mpdft.mp.br/portal/index.php/comunicacaomenu/noticias/noticias-2016>.Acesso em 12 jul. 2016.

Saúde pública é tema de reunião entre SES e MPDFT - 06 de Abril de 2016.

Disponível em: <http://www.mpdft.mp.br/portal/index.php/comunicacaomenu/noticias/noticias-2016>.Acesso em 12 jul. 2016.

. MPDFT celebra Dia Mundial da Saúde com fiscalização constante dos serviços oferecidos pelo SUS - 07 de Abril de 2016. Disponível em: $<$ http://www.mpdft.mp.br/portal/index.php/comunicacao-menu/noticias/noticias2016>.Acesso em 12 jul. 2016.

Saúde e dignidade - 18 de Abril de 2016. Disponível em: $<$ http://www.mpdft.mp.br/portal/index.php/comunicacao-menu/noticias/noticias2016>.Acesso em 12 jul. 2016.

Auditoria cívica - 07 de Junho de 2016. Disponível em: $<$ http://www.mpdft.mp.br/portal/index.php/comunicacao-menu/noticias/noticias2016>.Acesso em 12 jul. 2016. 
MINISTÉRIO PÚBLICO DO DISTRITO FEDERAL E TERRITÓRIOS. Auditoria cívica 10 de Junho de 2016. Disponível em:

$<$ http://www.mpdft.mp.br/portal/index.php/comunicacao-menu/noticias/noticias-

2016>.Acesso em 12 jul. 2016.

Leonardo Bessa destaca papel do Ministério Público na defesa de direitos coletivos -

21 de Junho de 2016. Disponível em:

$<$ http://www.mpdft.mp.br/portal/index.php/comunicacao-menu/noticias/noticias-

2016>.Acesso em 12 jul. 2016.

MINISTÉRIO PÚBLICO FEDERAL. Conheça o MPF. Disponível em: < http://www.mpf.mp.br/conheca-o-mpf>. Acesso em 28 set. 2016.

MINOGUE, M. Theory and pratice in public policy and administration. Policy and Politics, v. 11, p. 63-85, 1983.

MONTAIGNE, M. (1580). Os ensaios. Trad. de Rosa Freire D'Aguiar. São Paulo:

Companhia das Letras/Penguin, 2000.

MORAES, F. Executivo e legislativo no Brasil Pós-Constituinte. São Paulo

Perspec. vol.15 no.4 São Paulo Oct./Dec. 2001. Disponível em: <

http://www.scielo.br/scielo.php?script=sci_arttext\&pid=S0102-88392001000400006>.

Acesso em 14 out. 2016.

MOTA, D. M.; FERNANDES, M. E. P.; COELHO, H. L. L. Farmacoeconomia: um Instrumento de Eficiência para a Política de Medicamentos do Brasil. Acta Farm. Bonaerense, v. 22, n. 2, p. 177-186. 2003.

NAJAN, A. Learnin from the Literature on Policy Implementation: A Synthesis Perspective. (Working Papers). Inertnational Institute for Applied Systems Analysis - IIASA. A-2361 Luxwnburg, Áustria. 1995.

NETO, R.M. O Brasil e a síndrome do "bolo de caneca" na implantação de políticas públicas. Ariquemes, RO, v. 3, n. 2, p. 80-89, mai. 2015.

NOVELINO, M. Direito Constitucional. São Paulo: Editora Método, $3^{\circ}$ ed. 2009.

OLIVEIRA, J.A. Reformas e Reformismo: “Democracia Progressiva” e Políticas Sociais. Rio de Janeiro, Cadernos de Saúde Pública, v. 4, n. 3, p. 360-387, out/dez. 1987.

OLIVEIRA, M.R.M. A Judicialização da Saúde no Brasil. Revista Tempus - Actas de Saúde Coletiva, p. 79-90, 2013.

O' TOOLE, L. J. Research on Policy Implementation: Assessment and Prospects. Journal of Public Administration Research and Theory, v. 10, n. 2, p. 263-288. 20 2000. 
PAIM, J.; TRAVASSOS, C.; ALMEIDA, C.; BAHIA, L.; MACINKO, J. O sistema de saúde brasileiro: história, avanços e desafios. The Lancet, [s.1.], v. 370, n. 9779, p.11-31. 2011.

PAIM, P.; MARQUETTO, A.; LOPES, I.O. Câmara Permanente Distrital de Mediação em Saúde: experiência do Distrito Federal. CONASS - para entender a gestão do SUS, 1a ed. 2015. Disponível em: <www.conass.org.br>. Acesso em 15 jun 2016.

PALUMBO, D. J.; CALISTA, D. J. Implementation and the Policy Process: Opening Up the Black Box. New York: Greenwood Press, 1990.

PAULA, P.A.B.; ALVES, T.N.P.; VIEIRA, R.C.P.A.; SOUZA, A.I.S. Política de Medicamentos: da universalidade de direitos aos limites da operacionalidade. Revista de Saúde Coletiva, Rio de Janeiro, v. 19, n.4, p. 1111-1125, 2009.

PEPE, V.L.E.; FIGUEIREDO, T.A.; SIMAS, L; OSORIO-DE-CASTRO, C.G.S.; VENTURA, M. A judicialização da saúde e os novos desafios da gestão da assistência farmacêutica. Ciência e Saúde Coletiva, v. 15, n. 5, p. 2405-2414, 2010.

PEREIRA, C. A Política Pública como Caixa de Pandora: Organização de Interesses, Processo Decisório e Efeitos Perversos na Reforma Sanitária Brasileira - 1985-1989. Dados - Revista de Ciências Sociais, Rio de Janeiro, v. 39, n. 3, p. 423-478, 1996.

PEREIRA, L. Métodos de controle de legalidade da administração pública. Âmbito Jurídico. Disponível em:

$<$ http://www.ambitojuridico.com.br/site/?n_link=revista_artigos_leitura\&artigo_id=11027\&re vista_caderno=4>. Acesso em 18 out. 2016.

PERLINGEIRO, R. A tutela judicial do direito público à saúde no Brasil. Direito, Estado e Sociedade, n. 41, p. 184-203, jul/dez. 2012.

PETERS, B. G. American Public Policy. Chatham, N.J.: Chatham House. 1986.

Review: Understanding Governance: Policy Networks, Governance, Reflexivity and Accountability by R. W. Rhodes. Public Administration, v.76, p. 408-509, 1998.

PINDUR, W.; ROGERS, S. E.; KIM, P. S. The history of management: a global perspective. Journal of Management History, v. 1, iss 1, p. 59-77. 1995.

PRESSMAN, J. L.; WILDAVSKY, A. Implementation: how great expectations in Washington are dashed in Oakland. Berkeley: University of California Press. 1984.

PRISTA, L. N. e col. Tecnologia Farmacêutica, v. 1, Ed. 6, Fundação Calouste Gulbenkian. 2003.

PROCURADORIA-GERAL DA REPÚBLICA. Atuação. Disponível em: < http://www.mpf.mp.br/pgr/atuacao>. Acesso em 29 set. 2016. 
PROCURADORIA-GERAL DO DISTRITO FEDERAL. Recomendação $n^{\circ}$ 001/99, de 17 de maio de 1999. Disponível em: <http://www.mpdft.mp.br/pdf/recomendacoes/ PROSUS_1999_001.pdf>. Acesso em 08 jul. 2016.

Procuradoria do meio Ambiente, Patrimônio Urbanístico e Imobiliário e Saúde PROMAI. E Disponível em: < http://www.pg.df.gov.br/institucional/estrutura/374procuradoria-do-meio-ambiente-patrimonio-urbanistico-e-imobiliario-e-saude-promai.html>. Acesso em 07 jul. 2016.

REICHERT, V.; SCHWARTZ, G. Análise do entendimento jurisprudencial do Tribunal Regional Federal da $4^{\text {a }}$ Região acerca da teoria da reserva do possível. Revista de Iniciação Científica da ULBRA, p. 201-213. 2011.

ROCHA, D.; DEUSDARÁ, B. Análise de Conteúdo e Análise do Discurso: aproximações e afastamentos na (re)construção de uma trajetória. $A L E A$, v. 7, n. 2, jul/dez. 2005. p. 05322.

RODRIGUES, S.R. Judicialização: possível caminho à efetivação do direito à saúde no Brasil? Disponível em: <http://www.mpdft.mp.br/saude/index.php/judicializacao-dasaude/171-tutela-do-direito-a-saude-publica-e-sua-analise-jurisprudencial $>$. Acesso em 15 jun 2016.

ROLIM, L.B.; CRUZ, R.S.B.L.C.; SAMPAIO, K, J, A, J. Participação popular e o controle social como diretriz do SUS: uma revisão narrativa. Saúde em Debate, v. 37, n. 96, p. 139147, jan/mar, 2013.

RUA, M. G. Três hipóteses teóricas e uma situação empírica: a coordenação governamental na Rede de Proteção Social do governo do estado de Goiás. X Congresso Internacional del Clad sobre la Reforma del Estado y de la Administración Pública, Santiago, Chile. 2005.

SABATIER, P.A. Top-Down and Bottom-Up Approaches to Implementation Research: a Critical Analysis and Suggested Synthesis. Journal of Public Policy, v. 6 n.1 p. 21-48, January 1986.

SANT'ANA, J.M.B.; PEPE, V.L.E.; FIGUEIREDO, T.A.; OSORIO-DE-CASTRO, C.G.S.; VENTURA, M. Racionalidade terapêutica: elementos médico-sanitários nas demandas judiciais de medicamentos. Revista de Saúde Pública, v. 45, n. 4, p. 714-21. 2011.

SANTOS, R.S.; RIBEIRO, E.M.; GOMES, F.G. Compreendendo a natureza das políticas do Estado capitalista. Revista de Administração Pública, v. 41, n. 5, p. 819-34, 2007.

SANTOS, J.S.; BLIACHERIENE, A.C.; UETA, J. A via judicial para o acesso aos medicamentos e o equilíbrio entre as necessidades e desejos dos usuários, do sistema de saúde e da indústria. Boletim do Instituto de Saúde. Programa de Pesquisa para o SUS, v.13, n.1, p. $66-75.2011$. 
SANTOS, A.M.; MARCONDES, G.V.; ALVES, J.Q.; ZANFERDINI, F.A.M. Neoconstitucionalismo, neoprocessualismo e a tutela adequada dos direitos transindividuais. Direitos Fundamentais e Justiça. Ano 6, n. 18, p. 229-245, jan/mar. 2012.

SANTOS, M. O. V. A Obrigação Constitucional à Saúde Pública: Modelo Brasileiro. In: Judicialização da Saúde, Parte II: ética nos relacionamentos do setor saúde, IV Jornada Médico-jurídica de Saúde Suplementar, Seminário de Direito Sanitário. Rio de Janeiro: EMERJ, 2012. 238 p.

SARLET, I. W. A Eficácia dos Direitos Fundamentais. 6.ed. Porto Alegre: Livraria do Advogado, 2006.

SCHWARTZ-SHEA. P. Judging Quality: Evaluative criteria and episteic communities. In D. Yanow \& P. Schwartz-Shea, Interpretation and Method: Empirical Research Methods and the Interpretive Turn. Armonk, New York: M.E. Sharpe, pp. 89-113. 2006

SECRETARIA DE ESTADO DE SAÚDE DO DISTRITO FEDERAL. Diretoria de Assistência Farmacêutica - DIASF. Disponível em: < http://www.saude.df.gov.br/outroslinks/assistencia-farmaceutica.html>. Acesso em: 05 jul. 2016a.

Componente Especializado da Assistência Farmacêutica (Farmácia de Alto Custo). Disponível em: <http://www.saude.df.gov.br/outros-links/assistencia-farmaceutica/784componente-especializado-da-assistencia-farmaceutica-farmacia-de-alto-custo.html $>$. Acesso em: 05 jul. $2016 b$.

. Conselho de Saúde do Distrito Federal. Disponível em:

<http://www.saude.df.gov.br/conselho-distrital-de-saude>. Acesso em: 15 jul. 2016c.

SILVA, C.R.; GOBBI, B.C.; SIMÃO, A.A. O uso da análise de conteúdo como uma ferramenta para a pesquisa qualitativa: descrição e aplicação do método. Organ. Rurais agroind., Lavras, v. 7, n.1, p. 70-81. 2005.

SILVA, V.R.; MEDEIROS, M.R.A.M.; FONSECA, F.F.; PESTANO, C.R. Controle social no Sistema Único de Assistência Social: propostas, concepções e desafios. Revista Textos \& Contextos. v. 7, n. 2, p. 250-265, jul/dez. 2008.

SILVA, P.L.B.; MELO, M.A.B. O processo de implementação de políticas públicas no Brasil: características e determinantes de avaliação de programas e políticas. Cadernos de Pesquisa, n. 48, UNICAMP, NEPP, p. 1-17. 2000.

SILVA, C. M.; OLIVO, L. C. C.; SABINO, M. M. F. L. Perfil das ações judiciais de medicamentos atendidas até 2011 no município de Palhoça - Santa Catarina. In: Contribuições para a Gestão do SUS / Maurício Fernandes Pereira, Alexandre Marino Costa, Gilberto de Oliveira Moritz, Denise Aparecida Bunn, organizadores. - Florianópolis : Fundação Boiteux, 2013. 206p. - (Gestão da Saúde Pública; v.1)

SILVERMAN, D. Interpretação de Dados Qualitativos - Métodos para Análise de Entrevistas, Textos e Interações. 3 ed. Porto Alegre: Artmed, 2009. 
SIMON, H. Comportamento Administrativo. Rio de Janeiro: USAID. 1957.

SIMONETTI, V. M. M.; NOVAES, M. L. O.; GONÇALVES, A. A. Seleção de medicamentos, classificação $\mathrm{ABC}$ e redução do nível dos estoques da farmácia hospitalar. XXVII Encontro Nacional de Engenharia de Produção - Foz do Iguaçu - 09 a 11 de outubro de 2007.

SOUZA, C. Construção e Consolidação de Instituições Democráticas: Papel do Orçamento Participativo. São Paulo em Perspectiva, v. 15, n. 4, p. 84-97.

SOUZA, C. Políticas Públicas: uma revisão da literatura. Sociologias, Porto Alegre, ano 8, n. 16, p. 20-45, jul/dez. 2006.

SPINK, P.K. Informação, Transparência e Cidadania: O Controle da Execução

Orçamentária pelo Cidadão. In: Cadernos de Gestão Pública e Cidadania. v. 23. 2003.

SUPREMO TRIBUNAL FEDERAL. Medida cautelar na suspensão de liminar 1.019 (403). Disponível em: <http://www.jusbrasil.com.br/diarios/122045246/stf-03-08-2016-pg-38>. Acesso em: 22 ago. 2016.

SURESH, D. Administration of POSDCORB (March 8, 2016). Disponível em <SSRN: http://ssrn.com/abstract=2744705>. Acesso em 28 out 2016

TALBOTT, J. A. Management, Administration, Leadership: What's in a name? Psychiatric Quarterly, v. 58, n. 4. 1987.

TEIXEIRA, M.F. Criando alternativas ao processo de judicialização da saúde: o sistema de pedido administrativo, uma iniciativa pioneira do estado e município do Rio de Janeiro. / Rio de Janeiro: s.n., 2011. 71 f.

TIMNEY, M. M. The asynchronism of public administration and budget theories. Administrative Theory \& Praxis, v. 17, n. 2, p. 41 - 51. 1995.

TRIBUNAL DE JUSTIÇA DO DISTRITO FEDERAL E TERRITÓRIOS. Ementário de Jurisprudência jul/out 2008. O Tribunal, v. 1, n. 56. 2008.

. Ementário de Jurisprudência - nov/2008, fev/2009. O Tribunal, v. 1, n. 57. 2009.

Ementário de Jurisprudência - mar/jun 2009. O Tribunal, v. 1, n. 58. 2009.

Ementário de Jurisprudência - jul/out 2009. O Tribunal, v. 1, n. 59. 2009.

. Ementário de Jurisprudência - nov/2009, fev/2009. O Tribunal, v. 1, n. 60. 2009.

. Ementário de Jurisprudência - mar/jun 2010. O Tribunal, v. 1, n. 61. 2010.

Ementário de Jurisprudência - jul/out 2010. O Tribunal, v. 1, n. 62. 2010. 
TRIBUNAL DE JUSTIÇA DO DISTRITO FEDERAL E TERRITÓRIOS. Ementário de Jurisprudência - nov/2010, fev/2011. O Tribunal, v. 1, n. 63. 2011.

. Ementário de Jurisprudência - mar/jun 2011. O Tribunal, v. 1, n. 64. 2011.

Ementário de Jurisprudência - jul/out 2011. O Tribunal, v. 1, n. 65. 2011.

BRASÍLIA. TJDFT - Comitê discute aprimoramento de processos judiciais na área da saúde - 29 de junho de 2011. Disponível em:

$<$ http://www.tjdft.jus.br/institucional/comite-executivo-distrital-da-saude/noticias-do-tjdft $>$. Acesso em 14 jul. 2016.

BRASÍLIA. Comitê Executivo discute a saúde no Distrito Federal - 15 de agosto de 2011. Disponível em: <http://www.tjdft.jus.br/institucional/comite-executivo-distrital-dasaude/noticias-do-tjdft >. Acesso em 14 jul. 2016.

. BRASÍLIA. Terceira reunião do Comitê Executivo Distrital da Saúde acontece na próxima terça-feira - 09 de setembro de 2011. Disponível em:

$<$ http://www.tjdft.jus.br/institucional/comite-executivo-distrital-da-saude/noticias-do-tjdft >. Acesso em 14 jul. 2016.

BRASÍLIA. Comitê Executivo para a Saúde do DF divulga ata da $3^{\text {a }}$ reunião - 20 de setembro de 2011. Disponível em: <http://www.tjdft.jus.br/institucional/comiteexecutivo-distrital-da-saude/noticias-do-tjdft >. Acesso em 14 jul. 2016.

. BRASÍLIA. Comitê Executivo Distrital da Saúde realiza sua quarta reunião nesta quarta-feira - 04 de outubro de 2011. Disponível em:

$<$ http://www.tjdft.jus.br/institucional/comite-executivo-distrital-da-saude/noticias-do-tjdft $>$. Acesso em 14 jul. 2016.

. BRASÍLIA. Comitê Executivo Distrital para a saúde do DF avança na problemática das UTI'S - 05 de outubro de 2011. Disponível em:

$<$ http://www.tjdft.jus.br/institucional/comite-executivo-distrital-da-saude/noticias-do-tjdft $>$. Acesso em 14 jul. 2016.

. BRASÍLIA. Comitê Executivo Distrital da Saúde tem nova reunião nesta quarta-

feira - 26 de outubro de 2011. Disponível em: <http://www.tjdft.jus.br/institucional/comiteexecutivo-distrital-da-saude/noticias-do-tjdft >. Acesso em 14 jul. 2016.

. BRASÍLIA. Última reunião do ano do Comitê de Saúde termina com avaliação positiva dos trabalhos $\mathbf{- 1 3}$ de dezembro de 2011. Disponível em: <http://www.tjdft.jus.br/institucional/comite-executivo-distrital-da-saude/noticias-do-tjdft >. Acesso em 14 jul. 2016.

BRASÍLIA. Instrução orienta juízes acerca de processos de saúde pública - 28 de dezembro de 2011. Disponível em: <http://www.tjdft.jus.br/institucional/comite-executivodistrital-da-saude/noticias-do-tjdft >. Acesso em 14 jul. 2016. 
TRIBUNAL DE JUSTIÇA DO DISTRITO FEDERAL E TERRITÓRIOS. BRASÍLIA. Pauta da reunião de 14 de fevereiro de 2012 do Comitê de Saúde do Distrito Federal. Disponível em: <http://www.tjdft.jus.br/institucional/comite-executivo-distrital-dasaude/noticias-do-tjdft >. Acesso em 14 jul. 2016.

. BRASÍLIA. Comitê de Saúde se reúne para tratar de problemas relevantes no Distrito Federal - 14 de fevereiro de 2012. Disponível em:

<http://www.tjdft.jus.br/institucional/comite-executivo-distrital-da-saude/noticias-do-tjdft >. Acesso em 14 jul. 2016.

BRASÍLIA. Programação do $1^{\circ}$ Encontro Distrital de Agentes Públicos - Saúde e Direito - 10 de abril de 2012. Disponível em: <http://www.tjdft.jus.br/institucional/comiteexecutivo-distrital-da-saude/noticias-do-tjdft >. Acesso em 14 jul. 2016.

. BRASÍLIA. Comitê Executivo Distrital da Saúde realiza seminário sobre saúde e direito - 13 de abril de 2012. Disponível em: <http://www.tjdft.jus.br/institucional/comiteexecutivo-distrital-da-saude/noticias-do-tjdft >. Acesso em 14 jul. 2016.

BRASÍLIA. $1^{\circ}$ Encontro Distrital de Agentes Públicos começa nesta quarta-feira - 18 de abril de 2012. Disponível em: <http://www.tjdft.jus.br/institucional/comiteexecutivo-distrital-da-saude/noticias-do-tjdft >. Acesso em 14 jul. 2016.

BRASÍLIA. II Seminário de Saúde Pública do Distrito Federal conta com a participação do TJDFT - 14 de maio de 2012. Disponível em:

<http://www.tjdft.jus.br/institucional/comite-executivo-distrital-da-saude/noticias-do-tjdft >. Acesso em 14 jul. 2016.

BRASÍLIA. Comitê executivo de saúde do DF divulga ata da última reunião - 16 de maio de 2012. Disponível em: <http://www.tjdft.jus.br/institucional/comite-executivodistrital-da-saude/noticias-do-tjdft >. Acesso em 14 jul. 2016.

BRASÍLIA. Seminário de Saúde Suplementar encerra discutindo soluções inovadoras sobre o tema - 29 de junho de 2012. Disponível em: $<$ http://www.tjdft.jus.br/institucional/comite-executivo-distrital-da-saude/noticias-do-tjdft $>$. Acesso em 14 jul. 2016.

BRASÍLIA. Comitê de Saúde discute temas relevantes e atuais sobre saúde pública no DF - 06 de julho de 2012. Disponível em:

<http://www.tjdft.jus.br/institucional/comite-executivo-distrital-da-saude/noticias-do-tjdft >. Acesso em 14 jul. 2016.

BRASÍLIA. Comitê de Saúde discute sobre medicamentos, contratação e leitos de UTI - 14 de agosto de 2012. Disponível em: <http://www.tjdft.jus.br/institucional/comiteexecutivo-distrital-da-saude/noticias-do-tjdft >. Acesso em 14 jul. 2016. 
TRIBUNAL DE JUSTIÇA DO DISTRITO FEDERAL E TERRITÓRIOS. BRASÍLIA. Comitê Distrital da Saúde debate questões relativas a cirurgias realizadas por hospitais públicos - 29 de novembro de 2012. Disponível em:

<http://www.tjdft.jus.br/institucional/comite-executivo-distrital-da-saude/noticias-do-tjdft >. Acesso em 14 jul. 2016.

BRASÍLIA. Comitê de Saúde encerrou 2012 com propostas importantes - 29 de janeiro de 2013. Disponível em: <http://www.tjdft.jus.br/institucional/comite-executivodistrital-da-saude/noticias-do-tjdft >. Acesso em 14 jul. 2016.

BRASÍLIA. Comitê Distrital de saúde realiza primeira reunião de 2013 - 05 de fevereiro de 2013. Disponível em: <http://www.tjdft.jus.br/institucional/comite-executivodistrital-da-saude/noticias-do-tjdft >. Acesso em 14 jul. 2016.

BRASÍLIA. Comitê de Saúde institui Câmara de mediação em saúde - 28 de fevereiro de 2013. Disponível em: <http://www.tjdft.jus.br/institucional/comite-executivodistrital-da-saude/noticias-do-tjdft >. Acesso em 14 jul. 2016.

BRASÍLIA. TJDFT e Secretaria de Saúde vão assinar termo de cooperação - 05 de março de 2013. Disponível em: <http://www.tjdft.jus.br/institucional/comite-executivodistrital-da-saude/noticias-do-tjdft >. Acesso em 14 jul. 2016.

BRASÍLIA. TJDFT e Secretaria de Saúde assinam termo de cooperação - 06 de março de 2013. Disponível em: <http://www.tjdft.jus.br/institucional/comite-executivodistrital-da-saude/noticias-do-tjdft >. Acesso em 14 jul. 2016.

BRASÍLIA. Comitê de Saúde divulga balanço de processos atinentes à saúde - 20 de março de 2013. Disponível em: <http://www.tjdft.jus.br/institucional/comite-executivodistrital-da-saude/noticias-do-tjdft >. Acesso em 14 jul. 2016.

BRASÍLIA. Juiz do TJDFT palestra em simpósio sobre judicialização da saúde 24 de maio de 2013. Disponível em: <http://www.tjdft.jus.br/institucional/comite-executivodistrital-da-saude/noticias-do-tjdft >. Acesso em 14 jul. 2016.

. BRASÍLIA. TJDFT lança página do Comitê Executivo Distrital da Saúde - 27 de maio de 2013. Disponível em: <http://www.tjdft.jus.br/institucional/comite-executivodistrital-da-saude/noticias-do-tjdft >. Acesso em 14 jul. 2016.

BRASÍLIA. Comitê Distrital de Saúde se reúne e comemora 2 anos - 12 de juho de 2013. Disponível em: <http://www.tjdft.jus.br/institucional/comite-executivo-distrital-dasaude/noticias-do-tjdft >. Acesso em 14 jul. 2016.

BRASÍLIA. Biblioteca virtual pode auxiliar juízes em ações relacionadas à saúde - 10 de julho de 2013. Disponível em: <http://www.tjdft.jus.br/institucional/comiteexecutivo-distrital-da-saude/noticias-do-tjdft >. Acesso em 14 jul. 2016. 
TRIBUNAL DE JUSTIÇA DO DISTRITO FEDERAL E TERRITÓRIOS. BRASÍLIA. Decisões do TJDFT garantem medicação de alto custo a pacientes com doenças graves 18 de novembro de 2013. Disponível em: <http://www.tjdft.jus.br/institucional/comiteexecutivo-distrital-da-saude/noticias-do-tjdft >. Acesso em 14 jul. 2016.

. BRASÍLIA. Comitê Distrital de Saúde se reúne nesta sexta - 05 de dezembro de 2013. Disponível em: <http://www.tjdft.jus.br/institucional/comite-executivo-distrital-dasaude/noticias-do-tjdft >. Acesso em 14 jul. 2016.

BRASÍLIA. Comitê Distrital de Saúde apresenta propostas para solucionar problemas da pasta no DF - 09 de dezembro de 2013. Disponível em:

$<$ http://www.tjdft.jus.br/institucional/comite-executivo-distrital-da-saude/noticias-do-tjdft >. Acesso em 14 jul. 2016.

BRASÍLIA. Comitê Distrital de Saúde se reúne nesta quinta - 29 de janeiro de 2014. Disponível em: <http://www.tjdft.jus.br/institucional/comite-executivo-distrital-dasaude/noticias-do-tjdft >. Acesso em 14 jul. 2016.

BRASÍLIA. Comitê Executivo Distrital da Saúde realiza primeira reunião do ano - 06 de fevereiro de 2014. Disponível em: <http://www.tjdft.jus.br/institucional/comiteexecutivo-distrital-da-saude/noticias-do-tjdft >. Acesso em 14 jul. 2016.

BRASÍLIA. Comitê Executivo Distrital da Saúde compartilha avanços em reunião - 06 de março de 2014. Disponível em:

$<$ http://www.tjdft.jus.br/institucional/comite-executivo-distrital-da-saude/noticias-do-tjdft >. Acesso em 14 jul. 2016.

BRASÍLIA. Comitê Executivo Distrital de saúde se reúne na próxima quinta - 29 de maio de 2014. Disponível em: <http://www.tjdft.jus.br/institucional/comite-executivodistrital-da-saude/noticias-do-tjdft >. Acesso em 14 jul. 2016.

BRASÍLIA. Comitê de Saúde se reúne para buscar soluções aos problemas da saúde pública do DF - 06 de junho de 2016. Disponível em:

$<$ http://www.tjdft.jus.br/institucional/comite-executivo-distrital-da-saude/noticias-do-tjdft $>$. Acesso em 14 jul. 2016.

BRASÍLIA. Ata da Primeira reunião do Comitê de Saúde do Distrito Federal de 30 de junho de 2011a. Disponível em: <http://www.tjdft.jus.br/institucional/comiteexecutivo-distrital-da-saude/atas/1a-ata/view>. Acesso em 10 jul. 2016.

BRASÍLIA. Ata da Segunda reunião do Comitê de Saúde do Distrito Federal de 10 de agosto de 2011. Disponível em: <http://www.tjdft.jus.br/institucional/comiteexecutivo-distrital-da-saude/atas/2a-ata/view>. Acesso em 10 jul. 2016.

BRASÍLIA. Ata da Terceira reunião do Comitê de Saúde do Distrito Federal de 13 de setembro de 2011. Disponível em: <http://www.tjdft.jus.br/institucional/comiteexecutivo-distrital-da-saude/atas/3a-ata/view>. Acesso em 10 jul. 2016. 
TRIBUNAL DE JUSTIÇA DO DISTRITO FEDERAL E TERRITÓRIOS. BRASÍLIA. Ata da Quarta reunião do Comitê de Saúde do Distrito Federal de 5 de outubro de 2011. Disponível em: <http://www.tjdft.jus.br/institucional/comite-executivo-distrital-dasaude/atas/4a-ata/view>. Acesso em 10 jul. 2016.

BRASÍLIA. Ata da Quinta reunião do Comitê de Saúde do Distrito Federal de 17 de outubro de 2011. Disponível em: <http://www.tjdft.jus.br/institucional/comite-executivodistrital-da-saude/atas/5a-ata/view>. Acesso em 10 jul. 2016.

BRASÍLIA. Ata da Sexta reunião do Comitê de Saúde do Distrito Federal de 26

de outubro de 2011. Disponível em: <http://www.tjdft.jus.br/institucional/comite-executivodistrital-da-saude/atas/6a-ata/view>. Acesso em 10 jul. 2016.

. BRASÍLIA. Ata da Sétima reunião do Comitê de Saúde do Distrito Federal de 13 de dezembro de 2011. Disponível em: <http://www.tjdft.jus.br/institucional/comiteexecutivo-distrital-da-saude/atas/7a-ata/view>. Acesso em 10 jul. 2016.

. BRASÍLIA. Ata da Oitava reunião do Comitê de Saúde do Distrito Federal de 14 de fevereiro de 2012. Disponível em: <http://www.tjdft.jus.br/institucional/comiteexecutivo-distrital-da-saude/atas/8a-ata/view>. Acesso em 10 jul. 2016.

BRASÍLIA. Ata da Nona reunião do Comitê de Saúde do Distrito Federal de 29 de março de 2012. Disponível em: <http://www.tjdft.jus.br/institucional/comite-executivodistrital-da-saude/atas/9a-ata/view>. Acesso em 10 jul. 2016.

BRASÍLIA. Ata da Décima reunião do Comitê de Saúde do Distrito Federal de 21 de junho de 2012. Disponível em: <http://www.tjdft.jus.br/institucional/comite-executivodistrital-da-saude/atas/10a-ata/view>. Acesso em 10 jul. 2016.

BRASÍLIA. Ata da Décima primeira reunião do Comitê de Saúde do Distrito Federal de 13 de agosto de 2012. Disponível em:

$<$ http://www.tjdft.jus.br/institucional/comite-executivo-distrital-da-saude/atas/11a-ata/view $>$. Acesso em 10 jul. 2016.

BRASÍLIA. Ata da Décima segunda reunião do Comitê de Saúde do Distrito Federal de 24 de outubro de 2012. Disponível em:

$<$ http://www.tjdft.jus.br/institucional/comite-executivo-distrital-da-saude/atas/12a-ata/view > Acesso em 10 jul. 2016.

. BRASÍLIA. Ata da Décima terceira reunião do Comitê de Saúde do Distrito Federal de 26 de outubro de 2012. Disponível em:

$<$ http://www.tjdft.jus.br/institucional/comite-executivo-distrital-da-saude/atas/13a-ata/view $>$. Acesso em 10 jul. 2016.

BRASÍLIA. da Décima quarta reunião do Comitê de Saúde do Distrito Federal de 29 de novembro de 2012. Disponível em: <http://www.tjdft.jus.br/institucional/comiteexecutivo-distrital-da-saude/atas/14a-ata/view>. Acesso em 10 jul. 2016. 
TRIBUNAL DE JUSTIÇA DO DISTRITO FEDERAL E TERRITÓRIOS. BRASÍLIA. Ata da Décima quinta reunião do Comitê de Saúde do Distrito Federal de 4 de abril de 2013. Disponível em: <http://www.tjdft.jus.br/institucional/comite-executivo-distrital-dasaude/atas/ata-4-4-2013/view>. Acesso em 10 jul. 2016.

. BRASÍLIA. Ata da Décima sexta reunião do Comitê de Saúde do Distrito Federal de 17 de abril de 2013. Disponível em: <http://www.tjdft.jus.br/institucional/comiteexecutivo-distrital-da-saude/atas/16a-ata-17-04-2013/view>. Acesso em 10 jul. 2016.

BRASÍLIA. Ata da Décima sétima reunião do Comitê de Saúde do Distrito

Federal de 6 de dezembro de 2013. Disponível em:

$<$ http://www.tjdft.jus.br/institucional/comite-executivo-distrital-da-saude/atas/17a-ata-06-122013/view>. Acesso em 10 jul. 2016.

. BRASÍLIA. Ata da Décima oitava reunião do Comitê de Saúde do Distrito Federal de 30 de janeiro de 2014. Disponível em:

$<$ http://www.tjdft.jus.br/institucional/comite-executivo-distrital-da-saude/atas/ata-30-0114/view>. Acesso em 10 jul. 2016.

BRASÍLIA. Ata da Décima nona reunião do Comitê de Saúde do Distrito Federal de 20 de fevereiro de 2014. Disponível em: <http://www.tjdft.jus.br/institucional/comiteexecutivo-distrital-da-saude/atas/19a-ata-20-02-2014/view>. Acesso em 10 jul. 2016.

. BRASÍLIA. Ata da Vigésima reunião do Comitê de Saúde do Distrito Federal de 25 de abril de 2014. Disponível em: <http://www.tjdft.jus.br/institucional/comite-executivodistrital-da-saude/atas/20a-ata-20-04-2014/view>. Acesso em 10 jul. 2016.

. BRASÍLIA. Ata da Vigésima primeira reunião do Comitê de Saúde do Distrito Federal de 05 de junho de 2014. Disponível em:

$<$ http://www.tjdft.jus.br/institucional/comite-executivo-distrital-da-saude/atas/21a-ata-05-062014/view>. Acesso em 10 jul. 2016.

BRASÍLIA. Ata da reunião extraordinária do Comitê de Saúde do Distrito

Federal de 08 de agosto de 2014. Disponível em:

<http://www.tjdft.jus.br/institucional/comite-executivo-distrital-da-saude/atas/ataextraordinaria-08-08-2014/view>. Acesso em 10 jul. 2016.

. BRASÍLIA. Ata da Vigésima segunda reunião do Comitê de Saúde do Distrito Federal de 25 de setembro de 2014. Disponível em:

<http://www.tjdft.jus.br/institucional/comite-executivo-distrital-da-saude/atas/22a-ata-25-092014/view>. Acesso em 10 jul. 2016.

BRASÍLIA. Ata da reunião reunião do Comitê de Saúde do Distrito Federal de 2 de outubro de 2014. Disponível em: <http://www.tjdft.jus.br/institucional/comite-executivodistrital-da-saude/atas/ata-sintese-ses-02-10-2014/view>. Acesso em 10 jul. 2016. 
TRIBUNAL DE JUSTIÇA DO DISTRITO FEDERAL E TERRITÓRIOS. BRASÍLIA. Ata da reunião extraordinária do Comitê de Saúde do Distrito Federal de 10 de novembro de 2014. Disponível em: <http://www.tjdft.jus.br/institucional/comite-executivo-distrital-dasaude/atas/ata-extraordinaria-de-10-11-2014/view>. Acesso em 10 jul. 2016.

. BRASÍLIA. Ata da Vigésima terceira reunião do Comitê de Saúde do Distrito Federal de 20 de novembro de 2014. Disponível em:

$<$ http://www.tjdft.jus.br/institucional/comite-executivo-distrital-da-saude/atas/23a-ata-20-122014/view>. Acesso em 10 jul. 2016.

BRASÍLIA. Ata da Vigésima quarta reunião do Comitê de Saúde do Distrito Federal de 28 de janeiro de 2015. Disponível em:

$<$ http://www.tjdft.jus.br/institucional/comite-executivo-distrital-da-saude/atas/24a-ata-28-012015/view>. Acesso em 10 jul. 2016.

BRASÍLIA. Ata da Vigésima quinta reunião do Comitê de Saúde do Distrito Federal de 27 de março de 2015. Disponível em:

<http://www.tjdft.jus.br/institucional/comite-executivo-distrital-da-saude/atas/25a-ata-27-032015/view>. Acesso em 10 jul. 2016.

. BRASÍLIA. Ata da Vigésima sexta reunião do Comitê de Saúde do Distrito Federal de 29 de maio de 2015. Disponível em:

$<$ http://www.tjdft.jus.br/institucional/comite-executivo-distrital-da-saude/atas/26a-ata-29-052015/view>. Acesso em 10 jul. 2016.

. BRASÍLIA. Ata da Vigésima sétima reunião do Comitê de Saúde do Distrito Federal de 20 de agosto de 2015. Disponível em:

$<$ http://www.tjdft.jus.br/institucional/comite-executivo-distrital-da-saude/atas/27a-ata-20-082015/view>. Acesso em 10 jul. 2016.

BRASÍLIA. Ata da Vigésima oitava reunião do Comitê de Saúde do Distrito

Federal de 20 de abril de 2016. Disponível em:

$<$ http://www.tjdft.jus.br/institucional/comite-executivo-distrital-da-saude/atas/28a-ata-20-042016/view>. Acesso em 10 jul. 2016.

. BRASÍLIA. Ata da Vigésima nona reunião do Comitê de Saúde do Distrito

Federal de 3 de junho de 2016. Disponível em: <http://www.tjdft.jus.br/institucional/comiteexecutivo-distrital-da-saude/atas/29a-ata-03-06-2016/view>. Acesso em 10 jul. 2016.

. BRASÍLIA. Ata da reunião extraordinária do Comitê de Saúde do Distrito

Federal de 16 de junho de 2016. Disponível em:

$<$ http://www.tjdft.jus.br/institucional/comite-executivo-distrital-da-saude/atas/ataextraordinaria-de-16-06-2016/view>. Acesso em 10 jul. 2016.

Comitê Executivo Distrital da Saúde. Disponível em:

<http://www.tjdft.jus.br/institucional/comite-executivo-distrital-da-saude>. Acesso em 06 jul. 2016. 
VAN de VEN, Andrew H.; WALKER, Gordon. The Dynamics of Interorganizational Coordination. Administrative Science Quarterly.Vol. 29, p. 598-621, 1984.

VENTURA, M.; SIMAS, L.; PEPE, V.L.E.; SCHRAMM, F.R. Judicialização da saúde, acesso à justiça e a efetividade do direito à saúde. Revista de Saúde Coletiva, Rio de Janeiro, v. 20, n. 1, p.77-100. 2010.

VIANNA, João Ernesto Aragonés. Curso de direito previdenciário. $3^{\text {a }}$ ed. São Paulo: Atlas, 2010.

VIEIRA, M. Por uma boa pesquisa (qualitativa) em administração. In: VIEIRA, M.; ZOUAIN, D. (Ed.). Pesquisa Qualitativa em Administração. Rio de Janeiro: Editora FGV, 2004. p. 13-28.

VIEIRA, F.S.; ZUCCHI, P. Distorções causadas pelas ações judiciais à política de medicamentos no Brasil. Revista de Saúde Pública. v. 41, n. 2, p. 214-22. 2007.

VIEIRA, F.S. Ações judiciais e direito à saúde: reflexão sobre a observância aos princípios do SUS. Revista de Saúde Pública, p. 1-5. 2008.

VIEIRA, F.S.; ZUCCHI, P. Financiamento da Assistência Farmacêutica no Sistema Único de Saúde. Revista Saúde Sociedade. v. 22, n. 1, p. 73-84. 2013.

WANG, D. W. L. Escassez de recursos, custos dos direitos e reserva do possível na jurisprudência do STF. Revista Direito GV, São Paulo, v. 4, n. 2, p. 539-568, jul./dez. 2008.

YANOW, D. (2006). Neither rigorous nor objective? Interrogating criteria for knowledge claims in interpretive science. In D. Yanow \& P. Shwartz-Shea (Eds.), Interpretataion and Method: Empirical research methods and the interpretive turn. Armonk, New York: M.E. Sharpe, pp. 67-88. 400p.

YIN, R. K. Estudo de caso: planejamento e métodos / Robert K. Yin; trad. Daniel Grassi. 2 ed. Porto Alegre: Bookman. 2001. 
$\boldsymbol{A P} \hat{\boldsymbol{E}} \boldsymbol{N D I C E} \boldsymbol{A}$ - Organização das entrevistas

\begin{tabular}{|c|c|c|c|}
\hline Classificação EN & $\begin{array}{l}\text { Numeração/ } \\
\text { classificação }\end{array}$ & Área de atuação do entrevistado & $\begin{array}{l}\text { Depoimento sobre Sistema } \\
\text { de Saúde (SS) e/ou sobre } \\
\text { Judicialização da Saúde (JS) }\end{array}$ \\
\hline ENTREVISTAS & $1 \mathrm{EN}$ & $\begin{array}{l}\text { Gerência do CEAF no Ministério da } \\
\text { Saúde (GCEAF/DAF/SCTIE/MS) }\end{array}$ & $\mathrm{SS} / \mathrm{JS}$ \\
\hline ENTREVISTAS & $2 \mathrm{EN}$ & $\begin{array}{l}\text { Diretoria de Assistência Farmacêutica } \\
\text { (DIASF/SES-DF) }\end{array}$ & $\mathrm{SS} / \mathrm{JS}$ \\
\hline ENTREVISTAS & $3 \mathrm{EN}$ & Gerência do CEAF/DIASF/SES-DF & SS/JS \\
\hline ENTREVISTAS & $4 \mathrm{EN}$ & Núcleo de Farmácia do CEAF SES-DF & $\mathrm{SS} / \mathrm{JS}$ \\
\hline ENTREVISTAS & $5 \mathrm{EN}$ & Núcleo de Farmácia do CEAF SES-DF & SS/JS \\
\hline ENTREVISTAS & $6 \mathrm{EN}$ & $\begin{array}{l}\text { Núcleo de Farmácia do CEAF SES-DF } \\
\text { e antigo Núcleo de Judicialização da } \\
\text { SES-DF }\end{array}$ & JS \\
\hline ENTREVISTAS & $7 \mathrm{EN}$ & $\begin{array}{l}\text { Farmácia da Regional de Saúde de } \\
\text { Ceilândia da SES-DF e pesquisador } \\
\text { sobre a judicialização da saúde no DF }\end{array}$ & JS \\
\hline ENTREVISTAS & $8 \mathrm{EN}$ & Farmácia de Ações Judiciais da SES-DF & JS \\
\hline ENTREVISTAS & 9EN & Núcleo de Judicialização da SES-DF & JS \\
\hline ENTREVISTAS & $10 \mathrm{EN}$ & Núcleo de Judicialização da SES-DF & JS \\
\hline ENTREVISTAS & $11 \mathrm{EN}$ & Defensoria Pública do DF & $\mathrm{JS}$ \\
\hline ENTREVISTAS & $12 \mathrm{EN}$ & Defensoria Pública do DF & JS \\
\hline ENTREVISTAS & $13 \mathrm{EN}$ & Procuradoria da República no DF & JS \\
\hline ENTREVISTAS & 14EN & Advogado - OAB & JS \\
\hline
\end{tabular}


AP $\hat{E}$ NDICE B - Roteiro para entrevistas dos atores do Sistema de Saúde (REASS)

\section{PARTE I - CARACTERIZAÇÃO DA ENTREVISTA E DO ENTREVISTADO}

\begin{tabular}{l|l|l}
\hline \hline Número: & Data: & Duração: \\
\hline & $\begin{array}{l}\text { Apresentação dos objetivos da pesquisa; agradecimento pela } \\
\text { participação; consentimento e autorização da gravação; sigilo das } \\
\text { informaçôes prestadas; informação sobre divulgação dos dados; } \\
\text { questionamento sobre dúvidas. }\end{array}$ \\
\hline ENTREVISTADO (Iniciais do & \\
Nome): & \\
\hline ORGANIZAÇÃO: & \\
\hline CARGO/FUNÇÃO: &
\end{tabular}

PARTE II - PERGUNTAS ABERTAS

Categoria 1 - Aparato normativo

O seu trabalho segue alguma normatização para o funcionamento? Quais seriam essas normas? Há objetivos definidos para as suas tarefas e de seus colegas? Quais seriam?

Há previsões financeiras para as atividades realizadas pelo(a) Senhor(a) e por seu departamento? Elas estão disponíveis em qual documento? Na prática, como são as decisões para a disponibilização desses recursos? Há seguimento a rigor do que foi previsto?

Categoria 2 - Contexto social, econômico e político

$\mathrm{O}(\mathrm{a})$ Senhor(a) tem conhecimento sobre outros departamentos ou instituições que trabalham a favor do funcionamento do CEAF? Quais seriam os apoiadores e/ou interessados no sucesso do programa? E quais os tipos de ação que realizam em apoio ao funcionamento do CEAF?

$\mathrm{O}$ (a) Senhor observa alguma mudança nas condições econômicas para o funcionamento desse programa? Em que sentido? Atualmente, há recursos financeiros disponíveis para o adequado funcionamento do mesmo? Poderia dar uns exemplos concretos que mostram a disponibilidade ou não de recursos adequados?

Categoria 3 - Natureza do Problema

Qual é o seu conhecimento quanto à existência ou não de demanda não atendida? Há alguma ação prevista para o CEAF que não é ou não consegue ser realizada por alguma razão, na conjuntura atual? Qual(is) e por que? Considerando os princípios do SUS de igualdade e universalidade, você acha que a dispensação dos medicamentos do CEAF atende à esses princípios da forma como está sendo feita atualmente? Por quê ou porquê não?

Você percebeu mudança sobre o funcionamento do sistema de dispensação desses medicamentos ao longo do tempo? Caso sim, em que sentido? Há alguma mudança percebida como resultado da judicialização? Qual(is)? A judicialização influencia de alguma forma o funcionamento desse Programa? Se sim, que consequência gera sobre o funcionamento do Programa, do seu ponto de vista?

Há informações disponíveis ao público quanto à cobertura e custos relacionados à dispensação dos medicamentos do CEAF pelo Sistema Único de Saúde? Quais as informações e como estão disponibilizadas ao público? E há informações disponíveis ao público quanto à cobertura e custos relacionados ao acesso aos mesmos medicamentos pelo Sistema Judiciário? Novamente, quais as informações disponibilizadas e como estão disponibilizadas? 
Categoria 4 - Aparato administrativo

Sobre o sistema de saúde:

Estrutura organizacional - Quais são as responsabilidades compreendidas para o seu cargo, dentro da gestão do CEAF? Que perfil de trabalho você executa em sua rotina?

Qual seria o organograma do Ministério da Saúde/SES-DF relacionado a gestão do CEAF? Quais seriam as atividades sob responsabilidade destes departamentos?

Como os serviços (Farmácias de Alto Custo da SES-DF) se inserem no organograma da SES-DF? E quais seriam as atividades realizadas por esses serviços?

Para esses órgãos de gestão do CEAF, quais as diferenças operacionais entre os grupos 1A, 1B, 2 e 3 ?

Recursos humanos - Quais são os atores envolvidos com o CEAF no Governo Federal (Ministério da Saúde)? E quais são os atores responsáveis pelo CEAF no Governo do Distrito Federal? Quem seriam os atores envolvidos com a dispensação dos medicamentos do CEAF nos serviços (Farmácias de Alto Custo da SES.DF)?

A organização atual do aparato administrativo de gestão do CEAF estava prevista desde o início da operacionalização do Programa do CEAF? Caso não, quais as modificações que foram feitas, por quê e quando? Sobre as ações judiciais/ sistema judiciário:

Estrutura organizacional - No caso dos medicamentos a serem adquiridos por ganho de causas judiciais, como é feito o financiamento, a programação de compra, a aquisição e a dispensação? Quais seriam o organograma e órgãos envolvidos com essa prática? Há diferenças para a gestão dos grupos 1A, 1B, 2 e 3 solicitados por ações judiciais?

Recursos humanos - Quais são os atores envolvidos com a gestão de medicamentos do CEAF requeridos por ações judiciais?

Qual é a interface entre o Sistema de Saúde e o Sistema Judiciário na gestão do CEAF diante da judicialização de medicamentos desse grupo?

Categoria 5 - Discricionariedade

Para a sua rotina (gestão ou serviço), há algum roteiro/modelo de gestão a ser seguido para a execução das suas atividades/atendimentos? Como você o utiliza? Há casos em que o roteiro/modelo não se encaixa? Poderia descrever uma situação concreta em que isso aconteceu?

Considerando o seu conhecimento sobre as normas, é possível ou o(a) Senhor(a) mesmo já tomou decisões sobre a alocação de recursos relacionados ao CEAF? Poderia descrever uma situação concreta em que isso aconteceu? No dia-a-dia, há alguma prática que consiga reduzir a demanda pelos medicamentos ou ajustar as dificuldades de seu trabalho, que seja feita pelo(a) Senhor(a) ou seus colegas? É possível adaptar as atividades, metas ou objetivos? 
AP $\hat{E} N D I C E$ C - Roteiro para entrevistas dos atores do judiciário (REAJ)

\section{PARTE I - CARACTERIZAÇÃO DA ENTREVISTA E DO ENTREVISTADO}

\begin{tabular}{l|l|l|}
\hline Número: & Data: & Duração: \\
\hline & Apresentação dos objetivos da pesquisa; agradecimento pela \\
INFORMAÇÕES INICIAIS: & participação; consentimento e autorização da gravação; sigilo das \\
& $\begin{array}{l}\text { informações prestadas; informação sobre divulgação dos dados; } \\
\text { questionamento sobre dúvidas. }\end{array}$ \\
\hline
\end{tabular}

ENTREVISTADO (Iniciais do

Nome):

ORGANIZAÇÃO:

CARGO/FUNÇÃO:

OBSERVAÇÕES:

PARTE II - PERGUNTAS ABERTAS

Categoria 1 - Aparato normativo

O seu trabalho segue alguma normatização para o funcionamento quanto às ações judiciais em saúde? Quais seriam essas normas? Há objetivos definidos para as suas tarefas e de seus colegas? Quais seriam?

No que tange as ações em saúde, há previsões financeiras para as atividades realizadas pelo(a) Senhor(a) e por seu departamento? Elas estão disponíveis em qual documento? Na prática, como são as decisões para a disponibilização desses recursos? Há seguimento a rigor do que foi previsto?

Categoria 2 - Contexto social, econômico e político

O (a) Senhor(a) sabe dizer se Sistema Judiciário tem interface com o Sistema de Saúde, quando lida com ações relacionadas ao acesso de medicamentos? Qual é? O(a) Senhor(a) conhece essa organização? Como funciona?

Por favor, descreva em suas próprias palavras o que seria a problemática da judicialização da saúde?

Por favor, discorra seus conhecimentos sobre o funcionamento da gestão do CEAF no Sistema de Saúde?

Categoria 3 - Natureza do Problema

Na sua experiência, quais seriam as motivações para as ações de acesso à medicamentos?

Você percebeu mudança sobre a judicialização de medicamentos ao longo do tempo? Caso sim, em que sentido? $\mathrm{Na}$ sua opinião, qual a influência da judicialização sobre o acesso aos medicamentos? Sobre o funcionamento desse Programa no SUS?

Há informações disponíveis ao público quanto à cobertura e custos relacionados ao acesso aos mesmos medicamentos pelo ganho de causa dado pelo Sistema Judiciário? Quais as informações disponibilizadas e onde estão disponibilizadas? No mesmo sentido, há informações disponíveis sobre os processos judiciais relacionados aos medicamentos, quais são e onde estão disponibilizadas?

Categoria 4 - Aparato administrativo

Sobre as ações judiciais/ sistema judiciário:

Estrutura organizacional - Quais são as responsabilidades compreendidas para o seu cargo, quanto às ações de medicamentos? Que perfil de trabalho você executa em sua rotina?

Qual seria o organograma do Sistema Judiciário para as ações em saúde? Quais seriam as atividades sob responsabilidade de cada departamento?

Para as ações em saúde, existe diferença entre as ações de medicamentos dos diferentes grupos do CEAF ( $1 \mathrm{~A}$, 1B, 2 e 3)?

Recursos humanos - Quais são os atores envolvidos com as ações de medicamentos do CEAF no Sistema Judiciário?

A organização atual do aparato administrativo para ações em saúde sofreu mudanças ao longo do tempo? Se sim, quais as modificações que foram feitas, por quê e quando?

\section{Categoria 5 - Discricionariedade}

Para a sua rotina, há algum roteiro/modelo a ser seguido para a execução das suas atividades/atendimentos, ou variam de acordo com cada caso judicial? Como você o utiliza? Há casos em que o roteiro/modelo não se encaixa? Poderia descrever uma situação concreta em que isso aconteceu?

Há objetivos e metas fixas para as suas atividades diárias? 
$\boldsymbol{A P} \hat{\boldsymbol{E} N D I C E} \boldsymbol{D}$ - Organização da pesquisa documental - DOCUMENTOS LEGAIS E NORMATIVOS

\begin{tabular}{|c|c|c|c|c|}
\hline Tipo documental & $\begin{array}{l}\text { Numeração/ } \\
\text { classificação }\end{array}$ & Documentos analisados & Fontes de informações sobre & Referências \\
\hline $\begin{array}{l}\text { DOCUMENTOS } \\
\text { LEGAIS E } \\
\text { NORMATIVOS }\end{array}$ & $1 \mathrm{LN}$ & Constituição Federal de 1988 & $\begin{array}{l}\text { Constituição da república federativa do Brasil de } \\
1988 .\end{array}$ & (BRASIL, 1988) \\
\hline $\begin{array}{l}\text { DOCUMENTOS } \\
\text { LEGAIS E } \\
\text { NORMATIVOS }\end{array}$ & $2 \mathrm{LN}$ & Lei $\mathrm{n}^{\circ} 8.080$, de 19 de setembro de 1990 & $\begin{array}{l}\text { Condições para a promoção, proteção e recuperação } \\
\text { da saúde, a organização e o funcionamento dos } \\
\text { serviços correspondentes e dá outras providências. }\end{array}$ & (BRASIL, 1990a) \\
\hline $\begin{array}{l}\text { DOCUMENTOS } \\
\text { LEGAIS E } \\
\text { NORMATIVOS }\end{array}$ & $3 \mathrm{LN}$ & Lei $\mathrm{n}^{\circ} 12.401$, de 28 de abril de 2011 & $\begin{array}{l}\text { Alteração da Lei no } 8.080 \text {, de } 19 \text { de setembro de } 1990, \\
\text { para dispor sobre a assistência terapêutica e a } \\
\text { incorporação de tecnologia em saúde no âmbito do } \\
\text { Sistema Único de Saúde - SUS. }\end{array}$ & (BRASIL, 2011a) \\
\hline $\begin{array}{l}\text { DOCUMENTOS } \\
\text { LEGAIS E } \\
\text { NORMATIVOS }\end{array}$ & $4 \mathrm{LN}$ & Resolução nº 338/CNS/MS, de 6 de maio de 2004 & Política Nacional de Assistência Farmacêutica. & (BRASIL, 2004) \\
\hline $\begin{array}{l}\text { DOCUMENTOS } \\
\text { LEGAIS E } \\
\text { NORMATIVOS }\end{array}$ & $5 \mathrm{LN}$ & Portaria nº 204/GM/MS, de 29 de janeiro de 2007 & $\begin{array}{l}\text { Financiamento e a transferência dos recursos federais } \\
\text { para as ações e serviços de saúde. }\end{array}$ & (BRASIL, 2007a) \\
\hline $\begin{array}{l}\text { DOCUMENTOS } \\
\text { LEGAIS E } \\
\text { NORMATIVOS }\end{array}$ & $6 \mathrm{LN}$ & Portaria n ${ }^{\circ} 2.577$, DE 27 DE OUTUBRO DE 2006 & $\begin{array}{l}\text { Componente de Medicamentos de Dispensação } \\
\text { Excepcional. }\end{array}$ & (BRASIL, 2006) \\
\hline $\begin{array}{l}\text { DOCUMENTOS } \\
\text { LEGAIS E } \\
\text { NORMATIVOS }\end{array}$ & $7 \mathrm{LN}$ & Portaria nº 2981 DE 26 DE NOVEMBRO DE 2009 & $\begin{array}{l}\text { Componente Especializado da Assistência } \\
\text { Farmacêutica. }\end{array}$ & (BRASIL, 2009b) \\
\hline $\begin{array}{l}\text { DOCUMENTOS } \\
\text { LEGAIS E } \\
\text { NORMATIVOS }\end{array}$ & $8 \mathrm{LN}$ & Portaria $\mathrm{n}^{\circ} 1.554 / \mathrm{GM} / \mathrm{MS}$, de 30 de julho de 2013 & $\begin{array}{l}\text { Regras de financiamento e execução do Componente } \\
\text { Especializado da Assistência Farmacêutica no âmbito } \\
\text { do Sistema Único de Saúde (SUS). }\end{array}$ & (BRASIL, 2013b) \\
\hline $\begin{array}{l}\text { DOCUMENTOS } \\
\text { LEGAIS E } \\
\text { NORMATIVOS }\end{array}$ & 9LN & Decreto $^{\circ}{ }^{\circ} 7.646$, de 21 de dezembro de 2011 & $\begin{array}{l}\text { Comissão Nacional de Incorporação de Tecnologias } \\
\text { no Sistema Único de Saúde e sobre o processo } \\
\text { administrativo para incorporação, exclusão e alteração } \\
\text { de tecnologias em saúde pelo Sistema Único de } \\
\text { Saúde - SUS, e dá outras providências. }\end{array}$ & (BRASIL, 2011c) \\
\hline $\begin{array}{l}\text { DOCUMENTOS } \\
\text { LEGAIS E }\end{array}$ & $10 \mathrm{LN}$ & Decreto $n^{\circ} 7.508$, de 28 de junho de 2011 & $\begin{array}{l}\text { Organização do Sistema Único de Saúde - SUS, o } \\
\text { planejamento da saúde, a assistência à saúde e a }\end{array}$ & (BRASIL, 2011b) \\
\hline
\end{tabular}




\begin{tabular}{|c|c|c|c|c|}
\hline NORMATIVOS & & & articulação interfederativa, e dá outras providências. & \\
\hline $\begin{array}{l}\text { DOCUMENTOS } \\
\text { LEGAIS E } \\
\text { NORMATIVOS }\end{array}$ & $11 \mathrm{LN}$ & Portaria nº 3.916/GM/MS, de 30 de outubro de 1998 & Política Nacional de Medicamentos. & (BRASIL, 1998) \\
\hline $\begin{array}{l}\text { DOCUMENTOS } \\
\text { LEGAIS E } \\
\text { NORMATIVOS }\end{array}$ & $12 \mathrm{LN}$ & Lei $\mathrm{n}^{\circ} 10.742$, de 6 de outubro de 2003 & $\begin{array}{l}\text { Normas de regulação para o setor farmacêutico, cria a } \\
\text { Câmara de Regulação do Mercado de Medicamentos - } \\
\text { CMED e altera a Lei no } 6.360 \text {, de } 23 \text { de setembro de } \\
\text { 1976, e dá outras providências. }\end{array}$ & (BRASIL, 2003) \\
\hline $\begin{array}{l}\text { DOCUMENTOS } \\
\text { LEGAIS E } \\
\text { NORMATIVOS }\end{array}$ & $13 \mathrm{LN}$ & $\begin{array}{l}\text { Portaria Interministerial MPAS/MS/MEC n }{ }^{\circ} 3 \text {, de } 15 \\
\text { dezembro de } 1982\end{array}$ & $\begin{array}{l}\text { Que os serviços prestadores de assistência médica e } \\
\text { farmacêutica poderão adquirir e utilizar medicamentos } \\
\text { não constantes na RENAME, em caráter excepcional. }\end{array}$ & (BRASIL, 1982) \\
\hline $\begin{array}{l}\text { DOCUMENTOS } \\
\text { LEGAIS E } \\
\text { NORMATIVOS }\end{array}$ & $14 \mathrm{LN}$ & Portaria SAS/MS n 142, de 06 de outubro de 1993 & $\begin{array}{l}\text { A Tabela de Valores dos Procedimentos do SIA/SUS } \\
\text { e inclui os medicamentos considerados excepcionais } \\
\text { Ciclosporina } 25,50 \text { e } 100 \mathrm{mg} \text { cápsula, Ciclosporina } \\
100 \mathrm{mg} \text { solução oral - frasco e Eritropoetina Humana } \\
2.000 \text { e } 4.000 \text { UI injetável - ampola }\end{array}$ & (BRASIL, 1993c) \\
\hline $\begin{array}{l}\text { DOCUMENTOS } \\
\text { LEGAIS E } \\
\text { NORMATIVOS }\end{array}$ & $15 \mathrm{LN}$ & Portaria SAS/MS n 204, de 06 de novembro de 1996 & $\begin{array}{l}\text { Tabela Descritiva de Procedimentos do Sistema de } \\
\text { Informações do SIA/SUS e inclui novos códigos de } \\
\text { medicamentos excepcionais. }\end{array}$ & (BRASIL, 1996) \\
\hline $\begin{array}{l}\text { DOCUMENTOS } \\
\text { LEGAIS E } \\
\text { NORMATIVOS }\end{array}$ & $16 \mathrm{LN}$ & Portaria GM/MS n 1.318 , de 23 de julho de 2002 & $\begin{array}{l}\text { Regulamentação do Programa de Medicamentos } \\
\text { Excepcionais e determina critérios para a dispensação } \\
\text { dos medicamentos }\end{array}$ & (BRASIL, 2002a) \\
\hline $\begin{array}{l}\text { DOCUMENTOS } \\
\text { LEGAIS E } \\
\text { NORMATIVOS }\end{array}$ & $16 \mathrm{LN}$ & Lei Complementar $\mathrm{n}^{\circ} 141$, de 13 de janeiro de 2012 & $\begin{array}{l}\text { Valores mínimos a serem aplicados anualmente pela } \\
\text { União, Estados, Distrito Federal e Municípios em } \\
\text { ações e serviços públicos de saúde. }\end{array}$ & (BRASIL, 2012c) \\
\hline $\begin{array}{l}\text { DOCUMENTOS } \\
\text { LEGAIS E } \\
\text { NORMATIVOS }\end{array}$ & $17 \mathrm{LN}$ & Resolução no 1/CIT, de 17 de janeiro de 2012 & $\begin{array}{l}\text { Diretrizes nacionais da Relação Nacional de } \\
\text { Medicamentos Essenciais (RENAME) no âmbito do } \\
\text { Sistema Único de Saúde (SUS). }\end{array}$ & (BRASIL, 2012a) \\
\hline $\begin{array}{l}\text { DOCUMENTOS } \\
\text { LEGAIS E } \\
\text { NORMATIVOS }\end{array}$ & $18 \mathrm{LN}$ & Portaria $\mathrm{n}^{\circ}$ 533/GM/MS, de 28 de março de 2012 & $\begin{array}{l}\text { Elenco de medicamentos e insumos da Relação } \\
\text { Nacional de Medicamentos Essenciais (RENAME) no } \\
\text { âmbito do Sistema Único de Saúde (SUS). }\end{array}$ & (BRASIL, 2012b) \\
\hline $\begin{array}{l}\text { DOCUMENTOS } \\
\text { LEGAIS E } \\
\text { NORMATIVOS }\end{array}$ & $19 \mathrm{LN}$ & Portaria n ${ }^{\circ} 1.996$, de 11 de setembro de 2013 & $\begin{array}{l}\text { Alteração da Portaria n }{ }^{\circ} \text { 1.554/GM/MS, de } 30 \text { de } \\
\text { julho de } 2013 \text {. }\end{array}$ & (BRASIL, 2013b) \\
\hline $\begin{array}{l}\text { DOCUMENTOS } \\
\text { LEGAIS E } \\
\text { NORMATIVOS }\end{array}$ & $20 \mathrm{LN}$ & Lei nº 5.991, de 17 de dezembro de 1973 & $\begin{array}{l}\text { Controle Sanitário do Comércio de Drogas, } \\
\text { Medicamentos, Insumos Farmacêuticos e Correlatos, } \\
\text { e dá outras Providências. }\end{array}$ & (BRASIL, 1973) \\
\hline
\end{tabular}




\begin{tabular}{|c|c|c|c|c|}
\hline $\begin{array}{l}\text { DOCUMENTOS } \\
\text { LEGAIS E } \\
\text { NORMATIVOS }\end{array}$ & $21 \mathrm{LN}$ & Lei Orgânica do Distrito Federal, de 08 de junho de 1993 & Lei Orgânica do Distrito Federal de 1993 & (BRASIL, 1993b) \\
\hline $\begin{array}{l}\text { DOCUMENTOS } \\
\text { LEGAIS E } \\
\text { NORMATIVOS }\end{array}$ & $22 \mathrm{LN}$ & Portaria SAS/MS nº 17, de 22 de janeiro de 1997 & $\begin{array}{l}\text { Inclui na Tabela Descritiva de Procedimentos do } \\
\text { Sistema de Informações do SIA/SUS os novos } \\
\text { códigos para os medicamentos Interferon beta 1a } \\
\text { (3.000.000UI, injetável) e Interferon beta 1b } \\
\text { (9.600.000UI, injetável) como imunomoduladores } \\
\text { indicados para tratamento da esclerose múltipla }\end{array}$ & (BRASIL, 1997) \\
\hline $\begin{array}{l}\text { DOCUMENTOS } \\
\text { LEGAIS E } \\
\text { NORMATIVOS }\end{array}$ & $23 \mathrm{LN}$ & Portaria SAS/MS nº 409, de 05 de agosto de 1999 & $\begin{array}{l}\text { A sistemática de APAC, para fornecimento dos } \\
\text { medicamentos excepcionais, e regulamenta a } \\
\text { Solicitação de Medicamentos (SME), para o } \\
\text { fornecimento de medicamentos e formulários de } \\
\text { APAC para autorização e coleta de informações } \\
\text { gerenciais dos medicamentos excepcionais }\end{array}$ & (BRASIL, 1999) \\
\hline $\begin{array}{l}\text { DOCUMENTOS } \\
\text { LEGAIS E } \\
\text { NORMATIVOS }\end{array}$ & $24 \mathrm{LN}$ & Portaria SAS/MS n 921 , de 22 de novembro de 2002 & $\begin{array}{l}\text { Inclusão, na Tabela Descritiva do SIA/SUS - grupo } 36 \\
\text { - medicamentos, no subgrupo } 35 \text {-antiparkinsonianos, } \\
\text { o procedimento em anexo da Portaria. }\end{array}$ & (BRASIL, 2002b) \\
\hline $\begin{array}{l}\text { DOCUMENTOS } \\
\text { LEGAIS E } \\
\text { NORMATIVOS }\end{array}$ & $25 \mathrm{LN}$ & Portaria SAS/MS nº 203, de 19 de abril de 2005 & $\begin{array}{l}\text { Inclusão, na Tabela de Procedimentos Especiais do } \\
\text { Sistema de Informações Hospitalares do Sistema } \\
\text { Único de Saúde - SIH/SUS, os medicamentos } \\
\text { especificados em anexo. }\end{array}$ & (BRASIL, 2005) \\
\hline $\begin{array}{l}\text { DOCUMENTOS } \\
\text { LEGAIS E } \\
\text { NORMATIVOS }\end{array}$ & $26 \mathrm{LN}$ & Portaria SAS/MS nº 768, de 26 de outubro de 2006 & $\begin{array}{l}\text { Definição do novo laudo para solicitação/autorização } \\
\text { de medicamentos de dispensação excepcional e } \\
\text { estratégicos - LME }\end{array}$ & (BRASIL, 2006e) \\
\hline $\begin{array}{l}\text { DOCUMENTOS } \\
\text { LEGAIS E } \\
\text { NORMATIVOS }\end{array}$ & $27 \mathrm{LN}$ & $\begin{array}{l}\text { Primeira retificação da Portaria GM/MS nº } 2.577 \text { - } 26 \text { de } \\
\text { fevereiro de } 2007\end{array}$ & $\begin{array}{l}\text { Alteração da quantidade máxima e códigos para o } \\
\text { processamento das APAC no sistema SIA/SUS dos } \\
\text { seguintes medicamentos: levodopa+carbidopa, } \\
\text { levodopa+benserazida, risperidona, complemento } \\
\text { alimentar para fenilcetonúricos, ciclosporina, } \\
\text { rivastigmina, deferiprona, gosserrelina, leuprorrelina e } \\
\text { triptorrelina }\end{array}$ & (BRASIL, 2007b) \\
\hline $\begin{array}{l}\text { DOCUMENTOS } \\
\text { LEGAIS E } \\
\text { NORMATIVOS }\end{array}$ & $28 \mathrm{LN}$ & $\begin{array}{l}\text { Segunda retificação da Portaria GM/MS nº } 2.577 \text { - } 26 \text { de abril } \\
\text { de } 2007\end{array}$ & $\begin{array}{l}\text { Alteração da quantidade máxima dos medicamentos } \\
\text { Sirolimo e Pancrelipase e a forma de apresentação da } \\
\text { Gosserrelina }\end{array}$ & (BRASIL, 2007c) \\
\hline $\begin{array}{l}\text { DOCUMENTOS } \\
\text { LEGAIS E } \\
\text { NORMATIVOS }\end{array}$ & 29LN & Portaria GM/MS nº 1.869 , de 4 de setembro de 2008 & $\begin{array}{l}\text { Atualização do anexo II da Portaria 2577, inclui novos } \\
\text { procedimentos e atualiza os valores de co- } \\
\text { financiamento. Esta Portaria foi revogada pela }\end{array}$ & (BRASIL, 2008) \\
\hline
\end{tabular}




\begin{tabular}{|c|c|c|c|c|}
\hline & & & Portaria GM/MS n ${ }^{\circ} 106$, de 22 de janeiro de 2009 & \\
\hline $\begin{array}{l}\text { DOCUMENTOS } \\
\text { LEGAIS E } \\
\text { NORMATIVOS }\end{array}$ & $30 \mathrm{LN}$ & Portaria GM/MS nº 106, de 22 de janeiro de 2009 & $\begin{array}{l}\text { Alteração do Anexo II da Portaria n } 2.577 / \text { GM de } 27 \\
\text { de outubro de } 2006 \text {, que aprova o CMDE }\end{array}$ & (BRASIL, 2009f) \\
\hline $\begin{array}{l}\text { DOCUMENTOS } \\
\text { LEGAIS E } \\
\text { NORMATIVOS }\end{array}$ & $31 \mathrm{LN}$ & Portaria GM/MS n 343, de 22 de fevereiro de 2010 & $\begin{array}{l}\text { Alteração dos arts. } 3^{\circ}, 15,16,23,24 \text { e } 63 \text { e o Anexo } \\
\text { IV à Portaria no } 2981 / G M / M S \text {, de } 26 \text { de novembro de } \\
2009\end{array}$ & (BRASIL, 2010d) \\
\hline $\begin{array}{l}\text { DOCUMENTOS } \\
\text { LEGAIS E } \\
\text { NORMATIVOS }\end{array}$ & $32 \mathrm{LN}$ & Retificação da Portaria GM/MS no 343 - 3 de março de 2010 & $\begin{array}{l}\text { Alteração do artigo Art. } 23 \text { e } 24 \text { e demoninação de } 10 \\
\text { procedimentos }\end{array}$ & (BRASIL, 2010e) \\
\hline $\begin{array}{l}\text { DOCUMENTOS } \\
\text { LEGAIS E } \\
\text { NORMATIVOS }\end{array}$ & $33 \mathrm{LN}$ & Portaria GM/MS nº 743, de 8 de abril de 2010 & $\begin{array}{l}\text { Estabelecimento do processo de aquisição } \\
\text { centralizada pelo MS para Lamivudina } 150 \mathrm{mg} \text { e } \\
\text { Lamivudina } 10 \mathrm{mg} / \mathrm{ml} \text { solução oral }\end{array}$ & (BRASIL, 2010f) \\
\hline $\begin{array}{l}\text { DOCUMENTOS } \\
\text { LEGAIS E } \\
\text { NORMATIVOS }\end{array}$ & $34 \mathrm{LN}$ & Portaria GM/MS n 3.128 , de 14 de outubro de 2010 & $\begin{array}{l}\text { Estabelecimento do processo de aquisição } \\
\text { centralizada pelo MS para Clozapina } 25 \mathrm{mg} \text { e 100mg }\end{array}$ & (BRASIL, 2010g) \\
\hline $\begin{array}{l}\text { DOCUMENTOS } \\
\text { LEGAIS E } \\
\text { NORMATIVOS }\end{array}$ & $35 \mathrm{LN}$ & Portaria GM/MS nº 3.439, de 11 de novembro de 2010 & $\begin{array}{l}\text { Alteração dos arts. } 3^{\circ}, 15,16 \text { e } 63 \text { e os Anexos I, II, } \\
\text { III, IV e V à Portaria no } 2.981 / \mathrm{GM} / \mathrm{MS} \text {, de } 26 \text { de } \\
\text { novembro de } 2009 \text {, republicada em } 1^{\circ} \text { de dezembro de } \\
2009\end{array}$ & (BRASIL, 2010h) \\
\hline $\begin{array}{l}\text { DOCUMENTOS } \\
\text { LEGAIS E } \\
\text { NORMATIVOS }\end{array}$ & $36 \mathrm{LN}$ & Portaria SCTIE/MS nº 19, de 30 de dezembro de 2010 & $\begin{array}{l}\text { Inclusão de novo procedimento para o Adalimumabe } \\
\text { 40mg na Tabela de Procedimentos, Medicamentos, } \\
\text { Órteses/Próteses e Materiais Especiais do SUS. }\end{array}$ & (BRASIL, 2010i) \\
\hline $\begin{array}{l}\text { DOCUMENTOS } \\
\text { LEGAIS E } \\
\text { NORMATIVOS }\end{array}$ & $37 \mathrm{LN}$ & Portaria SCTIE/MS nº 2, de 16 de março de 2011 & $\begin{array}{l}\text { Inclui a Imiglucerase } 400 \text { U na Tabela de } \\
\text { Procedimentos, Medicamentos, Órteses/Próteses e } \\
\text { Materiais Especiais do SUS }\end{array}$ & (BRASIL, 2011i) \\
\hline $\begin{array}{l}\text { DOCUMENTOS } \\
\text { LEGAIS E } \\
\text { NORMATIVOS }\end{array}$ & $38 \mathrm{LN}$ & Portaria SCTIE/MS n ${ }^{\circ}$, de 13 de junho de 2011 & $\begin{array}{l}\text { Inclui o Entecavir 1,0 mg na Tabela de } \\
\text { Procedimentos, Medicamentos, Órteses/Próteses e } \\
\text { Materiais Especiais do SUS }\end{array}$ & (BRASIL, 2011j) \\
\hline $\begin{array}{l}\text { DOCUMENTOS } \\
\text { LEGAIS E } \\
\text { NORMATIVOS }\end{array}$ & $39 \mathrm{LN}$ & Portaria GM/MS nº 2.079, de 1 de setembro de 2011 & $\begin{array}{l}\text { Estabelece processo de aquisição centralizada pelo } \\
\text { Ministério da Saúde do medicamento quetiapina } \\
\text { 25mg, 100mg e 200mg, comprimido, do CEAF }\end{array}$ & (BRASIL, 20111) \\
\hline $\begin{array}{l}\text { DOCUMENTOS } \\
\text { LEGAIS E } \\
\text { NORMATIVOS }\end{array}$ & $40 \mathrm{LN}$ & Portaria GM/MS nº 2.928 , de 12 de dezembro de 2011 & $\begin{array}{l}\text { Dispõe sobre os } \S \S 1^{\circ} \text { e } 2^{\circ} \text { do art. } 28 \text { do Decreto } n^{\circ} \\
7.508 \text {, de } 28 \text { de junho de } 2011\end{array}$ & (BRASIL, 2011m) \\
\hline $\begin{array}{l}\text { DOCUMENTOS } \\
\text { LEGAIS E }\end{array}$ & $41 \mathrm{LN}$ & Lei 12.466 , de 24 de agosto de 2011 & $\begin{array}{l}\text { Comissões intergestores do SUS, o Conselho } \\
\text { Nacional de Secretários de Saúde (Conass), o }\end{array}$ & (BRASIL, 2011e) \\
\hline
\end{tabular}




\begin{tabular}{|c|c|c|c|c|}
\hline \multicolumn{3}{|l|}{ NORMATIVOS } & \multicolumn{2}{|l|}{$\begin{array}{l}\text { Conselho Nacional de Secretarias Municipais de } \\
\text { Saúde (Conasems) e suas respectivas composiçôes, e } \\
\text { dá outras providências. }\end{array}$} \\
\hline $\begin{array}{l}\text { DOCUMENTOS } \\
\text { LEGAIS E } \\
\text { NORMATIVOS }\end{array}$ & $42 \mathrm{LN}$ & Portaria GM/MS no 1.091 , de 28 de maio de 2012 & $\begin{array}{l}\text { Estabelece processo de aquisição centralizada pelo } \\
\text { Ministério da Saúde do medicamento olanzapina } 5 \mathrm{mg} \\
\text { e 10mg comprimido, do Componente Especializado } \\
\text { da Assistência Farmacêutica }\end{array}$ & (BRASIL, 2012f) \\
\hline $\begin{array}{l}\text { DOCUMENTOS } \\
\text { LEGAIS E } \\
\text { NORMATIVOS }\end{array}$ & $43 \mathrm{LN}$ & Portaria GM/MS n ${ }^{\circ} 1.103$, de 28 de maio de 2012 & $\begin{array}{l}\text { Estabelece processo de aquisição centralizada pelo } \\
\text { Ministério da Saúde do medicamento rivastigmina } \\
\text { 1,5mg, 3mg, } 4,5 \mathrm{mg} \text { e } 6 \mathrm{mg} \text { cápsula, do Componente } \\
\text { Especializado da Assistência Farmacêutica }\end{array}$ & (BRASIL, 2012g) \\
\hline $\begin{array}{l}\text { DOCUMENTOS } \\
\text { LEGAIS E } \\
\text { NORMATIVOS }\end{array}$ & $44 \mathrm{LN}$ & Portaria SAS/MS nº 257, de 12 de março de 2013 & $\begin{array}{l}\text { Inclui novos campos no layout da Autorização de } \\
\text { Procedimentos Ambulatoriais (APAC) }\end{array}$ & (BRASIL, 2013d) \\
\hline $\begin{array}{l}\text { DOCUMENTOS } \\
\text { LEGAIS E } \\
\text { NORMATIVOS }\end{array}$ & $45 \mathrm{LN}$ & Portaria SAS/MS nº 284, de 20 de março de 2013 & $\begin{array}{l}\text { Inclui os procedimentos Abatacepte } 250 \mathrm{mg} \text {, } \\
\text { Certolizumabe pegol } 200 \mathrm{mg} / \mathrm{ml}, \text { Golimumabe } 50 \mathrm{mg} \text {, } \\
\text { Rituximabe } 500 \mathrm{mg} \text {, Tocilizumabe } 20 \mathrm{mg} / \mathrm{ml} \text { na } \\
\text { Tabela de Procedimentos, Medicamentos, } \\
\text { Órteses/Próteses e Materiais Especiais do SUS, além } \\
\text { de dispor que o serviço } 125 / 001 \text { poderá ser informado } \\
\text { por qualquer tipo de estabelecimento de saúde da } \\
\text { esfera administrativa pública cadastrado no SCNES. }\end{array}$ & (BRASIL, 2013e) \\
\hline $\begin{array}{l}\text { DOCUMENTOS } \\
\text { LEGAIS E } \\
\text { NORMATIVOS }\end{array}$ & $46 \mathrm{LN}$ & Portaria SAS/MS n 745, de 5 de julho de 2013 & $\begin{array}{l}\text { Inclui os procedimentos Naproxeno } 250 \text { e } 500 \mathrm{mg} \text { na } \\
\text { Tabela de Procedimentos, Medicamentos, Órteses/ } \\
\text { Próteses e Materiais Especiais do SUS. }\end{array}$ & (BRASIL, 2013f) \\
\hline $\begin{array}{l}\text { DOCUMENTOS } \\
\text { LEGAIS E } \\
\text { NORMATIVOS }\end{array}$ & $47 \mathrm{LN}$ & Portaria $\mathrm{n}^{\circ} 1.996$, de 11 de setembro de 2013 & $\begin{array}{l}\text { Alteração da Portaria n }{ }^{\circ} \text { 1.554/GM/MS, de } 30 \text { de } \\
\text { julho de } 2013 .\end{array}$ & (BRASIL, 2013b) \\
\hline $\begin{array}{l}\text { DOCUMENTOS } \\
\text { LEGAIS E } \\
\text { NORMATIVOS }\end{array}$ & $48 \mathrm{LN}$ & Portaria GM/MS n 2.978 , de 4 de dezembro de 2013 & $\begin{array}{l}\text { Estabelece processo de aquisição centralizada pelo } \\
\text { Ministério da Saúde do medicamento leflunomida } \\
\text { 20mg comprimido, do Componente Especializado da } \\
\text { Assistência Farmacêutica. }\end{array}$ & (BRASIL, 2013g) \\
\hline $\begin{array}{l}\text { DOCUMENTOS } \\
\text { LEGAIS E } \\
\text { NORMATIVOS }\end{array}$ & $49 \mathrm{LN}$ & Portaria GM/MS n 2.979 , de 4 de dezembro de 2013 & $\begin{array}{l}\text { Estabelece processo de aquisição centralizada pelo } \\
\text { Ministério da Saúde dos medicamentos toxina } \\
\text { botulínica tipo A 100u injetável - por frasco-ampola, } \\
\text { do Componente Especializado da Assistência } \\
\text { Farmacêutica. }\end{array}$ & (BRASIL, 2013h) \\
\hline
\end{tabular}




\begin{tabular}{|c|c|c|c|c|}
\hline $\begin{array}{l}\text { DOCUMENTOS } \\
\text { LEGAIS E } \\
\text { NORMATIVOS }\end{array}$ & $50 \mathrm{LN}$ & Portaria GM/MS nº 2.981, de 4 de dezembro de 2013 & $\begin{array}{l}\text { Estabelece processo de aquisição centralizada pelo } \\
\text { Ministério da Saúde do medicamento pramipexol } \\
0,125 \mathrm{mg}, 0,25 \mathrm{mg} \text { e } 1 \mathrm{mg} \text { - comprimido, do } \\
\text { Componente Especializado da Assistência } \\
\text { Farmacêutica. }\end{array}$ & (BRASIL, 2013i) \\
\hline $\begin{array}{l}\text { DOCUMENTOS } \\
\text { LEGAIS E } \\
\text { NORMATIVOS }\end{array}$ & $51 \mathrm{LN}$ & Portaria SAS/MS n 1.447 , de 26 de dezembro de 2013 & $\begin{array}{l}\text { Altera a Portaria SAS/MS no 257/2013 quanto as } \\
\text { definições do profissional executante no âmbito do } \\
\text { Componente Especializado da Assistência } \\
\text { Farmacêutica. }\end{array}$ & (BRASIL, 2013j) \\
\hline $\begin{array}{l}\text { DOCUMENTOS } \\
\text { LEGAIS E } \\
\text { NORMATIVOS }\end{array}$ & $52 \mathrm{LN}$ & Portaria GM/MS n 3.293, de 26 de dezembro de 2013 & $\begin{array}{l}\text { Altera o prazo para disponibilização dos } \\
\text { medicamentos acetazolamida, bimatoprosta, } \\
\text { brimonidina, brinzolamida, dorzolamida, latanoprosta, } \\
\text { pilocarpina, timolol e travoprosta do Componente } \\
\text { Especializado da Assistência Farmacêutica. }\end{array}$ & (BRASIL, 20131) \\
\hline $\begin{array}{l}\text { DOCUMENTOS } \\
\text { LEGAIS E } \\
\text { NORMATIVOS }\end{array}$ & $53 \mathrm{LN}$ & Portaria $\mathrm{n}^{\circ} 2.135 / \mathrm{GM} / \mathrm{MS}$ de 25 de setembro de 2013 & $\begin{array}{l}\text { Diretrizes para o processo de planejamento no âmbito } \\
\text { do Sistema Único de Saúde (SUS). }\end{array}$ & (BRASIL, 2013c) \\
\hline $\begin{array}{l}\text { DOCUMENTOS } \\
\text { LEGAIS E } \\
\text { NORMATIVOS }\end{array}$ & $54 \mathrm{LN}$ & Portaria SCTIE/MS nº 6, de 25 de fevereiro de 2014 & $\begin{array}{l}\text { Inclui os medicamentos ambrisentana } 5 \text { e } 10 \mathrm{mg} \text { e } \\
\text { bosentana } 62,5 \text { e } 125 \mathrm{mg} \text { na Tabela de Procedimentos, } \\
\text { Medicamentos, Órteses/Próteses e Materiais Especiais } \\
\text { do SUS. }\end{array}$ & (BRASIL, 2014b) \\
\hline $\begin{array}{l}\text { DOCUMENTOS } \\
\text { LEGAIS E } \\
\text { NORMATIVOS }\end{array}$ & $55 \mathrm{LN}$ & Portaria GM/MS nº 799, de 5 de maio de 2014 & $\begin{array}{l}\text { Altera o prazo para disponibilização dos } \\
\text { medicamentos acetazolamida, bimatoprosta, } \\
\text { brimonidina, brinzolamida, dorzolamida, latanoprosta, } \\
\text { pilocarpina, timolol e travoprosta do Componente } \\
\text { Especializado da Assistência Farmacêutica. }\end{array}$ & (BRASIL, 2014c) \\
\hline $\begin{array}{l}\text { DOCUMENTOS } \\
\text { LEGAIS E } \\
\text { NORMATIVOS }\end{array}$ & $56 \mathrm{LN}$ & Portaria SAS/MS n 683, de 06 de agosto de 2014 & $\begin{array}{l}\text { Altera procedimentos referentes aos medicamentos } \\
\text { tocilizumabe } 20 \mathrm{mg} / \mathrm{mL} \text {, calcitriol } 0,25 \mathrm{mcg}, \\
\text { leflunomida } 20 \mathrm{mg} \text {, toxina botulínica } 100 \mathrm{U} \text { e } \\
\text { pramipexol } 0,125 \mathrm{mg}, 0,25 \mathrm{mg} \text { e } 1 \mathrm{mg} \text { do Componente } \\
\text { Especializado da Assistência Farmacêutica na Tabela } \\
\text { de Procedimentos, Medicamentos Órteses/Próteses e } \\
\text { Materiais Especiais do SUS. }\end{array}$ & (BRASIL, 2014d) \\
\hline $\begin{array}{l}\text { DOCUMENTOS } \\
\text { LEGAIS E } \\
\text { NORMATIVOS }\end{array}$ & $57 \mathrm{LN}$ & Portaria $\mathrm{n}^{\circ} 2.127$, de 30 de setembro de 2014 & $\begin{array}{l}\text { Estabelece processo de aquisição centralizada pelo } \\
\text { Ministério da Saúde do medicamento cabergolina } \\
\text { 0,5mg comprimido, do Componente Especializado da } \\
\text { Assistência Farmacêutica. }\end{array}$ & (BRASIL, 2014e) \\
\hline
\end{tabular}




\begin{tabular}{|c|c|c|c|c|}
\hline $\begin{array}{l}\text { DOCUMENTOS } \\
\text { LEGAIS E } \\
\text { NORMATIVOS }\end{array}$ & $58 \mathrm{LN}$ & Portaria $\mathrm{n}^{\circ} 49$, de 22 de dezembro de 2014 & $\begin{array}{l}\text { Inclui o procedimento fingolimode } 0,5 \mathrm{mg} \text { na Tabela } \\
\text { de Procedimentos, Medicamentos, Órteses/Próteses e } \\
\text { Materiais Especiais do SUS. }\end{array}$ & (BRASIL, 2014f) \\
\hline $\begin{array}{l}\text { DOCUMENTOS } \\
\text { LEGAIS E } \\
\text { NORMATIVOS }\end{array}$ & $59 \mathrm{LN}$ & Portaria $\mathrm{n}^{\circ} 2.865$, de 29 de dezembro de 2014 & $\begin{array}{l}\text { Prorroga o prazo para disponibilização dos } \\
\text { medicamentos acetazolamida, bimatoprosta, } \\
\text { brimonidina, brinzolamida, dorzolamida, latanoprosta, } \\
\text { pilocarpina, timolol e travoprosta do Componente } \\
\text { Especializado da Assistência Farmacêutica. }\end{array}$ & (BRASIL, 2014g) \\
\hline $\begin{array}{l}\text { DOCUMENTOS } \\
\text { LEGAIS E } \\
\text { NORMATIVOS }\end{array}$ & $60 \mathrm{LN}$ & Portaria GM/MS n 410 , de 13 de abril de 2015 & $\begin{array}{l}\text { Estabelece processo de aquisição centralizada pelo } \\
\text { Ministério da Saúde do medicamento Ziprasidona } \\
\text { 40mg e 80mg (cápsula), do } \\
\text { Componente Especializado da Assistência } \\
\text { Farmacêutica. }\end{array}$ & (BRASIL, 2015a) \\
\hline $\begin{array}{l}\text { DOCUMENTOS } \\
\text { LEGAIS E } \\
\text { NORMATIVOS }\end{array}$ & $61 \mathrm{LN}$ & Portaria SAS/MS no 361 , de 23 de abril de 2015 & $\begin{array}{l}\text { Exclui procedimento do Componente Especializado } \\
\text { da Assistência Farmacêutica na Tabela de } \\
\text { Procedimentos, Medicamentos, Órteses/Próteses e } \\
\text { Materiais do SUS. }\end{array}$ & (BRASIL, 2015b) \\
\hline $\begin{array}{l}\text { DOCUMENTOS } \\
\text { LEGAIS E } \\
\text { NORMATIVOS }\end{array}$ & $62 \mathrm{LN}$ & Portaria SCTIE/MS n ${ }^{\circ} 29$, de 22 de junho de 2015 & $\begin{array}{l}\text { Torna pública a decisão de incorporar os } \\
\text { medicamentos sofosbuvir, daclatasvir e simeprevir } \\
\text { para o tratamento da hepatite viral C crônica no } \\
\text { âmbito do Sistema Único de Saúde - SUS. }\end{array}$ & (BRASIL, 2015c) \\
\hline $\begin{array}{l}\text { DOCUMENTOS } \\
\text { LEGAIS E } \\
\text { NORMATIVOS }\end{array}$ & $63 \mathrm{LN}$ & Portaria SAS/MS nº 583 , de 8 de julho de 2015 & $\begin{array}{l}\text { Inclui Forma de Organização e Procedimentos } \\
\text { relacionados ao Componente Especializado da } \\
\text { Assistência Farmacêutica na Tabela de } \\
\text { Procedimentos, Medicamentos, Órteses/Próteses e } \\
\text { Materiais do SUS. }\end{array}$ & (BRASIL, 2015d) \\
\hline $\begin{array}{l}\text { DOCUMENTOS } \\
\text { LEGAIS E } \\
\text { NORMATIVOS }\end{array}$ & $64 \mathrm{LN}$ & Portaria GM/MS n 1.330 , de 08 de setembro de 2015 & $\begin{array}{l}\text { Estabelece processo de aquisição centralizada pelo } \\
\text { Ministério da Saúde do medicamento Riluzol 50mg } \\
\text { (comprimido), do Componente Especializado da } \\
\text { Assistência Farmacêutica. }\end{array}$ & (BRASIL, 2015e) \\
\hline $\begin{array}{l}\text { DOCUMENTOS } \\
\text { LEGAIS E } \\
\text { NORMATIVOS }\end{array}$ & $65 \mathrm{LN}$ & Portaria $\mathrm{n}^{\circ} 1.055$, de 24 de maio 2016 & $\begin{array}{l}\text { Repasse de recursos para Estados e Distrito Federal, a } \\
\text { título de financiamento, referente a abril, maio e junho } \\
\text { de } 2016 \text {, para aquisição de medicamentos do } \\
\text { Componente Especializado da Assistência } \\
\text { Farmacêutica. }\end{array}$ & (BRASIL, 2016a) \\
\hline $\begin{array}{l}\text { DOCUMENTOS } \\
\text { LEGAIS E } \\
\text { NORMATIVOS }\end{array}$ & $66 \mathrm{LN}$ & Decreto $^{\circ} 36.918$, de 26 de novembro de 2015 & $\begin{array}{l}\text { Dispõe sobre a estrutura administrativa da Secretaria } \\
\text { de Estado de Saúde do Distrito Federal. }\end{array}$ & (BRASIL, 2015g) \\
\hline
\end{tabular}




\begin{tabular}{|c|c|c|c|c|}
\hline $\begin{array}{l}\text { DOCUMENTOS } \\
\text { LEGAIS E } \\
\text { NORMATIVOS }\end{array}$ & $67 \mathrm{LN}$ & Portaria nº653/PGJ, de 01 de setembro de 1997 & $\begin{array}{l}\text { Criou e definiu as atribuições da Promotoria de Justiça } \\
\text { de Defesa da Saúde - PROSUS na estrutura do } \\
\text { Ministério Público do Distrito Federal e Territórios. }\end{array}$ & (BRASIL, 1997b) \\
\hline $\begin{array}{l}\text { DOCUMENTOS } \\
\text { LEGAIS E } \\
\text { NORMATIVOS }\end{array}$ & $68 \mathrm{LN}$ & Lei $\mathrm{n}^{\circ} 2.804$, de 25 de outubro de 2001 & $\begin{array}{l}\text { Direitos dos usuários dos serviços e das ações de } \\
\text { saúde no Distrito Federal }\end{array}$ & (BRASIL, 2001) \\
\hline $\begin{array}{l}\text { DOCUMENTOS } \\
\text { LEGAIS E } \\
\text { NORMATIVOS }\end{array}$ & $69 \mathrm{LN}$ & $\begin{array}{l}\text { Portaria } \mathrm{N}^{\circ} 650 \text { de } 20 \text { de novembro de } 2009 \text { Atos } \\
\text { Administrativos }\end{array}$ & $\begin{array}{l}\text { Criação de grupo de trabalho para estudo e proposta } \\
\text { de medidas concretas e normativas para as demandas } \\
\text { judiciais envolvendo a assistência à saúde. }\end{array}$ & (BRASIL, 2009e) \\
\hline $\begin{array}{l}\text { DOCUMENTOS } \\
\text { LEGAIS E } \\
\text { NORMATIVOS }\end{array}$ & 70LN & Portaria $\mathrm{n}^{\circ} 1.820$, de 13 de agosto de 2009 & Direitos e deveres dos usuários da saúde. & (BRASIL, 2009f) \\
\hline $\begin{array}{l}\text { DOCUMENTOS } \\
\text { LEGAIS E } \\
\text { NORMATIVOS }\end{array}$ & 71LN & Resolução 107 do CNJ, de 06 de abril de 2010 & $\begin{array}{l}\text { Instituição do Fórum Nacional do Judiciário para } \\
\text { monitoramento e resolução das demandas de } \\
\text { assistência à saúde. }\end{array}$ & (BRASIL, 2010b) \\
\hline $\begin{array}{l}\text { DOCUMENTOS } \\
\text { LEGAIS E } \\
\text { NORMATIVOS }\end{array}$ & 72LN & Portaria 25 do CNJ, de 22 de março de 2011 & $\begin{array}{l}\text { Designação de membros para compor os Comitês } \\
\text { Executivos Estaduais no âmbito do Fórum Nacional } \\
\text { do Judiciário para a Saúde. }\end{array}$ & (BRASIL, 2011g) \\
\hline $\begin{array}{l}\text { DOCUMENTOS } \\
\text { LEGAIS E } \\
\text { NORMATIVOS }\end{array}$ & 73LN & $\begin{array}{l}\text { Instrução Normativa } 06 \text { da Corregedoria do TJDFT, de } 23 \text { de } \\
\text { dezembro de } 2011\end{array}$ & $\begin{array}{l}\text { Recomendações aos juízes de direito do TJDFT } \\
\text { quanto a observância de critérios para assegurar maior } \\
\text { eficiência na solução das demandas judiciais } \\
\text { envolvendo a saúde pública. }\end{array}$ & (BRASIL, 2011f) \\
\hline $\begin{array}{l}\text { DOCUMENTOS } \\
\text { LEGAIS E } \\
\text { NORMATIVOS }\end{array}$ & 74LN & Portaria 40 de 25 de março de 2014 & $\begin{array}{l}\text { Comitê Organizador do Fórum Nacional do Poder } \\
\text { Judiciário para monitoramento e resolução das } \\
\text { demandas de assistência à saúde. }\end{array}$ & (BRASIL, 2014h) \\
\hline $\begin{array}{l}\text { DOCUMENTOS } \\
\text { LEGAIS E } \\
\text { NORMATIVOS }\end{array}$ & $75 \mathrm{LN}$ & Portaria 8 de 2 de fevereiro de 2016 & $\begin{array}{l}\text { Criação do Comitê Organizador do Fórum Nacional } \\
\text { do Poder Judiciário para monitoramento e resolução } \\
\text { das demandas de assistência à saúde. }\end{array}$ & (BRASIL, 2016c) \\
\hline $\begin{array}{l}\text { DOCUMENTOS } \\
\text { LEGAIS E } \\
\text { NORMATIVOS }\end{array}$ & $76 \mathrm{LN}$ & Portaria 49 do CNJ, de 6 de junho de 2011 & $\begin{array}{l}\text { Acréscimo de incisos à Portaria } 25 \text { e altera } \\
\text { dispositivos da mesma norma. }\end{array}$ & (BRASIL, 2011h) \\
\hline $\begin{array}{l}\text { DOCUMENTOS } \\
\text { LEGAIS E } \\
\text { NORMATIVOS }\end{array}$ & 77LN & Portaria GPR 464 do TJDFT, de 17 de abril de 2012 & $\begin{array}{l}\text { Alteração da composição do Comitê Executivo do } \\
\text { Distrito Federal no âmbito do Fórum Nacional do } \\
\text { Judiciário para a Saúde. }\end{array}$ & (BRASIL, 2012d) \\
\hline $\begin{array}{l}\text { DOCUMENTOS } \\
\text { LEGAIS E } \\
\text { NORMATIVOS }\end{array}$ & $78 \mathrm{LN}$ & Portaria GPR 1.423 do TJDFT, de 25 de outubro de 2012 & $\begin{array}{l}\text { Alteração da composição do Comitê Executivo do } \\
\text { Distrito Federal no âmbito do Fórum Nacional do } \\
\text { Judiciário para a Saúde. }\end{array}$ & (BRASIL, 2012e) \\
\hline DOCUMENTOS & 79LN & Portaria GPR 1735 do TJDFT, de 14 de outubro de 2014 & Revogação das Portarias GPR 464 e 1423, ambas de & (BRASIL, 2014i) \\
\hline
\end{tabular}


LEGAIS E

NORMATIVOS

\section{DOCUMENTOS}

LEGAIS E

NORMATIVOS
2012 e altera a composição do Comitê Executivo do

Distrito Federal no âmbito do Fórum Nacional do

Judiciário para monitoramento e resolução das

demandas de assistência à Saúde.

Instituição da Câmara Permanente Distrital de Mediação em Saúde (CAMEDIS).

(BRASIL, 2013m) 
$\boldsymbol{A P \hat { E } N D I C E} \boldsymbol{E}$ - Organização da pesquisa documental - ATAS

\begin{tabular}{|c|c|c|c|c|}
\hline Tipo documental & $\begin{array}{l}\text { Numeração/ } \\
\text { classificação }\end{array}$ & Documentos analisados & Fontes de informações sobre & Referências \\
\hline ATAS & $1 \mathrm{AT}$ & $1^{\mathrm{a}}$ Reunião - Ordinária & $\begin{array}{l}\text { Registros do Comitê Executivo de Saúde do Distrito Federal do } \\
\text { Tribunal de Justiça do Distrito Federal e dos Territórios. }\end{array}$ & $\begin{array}{l}\text { (TRIBUNAL DE JUSTIÇA DO DISTRITO } \\
\text { FEDERAL E TERRITORIOS, 2011m) }\end{array}$ \\
\hline ATAS & $2 \mathrm{AT}$ & $2^{\mathrm{a}}$ Reunião - Ordinária & $\begin{array}{l}\text { Registros do Comitê Executivo de Saúde do Distrito Federal do } \\
\text { Tribunal de Justiça do Distrito Federal e dos Territórios. }\end{array}$ & $\begin{array}{l}\text { (TRIBUNAL DE JUSTIÇA DO DISTRITO } \\
\text { FEDERAL E TERRITÓRIOS, 20111) }\end{array}$ \\
\hline ATAS & 3AT & $3^{\text {a }}$ Reunião - Ordinária & $\begin{array}{l}\text { Registros do Comitê Executivo de Saúde do Distrito Federal do } \\
\text { Tribunal de Justiça do Distrito Federal e dos Territórios. }\end{array}$ & $\begin{array}{l}\text { (TRIBUNAL DE JUSTIÇA DO DISTRITO } \\
\text { FEDERAL E TERRITORIOS, 2011n) }\end{array}$ \\
\hline ATAS & 4AT & $4^{\mathrm{a}}$ Reunião - Ordinária & $\begin{array}{l}\text { Registros do Comitê Executivo de Saúde do Distrito Federal do } \\
\text { Tribunal de Justiça do Distrito Federal e dos Territórios. }\end{array}$ & $\begin{array}{l}\text { (TRIBUNAL DE JUSTIÇA DO DISTRITO } \\
\text { FEDERAL E TERRITORIOS, 2011o) }\end{array}$ \\
\hline ATAS & $5 \mathrm{AT}$ & 5ª Reunião - Ordinária & $\begin{array}{l}\text { Registros do Comitê Executivo de Saúde do Distrito Federal do } \\
\text { Tribunal de Justiça do Distrito Federal e dos Territórios. }\end{array}$ & $\begin{array}{l}\text { (TRIBUNAL DE JUSTIÇA DO DISTRITO } \\
\text { FEDERAL E TERRITORIOS, 2011p) }\end{array}$ \\
\hline ATAS & 6AT & 6ª Reunião - Ordinária & $\begin{array}{l}\text { Registros do Comitê Executivo de Saúde do Distrito Federal do } \\
\text { Tribunal de Justiça do Distrito Federal e dos Territórios. }\end{array}$ & $\begin{array}{l}\text { (TRIBUNAL DE JUSTIÇA DO DISTRITO } \\
\text { FEDERAL E TERRITÓRIOS, 2011q) }\end{array}$ \\
\hline ATAS & 7AT & 7ª Reunião - Ordinária & $\begin{array}{l}\text { Registros do Comitê Executivo de Saúde do Distrito Federal do } \\
\text { Tribunal de Justiça do Distrito Federal e dos Territórios. }\end{array}$ & $\begin{array}{l}\text { (TRIBUNAL DE JUSTIÇA DO DISTRITO } \\
\text { FEDERAL E TERRITÓRIOS, 2011r) }\end{array}$ \\
\hline ATAS & $8 \mathrm{AT}$ & 8ª Reunião - Ordinária & $\begin{array}{l}\text { Registros do Comitê Executivo de Saúde do Distrito Federal do } \\
\text { Tribunal de Justiça do Distrito Federal e dos Territórios. }\end{array}$ & $\begin{array}{l}\text { (TRIBUNAL DE JUSTIÇA DO DISTRITO } \\
\text { FEDERAL E TERRITÓRIOS, 2012m) }\end{array}$ \\
\hline ATAS & 9AT & 9ª Reunião - Ordinária & $\begin{array}{l}\text { Registros do Comitê Executivo de Saúde do Distrito Federal do } \\
\text { Tribunal de Justiça do Distrito Federal e dos Territórios. }\end{array}$ & $\begin{array}{l}\text { (TRIBUNAL DE JUSTIÇA DO DISTRITO } \\
\text { FEDERAL E TERRITÓRIOS, 2012n) }\end{array}$ \\
\hline ATAS & $10 \mathrm{AT}$ & $10^{\mathrm{a}}$ Reunião - Ordinária & $\begin{array}{l}\text { Registros do Comitê Executivo de Saúde do Distrito Federal do } \\
\text { Tribunal de Justiça do Distrito Federal e dos Territórios. }\end{array}$ & $\begin{array}{l}\text { (TRIBUNAL DE JUSTIÇA DO DISTRITO } \\
\text { FEDERAL E TERRITÓRIOS, 2012o) }\end{array}$ \\
\hline ATAS & $11 \mathrm{AT}$ & $11^{\mathrm{a}}$ Reunião - Ordinária & $\begin{array}{l}\text { Registros do Comitê Executivo de Saúde do Distrito Federal do } \\
\text { Tribunal de Justiça do Distrito Federal e dos Territórios. }\end{array}$ & $\begin{array}{l}\text { (TRIBUNAL DE JUSTIÇA DO DISTRITO } \\
\text { FEDERAL E TERRITÓRIOS, 2012p) }\end{array}$ \\
\hline ATAS & $12 \mathrm{AT}$ & $12^{\mathrm{a}}$ Reunião - Ordinária & $\begin{array}{l}\text { Registros do Comitê Executivo de Saúde do Distrito Federal do } \\
\text { Tribunal de Justiça do Distrito Federal e dos Territórios. }\end{array}$ & $\begin{array}{l}\text { (TRIBUNAL DE JUSTIÇA DO DISTRITO } \\
\text { FEDERAL E TERRITÓRIOS, 2012q) }\end{array}$ \\
\hline ATAS & $13 \mathrm{AT}$ & 13ª Reunião - Ordinária & $\begin{array}{l}\text { Registros do Comitê Executivo de Saúde do Distrito Federal do } \\
\text { Tribunal de Justiça do Distrito Federal e dos Territórios. }\end{array}$ & $\begin{array}{l}\text { (TRIBUNAL DE JUSTIÇA DO DISTRITO } \\
\text { FEDERAL E TERRITÓRIOS, 2012r) }\end{array}$ \\
\hline ATAS & $14 \mathrm{AT}$ & 14ª Reunião - Ordinária & $\begin{array}{l}\text { Registros do Comitê Executivo de Saúde do Distrito Federal do } \\
\text { Tribunal de Justiça do Distrito Federal e dos Territórios. }\end{array}$ & $\begin{array}{l}\text { (TRIBUNAL DE JUSTIÇA DO DISTRITO } \\
\text { FEDERAL E TERRITORIOS, 2012s) }\end{array}$ \\
\hline ATAS & $15 \mathrm{AT}$ & $15^{\mathrm{a}}$ Reunião - Ordinária & $\begin{array}{l}\text { Registros do Comitê Executivo de Saúde do Distrito Federal do } \\
\text { Tribunal de Justiça do Distrito Federal e dos Territórios. }\end{array}$ & $\begin{array}{l}\text { (TRIBUNAL DE JUSTIÇA DO DISTRITO } \\
\text { FEDERAL E TERRITORIOS, 20130) }\end{array}$ \\
\hline
\end{tabular}




\begin{tabular}{|c|c|c|c|c|}
\hline ATAS & $16 \mathrm{AT}$ & $\begin{array}{l}16^{\mathrm{a}} \text { Reunião - } \\
\text { Extraordinária }\end{array}$ & $\begin{array}{l}\text { Registros do Comitê Executivo de Saúde do Distrito Federal do } \\
\text { Tribunal de Justiça do Distrito Federal e dos Territórios. }\end{array}$ & $\begin{array}{l}\text { (TRIBUNAL DE JUSTIÇA DO DISTRITO } \\
\text { FEDERAL E TERRITÓRIOS, 2013p) }\end{array}$ \\
\hline ATAS & $17 \mathrm{AT}$ & 17ª Reunião - Ordinária & $\begin{array}{l}\text { Registros do Comitê Executivo de Saúde do Distrito Federal do } \\
\text { Tribunal de Justiça do Distrito Federal e dos Territórios. }\end{array}$ & $\begin{array}{l}\text { (TRIBUNAL DE JUSTIÇA DO DISTRITO } \\
\text { FEDERAL E TERRITÓRIOS, 2013q) }\end{array}$ \\
\hline ATAS & $18 \mathrm{AT}$ & 18ª Reunião - Ordinária & $\begin{array}{l}\text { Registros do Comitê Executivo de Saúde do Distrito Federal do } \\
\text { Tribunal de Justiça do Distrito Federal e dos Territórios. }\end{array}$ & $\begin{array}{l}\text { (TRIBUNAL DE JUSTIÇA DO DISTRITO } \\
\text { FEDERAL E TERRITÓRIOS, 2014e) }\end{array}$ \\
\hline ATAS & 19AT & 19a Reunião - Ordinária & $\begin{array}{l}\text { Registros do Comitê Executivo de Saúde do Distrito Federal do } \\
\text { Tribunal de Justiça do Distrito Federal e dos Territórios. }\end{array}$ & $\begin{array}{l}\text { (TRIBUNAL DE JUSTIÇA DO DISTRITO } \\
\text { FEDERAL E TERRITÓRIOS, 2014f) }\end{array}$ \\
\hline ATAS & $20 \mathrm{AT}$ & 20ª Reunião - Ordinária & $\begin{array}{l}\text { Registros do Comitê Executivo de Saúde do Distrito Federal do } \\
\text { Tribunal de Justiça do Distrito Federal e dos Territórios. }\end{array}$ & $\begin{array}{l}\text { (TRIBUNAL DE JUSTIÇA DO DISTRITO } \\
\text { FEDERAL E TERRITÓRIOS, 2014g) }\end{array}$ \\
\hline ATAS & $21 \mathrm{AT}$ & 21 a Reunião - Ordinária & $\begin{array}{l}\text { Registros do Comitê Executivo de Saúde do Distrito Federal do } \\
\text { Tribunal de Justiça do Distrito Federal e dos Territórios. }\end{array}$ & $\begin{array}{l}\text { (TRIBUNAL DE JUSTIÇA DO DISTRITO } \\
\text { FEDERAL E TERRITÓRIOS, 2014h) }\end{array}$ \\
\hline ATAS & $22 \mathrm{AT}$ & $\begin{array}{l}22^{\mathrm{a}} \text { Reunião - } \\
\text { Extraordinária }\end{array}$ & $\begin{array}{l}\text { Registros do Comitê Executivo de Saúde do Distrito Federal do } \\
\text { Tribunal de Justiça do Distrito Federal e dos Territórios. }\end{array}$ & $\begin{array}{l}\text { (TRIBUNAL DE JUSTIÇA DO DISTRITO } \\
\text { FEDERAL E TERRITÓRIOS, 2014i) }\end{array}$ \\
\hline ATAS & $23 \mathrm{AT}$ & $23^{a}$ Reunião - Ordinária & $\begin{array}{l}\text { Registros do Comitê Executivo de Saúde do Distrito Federal do } \\
\text { Tribunal de Justiça do Distrito Federal e dos Territórios. }\end{array}$ & $\begin{array}{l}\text { (TRIBUNAL DE JUSTIÇA DO DISTRITO } \\
\text { FEDERAL E TERRITÓRIOS, 2014j) }\end{array}$ \\
\hline ATAS & $24 \mathrm{AT}$ & 24a Reunião - Ordinária & $\begin{array}{l}\text { Registros do Comitê Executivo de Saúde do Distrito Federal do } \\
\text { Tribunal de Justiça do Distrito Federal e dos Territórios. }\end{array}$ & $\begin{array}{l}\text { (TRIBUNAL DE JUSTIÇA DO DISTRITO } \\
\text { FEDERAL E TERRITÓRIOS, 2014l) }\end{array}$ \\
\hline ATAS & $25 \mathrm{AT}$ & $\begin{array}{l}25^{\text {a }} \text { Reunião - } \\
\text { Extraordinária }\end{array}$ & $\begin{array}{l}\text { Registros do Comitê Executivo de Saúde do Distrito Federal do } \\
\text { Tribunal de Justiça do Distrito Federal e dos Territórios. }\end{array}$ & $\begin{array}{l}\text { (TRIBUNAL DE JUSTIÇA DO DISTRITO } \\
\text { FEDERAL E TERRITÓRIOS, 2014m) }\end{array}$ \\
\hline ATAS & 26AT & 26a Reunião - Ordinária & $\begin{array}{l}\text { Registros do Comitê Executivo de Saúde do Distrito Federal do } \\
\text { Tribunal de Justiça do Distrito Federal e dos Territórios. }\end{array}$ & $\begin{array}{l}\text { (TRIBUNAL DE JUSTIÇA DO DISTRITO } \\
\text { FEDERAL E TERRITÓRIOS, 2014n) }\end{array}$ \\
\hline ATAS & 27AT & $27^{a}$ Reunião - Ordinária & $\begin{array}{l}\text { Registros do Comitê Executivo de Saúde do Distrito Federal do } \\
\text { Tribunal de Justiça do Distrito Federal e dos Territórios. }\end{array}$ & $\begin{array}{l}\text { (TRIBUNAL DE JUSTIÇA DO DISTRITO } \\
\text { FEDERAL E TERRITÓRIOS, 2015a) }\end{array}$ \\
\hline ATAS & $28 \mathrm{AT}$ & $28^{\mathrm{a}}$ Reunião - Ordinária & $\begin{array}{l}\text { Registros do Comitê Executivo de Saúde do Distrito Federal do } \\
\text { Tribunal de Justiça do Distrito Federal e dos Territórios. }\end{array}$ & $\begin{array}{l}\text { (TRIBUNAL DE JUSTIÇA DO DISTRITO } \\
\text { FEDERAL E TERRITÓRIOS, 2015b) }\end{array}$ \\
\hline ATAS & 29AT & 29a Reunião - Ordinária & $\begin{array}{l}\text { Registros do Comitê Executivo de Saúde do Distrito Federal do } \\
\text { Tribunal de Justiça do Distrito Federal e dos Territórios. }\end{array}$ & $\begin{array}{l}\text { (TRIBUNAL DE JUSTIÇA DO DISTRITO } \\
\text { FEDERAL E TERRITÓRIOS, 2015c) }\end{array}$ \\
\hline ATAS & 30AT & $30^{a}$ Reunião - Ordinária & $\begin{array}{l}\text { Registros do Comitê Executivo de Saúde do Distrito Federal do } \\
\text { Tribunal de Justiça do Distrito Federal e dos Territórios. }\end{array}$ & $\begin{array}{l}\text { (TRIBUNAL DE JUSTIÇA DO DISTRITO } \\
\text { FEDERAL E TERRITÓRIOS, 2015d) }\end{array}$ \\
\hline ATAS & $31 \mathrm{AT}$ & $31^{\mathrm{a}}$ Reunião - Ordinária & $\begin{array}{l}\text { Registros do Comitê Executivo de Saúde do Distrito Federal do } \\
\text { Tribunal de Justiça do Distrito Federal e dos Territórios. }\end{array}$ & $\begin{array}{l}\text { (TRIBUNAL DE JUSTIÇA DO DISTRITO } \\
\text { FEDERAL E TERRITÓRIOS, 2016e) }\end{array}$ \\
\hline ATAS & $32 \mathrm{AT}$ & $32^{\mathrm{a}}$ Reunião - Ordinária & $\begin{array}{l}\text { Registros do Comitê Executivo de Saúde do Distrito Federal do } \\
\text { Tribunal de Justiça do Distrito Federal e dos Territórios. }\end{array}$ & $\begin{array}{l}\text { (TRIBUNAL DE JUSTIÇA DO DISTRITO } \\
\text { FEDERAL E TERRITÓRIOS, 2016f) }\end{array}$ \\
\hline ATAS & 33AT & $\begin{array}{l}33^{\mathrm{a}} \text { Reunião - } \\
\text { Extraordinária }\end{array}$ & $\begin{array}{l}\text { Registros do Comitê Executivo de Saúde do Distrito Federal do } \\
\text { Tribunal de Justiça do Distrito Federal e dos Territórios. }\end{array}$ & $\begin{array}{l}\text { (TRIBUNAL DE JUSTIÇA DO DISTRITO } \\
\text { FEDERAL E TERRITÓRIOS, 2016d) }\end{array}$ \\
\hline
\end{tabular}


AP $\hat{E} N D I C E \boldsymbol{F}$ - Organização da pesquisa documental - LIVROS E MANUAIS

\begin{tabular}{|c|c|c|c|c|}
\hline Tipo documental & $\begin{array}{l}\text { Numeração/ } \\
\text { classificação }\end{array}$ & Documentos analisados & Fontes de informações sobre & Referências \\
\hline LIVROS E MANUAIS & $1 \mathrm{LM}$ & $\begin{array}{l}\text { BRASIL. Ministério da Saúde. Componente Especializado da Assistência } \\
\text { Farmacêutica: inovação para a garantia do acesso a medicamentos no SUS. } \\
\text { Brasília: Ministério da Saúde, 2014. } 163 \text { p. }\end{array}$ & $\begin{array}{l}\text { A consolidação e perspectivas } \\
\text { para o CEAF/PNAF. }\end{array}$ & (BRASIL, 2014a) \\
\hline LIVROS E MANUAIS & $2 \mathrm{LM}$ & $\begin{array}{l}\text { BRASIL. Ministério da Saúde. Da excepcionalidade às linhas de cuidado: o } \\
\text { Componente Especializado da Assistência Farmacêutica. Brasília: Ministério da } \\
\text { Saúde, 2010. } 262 \text { p. }\end{array}$ & $\begin{array}{l}\text { Definição e organização do } \\
\text { CEAF/PNAF. }\end{array}$ & (BRASIL, 2010a) \\
\hline LIVROS E MANUAIS & $3 \mathrm{LM}$ & $\begin{array}{l}\text { BRASIL. Conselho Nacional de Secretários de Saúde.sépl SUS: avanços e } \\
\text { desafios./Conselho Nacional de Secretários de Saúde. - Brasília: CONASS, } \\
2006.164 \text { p. }\end{array}$ & $\begin{array}{l}\text { Os avanços e desafios do } \\
\text { SUS. }\end{array}$ & (BRASIL, 2006c) \\
\hline LIVROS E MANUAIS & $4 \mathrm{LM}$ & $\begin{array}{l}\text { BRASIL. Ministério da Saúde. O Sistema Público de Saúde Brasileiro. } \\
\text { Seminário Internacional: Tendências e Desafios dos Sistemas de Saúde nas } \\
\text { Américas. Brasília: Editora do Ministério da Saúde, 2002c. } 44 \text { p. }\end{array}$ & $\begin{array}{l}\text { O Sistema Único de Saúde - } \\
\text { SUS. }\end{array}$ & (BRASIL, 2002c) \\
\hline
\end{tabular}


APÂEDICE G - Organização da pesquisa documental - JURISPRUDÊNCIAS E OUTROS REGISTROS JUDICIAIS

\begin{tabular}{|c|c|c|c|c|}
\hline Tipo documental & $\begin{array}{l}\text { Numeração/ } \\
\text { classificação }\end{array}$ & Documentos analisados & Fontes de informações sobre & Referências \\
\hline $\begin{array}{l}\text { JURISPRUDÊNCIAS E } \\
\text { OUTROS REGISTROS } \\
\text { JUDICIAIS }\end{array}$ & $1 \mathrm{~J}$ & $\begin{array}{l}\text { Ementário } 56 \text { de Jurisprudências do Tribunal } \\
\text { de Justiça do Distrito Federal e Territórios. }\end{array}$ & Registro judiciais e jurisprudências & $\begin{array}{l}\text { (TRIBUNAL DE JUSTIÇA DO } \\
\text { DISTRITO FEDERAL E } \\
\text { TERRITÓRIOS, 2008) }\end{array}$ \\
\hline $\begin{array}{l}\text { JURISPRUDÊNCIAS E } \\
\text { OUTROS REGISTROS } \\
\text { JUDICIAIS }\end{array}$ & $2 \mathrm{~J}$ & $\begin{array}{l}\text { Ementário } 57 \text { de Jurisprudências do Tribunal } \\
\text { de Justiça do Distrito Federal e Territórios. }\end{array}$ & Registro judiciais e jurisprudências & $\begin{array}{l}\text { (TRIBUNAL DE JUSTIÇA DO } \\
\text { DISTRITO FEDERAL E } \\
\text { TERRITÓRIOS, 2009a) }\end{array}$ \\
\hline $\begin{array}{l}\text { JURISPRUDÊNCIAS E } \\
\text { OUTROS REGISTROS } \\
\text { JUDICIAIS }\end{array}$ & $3 \mathrm{~J}$ & $\begin{array}{l}\text { Ementário } 58 \text { de Jurisprudências do Tribunal } \\
\text { de Justiça do Distrito Federal e Territórios. }\end{array}$ & Registro judiciais e jurisprudências & $\begin{array}{l}\text { (TRIBUNAL DE JUSTIÇA DO } \\
\text { DISTRITO FEDERAL E } \\
\text { TERRITÓRIOS, 2009b) }\end{array}$ \\
\hline $\begin{array}{l}\text { JURISPRUDÊNCIAS E } \\
\text { OUTROS REGISTROS } \\
\text { JUDICIAIS }\end{array}$ & $4 \mathrm{~J}$ & $\begin{array}{l}\text { Ementário } 60 \text { de Jurisprudências do Tribunal } \\
\text { de Justiça do Distrito Federal e Territórios. }\end{array}$ & Registro judiciais e jurisprudências & $\begin{array}{l}\text { (TRIBUNAL DE JUSTIÇA DO } \\
\text { DISTRITO FEDERAL E } \\
\text { TERRITÓRIOS, 2009c) }\end{array}$ \\
\hline $\begin{array}{l}\text { JURISPRUDÊNCIAS E } \\
\text { OUTROS REGISTROS } \\
\text { JUDICIAIS }\end{array}$ & $5 \mathrm{~J}$ & $\begin{array}{l}\text { Ementário } 63 \text { de Jurisprudências do Tribunal } \\
\text { de Justiça do Distrito Federal e Territórios. }\end{array}$ & Registro judiciais e jurisprudências & $\begin{array}{l}\text { (TRIBUNAL DE JUSTIÇA DO } \\
\text { DISTRITO FEDERAL E } \\
\text { TERRITÓRIOS, 2011s) }\end{array}$ \\
\hline $\begin{array}{l}\text { JURISPRUDÊNCIAS E } \\
\text { OUTROS REGISTROS } \\
\text { JUDICIAIS }\end{array}$ & $6 \mathrm{~J}$ & $\begin{array}{l}\text { Ementário } 64 \text { de Jurisprudências do Tribunal } \\
\text { de Justiça do Distrito Federal e Territórios. }\end{array}$ & Registro judiciais e jurisprudências & $\begin{array}{l}\text { (TRIBUNAL DE JUSTIÇA DO } \\
\text { DISTRITO FEDERAL E } \\
\text { TERRITÓRIOS, 2011t) }\end{array}$ \\
\hline $\begin{array}{l}\text { JURISPRUDÊNCIAS E } \\
\text { OUTROS REGISTROS } \\
\text { JUDICIAIS }\end{array}$ & $7 \mathrm{~J}$ & $\begin{array}{l}\text { Parecer da CONJUR/MS sobre ações } \\
\text { judiciais relacionadas à medicamentos. }\end{array}$ & $\begin{array}{l}\text { Informações técnicas para defesa judicial em casos } \\
\text { relacionados à acesso à medicamentos. }\end{array}$ & $\begin{array}{l}\text { (MINISTÉRIO DA SAÚDE, } \\
\text { 2016i) }\end{array}$ \\
\hline $\begin{array}{l}\text { JURISPRUDÊNCIAS E } \\
\text { OUTROS REGISTROS } \\
\text { JUDICIAIS }\end{array}$ & $8 \mathrm{~J}$ & $\begin{array}{l}\text { Parecer da CONJUR/MS sobre ações } \\
\text { judiciais relacionadas à medicamentos. }\end{array}$ & $\begin{array}{l}\text { Informações técnicas para defesa judicial em casos } \\
\text { relacionados à acesso à medicamentos. }\end{array}$ & $\begin{array}{l}\text { (MINISTÉRIO DA SAÚDE, } \\
\text { 2016j) }\end{array}$ \\
\hline $\begin{array}{l}\text { JURISPRUDÊNCIAS E } \\
\text { OUTROS REGISTROS } \\
\text { JUDICIAIS }\end{array}$ & $9 \mathrm{~J}$ & $\begin{array}{l}\text { Parecer da CONJUR/MS sobre ações } \\
\text { judiciais relacionadas à medicamentos. }\end{array}$ & $\begin{array}{l}\text { Informações técnicas para defesa judicial em casos } \\
\text { relacionados à acesso à medicamentos. }\end{array}$ & $\begin{array}{l}\text { (MINISTÉRIO DA SAÚDE, } \\
\text { 20161) }\end{array}$ \\
\hline $\begin{array}{l}\text { JURISPRUDÊNCIAS E } \\
\text { OUTROS REGISTROS } \\
\text { JUDICIAIS }\end{array}$ & $10 \mathrm{~J}$ & $\begin{array}{l}\text { Parecer da CONJUR/MS sobre ações } \\
\text { judiciais relacionadas à medicamentos. }\end{array}$ & $\begin{array}{l}\text { Informações técnicas para defesa judicial em casos } \\
\text { relacionados à acesso à medicamentos. }\end{array}$ & $\begin{array}{l}\text { (MINISTÉRIO DA SAÚDE, } \\
\text { 2016f) }\end{array}$ \\
\hline $\begin{array}{l}\text { JURISPRUDÊNCIAS E } \\
\text { OUTROS REGISTROS }\end{array}$ & $11 \mathrm{~J}$ & $\begin{array}{l}\text { Recomendação da Procuradoria-Geral de } \\
\text { Justiça do Distrito Federal e Territórios sobre }\end{array}$ & $\begin{array}{l}\text { Recomendações à SES-GDF sobre gestão de } \\
\text { medicamentos. }\end{array}$ & $\begin{array}{l}\text { (PROCURADORIA-GERAL } \\
\text { DO DISTRITO FEDERAL, }\end{array}$ \\
\hline
\end{tabular}




\begin{tabular}{|c|c|c|c|c|}
\hline \multicolumn{2}{|l|}{\begin{tabular}{|l|} 
JUDICIAIS \\
\end{tabular}} & \multicolumn{2}{|l|}{ ações judicias em saúde. } & \multirow{2}{*}{$\begin{array}{l}1999) \\
\text { (BRASIL, 2010c) }\end{array}$} \\
\hline $\begin{array}{l}\text { JURISPRUDÊNCIAS E } \\
\text { OUTROS REGISTROS } \\
\text { JUDICIAIS }\end{array}$ & $12 \mathrm{~J}$ & $\begin{array}{l}\text { Recomendação do Conselho Nacional de } \\
\text { Justiça, n } 31 \text { de 30/03/2010. }\end{array}$ & $\begin{array}{l}\text { Recomendações aos Tribunais para maior eficiência } \\
\text { na solução das demandas judiciais envolvendo a } \\
\text { assistência à saúde. }\end{array}$ & \\
\hline $\begin{array}{l}\text { JURISPRUDÊNCIAS E } \\
\text { OUTROS REGISTROS } \\
\text { JUDICIAIS }\end{array}$ & $13 \mathrm{~J}$ & $\begin{array}{l}\text { Declaração do I Encontro do Fórum Nacional } \\
\text { do Judiciário para a Saúde }\end{array}$ & $\begin{array}{l}\text { Resultado do I Encontro do Fórum Nacional do } \\
\text { Judiciário para a Saúde. }\end{array}$ & $\begin{array}{l}\text { (CONSELHO NACIONAL DE } \\
\text { JUSTIÇA, 2016b) }\end{array}$ \\
\hline $\begin{array}{l}\text { JURISPRUDÊNCIAS E } \\
\text { OUTROS REGISTROS } \\
\text { JUDICIAIS }\end{array}$ & $14 \mathrm{~J}$ & $\begin{array}{l}\text { Processos judiciais da Defensoria Pública da } \\
\text { União contra o governo. }\end{array}$ & $\begin{array}{l}\text { Decisões Judiciais relacionadas à processos abertos } \\
\text { pela Defensoria Pública da União contra o governo. }\end{array}$ & $\begin{array}{l}\text { (DEFENSORIA PÚBLICA DA } \\
\text { UNIÃO, 2016c) }\end{array}$ \\
\hline $\begin{array}{l}\text { JURISPRUDÊNCIAS E } \\
\text { OUTROS REGISTROS } \\
\text { JUDICIAIS }\end{array}$ & $15 \mathrm{~J}$ & $\begin{array}{l}\text { Processos judiciais da Defensoria Pública da } \\
\text { União contra o governo. }\end{array}$ & $\begin{array}{l}\text { Decisões Judiciais relacionadas à processos abertos } \\
\text { pela Defensoria Pública da União contra o governo. }\end{array}$ & $\begin{array}{l}\text { (DEFENSORIA PÚBLICA DA } \\
\text { UNIÃO, 2016d) }\end{array}$ \\
\hline $\begin{array}{l}\text { JURISPRUDÊNCIAS E } \\
\text { OUTROS REGISTROS } \\
\text { JUDICIAIS }\end{array}$ & $16 \mathrm{~J}$ & $\begin{array}{l}\text { Processos judiciais da Defensoria Pública da } \\
\text { União contra o governo. }\end{array}$ & $\begin{array}{l}\text { Decisões Judiciais relacionadas à processos abertos } \\
\text { pela Defensoria Pública da União contra o governo. }\end{array}$ & $\begin{array}{l}\text { (DEFENSORIA PÚBLICA DA } \\
\text { UNIÃO, 2016e) }\end{array}$ \\
\hline $\begin{array}{l}\text { JURISPRUDÊNCIAS E } \\
\text { OUTROS REGISTROS } \\
\text { JUDICIAIS }\end{array}$ & $17 \mathrm{~J}$ & $\begin{array}{l}\text { Relatório de processos judiciais em saúde do } \\
\text { Conselho Nacional de Justiça. }\end{array}$ & Quantitativo de ações judiciais em saúde & $\begin{array}{l}\text { (CONSELHO NACIONAL DE } \\
\text { JUSTIÇA, 2016c) }\end{array}$ \\
\hline $\begin{array}{l}\text { JURISPRUDÊNCIAS E } \\
\text { OUTROS REGISTROS } \\
\text { JUDICIAIS }\end{array}$ & $18 \mathrm{~J}$ & $\begin{array}{l}\text { Relatório de processos judiciais em saúde do } \\
\text { Conselho Nacional de Justiça. }\end{array}$ & Quantitativo de ações judiciais em saúde & $\begin{array}{l}\text { (CONSELHO NACIONAL DE } \\
\text { JUSTIÇA, 2016d) }\end{array}$ \\
\hline $\begin{array}{l}\text { JURISPRUDÊNCIAS E } \\
\text { OUTROS REGISTROS } \\
\text { JUDICIAIS }\end{array}$ & $19 J$ & $\begin{array}{l}\text { Jursiprudência do STF quanto ao Fator } 9 \\
\text { Recombinante. }\end{array}$ & $\begin{array}{l}\text { Registro de ações judiciais e respectivas } \\
\text { jurisprudências. }\end{array}$ & $\begin{array}{l}\text { (SUPREMO TRIBUNAL } \\
\text { FEDERAL, 2016d) }\end{array}$ \\
\hline $\begin{array}{l}\text { JURISPRUDÊNCIAS E } \\
\text { OUTROS REGISTROS } \\
\text { JUDICIAIS }\end{array}$ & $20 \mathrm{~J}$ & $\begin{array}{l}\text { Parecer da CONJUR/MS sobre ações } \\
\text { judiciais relacionadas à medicamentos. }\end{array}$ & $\begin{array}{l}\text { Informações sobre a Judicialização da Saúde no } \\
\text { Brasil }\end{array}$ & $\begin{array}{l}\text { (MINISTÉRIO DA SAÚDE, } \\
2016 \mathrm{~g})\end{array}$ \\
\hline $\begin{array}{l}\text { JURISPRUDÊNCIAS E } \\
\text { OUTROS REGISTROS } \\
\text { JUDICIAIS }\end{array}$ & $21 \mathrm{~J}$ & $\begin{array}{l}\text { Documento entre MS e Procuradoria sobre } \\
\text { ações judiciais relacionadas à medicamentos. }\end{array}$ & $\begin{array}{l}\text { Informações sobre a Judicialização da Saúde no } \\
\text { Brasil }\end{array}$ & $\begin{array}{l}\text { (MINISTÉRIO DA SAÚDE, } \\
\text { 2016h) }\end{array}$ \\
\hline
\end{tabular}


AP $\hat{E} N D I C E \boldsymbol{H}$ - Organização da pesquisa documental - SITES INSTITUCIONAIS

\begin{tabular}{|c|c|c|c|c|}
\hline Tipo documental & $\begin{array}{l}\text { Numeração/ } \\
\text { classificação }\end{array}$ & Documentos analisados & $\begin{array}{l}\text { Fontes de informações } \\
\text { sobre }\end{array}$ & Referências \\
\hline $\begin{array}{l}\text { SITES } \\
\text { INSTITUCIONAIS }\end{array}$ & $1 \mathrm{SI}$ & $\begin{array}{l}\text { SECRETARIA DE ESTADO DE SAÚDE DO DISTRITO FEDERAL: } \\
\text { http://www.saude.df.gov.br/outros-links/assistencia-farmaceutica.html }\end{array}$ & $\begin{array}{l}\text { Diretoria de Assistência } \\
\text { Farmacêutica - DIASF }\end{array}$ & $\begin{array}{l}\text { (SECRETARIA DE ESTADO DE } \\
\text { SAÚDE DO DISTRITO } \\
\text { FEDERAL, 2016a) }\end{array}$ \\
\hline $\begin{array}{l}\text { SITES } \\
\text { INSTITUCIONAIS }\end{array}$ & $2 \mathrm{SI}$ & $\begin{array}{l}\text { MINISTÉRIO DA SAÚDE: } \\
\text { http://portalsaude.saude.gov.br/index.php?option=com_content \&view=article\&i } \\
\text { d=11635\&Itemid=702 }\end{array}$ & $\begin{array}{l}\text { Assistência Farmacêutica - } \\
\text { Componente Especializado } \\
\text { da Assistência Farmacêutica } \\
\text { no Distrito Federal. }\end{array}$ & $\begin{array}{l}\text { (MINISTÉRIO DA SAÚDE, } \\
\text { 2016a) }\end{array}$ \\
\hline $\begin{array}{l}\text { SITES } \\
\text { INSTITUCIONAIS }\end{array}$ & $3 \mathrm{SI}$ & $\begin{array}{l}\text { SECRETARIA DE ESTADO DE SAÚDE DO DISTRITO FEDERAL: } \\
\text { http://www.saude.df.gov.br/outros-links/assistencia-farmaceutica/784- } \\
\text { componente-especializado-da-assistencia-farmaceutica-farmacia-de-alto- } \\
\text { custo.html }\end{array}$ & $\begin{array}{l}\text { Componente Especializado } \\
\text { da Assistência Farmacêutica } \\
\text { (Farmácia de Alto Custo) }\end{array}$ & $\begin{array}{l}\text { (SECRETARIA DE ESTADO DE } \\
\text { SAÚDE DO DISTRITO } \\
\text { FEDERAL, 2016b) }\end{array}$ \\
\hline $\begin{array}{l}\text { SITES } \\
\text { INSTITUCIONAIS }\end{array}$ & $4 \mathrm{SI}$ & $\begin{array}{l}\text { SECRETARIA DE ESTADO DE SAÚDE DO DISTRITO FEDERAL: } \\
\text { http://www.saude.df.gov.br/conselho-distrital-de-saude }\end{array}$ & $\begin{array}{l}\text { Conselho de Saúde do } \\
\text { Distrito Federal - CSDF }\end{array}$ & $\begin{array}{l}\text { (SECRETARIA DE ESTADO DE } \\
\text { SAÚDE DO DISTRITO } \\
\text { FEDERAL, 2016c) }\end{array}$ \\
\hline $\begin{array}{l}\text { SITES } \\
\text { INSTITUCIONAIS }\end{array}$ & $5 \mathrm{SI}$ & $\begin{array}{l}\text { MINISTÉRIO DA SAÚDE } \\
\text { http://conselho.saude.gov.br/apresentacao/composicao.htm }\end{array}$ & $\begin{array}{l}\text { Conselho Nacional de } \\
\text { Saúde }\end{array}$ & $\begin{array}{l}\text { (MINISTÉRIO DA SAÚDE, } \\
\text { 2016b) }\end{array}$ \\
\hline $\begin{array}{l}\text { SITES } \\
\text { INSTITUCIONAIS }\end{array}$ & 7SI & $\begin{array}{l}\text { MINISTÉRIO PÚBLICO DO DISTRITO FEDERAL E TERRITÓRIOS: } \\
\text { http://www.mpdft.mp.br/portal/index.php/conhecampdft-menu/promotorias- } \\
\text { justica-menu/promotoria-de-justia-de-defesa-da-sade-prosus-mainmenu-105 }\end{array}$ & $\begin{array}{l}\text { Promotoria de Justiça de } \\
\text { Defesa da Saúde - Prosus }\end{array}$ & $\begin{array}{l}\text { (MINISTÉRIO PÚBLICO DO } \\
\text { DISTRITO FEDERAL E } \\
\text { TERRITÓRIOS, 2016a) }\end{array}$ \\
\hline $\begin{array}{l}\text { SITES } \\
\text { INSTITUCIONAIS }\end{array}$ & $8 \mathrm{SI}$ & $\begin{array}{l}\text { MINISTÉRIO DA SAÚDE: http://portalsaude.saude.gov.br/index.php/o- } \\
\text { ministerio/principal/conjur }\end{array}$ & $\begin{array}{l}\text { Consultoria Jurídica junto } \\
\text { ao Ministério da Saúde }\end{array}$ & $\begin{array}{l}\text { (MINISTÉRIO DA SAÚDE, } \\
\text { 2016e) }\end{array}$ \\
\hline $\begin{array}{l}\text { SITES } \\
\text { INSTITUCIONAIS }\end{array}$ & 9SI & $\begin{array}{l}\text { MINISTÉRIO DA SAÚDE: http://portalsaude.saude.gov.br/index.php/o- } \\
\text { ministerio/principal/secretarias/sctie/noticias-sctie/23341-telefones-da-secretara- } \\
\text { de-ciencia-tecnologia-e-insumos-estrategicos }\end{array}$ & Núcleo Jurídico & $\begin{array}{l}\text { (MINISTÉRIO DA SAÚDE, } \\
\text { 2016f) }\end{array}$ \\
\hline $\begin{array}{l}\text { SITES } \\
\text { INSTITUCIONAIS }\end{array}$ & $10 S I$ & $\begin{array}{l}\text { MINISTÉRIO PÚBLICO DA UNIÃO: } \\
\text { http://www.mpu.mp.br/navegacao/institucional/organograma }\end{array}$ & Organograma do MPU & $\begin{array}{l}\text { (MINISTÉRIO PÚBLICO DA } \\
\text { UNIÃO, 2016) }\end{array}$ \\
\hline $\begin{array}{l}\text { SITES } \\
\text { INSTITUCIONAIS }\end{array}$ & $11 \mathrm{SI}$ & $\begin{array}{l}\text { MINISTÉRIO PÚBLICO FEDERAL: http://www.mpf.mp.br/conheca-o- } \\
\text { mpf/atuacao }\end{array}$ & Atuação do MPF & $\begin{array}{l}\text { (MINISTÉRIO PÚBLICO } \\
\text { FEDERAL, 2016) }\end{array}$ \\
\hline
\end{tabular}




\begin{tabular}{|c|c|c|c|c|}
\hline $\begin{array}{l}\text { SITES } \\
\text { INSTITUCIONAIS }\end{array}$ & $12 \mathrm{SI}$ & DEFENSORIA PÚBLICA DA UNIÃO: http://www.dpu.gov.br/saude & $\begin{array}{l}\text { Atuação da Defensoria } \\
\text { Pública da União na defesa } \\
\text { pela saúde. }\end{array}$ & $\begin{array}{l}\text { (DEFENSORIA PÚBLICA DA } \\
\text { UNIÃO, 2016a) }\end{array}$ \\
\hline $\begin{array}{l}\text { SITES } \\
\text { INSTITUCIONAIS }\end{array}$ & $13 \mathrm{SI}$ & $\begin{array}{l}\text { TRIBUNAL DE JUSTIÇA DO DISTRITO FEDERAL: } \\
\text { http://www.tjdft.jus.br/acesso-rapido/informacoes/perguntas-mais- } \\
\text { frequentes/relacionamento-com-o-judiciario }\end{array}$ & TJDFT & $\begin{array}{l}\text { (TRIBUNAL DE JUSTIÇA DO } \\
\text { DISTRITO FEDERAL, 2016a) }\end{array}$ \\
\hline $\begin{array}{l}\text { SITES } \\
\text { INSTITUCIONAIS }\end{array}$ & $14 \mathrm{SI}$ & $\begin{array}{l}\text { TRIBUNAL DE JUSTIÇA DO DISTRITO FEDERAL: } \\
\text { http://www.tjdft.jus.br/institucional/comite-executivo-distrital-da-saude }\end{array}$ & $\begin{array}{l}\text { Comitê Executivo Distrital } \\
\text { da Saúde }\end{array}$ & $\begin{array}{l}\text { (TRIBUNAL DE JUSTIÇA DO } \\
\text { DISTRITO FEDERAL, 2016b) }\end{array}$ \\
\hline $\begin{array}{l}\text { SITES } \\
\text { INSTITUCIONAIS }\end{array}$ & $15 \mathrm{SI}$ & $\begin{array}{l}\text { PROCURADORIA-GERAL DO DISTRITO FEDERAL: } \\
\text { http://www.pg.df.gov.br/institucional/estrutura/374-procuradoria-do-meio- } \\
\text { ambiente-patrimonio-urbanistico-e-imobiliario-e-saude-promai.html }\end{array}$ & $\begin{array}{l}\text { Procuradoria do meio } \\
\text { Ambiente, Patrimônio } \\
\text { Urbanístico e Imobiliário e } \\
\text { Saúde - PROMAI }\end{array}$ & $\begin{array}{l}\text { (PROCURADORIA-GERAL DO } \\
\text { DISTRITO FEDERAL, 2016) }\end{array}$ \\
\hline $\begin{array}{l}\text { SITES } \\
\text { INSTITUCIONAIS }\end{array}$ & $16 \mathrm{SI}$ & $\begin{array}{l}\text { DEFENSORIA PÚBLICA DO DISTRITO FEDERAL: } \\
\text { http://www.defensoria.df.gov.br/?page_id=2376 }\end{array}$ & $\begin{array}{l}\text { Atuação da Defensoria } \\
\text { Pública do Distrito Federal } \\
\text { na defesa pela saúde. }\end{array}$ & $\begin{array}{l}\text { (DEFENSORIA PÚBLICA DO } \\
\text { DISTRITO FEDERAL, 2016a) }\end{array}$ \\
\hline $\begin{array}{l}\text { SITES } \\
\text { INSTITUCIONAIS }\end{array}$ & $17 \mathrm{SI}$ & $\begin{array}{l}\text { CONSELHO NACIONAL DE JUSTIÇA: http://www.cnj.jus.br/programas-e- } \\
\text { acoes/forum-da-saude }\end{array}$ & $\begin{array}{l}\text { Controle Judicial de } \\
\text { Políticas Públicas - Fórum } \\
\text { da Saúde }\end{array}$ & $\begin{array}{l}\text { (CONSELHO NACIONAL DE } \\
\text { JUSTIÇA, 2016a) }\end{array}$ \\
\hline $\begin{array}{l}\text { SITES } \\
\text { INSTITUCIONAIS }\end{array}$ & $18 \mathrm{SI}$ & $\begin{array}{l}\text { PROCURADORIA-GERAL DA REPÚBLICA: } \\
\text { http://www.mpf.mp.br/pgr/atuacao }\end{array}$ & Atuação da PGR & $\begin{array}{l}\text { (PROCURADORIA-GERAL DA } \\
\text { REPÚBLICA, 2016) }\end{array}$ \\
\hline $\begin{array}{l}\text { SITES } \\
\text { INSTITUCIONAIS }\end{array}$ & 19SI & $\begin{array}{l}\text { MINISTÉRIO PÚBLICO DO DISTRITO FEDERAL E TERRITÓRIOS: } \\
\text { http://www.mpdft.mp.br/saude/>. }\end{array}$ & $\begin{array}{l}\text { Portal Direito e Saúde do } \\
\text { MPDFT }\end{array}$ & $\begin{array}{l}\text { (MINISTÉRIO PÚBLICO DO } \\
\text { DISTRITO FEDERAL E } \\
\text { TERRITÓRIOS, 2016c) }\end{array}$ \\
\hline $\begin{array}{l}\text { SITES } \\
\text { INSTITUCIONAIS }\end{array}$ & 20SI & $\begin{array}{l}\text { MINISTÉRIO PÚBLICO DO DISTRITO FEDERAL E TERRITÓRIOS: } \\
\text { http://www.mpdft.mp.br/portal/index.php/mpdft-acao/recomendacoes- } \\
\text { menu/2366-promotoria-de-justica-de-defesa-da-saude-prosus }\end{array}$ & $\begin{array}{l}\text { Recomendações da } \\
\text { PROSUS - MPDFT }\end{array}$ & $\begin{array}{l}\text { (MINISTÉRIO PÚBLICO DO } \\
\text { DISTRITO FEDERAL E } \\
\text { TERRITÓRIOS, 2016d) }\end{array}$ \\
\hline
\end{tabular}


AP $\hat{E}$ NDICE I - Organização da pesquisa documental - NOTÍCIAS DO SISTEMA DE SAÚDE

\begin{tabular}{|c|c|c|c|c|}
\hline Tipo documental & $\begin{array}{l}\text { Numeração/ } \\
\text { classificação }\end{array}$ & Documentos analisados & Fontes de informações sobre & Referências \\
\hline $\begin{array}{l}\text { NOTÍCIAS DO } \\
\text { SISTEMA DE SAÚDE }\end{array}$ & $1 \mathrm{NS}$ & $\begin{array}{l}\text { Reportagem sobre judicialização da saúde } \\
\text { veiculada pelo site do MS. }\end{array}$ & $\begin{array}{l}\text { Judicialização da saúde, sob a perspectiva do } \\
\text { Sistema de Saúde }\end{array}$ & $\begin{array}{l}\text { (MINISTÉRIO DA SAÚDE, } \\
\text { 2015) }\end{array}$ \\
\hline $\begin{array}{l}\text { NOTÍCIAS DO } \\
\text { SISTEMA DE SAÚDE }\end{array}$ & $2 \mathrm{NS}$ & $\begin{array}{l}\text { Reportagem sobre judicialização da saúde } \\
\text { veiculada pelo site do MS. }\end{array}$ & $\begin{array}{l}\text { Judicialização da saúde, sob a perspectiva do } \\
\text { Sistema de Saúde }\end{array}$ & $\begin{array}{l}\text { (MINISTÉRIO DA SAÚDE, } \\
\text { 2016c) }\end{array}$ \\
\hline $\begin{array}{l}\text { NOTÍCIAS DO } \\
\text { SISTEMA DE SAÚDE }\end{array}$ & $3 \mathrm{NS}$ & $\begin{array}{l}\text { Reportagem sobre judicialização da saúde } \\
\text { veiculada pelo site da Agência Braślia (GDF). }\end{array}$ & $\begin{array}{l}\text { Judicialização da saúde, sob a perspectiva do } \\
\text { Sistema de Saúde }\end{array}$ & (AGENCIA BRASÍLIA, 2012a) \\
\hline $\begin{array}{l}\text { NOTÍCIAS DO } \\
\text { SISTEMA DE SAÚDE }\end{array}$ & $4 \mathrm{NS}$ & $\begin{array}{l}\text { Reportagem sobre judicialização da saúde } \\
\text { veiculada pelo site do Conselho Nacional de } \\
\text { Secretários de Saúde. }\end{array}$ & $\begin{array}{l}\text { Judicialização da saúde, sob a perspectiva do } \\
\text { Sistema de Saúde }\end{array}$ & $\begin{array}{l}\text { (CONSELHO NACIONAL DE } \\
\text { SECRETÁRIOS DE SAÚDE, } \\
\text { 2016c) }\end{array}$ \\
\hline $\begin{array}{l}\text { NOTÍCIAS DO } \\
\text { SISTEMA DE SAÚDE }\end{array}$ & $5 \mathrm{NS}$ & $\begin{array}{l}\text { Reportagem sobre judicialização da saúde } \\
\text { veiculada pelo site do Correio Braziliense. }\end{array}$ & $\begin{array}{l}\text { Judicialização da saúde, sob a perspectiva do } \\
\text { Sistema de Saúde }\end{array}$ & $\begin{array}{l}\text { (CORREIO BRAZILIENSE, } \\
\text { 2015) }\end{array}$ \\
\hline $\begin{array}{l}\text { NOTÍCIAS DO } \\
\text { SISTEMA DE SAÚDE }\end{array}$ & $6 \mathrm{NS}$ & $\begin{array}{l}\text { Reportagem sobre judicialização da saúde } \\
\text { veiculada pelo site da Agência Brasília (GDF). }\end{array}$ & $\begin{array}{l}\text { Judicialização da saúde, sob a perspectiva do } \\
\text { Sistema de Saúde }\end{array}$ & (AGENCIA BRASÍLIA, 2012b) \\
\hline $\begin{array}{l}\text { NOTÍCIAS DO } \\
\text { SISTEMA DE SAÚDE }\end{array}$ & $7 \mathrm{NS}$ & $\begin{array}{l}\text { Reportagem sobre judicialização da saúde } \\
\text { veiculada pelo site da Agência Brasília (GDF). }\end{array}$ & $\begin{array}{l}\text { Judicialização da saúde, sob a perspectiva do } \\
\text { Sistema de Saúde }\end{array}$ & (AGENCIA BRASÍLIA, 2012c) \\
\hline $\begin{array}{l}\text { NOTÍCIAS DO } \\
\text { SISTEMA DE SAÚDE }\end{array}$ & $8 \mathrm{NS}$ & $\begin{array}{l}\text { Reportagem sobre judicialização da saúde } \\
\text { veiculada pelo site do Correio Braziliense. }\end{array}$ & $\begin{array}{l}\text { Judicialização da saúde, sob a perspectiva do } \\
\text { Sistema de Saúde }\end{array}$ & $\begin{array}{l}\text { (CORREIO BRAZILIENSE, } \\
\text { 2012) }\end{array}$ \\
\hline $\begin{array}{l}\text { NOTÍCIAS DO } \\
\text { SISTEMA DE SAÚDE }\end{array}$ & 9NS & $\begin{array}{l}\text { Reportagem sobre judicialização da saúde } \\
\text { veiculada pelo site da Agência Brasília (GDF). }\end{array}$ & $\begin{array}{l}\text { Judicialização da saúde, sob a perspectiva do } \\
\text { Sistema de Saúde }\end{array}$ & (AGENCIA BRASÍLIA, 2013) \\
\hline $\begin{array}{l}\text { NOTÍCIAS DO } \\
\text { SISTEMA DE SAÚDE }\end{array}$ & $10 \mathrm{NS}$ & $\begin{array}{l}\text { Reportagem sobre judicialização da saúde } \\
\text { veiculada pelo site da Agência Brasília (GDF). }\end{array}$ & $\begin{array}{l}\text { Judicialização da saúde, sob a perspectiva do } \\
\text { Sistema de Saúde }\end{array}$ & (AGENCIA BRASÍLIA, 2016) \\
\hline $\begin{array}{l}\text { NOTÍCIAS DO } \\
\text { SISTEMA DE SAÚDE }\end{array}$ & $11 \mathrm{NS}$ & $\begin{array}{l}\text { Reportagem sobre judicialização da saúde } \\
\text { veiculada pelo site do Correio Braziliense. }\end{array}$ & $\begin{array}{l}\text { Judicialização da saúde, sob a perspectiva do } \\
\text { Sistema de Saúde }\end{array}$ & $\begin{array}{l}\text { (CORREIO BRAZILIENSE, } \\
\text { 2016) }\end{array}$ \\
\hline $\begin{array}{l}\text { NOTÍCIAS DO } \\
\text { SISTEMA DE SAÚDE }\end{array}$ & $12 \mathrm{NS}$ & $\begin{array}{l}\text { Reportagem sobre judicialização da saúde } \\
\text { veiculada pelo site do Folha de São Paulo. }\end{array}$ & $\begin{array}{l}\text { Judicialização da saúde, sob a perspectiva do } \\
\text { Sistema de Saúde }\end{array}$ & $\begin{array}{l}\text { (FOLHA DE SÃO PAULO, } \\
\text { 2016a) }\end{array}$ \\
\hline $\begin{array}{l}\text { NOTÍCIAS DO } \\
\text { SISTEMA DE SAÚDE }\end{array}$ & $13 \mathrm{NS}$ & $\begin{array}{l}\text { Reportagem sobre judicialização da saúde } \\
\text { veiculada pelo site do Folha de São Paulo. }\end{array}$ & $\begin{array}{l}\text { Judicialização da saúde, sob a perspectiva do } \\
\text { Sistema de Saúde }\end{array}$ & $\begin{array}{l}\text { (FOLHA DE SÃO PAULO, } \\
2016 \mathrm{~b})\end{array}$ \\
\hline
\end{tabular}




\begin{tabular}{|lllll|}
\hline $\begin{array}{l}\text { NOTÍCIAS DO } \\
\text { SISTEMA DE SAÚDE }\end{array}$ & 14NS & $\begin{array}{l}\text { Reportagem sobre judicialização da saúde } \\
\text { veiculada pelo site da Agência Brasil. }\end{array}$ & $\begin{array}{l}\text { Judicialização da saúde, sob a perspectiva do } \\
\text { Sistema de Saúde }\end{array}$ & (AGÊNCIA BRASIL, 2016) \\
\hline $\begin{array}{l}\text { NOTÍCIAS DO } \\
\text { SISTEMA DE SAÚDE }\end{array}$ & 15NS & $\begin{array}{l}\text { Reportagem sobre judicialização da saúde } \\
\text { veiculada pelo site do Folha de São Paulo. }\end{array}$ & $\begin{array}{l}\text { Judicialização da saúde, sob a perspectiva do } \\
\text { Sistema de Saúde }\end{array}$ & (FOLHA DE SÃO PAULO, \\
\hline $\begin{array}{l}\text { NOTÍCIAS DO } \\
\text { SISTEMA DE SAÚDE }\end{array}$ & 16NS & $\begin{array}{l}\text { Reportagem sobre judicialização da saúde } \\
\text { veiculada pelo site do Estadão. }\end{array}$ & $\begin{array}{l}\text { Judicialização da saúde, sob a perspectiva do } \\
\text { Sistema de Saúde }\end{array}$ & (ESTADAO, 2016a) \\
\hline $\begin{array}{l}\text { NOTÍCIAS DO } \\
\text { SISTEMA DE SAÚDE }\end{array}$ & \multirow{2}{*}{ 17NS } & $\begin{array}{l}\text { Reportagem sobre judicialização da saúde } \\
\text { veiculada pelo site do Estadão }\end{array}$ & $\begin{array}{l}\text { Judicialização da saúde, sob a perspectiva do } \\
\text { Sistema de Saúde }\end{array}$ & (ESTADAO, 2016b) \\
\hline \hline
\end{tabular}


$\boldsymbol{A P \hat { E } N D I C E} \boldsymbol{J}$ - Organização da pesquisa documental - NOTÍCIAS DO SISTEMA JUDICIÁRIO

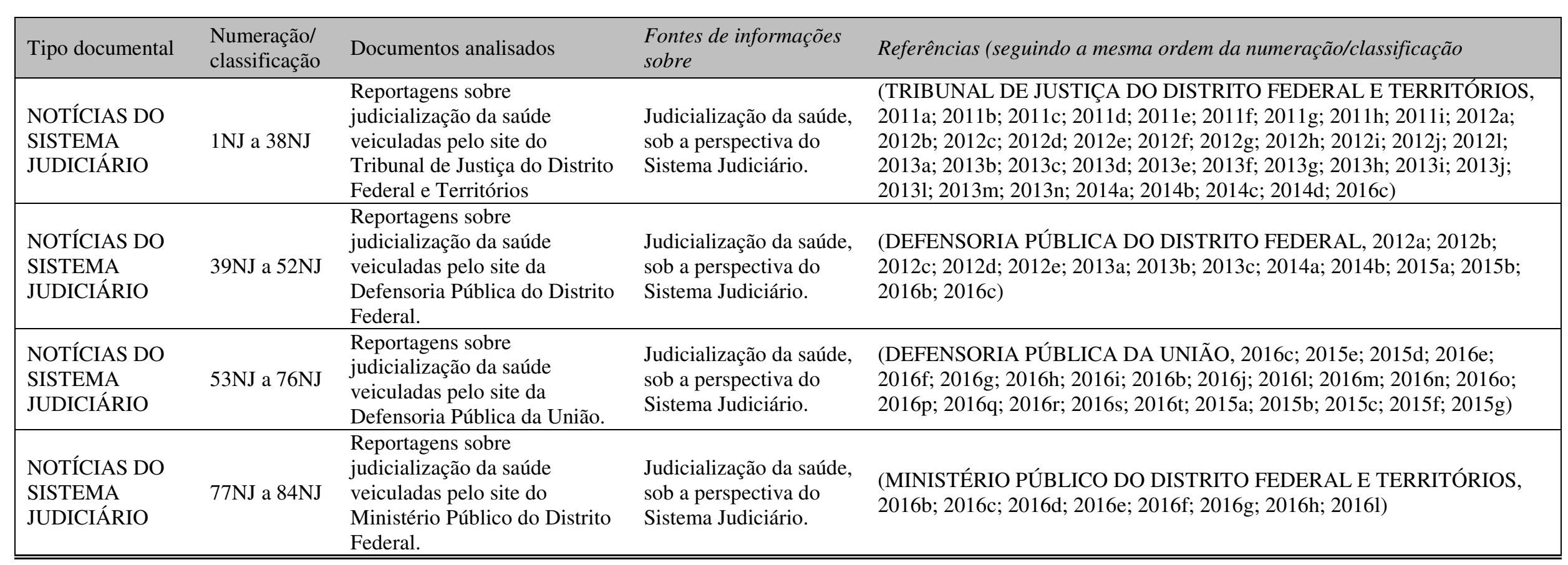


APÂEDICE K - Organização da pesquisa documental - ARTIGOS CIENTÍFICOS

\begin{tabular}{|c|c|c|c|c|}
\hline Tipo documental & $\begin{array}{l}\text { Numeração/ } \\
\text { classificação }\end{array}$ & Documentos analisados & Fontes de informações sobre & Referências \\
\hline ARTIGOS & $1 \mathrm{AR}$ & $\begin{array}{l}\text { Distorções causadas pelas ações judiciais à política de medicamentos no } \\
\text { Brasil. }\end{array}$ & $\begin{array}{l}\text { Informações relevantes sobre a } \\
\text { Judicialização ou questões correlatas. }\end{array}$ & (VIEIRA; ZUCCHI, 2007) \\
\hline ARTIGOS & $2 \mathrm{AR}$ & $\begin{array}{l}\text { Da falta de efetividade à judicialização excessiva: direito à saúde, } \\
\text { fornecimento gratuito de medicamentos e parâmetros para a atuação } \\
\text { judicial. }\end{array}$ & $\begin{array}{l}\text { Informações relevantes sobre a } \\
\text { Judicialização ou questões correlatas. }\end{array}$ & (BARROSO, 2016) \\
\hline ARTIGOS & $3 \mathrm{AR}$ & $\begin{array}{l}\text { Os marcos legais das políticas de medicamentos no Brasil contemporâneo } \\
(1990-2006) .\end{array}$ & $\begin{array}{l}\text { Informações relevantes sobre a } \\
\text { Judicialização ou questões correlatas. }\end{array}$ & $\begin{array}{l}\text { (KORNIS; BRAGA; ZAIRE, } \\
\text { 2008) }\end{array}$ \\
\hline ARTIGOS & 4AR & Judicialização: possível caminho à efetivação do direito à saúde no Brasil? & $\begin{array}{l}\text { Informações relevantes sobre a } \\
\text { Judicialização ou questões correlatas. }\end{array}$ & (RODRIGUES, 2016) \\
\hline ARTIGOS & $5 \mathrm{AR}$ & $\begin{array}{l}\text { Política de Medicamentos: da universalidade de direitos aos limites da } \\
\text { operacionalidade. }\end{array}$ & $\begin{array}{l}\text { Informações relevantes sobre a } \\
\text { Judicialização ou questões correlatas. }\end{array}$ & (PAULA et al, 2009) \\
\hline ARTIGOS & $6 \mathrm{AR}$ & O direito à saúde e o papel do judiciário para a sua efetividade no Brasil. & $\begin{array}{l}\text { Informações relevantes sobre a } \\
\text { Judicialização ou questões correlatas. }\end{array}$ & $\begin{array}{l}\text { (CORREA; MASSAFRA, } \\
\text { 2004) }\end{array}$ \\
\hline ARTIGOS & 7AR & $\begin{array}{l}\text { Estruturação da assistência farmacêutica: plano de ação para a seleção de } \\
\text { medicamentos essenciais. }\end{array}$ & $\begin{array}{l}\text { Informações relevantes sobre a } \\
\text { Judicialização ou questões correlatas. }\end{array}$ & $\begin{array}{l}\text { (MAGARINOS-TORRES; } \\
\text { PEPE; OSORIO-DE- } \\
\text { CASTRO, 2013) }\end{array}$ \\
\hline ARTIGOS & $8 \mathrm{AR}$ & Financiamento da Assistência Farmacêutica no Sistema Único de Saúde. & $\begin{array}{l}\text { Informações relevantes sobre a } \\
\text { Judicialização ou questões correlatas. }\end{array}$ & (VIEIRA; ZUCCHI, 2013) \\
\hline ARTIGOS & 9AR & O direito à saúde e a proposta de cobertura universal. & $\begin{array}{l}\text { Informações relevantes sobre a } \\
\text { Judicialização ou questões correlatas. }\end{array}$ & $\begin{array}{l}\text { (CONSELHO NACIONAL } \\
\text { DE SECRETÁRIOS DE } \\
\text { SAÚDE, 2016a) }\end{array}$ \\
\hline ARTIGOS & $10 \mathrm{AR}$ & $\begin{array}{l}\text { Criando alternativas ao processo de judicialização da saúde: o sistema de } \\
\text { pedido administrativo, uma iniciativa pioneira do estado e município do } \\
\text { Rio de Janeiro. }\end{array}$ & $\begin{array}{l}\text { Informações relevantes sobre a } \\
\text { Judicialização ou questões correlatas. }\end{array}$ & (TEIXEIRA, 2011) \\
\hline ARTIGOS & $11 \mathrm{AR}$ & A Judicialização da Saúde no Brasil & $\begin{array}{l}\text { Informações relevantes sobre a } \\
\text { Judicialização ou questões correlatas. }\end{array}$ & (OLIVEIRA, 2013) \\
\hline ARTIGOS & $12 \mathrm{AR}$ & $\begin{array}{l}\text { A configuração pós-moderna dos direitos fundamentais sociais: uma } \\
\text { análise da ingerência jurisdictional no âmbito de efetivação desses direitos. }\end{array}$ & $\begin{array}{l}\text { Informações relevantes sobre a } \\
\text { Judicialização ou questões correlatas. }\end{array}$ & (MAGALHÃES, 2012) \\
\hline ARTIGOS & $13 \mathrm{AR}$ & $\begin{array}{l}\text { Crítica aos limites do controle jurisdictional de políticas públicas em } \\
\text { direitos sociais. }\end{array}$ & $\begin{array}{l}\text { Informações relevantes sobre a } \\
\text { Judicialização ou questões correlatas. }\end{array}$ & (GNATA, 2011) \\
\hline
\end{tabular}




\begin{tabular}{|c|c|c|c|c|}
\hline ARTIGOS & $14 \mathrm{AR}$ & Curso de Direito Constitucional. & $\begin{array}{l}\text { Informações relevantes sobre a } \\
\text { Judicialização ou questões correlatas. }\end{array}$ & (BONAVIDES, 2009) \\
\hline ARTIGOS & $15 \mathrm{AR}$ & Direito Constitucional. & $\begin{array}{l}\text { Informações relevantes sobre a } \\
\text { Judicialização ou questões correlatas. }\end{array}$ & (NOVELINO, 2009) \\
\hline ARTIGOS & 16AR & Decisões judiciais e orçamento: um olhar sobre a saúde pública. & $\begin{array}{l}\text { Informações relevantes sobre a } \\
\text { Judicialização ou questões correlatas. }\end{array}$ & (MAZZA; MENDES, 2014) \\
\hline ARTIGOS & $17 \mathrm{AR}$ & $\begin{array}{l}\text { Análise técnica para a tomada de decisão do fornecimento de } \\
\text { medicamentos pela via judicial. }\end{array}$ & $\begin{array}{l}\text { Informações relevantes sobre a } \\
\text { Judicialização ou questões correlatas. }\end{array}$ & $\begin{array}{l}\text { (MACEDO; LOPES; } \\
\text { BARBERATO-FILHO; 2011) }\end{array}$ \\
\hline ARTIGOS & $18 \mathrm{AR}$ & $\begin{array}{l}\text { SOS SUS: Muita Justiça, Pouca Gestão? Estudo sobre a Judicialização da } \\
\text { Saúde. }\end{array}$ & $\begin{array}{l}\text { Informações relevantes sobre a } \\
\text { Judicialização ou questões correlatas. }\end{array}$ & (MEDRADO, 2016) \\
\hline ARTIGOS & 19AR & $\begin{array}{l}\text { Ações judiciais e direito à saúde: reflexão sobre a observância aos } \\
\text { princípios do SUS. }\end{array}$ & $\begin{array}{l}\text { Informações relevantes sobre a } \\
\text { Judicialização ou questões correlatas. }\end{array}$ & (VIEIRA, 2008) \\
\hline ARTIGOS & $20 \mathrm{AR}$ & $\begin{array}{l}\text { Racionalidade terapêutica: elementos médico-sanitários nas demandas } \\
\text { judiciais de medicamentos. }\end{array}$ & $\begin{array}{l}\text { Informações relevantes sobre a } \\
\text { Judicialização ou questões correlatas. }\end{array}$ & (SANT'ANA et al, 2011) \\
\hline ARTIGOS & $21 \mathrm{AR}$ & Cidadania no Brasil: o longo caminho. & $\begin{array}{l}\text { Informações relevantes sobre a } \\
\text { Judicialização ou questões correlatas. }\end{array}$ & (CARVALHO, 2002) \\
\hline ARTIGOS & $22 \mathrm{AR}$ & $\begin{array}{l}\text { Câmara Permanente Distrital de Mediação em Saúde: experiência do } \\
\text { Distrito Federal. }\end{array}$ & $\begin{array}{l}\text { Informações relevantes sobre a } \\
\text { Judicialização ou questões correlatas. }\end{array}$ & $\begin{array}{l}\text { (PAIM; MARQUETTO; } \\
\text { LOPES, 2016) }\end{array}$ \\
\hline ARTIGOS & $23 \mathrm{AR}$ & Discricionariedade judicial e teoria do direito. & $\begin{array}{l}\text { Informações relevantes sobre a } \\
\text { Judicialização ou questões correlatas. }\end{array}$ & (ALMEIDA 2013) \\
\hline ARTIGOS & $24 \mathrm{AR}$ & Discricionariedade Jurídica & $\begin{array}{l}\text { Informações relevantes sobre a } \\
\text { Judicialização ou questões correlatas. }\end{array}$ & $\begin{array}{l}\text { (ALMEIDA JUNIOR, 2005, } \\
\text { p.3) }\end{array}$ \\
\hline ARTIGOS & $25 \mathrm{AR}$ & Juízes Legisladores? & $\begin{array}{l}\text { Informações relevantes sobre a } \\
\text { Judicialização ou questões correlatas. }\end{array}$ & (CAPPELLETTI, 1993) \\
\hline ARTIGOS & 26AR & $\begin{array}{l}\text { Políticas públicas e o direito ao fornecimento gratuito de medicamentos: } \\
\text { desafios ao poder judiciário. }\end{array}$ & $\begin{array}{l}\text { Informações relevantes sobre a } \\
\text { Judicialização ou questões correlatas. }\end{array}$ & $\begin{array}{l}\text { (LIMBERGER; SOARES, } \\
\text { 2010) }\end{array}$ \\
\hline ARTIGOS & $27 \mathrm{AR}$ & $\begin{array}{l}\text { Núcleos de assessoria técnica e judicialização da saúde: constitucionais ou } \\
\text { inconstitucionais? }\end{array}$ & $\begin{array}{l}\text { Informações relevantes sobre a } \\
\text { Judicialização ou questões correlatas. }\end{array}$ & (FERREIRA; COSTA, 2013) \\
\hline ARTIGOS & 28AR & $\begin{array}{l}\text { Aspectos farmacoeconômicos das ações judiciais impetradas à Secretaria } \\
\text { de Estado de Saúde do Distrito Federal. }\end{array}$ & $\begin{array}{l}\text { Informações relevantes sobre a } \\
\text { Judicialização ou questões correlatas. }\end{array}$ & (KARNIKOWSKI et al, 2016) \\
\hline ARTIGOS & 29AR & $\begin{array}{l}\text { Avaliação das demandas judiciais por acesso a medicamentos do Distrito } \\
\text { Federal. }\end{array}$ & $\begin{array}{l}\text { Informações relevantes sobre a } \\
\text { Judicialização ou questões correlatas. }\end{array}$ & (CONTI et al, 2015) \\
\hline
\end{tabular}




\begin{tabular}{|c|c|c|c|c|}
\hline ARTIGOS & $30 \mathrm{AR}$ & $\begin{array}{l}\text { Consequências da judicialização das políticas de saúde: custos de } \\
\text { medicamentos para as mucopolissacaridoses. }\end{array}$ & $\begin{array}{l}\text { Informações relevantes sobre a } \\
\text { Judicialização ou questões correlatas. }\end{array}$ & $\begin{array}{l}\text { (DINIZ; MEDEIROS; } \\
\text { SCHWARTZ, 2012) }\end{array}$ \\
\hline ARTIGOS & $31 \mathrm{AR}$ & O esgotamento do modelo de financiamento do SUS. & $\begin{array}{l}\text { Informações relevantes sobre a } \\
\text { Judicialização ou questões correlatas. }\end{array}$ & $\begin{array}{l}\text { (CONSELHO NACIONAL } \\
\text { DE SECRETÁRIOS DE } \\
\text { SAÚDE, 2016b) }\end{array}$ \\
\hline ARTIGOS & $32 \mathrm{AR}$ & Por que o brasileiro recorre à justiça para adquirir medicamentos? & $\begin{array}{l}\text { Informações relevantes sobre a } \\
\text { Judicialização ou questões correlatas. }\end{array}$ & (INTERFARMA, 2016) \\
\hline ARTIGOS & $33 \mathrm{AR}$ & $\begin{array}{l}\text { A judicialização da saúde e os novos desafios da gestão da assistência } \\
\text { farmacêutica.. }\end{array}$ & $\begin{array}{l}\text { Informações relevantes sobre a } \\
\text { Judicialização ou questões correlatas. }\end{array}$ & PEPE et al, 2010) \\
\hline ARTIGOS & $34 \mathrm{AR}$ & $\begin{array}{l}\text { A via judicial para o acesso aos medicamentos e o equilíbrio entre as } \\
\text { necessidades e desejos dos usuários, do sistema de saúde e da indústria. }\end{array}$ & $\begin{array}{l}\text { Informações relevantes sobre a } \\
\text { Judicialização ou questões correlatas. }\end{array}$ & $\begin{array}{l}\text { (SANTOS; BLIACHERIENE } \\
\text { UETA, 2011) }\end{array}$ \\
\hline ARTIGOS & $35 \mathrm{AR}$ & $\begin{array}{l}\text { Judicialização do acesso a medicamentos no Estado de Minas Gerais, } \\
\text { Brasil. }\end{array}$ & $\begin{array}{l}\text { Informações relevantes sobre a } \\
\text { Judicialização ou questões correlatas. }\end{array}$ & (MACHADO et al, 2011) \\
\hline ARTIGOS & $36 \mathrm{AR}$ & $\begin{array}{l}\text { Aprovação do tratamento de câncer pela corte brasileira, ademais a falta de teses } \\
\text { clínicos. }\end{array}$ & $\begin{array}{l}\text { Informações relevantes sobre a } \\
\text { Judicialização ou questões correlatas. }\end{array}$ & (LEDFORD, 2015) \\
\hline
\end{tabular}


APÊNDICE L - Relação de normas que amparam a Assistência Farmacêutica brasileira e o CEAF/PNAF - publicações entre os anos 1970 e 1999

\begin{tabular}{|c|c|c|}
\hline $\begin{array}{l}\text { NORMAS QUE AMPARAM A } \\
\text { AF E O CEAF/PNAF }\end{array}$ & VERSA SOBRE & REFERÊNCIA \\
\hline $\begin{array}{l}\text { Lei } n^{\circ} 5.991 \text {, de } 17 \text { de dezembro } \\
\text { de } 1973\end{array}$ & $\begin{array}{l}\text { Controle Sanitário do Comércio de Drogas, } \\
\text { Medicamentos, Insumos Farmacêuticos e } \\
\text { Correlatos, e dá outras Providências. }\end{array}$ & (BRASIL, 1973) \\
\hline $\begin{array}{l}\text { Portaria Interministerial } \\
\text { MPAS/MS/MEC n } 3 \text {, de } 15 \\
\text { dezembro de } 1982\end{array}$ & $\begin{array}{l}\text { Que os serviços prestadores de assistência } \\
\text { médica e farmacêutica poderão adquirir e } \\
\text { utilizar medicamentos não constantes na } \\
\text { RENAME, em caráter excepcional. }\end{array}$ & (BRASIL, 1982) \\
\hline Constituição Federal de 1988 & $\begin{array}{l}\text { Constituição da república federativa do Brasil } \\
\text { de } 1988 .\end{array}$ & (BRASIL, 1988) \\
\hline $\begin{array}{l}\text { Lei } \mathrm{n}^{\circ} 8.080 \text {, de } 19 \text { de setembro } \\
\text { de } 1990\end{array}$ & $\begin{array}{l}\text { Condições para a promoção, proteção e } \\
\text { recuperação da saúde, a organização e o } \\
\text { funcionamento dos serviços correspondentes e } \\
\text { dá outras providências. }\end{array}$ & (BRASIL, 1990a) \\
\hline $\begin{array}{l}\text { Lei Orgânica do Distrito Federal, } \\
\text { de } 08 \text { de junho de } 1993\end{array}$ & Lei Orgânica do Distrito Federal de 1993 & (BRASIL, 1993b) \\
\hline $\begin{array}{l}\text { Portaria SAS/MS n } 142 \text {, de } 06 \text { de } \\
\text { outubro de } 1993\end{array}$ & $\begin{array}{l}\text { A Tabela de Valores dos Procedimentos do } \\
\text { SIA/SUS e inclui os medicamentos } \\
\text { considerados excepcionais Ciclosporina } 25,50 \text { e } \\
\text { 100mg cápsula, Ciclosporina 100mg solução } \\
\text { oral - frasco e Eritropoetina Humana } 2.000 \text { e } \\
4.000 \text { UI injetável - ampola }\end{array}$ & (BRASIL, 1993c) \\
\hline $\begin{array}{l}\text { Portaria SAS/MS n }{ }^{\circ} 204 \text {, de } 06 \text { de } \\
\text { novembro de } 1996\end{array}$ & $\begin{array}{l}\text { Tabela Descritiva de Procedimentos do Sistema } \\
\text { de Informações do SIA/SUS e inclui novos } \\
\text { códigos de medicamentos excepcionais. }\end{array}$ & (BRASIL, 1996) \\
\hline $\begin{array}{l}\text { Portaria SAS/MS n }{ }^{\circ} 17 \text {, de } 22 \text { de } \\
\text { janeiro de } 1997\end{array}$ & $\begin{array}{l}\text { Inclui na Tabela Descritiva de Procedimentos } \\
\text { do Sistema de Informações do SIA/SUS os } \\
\text { novos códigos para os medicamentos Interferon } \\
\text { beta 1a (3.000.000UI, injetável) e Interferon } \\
\text { beta 1b (9.600.000UI, injetável) como } \\
\text { imunomoduladores indicados para tratamento } \\
\text { da esclerose múltipla }\end{array}$ & (BRASIL, 1997) \\
\hline $\begin{array}{l}\text { Portaria } \mathrm{n}^{\circ} 3.916 / \mathrm{GM} / \mathrm{MS} \text {, de } 30 \\
\text { de outubro de } 1998\end{array}$ & Política Nacional de Medicamentos. & (BRASIL, 1998) \\
\hline $\begin{array}{l}\text { Portaria SAS/MS n } 409 \text {, de } 05 \text { de } \\
\text { agosto de } 1999\end{array}$ & $\begin{array}{l}\text { A sistemática de APAC, para fornecimento dos } \\
\text { medicamentos excepcionais, e regulamenta a } \\
\text { Solicitação de Medicamentos (SME), para o } \\
\text { fornecimento de medicamentos e formulários de } \\
\text { APAC para autorização e coleta de informações } \\
\text { gerenciais dos medicamentos excepcionais }\end{array}$ & (BRASIL, 1999) \\
\hline
\end{tabular}

Onde: GM - Gabinete do Ministro; MEC - Ministério da Educação; MPAS - Ministério da Previdência

Social; SAS - Secretaria de Atenção à Saúde; SIA- Sistema de Informações Ambulatoriais do Sistema Único de Saúde. 
APÊNDICE M - Relação de normas que amparam a Assistência Farmacêutica brasileira e o CEAF/PNAF - publicações entre os anos 2000 e 2005

\begin{tabular}{|c|c|c|}
\hline $\begin{array}{l}\text { NORMAS QUE AMPARAM A } \\
\text { AF E O CEAF/PNAF }\end{array}$ & VERSA SOBRE & REFERÊNCIA \\
\hline $\begin{array}{l}\text { Portaria GM/MS no } 1.318, \text { de } 23 \\
\text { de julho de } 2002\end{array}$ & $\begin{array}{l}\text { Regulamentação do Programa de Medicamentos } \\
\text { Excepcionais e determina critérios para a } \\
\text { dispensação dos medicamentos }\end{array}$ & (BRASIL, 2002a) \\
\hline $\begin{array}{l}\text { Portaria SAS/MS n } 921 \text {, de } 22 \\
\text { de novembro de } 2002\end{array}$ & $\begin{array}{l}\text { Inclusão, na Tabela Descritiva do SIA/SUS - } \\
\text { grupo } 36 \text { - medicamentos, no subgrupo 35- } \\
\text { antiparkinsonianos, o procedimento em anexo } \\
\text { da Portaria. }\end{array}$ & (BRASIL, 2002b) \\
\hline $\begin{array}{l}\text { Lei } n^{\circ} 10.742 \text {, de } 6 \text { de outubro de } \\
2003\end{array}$ & $\begin{array}{l}\text { Normas de regulação para o setor farmacêutico, } \\
\text { cria a Câmara de Regulação do Mercado de } \\
\text { Medicamentos - CMED e altera a Lei no } 6.360 \text {, } \\
\text { de } 23 \text { de setembro de } 1976 \text {, e dá outras } \\
\text { providências. }\end{array}$ & (BRASIL, 2003) \\
\hline $\begin{array}{l}\text { Resolução CNS/MS n }{ }^{\circ} 338 \text {, de } 6 \\
\text { de maio de } 2004\end{array}$ & Política Nacional de Assistência Farmacêutica. & (BRASIL, 2004) \\
\hline $\begin{array}{l}\text { Portaria SAS/MS n } 203 \text {, de } 19 \text { de } \\
\text { abril de } 2005\end{array}$ & $\begin{array}{l}\text { Inclusão, na Tabela de Procedimentos Especiais } \\
\text { do Sistema de Informações Hospitalares do } \\
\text { Sistema Único de Saúde - SIH/SUS, os } \\
\text { medicamentos especificados em anexo. }\end{array}$ & (BRASIL, 2005) \\
\hline
\end{tabular}


APÊNDICE N - Relação de normas que amparam a Assistência Farmacêutica brasileira e o CEAF/PNAF - publicações entre os anos 2006 e 2010

\begin{tabular}{|c|c|c|}
\hline $\begin{array}{l}\text { NORMAS QUE AMPARAM A } \\
\text { AF E O CEAF/PNAF }\end{array}$ & VERSA SOBRE & REFERÊNCIA \\
\hline $\begin{array}{l}\text { Portaria SAS/MS n }{ }^{\circ} 768 \text {, de } 26 \text { de } \\
\text { outubro de } 2006\end{array}$ & $\begin{array}{l}\text { Definição do novo laudo para } \\
\text { solicitação/autorização de medicamentos de } \\
\text { dispensação excepcional e estratégicos - LME }\end{array}$ & (BRASIL, 2006e) \\
\hline 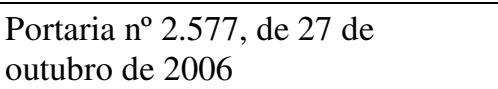 & $\begin{array}{l}\text { Componente de Medicamentos de Dispensação } \\
\text { Excepcional. }\end{array}$ & (BRASIL, 2006d) \\
\hline $\begin{array}{l}\text { Portaria GM/MS n }{ }^{\circ} 204 \text {, de } 29 \text { de } \\
\text { janeiro de } 2007\end{array}$ & $\begin{array}{l}\text { Financiamento e a transferência dos recursos } \\
\text { federais para as ações e serviços de saúde. }\end{array}$ & (BRASIL, 2007a) \\
\hline $\begin{array}{l}\text { Primeira retificação da Portaria } \\
\text { GM/MS nº } 2.577 \text { - } 26 \text { de fevereiro } \\
\text { de } 2007\end{array}$ & $\begin{array}{l}\text { Alteração da quantidade máxima e códigos para } \\
\text { o processamento das APAC no sistema } \\
\text { SIA/SUS dos seguintes medicamentos: } \\
\text { levodopa+carbidopa, levodopa+benserazida, } \\
\text { risperidona, complemento alimentar para } \\
\text { fenilcetonúricos, ciclosporina, rivastigmina, } \\
\text { deferiprona, gosserrelina, leuprorrelina e } \\
\text { triptorrelina }\end{array}$ & (BRASIL, 2007b) \\
\hline $\begin{array}{l}\text { Segunda retificação da Portaria } \\
\text { GM/MS no } 2.577 \text { - } 26 \text { de abril de } \\
2007\end{array}$ & $\begin{array}{l}\text { Alteração da quantidade máxima dos } \\
\text { medicamentos Sirolimo e Pancrelipase e a forma } \\
\text { de apresentação da Gosserrelina }\end{array}$ & (BRASIL, 2007c) \\
\hline $\begin{array}{l}\text { Portaria GM/MS n }{ }^{\circ} 1.869 \text {, de } 4 \text { de } \\
\text { setembro de } 2008\end{array}$ & $\begin{array}{l}\text { Atualização do anexo II da Portaria } 2577 \text {, inclui } \\
\text { novos procedimentos e atualiza os valores de } \\
\text { co-financiamento. Esta Portaria foi revogada } \\
\text { pela Portaria GM/MS n }{ }^{\circ} 106 \text {, de } 22 \text { de janeiro } \\
\text { de } 2009\end{array}$ & (BRASIL, 2008) \\
\hline $\begin{array}{l}\text { Portaria GM/MS n }{ }^{\circ} 106 \text {, de } 22 \text { de } \\
\text { janeiro de } 2009\end{array}$ & $\begin{array}{l}\text { Alteração do Anexo II da Portaria n 2.577/GM } \\
\text { de } 27 \text { de outubro de 2006, que aprova o CMDE }\end{array}$ & (BRASIL, 2009f) \\
\hline $\begin{array}{l}\text { Portaria }^{\text {o }} 2981 \text {, de } 26 \text { de } \\
\text { novembro de } 2009\end{array}$ & $\begin{array}{l}\text { Componente Especializado da Assistência } \\
\text { Farmacêutica. }\end{array}$ & (BRASIL, 2009b) \\
\hline $\begin{array}{l}\text { Portaria GM/MS n } \\
\text { fevereiro de } 2010\end{array}$ & $\begin{array}{l}\text { Alteração dos arts. } 3^{\circ}, 15,16,23,24 \text { e } 63 \text { e o } \\
\text { Anexo IV à Portaria no } 2981 / \mathrm{GM} / \mathrm{MS} \text {, de } 26 \text { de } \\
\text { novembro de } 2009\end{array}$ & (BRASIL, 2010d) \\
\hline $\begin{array}{l}\text { Retificação da Portaria GM/MS n } \\
343 \text { - } 3 \text { de março de } 2010\end{array}$ & $\begin{array}{l}\text { Alteração do artigo Art. } 23 \text { e } 24 \text { e demoninação } \\
\text { de } 10 \text { procedimentos }\end{array}$ & (BRASIL, 2010e) \\
\hline $\begin{array}{l}\text { Portaria GM/MS n }{ }^{\circ} 743 \text {, de } 8 \text { de } \\
\text { abril de } 2010\end{array}$ & $\begin{array}{l}\text { Estabelecimento do processo de aquisição } \\
\text { centralizada pelo MS para Lamivudina } 150 \mathrm{mg} \text { e } \\
\text { Lamivudina } 10 \mathrm{mg} / \mathrm{ml} \text { solução oral }\end{array}$ & (BRASIL, 2010f) \\
\hline $\begin{array}{l}\text { Portaria GM/MS n } 3.128 \text {, de } 14 \\
\text { de outubro de } 2010\end{array}$ & $\begin{array}{l}\text { Estabelecimento do processo de aquisição } \\
\text { centralizada pelo MS para Clozapina } 25 \mathrm{mg} \text { e } \\
\text { 100mg }\end{array}$ & (BRASIL, 2010g) \\
\hline $\begin{array}{l}\text { Portaria GM/MS n } 3.439 \text {, de } 11 \\
\text { de novembro de } 2010\end{array}$ & $\begin{array}{l}\text { Alteração dos arts. } 3^{\circ}, 15,16 \text { e } 63 \text { e os Anexos I, } \\
\text { II, III, IV e V à Portaria no } 2.981 / \mathrm{GM} / \mathrm{MS} \text {, de } 26 \\
\text { de novembro de } 2009 \text {, republicada em } 1^{\circ} \text { de } \\
\text { dezembro de } 2009\end{array}$ & (BRASIL, 2010h) \\
\hline $\begin{array}{l}\text { Portaria SCTIE/MS n }{ }^{\circ} 19 \text {, de } 30 \\
\text { de dezembro de } 2010\end{array}$ & $\begin{array}{l}\text { Inclusão de novo procedimento para o } \\
\text { Adalimumabe 40mg na Tabela de } \\
\text { Procedimentos, Medicamentos, Órteses/Próteses } \\
\text { e Materiais Especiais do SUS. }\end{array}$ & (BRASIL, 2010i) \\
\hline
\end{tabular}

Onde: SCTIE - Secretaria de Ciência, Tecnologia e Insumos Estratégicos. 
APÊNDICE O - Relação de normas que amparam a Assistência Farmacêutica brasileira e o CEAF/PNAF - publicações no ano de 2011

\begin{tabular}{|c|c|c|}
\hline $\begin{array}{l}\text { NORMAS QUE AMPARAM A } \\
\text { AF E O CEAF/PNAF }\end{array}$ & VERSA SOBRE & REFERÊNCIA \\
\hline $\begin{array}{l}\text { Portaria SCTIE/MS n }{ }^{\circ} 2 \text {, de } 16 \text { de } \\
\text { março de } 2011\end{array}$ & $\begin{array}{l}\text { Inclui a Imiglucerase } 400 \text { U na Tabela de } \\
\text { Procedimentos, Medicamentos, Órteses/Próteses } \\
\text { e Materiais Especiais do SUS }\end{array}$ & (BRASIL, 2011i) \\
\hline $\begin{array}{l}\text { Lei }{ }^{\circ} 12.401 \text {, de } 28 \text { de abril de } \\
2011\end{array}$ & $\begin{array}{l}\text { Alteração da Lei no } 8.080 \text {, de } 19 \text { de setembro de } \\
\text { 1990, para dispor sobre a assistência terapêutica } \\
\text { e a incorporação de tecnologia em saúde no } \\
\text { âmbito do Sistema Único de Saúde - SUS. }\end{array}$ & (BRASIL, 2011a) \\
\hline $\begin{array}{l}\text { Portaria SCTIE/MS n }{ }^{\circ} 7 \text {, de } 13 \text { de } \\
\text { junho de } 2011\end{array}$ & $\begin{array}{l}\text { Inclui o Entecavir } 1,0 \mathrm{mg} \text { na Tabela de } \\
\text { Procedimentos, Medicamentos, Órteses/Próteses } \\
\text { e Materiais Especiais do SUS }\end{array}$ & (BRASIL, 2011j) \\
\hline $\begin{array}{l}\text { Decreto } n^{\circ} 7.508 \text {, de } 28 \text { de junho } \\
\text { de } 2011\end{array}$ & $\begin{array}{l}\text { Organização do Sistema Único de Saúde - SUS, } \\
\text { o planejamento da saúde, a assistência à saúde e } \\
\text { a articulação interfederativa, e dá outras } \\
\text { providências. }\end{array}$ & (BRASIL, 2011b) \\
\hline $\begin{array}{l}\text { Lei } 12.466 \text {, de } 24 \text { de agosto de } \\
2011\end{array}$ & $\begin{array}{l}\text { Comissões intergestores do SUS, o Conselho } \\
\text { Nacional de Secretários de Saúde (Conass), o } \\
\text { Conselho Nacional de Secretarias Municipais de } \\
\text { Saúde (Conasems) e suas respectivas } \\
\text { composições, e dá outras providências. }\end{array}$ & (BRASIL, 2011e) \\
\hline $\begin{array}{l}\text { Portaria GM/MS no } 2.079 \text {, de } 1 \text { de } \\
\text { setembro de } 2011\end{array}$ & $\begin{array}{l}\text { Estabelece processo de aquisição centralizada } \\
\text { pelo Ministério da Saúde do medicamento } \\
\text { quetiapina } 25 \mathrm{mg}, 100 \mathrm{mg} \text { e } 200 \mathrm{mg} \text {, comprimido, } \\
\text { do CEAF }\end{array}$ & (BRASIL, 20111) \\
\hline $\begin{array}{l}\text { Portaria GM/MS n }{ }^{\circ} 2.928 \text {, de } 12 \\
\text { de dezembro de } 2011\end{array}$ & $\begin{array}{l}\text { Dispõe sobre os } \S \S 1^{\circ} \text { e } 2^{\circ} \text { do art. } 28 \text { do Decreto } \\
\mathrm{n}^{\circ} 7.508 \text {, de } 28 \text { de junho de } 2011\end{array}$ & (BRASIL, 2011m) \\
\hline $\begin{array}{l}\text { Decreto } n^{\circ} 7.646, \text { de } 21 \text { de } \\
\text { dezembro de } 2011\end{array}$ & $\begin{array}{l}\text { Comissão Nacional de Incorporação de } \\
\text { Tecnologias no Sistema Único de Saúde e sobre } \\
\text { o processo administrativo para incorporação, } \\
\text { exclusão e alteração de tecnologias em saúde } \\
\text { pelo Sistema Único de Saúde - SUS, e dá outras } \\
\text { providências. }\end{array}$ & (BRASIL, 2011c) \\
\hline
\end{tabular}

Onde: SE - Secretaria Executiva. 
APÊNDICE P - Relação de normas que amparam a Assistência Farmacêutica brasileira e o CEAF/PNAF - publicações no ano de 2012

\begin{tabular}{|c|c|c|}
\hline $\begin{array}{l}\text { NORMAS QUE AMPARAM A } \\
\text { AF E O CEAF/PNAF }\end{array}$ & VERSA SOBRE & REFERÊNCIA \\
\hline $\begin{array}{l}\text { Lei Complementar } n^{\circ} 141 \text {, de } 13 \\
\text { de janeiro de } 2012\end{array}$ & $\begin{array}{l}\text { Valores mínimos a serem aplicados anualmente } \\
\text { pela União, Estados, Distrito Federal e } \\
\text { Municípios em ações e serviços públicos de } \\
\text { saúde. }\end{array}$ & (BRASIL, 2012c) \\
\hline $\begin{array}{l}\text { Resolução no } 1 / \text { CIT, de } 17 \text { de } \\
\text { janeiro de } 2012\end{array}$ & $\begin{array}{l}\text { Diretrizes nacionais da Relação Nacional de } \\
\text { Medicamentos Essenciais (RENAME) no } \\
\text { âmbito do Sistema Único de Saúde (SUS). }\end{array}$ & (BRASIL, 2012a) \\
\hline $\begin{array}{l}\text { Portaria n }{ }^{\circ} 533 / \mathrm{GM} / \mathrm{MS} \text {, de } 28 \text { de } \\
\text { março de } 2012\end{array}$ & $\begin{array}{l}\text { Elenco de medicamentos e insumos da Relação } \\
\text { Nacional de Medicamentos Essenciais } \\
\text { (RENAME) no âmbito do Sistema Único de } \\
\text { Saúde (SUS). }\end{array}$ & (BRASIL, 2012b) \\
\hline $\begin{array}{l}\text { Portaria GM/MS n }{ }^{\circ} 1.091 \text {, de } 28 \\
\text { de maio de } 2012\end{array}$ & $\begin{array}{l}\text { Estabelece processo de aquisição centralizada } \\
\text { pelo Ministério da Saúde do medicamento } \\
\text { olanzapina } 5 \mathrm{mg} \text { e } 10 \mathrm{mg} \text { comprimido, do } \\
\text { Componente Especializado da Assistência } \\
\text { Farmacêutica }\end{array}$ & (BRASIL, 2012f) \\
\hline $\begin{array}{l}\text { Portaria GM/MS n }{ }^{\circ} 1.103 \text {, de } 28 \\
\text { de maio de } 2012\end{array}$ & $\begin{array}{l}\text { Estabelece processo de aquisição centralizada } \\
\text { pelo Ministério da Saúde do medicamento } \\
\text { rivastigmina } 1,5 \mathrm{mg}, 3 \mathrm{mg}, 4,5 \mathrm{mg} \text { e } 6 \mathrm{mg} \text { cápsula, } \\
\text { do Componente Especializado da Assistência } \\
\text { Farmacêutica }\end{array}$ & (BRASIL, 2012g) \\
\hline
\end{tabular}

Onde: CIT - Comissão Intergestores Tripartite; SEGEP - Secretaria de Gestão Estratégica e Participativa. 
APÊNDICE Q - Relação de normas que amparam a Assistência Farmacêutica brasileira e o CEAF/PNAF - publicações no ano de 2013

\begin{tabular}{|c|c|c|}
\hline $\begin{array}{l}\text { NORMAS QUE AMPARAM A } \\
\text { AF E O CEAF/PNAF }\end{array}$ & VERSA SOBRE & REFERÊNCIA \\
\hline $\begin{array}{l}\text { Portaria SAS/MS n } 257 \text {, de } 12 \text { de } \\
\text { março de } 2013\end{array}$ & $\begin{array}{l}\text { Inclui novos campos no layout da Autorização } \\
\text { de Procedimentos Ambulatoriais (APAC) }\end{array}$ & (BRASIL, 2013d) \\
\hline $\begin{array}{l}\text { Portaria SAS/MS n } 284 \text {, de } 20 \text { de } \\
\text { março de } 2013\end{array}$ & $\begin{array}{l}\text { Inclui os procedimentos Abatacepte } 250 \mathrm{mg} \text {, } \\
\text { Certolizumabe pegol } 200 \mathrm{mg} / \mathrm{ml} \text {, Golimumabe } \\
\text { 50mg, Rituximabe } 500 \mathrm{mg} \text {, Tocilizumabe } 20 \\
\mathrm{mg} / \mathrm{ml} \text { na Tabela de Procedimentos, } \\
\text { Medicamentos, Órteses/Próteses e Materiais } \\
\text { Especiais do SUS, além de dispor que o serviço } \\
125 / 001 \text { poderá ser informado por qualquer tipo } \\
\text { de estabelecimento de saúde da esfera } \\
\text { administrativa pública cadastrado no SCNES. }\end{array}$ & (BRASIL, 2013e) \\
\hline $\begin{array}{l}\text { Portaria SAS/MS n }{ }^{\circ} 745 \text {, de } 5 \text { de } \\
\text { julho de } 2013\end{array}$ & $\begin{array}{l}\text { Inclui os procedimentos Naproxeno } 250 \text { e } \\
\text { 500mg na Tabela de Procedimentos, } \\
\text { Medicamentos, Órteses/ Próteses e Materiais } \\
\text { Especiais do SUS. }\end{array}$ & (BRASIL, 2013f) \\
\hline $\begin{array}{l}\text { Portaria GM/MS n } 1.554 \text {, de } 30 \\
\text { de julho de } 2013\end{array}$ & $\begin{array}{l}\text { Regras de financiamento e execução do } \\
\text { Componente Especializado da Assistência } \\
\text { Farmacêutica no âmbito do Sistema Único de } \\
\text { Saúde (SUS). }\end{array}$ & (BRASIL, 2013a) \\
\hline $\begin{array}{l}\text { Portaria }^{\circ} 1.996, \text { de } 11 \mathrm{de} \\
\text { setembro de } 2013\end{array}$ & $\begin{array}{l}\text { Alteração da Portaria n }{ }^{\circ} \text { 1.554/GM/MS, de } 30 \\
\text { de julho de } 2013 .\end{array}$ & (BRASIL, 2013b) \\
\hline $\begin{array}{l}\text { Portaria } n^{\circ} 2.135 / \mathrm{GM} / \mathrm{MS} \text { de } 25 \\
\text { de setembro de } 2013\end{array}$ & $\begin{array}{l}\text { Diretrizes para o processo de planejamento no } \\
\text { âmbito do Sistema Único de Saúde (SUS). }\end{array}$ & (BRASIL, 2013c) \\
\hline $\begin{array}{l}\text { Portaria GM/MS no } 2.978 \text {, de } 4 \text { de } \\
\text { dezembro de } 2013\end{array}$ & $\begin{array}{l}\text { Estabelece processo de aquisição } \\
\text { centralizada pelo Ministério da Saúde do } \\
\text { medicamento leflunomida 20mg comprimido, } \\
\text { do Componente Especializado da } \\
\text { Assistência Farmacêutica. }\end{array}$ & (BRASIL, 2013g) \\
\hline $\begin{array}{l}\text { Portaria GM/MS no } 2.979 \text {, de } 4 \text { de } \\
\text { dezembro de } 2013\end{array}$ & $\begin{array}{l}\text { Estabelece processo de aquisição } \\
\text { centralizada pelo Ministério da Saúde dos } \\
\text { medicamentos toxina botulínica tipo A 100u } \\
\text { injetável - por frasco-ampola, do } \\
\text { Componente Especializado da Assistência } \\
\text { Farmacêutica. }\end{array}$ & (BRASIL, 2013h) \\
\hline $\begin{array}{l}\text { Portaria GM/MS no } 2.981 \text {, de } 4 \text { de } \\
\text { dezembro de } 2013\end{array}$ & $\begin{array}{l}\text { Estabelece processo de aquisição } \\
\text { centralizada pelo Ministério da Saúde do } \\
\text { medicamento pramipexol } 0,125 \mathrm{mg}, 0,25 \mathrm{mg} \\
\text { e } 1 \mathrm{mg} \text { - comprimido, do Componente } \\
\text { Especializado da Assistência Farmacêutica. }\end{array}$ & (BRASIL, 2013i) \\
\hline $\begin{array}{l}\text { Portaria SAS/MS n }{ }^{\circ} 1.447 \text {, de } 26 \\
\text { de dezembro de } 2013\end{array}$ & $\begin{array}{l}\text { Altera a Portaria SAS/MS n } 257 / 2013 \text { quanto as } \\
\text { definições do profissional executante no âmbito } \\
\text { do Componente Especializado da Assistência } \\
\text { Farmacêutica. }\end{array}$ & (BRASIL, 2013j) \\
\hline $\begin{array}{l}\text { Portaria GM/MS n } 3.293 \text {, de } 26 \\
\text { de dezembro de } 2013\end{array}$ & $\begin{array}{l}\text { Altera o prazo para disponibilização dos } \\
\text { medicamentos acetazolamida, bimatoprosta, } \\
\text { brimonidina, brinzolamida, dorzolamida, } \\
\text { latanoprosta, pilocarpina, timolol e travoprosta } \\
\text { do Componente Especializado da Assistência } \\
\text { Farmacêutica. }\end{array}$ & (BRASIL, 20131) \\
\hline
\end{tabular}


APÊNDICE R - Relação de normas que amparam a Assistência Farmacêutica brasileira e o CEAF/PNAF - publicações no ano de 2014

\begin{tabular}{|c|c|c|}
\hline $\begin{array}{l}\text { NORMAS QUE AMPARAM A } \\
\text { AF E O CEAF/PNAF }\end{array}$ & VERSA SOBRE & REFERÊNCIA \\
\hline $\begin{array}{l}\text { Portaria SCTIE/MS nº } 6 \text {, de } 25 \text { de } \\
\text { fevereiro de } 2014\end{array}$ & $\begin{array}{l}\text { Inclui os medicamentos ambrisentana } 5 \text { e } 10 \mathrm{mg} \\
\text { e bosentana } 62,5 \text { e } 125 \mathrm{mg} \text { na Tabela de } \\
\text { Procedimentos, Medicamentos, } \\
\text { Órteses/Próteses e Materiais Especiais do SUS. }\end{array}$ & (BRASIL, 2014b) \\
\hline $\begin{array}{l}\text { Portaria GM/MS no } 799 \text {, de } 5 \text { de } \\
\text { maio de } 2014\end{array}$ & $\begin{array}{l}\text { Altera o prazo para disponibilização dos } \\
\text { medicamentos acetazolamida, bimatoprosta, } \\
\text { brimonidina, brinzolamida, dorzolamida, } \\
\text { latanoprosta, pilocarpina, timolol e travoprosta } \\
\text { do Componente Especializado da Assistência } \\
\text { Farmacêutica. }\end{array}$ & (BRASIL, 2014c) \\
\hline $\begin{array}{l}\text { Portaria SAS/MS n } 683 \text {, de } 06 \text { de } \\
\text { agosto de } 2014\end{array}$ & $\begin{array}{l}\text { Altera procedimentos referentes aos } \\
\text { medicamentos tocilizumabe } 20 \mathrm{mg} / \mathrm{mL} \text {, calcitriol } \\
0,25 \mathrm{mcg} \text {, leflunomida } 20 \mathrm{mg} \text {, toxina botulínica } \\
100 \mathrm{U} \text { e pramipexol } 0,125 \mathrm{mg}, 0,25 \mathrm{mg} \text { e } 1 \mathrm{mg} \text { do } \\
\text { Componente Especializado da Assistência } \\
\text { Farmacêutica na Tabela de Procedimentos, } \\
\text { Medicamentos Órteses/Próteses e Materiais } \\
\text { Especiais do SUS. }\end{array}$ & (BRASIL, 2014d) \\
\hline $\begin{array}{l}\text { Portaria } \mathrm{n}^{\mathrm{o}} 2.127 \text {, de } 30 \text { de } \\
\text { setembro de } 2014\end{array}$ & $\begin{array}{l}\text { Estabelece processo de aquisição centralizada } \\
\text { pelo Ministério da Saúde do medicamento } \\
\text { cabergolina } 0,5 \mathrm{mg} \text { comprimido, do Componente } \\
\text { Especializado da Assistência Farmacêutica. }\end{array}$ & (BRASIL, 2014e) \\
\hline $\begin{array}{l}\text { Portaria } n^{\circ} 49, \text { de } 22 \text { de dezembro } \\
\text { de } 2014\end{array}$ & $\begin{array}{l}\text { Inclui o procedimento fingolimode } 0,5 \mathrm{mg} \text { na } \\
\text { Tabela de Procedimentos, Medicamentos, } \\
\text { Orteses/Próteses e Materiais Especiais do SUS. }\end{array}$ & (BRASIL, 2014f) \\
\hline $\begin{array}{l}\text { Portaria } \mathrm{n}^{\circ} 2.865 \text {, de } 29 \text { de } \\
\text { dezembro de } 2014\end{array}$ & $\begin{array}{l}\text { Prorroga o prazo para disponibilização dos } \\
\text { medicamentos acetazolamida, bimatoprosta, } \\
\text { brimonidina, brinzolamida, dorzolamida, } \\
\text { latanoprosta, pilocarpina, timolol e travoprosta } \\
\text { do Componente Especializado da Assistência } \\
\text { Farmacêutica. }\end{array}$ & (BRASIL, 2014g) \\
\hline
\end{tabular}


APÊEDICE S - Relação de normas que amparam a Assistência Farmacêutica brasileira e o CEAF/PNAF - publicações entre os anos 2015 e 2016

\begin{tabular}{|c|c|c|}
\hline $\begin{array}{l}\text { NORMAS QUE AMPARAM A } \\
\text { AF E O CEAF/PNAF }\end{array}$ & VERSA SOBRE & REFERÊNCIA \\
\hline $\begin{array}{l}\text { Portaria GM/MS n }{ }^{\circ} 410 \text {, de } 13 \\
\text { de abril de } 2015\end{array}$ & $\begin{array}{l}\text { Estabelece processo de aquisição } \\
\text { centralizada pelo Ministério da Saúde do } \\
\text { medicamento Ziprasidona } 40 \mathrm{mg} \text { e } 80 \mathrm{mg} \\
\text { (cápsula), do Componente Especializado da } \\
\text { Assistência Farmacêutica. }\end{array}$ & (BRASIL, 2015a) \\
\hline $\begin{array}{l}\text { Portaria SAS/MS n }{ }^{\circ} 361 \text {, de } 23 \\
\text { de abril de } 2015\end{array}$ & $\begin{array}{l}\text { Exclui procedimento do Componente } \\
\text { Especializado da Assistência Farmacêutica na } \\
\text { Tabela de Procedimentos, Medicamentos, } \\
\text { Órteses/Próteses e Materiais do SUS. }\end{array}$ & (BRASIL, 2015b) \\
\hline $\begin{array}{l}\text { Portaria SCTIE/MS n }{ }^{\circ} 29, \text { de } 22 \\
\text { de junho de } 2015\end{array}$ & $\begin{array}{l}\text { Torna pública a decisão de incorporar os } \\
\text { medicamentos sofosbuvir, daclatasvir e } \\
\text { simeprevir para o tratamento da hepatite viral C } \\
\text { crônica no âmbito do Sistema Único de Saúde - } \\
\text { SUS. }\end{array}$ & (BRASIL, 2015c) \\
\hline $\begin{array}{l}\text { Portaria SAS/MS n }{ }^{\circ} 583 \text {, de } 8 \\
\text { de julho de } 2015\end{array}$ & $\begin{array}{l}\text { Inclui Forma de Organização e Procedimentos } \\
\text { relacionados ao Componente Especializado da } \\
\text { Assistência Farmacêutica na Tabela de } \\
\text { Procedimentos, Medicamentos, Órteses/Próteses } \\
\text { e Materiais do SUS. }\end{array}$ & (BRASIL, 2015d) \\
\hline $\begin{array}{l}\text { Portaria GM/MS n }{ }^{\circ} 1.330 \text {, de } 08 \\
\text { de setembro de } 2015\end{array}$ & $\begin{array}{l}\text { Estabelece processo de aquisição } \\
\text { centralizada pelo Ministério da Saúde do } \\
\text { medicamento Riluzol 50mg (comprimido), do } \\
\text { Componente Especializado da Assistência } \\
\text { Farmacêutica. }\end{array}$ & (BRASIL, 2015e) \\
\hline $\begin{array}{l}\text { Portaria } \mathrm{n}^{\circ} 1.055 \text {, de } 24 \text { de maio } \\
2016\end{array}$ & $\begin{array}{l}\text { Repasse de recursos para Estados e Distrito } \\
\text { Federal, a título de financiamento, referente a } \\
\text { abril, maio e junho de 2016, para aquisição de } \\
\text { medicamentos do Componente Especializado da } \\
\text { Assistência Farmacêutica. }\end{array}$ & (BRASIL, 2016a) \\
\hline
\end{tabular}


APÊNDICE T - Estrutura organizacional responsável pela implementação do CEAF/PNAF no DF

\begin{tabular}{|c|c|c|}
\hline NÍVEIS DO GOVERNO & ESTRUTURAS ORGANIZACIONAIS & REFERÊNCIAS \\
\hline \multirow[b]{4}{*}{ Nível Federal } & CNS - Conselho Nacional de Saúde & (BRASIL, 1993c; 2013c) \\
\hline & CIT - Comissão Intergestores Tripartite & (BRASIL, 2010a; 2013c). \\
\hline & Conferência Nacional de Saúde & (BRASIL, 1993c; 2013c) \\
\hline & $\begin{array}{l}\text { MS - Ministério da Saúde } \\
\text { SCTIE - Secretaria de Ciência, } \\
\text { Tecnologia e Insumos Estratégicos } \\
\text { DAF - Departamento de Assistência } \\
\text { Farmacêutica } \\
\text { CGCEAF - Coordenação-geral do } \\
\text { Componente Especializado da } \\
\text { Assistência Farmacêutica. } \\
\text { DGITS - Departamento de Gestão e } \\
\text { Incorporação de Tecnologias em Saúde } \\
\text { CONITEC - Comissão Nacional de } \\
\text { Incorporação de Tecnologias }\end{array}$ & $\begin{array}{l}\text { (BRASIL, 2011c; 2012a; } \\
\text { 2012b; 2013a); } \\
\text { (MINISTÉRIO DA SAÚDE, } \\
\text { 2015; 2016a; 2016b) }\end{array}$ \\
\hline \multirow[b]{3}{*}{ Nível Distrital } & $\begin{array}{l}\text { CSDF - Conselho de Saúde do Distrito } \\
\text { Federal }\end{array}$ & $\begin{array}{l}\text { (SECRETARIA DE ESTADO } \\
\text { DE SAÚDE DO DISTRITO } \\
\text { FEDERAL, 2016c) }\end{array}$ \\
\hline & Conferência de Saúde do Distrito Federal & (BRASIL, 2016c) \\
\hline & $\begin{array}{l}\text { SES-DF - Secretaria de Estado de Saúde } \\
\text { do Distrito Federal } \\
\text { DIASF } \\
\text { GCEAF } \\
\text { Núcleo de Farmácia do Componente } \\
\text { Especializado na Asa Sul } \\
\text { Núcleo de Farmácia do Componente } \\
\text { Especializado na Ceilândia } \\
\text { CCFT - Comissão Central de Farmácia e } \\
\text { Terapêutica }\end{array}$ & $\begin{array}{l}\text { (AGÊNCIA BRASÍLIA, } \\
\text { 2012a); (BRASIL, 2013a); } \\
\text { (SECRETARIA DE ESTADO } \\
\text { DE SAÚDE DO DISTRITO } \\
\text { FEDERAL, 2016a; 2016b) }\end{array}$ \\
\hline
\end{tabular}


APÊNDICE U - Recursos humanos envolvidos com a implementação do CEAF/PNAF no DF

\begin{tabular}{|c|c|c|c|}
\hline $\begin{array}{l}\text { NÍVEIS DO } \\
\text { GOVERNO }\end{array}$ & $\begin{array}{l}\text { ESTRUTURAS } \\
\text { ORGANIZACIONAIS }\end{array}$ & RECURSOS HUMANOS & REFERÊNCIAS \\
\hline \multirow{4}{*}{ Nível Federal } & $\begin{array}{l}\text { CNS - Conselho Nacional de } \\
\text { Saúde }\end{array}$ & $\begin{array}{l}\text { Representantes de: } \\
\text { 1. entidades e movimentos } \\
\text { sociais de usuários do } \\
\text { Sistema Único de Saúde } \\
\text { (SUS); } \\
\text { 2. entidades de profissionais } \\
\text { de saúde, incluída a } \\
\text { comunidade científica; } \\
\text { 3. entidades de prestadores de } \\
\text { serviço; } \\
\text { 4. entidades empresariais da } \\
\text { área da saúde; e } \\
\text { 5. governo federal. }\end{array}$ & $\begin{array}{l}\text { (MINISTÉRIO DA } \\
\text { SAÚDE, 2016b) }\end{array}$ \\
\hline & $\begin{array}{l}\text { CIT - Comissão Intergestores } \\
\text { Tripartite }\end{array}$ & $\begin{array}{l}\text { Representantes de: } \\
\text { 1. Ministério da Saúde; } \\
\text { 2. Conselho Nacional de } \\
\text { Secretários de Saúde - } \\
\text { CONASS; e } \\
\text { 3. Conselho Nacional de } \\
\text { Secretários Municipais de } \\
\text { Saúde - CONASEMS. }\end{array}$ & (BRASIL, 2009d) \\
\hline & Conferência Nacional de Saúde & $\begin{array}{l}\text { Representantes do: } \\
\text { 1. governo; } \\
\text { 2. dos prestadores de serviços } \\
\text { de saúde; } \\
\text { 3. dos profissionais de saúde; } \\
\text { e } \\
\text { 4. dos usuários do SUS }\end{array}$ & (BRASIL, 2016b) \\
\hline & $\begin{array}{l}\text { MS - Ministério da Saúde } \\
\text { SCTIE - Secretaria de Ciência, } \\
\text { Tecnologia e Insumos Estratégicos } \\
\text { DAF - Departamento de } \\
\text { Assistência Farmacêutica } \\
\text { CGCEAF - Coordenação-geral do } \\
\text { Componente Especializado da } \\
\text { Assistência Farmacêutica. } \\
\text { DGITS - Departamento de Gestão } \\
\text { e Incorporação de Tecnologias em } \\
\text { Saúde } \\
\text { CONITEC - Comissão Nacional } \\
\text { de Incorporação de Tecnologias }\end{array}$ & $\begin{array}{l}\text { CGCEAF/DAF: } \\
\text { - composta por } 4 \text { equipes, } \\
\text { com } 25 \text { profissionais e um } \\
\text { coordenador. } \\
\text { CONITEC: Representantes } \\
\text { I - do Ministério da Saúde (7 } \\
\text { secretarias): } \\
\text { II - da Agência Nacional de } \\
\text { Saúde Suplementar -ANS; } \\
\text { III - da Agência Nacional de } \\
\text { Vigilância Sanitária - } \\
\text { ANVISA; } \\
\text { IV - do Conselho Nacional de } \\
\text { Saúde - CNS; } \\
\text { V - do Conselho Nacional de } \\
\text { Secretários de Saúde - } \\
\text { CONASS; } \\
\text { VI - do Conselho Nacional de } \\
\text { Secretarias Municipais de } \\
\text { Saúde - CONASEMS; e } \\
\text { VII - do Conselho Federal de } \\
\text { Medicina - CFM, especialista } \\
\text { na área. }\end{array}$ & $\begin{array}{l}\text { Entrevistado 1EN; } \\
\text { (CONITEC, 2016) }\end{array}$ \\
\hline Nível Distrital & CSDF - Conselho de Saúde do & Representantes de: & (BRASIL, 2016b); \\
\hline
\end{tabular}




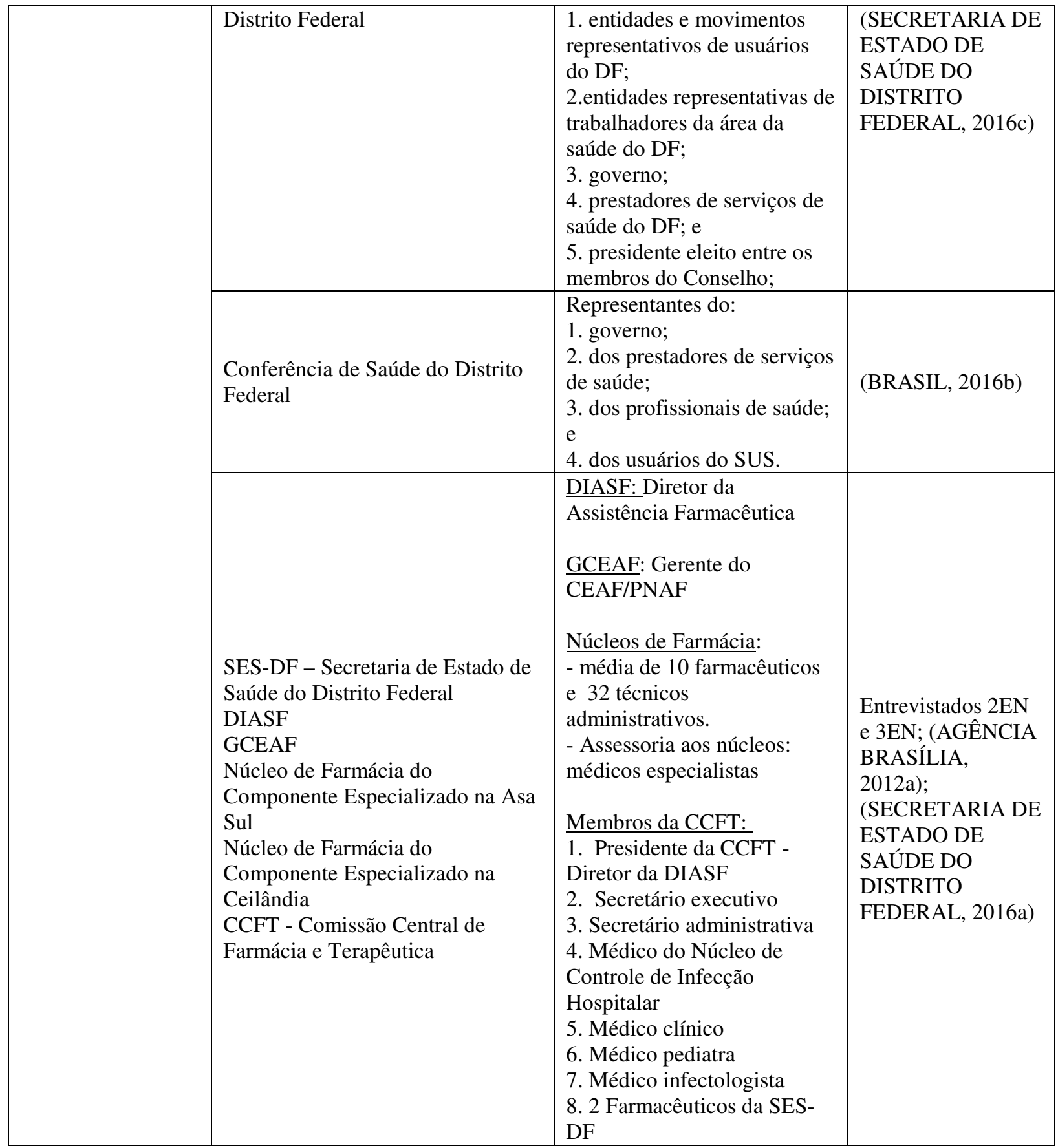


APÊNDICE V - Órgãos e respectivas competências financeiras relacionadas à implementação do CEAF/PNAF no DF

\begin{tabular}{|c|c|c|c|}
\hline $\begin{array}{l}\text { NÍVEIS DO } \\
\text { GOVERNO }\end{array}$ & $\begin{array}{l}\text { ESTRUTURAS } \\
\text { ORGANIZACIONAIS }\end{array}$ & $\begin{array}{l}\text { COMPETÊNCIAS } \\
\text { FINANCEIRAS }\end{array}$ & REFERÊNCIAS \\
\hline Nível Federal & $\begin{array}{l}\text { MS - Ministério da Saúde } \\
\text { SCTIE - Secretaria de Ciência, } \\
\text { Tecnologia e Insumos Estratégicos } \\
\text { DAF - Departamento de } \\
\text { Assistência Farmacêutica }\end{array}$ & $\begin{array}{l}\text { Financiamento dos grupos } \\
1 \text { A e 1B; aquisição } \\
\text { centralizada dos } \\
\text { medicamentos do grupo 1A; } \\
\text { transferência de recursos para } \\
\text { o grupo 1B; elaboração do } \\
\text { Plano Nacional de Saúde com } \\
\text { previsão do orçamento em } \\
\text { saúde; pactuação dos valores } \\
\text { com a CIT. }\end{array}$ & $\begin{array}{l}\text { (BRASIL, 2011c; } \\
\text { 2012a; 2012b; } \\
\text { 2013a); } \\
\text { (MINISTÉRIO DA } \\
\text { SAÚDE, 2015; } \\
\text { 2016a) }\end{array}$ \\
\hline Nível Distrital & $\begin{array}{l}\text { SES-DF - Secretaria de Estado de } \\
\text { Saúde do Distrito Federal } \\
\text { DIASF } \\
\text { GCEAF }\end{array}$ & $\begin{array}{l}\text { Financiamento do grupo 2; } \\
\text { elaboração do Plano de Saúde } \\
\text { do DF com previsão de } \\
\text { orçamento em saúde; } \\
\text { aprovação dos valores com o } \\
\text { Conselho de Saúde do DF. }\end{array}$ & (BRASIL, 2013a) \\
\hline
\end{tabular}


APÊNDICE W - Estrutura organizacional e respectivas atividades na implementação do CEAF/PNAF no DF

\begin{tabular}{|c|c|c|c|}
\hline $\begin{array}{l}\text { NÍVEIS DO } \\
\text { GOVERNO }\end{array}$ & $\begin{array}{l}\text { ESTRUTURAS } \\
\text { ORGANIZACIONAIS }\end{array}$ & ATIVIDADES & REFERÊNCIAS \\
\hline \multirow{4}{*}{ Nível Federal } & $\begin{array}{l}\text { CNS - Conselho Nacional de } \\
\text { Saúde }\end{array}$ & $\begin{array}{l}\text { Discussão e pactuação com o } \\
\text { MS sobre a gestão e execução } \\
\text { da AF, os recursos investidos, a } \\
\text { revisão das listas de } \\
\text { medicamentos e outros. }\end{array}$ & $\begin{array}{l}\text { (BRASIL, 1993c; } \\
\text { 2013c) }\end{array}$ \\
\hline & $\begin{array}{l}\text { CIT - Comissão Intergestores } \\
\text { Tripartite }\end{array}$ & $\begin{array}{l}\text { Pactuação com o MS sobre a } \\
\text { ampliação da lista do } \\
\text { CEAF/PNAF, o aumento da } \\
\text { cobertura de tratamentos com } \\
\text { os medicamentos já } \\
\text { incorporados e de quem será a } \\
\text { responsabilidade do } \\
\text { financiamento }\end{array}$ & $\begin{array}{l}\text { (BRASIL, 2010a; } \\
\text { 2013c). }\end{array}$ \\
\hline & Conferência Nacional de Saúde & $\begin{array}{l}\text { Elaboração de relatórios com } \\
\text { recomendações e diretrizes } \\
\text { pactuadas entre os diferentes } \\
\text { grupos de interesse pela saúde } \\
\text { pública. }\end{array}$ & $\begin{array}{l}\text { (BRASIL, 1993c; } \\
\text { 2013c) }\end{array}$ \\
\hline & $\begin{array}{l}\text { MS - Ministério da Saúde } \\
\text { DAF - Departamento de } \\
\text { Assistência Farmacêutica } \\
\text { CGCEAF - Coordenação-geral do } \\
\text { Componente Especializado da } \\
\text { Assistência Farmacêutica. } \\
\text { DGITS - Departamento de Gestão } \\
\text { e Incorporação de Tecnologias em } \\
\text { Saúde } \\
\text { CONITEC - Comissão Nacional } \\
\text { de Incorporação de Tecnologias }\end{array}$ & $\begin{array}{l}\text { CGCEAF - planejamento } \\
\text { federal da assistência } \\
\text { farmacêutica e do } \\
\text { CEAF/PNAF; o monitoramento } \\
\text { e avaliação do CEAF/PNAF no } \\
\text { Brasil; o financiamento dos } \\
\text { grupos 1A e 1B; a aquisição } \\
\text { centralizada dos medicamentos } \\
\text { do grupo 1A; a revisão dos } \\
\text { grupos do CEAF/PNAF } \\
\text { mediante pactuação na CIT; } \\
\text { revisão da RENAME e dos } \\
\text { PCDT junto à CONITEC. } \\
\text { CONITEC - a inclusão, a } \\
\text { exclusão e a alteração de } \\
\text { medicamentos da RENAME, } \\
\text { além da revisão dos PCDT. }\end{array}$ & $\begin{array}{l}\text { (BRASIL, 2009b; } \\
\text { 2013a); } \\
\text { (MINISTÉRIO DA } \\
\text { SAÚDE, 2016a) }\end{array}$ \\
\hline \multirow{3}{*}{ Nível Distrital } & $\begin{array}{l}\text { CSDF - Conselho de Saúde do } \\
\text { Distrito Federal }\end{array}$ & $\begin{array}{l}\text { Aprovação do orçamento da } \\
\text { saúde do DF e } \\
\text { acompanhamento de sua } \\
\text { execução, e a aprovação do } \\
\text { Plano se Saúde do DF. }\end{array}$ & $\begin{array}{l}\text { (SECRETARIA DE } \\
\text { ESTADO DE } \\
\text { SAÚDE DO } \\
\text { DISTRITO } \\
\text { FEDERAL, 2016c) }\end{array}$ \\
\hline & $\begin{array}{l}\text { Conferência de Saúde do Distrito } \\
\text { Federal }\end{array}$ & $\begin{array}{l}\text { Elaboração de relatórios com } \\
\text { recomendações e diretrizes } \\
\text { pactuadas entre os diferentes } \\
\text { grupos de interesse pela saúde } \\
\text { pública. }\end{array}$ & (BRASIL, 2016c) \\
\hline & $\begin{array}{l}\text { SES-DF - Secretaria de Estado de } \\
\text { Saúde do Distrito Federal } \\
\text { DIASF } \\
\text { GCEAF } \\
\text { Núcleo de Farmácia do } \\
\text { Componente Especializado na Asa } \\
\text { Sul } \\
\text { Núcleo de Farmácia do }\end{array}$ & $\begin{array}{l}\text { DIASF/SES-DF-formular a } \\
\text { Política de Assistência } \\
\text { Farmacêutica do DF; planejar a } \\
\text { operacionalização dos } \\
\text { componentes no DF;_coordenar } \\
\text { a seleção de medicamentos, a } \\
\text { padronização da REME-DF e } \\
\text { do Formulário Terapêutico da }\end{array}$ & $\begin{array}{l}\text { (BRASIL, 2009b; } \\
\text { 2013a); } \\
\text { (SECRETARIA DE } \\
\text { ESTADO DE } \\
\text { SAÚDE DO } \\
\text { DISTRITO } \\
\text { FEDERAL, 2016a; } \\
\text { 2016b) }\end{array}$ \\
\hline
\end{tabular}




\begin{tabular}{|l|l|l|}
\hline & $\begin{array}{l}\text { Componente Especializado na } \\
\text { Ceilândia } \\
\text { CCFT - Comissão Central de } \\
\text { Farmácia e Terapêutica }\end{array}$ & $\begin{array}{l}\text { SES-DF; coordenar a gestão } \\
\text { dos medicamentos da SES-DF; } \\
\text { coordenar as atividades do } \\
\text { CEAF/PNAF no DF; e } \\
\text { coordenar as atividades que } \\
\text { garantam o acesso à } \\
\text { medicamentos pela SES-DF. } \\
\text { GCEAF/DIASF/SES-DF - } \\
\text { gestão do CEAF/PNAF no DF } \\
\text { Farmácias do Componente } \\
\text { Especializado - Acolhimento } \\
\text { do usuário, cadastro, abertura } \\
\text { do processo de solicitação do } \\
\text { medicamento, avaliação do } \\
\text { caso por meio dos documentos } \\
\text { entregues, autorização, } \\
\text { dispensação do medicamento e } \\
\text { renovação do cadastro. }\end{array}$ \\
\hline
\end{tabular}


APÊNDICE X - Relação de normas que amparam a judicialização da saúde no Brasil publicações entre os anos 1980 a 2005

\begin{tabular}{|c|c|c|}
\hline $\begin{array}{l}\text { NORMAS QUE AMPARAM A } \\
\text { JUDICIALIZAÇÃO DO } \\
\text { ACESSO A MEDICAMENTOS }\end{array}$ & VERSA SOBRE & REFERÊNCIA \\
\hline Constituição Federal de 1988 & $\begin{array}{l}\text { Constituição da república federativa do Brasil } \\
\text { de } 1988 .\end{array}$ & (BRASIL, 1988) \\
\hline $\begin{array}{l}\text { Lei } n^{\circ} 8.080 \text {, de } 19 \text { de setembro } \\
\text { de } 1990\end{array}$ & $\begin{array}{l}\text { Condições para a promoção, proteção e } \\
\text { recuperação da saúde, a organização e o } \\
\text { funcionamento dos serviços correspondentes e } \\
\text { dá outras providências. }\end{array}$ & (BRASIL, 1990a) \\
\hline $\begin{array}{l}\text { Lei Orgânica do Distrito Federal, } \\
\text { de } 08 \text { de junho de } 1993\end{array}$ & Lei Orgânica do Distrito Federal de 1993 & (BRASIL, 1993b) \\
\hline $\begin{array}{l}\text { Portaria } n^{\circ} 653 / \text { PGJ, de } 01 \text { de } \\
\text { setembro de } 1997\end{array}$ & $\begin{array}{l}\text { Criou e definiu as atribuições da Promotoria de } \\
\text { Justiça de Defesa da Saúde - PROSUS na } \\
\text { estrutura do Ministério Público do Distrito } \\
\text { Federal e Territórios. }\end{array}$ & (BRASIL, 1997b) \\
\hline $\begin{array}{l}\text { Portaria } n^{\circ} 3.916 / \text { GM/MS, de } 30 \\
\text { de outubro de } 1998\end{array}$ & Política Nacional de Medicamentos. & (BRASIL, 1998) \\
\hline $\begin{array}{l}\text { Lei } n^{\circ} 2.804, \text { de } 25 \text { de outubro de } \\
2001\end{array}$ & $\begin{array}{l}\text { Direitos dos usuários dos serviços e das ações } \\
\text { de saúde no Distrito Federal }\end{array}$ & (BRASIL, 2001) \\
\hline $\begin{array}{l}\text { Resolução CNS/MS n }{ }^{\circ} 338 \text {, de } 6 \\
\text { de maio de } 2004\end{array}$ & Política Nacional de Assistência Farmacêutica. & (BRASIL, 2004) \\
\hline
\end{tabular}


APÊNDICE Y - Relação de normas que amparam a judicialização da saúde no Brasil publicações entre os anos 2007 a 2009

\begin{tabular}{|l|l|l|}
\hline $\begin{array}{l}\text { NORMAS QUE AMPARAM A } \\
\text { NORMAS QUE AMPARAM A } \\
\text { JUDICIALIZAÇÃO DO } \\
\text { ACESSO A MEDICAMENTOS }\end{array}$ & VERSA SOBRE & REFERÊNCIA \\
\hline $\begin{array}{l}\text { Portaria GM/MS no } 204 \text {, de 29 de } \\
\text { janeiro de 2007 }\end{array}$ & $\begin{array}{l}\text { Financiamento e a transferência dos recursos } \\
\text { federais para as ações e serviços de saúde. }\end{array}$ & (BRASIL, 2007a) \\
\hline $\begin{array}{l}\text { Portaria } \mathrm{n}^{\circ} 1.820 \text {, de } 13 \text { de agosto } \\
\text { de } 2009\end{array}$ & Direitos e deveres dos usuários da saúde. & (BRASIL, 2009f) \\
\hline $\begin{array}{l}\text { Portaria } \mathrm{n}^{\circ} \text { 650 de } 20 \text { de } \\
\text { novembro de } 2009\end{array}$ & $\begin{array}{l}\text { Criação de grupo de trabalho para estudo e } \\
\text { proposta de medidas concretas e normativas } \\
\text { para as demandas judiciais envolvendo a } \\
\text { assistência à saúde. }\end{array}$ & (BRASIL, 2009e) \\
\hline $\begin{array}{l}\text { Portaria } \mathrm{n}^{\circ} \text { 2.981, de 26 de } \\
\text { novembro de } 2009\end{array}$ & $\begin{array}{l}\text { Componente Especializado da Assistência } \\
\text { Farmacêutica. }\end{array}$ & (BRASIL, 2009b) \\
\hline
\end{tabular}


APÊNDICE Z - Relação de normas que amparam a judicialização da saúde no Brasil publicações entre os anos 2010 e 2011

\begin{tabular}{|l|l|l|}
\hline $\begin{array}{l}\text { NORMAS QUE AMPARAM A } \\
\text { JUDICIALIZAÇÃO DO } \\
\text { ACESSO A MEDICAMENTOS }\end{array}$ & VERSA SOBRE & REFERÊNCIA \\
\hline $\begin{array}{l}\text { Recomendação no } 31 \text { do CNJ, de } \\
30 \text { de março de } 2010\end{array}$ & $\begin{array}{l}\text { Recomendação aos Tribunais a adoção de } \\
\text { medidas visando a melhor subsidiar os } \\
\text { magistrados e demais operadores do direito, } \\
\text { para assegurar maior eficiência na solução das } \\
\text { demandas judiciais envolvendo a assistência à } \\
\text { saúde. }\end{array}$ & (BRASIL, 2010c) \\
\hline $\begin{array}{l}\text { Resolução } 107 \text { do CNJ, de } 06 \text { de } \\
\text { abril de } 2010\end{array}$ & $\begin{array}{l}\text { Instituição do Fórum Nacional do Judiciário } \\
\text { para monitoramento e resolução das demandas } \\
\text { de assistência à saúde. }\end{array}$ & (BRASIL, 2010b) \\
\hline $\begin{array}{l}\text { Portaria 25 do CNJ, de 22 de } \\
\text { março de } 2011\end{array}$ & $\begin{array}{l}\text { Designação de membros para compor os } \\
\text { Comitês Executivos Estaduais no âmbito do } \\
\text { Fórum Nacional do Judiciário para a Saúde. }\end{array}$ & (BRASIL, 2011g) \\
\hline $\begin{array}{l}\text { Portaria 49 do CNJ, de } 6 \text { de junho } \\
\text { de 2011 }\end{array}$ & $\begin{array}{l}\text { Acréscimo de incisos à Portaria 25 e altera } \\
\text { dispositivos da mesma norma. }\end{array}$ & (BRASIL, 2011h) \\
\hline $\begin{array}{l}\text { Instrução Normativa 06 da } \\
\text { Corregedoria do TJDFT, de 23 de } \\
\text { dezembro de 2011 }\end{array}$ & $\begin{array}{l}\text { Recomendaçães aos juízes de direito do TJDFT } \\
\text { quanto a observância de critérios para assegurar } \\
\text { maior eficiência na solução das demandas } \\
\text { judiciais envolvendo a saúde pública. }\end{array}$ & (BRASIL, 2011f) \\
\hline
\end{tabular}


APÊNDICE AA - Relação de normas que amparam a judicialização da saúde no Brasil publicações entre os anos 2012 a 2016

\begin{tabular}{|l|l|l|}
\hline $\begin{array}{l}\text { NORMAS QUE AMPARAM A } \\
\text { JUDICIALIZAÇÃO DO } \\
\text { ACESSO A MEDICAMENTOS }\end{array}$ & VERSA SOBRE & REFERÊNCIA \\
\hline $\begin{array}{l}\text { Lei Complementar no } 141, \text { de } 13 \\
\text { de janeiro de } 2012\end{array}$ & $\begin{array}{l}\text { Valores mínimos a serem aplicados anualmente } \\
\text { pela União, Estados, Distrito Federal e } \\
\text { Municípios em ações e serviços públicos de } \\
\text { saúde. }\end{array}$ & (BRASIL, 2012c) \\
\hline $\begin{array}{l}\text { Portaria GPR 464 do TJDFT, de } \\
17 \text { de abril de 2012 }\end{array}$ & $\begin{array}{l}\text { Alteração da composição do Comitê Executivo } \\
\text { do Distrito Federal no âmbito do Fórum } \\
\text { Nacional do Judiciário para a Saúde. }\end{array}$ & (BRASIL, 2012d) \\
\hline $\begin{array}{l}\text { Portaria GPR } 1.423 \text { do TJDFT, de } \\
25 \text { de outubro de 2012 }\end{array}$ & $\begin{array}{l}\text { Alteração da composição do Comitê Executivo } \\
\text { do Distrito Federal no âmbito do Fórum } \\
\text { Nacional do Poder Judiciário para a Saúde. }\end{array}$ & (BRASIL, 2012e) \\
\hline $\begin{array}{l}\text { Portaria Conjunta no 01 de 26 de } \\
\text { fevereiro de 2013. }\end{array}$ & $\begin{array}{l}\text { Instituição da Câmara Permanente Distrital de } \\
\text { Mediação em Saúde (CAMEDIS). }\end{array}$ & (BRASIL, 2013m) \\
\hline $\begin{array}{l}\text { Portaria GM/MS no } 1.554, \text { de 30 } \\
\text { de julho de 2013 }\end{array}$ & $\begin{array}{l}\text { Regras de financiamento e execução do } \\
\text { Componente Especializado da Assistência } \\
\text { Farmacêutica no âmbito do Sistema Único de } \\
\text { Saúde (SUS). }\end{array}$ & (BRASIL, 2013a) \\
\hline $\begin{array}{l}\text { Portaria 40 de 25 de março de } \\
2014\end{array}$ & $\begin{array}{l}\text { Comitê Organizador do Fórum Nacional do } \\
\text { Poder Judiciário para monitoramento e } \\
\text { resolução das demandas de assistência à saúde. }\end{array}$ & (BRASIL, 2014h) \\
\hline $\begin{array}{l}\text { Portaria GPR } 1735 \text { do TJDFT, de } \\
14 \text { de outubro de 2014 }\end{array}$ & $\begin{array}{l}\text { Revogação das Portarias GPR 464 e 1423, } \\
\text { ambas de 2012 e altera a composição do Comitê } \\
\text { Executivo do Distrito Federal no âmbito do } \\
\text { Fórum Nacional do Judiciário para } \\
\text { monitoramento e resolução das demandas de } \\
\text { assistência à Saúde. }\end{array}$ & (BRASIL, 2014i) \\
\hline $\begin{array}{l}\text { Portaria } 8 \text { de } 2 \text { de fevereiro de } \\
\text { (riação do Comitê Organizador do Fórum } \\
\text { Nacional do Poder Judiciário para } \\
\text { monitoramento e resolução das demandas de } \\
\text { assistência à saúde. }\end{array}$ & (BRASIL, 2016c) \\
\hline
\end{tabular}


APÊNDICE AB - Síntese do conceito de discricionariedade jurídica e seus aspectos principais

\begin{tabular}{|c|c|}
\hline $\begin{array}{l}\text { CONCEPÇÕES ACERCA DA } \\
\text { DISCRICIONARIEDADE JURÍDICA }\end{array}$ & $\begin{array}{l}\text { ASPECTOS DA DISCRICIONARIEDADE } \\
\text { JURÍDICA }\end{array}$ \\
\hline \multirow{7}{*}{$\begin{array}{l}\text { Duas concepções: } \\
\text { discricionariedade relativa à liberdade de atuação e } \\
\text { decisão pelo profissional do direito no julgamento dos } \\
\text { casos; e } \\
\text { discricionariedade relativa à liberdade de atuação que } \\
\text { as normas aplicadas aos casos judiciais permitem. }\end{array}$} & $\begin{array}{l}\text { Existência ou não da discricionariedade na atuação do } \\
\text { juiz - concepção da natureza do direito. }\end{array}$ \\
\hline & $\begin{array}{l}\text { Discricionariedade limitada pela eficácia da prestação } \\
\text { jurídica - somente uma decisão apropriada possível. }\end{array}$ \\
\hline & $\begin{array}{l}\text { A investigação jurídica e a reflexão deverão levar à } \\
\text { melhor solução. }\end{array}$ \\
\hline & $\begin{array}{l}\text { Se a verdade jurídica não foi aplicada, poderá sê-lo em } \\
\text { grau de recurso. }\end{array}$ \\
\hline & $\begin{array}{l}\text { Atuação mais ativa e criativa dos juízes na condução } \\
\text { dos processos judiciais. }\end{array}$ \\
\hline & $\begin{array}{l}\text { Necessidade de critérios para a intervenção do Poder } \\
\text { Judiciário nas demandas em saúde, em função da } \\
\text { complexidade dos casos. }\end{array}$ \\
\hline & $\begin{array}{l}\text { As capacidades investigatórias dos juízes não estão } \\
\text { isentas de premissas sociais, econômicas e religiosas. }\end{array}$ \\
\hline
\end{tabular}


APÊNDICE AC - Estrutura organizacional responsável pelo controle jurisdicional da PNAF no DF e na União

\begin{tabular}{|c|c|c|}
\hline NÍVEIS DO GOVERNO & ESTRUTURAS ORGANIZACIONAIS & REFERÊNCIAS \\
\hline \multirow{5}{*}{ Nível Federal } & $\begin{array}{l}\text { CNJ - Conselho Nacional de Justiça } \\
\text { Grupo de Trabalho para estudo das ações em } \\
\text { saúde } \\
\text { Fórum Nacional do Poder Judiciário para } \\
\text { monitoramento e resolução das demandas de } \\
\text { assistência à saúde }\end{array}$ & $\begin{array}{l}\text { (BRASIL, 2009e; 2010b; } \\
2016 \mathrm{c})\end{array}$ \\
\hline & STF - Supremo Tribunal Federal & $\begin{array}{l}\text { (AGÊNCIA BRASÍLIA, } \\
\text { 2012b; BRASIL, 1988). }\end{array}$ \\
\hline & $\begin{array}{l}\text { MS - Ministério da Saúde } \\
\text { CONJUR - Consultoria Jurídica do Ministério } \\
\text { da Saúde } \\
\text { SCTIE - Secretaria de Ciência, Tecnologia e } \\
\text { Insumos Estratégicos } \\
\text { NJ - Núcleo Jurídico }\end{array}$ & $\begin{array}{l}\text { (MINISTÉRIO DA } \\
\text { SAÚDE, 2015; 2016a; } \\
\text { 2016e) }\end{array}$ \\
\hline & $\begin{array}{l}\text { MPU - Ministério Público da União } \\
\text { MPF - Ministério Público Federal } \\
\text { PGR - Procuradoria-Geral da República } \\
\text { Procuradoria Federal dos Direitos dos } \\
\text { Cidadãos }\end{array}$ & (BRASIL, 1988). \\
\hline & DPU - Defensoria Pública da União & $\begin{array}{l}\text { (DEFENSORIA } \\
\text { PÚBLICA DA UNIÃO, } \\
2016 a)\end{array}$ \\
\hline \multirow{5}{*}{ Nível Distrital } & $\begin{array}{l}\text { TJDFT - Conselho de Saúde do Distrito } \\
\text { Federal } \\
\text { Comitê Executivo Distrital da Saúde (Fórum } \\
\text { Nacional em Saúde) } \\
\text { NAT - Núcleo de Apoio Técnico do Poder } \\
\text { Judiciário }\end{array}$ & $\begin{array}{l}\text { (BRASIL, 2014i; } \\
\text { TRIBUNAL DE } \\
\text { JUSTIÇA DO DISTRITO } \\
\text { FEDERAL, 2016) }\end{array}$ \\
\hline & $\begin{array}{l}\text { SES-DF - Secretaria de Estado de Saúde do } \\
\text { Distrito Federal } \\
\text { NJUD - Núcleo de Judicialização da SES-DF } \\
\text { CAMEDIS - Câmara Permanente Distrital de } \\
\text { Mediação em Saúde } \\
\text { DIASF } \\
\text { Núcleo de Farmácia Ambulatorial Judicial }\end{array}$ & $\begin{array}{l}\text { (BRASIL, 2013m; PAIM; } \\
\text { MARQUETTO; LOPES, } \\
\text { 2016; SECRETARIA DE } \\
\text { ESTADO DE SAÚDE } \\
\text { DO DISTRITO } \\
\text { FEDERAL, 2016a; } \\
\text { 2016b; TRIBUNAL DE } \\
\text { JUSTIÇA DO DISTRITO } \\
\text { FEDERAL, 2016). }\end{array}$ \\
\hline & $\begin{array}{l}\text { MPDFT - Ministério Público do Distrito } \\
\text { Federal e Territórios } \\
\text { PROSUS - Promotoria de Justiça de Defesa } \\
\text { da Saúde } \\
\text { PRÓ-VIDA - Promotoria de Justiça Criminal } \\
\text { de Defesa dos Usuários dos Serviços de Saúde }\end{array}$ & $\begin{array}{l}\text { (MINISTÉRIO PÚBLICO } \\
\text { DO DISTRITO } \\
\text { FEDERAL E } \\
\text { TERRITÓRIOS, 2016a; } \\
\text { 2016i) }\end{array}$ \\
\hline & $\begin{array}{l}\text { PGDF - Procuradoria-Geral do Distrito } \\
\text { Federal } \\
\text { PROMAI - Procuradoria do Meio Ambiente, } \\
\text { Patrimônio Urbanístico e Imobiliário e Saúde }\end{array}$ & $\begin{array}{l}\text { (PROCURADORIA- } \\
\text { GERAL DO DISTRITO } \\
\text { FEDERAL, 2016) }\end{array}$ \\
\hline & $\begin{array}{l}\text { DPDF - Defensoria Pública do Distrito } \\
\text { Federal } \\
\text { Núcleo da Saúde }\end{array}$ & $\begin{array}{l}\text { (BRASIL, 1988; } \\
\text { DEFENSORIA } \\
\text { PÚBLICA DO } \\
\text { DISTRITO FEDERAL, } \\
\text { 2016a) }\end{array}$ \\
\hline
\end{tabular}


APÊNDICE AD - Recursos humanos envolvidos com o controle jurisdicional da PNAF no DF e na União

\begin{tabular}{|c|c|c|c|}
\hline $\begin{array}{l}\text { NÍVEIS DO } \\
\text { GOVERNO }\end{array}$ & $\begin{array}{l}\text { ESTRUTURAS } \\
\text { ORGANIZACIONAIS }\end{array}$ & RECURSOS HUMANOS & REFERÊNCIAS \\
\hline \multirow[t]{4}{*}{ Nível Federal } & $\begin{array}{l}\text { CNJ - Conselho Nacional de Justiça } \\
\text { Grupo de Trabalho para estudo das } \\
\text { ações em saúde } \\
\text { Fórum Nacional do Poder Judiciário } \\
\text { para monitoramento e resolução das } \\
\text { demandas de assistência à saúde }\end{array}$ & $\begin{array}{l}\text { Grupo de Trabalho (2009): juiz da } 5^{\text {a }} \text { Vara da Fazenda Pública do Estado da Bahia; juiz da } 10^{a} \\
\text { Vara da Fazenda Pública do Estado do Rio de Janeiro; juiz da } 5^{\text {a }} \text { Vara Federal de Pernambuco; } \\
\text { desembargador do Tribunal Regional Federal da } 4^{\text {a }} \text { Região; especialista em direito sanitário; } \\
\text { outras autoridades e especialistas. } \\
\text { Fórum Nacional: coordenado pelos Conselheiros integrantes da Comissão de Relacionamento } \\
\text { Institucional e Comunicação do CNJ; constituído por comitês executivos; e auxílio de } \\
\text { autoridades e especialistas com atuação nas áreas correlatas. } \\
\text { Comitê Organizador: juiz Auxiliar da Presidência do CNJ; um conselheiro representante do } \\
\text { Conselho Nacional do Ministério Público (CNMP); promotor de Justiça do Ministério Público } \\
\text { do Estado de São Paulo; desembargador do Tribunal Regional Federal da 4a Região; } \\
\text { desembargador do Tribunal de Justiça do Estado de Minas Gerais; juiz do Tribunal de Justiça } \\
\text { do Estado da Paraíba; defensor Público da Defensoria Pública do Distrito Federal; diretor } \\
\text { substituto do Departamento de Atenção Especializada do Ministério da Saúde; secretário-Geral } \\
\text { da Agência Nacional de Saúde Suplementar (ANS); diretor da Agência Nacional de Vigilância } \\
\text { Sanitária (Anvisa); assessora Jurídica do Conselho Nacional de Secretários de Saúde } \\
\text { (CONASS); assessora Jurídica do Conselho Nacional de Secretarias Municipais de Saúde } \\
\text { (CONASEMS); dois médicos e professores da Faculdade de Medicina da Universidade de São } \\
\text { Paulo. }\end{array}$ & $\begin{array}{l}\text { (BRASIL, 2009e; } \\
\text { 2010b; 2016c) }\end{array}$ \\
\hline & STF - Supremo Tribunal Federal & Onze ministros. & $\begin{array}{l}\text { (AGÊNCIA } \\
\text { BRASÍLIA, 2012b; } \\
\text { BRASIL, 1988) }\end{array}$ \\
\hline & $\begin{array}{l}\text { MS - Ministério da Saúde } \\
\text { CONJUR - Consultoria Jurídica do } \\
\text { Ministério da Saúde } \\
\text { SCTIE - Secretaria de Ciência, } \\
\text { Tecnologia e Insumos Estratégicos } \\
\text { NJ - Núcleo Jurídico }\end{array}$ & $\begin{array}{l}\text { CONJUR/MS: consultor; coordenador-geral de acompanhamento jurídico; responsável pelo } \\
\text { Núcleo em matérias de saúde e atos; responsável pelo Núcleo de Gestão - NUGEST/MS; chefe } \\
\text { de gabinete; assessores do Núcleo de Gestão - NUGEST/MS. } \\
\text { NJ/SCTIE/MS: advogados competentes, aliados às comissões do NUT/CONJUR e da } \\
\text { CONITEC. }\end{array}$ & $\begin{array}{l}\text { (BRASIL, 2011c; } \\
\text { 2012a; 2012b; 2013a); } \\
\text { (MINISTÉRIO DA } \\
\text { SAÚDE, 2015; 2016a; } \\
\text { 2016b; 2016e) }\end{array}$ \\
\hline & $\begin{array}{l}\text { MPU - Ministério Público da União } \\
\text { MPF - Ministério Público Federal } \\
\text { PGR - Procuradoria-Geral da } \\
\text { República }\end{array}$ & $\begin{array}{l}\text { MPF: servidores analistas, servidores técnicos e membros procuradores da república. } \\
\text { PGR: procurador-Geral da República; } 73 \text { subprocuradores-Geral da República; analista para } \\
\text { apoio jurídico, apoio técnico-administrativo, técnico-especializado, médico, perito, saúde e } \\
\text { técnico da informação e comunicação; e técnicos em apoio técnico-administrativo e saúde. }\end{array}$ & $\begin{array}{l}\text { (MINISTÉRIO } \\
\text { PÚBLICO DA } \\
\text { UNIÃO, 2016; } \\
\text { MINISTÉRIO } \\
\text { PÚBLICO FEDERAL, } \\
\text { 2016). }\end{array}$ \\
\hline
\end{tabular}




\begin{tabular}{|c|c|c|c|}
\hline & DPU - Defensoria Pública da União & $\begin{array}{l}\text { DPU: dois defensores públicos da área da saúde, dois defensores públicos-chefe e dois } \\
\text { defensores públicos-chefe substituto, em cada uma das duas unidades. }\end{array}$ & $\begin{array}{l}\text { (DEFENSORIA } \\
\text { PÚBLICA DA } \\
\text { UNIÃO, 2016b) }\end{array}$ \\
\hline \multirow{5}{*}{ Nível Distrital } & $\begin{array}{l}\text { TJDFT - Conselho de Saúde do } \\
\text { Distrito Federal } \\
\text { Comitê Executivo Distrital da } \\
\text { Saúde (Fórum Nacional em Saúde) } \\
\text { NAT - Núcleo de Apoio Técnico do } \\
\text { Poder Judiciário }\end{array}$ & $\begin{array}{l}\text { Comitê Executivo Distrital da Saúde: alguns magistrados do TJDFT e da Justiça Federal; } \\
\text { defensores públicos do DF e também da União; advogados da OAB; gestores da SES/DF; } \\
\text { membros do Conselho Regional de Medicina do DF; pesquisador da FIOCRUZ; representantes } \\
\text { de planos de saúde; de empresas de seguro; de cooperativas e outras instituições. } \\
\text { NAT: funcionários administrativos; farmacêuticos; nutricionistas; enfermeiros, médicos }\end{array}$ & $\begin{array}{l}\text { (FERREIRA; COSTA, } \\
\text { 2013;TRIBUNAL DE } \\
\text { JUSTIÇA DO } \\
\text { DISTRITO } \\
\text { FEDERAL, 2016). }\end{array}$ \\
\hline & $\begin{array}{l}\text { SES-DF - Secretaria de Estado de } \\
\text { Saúde do Distrito Federal } \\
\text { NJUD - Núcleo de Judicialização } \\
\text { da SES-DF } \\
\text { CAMEDIS -Câmara Permanente } \\
\text { Distrital de Mediação em Saúde } \\
\text { DIASF } \\
\text { Núcleo de Farmácia Ambulatorial } \\
\text { Judicial }\end{array}$ & $\begin{array}{l}\text { NJUD/SES-DF: Advogados, funcionários administrativos e } 1 \text { farmacêutico. } \\
\text { CAMEDIS: um representante titular e um representante suplente de cada um dos órgãos: SES- } \\
\text { DF e DPDF. } \\
\text { Núcleo de Farmácia Ambulatorial Judicial/DIASF/SES-DF: um farmacêutico chefe e } \\
\text { farmacêuticos colaboradores. }\end{array}$ & $\begin{array}{l}\text { (BRASIL, 2013a; } \\
\text { 2013m; } \\
\text { SECRETARIA DE } \\
\text { ESTADO DE SAÚDE } \\
\text { DO DISTRITO } \\
\text { FEDERAL, 2016a; } \\
\text { 2016b) }\end{array}$ \\
\hline & $\begin{array}{l}\text { MPDFT - Ministério Público do } \\
\text { Distrito Federal e Territórios } \\
\text { PROSUS - Promotoria de Justiça de } \\
\text { Defesa da Saúde }\end{array}$ & PROSUS: promotores de justiça e promotores de justiça adjuntos. & $\begin{array}{l}\text { (MINISTÉRIO } \\
\text { PÚBLICO DO } \\
\text { DISTRITO FEDERAL } \\
\text { E TERRITÓRIOS, } \\
\text { 2016j) }\end{array}$ \\
\hline & $\begin{array}{l}\text { PGDF - Procuradoria-Geral do } \\
\text { Distrito Federal } \\
\text { PROMAI - Procuradoria do Meio } \\
\text { Ambiente, Patrimônio Urbanístico e } \\
\text { Imobiliário e Saúde }\end{array}$ & $\begin{array}{l}\text { PROMAI: um procurador-chefe e duas assessoras, um procurador-coordenador de saúde, um } \\
\text { procurador-coordenador de meio-ambiente e um diretor de suporte administrativo. }\end{array}$ & $\begin{array}{l}\text { (PROCURADORIA- } \\
\text { GERAL DO } \\
\text { DISTRITO } \\
\text { FEDERAL, 2016) }\end{array}$ \\
\hline & $\begin{array}{l}\text { DPDF - Defensoria Pública do } \\
\text { Distrito Federal } \\
\text { Núcleo da Saúde }\end{array}$ & $\begin{array}{l}\text { Núcleo da Saúde: } 2 \text { defensores públicos coordenadores, agentes administrativos, } 1 \\
\text { farmacêutica voluntária. }\end{array}$ & $\begin{array}{l}\text { (AGÊNCIA } \\
\text { BRASÍLIA, 2013). }\end{array}$ \\
\hline
\end{tabular}


APÊNDICE AE - Órgãos e respectivas competências financeiras relacionadas à judicialização de medicamentos

\begin{tabular}{|c|c|c|c|}
\hline $\begin{array}{l}\text { NÍVEIS DO } \\
\text { GOVERNO }\end{array}$ & $\begin{array}{l}\text { ESTRUTURAS } \\
\text { ORGANIZACIONAIS }\end{array}$ & COMPETÊNCIAS FINANCEIRAS & REFERÊNCIAS \\
\hline Nível Federal & MS - Ministério da Saúde & $\begin{array}{l}\text { Financiamento dos medicamentos } \\
\text { conforme responsabilidade sobre os } \\
\text { componentes da PNAF (para o CEAF, } \\
\text { financiamento dos grupos 1A e 1B); } \\
\text { transferência dos recursos conforme } \\
\text { responsabilidade sobre os componentes } \\
\text { da PNAF se ação for contra o GDF } \\
\text { (estados), financiamento de outros } \\
\text { medicamentos não padronizados (quando } \\
\text { a ação é contra a União). }\end{array}$ & $\begin{array}{l}\text { (BRASIL, 2011c; } \\
\text { 2012a; 2012b; } \\
\text { 2013a); } \\
\text { (MINISTÉRIO DA } \\
\text { SAÚDE, 2015; } \\
\text { 2016a; 2016b) }\end{array}$ \\
\hline Nível Distrital & $\begin{array}{l}\text { SES-DF - Secretaria de } \\
\text { Estado de Saúde do } \\
\text { Distrito Federal }\end{array}$ & $\begin{array}{l}\text { Financiamento conforme } \\
\text { responsabilidade sobre os componentes } \\
\text { da PNAF( para o CEAF, financiamento } \\
\text { do grupo 2), financiamento de outros } \\
\text { medicamentos não padronizados (quando } \\
\text { a ação é contra o GDF). }\end{array}$ & (BRASIL, 2013a) \\
\hline
\end{tabular}


APÊNDICE AF - Relação das datas das reuniões do Comitê Executivo de Saúde do Distrito Federal

\begin{tabular}{|c|c|c|}
\hline DATA & REUNIÃO & REFERÊNCIA \\
\hline $30 / 06 / 2011$ & $1^{a}$ Reunião - Ordinária & $\begin{array}{l}\text { (TRIBUNAL DE JUSTIÇA DO DISTRITO FEDERAL E } \\
\text { TERRITÓRIOS, } 2011 \mathrm{~m} \text { ) }\end{array}$ \\
\hline $10 / 08 / 2011$ & $2^{\mathrm{a}}$ Reunião - Ordinária & $\begin{array}{l}\text { (TRIBUNAL DE JUSTIÇA DO DISTRITO FEDERAL E } \\
\text { TERRITÓRIOS, 20111) }\end{array}$ \\
\hline $13 / 09 / 2011$ & $3^{a}$ Reunião - Ordinária & $\begin{array}{l}\text { (TRIBUNAL DE JUSTIÇA DO DISTRITO FEDERAL E } \\
\text { TERRITÓRIOS, 2011n) }\end{array}$ \\
\hline 05/10/2011 & 4ª Reunião - Ordinária & $\begin{array}{l}\text { (TRIBUNAL DE JUSTIÇA DO DISTRITO FEDERAL E } \\
\text { TERRITÓRIOS, 2011o) }\end{array}$ \\
\hline $17 / 10 / 2011$ & 5 Reunião - Ordinária & $\begin{array}{l}\text { (TRIBUNAL DE JUSTIÇA DO DISTRITO FEDERAL E } \\
\text { TERRITÓRIOS, 2011p) }\end{array}$ \\
\hline $26 / 10 / 2011$ & $6^{\mathrm{a}}$ Reunião - Ordinária & $\begin{array}{l}\text { (TRIBUNAL DE JUSTIÇA DO DISTRITO FEDERAL E } \\
\text { TERRITÓRIOS, 2011q) }\end{array}$ \\
\hline $13 / 12 / 2011$ & $7^{\mathrm{a}}$ Reunião - Ordinária & $\begin{array}{l}\text { (TRIBUNAL DE JUSTIÇA DO DISTRITO FEDERAL E } \\
\text { TERRITÓRIOS, 2011r) }\end{array}$ \\
\hline $14 / 02 / 2012$ & $8^{\mathrm{a}}$ Reunião - Ordinária & $\begin{array}{l}\text { (TRIBUNAL DE JUSTIÇA DO DISTRITO FEDERAL E } \\
\text { TERRITÓRIOS, 2012m) }\end{array}$ \\
\hline $29 / 03 / 2012$ & $9^{a}$ Reunião - Ordinária & $\begin{array}{l}\text { (TRIBUNAL DE JUSTIÇA DO DISTRITO FEDERAL E } \\
\text { TERRITÓRIOS, 2012n) }\end{array}$ \\
\hline $21 / 06 / 2012$ & $10^{\mathrm{a}}$ Reunião - Ordinária & $\begin{array}{l}\text { (TRIBUNAL DE JUSTIÇA DO DISTRITO FEDERAL E } \\
\text { TERRITÓRIOS, 2012o) }\end{array}$ \\
\hline $13 / 08 / 2012$ & $11^{a}$ Reunião - Ordinária & $\begin{array}{l}\text { (TRIBUNAL DE JUSTIÇA DO DISTRITO FEDERAL E } \\
\text { TERRITÓRIOS, 2012p) }\end{array}$ \\
\hline $24 / 10 / 2012$ & 12ª Reunião - Ordinária & $\begin{array}{l}\text { (TRIBUNAL DE JUSTIÇA DO DISTRITO FEDERAL E } \\
\text { TERRITÓRIOS, 2012q) }\end{array}$ \\
\hline $26 / 10 / 2012$ & 13ª Reunião - Ordinária & $\begin{array}{l}\text { (TRIBUNAL DE JUSTIÇA DO DISTRITO FEDERAL E } \\
\text { TERRITÓRIOS, 2012r) }\end{array}$ \\
\hline $29 / 11 / 2012$ & $14^{\mathrm{a}}$ Reunião - Ordinária & $\begin{array}{l}\text { (TRIBUNAL DE JUSTIÇA DO DISTRITO FEDERAL E } \\
\text { TERRITÓRIOS, 2012s) } \\
\end{array}$ \\
\hline $04 / 04 / 2013$ & $15^{\mathrm{a}}$ Reunião - Ordinária & $\begin{array}{l}\text { (TRIBUNAL DE JUSTIÇA DO DISTRITO FEDERAL E } \\
\text { TERRITÓRIOS, 2013o) } \\
\end{array}$ \\
\hline $17 / 04 / 2013$ & $16^{\mathrm{a}}$ Reunião - Extraordinária & $\begin{array}{l}\text { (TRIBUNAL DE JUSTIÇA DO DISTRITO FEDERAL E } \\
\text { TERRITÓRIOS, 2013p) } \\
\end{array}$ \\
\hline $06 / 12 / 2013$ & 17ª Reunião - Ordinária & $\begin{array}{l}\text { (TRIBUNAL DE JUSTIÇA DO DISTRITO FEDERAL E } \\
\text { TERRITÓRIOS, 2013q) }\end{array}$ \\
\hline $30 / 01 / 2014$ & $18^{\mathrm{a}}$ Reunião - Ordinária & $\begin{array}{l}\text { (TRIBUNAL DE JUSTIÇA DO DISTRITO FEDERAL E } \\
\text { TERRITÓRIOS, 2014e) }\end{array}$ \\
\hline $20 / 02 / 2014$ & $19^{\mathrm{a}}$ Reunião - Ordinária & $\begin{array}{l}\text { (TRIBUNAL DE JUSTIÇA DO DISTRITO FEDERAL E } \\
\text { TERRITÓRIOS, 2014f) }\end{array}$ \\
\hline $25 / 04 / 2014$ & $20^{\mathrm{a}}$ Reunião - Ordinária & $\begin{array}{l}\text { (TRIBUNAL DE JUSTIÇA DO DISTRITO FEDERAL E } \\
\text { TERRITÓRIOS, 2014g) }\end{array}$ \\
\hline $05 / 06 / 2014$ & $21^{a}$ Reunião - Ordinária & $\begin{array}{l}\text { (TRIBUNAL DE JUSTIÇA DO DISTRITO FEDERAL E } \\
\text { TERRITÓRIOS, 2014h) }\end{array}$ \\
\hline 08/08/2014 & 22ª Reunião - Extraordinária & $\begin{array}{l}\text { (TRIBUNAL DE JUSTIÇA DO DISTRITO FEDERAL E } \\
\text { TERRITÓRIOS, 2014i) }\end{array}$ \\
\hline $25 / 09 / 2014$ & $23^{\mathrm{a}}$ Reunião - Ordinária & $\begin{array}{l}\text { (TRIBUNAL DE JUSTIÇA DO DISTRITO FEDERAL E } \\
\text { TERRITÓRIOS, 2014j) }\end{array}$ \\
\hline
\end{tabular}




\begin{tabular}{|c|c|c|}
\hline 02/10/2014 & $24^{\mathrm{a}}$ Reunião - Ordinária & $\begin{array}{l}\text { (TRIBUNAL DE JUSTIÇA DO DISTRITO FEDERAL E } \\
\text { TERRITÓRIOS, 20141) }\end{array}$ \\
\hline $10 / 11 / 2014$ & 25ª Reunião - Extraordinária & $\begin{array}{l}\text { (TRIBUNAL DE JUSTIÇA DO DISTRITO FEDERAL E } \\
\text { TERRITÓRIOS, 2014m) }\end{array}$ \\
\hline $20 / 11 / 2014$ & $26^{\mathrm{a}}$ Reunião - Ordinária & $\begin{array}{l}\text { (TRIBUNAL DE JUSTIÇA DO DISTRITO FEDERAL E } \\
\text { TERRITÓRIOS, 2014n) }\end{array}$ \\
\hline $28 / 01 / 2015$ & $27^{\mathrm{a}}$ Reunião - Ordinária & $\begin{array}{l}\text { (TRIBUNAL DE JUSTIÇA DO DISTRITO FEDERAL E } \\
\text { TERRITÓRIOS, 2015a) }\end{array}$ \\
\hline 27/03/2015 & $28^{\mathrm{a}}$ Reunião - Ordinária & $\begin{array}{l}\text { (TRIBUNAL DE JUSTIÇA DO DISTRITO FEDERAL E } \\
\text { TERRITÓRIOS, 2015b) }\end{array}$ \\
\hline $29 / 05 / 2015$ & 29a Reunião - Ordinária & $\begin{array}{l}\text { (TRIBUNAL DE JUSTIÇA DO DISTRITO FEDERAL E } \\
\text { TERRITÓRIOS, 2015c) }\end{array}$ \\
\hline $20 / 08 / 2015$ & 30ª Reunião - Ordinária & $\begin{array}{l}\text { (TRIBUNAL DE JUSTIÇA DO DISTRITO FEDERAL E } \\
\text { TERRITÓRIOS, 2015d) }\end{array}$ \\
\hline $20 / 04 / 2016$ & $31^{\mathrm{a}}$ Reunião - Ordinária & $\begin{array}{l}\text { (TRIBUNAL DE JUSTIÇA DO DISTRITO FEDERAL E } \\
\text { TERRITÓRIOS, 2016e) }\end{array}$ \\
\hline 03/06/2016 & 32ª Reunião - Ordinária & $\begin{array}{l}\text { (TRIBUNAL DE JUSTIÇA DO DISTRITO FEDERAL E } \\
\text { TERRITÓRIOS, 2016f) }\end{array}$ \\
\hline $16 / 06 / 2016$ & 33ª Reunião - Extraordinária & $\begin{array}{l}\text { (TRIBUNAL DE JUSTIÇA DO DISTRITO FEDERAL E } \\
\text { TERRITÓRIOS, 2016d) }\end{array}$ \\
\hline
\end{tabular}


APÊNDICE AG - Estrutura organizacional e respectivas atividades no controle jurisdicional da PNAF no DF e na União

\begin{tabular}{|c|c|c|c|}
\hline $\begin{array}{l}\text { NÍVEIS DO } \\
\text { GOVERNO }\end{array}$ & ESTRUTURAS ORGANIZACIONAIS & ATIVIDADES & REFERÊNCIAS \\
\hline \multirow{5}{*}{$\begin{array}{l}\text { Nível } \\
\text { Federal }\end{array}$} & $\begin{array}{l}\text { CNJ - Conselho Nacional de Justiça } \\
\text { Grupo de Trabalho para estudo das ações } \\
\text { em saúde } \\
\text { Fórum Nacional do Poder Judiciário para } \\
\text { monitoramento e resolução das demandas } \\
\text { de assistência à saúde }\end{array}$ & $\begin{array}{l}\text { CNJ: controlar a atuação administrativa e financeira dos demais órgãos do poder judiciário. } \\
\text { Grupo de Trabalho (2009): elaborar estudos e propor medidas concretas e normativas } \\
\text { referentes às demandas judiciais envolvendo a assistência à saúde. } \\
\text { Fórum Nacional: monitoramento das ações judiciais da saúde; monitoramento das ações } \\
\text { judiciais relativas ao SUS; proposição de medidas concretas e normativas voltadas à } \\
\text { otimização de rotinas processuais, à organização e estruturação de unidades judiciárias } \\
\text { especializadas, à prevenção de conflitos judiciais e à definição de estratégias nas questões } \\
\text { de direito sanitário. } \\
\text { Comitê Organizador: conduzir as atividades, organizar a instalação e o funcionamento; } \\
\text { elaborar e fazer cumprir o programa de trabalho; organizar encontros nacionais; promover a } \\
\text { realização de seminários e outros eventos regionais; coordenar os trabalhos dos Comitês } \\
\text { Estaduais; realizar reuniões periódicas ordinárias ou extraordinárias; participar de outros } \\
\text { eventos promovidos por entes públicos ou entidades privadas; e indicar membros dos } \\
\text { Comitês Estaduais ou Regionais para representar o Fórum. }\end{array}$ & $\begin{array}{l}(B R A S I L, 2009 e \\
2010 b ; 2016 c ; \\
\text { CONSELHO } \\
\text { NACIONAL DE } \\
\text { JUSTIÇA, 2016a; } \\
\text { OLIVEIRA, 2013) }\end{array}$ \\
\hline & STF - Supremo Tribunal Federal & $\begin{array}{l}\text { Processar e julgar litígios de inconstitucionalidade, de infrações penais comuns, de crimes } \\
\text { de responsabilidade e de habeas corpus de autoridades. }\end{array}$ & $\begin{array}{l}\text { (BRASIL, 1988; } \\
\text { AGÊNCIA BRASÍLIA, } \\
\text { 2012b). }\end{array}$ \\
\hline & $\begin{array}{l}\text { MS - Ministério da Saúde } \\
\text { CONJUR - Consultoria Jurídica do } \\
\text { Ministério da Saúde } \\
\text { SCTIE - Secretaria de Ciência, Tecnologia } \\
\text { e Insumos Estratégicos } \\
\text { NJ - Núcleo Jurídico }\end{array}$ & $\begin{array}{l}\text { CONJUR/MS: assessorar o Ministro da Saúde; coordenar as atividades jurídicas do MS; } \\
\text { explicar a interpretação da CF de } 88 \text { e das demais normas, garantindo a legalidade } \\
\text { administrativa das atividades do Ministério; e examinar os editais de licitação, contratos e } \\
\text { instrumentos congêneres; os atos de inexigibilidade ou de dispensa de licitação. } \\
\text { NJ/SCTIE/MS: assessorar a Secretaria de Ciência, Tecnologia e Insumos Estratégicos no } \\
\text { que tange as demandas judiciais relacionadas às tecnologias em saúde. }\end{array}$ & $\begin{array}{l}\text { (MINISTÉRIO DA } \\
\text { SAÚDE, 2016e; } \\
\text { TRIBUNAL DE } \\
\text { JUSTIÇA DO } \\
\text { DISTRITO FEDERAL } \\
\text { E TERRITÓRIOS, } \\
\text { 2011a) }\end{array}$ \\
\hline & $\begin{array}{l}\text { MPU - Ministério Público da União } \\
\text { MPF - Ministério Público Federal } \\
\text { PGR - Procuradoria-Geral da República }\end{array}$ & $\begin{array}{l}\text { MPU: fiscalização do Estado, em prol do cumprimento da lei e da oferta dos direitos } \\
\text { constitucionais. } \\
\text { MPF: julgar e processar competências apresentadas pelo artigo } 102 \text { da CF de } 1988 . \\
\text { PGR: solicitar informações sobre atividades administrativas do Ministério da Saúde para a } \\
\text { representação e defesa do órgão perante o sistema judiciário. } \\
\text { DPU: }\end{array}$ & $\begin{array}{l}\text { (BRASIL, 1988; } \\
\text { MINISTÉRIO DA } \\
\text { SAÚDE, 2016g; } \\
\text { MINISTÉRIO } \\
\text { PÚBLICO DO } \\
\text { DISTRITO FEDERAL } \\
\text { E TERRITÓRIOS, } \\
\text { 2016a) }\end{array}$ \\
\hline & DPU - Defensoria Pública da União & $\begin{array}{l}\text { Atender a população que necessita de representação jurídica, de forma gratuita; organizar } \\
\text { atendimentos itinerantes nas comunidades do interior e realizar atividade de estímulo dos } \\
\text { alunos das escolas públicas sobre os direitos. }\end{array}$ & $\begin{array}{l}\text { (DEFENSORIA } \\
\text { PÚBLICA DA UNIÃO, } \\
\text { 2016a). }\end{array}$ \\
\hline
\end{tabular}




\begin{tabular}{|c|c|c|c|}
\hline \multirow{5}{*}{$\begin{array}{l}\text { Nível } \\
\text { Distrital }\end{array}$} & $\begin{array}{l}\text { TJDFT - Conselho de Saúde do Distrito } \\
\text { Federal } \\
\text { Comitê Executivo Distrital da Saúde } \\
\text { (Fórum Nacional em Saúde) } \\
\text { NAT - Núcleo de Apoio Técnico do Poder } \\
\text { Judiciário }\end{array}$ & $\begin{array}{l}\text { Comitê Executivo Distrital da Saúde/TJDFT: promover a integração dos Tribunais } \\
\text { Estaduais, Regionais Federais e do Trabalho com o Comitê Executivo Nacional do Fórum; } \\
\text { manter permanente interlocução com o Comitê Executivo Nacional; realizar e cooperar nos } \\
\text { trabalhos relacionados as objetivos do Fórum no âmbito de seus Estados e Regiões, sob a } \\
\text { coordenação do Comitê Executivo Nacional; propor, ao Comitê Executivo Nacional, ações } \\
\text { concretas e soluções que busquem a realização dos objetivos do Fórum; participar das } \\
\text { reuniões nacionais e realizar reuniões locais periódicas. } \\
\text { NATs: atividades de suporte aos magistrados nas decisões de ações judiciais relacionadas } \\
\text { ao direito à saúde, por meio da disponibilização de conhecimento técnico. }\end{array}$ & $\begin{array}{l}\text { (BRASIL, 2011g; } \\
\text { FERREIRA; COSTA, } \\
\text { 2013; MINISTÉRIO } \\
\text { DA SAÚDE, 2016a; } \\
\text { TRIBUNAL DE } \\
\text { JUSTIÇA DO } \\
\text { DISTRITO FEDERAL, } \\
\text { 2016c) }\end{array}$ \\
\hline & $\begin{array}{l}\text { SES-DF - Secretaria de Estado de Saúde } \\
\text { do Distrito Federal } \\
\text { NJUD - Núcleo de Judicialização da SES- } \\
\text { DF } \\
\text { CAMEDIS -Câmara Permanente Distrital } \\
\text { de Mediação em Saúde } \\
\text { DIASF } \\
\text { Núcleo de Farmácia Ambulatorial Judicial }\end{array}$ & $\begin{array}{l}\text { NJUD/SES-DF: receber e lidar com as demandas judiciais impostas sobre a SES-DF, } \\
\text { desenvolver atividades de melhoria do fornecimento de serviços do SUS e ampliar a } \\
\text { informação dos usuários. } \\
\text { Núcleo de Farmácia Ambulatorial Judicial/DIASF/SES-DF: receber os medicamentos do } \\
\text { NJ/SES-DF, gerenciar seu estoque, estabelecer e seguir rotina de contato e recepção dos } \\
\text { pacientes e dispensar os medicamentos aos usuários, requerentes das ações judiciais. } \\
\text { CAMEDIS: promover mediação em demandas da saúde; buscar conciliação e propor } \\
\text { soluções para as demandas em trâmite; tomar conhecimento de demandas judiciais e } \\
\text { administrativas levadas à CAMEDIS e propor medidas para a melhoria das políticas } \\
\text { públicas. }\end{array}$ & $\begin{array}{l}\text { (BRASIL, 2013a; } \\
\text { 2013m; CONTI et al, } \\
\text { 2015; SECRETARIA } \\
\text { DE ESTADO DE } \\
\text { SAÚDE DO } \\
\text { DISTRITO FEDERAL, } \\
\text { 2016a; 2016b) }\end{array}$ \\
\hline & $\begin{array}{l}\text { MPDFT - Ministério Público do Distrito } \\
\text { Federal e Territórios } \\
\text { PROSUS - Promotoria de Justiça de } \\
\text { Defesa da Saúde }\end{array}$ & $\begin{array}{l}\text { MPDFT: investigação e relatoria sobre os aspectos de gestão do sistema de saúde que } \\
\text { possam impactar na qualidade do atendimento ao cidadão. } \\
\text { PROSUS/MPDFT: acompanhar e fiscalizar o atendimento ao cidadão oferecido pelo SUS; } \\
\text { acompanhar a execução de convênios e de contratos firmados entre o SUS e entidades sem } \\
\text { fins lucrativos, filantrópicas e de iniciativa privada; fiscalizar as atividades de vigilância } \\
\text { sanitária e epidemiológica, de saúde do trabalhador, de assistência terapêutica e } \\
\text { farmacêutica; fiscalizar o seguimento dos princípios constitucionais da gratuidade, da } \\
\text { integralidade e da universalidade das ações e serviços de saúde; verificar a abertura de } \\
\text { processo de sindicância e/ou administrativo para apurar as responsabilidades; verificar o } \\
\text { descarte de resíduos de saúde; fiscalizar a atuação dos profissionais de saúde; fiscalizar } \\
\text { serviços para a saúde; elaborar normas educativas e regulamentadoras na área de saúde. }\end{array}$ & $\begin{array}{l}\text { (CORREIO } \\
\text { BRAZILIENSE, 2012; } \\
\text { MINISTÉRIO } \\
\text { PÚBLICO DO } \\
\text { DISTRITO FEDERAL } \\
\text { E TERRITÓRIOS, } \\
\text { 2016a) }\end{array}$ \\
\hline & $\begin{array}{l}\text { PGDF - Procuradoria-Geral do Distrito } \\
\text { Federal PROMAI - Procuradoria do Meio } \\
\text { Ambiente, Patrimônio Urbanístico e } \\
\text { Imobiliário e Saúde } \\
\end{array}$ & $\begin{array}{l}\text { PROMAI: desenvolve as atividades de planejamento, orientação, coordenação e controle } \\
\text { das ações relativas à tutela ambiental, de patrimônio urbanístico, imobiliário e de saúde. }\end{array}$ & $\begin{array}{l}\text { (PROCURADORIA- } \\
\text { GERAL DA } \\
\text { REPÚBLICA, 2016) }\end{array}$ \\
\hline & $\begin{array}{l}\text { DPDF - Defensoria Pública do Distrito } \\
\text { Federal - Núcleo da Saúde }\end{array}$ & $\begin{array}{l}\text { Núcleo da Saúde/DPDF: orientação do cidadão e a prestação de assistência jurídica em } \\
\text { todas as áreas. }\end{array}$ & $\begin{array}{l}\text { (AGÊNCIA } \\
\text { BRASÍLIA, 2012c) }\end{array}$ \\
\hline
\end{tabular}


APÊNDICE AH - Relação de normas da saúde que amparam a judicialização

\begin{tabular}{|c|c|c|}
\hline $\begin{array}{l}\text { NORMAS QUE AMPARAM A } \\
\text { AF, O CEAF/PNAF E A . } \\
\text { JUDICIALIZAÇÃO DA SAÚDE }\end{array}$ & VERSA SOBRE & REFERÊNCIA \\
\hline Constituição Federal de 1988 & $\begin{array}{l}\text { Constituição da república federativa do Brasil } \\
\text { de } 1988 \text {. }\end{array}$ & (BRASIL, 1988) \\
\hline $\begin{array}{l}\text { Lei } n^{\circ} 8.080 \text {, de } 19 \text { de setembro } \\
\text { de } 1990\end{array}$ & $\begin{array}{l}\text { Condições para a promoção, proteção e } \\
\text { recuperação da saúde, a organização e o } \\
\text { funcionamento dos serviços correspondentes e } \\
\text { dá outras providências. }\end{array}$ & (BRASIL, 1990a) \\
\hline $\begin{array}{l}\text { Lei Orgânica do Distrito Federal, } \\
\text { de } 08 \text { de junho de } 1993\end{array}$ & Lei Orgânica do Distrito Federal de 1993 & (BRASIL, 1993b) \\
\hline $\begin{array}{l}\text { Portaria } \mathrm{n}^{\mathrm{o}} 3.916 / \mathrm{GM} / \mathrm{MS} \text {, de } 30 \\
\text { de outubro de } 1998\end{array}$ & Política Nacional de Medicamentos. & (BRASIL, 1998) \\
\hline $\begin{array}{l}\text { Resolução CNS/MS n }{ }^{\circ} 338 \text {, de } 6 \\
\text { de maio de } 2004\end{array}$ & Política Nacional de Assistência Farmacêutica. & (BRASIL, 2004) \\
\hline $\begin{array}{l}\text { Portaria GM/MS n }{ }^{\circ} 204 \text {, de } 29 \text { de } \\
\text { janeiro de } 2007\end{array}$ & $\begin{array}{l}\text { Financiamento e a transferência dos recursos } \\
\text { federais para as ações e serviços de saúde. }\end{array}$ & (BRASIL, 2007a) \\
\hline $\begin{array}{l}\text { Portaria }^{\circ} 2981, \text { de } 26 \text { de } \\
\text { novembro de } 2009\end{array}$ & $\begin{array}{l}\text { Componente Especializado da Assistência } \\
\text { Farmacêutica. }\end{array}$ & (BRASIL, 2009b) \\
\hline $\begin{array}{l}\text { Lei Complementar } n^{\circ} 141 \text {, de } 13 \\
\text { de janeiro de } 2012\end{array}$ & $\begin{array}{l}\text { Valores mínimos a serem aplicados anualmente } \\
\text { pela União, Estados, Distrito Federal e } \\
\text { Municípios em ações e serviços públicos de } \\
\text { saúde. }\end{array}$ & (BRASIL, 2012c) \\
\hline
\end{tabular}


APÊEDICE AI - Relação de normas importantes para contribuir com a judicialização da saúde

\begin{tabular}{|c|c|c|c|}
\hline $\begin{array}{l}\text { NORMAS QUE } \\
\text { DEVERIAM RECEBER } \\
\text { MAIS ATENÇÃO NO } \\
\text { CONTEXTO DA } \\
\text { JUDICIALIZAÇÃO DA } \\
\text { SAÚDE } \\
\end{array}$ & VERSA SOBRE & REFERÊNCIA & ASPECTO \\
\hline $\begin{array}{l}\text { Lei n }{ }^{\circ} 5.991 \text {, de } 17 \text { de } \\
\text { dezembro de } 1973\end{array}$ & $\begin{array}{l}\text { Controle Sanitário do Comércio de } \\
\text { Drogas, Medicamentos, Insumos } \\
\text { Farmacêuticos e Correlatos, e dá } \\
\text { outras Providências. }\end{array}$ & (BRASIL, 1988) & $\begin{array}{l}\text { Exigência de } \\
\text { registro na } \\
\text { ANVISA. }\end{array}$ \\
\hline $\begin{array}{l}\text { Portaria SAS/MS n }{ }^{\circ} 409, \text { de } \\
05 \text { de agosto de } 1999\end{array}$ & $\begin{array}{l}\text { A sistemática de APAC, para } \\
\text { fornecimento dos medicamentos } \\
\text { excepcionais, e regulamenta a } \\
\text { Solicitação de Medicamentos (SME), } \\
\text { para o fornecimento de medicamentos } \\
\text { e formulários de APAC para } \\
\text { autorização e coleta de informações } \\
\text { gerenciais dos medicamentos } \\
\text { excepcionais }\end{array}$ & (BRASIL, 1999) & \multirow{3}{*}{$\begin{array}{l}\text { A APAC } \\
\text { autoriza o uso } \\
\text { da tecnologia } \\
\text { para pacientes } \\
\text { que se } \\
\text { beneficiarão e } \\
\text { terão segurança } \\
\text { com o uso. }\end{array}$} \\
\hline $\begin{array}{l}\text { Portaria SAS/MS n }{ }^{\circ} 768, \text { de } \\
26 \text { de outubro de } 2006\end{array}$ & $\begin{array}{l}\text { Definição do novo laudo para } \\
\text { solicitação/autorização de } \\
\text { medicamentos de dispensação } \\
\text { excepcional e estratégicos - LME }\end{array}$ & (BRASIL, 2006e) & \\
\hline $\begin{array}{l}\text { Portaria SAS/MS no } 257 \text {, de } \\
12 \text { de março de } 2013\end{array}$ & $\begin{array}{l}\text { Inclui novos campos no layout da } \\
\text { Autorização de Procedimentos } \\
\text { Ambulatoriais (APAC) }\end{array}$ & (BRASIL, 2013d) & \\
\hline $\begin{array}{l}\text { Lei } n^{\circ} 12.401 \text {, de } 28 \text { de abril } \\
\text { de } 2011\end{array}$ & $\begin{array}{l}\text { Alteração da Lei no } 8.080 \text {, de } 19 \text { de } \\
\text { setembro de } 1990 \text {, para dispor sobre a } \\
\text { assistência terapêutica e a } \\
\text { incorporação de tecnologia em saúde } \\
\text { no âmbito do Sistema Único de Saúde } \\
\text { - SUS. }\end{array}$ & (BRASIL, 2011a) & \multirow{2}{*}{$\begin{array}{l}\text { Importância } \\
\text { dos critérios } \\
\text { objetivos para } \\
\text { inclusão de } \\
\text { novas } \\
\text { tecnologias no } \\
\text { SUS, para } \\
\text { seguimento dos } \\
\text { PCDT e do } \\
\text { trabalho } \\
\text { multidisciplinar } \\
\text { de equipe } \\
\text { competente } \\
\text { para isto } \\
\text { (CONITEC). } \\
\end{array}$} \\
\hline $\begin{array}{l}\text { Decreto } \mathrm{n}^{\circ} 7.646 \text {, de } 21 \text { de } \\
\text { dezembro de } 2011\end{array}$ & $\begin{array}{l}\text { Comissão Nacional de Incorporação } \\
\text { de Tecnologias no Sistema Único de } \\
\text { Saúde e sobre o processo } \\
\text { administrativo para incorporação, } \\
\text { exclusão e alteração de tecnologias em } \\
\text { saúde pelo Sistema Único de Saúde - } \\
\text { SUS, e dá outras providências. }\end{array}$ & (BRASIL, 2011c) & \\
\hline $\begin{array}{l}\text { Lei } 12.466 \text {, de } 24 \text { de agosto } \\
\text { de } 2011\end{array}$ & $\begin{array}{l}\text { Comissões intergestores do SUS, o } \\
\text { Conselho Nacional de Secretários de } \\
\text { Saúde (Conass), o Conselho Nacional } \\
\text { de Secretarias Municipais de Saúde } \\
\text { (Conasems) e suas respectivas } \\
\text { composições, e dá outras } \\
\text { providências. }\end{array}$ & (BRASIL, 2011e) & $\begin{array}{l}\text { Importância da } \\
\text { pactuação para } \\
\text { melhor } \\
\text { elucidação dos } \\
\text { problemas } \\
\text { priorizados e } \\
\text { ações mais } \\
\text { democráticas. }\end{array}$ \\
\hline $\begin{array}{l}\text { Resolução } n^{\circ} \text { 1/CIT, de } 17 \\
\text { de janeiro de } 2012\end{array}$ & $\begin{array}{l}\text { Diretrizes nacionais da Relação } \\
\text { Nacional de Medicamentos Essenciais } \\
\text { (RENAME) no âmbito do Sistema } \\
\text { Único de Saúde (SUS). }\end{array}$ & (BRASIL, 2012a) & \multirow{2}{*}{$\begin{array}{l}\text { Conhecimento } \\
\text { sobre as } \\
\text { tecnologias já } \\
\text { incorporadas, } \\
\text { as excluídas e } \\
\text { os motivos das }\end{array}$} \\
\hline $\begin{array}{l}\text { Portaria }{ }^{\circ} \text { 533/GM/MS, de } \\
28 \text { de março de } 2012\end{array}$ & $\begin{array}{l}\text { Elenco de medicamentos e insumos da } \\
\text { Relação Nacional de Medicamentos }\end{array}$ & (BRASIL, 2012b) & \\
\hline
\end{tabular}




\begin{tabular}{|l|l|l|l|}
\hline & $\begin{array}{l}\text { Essenciais (RENAME) no âmbito do } \\
\text { Sistema Único de Saúde (SUS). }\end{array}$ & & exclusões. \\
\hline & $\begin{array}{l}\text { Regras de financiamento e execução } \\
\text { do Componente Especializado da } \\
\text { Assistência Farmacêutica no âmbito } \\
\text { do Sistema Único de Saúde (SUS). } \\
\text { de 30 de julho de 2013 }\end{array}$ & (BRASIL, 2013a) & $\begin{array}{l}\text { Compreensão } \\
\text { sobre a } \\
\text { otimização de } \\
\text { recursos } \\
\text { realizada pelas } \\
\text { compras } \\
\text { centralizadas. }\end{array}$ \\
\hline
\end{tabular}

